Werner Riess

Performing Interpersonal Violence 


\title{
MythosEikonPoiesis
}

Herausgegeben von

Anton Bierl

\author{
Wissenschaftlicher Beirat \\ Gregory Nagy $\cdot$ Richard Martin
}

Band 4

De Gruyter 


\title{
Werner Riess
}

\section{Performing Interpersonal Violence}

\author{
Court, Curse, and Comedy \\ in Fourth-Century BCE Athens
}




\title{
(cc) BY-NC-ND
}

This work is licensed under the Creative Commons Attribution-NonCommercial-NoDerivs 4.0 License, as of February 20, 2018. For details go to http://creativecommons.org/licenses/by-nc-nd/4.0/.

\footnotetext{
An electronic version of this book is freely available, thanks to the support of libraries working with Knowledge Unlatched. $\mathrm{KU}$ is a collaborative initiative designed to make high quality books Open Access. More information about the initiative can be found at www.knowledgeunlatched.org
}

\author{
ISBN 978-3-11-024559-2 \\ e-ISBN 978-3-11-024560-8 \\ ISSN 1868-5080
}

\section{Library of Congress Cataloging-in-Publication Data}

A CIP catalog record for this book has been applied for at the Library of Congress.

\section{Bibliografische Information der Deutschen Nationalbibliothek}

Die Deutsche Nationalbibliothek verzeichnet diese Publikation in der Deutschen Nationalbibliografie; detaillierte bibliografische Daten sind im Internet über http://dnb.d-nb.de abrufbar.

(C) 2012 Walter de Gruyter GmbH \& Co. KG, Berlin/Boston

Druck: Hubert \& Co. GmbH \& Co. KG, Göttingen

$\infty$ Gedruckt auf säurefreiem Papier

Printed in Germany

www.degruyter.com 


\section{Acknowledgments}

This book is the revised version of my Habilitationsschrift, which was accepted by the faculty of the humanities at Augsburg University, Germany, in the fall of 2008. First, my thanks go to Gregor Weber, head of the committee, who was the greatest supporter of this project from its beginning. His boundless willingness to engage in fruitful discussions and his unstinting help in academia and beyond will always be remembered. I also thank Anton Bierl, Martin Dreher, and Marion Lausberg for serving on the committee and making many suggestions for improvement. Anton Bierl's unflagging belief in my ideas, and his excellent advice and encouragement, as well as his kind invitation to publish this book in his new series, deserve my sincere gratitude.

Since the book has been long in the making, I am grateful to the audiences who listened to my ideas at various stages of the project and provided valuable feedback, at Emory University, the University of Florida at Gainesville, and Penn State at University Park, as well as at Augsburg, Basel, Berlin (Humboldt University), Bielefeld, Bonn, Freiburg, Heidelberg, Jena, Munich, Trier, and Wuppertal. I was also given the chance to present my findings at the annual meeting of the Association of Ancient Historians held at Princeton University (2007); at the international conference "Ritual Dynamics and the Science of Ritual," organized by the Heidelberg Collaborative Research Center "Ritual Dynamics" (2008); at the annual meeting of the Classical Association of the Middle West and South in Minneapolis (2009); and on the occasion of the international conference "The Archaeology of Violence: An Integrated Approach to the Study of Violence and Conflict," organized by the Institute for European and Mediterranean Archaeology at the State University of New York at Buffalo (2009). I would like to thank all hosts and organizers for their kind invitations. The comments I received greatly helped me refine my thinking.

This book could not have been written without the support of many individuals and various institutions. The foundations of this study were laid during a Feodor Lynen Research Fellowship of the Alexander von Humboldt Foundation that allowed to me to teach and do research under congenial circumstances at Emory University (2002/3). I am grate- 
ful to Thomas S. Burns and Niall W. Slater for their invitation and kindness during that year and beyond. The University of North Carolina at Chapel Hill granted me two one-semester research leaves, which were instrumental in continuing and finishing my studies. I feel indebted to the directors of the Kommission für Alte Geschichte und Epigraphik at Munich, Christof Schuler and Rudolf Haensch, for their kind hospitality to stay and work for a couple of days at this splendid institution in the summer of 2006. I would also like to express my thanks to Carolyn L. and Walter R. Connor, Fritz Graf, Jon E. Lendon, Elizabeth A. Meyer, and Kurt A. Raaflaub for their never-ending willingness to support me over the years. Further thanks are due to Felix Lukas, Günter Hägele, and their library staff at Augsburg University, for providing me with outstanding working conditions during the summers. Most of all, I am eager to thank the Harvard Center for Hellenic Studies at Washington, DC, its Senior Fellows, library staff, and especially Greg Nagy and Douglas Frame, for granting me the great privilege to work uninterruptedly for a whole academic year under most favorable circumstances (2007/8). In the serene atmosphere up on Whitehaven Street I could finally write the larger portion of this book.

I owe a great debt of gratitude to all those friends and colleagues who generously gave their time to read chapters of the manuscript, which benefited enormously from their wisdom and insightful criticism. I mention with warm gratitude Radcliffe G. Edmonds III, Michael Gagarin, Phillip S. Horky, Sharon L. James, David Konstan, John Marincola, S. Douglas Olson, Zinon Papakonstantinou, Kurt A. Raaflaub, as well as the anonymous referees for the press whose comments helped me improve the book. I owe particular thanks to David D. Phillips, who read the chapter on the curse tablets and the section on the forensic speeches, and from whom I learned a great deal about Athenian law, as well as to Anton Bierl and Peter von Möllendorff, who never got tired of reading and discussing matters of comedy with me. Above all, I must single out William H. Race, dear colleague and mentor, master of the English tongue, who read the whole manuscript twice with his sharp eye for detail and precision. I cannot appreciate enough his endless patience in discussing matters of substance and style with me.

If the final product does not betray the non-native speaker of English on every page, it is thanks to David P. C. Carlisle, who edited my English at an early stage of the draft, and to Amanda G. Mathis' meticulous copyediting, for which I owe her heartfelt thanks. Further thanks go to Hannah L. Rich and Patrick J. Dombrowski for checking many references, 
and to Sebastian Bündgens, Matthias Dewald, and Patrick Weixelmann for help with the indices. For any remaining mistakes, flaws, and inaccuracies I take full responsibility.

Finally, Sabine Vogt, Katrin Hofmann, Katharina Legutke, and Jens Lindenhain made the publishing venture with Walter de Gruyter a most pleasant experience. I thank them for so circumspect and fast a printing process. The University of North Carolina at Chapel Hill granted sizeable printing subsidies, for which I am very grateful.

Words cannot express what kind of loving support and unstinting help I have been fortunate to receive over the years from my wife Claudia and my family. Their endless patience and encouragement have guided me all along. Last but not least, Philipp's good humor has always cheered me up. To them I dedicate this book.

\section{Note to the reader}

Monographs could be considered selectively through 2010. Anyone working on classical Athens knows that it is impossible to take into consideration all pertinent secondary literature, but I hope I consulted the works of major relevance for my topic. If I have failed to reach the depth of specialization in every corner of the respective fields I am treating here, and if some seemingly far-flung results offend the eyes of the specialist because of my endeavor to synthesize and take a broad look at things beyond highly specialized disciplinary compartments, I ask for indulgence and hope that the project of shedding light on domains usually treated separately has remained a worthwhile endeavor.

Apart from Athenian political and legal institutions, Greek names are Latinized unless the Greek form is common in English (so Kerameikos, not Ceramicus). Greek words are transliterated with vowel lengths marked, unless the words are common in English. Adjectives derived from Greek words are anglicized, so komastic, not kômastic, etc. 
All translations from the orators are taken from the new translations in the Oratory of Classical Greece series by the University of Texas Press, or, where not available yet, from the Loeb editions. Translations of other literary texts are mainly taken from the Loeb series. Where I felt slight changes should be made, I have indicated them as such. Translations of curse tablets are taken from Gager, or the respective editions, or are my own.

Hamburg, September 2011 


\section{Contents}

Acknowledgments ............................ V

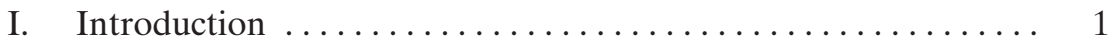

Notions of Violence - State of Research - Goals ........... 1

Methodology: The Performative Turn and Ritual Studies

(A Brief Overview) .......................... 10

The Controlling Function of Ritualization $\ldots \ldots \ldots \ldots \ldots \ldots \ldots . . \ldots$

Sources - Chronological Scope ....................... 19

II. Forensic Speeches $\ldots \ldots \ldots \ldots \ldots \ldots \ldots \ldots \ldots \ldots \ldots \ldots \ldots \ldots \ldots \ldots, 22$

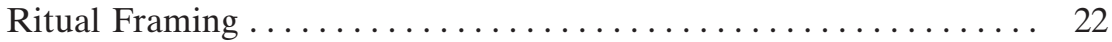

Constructing Violence: Discursive Rules of Violence I (Interaction) 32

Contexts ............................... 33

First Blow versus Self-Defense ................... 34

Murder versus Lawful Homicide .................... 35

Public versus Hidden Violence ..................... 51

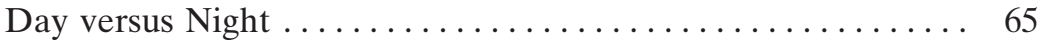

Inebriation versus Sobriety $\ldots \ldots \ldots \ldots \ldots \ldots \ldots \ldots \ldots$

Old Age versus Young Age .................... 70

Thresholds (invasion of homes versus protection of oikos) .... 72

Disturbance of Public Duty versus Maintenance of Public Order 82

Perversion of Religious Customs $\ldots \ldots \ldots \ldots \ldots \ldots \ldots \ldots .63$

Perversion of Gender, Citizenship Status, Social Rank and Role 84

Mediated (Sanctioned) versus Direct Violence ........... 94

Escalation versus De-escalation .................... 96

Images of Violence: Discursive Rules of Violence II

(Mental and Cultural Representation) $\ldots \ldots \ldots \ldots \ldots \ldots \ldots \ldots . \ldots . \ldots 102$

The Depiction of Violence ....................... 104

Selfless Motives versus Selfishness ................... 114

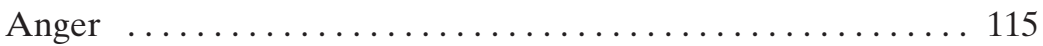

Transgression of Boundaries ..................... 119

Hubris .................................. 120

Tyrants ................................ 126 
Barbarians .................................. 130

Old versus New Discourse Strategies $\ldots \ldots \ldots \ldots \ldots \ldots \ldots . \ldots 131$

Functions of Ritualization ......................... 140

How to Plead in Court - A Conclusion $\ldots \ldots \ldots \ldots \ldots \ldots \ldots . \ldots 158$

III. Curse Tablets .................................. 164

Proportions - Social Origins of Cursers - Functions of Tablets ... 169

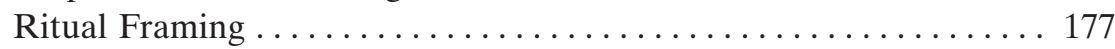

Ritual Actions (drômena) ........................ 178

Ritual Words (legomena) ........................ 182

Degree of Violence ............................ 189

Diachronic Development .......................... 222

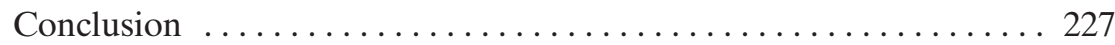

IV. Old and New Comedy $\ldots \ldots \ldots \ldots \ldots \ldots \ldots \ldots \ldots \ldots \ldots \ldots$

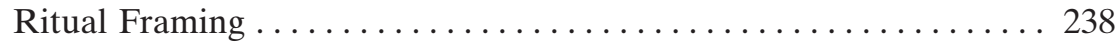

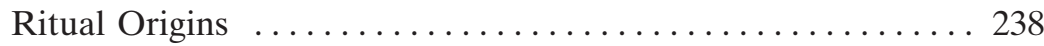

Theater Production as Ritual Process ................ 243

Ritual Efficacy ............................. 247

The Discursive Rules of Violence .................... 251

Aristophanes .............................. 251

Three Case Studies: Wasps, Birds, and Clouds ............ 285

The Double-Layerdness of Violence ................ 311

Aristophanes' Discourse on Democracy - Summary ....... 316

Menander ..................................... 319

Menander's Discourse on Society - Summary ............ 364

Ritual Functions of Scenes of Violence in Comedy ........... 367

Conclusion ................................... 373

V. Conclusions ................................... 379

Chronological Development of the Violence Discourse in Different

Genres ...................................... 379

Three Theses on Athenian Violence ................... 384

Controlling Function of Ritualization .................. 387

Social Origins of Perpetrators of Violence ................ 389 


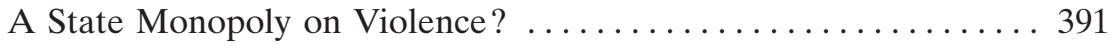

Outlook on Violence in Athenian Foreign Policy ............. 392

VI. References ................................. 395

1. Corpora of Athenian Curse Tablets ............... 395

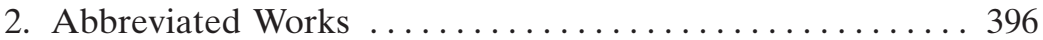

3. English Translations ........................... 397

4. Secondary Literature ........................... 398

Index locorum ................................ 441

Literary Sources ........................... 441

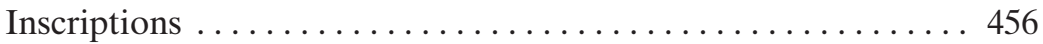

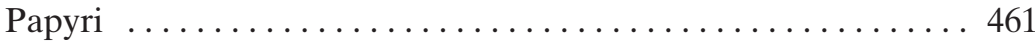

Iconographical Sources ...................... 461

General Index ............................... 463

Important Greek and Latin terms $\ldots \ldots \ldots \ldots \ldots \ldots \ldots . \ldots 41$

Ancient proper names (historical and fictional persons) ...... 474 



\title{
I. Introduction
}

\author{
And found in Accusatia, near \\ the Clepsydra, is the villainous \\ race of Tongue-to-Belly Men, \\ who reap and sow \\ and gather vintage with their tongues - \\ and also figs; \\ they are barbarian stock, \\ Gorgiases and Philips. \\ And it is because of these \\ philippic Tongue-to-Belly Men \\ that everywhere in Attica \\ the tongue is cut out by itself. \\ (Aristophanes, Birds 1694-1705, transl.
}

A. Sommerstein 1987, p. 193.)

\section{Notions of Violence - State of Research - Goals}

At the Athenian Great Dionysia festival of 348 BCE, Demosthenes, if we want to believe him, suffered the worst humiliation of his life. He was serving as chorêgos, thus being responsible for the equipment and training of the chorus required for a dramatic performance at this religious festival. For any Athenian citizen, this high-ranking religious and civic function brought considerable prestige and public esteem, and constituted one of the highlights of a citizen's career. Demosthenes, however, was denied success. In the theater of Dionysus, in front of the assembled dêmos, Meidias, one of Demosthenes' long-time opponents, punched him in the face, a severe insult and provocation. Demosthenes did not strike back, but instead wrote what is today one of the most famous Athenian courtroom speeches (Dem. 21: Against Meidias). Whether or not he actually delivered the speech is open to debate and need not concern us here. What is important, however, is the way Demosthenes dealt with this outbreak of violence against his person, as well as the cultural implications that the blatant use of violence entailed in classical Athens.

Violence is an intrinsic part of every human society, its notion being culturally determined. But the highly heterogeneous forms of violence 
make the phenomenon elusive and hard to define, ${ }^{1}$ and since various disciplines in the humanities and natural sciences are preoccupied with this phenomenon, there is a multitude of divergent definitions of "violence." 2 Because of these enormous difficulties of definition and despite intensive research, sociologists have not yet been able to establish a sociology of violence up to the present day. ${ }^{3}$ The broad notion of the so-called "structural violence," as developed by Galtung, ${ }^{4}$ can hardly be applied to antiquity. Only the application of a narrow definition of violence enables the historian to analyze a vast body of sources under a coherent set of questions. In the context of this work, therefore, I mean by violence a physical act, a "process in which a human being inflicts harm on another human being via physical strength"

This book seeks to investigate the civic, interpersonal violence in fourth-century $\mathrm{BCE}^{6}$ Athens perpetrated mainly upon fellow citizens. ${ }^{7}$

1 Cf. von Trotha 1997, 9-19.

2 With regard to the plethora of definitions, cf. Reinhold - Lamnek - Recker 2000, $231-232$.

3 Cf. the stimulating volume edited by von Trotha 1997 . The Marburg volumes Bonacker 2002, Imbusch - Zoll 1999, and Meyer 1997 put the phenomenon of violence into the larger context of peace and conflict research, as well as the sociology of conflict. Oberwittler - Karstedt 2003 furnish a sociology of criminality in general, but not of violence. Rapoport 1990 is a broadly cast introduction to peace and conflict research. Only a few works strive to the lay the foundations for a sociology of violence. Cf., e.g., Mader - Eberwein - Vogt 2000 and Riches 1986. Sofsky 1996 is decidedly interested in the symbolic contents of violent actions.

4 Galtung 1975.

5 Fuchs-Heinritz - Lautmann - Rammstedt - Wienold ${ }^{3} 1994,247$ (my transl.). As we will see, cursing someone via malign magic was understood as indirect violence with physical consequences for the victim. Therefore, the perceived violence committed via the deposition of curse tablets will be treated in this study. An investigation of the psychological violence that was committed in Athens would exceed the scope of this book. Especially verbal abuse and character denigration, which abound in Attic forensic oratory, deserve a comprehensive, book-length study. On speech acts as violence, cf. Butler 1997. Rather than violence, character assassination is a technique of applying peithô, persuading judges to render a harsh judgment on one's opponent. Similar to the narrow meaning of violence suggested here is the definition by Hillmann ${ }^{3} 1972,264$.

6 It is the wealth of evidence preserved from the fourth century that makes such an undertaking possible. For other epochs of Greek history, alas, we are in a worse situation.

7 The inquiry into how male citizens treat each other will automatically address the use of violence against people socially discriminated against. These are, in 
No society is free of conflicts. One way to deal with them is resolve them violently. Hence, this study has a narrower focus than many others in the vast realm of conflict studies. ${ }^{8}$ This book is about violence itself.

A brief note on Greek terminology may be appropriate here. The Greeks had several terms at their disposal to express "violence," which all held special positions in the mythological cosmos. Bia is the personification of physical violence. She is the daughter of Pallas and Styx and sister of Zelos, Nike, and Cratus. ${ }^{9}$ Cratus is strength and force, which can manifest themselves in violence. Cratus means 'brute force, ${ }^{, 10}$ including both power and rule, according to Weber's terminology. ${ }^{11}$ The Greeks were always aware that every form of dominance is ultimately based on potential violence. Anangkê denotes physical compulsion. ${ }^{12}$ Hubris generally means aggressive arrogance that in most cases humiliates a victim by violating his or her status in society. ${ }^{13}$ This last term is especially hard to pin down. It will be treated in detail in chapter II of this study.

For the sake of clarity and concision, I exclude: (1) violence in the political realm, especially in the context of the Thirty Tyrants and their harsh rule over Athens in 404/03 BCE; (2) violence in myth and tragedy, which is an entirely different topic in its own right; ${ }^{14}$ (3) violence against

the first place, slaves, foreigners, metics, and women. Cf. e.g., Klees 1998, 176217.

8 A thorough study of conflict in the Greek world has yet to be written. An important step in this direction is Fuks 1984.

9 R. Bloch, s.v. “Bia,” Der Neue Pauly 2, Stuttgart - Weimar 1997, col. 616. D'Agostino 1983 analyzes the usage of this term also in the Greek philosophers.

10 J. Tambornino, s.v. "Kratos," RE 11.2, Stuttgart 1922, col. 1660.

11 In the terminology of Weber 1925, 122-125 governmental, that is legalized, violence is "rule" (Herrschaft), not the exertion of brute "force" or "power" (Macht). In the case of Athens we can discern the beginnings of a governmental monopoly of power. This gradual development opens up a vast area of research that would exceed the scope of this study.

12 P. Dräger, s.v. "Ananke," Der Neue Pauly 1, Stuttgart - Weimar 1996, col. 653 654: "die Kraft, die hinter allen Erscheinungen mechanisch wirkt und das göttliche Urprinzip zu seiner vielfachen Ausgestaltung zwingt."

13 G. Thür, s.v. "Hybris," Der Neue Pauly 5, Stuttgart - Weimar 1998, 771-772.

14 Athenian tragedies are mainly based on myths, and although it is true that the classical playwrights commented upon Athenian themes with their dramas, the relationship between violence on the Athenian tragic stage and violence in daily life is only an indirect one. The high degree of violence in Athenian tragedy hardly reflects Athenian reality. This is not to say that Attic tragedy is not an important and indispensable source for the study of Athenian mentality, but the problems involved in the attempt to disentangle the connection between vi- 
animals as committed on the occasion of religious sacrifices; ${ }^{15}$ and (4) violence in sports and war. ${ }^{16}$ This project concentrates on violence that is reported because it exceeds a certain accepted framework. In the eyes of the victim, the use of violence is the transgression of rules and social conventions. ${ }^{17}$

Sociologists feel a moral obligation to penetrate contemporary Western societies in search of the reasons for violence and to find remedies to improve the situation. Only a thorough understanding of the underlying causes of violence, according to public opinion, allows its efficient prevention and control. The scant evidence we have from antiquity, however, seems to prevent an adequate investigation of the causes of violence. Thus, the ancient historian is free to concentrate on the phenomenon of violence itself, its forms and symbolic meanings.

From the 1970s, historians have looked upon violence as a historical phenomenon without striving for the systematic rigor embraced by sociology. Ancient history lags behind comparable research endeavors illuminating the early modern period mainly because of a lack of evidence. For the modern period, many cities, and especially English counties, have well-established histories of crime (including violence), thanks to a wealth of serial sources, such as minutes of court proceedings and easily accessible archives. ${ }^{18}$ There is even an abundance of overarching studies of violence for this particular epoch. ${ }^{19}$ In the meantime, the beginnings

olence in myth and the contemporary audience's notions and expectations have prevented a comprehensive and in-depth analysis of violence in myth and tragedy up to the present day. Alongside the numerous works of Burkert and Henrichs, many articles and, as far as I can see, one dissertation (Eduntoulakis 1995) explicitly deal with violence in Attic tragedy, e.g., Goldhill 2006 and 1991; Seidensticker 2006; Sommerstein 2004a; De Romilly 2000, 35-78; Kaimio 1992 and 1988, 62-78. On revenge in tragedy, cf. Burnett 1998.

15 Cf., e.g., Burkert ${ }^{2} 1997$ and 1984; Hamerton-Kelly - Rosaldo - Burton 1987; Girard 1972.

16 Violence in sports and war (e.g., Bertrand 2005, 24-30; Poliakoff 1987) was situated within the frame of accepted violence. In both domains, violence in our sense of the term was not only tolerable, but even expected. Both areas deserve thorough investigations.

17 Groebner 1995, 189.

18 Cf., e.g., Frank 1995; Schwerhoff 1991; Sharpe 1983.

19 Cf. Eriksson - Krug-Richter 2003; Ruff 2001; Hugger - Stadler 1995; Lindenberger 1993; Sharpe 1984; Stone 1983. 
of a history of crime in the Roman world have been emerging mainly in the Anglo-American world, ${ }^{20}$ but also in continental Europe. ${ }^{21}$

For the Greek world, this agenda seems to be more difficult to put into practice, because most sources are centered upon Athens and do not necessarily articulate issues of violence and crime. ${ }^{22}$ The focus of predominantly Anglophone research in this area is on traditional legal history. Here great progress has been made during the past fifty years, especially in the realm of the law of violent offenses. ${ }^{23}$ Syntheses are available today that allow easy access to the subject matter. ${ }^{24}$ With regard to the oscillating and therefore elusive term of hubris, a sub-field within legal history has emerged. ${ }^{25}$ As important as these normative approaches are, especially in order to understand the highly complex Athenian procedural law, they do little to open up windows onto social and anthropological issues. ${ }^{26}$ Two areas are an exception: the torture of slaves, metics, and aliens ${ }^{27}$ and rape. Since rape is a constituent element of New Comedy, works in the field of gender studies in particular have delved into this topic. ${ }^{28}$ Whereas research, to date, has often addressed violence against slaves, foreigners, and women in Athens, it has largely neglected the kind of civic violence that Athenian men exerted against each other.

20 The most important recent publications are Hopwood 2002 and 1998; and the fundamental Shaw 1984.

21 E.g., Krause 2004; Wolff 2003; Riess 2001; Neri 1998; Nippel 1995.

22 Sagan 1979, 1-7 makes a fervent plea for illuminating the dark side of the Greeks, but his study stops with Thucydides, thus not making use of the richest material we have with regard to violence, the fourth-century speeches.

23 Stroud is to be credited with laying the foundation for the scholarly study of the Athenian homicide law by editing the epigraphically preserved Draconian law of unintentional homicide (Stroud 1968). Cf. MacDowell 21966; Gagarin 1981; Tulin 1996. Cohen 2005a provides an excellent overview of the development and trends in Athenian legal history.

24 Gagarin - Cohen 2005; Harris - Rubinstein 2004; Todd 1993; MacDowell 1978; Harrison 1968/1971. Boegehold 1995 provides a useful overview of the various Attic law courts.

25 Fisher 2000; Cairns 1996; Fisher 1992; Cohen 1991a; Gagarin 1979a; Fisher 1979 and 1976; MacDowell 1976; Ruschenbusch 1965.

26 Allen 2000 is one of the few exceptions.

27 Gagarin 1996; Mirhady 1996; DuBois 1991; Carey 1988; Thür 1977; Bushala 1968.

28 Cf. Omitowoju 2002; Deacy - Pierce 1997 and Doblhofer 1994 for general matters. On specific problems cf. Traill 2008, 21, 48-49, 65, 70-72, 148-155, 178, 192, 194, 228-229, 231, 247, 257, 259; Lape 2001; Rosivach 1998; Sommerstein 1998a; Carey 1995a; Harris 1990; Cole 1984. 
Only a comparative analysis of as many forms of violence as possible can provide us with more concrete information as to how the Athenians themselves perceived violence. More recent and explicit treatments of violence in Athens do offer useful overviews of some parts of the source material, ${ }^{29}$ but they do not provide further-reaching analyses or thorough interpretations from the perspective of cultural history. Schmitz elucidates violence committed in the context of kômoi, that is, in private and public festive processions, from an anthropological point of view, and arrives at convincing conclusions, ${ }^{30}$ but the general focus of his book is on neighborhood. More recent scholarly initiatives on violence have come from archaeologists, classical philologists, and ancient historians alike. Conferences held, for example, at Bonn and Paris in 2002, Santa Barbara and Munich in 2003, and Berlin in 2005, have all led to edited volumes. ${ }^{31}$ In particular, the interpretation of violence represented in vase paintings of the sixth, fifth, and fourth centuries BCE has made remarkable progress. ${ }^{32}$

During the past few years, Cohen has made decisive but highly contested contributions to the research on violence. ${ }^{33} \mathrm{He}$ applies anthropological models derived from Mediterranean societies to ancient Athens, and argues that the dichotomy of "honor" and "shame" fundamentally informed the societies in question. Legal historians such as E. Harris and Herman, however, have rejected the application of these Mediterranean models to the context of ancient Athens. ${ }^{34}$ Herman, in particular, wishes to abandon the entire model, because he believes it is far too general to provide conclusive results. ${ }^{35}$ These legal historians even question the fundamental premises of the model-honor and shame also play a crucial role, for example, in old Nordic cultures-and insist on the special and unique position of Athens within pre-modern societies. The completely different notions which both sides have of the function of Athenian law courts is representative of their opposing viewpoints.

29 E.g., the dissertation by Ruiz 1994.

30 Schmitz 2004, 280-312.

31 Fischer - Moraw 2005; Bertrand 2005; Drake 2006; Zimmermann 2009; Seidensticker - Vöhler 2006.

32 Cf., e.g., Muth 2008 with a penetrating analysis of the development of an iconography of violence on Attic vases, and the contributions to the edited volumes mentioned above n. 31.

33 E.g., Cohen 1995; 1993; 1991a; 1991b; 1984.

34 E.g., Harris 2005; Herman 2000; 1998; 1996; 1995; 1994.

35 Herman 2006, 95-97, 268-269, 413; 1996. 
On the one hand, legal historians using an anthropological approach claim that the Athenian lawcourt system can by no means be compared to modern Western courts and their procedures, which are rational, at least in theory. ${ }^{36}$ Athenian courts provided litigants with just another means of continuing their conflicts, and often simply advanced long-term struggles to the next stage of the conflict. Thus, courts scarcely provided genuine resolution of conflict and were simply one tool of strife among many others.

On the other hand, legal historians relying exclusively on Athenian law emphasize the exceptionality of the Athenian court system in its successful containment of violence. The unusual success of the Athenian courts contributed crucially to the stabilization of the political, social, and economic system of this polis for over two hundred years. Turning to courts was a salient departure from "primitive" feuding. ${ }^{37}$

The discussion over using anthropological models to examine legal conflicts in ancient Athens, however, is currently at an impasse. The participants have withdrawn to entrenched positions, which makes a rapprochement less than likely in the near future. Especially Herman is very much concerned with the unanswerable question of how violent Athenian society was. ${ }^{38}$ Since this quantifying question is irresolvable, I raise different questions in the attempt to take a fresh and comprehensive look at all available sources. By taking this kind of integrative approach, I hope to revive the discussion and give it a new direction. Indeed, instead of struggling to gauge the irretrievable level of violence in an ancient society, we should formulate the following questions:

(1) As a point of departure, a philological question imposes itself: what does the discursive treatment of violence look like in the various types of sources? It will be important to illuminate patterns of how Athenians talked about violence-what I call the semantic grammar of violence. Since we know that the notion of violence was culturally defined, I seek to explore how this semantics was structured and, as a consequence, how it was ideologically constructed and represented.

(2) Closely related is the question of how this textual grammar of violence may reflect the "lived reality" of the Athenians. How did they perceive violence, react to it, and define it, in constructing the conceptual boundary between acceptable and unacceptable behavior

36 Cf., e.g., Cohen 1995; 1991b; Humphreys 1985a.

37 Herman 2006 summarizes the results of his research.

38 Herman 1995; 1994. 
and between tolerable and impermissible violence? What did violence symbolize and mean to them? By suggesting possible answers, I will try to determine the place of violence in the Athenian value system and social fabric. We will see that that the creation of ritual spaces, however implicitly, was necessary in order to enable reflection on the definition of violence.

(3) Unlike other Greek cities (e.g., Corinth, Thebes, Rhodes), Athens was a relatively stable society for two hundred years, and it is remarkable how violence was checked or at least made tolerable in the absence of public prosecutors and a regular police force, in the modern sense. ${ }^{39}$

These research endeavors are, in large part, informed by cultural history, as essentially shaped by the ethnologist Geertz. With his definition of culture as a "web of meanings," ${ }^{40}$ he triggered a paradigm shift in the humanities. "Thick descriptions" ${ }^{41}$ help to decipher the semantics of symbolic meanings. Similar to the ethnologist who investigates contemporary societies, it is the historian's task to explore past phenomena in an interpretive mode. The renewed interest in a complex and integrative notion of culture (cultural turn) ${ }^{42}$ makes a cultural history of civic violence in fourth-century Athens timely and needed. This book is not only intended as a contribution to the history of violence in antiquity, but it is also meant to catch up with analogous research on early modern times.

The evidence I use to answer the questions sketched above is highly diverse, consisting of courtroom speeches and curse tablets, as well as Old and New Comedy. These genres are based on very different speech acts. Forensic speeches were performed in public, whereas curse tablets were deposited in a clandestine manner. The plots of dramas are fictional and were staged in festive contexts, and yet, all these genres, despite the different quality of their respective speech acts, lend themselves to

39 Cf. Riess 2008, 49-50, n. 1 with a list of all agents entrusted with the daunting challenge of enforcing law and order in Athens. But cf. Harris 2007 passim who regards these agents as fulfilling the functions of a regular police force. The Scythian archers were on duty until 404/03 BCE.

40 Geertz 1987, 9. Cf. Geertz 1973, 311-326; 1971; Dressel 1996, 167-169, 248.

41 Geertz makes a case for taking into account all concomitant circumstances framing a social action in order to elicit as much information as possible. He exemplified this method paradigmatically in his study "The Balinese Cockfight," which has become a classic (Geertz 1971).

42 Cf., e.g., Maza 1996. With regard to cultural history in Germany, cf., e.g., Tschopp 2007; Landwehr - Stockhorst 2004; Siegenthaler 1999; Vierhaus 1995. 
a comparison because they were all embedded in and shaped by performative frames, however different individual frames may be from one another. The common denominator lies in the very fact that they all exhibit, from different perspectives, the same general understanding of and attitudes toward violence, a nexus of ideas which I call the "violence discourse." This preserved textual evidence, however, provides us with a decidedly incomplete picture of the original discourse. The actions reported within these discourses became meaningful chiefly on the level of performance, because each performance redefined the significance of discourse as well as more general values and opened them up to constant change and adaptation. Therefore, the decipherment and interpretation of the symbolic meaning of violence requires a closer look at the performative representation of the violence discourse in all genres of source material available.

Speeches and plays (and even curse tablets) share many features of theatricality. The staging of a rhetorically brilliant courtroom speech was akin to the aesthetic staging of a play in the theater of Dionysus. ${ }^{43}$ There are further analogies between courts and the theater: the six thousand judges ${ }^{44}$ in the various courts were also part of the audience in the theater. They were highly skilled at listening to oral performances and evaluated "real" events narrated in court in much the same way as they would fictive plots on stage. As we will see, these three genres were not only performative and theatrical, but they also fulfilled partly ritual functions in so far as they were all embedded within a ritual frame and conveyed symbolic messages.

43 The aesthetic staging and self-representation of a public speaker must not be underestimated. Cf. the dignified pose of the Sophocles Lateranus statue, a Roman copy of an original Greek bronze statue, erected in the theater of Dionysus during the Lycurgan era (Knell 2000, 139-145).

44 Neither the English 'judge' nor 'juror' renders the Athenian term dikastês correctly. Athenian dikastai were juridical laymen in the people's courts, the dikastêria, who were drawn by lot to serve on "jury duty," but they actually rendered verdicts like judges. In addition, the homicide courts of the Palladion and the Delphinion were staffed with fifty-one ephetai. Therefore, I will speak henceforth of "judges," a term that also encompasses the ephetai and the councilors on the Areopagos. 


\section{Methodology: The Performative Turn and Ritual Studies} (A Brief Overview)

Within post-structural debates and various forms of discourse analysis originating in France, the "linguistic turn," which involves the claim that all reality is exclusively constructed by language, gained importance. ${ }^{45}$ Even if historians could not put the more radical postulates of the linguistic turn into practice, this theoretical movement has decisively sharpened the awareness of the importance of language in historical processes. Historical research, however, did not content itself with discourse analysis, but it also recognized that many preserved texts were originally staged before an audience in a particular socio-cultural context. With the introduction of the "performative turn," ${ }^{46}$ classical and modern philologists as well as historians have learned to direct their focus to the analysis of concrete social actions and their manner of performance. The texts we have are often derivatives, written renderings of original performances, and, as such, represent interpretations of original actions. Since it is the performance of discourses that has found its echo in diverse genres, we would deprive the sources of much of their original meaning by neglecting their performative dimension. ${ }^{47}$ Many fourth-century Athenian written sources have emanated from performances and derived their original thrust through performance. ${ }^{48}$

Performance studies have dovetailed nicely with ritual studies, which had long before been recognized in religious studies, for rituals mainly define themselves via their performative character. ${ }^{49}$ In the wake of the performative turn in the humanities, ritual studies can provide us with the appropriate tools to write cultural history. This is not the place to trace the history of ritual studies, but some contextualization of the present book

45 Iggers 1995 offers a good overview of the theory discussion.

46 On the history of research, cf. in detail Martschukat - Patzold 2003. An important collection of essays on performance that has become "classical" is Wirth 2002.

47 A useful definition of "performance" is provided by Gänszle 2000, 41-42. Cf. also Carlson 1996; Diamond 1996; Parker - Sedgwick 1995; Benston 1992.

48 Demosthenes realized how important performance was. In a famous anecdote (Plu. Vit. X Orat. 845b; Cic. De Orat. 3.213; Brut. 142; Orat. 56), he ascribes the utmost importance to performance by only mentioning three priorities in rhetoric: delivery, delivery, delivery (hupokrisis; actio).

49 Turner 1988; 1984. 
within the history of research is in order. ${ }^{50}$ The heuristic value offered by the theoretical implications of ritual studies was rapidly recognized throughout the humanities and triggered a boom in ritual and performance studies in the late 1980s. It is important to note, however, that at first, ritual approaches were mainly applied to religious studies, and more precisely to the study of religious rites of passage that mark the participants' initiation into a different status. ${ }^{51}$ The potential cognitive value of ritual studies soon led to their detachment from religious studies and their application to other, secular fields in the humanities. ${ }^{52}$ This development can also be observed in historical studies. ${ }^{53}$ As in the history of crime and violence, medieval and early modern studies energetically took the lead again. Above all, Althoff is to be credited with having uncovered the rational side of many political rituals in his works on medieval history. His studies have transmitted the pre-eminent role of rituals in pre-modern societies to a broad public, thus paving the way for the shift of paradigms in many areas of European historiography. ${ }^{54}$ Roman historians, as well, are more interested today in the socio-political than the religious functions of rituals in Roman society. ${ }^{55}$

The detachment of ritual from religious studies is also observable in ancient Greek studies. Religious historians of the Greek world were the first to adopt the new paradigm, especially as an approach to religious sacrifice. This branch of research is inseparably connected with the names of Burkert ${ }^{56}$ and $\mathrm{Graf}^{57}$ and has had a lasting impact on the study of religion in the Hellenistic period up to the present day. ${ }^{58} \mathrm{In}$

50 Bierl 2009, 1-24; Belliger - Krieger 1998, 1-48; Bell 1997, 1-95; Versnel 1993, 1-14, 20-37 offer detailed overviews.

51 The basic source is still van Gennep 1909. From the very beginnings of ritual studies, however, there were also different strands. The sociologist Durkheim, for example, completely ignored van Gennep. Cf. now, nuanced on ritual studies in general, Dodd - Faraone 2005.

52 An often-quoted turning point is marked by the volume edited by Moore Myerhoff 1977. Cf. also Fischer-Lichte 2003, 47-50.

53 Cf. the volume edited by Ambos - Hotz - Schwedler - Weinfurter 2005, which cuts across historical epochs.

54 E.g., Althoff 2003a; 2003b; 1997. From the plethora of works on the early modern epoch, cf. especially Muir 1997 and Davis 1975.

55 Representative are Flaig 2003; Jehne 2001; Jehne - Mutschler 2000.

56 Representative are Burkert ${ }^{2}$ 1997; 1984.

57 Cf., e.g., Graf 1998a.

58 Cf. the numerous studies presented by Chaniotis, e.g., 2005; 2003; 2002a; 2002b; 1997. 
the wake of these milestones of research, approaches to ritual studies began to be applied to various genres of Greek literature that have their origins in religious and cultic practice, especially tragedy ${ }^{59}$ and comedy. ${ }^{60}$ These studies are so convincing because Greek and Athenian life and social mores were steeped in religion to such an extent that one cannot look at any part of Greek daily practice from a purely secular viewpoint. There were no spaces without religion, only different gradations of the religious. This fact has allowed researchers to broaden ritual studies in their application to Greek culture and, in so doing, include the social and political dimensions of life. As a result, the penetration of every aspect of Greek daily life by rituals came to be discussed intensively, so that experts on Hellenic rituals soon turned to phenomena beyond religion. That is how the performative character of Athenian lawcourt trials, in particular, became the focus of many studies. ${ }^{61}$ Surprisingly enough, the violence discourse, which explicitly pervades all sources and was publicly staged and performed, has not yet found comprehensive treatment.

This is not the place to offer another definition of ritual, but it is crucial to delineate the broad notion of ritual as understood and employed in the context of this book. All studies on rituals agree that they are standardized, repetitive, symbolic actions embedded within a certain frame distinct from the actions of daily life. In many cases, they were performed in front of a selected audience at a certain place and time,${ }^{62}$ not necessarily in connection with a religious or cultic act. ${ }^{63}$ In conveying specific, so-

59 Some selective literature on Euripides' Bacchae: Goff 2004; Seaford 1996; Segal $1985 ; 1982$.

60 E.g., Bierl 2009; N. Slater 2002; Lada-Richards 1999.

61 Hall 2006, 14, 353-390; 1995; Bers 2000; Burckhardt - von Ungern-Sternberg 2000; Johnstone 1999; Christ 1998a; Lanni 1997; W. Slater 1995; Ober - Strauss 1990; Humphreys 1985a. The contributions to the volumes edited by Goldhill Osborne 1999 and Osborne - Hornblower 1994 are only partly concerned with the methods of ritual studies.

62 Köpping - Rao 2000b, 20. People also stage rituals on their own so that publicity is not an absolute requirement for a social action to be considered a ritual. No one would deny that the deposition of a curse tablet is a ritual act (see chapter III below). The message was intended for the agent of the curse, and gods were thought to be present during the magical act.

63 The literature is immense by now. Because of their introductory and paradigmatic character, cf. Bell 1997; 1992; Grimes 1982. Definitions, for example, in Wiles 2000, 27-29; Muir 1997, 1-11; Bell 1992, 16; Turner 1989b, 126; 1988, 75; Kertzer 1988, 8-12; Tambiah 1985b, 29; Grimes 1982, 19-33; Tambiah 1979, 119; Douglas 1974, IV. 
cially relevant, and symbolic messages, they are flexible and dynamic and can thus be adapted to ever-changing situations and requirements of society. ${ }^{64}$ Rituals often define the boundaries of space and thus close it to non-participants. Ritual objects increase solemnity and, in the case of Athenian law courts, conveyed the impression of fairness. ${ }^{65}$ Ritual sound and language enhance the attendees' feelings of belonging together and having a common identity. This means that rituals also construct and represent reality, solidarity, and identity ${ }^{66}$ by excluding others through drawing boundaries. Some of them heal through their integrative power. ${ }^{67}$

In accordance with this definition and under the assumption that each and every ritual is performative, but not every performance is a ritual, I work from the basic premise that the enactments of forensic speeches, binding spells, and comedies were not only performative, but also worked like rituals and fulfilled the various functions of rituals. In sum: although Athenian society was imbued with religion, and religious rites permeated Athenian life, I will use a secular and broad definition of ritual in this book, as offered by anthropology. By applying methods of ritual studies to the quotidian phenomenon of violence, I hope to contribute to a further rapprochement between ancient history and the type of ritually oriented research more typically conducted in sociology, anthropology, and political science. ${ }^{68}$

As to terminology, van Gennep's and V. Turner's theories are still fundamental. According to van Gennep, most ritual processes fall into three phases: rites of separation, rites of limen or margin, and finally rites of reaggregation, the reintegration of the participants into the community. We should keep in mind that, for van Gennep, all rituals were rites of passage, a view that has long become obsolete. ${ }^{69}$ Turner intended

64 Cf. the contributions to Harth - Schenk 2004; Köpping - Rao 2000a.

65 An example is the Athenian lot machine (klêrôtêrion) that hundreds of men used every morning to ensure the proper functioning of the courts by making bribery impossible through the process of selecting the judges.

66 E.g., Hughes-Freeland - Crain 1998, 6-7.

67 It should not be forgotten that rituals are not just a means to achieve compromise and social equilibrium. Gluckman overcame this narrow functionalism by expanding on van Gennep. He demonstrated that rituals can also express social tensions. Cf. summarizing Bell 1997, 29, 38-39.

68 Symbolic anthropology was carried out in ancient studies with great success in the 1980s (e.g., Connor 1989; 1988a; 1988b; 1987; 1985; Strauss 1985), but its implications have not yet found sufficient resonance.

69 Originally, van Gennep referred, with these three phases, exclusively to rituals of transition in terms of space, time, and social status. But with the increasing ex- 
to overcome van Gennep's static approach and integrate it into his own model of the "Social Drama," To Turner, rituals not only lead to a new state of equilibrium and stability after a disturbance, but also initiate an endless dynamic process, in and through which society can at times redefine and reconstitute itself.

Turner regarded the liminal phase as being of utmost importance. ${ }^{71}$ In this sphere of the famous "betwixt and between,"72 a playful atmosphere holds sway with enormous leeway for reflection and creativity. The participants act and speak during this core phase of the ritual. We call their ritual actions drômena and their ritual words legomena, terms I will refer to in the subsequent chapters. In this ludic atmosphere, configurations of daily life can be reversed-Turner speaks of anti-structural elementsand, just as in fictional space, the participants can have experiences that their normal, daily routines would not allow. Through these experiences, the "initiates" are welded together and develop a sense of belonging, a community spirit (communitas) that shapes their identity and has a lasting effect on them. In the last stage of reaggregation, the "initiates" ideally undergo a change; sometimes the transformative power of rituals transposes the participants to social or cognitive levels they had not experienced before. This is especially true for van Gennep's rites de passage. ${ }^{73}$ By no means, however, are all rituals rites of passage. Despite all the dif-

pansion of ritual studies, this model was transferred to ritual structures in general.

70 Turner recognized that all conflicts typically unfold in four distinct phases, thus showing a ritual structure. He calls this kind of regular pattern of conflict "Social Drama": (1) A breach of rules, laws, taboos or rituals leads to a crisis (2). Some culturally determined authorities try to resolve the conflict through some form of redress (3). The outcome is either the reconciliation of the rivaling parties (reintegration) or the recognition of an irreparable schism (4). The redressive phase, the phase of conflict resolution, is characterized by a multitude of possibilities; for example, political (from debate to revolution and war), legal-judicial (from arbitration within the family to mediation and formal court proceedings), or ritual processes, like the commission of oracular responses, divination, trials by ordeal, or sacrifices. Of course, social agents can also see violence as a means of phase three, the redressive phase. Turner concedes that violence can temporarily be regarded as "remedy." Turner explained this model in many publications, e.g., 1989a, 11-15, 108-139; 1984, 23-25; 1974a = 1976. Especially useful, since illustrated by a graph, is Turner 1990, 10 .

71 Turner 1989a passim; ${ }^{2} 1973$ b.

72 This term was coined by van Gennep 1909, but only found wide acceptance through Turner.

73 Van Gennep's theories have also found recent applications, e.g., Padilla 1999. 
ferentiations to which theories of ritual have been subjected since the days of Turner and Schechner, ${ }^{74}$ the lasting contribution of these early theorists can be seen in the fact that they placed special emphasis on the performative aspect of rituals and thus combined ritual and performance studies in a fruitful and far-reaching manner, forming what is today an almost inseparable unity.

Although lawcourt speeches, curse tablets, and comedies are highly heterogeneous in their character and message, they are, as stated above, united by one common factor: in their bodily enactment, they were all ritually framed and communicated symbolic messages, so that their stagings can be regarded as ritual processes. ${ }^{75}$

These three types of rituals created, performed and represented, negotiated and commented upon a specifically Athenian violence discourse; lawcourt speeches and curse tablets even exerted violence indirectly. The ritual framing of each speech situation semantically charged the violence discourse, thus increasing its significance. In addition, the carefully prepared performance endowed this form of enacted discourse with a very special power over the audience. The participants underwent the typical phases of separation, liminality, and also, to a certain extent, reaggregation.

We can distinguish two basic types of rituals: rituals of interaction and rituals of representation. ${ }^{76}$ The defining markers mentioned above are valid for both forms of rituals. Rituals of interaction emerge between

74 E.g., in the Heidelberg-based Collaborative Research Center "Ritual Dynamics." Cf., e. g., Harth - Schenk 2004; Köpping - Rao 2000a.

75 From this perspective, all three genres are neglected in particular ways. Ancient historians concerned with speeches do not apply ritual theories to this immense material. Philologists have worked on ritual structures in comedy, but less so in oratory. Both philologists and historians tend to overlook the historical value of comedies, however fictional they may be. Exceptions confirm the rule; cf. Lape 2004. Curse tablets are neglected altogether from this viewpoint.

76 Based on Goffmann 1967, 19-20 ("ritual equilibrium"), Gerhardt 2004 came up with this fruitful categorization and interprets these two types in too narrow a sense, interactionist rituals being characteristic of democratic regimes, rituals of representation being typical of authoritarian regimes. In fact, these categories are much more broadly applicable. Harth 2004, 100 neatly summarizes Goffman's thesis: "Nach Erving Goffman ist der Begriff der 'ritual order' geeignet, die symbolischen Kontrollmechanismen zu benennen, die gewohnheitsmäßig von den Akteuren eingesetzt werden, um die in alltäglichen Face-to-Face Situationen unvermeidlich auftretenden Risiken des Gesichts- oder Persönlichkeitsverlusts abzumildern, wenn nicht zu vermeiden." This work attempts to reveal these symbolic mechanisms of control, which amount to a "ritual order." 
human beings on concrete, face-to-face levels of daily life. Since violent acts were by no means always ritualized in Athens, I rather speak of rules of interaction in the context of this book. They are the unwritten social norms or conventions underlying many outbreaks of violence. In this study, I seek to define these very norms by deciphering the semantic grammar of violence that constituted the line between acceptable and intolerable conduct. Rituals of representation, like forensic speeches and drama, staged discourses in public. The deposition of a curse tablet was most of all a ritual of interaction with the gods of the underworld, who were thought to be present, and the envisioned target.

The distinction of these two levels is of major relevance when dealing with societies from the past. It is correct that we only have access to discourses (level of representation) and not directly to Athenian reality (level of interaction), but discourses and social practices are nevertheless always inextricably intertwined. By suggesting a braid model, ${ }^{77}$ the anthropologist of theater Schechner stressed the mutual penetration of socio-political life and staged public discourse.

Applied to Athens, the braid model shows that real-life actions more or less followed social norms and conveyed, more or less, a certain meaning, depending on how consciously and theatrically the perpetrators performed their actions. These events were then verbally rendered in court, more or less embellished, and structured in a more or less deliberately shaped narrative. Hence, real life influenced spoken discourse decisively, while the level of representation, in turn, had repercussions on reality. Athenian rituals of representation (trials, dramas) enacted the violence discourse in their respective performances and thereby also affected the actual perpetration of violence.

\section{The Controlling Function of Ritualization}

Athenian courtroom speeches and dramas (level of representation) were interconnected with daily life (level of interaction), which in turn shaped the cultural performances of speeches, tragedies, and comedies. Conversely, these large-scale rituals had a profound impact on how Athenians perceived and lived their lives. People learned in the courtroom and in

77 Schechner 1990, 96. Schechner (1990, 96-102; 1977, 76-77; 1976, 208) visualized this interdependence in his famous braid model (see the graph, e.g., in Turner 1990, 17). 
the theater what the appropriate exertion of violence had to look like to be publicly justified and successfully defended if need be. It was only possible to utter things in the law court and in the theater that spectators could somehow recognize in daily life. The protagonists on the courtroom stage and in the theater of Dionysus were actors who performed the violence discourse in front of an audience.

The spectators, however, became actors themselves whenever they performed acts of violence in their daily interactions with other people. These acts were in many cases seen, watched, evaluated, and interpreted by other citizens, and thus gained significance. Not only words, but also deeds, especially theatrical actions, impart messages to spectators through their performative character. ${ }^{78}$ Whenever human beings regularly perform actions within a certain frame and thereby follow culturally determined patterns of action at certain times and places, and if these patterns also convey symbolic contents, then it seems safe to conclude that these people enact rituals before an audience because rituals charge important actions with meaning. ${ }^{79}$ From this perspective, we can assume that actual violence, as well, was sometimes ritually circumscribed and thus restrained. In these cases, we could rightly speak of the aforementioned rituals of violent interaction. While we can grasp such elaborate rituals of violence in medieval evidence, ${ }^{80}$ and the staging and performance of rituals are of extraordinary importance in pre-modern and semi-oral societies, ${ }^{81}$ the evidence for Athenian rituals of violence, unfortunately, is scant, and I will henceforth mostly confine myself to speaking of rules of violent interaction.

The hypothesis of a ritually contained violence will help us answer a question of paramount historical importance. Why did the Athenians need to ritualize the violence discourse and perhaps even the perpetration of violence itself? That rituals play an essential role in conflict resolution is a crucial theoretical premise of this book. Mediation and arbitration, the elaborate court culture, the Boulê, the Areopagos, the Eleven,

78 Kertzer 1988, 68: "Socially and politically speaking, we are what we do, not what we think."

79 How they do it is still a matter of debate (Koziol 2002, 387). Tambiah 1985a, 84: "Thus, through ritual man imposes meaning on the world."

80 The volume edited by Sieferle - Breuninger 1998 on rituals of violence in medieval times is a model of what such research can look like today.

81 This is not to say that rituals are less important in modern societies. Cf. the contributions in Belliger - Krieger 1998 on modern rituals. 
the cultural practice of gossip, social control, ${ }^{82}$ and religion were probably not sufficient to keep the large population of Athens under control. ${ }^{83}$ Other means, hidden to the modern eye at first glance, must have played a crucial role in preventing, regulating, and restraining violence, and eventually in overcoming conflicts.

On the level of daily interaction, unwritten conventions and perhaps even rituals of violent interaction must have contributed to keeping Athens relatively peaceful. They made up for inherent administrative shortcomings and guaranteed that Athens would remain governable for the dêmos during the fourth century.

On the level of representation, the ritualization of the violence discourse served the purpose of symbolic communication. ${ }^{84}$ The performances of forensic speeches and dramas instilled the prevalent values into citizens. Thus, these large-scale rituals of representation also contributed to restrain the most serious forms of violence without creating what we would consider a pacified society. At the same time, the ritually embedded narrations charged real-life acts with significance, another crucial communicative aspect of these large-scale performances.

These two vital functions-indirect containment of violence and facilitation of communication-ultimately strengthened the community's identity. Communicative rituals allowed for an inter-subjective exchange of opinions about the cases in question. The dissemination of this civic and civil violence discourse, which prevailed more and more during the fourth century, was only possible as a result of Athens' vibrant democratic structures, which were perpetuated by the democratic socialization of the citizens from childhood on.

82 In anthropology, gossip plays an important role in this context. The most detailed study on Athens in this respect is Hunter 1994. For questions regarding social control, the procedure of dokimasia is important as well, for only those being socially integrated could enlist witnesses for the questions to be answered during that procedure.

83 Hunter 1994, 151 raises this question poignantly, but is at a loss for an answer. Also Fisher 1998b, 71 emphasizes the stability of the Athenian social and political system without providing a sufficient explanation for this phenomenon.

84 Cf. Köpping - Rao 2000b, 7-8. 


\section{Sources - Chronological Scope}

In order to make full use of the sources available and trace long-term developments, I regard the fourth century as a long century. Antiphon's earliest speeches from the 430s and Aristophanes' plays from $425 \mathrm{BCE}$ on belong to it, as well as Menander's last comedies, dated to the beginning of the third century. I consider this long timeframe as a political, economic, and intellectual unity, in which, however, fundamental changes were gradually taking place, also and especially with regard to the discursive treatment of violence..$^{85}$

Hence, this book is about how Athenians reflected upon violence over time in the different performative genres they had at their disposal. The focus will lie on the axis separating tolerable from intolerable behavior around which the conversation on violence was organized. Since each genre warrants its own discussion and yields different information about the violence discourse, each will be treated in a separate chapter.

Speeches: Alongside the most famous instances (Lysias 1; Demosthenes 21 and 54), other incidents of battery and homicide shall be examined. Around thirty-five speeches altogether (out of approximately 150) mention or are concerned with some kind of violent behavior. The extant speeches are narratives and we have to adjust the "lenses" of our research tools accordingly. Ritualization on the level of representation engenders narrativity, a verbal description of a process in time. The creativity of the ritual transforms the purely empirical coexistence of experiences into stories. ${ }^{86}$ Thus, the raw material of daily life occurrences is translated into more or less fictional tales. This is exactly what happened in the case of the forensic speeches. They are not mirrors of reality, but rather reflect how litigants perceived violence, dealt with it, and orally presented it to an audience. Narrativity, especially in a performative frame, engenders the meanings that cultural history intends to decipher.

Curse tablets: Around 270 curse tablets are preserved from fourthcentury Athens, and these offer a unique insight into Athenian conflict mentality. Their violent language and perceived destructive power in the context of their ritual deposition are crucial to the questions explored in this book. Most curse tablets are judicial spells cast on adversaries before trials. Therefore, the tablets shed light on the courtroom speeches from a different angle. Elite members of society wrote or commissioned

85 Cf. Christ 1998a, 6.

86 Turner 1989b, 120-122. 
most of these judicial spells. Many curse tablets, however, were written by members of the lower classes and are thus invaluable corrections to the speeches and the upper-class values expressed in them. For the underprivileged and weak, the magic explicit in the tablets was an opportunity to exert indirect violence.

Comedies: All eleven plays of Aristophanes yield a great deal of information about violence. They will serve as contrasting foils to Menander's Samia (314 BCE?) and the completely preserved Dyscolus (316 $\mathrm{BCE}$ ). The larger fragments of New Comedy that deal with violence (Epitrepontes, Periceiromene, Misoumenos, Perinthia, Georgos, Heros, Colax, and Phasma) will also be considered. The numerous fragments of the later Old, Middle, and early New Comedy will play a minor role because of the lack of context.

This study is situated at the interface between violence and ritual studies. It is the first concerted attempt at fully understanding interpersonal violence in classical Athens in its discursive and social ramifications. The ritualistic approach allows the historian to cast a wide net and combine heterogeneous sources into the context of a coherent methodological framework, so as to yield a comprehensive view of the Athenian violence discourse, its ritual framing, and cultural function.$^{87}$ It is only by trying to break up the specialization in the academic field that new windows will open up on the before-mentioned over-arching questions. ${ }^{88}$

This study, finally, seeks to demonstrate that the symbolic meaning of violence was not defined by written laws ${ }^{89}$ - the definition of offenses being under-defined-but was rather constructed by rituals of representation. The question of definition was linked to questions of power structures, and one wonders how social norms and rituals of representation produced, reproduced, and thus perpetuated social hierarchies. The notion of violence in ancient Athens was constantly being publicly negotiat-

87 Vase paintings pose altogether different problems that can only be tackled by archaeologists and art historians. Cf. above 6, n. 32.

88 Athenians did not think in neatly separated compartments. Their violence discourse found its genre-specific echo in all sources.

89 Here lies, for example, the difficulty in defining an elusive term like hubris. Cf. above 3, n. 13 and 5, n. 25. According to circumstances and based on a culturally predetermined understanding, the litigants and changing court juries could ascribe a different meaning to it every day. If we understand Athenian courts as dynamic rituals, we see that the definition of terms like these must have been in constant flux according to the speakers' purposes and the audience's mood on any given day. 
ed and ritually conveyed to the citizenry. It was the ritualization of violence on the level of representation (violence discourse) and, to a lesser degree, on the interpersonal level (exertion of violence according to rules of interaction) that guaranteed the continuity of Athens' social and political order. Analyzing the phenomenon of violence on various levels will reveal the fundamental differences between the Athenians' and our perception of violence. 


\title{
II. Forensic Speeches
}

\author{
Illae omnium doctrinarum \\ inventrices Athenae, \\ in quibus summa dicendi vis et inventa \\ est et perfecta. \\ (Cicero, De oratore 1.13)
}

\section{Ritual Framing}

While Athenian trials were first and foremost legal procedures, they also fulfilled the functions of rituals. Religious rites permeated every aspect of Athenian life, including politics and jurisdiction, but even if we approached the legal sphere solely from a non-religious angle, we could still employ the broad, anthropological definition of ritual, as explicated above, and consider Athenian lawsuits as secular rituals, much as anthropologists regard today's sporting events and rock concerts as rituals. Since the litigants regularly enacted their disputes in front of an audience (judges, bystanders), we can also say that they staged their cases and, in so doing, conveyed symbolic meanings to the onlookers in and through a performative narration that worked very much like a large-scale ritual. ${ }^{1}$ The corporeal aspect was of paramount importance and will concern us not only when dealing with the law courts as ritual communities, but also in the ensuing chapters on the magical curses and comedy. ${ }^{2}$ The courtroom ritual

1 The creativity of the ritual transforms the merely empirical coexistence of experiences into narrations. Cf. Davis 1987, 120-121.

2 Turner and Schechner have frequently highlighted the close connections between real-life Social Dramas and stage dramas: Turner 1990, 17; 1989a, 161195; 1989b, 116; 1979; Schechner 1990, 96-102; 1977, 76-94; 1976, 208. According to Schechner, "ritual dramas" such as courtroom speeches are designed to show a high degree of efficacy, whereas "stage dramas" show a high degree of entertainment. Since Athenian trials were often as entertaining (cf., e.g., Lysias 1 [On the Death of Eratosthenes] and 24 [For the Disabled Man]) as dramas may have been efficacious at reaching out into the polis, we have an additional criterion at hand to draw a parallel between the performance of a court session and a stage drama. Consequently, the analogies between the "ritual drama" of the courtroom and stage drama are significant. There is a reciprocal movement between ritual and theater. The ritual always tends to become theater, and vice 
could only work if the actions (drômena) of the litigants (gesture and tone) and the words they spoke (legomena) were performed in a special context, a ritually marked-off place that all participants acknowledged as being distinct from the occurrences of daily life.

This ritual demarcation is better attested for the meetings of the Assembly of the People than for most courts. Considering some ritual features of the Ekklêsia first will enable us to draw cautious analogies between the Assembly of the People and the dikastêria. The Athenians were highly conscious of the political privileges they enjoyed through and in the general Assembly. Any citizen (ho boulomenos) could step forward to the bêma and speak on any issue of importance, as long as he did so in accordance with certain rules that the Athenians had given themselves in order to ensure the orderly conduct of the meetings. By the fourth century, Athenians differentiated between laws and decrees, but in fact a vote by the Assembly in the form of a decree carried great weight and almost had the power of a law. Given this solemn character of the occasion, every statement publicly uttered in the Assembly was a speech act that all participants in the ritual took seriously by default. Because of the prerogatives Athenian citizens enjoyed in this Assembly, it was closed to foreigners and metics. Latecomers were penalized by having to step over a dyed rope that was stretched around the Pnyx. ${ }^{3}$ The ritual event started with the drawing of a purifying boundary around the meeting place. The peristiarch, a priest who was responsible for the ritual purity of the meeting place, sacrificed young piglets, cut off their testicles, and carried them around the Pnyx. ${ }^{4}$ The periphery of this meeting area was sprinkled with their blood so as to make the confinement of the meeting place visible and cleanse it from all potential pollution, which might otherwise endanger the successful holding of this secular ritual. ${ }^{5}$ Before the actual session began, a herald performed prayers ${ }^{6}$ and cursed everyone intending to de-

versa. In other words, daily life has an impact on cultural performances (e.g., stage dramas). Conversely, the aesthetic performance of a stage drama affects ordinary life. This interdependence certainly applies to Athenian courtroom trials as well as drama.

3 Ar. Ach. 22; Ec. 378-379. The rope might also have served to gather the citizens together.

4 Moulinier 1952, 99-100.

5 D. 54.39; Aeschin. 1.23. The idea of the Pnyx as a sacred precinct characterized by purity is neatly expressed in Ar. Ach. 44. To ensure ritual purity, orators washed their hands in water before they spoke (Ar. $A v .463-465)$.

6 Aeschin. 1.23; Din. 2.14-16. 
ceive the Athenian people, including traitors and enemies of the state. ${ }^{7} \mathrm{~A}$ similar procedure is also attested for meetings of the Boulê. ${ }^{8}$ This means that public meetings took place within a ritual and theatrical framework, like the performance of a stage drama. And indeed, Athenians frequently equated the political with the dramatic stage by using metaphors borrowed from the sphere of theater to characterize behavior in the Ekklêsia. ${ }^{9}$ To the Athenians, all public events were political and thus meaningful social practices. The ritual frame had a profound impact on the performers' behavior and their speeches. The speakers should display temperance in appearance and language. Speaking in too loud a voice and exaggerated gesticulating were frowned upon. Ideally, a speaker would hide one hand in his cloak. ${ }^{10}$ This ideal is visualized, for example, in the statue of Sophocles that was erected near the theater of Dionysus during the Lycurgan era. ${ }^{11}$ The speeches themselves were highly ritualistic in their internal rhetorical structure, ${ }^{12}$ a fact that we will investigate further below.

In the context of this book, however, I am less concerned with political speeches held on the occasion of an Assembly meeting than with the staging of forensic speeches, most of which were delivered in the dicastic courts. The buildings of the heliastic courts were firmly integrated into the Agora, ${ }^{13}$ and we can observe how carefully the Agora, as the center of Athens' political, social, and economic life, was delimited by a variety of rituals and other markers. First of all, the Agora seems to have been

7 And. 1.31; D. 19.70-71; 20.107; 23.97; Lycurg. 1.31; Din. 1.47; 2.16. The curse is parodied in Ar. Th. 331-371. Cf. on this curse Ziehbarth 1895, 61.

8 D. 23.97 and $19.70-71$ both mention the Boulê, D. 23.97 also the courts. Cf. Kagarow 1929, 8.

9 E.g., Aeschin. 2.4. Dem. 5.7 is not a metaphor, but an explicit comparison. On the multiple analogies between theater and the Assembly of the People or the courtrooms, cf. Harris - Leão - Rhodes 2010; Hall 2006, 14, 353-390; 1995; Cohen 2005a, 22; Bers 2000; Lanni 1997; W. Slater 1995, esp. 144-147; Wilson 1991/92; Ober - Strauss 1990, esp. 238, 270; Humphreys 1988, 482.

10 D. 19.251-252 (with an idealizing reference to Solon); D. 22.68 (referring to Androtion's misbehavior in the Ekklêsia); Aeschin. 1.25-26 (referring to Timarchus' misbehavior in the Ekklêsia in contrast to Solon's ideal conduct imbued with self-restraint). In general, speakers were not supposed to burst into uncontrolled laughter (Isoc. 1.15).

11 Knell 2000, 139-145.

12 A good example of the ritual character of rhetoric is Demosthenes' speech against Meidias before a dicastic court. On its structure, cf. MacDowell 1990, 29-30.

13 Thompson - Wycherley 1972, 52. 
surrounded by a "system of horoi," 14 boundary stones that visually and physically delineated the confines of the Agora. This was all the more necessary, because murderers and other people who had lost some or all citizens' rights (atimoi) had to keep away from all public places so as not to defile them. ${ }^{15}$ This stipulation included the court buildings and demonstrates that the drawing of ritual boundaries was meant to be territorial and physical. We have ample evidence that it was especially in the courts that atimoi could not appear. ${ }^{16}$

The course of a standard dicastic trial was also highly ritualized. Multiple rites of separation dissociated the lay judges, in respect to time and space, from their daily routines outside court. At the beginning of the year, all Athenian citizens above the age of thirty who were willing to serve as judges took part in a lot procedure, which selected six thousand of them at random. These men swore a solemn oath that transformed them into potential judges. ${ }^{17}$ Thus, it was drummed into each layman's head that, as a heliast, he was about to fulfill a crucial duty in the service

14 Lalonde - Langdon - Walbank 1991, 10; Thompson - Wycherley 1972, 117-119; pls. 4, 64: a, b.

15 D. 23.40-41. Even more explicit is D. 23.80, where he explains the apagôgê phonou procedure. Athenian law distinguishes total from partial atimia (Hansen 1976, 61-66). Connected to these different degrees of atimia are serious social consequences, such as shunning persons considered to be atimoi. Cf. And. 1.73-79; Aeschin. 1.19-22, 28-30; Lys. 6.24-25; Arist. Ath. 57.4; IG I ${ }^{3}$ 104, lines 26-28 (Draco's homicide law). On the various aspects of self-incurred and imposed atimia, cf. Hansen 1976, 66-67.

16 This is one of the reasons why Aeschines went into voluntary exile after Demosthenes defeated him in court. Having lost the graphê paranomôn against Ctesiphon-he had not received one-fifth of the votes-Aeschines suffered partial atimia. In his speech against Timarchus and his defense in the embassy case, Aeschines had tried hard to bring Demosthenes into some connection with the brutal murder of Nicodemus of Aphidna (Aeschin. 1.171-172; 2.148, 166 with scholia). A well-grounded suspicion that Demosthenes was a murderer would have been enough to make Demosthenes a partial atimos and thus bar him from public business. A similar strategy to knock out a political opponent is attested in Antiphon 6. The chorêgos, accused of being responsible for the accidental death of one of his chorus boys, claims that the charge against him is politically motivated. Philocrates, the brother of the dead Diodotus, only filed charges of homicide against him to prevent him from lodging an eisangelia against Philocrates' friends. For this technique of framing for homicide, cf. below 46-48.

17 The oath of the heliasts is partly preserved verbatim: D. 24.149-151. Cf. Mirhady $2007,49-50,229$ on the historicity of this passage and other sources pertaining to this particular oath. 
of democracy. This oath defined and established the assembly of the $d i-$ kastai as a ritual community and a vital organ of the democracy. ${ }^{18}$ Every court day began in the early morning with the complicated use of the allotment machine (klêrôtêrion), which randomly assigned every pre-selected citizen to a certain law court. ${ }^{19}$ The potential judge taking part in this elaborate ritual experienced with his own body how he was being treated as part of a larger whole, a representative sample of the citizen body rendering verdicts on that particular day. He also realized with all his senses that Athenian legal procedures were conducted in such a way as to prevent anyone from meddling with the composition of the law courts through bribery or other illegal means. "Playing" with the lot machine turned the former potential judge into an actual judge for a day. We could also speak of a twofold initiation "rite" ${ }^{20}$ that a citizen had to undergo to serve as a dikastês, one at the beginning of the year, the other immediately before the court session itself. ${ }^{21}$ As with the Pnyx, the court buildings were probably also purified by the peristiarch. ${ }^{22}$ Before the sessions began, fire, myrtle wreaths, and incense were brought in, libations made, and Apollo invoked. ${ }^{23}$ Courtroom trials were understood as secular rituals within a sacred sphere. The actual court proceedings were then opened by a sacrifice, the accused taking the sacrificial victim in his hand and swearing that the charge against him was not true. In doing so, he called down destruction upon himself. ${ }^{24}$

Cases of intentional killings or serious woundings of citizens were not heard before dicastic courts, but before the Areopagos. There, the ritual oath of the diomosia, sworn only in trials for homicide (by dikê phonou) and wounding, was especially gory and thus charged with a high degree of significance. Standing over the entrails of a ram, a boar, and a bull, the litigants swore a horrible oath of self-execration upon themselves, their children, and their entire household. The prosecutor swore that one of his relatives had been killed, or himself or a relative wounded, by the ac-

18 On the identity-creating function of oaths, cf. Cole 1996.

19 Thür 2000, 42-45. Boegehold 1995, 32-33, 58 dates the introduction of this novel method of assigning dikastai to courts to ca. $410 \mathrm{BCE}$.

20 I use the word "rite" in the meaning of "religious ritual," thus following the terminology of Ambos - Hotz - Schwedler 2005, 1.

21 Bers 2000, 557 speaks of a "civic ritual."

22 Moulinier 1952, 101.

23 Ar. V. 859-874.

24 Aeschin. 1.114. On oath curses in courts, cf. Gagarin 2007; Faraone 1999a, $103-$ 111. 
cused; the accused swore that he was innocent. This oath ceremony had the purpose of discouraging frivolous charges for homicide and averting guilt from the judges in case they convicted the accused of intentional homicide and meted out capital punishment. ${ }^{25}$ This practice did not apply to the Delphinion, where cases of lawful killing were heard. ${ }^{26}$ Ritual sacrifices are attested for the Palladion, where cases of the unintentional killing of citizens and of killing non-citizens (regardless of intent) were tried. ${ }^{27}$ The witnesses, too, took oaths at all court proceedings. ${ }^{28}$ During the trial, the klepsudra habitually allotted a certain amount of time to each speaker. ${ }^{29}$ This device helped stage the ritual and convey the impression of fairness to all parties involved. The speeches were interspersed with the readings of documents such as laws and decrees, private documents, statements of witnesses, evidence given by slaves under torture, oaths, and challenges. ${ }^{30}$ These different genres of evidence helped structure the performance of the speeches and further enhanced the ritual character of the proceedings by drawing a line, time and again, between the daily life of the judges and their elevated, significant activity within this ritual circle. All of the evidence and instruments they saw, heard, and experienced enabled the judges to step out of the routines of their daily lives to fulfill the public duty required of them. ${ }^{31}$

25 I follow Loomis' argumentation (1972, 90), according to which Athenians did not differentiate between premeditated (ek pronoias) and intentional (hekôn or hekousios) manslaughter in the judicial context. Consequently, unpremeditated (mê ek pronoias) is equated with unintentional (akôn). Therefore, we should translate mê ek pronoias as "unintentionally," not as "without premeditation" (Phillips 2007 passim contra Wallace 1985, 98-100).

26 Antiphon 6.6, 14, 16; D. 23.67-69; 59.10; Lys. 10.11; Aeschin. 2.87 on the oath that a winner in a homicide trial had to take. Cf. Boegehold 1995, 46-47; MacDowell ${ }^{2} 1966,99-100$.

27 Aeschin. 2.87; Ps.-D. 47.70. Our main sources for the different homicide courts are Arist. Ath. 57.3-4; D. 23.65-79. Phillips 2008, 59-61 gives an excellent overview of all homicide courts. Cf. also Sealey 1983, who tries to date the introduction of the different courts, and Boegehold 1995, 43-50 on their locations.

28 Carey 1995b.

29 Thür 2000, 46-47.

30 Cf. Harrison 1971, 133-153.

31 In this way, inserted documents are ritual attributes, which are supposed to underscore the rationality of the speech. Cf., e.g., the documents presented by Demosthenes against Meidias (laws, witness statements, oracles): MacDowell 1990, $43-47$. 
To Huizinga, the courtroom is a hieros kuklos, "a sacred spot cut off and hedged in from the "ordinary' world" as a "veritable temenos." 32 The sacredness, or rather the solemn character, of the secular courtroom ritual could not be better expressed. If it is true that the Athenian courtroom circumscribed a kind of play-ground where the customary differences of rank were temporarily abolished, ${ }^{33}$ we can speak of a liminal sphere with all its constituent parts as described by Turner and many others. And in fact, in the liminality of the Athenian courtroom trial, there was enormous scope for reflection, creativity, and the establishment of a special community spirit (communitas) for the judges, which promoted citizen identity through the public performance of the forensic speeches. ${ }^{34}$ In ascribing certain qualities to opponents, judges, and spectators, the speakers were highly creative. The judges were required either to accept or reject a certain construction of character. By judging the case, the judges rendered a legal and moral verdict, exerted the supreme power of the dêmos, and represented it visually. Since the attendants of a law court constituted a public, the judges' decision was open for all to see and carried political weight. The creative delivery of the speeches and the performative rendering of moral and legal judgment in the lawsuit ritual helped maintain the cosmos of the Athenian democracy, ${ }^{35}$ for without courts Athenian democracy was inconceivable, and without courts the state would fall prey to tyrants. For fourth-century Athenians, the memory of the Thirty Tyrants remained a haunting specter. We will see to what a great extent the traumatic experience of the Thirty shaped the violence discourse. ${ }^{36}$ The speeches dealing with violence clearly reflect the preoccupation with this previous rampant violence and civic strife.

In the ritual space of the courtroom, anti-structural elements were designed and put to debate: the social elites who set the tone in daily life "voluntarily" surrendered to the verdict of the masses in front of the people's court. They humbled themselves and implored the judges, citizens of mostly low origins, to confirm them in their social status or to negotiate it anew. Mainly in the courtroom, otherwise underprivileged Athenians

32 Huizinga ${ }^{4} 1964,77$.

33 Huizinga ${ }^{4} 1964,76-88$ regards the staging of a lawsuit as a ritual play.

34 On citizenship as performance, cf. Farenga 2006, 6-7.

35 Cf. Köpping - Rao 2000b, 17-18, 24; J. Assmann 2000, 152-153 and below 146, n. 551.

36 On the difficulties and the politics of forgetting at Athens, cf. Wolpert 2002 passim; Flaig 2004a; 2004b; 1999; 1991; Loraux 2002. 
held power over social superiors. ${ }^{37}$ Judges and bystanders ${ }^{38}$ were influenced and persuaded by arguments and learned a lot about acceptable and unacceptable behavior, which the judges had to "define" through the ritual of rendering the verdict. ${ }^{39}$ The main protagonists of a lawsuit, prosecutors and accused, both of them acting on private initiative, vied for social prestige in front of an audience. The ritual of the court session turned them into winners and losers. All this was brought about by language and its performative enactment through persons. Persuasion by rhetoric (peithô) was regarded by many contemporaries as a magical force, ${ }^{40}$ powerful and yet invisible. The gifted speaker who could enchant his audience with his words was a magos who could lead the listeners in any direction he wanted, the supreme goal of the sophists. In the realm of magic, the goês who wrote curses for a client was analogous to the logographer in the forensic sphere who wrote speeches for anyone who could pay his services. ${ }^{41}$ These analogies can be carried so far that it is hardly surprising that some wealthy Athenian litigants hired talented speechwriters and professional sorcerers side by side to crush their opponents. ${ }^{42}$ This close relationship between forensic speeches and curse tablets ${ }^{43}$ will occupy us more in the next chapter, but, for our present argument, it is important to note that both forensic speeches and curse tablets amply testify to a world full of phthonos and baskania, traditionally translated as "envy"44 and 'the evil eye." ${ }^{45}$ It is telling that Athenian society found various ritual forms to express these problematic emotions.

37 In this sense, Philocleon's addiction to courts in Aristophanes' Wasps can be better understood. Taking an active part in the lawcourt procedures must have led to a tremendous degree of self-esteem among humble Athenians.

38 Cf. Lanni 1997, esp. 189 on the key role that bystanders played during court proceedings.

39 On the informal learning in court, cf. Rubinstein 2005b, 135-136.

40 Johnston 1999a, 118. On the close connection between magic and rhetoric, cf. below 184, n. 100.

41 On the analogies between rhetoric and magic, cf. De Romilly 1975 on the basis of Gorgias' Helen.

42 Faraone 1999a, 116, 118.

43 On this relationship, cf. Bernand 1991, 234.

44 On envy, cf. below 169, n. 19. Envy was seen negatively throughout the fourth century (Walcot 1978, 67-76). Fisher 2003, 211 refines this view and differentiates between malicious phthonos and justified envy. The first variant dominated, however.

45 Dionisopoulos-Mass 1976 connects envy and the evil eye in a modern Greek village setting. Walcot $1978,77-90$ is still useful on the evil eye. Cf. below 169, n. 20. 
The consequences of this ritual framing of the violence discourse cannot be overestimated. Whether in the Assembly of the People or in court or in the theater, the violence discourse was always enacted on the public stage within a ritually delimited precinct. If it is true that the congregation of the judges was a ritual community that was pre-eminent in constructing Athenian identity, the violence discourse must have played a key role in this dynamic process. This hypothesis will guide us in the ensuing treatment of the subject, establishing the discursive patterns of how Athenians talked about violence and thus constructed a semantic grammar of violence. The large body of orations, in which we can grasp most clearly the Athenian perception of violence and its evaluation by speakers, allows the historian to examine under what circumstances violence was regarded as legitimate or illegitimate. What we have access to in the speeches, however, are only discourses. In what follows I differentiate between discursive rules of interaction and discursive rules of representation. Sometimes the exertion of violence itself unfolded in accordance with the discursive rules of interaction. In these cases, the violence in question was characterized by some ritual traits: it followed certain behavioral patterns, occurred at a certain time and space, within a certain frame of onlookers, and displayed meaning to the audience. In these scenarios, we could say that the rules of violent interaction were ritualistic themselves and provided unwritten guidelines for committing violence. ${ }^{46}$

Rituals circumscribing the actual perpetration of violence fulfill two major purposes: regulating violence and charging it with symbolic meanings that facilitate communication between the conflicting parties and the audience. ${ }^{47}$ That such unwritten rules of interaction exist in every society is made clear by the disastrous consequences that failure to abide by them can entail. ${ }^{48}$ How, then, can we extract rules of violent interaction, if the orators construct and rhetorically represent them in their speeches? We have to acknowledge that interactionist rules and their representation on the discursive level are inextricably intertwined and influence each other. This is a far more complicated problem than the conventional concept of the orators' "rhetorical distortion" of facts. Schechner's braid

46 Bell 1997, 138-169 speaks of ritual-like activities, which correspond to my concept of interactionist rules in the context of violence.

47 Köpping - Rao 2000b, 7-8 speak of rituals as a condensed and sublimated form of social communication. Bauman 1977, 9, 15 emphasizes the importance of the ritual as the communicative frame for the performance. Similar now is Stavrianopoulou 2006, 18.

48 Ambos - Hotz - Schwedler 2005, 4 with examples from the Middle Ages. 
model is applicable to this context, too, ${ }^{49}$ and provides a heuristic tool to untangle the two levels, or at least to become more acutely aware of them.

Rules of interaction and representation condition each other. Whatever one did in reality, one would represent in similar terms in court, or at least one would try to make the happenings probable and plausible.$^{50}$ Otherwise, one would not win the favor of the bystanders and the judges. Whatever one saw and learned in court, one would imitate in reality so as to make one's commitment of violence more defensible in the future. The ritualistic representation of violence influenced violence proper by partially ritualizing the actual perpetration of violence. In turn, actual violence often followed certain rules and thus facilitated its ritualistic representation in the courtroom and on the dramatic stage. Given these two distinct layers, we can postulate that rules of violent interaction and of representing violence show symbolic meanings on at least two distinct levels: in daily life, partly because the courtroom speeches endowed actual violent interactions with a certain significance, and in the forensic speeches, partly because daily-life occurrences already had some symbolic meanings and were furthermore semantically charged through the process of turning these occurrences into courtroom narrations.

The following discourse analysis will demonstrate that the speaker represents himself by characterizing his opponent as the complete opposite. The speaker's self-definition and the "otherness" of his rival create multiple dichotomies. ${ }^{51}$ Also, the notion of violence was not a stable entity, but depended heavily on the viewpoint of the speaker. What constituted violence lay in the eyes of the beholder, be it the victim of violent aggression, playing mostly the part of the prosecutor, or the perpetrator, starring mostly in the role of the accused. This creation of dichotomies, roles, and masks was an integral part of the courtroom experience and is precisely what brings forensic speeches into close proximity to theatrical performances. The audience, made up mainly of judges and bystanders, had to decide at the moment of performance which "role" was more

49 Cf. above 16, n. 77. In terms similar to Schechner's on the relationship between drama and reality, cf. Hall 2006, 1-15.

50 Cf. Pl. Phdr. 272d-e.

51 Cf. as well the constant negotiation between mass and elite in democratic Athens (Ober 1989). 
convincing, the prosecutor's or the defendant's $;{ }^{52}$ this must have created an exhilarating experience of communitas, full of suspense.

In the eyes of the victim, violence was the breach of rules and the transgression of boundaries by a perpetrator. Spotting the manifold features that made up these boundaries, and thus contributing to the decipherment of the semantics of violence at Athens, are the primary goals of this chapter. As a first step, I focus on what the orators tell us about concrete violent actions, violent behavior that could be observed by a third party. In this way, the first part of the ensuing analysis is oriented toward discursive "facts" as far as they might have been discernible. The close reading of violent conduct in its wildly contradictory character will reveal codes of behavior which I call (ritualistic) rules of violent interaction. Overlaps with (ritualistic) rules of representation will be unavoidable, but will, it is hoped, be kept to a minimum. A second part will then concentrate on the interpretation and evaluation of these violent acts through the orators, that is, on the ritualistic representation of violence.

\section{Constructing Violence: Discursive Rules of Violence I (Interaction)}

In this section, only visible breaches, the violation of certain codes or rules of behavior, will be described. Taken all together, these actions constructed the notion of violence in the Athenian imagination. Threshold transgressions removed an action from the culturally constructed norms of proper conduct. The further the derangement from acceptable behavior, the more serious, relevant, and shocking an act was deemed. But even the breaking of rules often followed certain established patterns and was often to be expected by the involved parties. The axis around which the following presentation of all these breaches is structured is the fundamental dividing line between the defendant's and the prosecutor's points of view. The accused claimed the legitimacy of the violence he had used,

52 It must be noted that the strict dichotomy between speaker and opponent that is portrayed in this book is an idealization rather than reality, constructed by the litigants themselves. This binary system is only to be found on the discursive level. In practice, many more people and factions were involved in major lawsuits, as is evident, e.g., from judicial curse tablets, which lump many people together as adversaries. Cf. below 171, n. 29. 
if he could not deny it outright or downplay it to a considerable degree. In the eyes of the prosecutor, the violence suffered was illegitimate. The following list of dichotomies will circumscribe the highly flexible line between legitimate and illegitimate violence.

\section{Contexts}

Mapping the context in which violence took place is crucial for understanding any act of violence, ${ }^{53}$ for context frames the violent act and makes it comprehensible to the involved parties and bystanders. In fourth-century Athens, violence could be expected at drinking parties (symposia), ${ }^{54}$ festive processions after public events (kômoi), during the training of choruses, in gumnasia, at games, and on the occasion of quarrels between neighbors. Violence was also foreseeable in lovers' quarrels, ${ }^{55}$ on the occasion of the seduction of a female relative (moicheia), ${ }^{56}$ when people felt offended by insults, in cases of a contested inheritance or unclear boundaries of plots of land, ${ }^{57}$ and when goods were seized, either with or without state authorization. ${ }^{58}$ Brawls could also erupt because of unclear citizenship status. ${ }^{59}$ Lysias and Ps.-Demosthenes were aware of these situational hotbeds of violence and have left us telling

53 On the contexts of violence, cf. Fisher 1998a, 75.

54 Similar outbreaks of violence are frequently attested for medieval convivia (Kaiser 2002, 165-180). For violence in the context of Greek symposia, cf. Borg 2006, 224, n. 4 (with older literature).

55 Lys. 3 and 4; Aeschin. 1.135. In D. 54.14 Conon downplays the violence of his sons by claiming that it was not excessive and quite normal in the customary adolescents' competition to win young women as mistresses.

56 E.g., Lys. 1. Todd 2007, 43-60 provides an excellent introduction to Lysias' first speech. To Cohen 1991b, 100-101; 1984 passim, moicheia is the sexual "violation of the marital bond" only; a broader notion of moicheia would render Athens unique among Mediterranean societies. With this view, he is alone as far as I can see. Cf. Herman 2006, 268. Herman 1996, 33-36 argues in favor of abandoning the Mediterranean model altogether, because it is not applicable to ancient Athens. The communis opinio is that moicheia is illicit, consensual sex. Representative are Schmitz 1997, 124-140; Kapparis 1995, 122; Cantarella 1991b (with older literature). Moicheia, therefore, should be translated as 'seduction,' not as 'adultery.'

57 D. 37.33; Is. 8; 9; Hyp. fr. 21 (97-99).

58 Ps.-D. 47.

59 Lys. 23. 
lists of the contexts in which people were particularly prone to violence.$^{60}$ Within these social frameworks, rules of violent interaction had developed and people were not surprised about outbreaks of violence. One of the most famous examples of violence outside these contexts is preserved by Demosthenes, and entails the prison neurosis from which Aristogeiton obviously suffered. After being imprisoned for a long time, he picked a fight with another inmate, a man from Tanagra, bit off his nose, and swallowed it. The other inmates were so horrified that they socially shunned him by sharing neither light nor food and drink with him. His extreme violence far beyond acceptable norms had made him an outsider in the eyes of the other prisoners. ${ }^{61}$ As we will see, speakers in court normally tried to represent the violence committed by their opponents as being deprived of all sense, or rather tried to charge it with a blatantly negative sense, while trying at the same time to cast their own violence in a positive light, as something tactful and replete with social sense.

\section{First Blow versus Self-Defense}

Concerning the origin of a fight, it was of paramount importance to demonstrate that the opponent struck the first blow and was thus the aggressor. ${ }^{62}$ Every speaker would portray his own share in violence as self-defense: the opponent had forced him to strike back. ${ }^{63}$ At first glance, this statement sounds trivial, but there is more to it. Since in a confused mêlée, and especially afterward, it was hardly possible to make out who actually started the fisticuffs, the insistence on the "first-blow" rhetoric

60 Lys. $1.43-45 ; 3.43$; Ps.-D. 47.19.

61 D. 25.60-62. A less serious incident is rendered at Plu. Alc. 8.1. Because of a bet with his friends and for the fun of it, Alcibiades hit the famous Hipponicus, the father of Callias. Since there was neither a genuine reason nor a customary context for this outburst of violence, people were outraged. The next day, Alcibiades repented by exposing his bare back to Hipponicus to be scourged. The latter, however, renounced his claim to revenge.

62 Striking the first blow made one liable for different offences: Hes. Op. 708 (general moral principle); Lys. 4.11, 15 (trauma ek pronoias); D. 23.50 (aikeia?); Ps.D. 47.7-8, 35, 39-40, 47 (aikeia); D. 54.33 (hubris); Isoc. 20.1 (aikeia and hubris); Men. Sam. 576 (hubris indirectly); Arist. Rh. 1402a1-2 (hubris); IG I ${ }^{3}$ 104, lines 33-34 (homicide); Antiphon 4.4.2 (homicide); cf. Scheid 2005, 409; MacDowell 1978, 123.

63 E.g., Lys. 3.18. 
was mainly of symbolic value. ${ }^{64}$ It distributed guilt and innocence in the interest of the speaker. As in many pre-modern societies, retributive violence was considered socially acceptable at Athens under certain circumstances, a typical feature of a society that lacked a state monopoly on violence to a large degree, and therefore had to rely on a considerable amount of self-help, ${ }^{65}$ including immediate self-defense, which is still permitted in modern law. Even retaliating disproportionately to the violence received was acceptable as long as the violence resorted to remained within certain limits and did not entail the killing of the opponent. ${ }^{66}$

\section{Murder versus Lawful Homicide}

Homicide was the ultimate boundary that could not be transgressed except under very special circumstances, such as self-defense. Killing an Athenian citizen was too extreme a reaction to an insult suffered ${ }^{67}$ and

64 Flaig 2006, 38 aptly speaks of the "mythische Qualität des 'Anfangens." This holds especially true for historiography. Cf. Gould 1989, 63-65 on Herodotus' probing into the causes of the Persian Wars and blaming Croesus for having committed the first injustices (Hdt. 1.5.3).

65 Hunter 1994, 120-153, 188 distinguishes between private initiative and self-help, the latter denoting concrete physical action against a malefactor. At the same time, self-help is a subcategory of self-regulation. This wider term describes the sum of all actions an aggrieved party had to take to compensate for the shortcomings of the state in terms of law enforcement. Schmitz 2004, 423-431 and Fisher 1998a, 88 stress the role of mutual help among neighbors. Phillips 2000, 256: "The law of classical Athens did not seek to eliminate or suppress self-help to any meaningful extent. Rather, given the ... dichotomy of a highly-developed legal system with very limited personnel, the Athenians relied on the initiative of private individuals for the administration of justice at all stages, before (the initiation of the lawsuit), during (the conduct of the prosecution and defense), and after trial (the execution of judgement)."

66 Flaig 2006, 38. This is the problematic point about the speaker's allegation in Antiphon 4.2.2-3, where he pleads for "a head for an eye" approach. Cf. Dover 1974, 184.

67 A good example is the homicide in D. 21.71-75. In a fit of anger, Euaeon killed Boeotus with his bare hands, because he had insulted his honor during a symposion. This incident is often described as self-defense, but the trial was rather about Euaeon's exaggerated revenge. Cf. Flaig 2006, 36-38. Flaig's reasoning supports Gagarin's view that cases of self-defense were heard before the Areopagos and not the Delphinion, because the question at stake was whether or not the killing had been intentional homicide (Gagarin 1978, 112, 120). It is telling that Euaeon was convicted by a single vote only, which means that many judges 
was often regarded as disruptive to the citizen body because of its potential to trigger stasis. Exceptions stated in the Athenian homicide statute confirm the rule. ${ }^{68}$ The Draconian law of homicide was geared toward calming down emotions after a homicide had been committed and toward removing the culprit from the community so as to prevent private vengeance. No other offense but homicide drew the line so sharply between permissible and impermissible use of violence. The Solonian regulation concerning an adulteress, for example, makes this abundantly clear. The husband had to divorce her. She was barred from all public places and was not allowed to participate in religious rites and festivals. If she did not respect these rules of social exclusion, anyone could do with her what-

must have found his deadly action legitimate. Therefore, Herman's insistence on the non-retaliatory philosophy of the dikastai (2006, e.g., 175) is untenable. Cf. below 59, n. 167 on Demosthenes' uncertainty how the judges would evaluate Meidias' punching him.

68 Draco's homicide statute is partly preserved. The epigraphic fragment from 409/8 BCE, a copy of the law issued in 621/20 BCE (IG I ${ }^{3} 104=\mathrm{IG} \mathrm{I}^{2} 115=$ Syll. $\mathrm{I}^{3} 111=\mathrm{M} / \mathrm{L} 86=$ GHI I $87=$ HGIÜ I 145), was republished by Stroud 1968. Gagarin 1981 also gives the text, provides an English translation (xiv-xvi), and a detailed interpretation of the Draconian law. In the epigraphical text, lines $33-36$ refer to self-defense, lines 37-38 to lawful homicide. D. 23.60-61 is a verbatim quote from the part on self-defense. D. 24.113 mentions the justified killing of a thief at night, but ascribes this regulation to Solon. Lys. 1.30-33; Aeschin. 1.91; D. 23.53-56; Arist. Ath. 57.3; Ath. 13.569; and Plu. Sol. 23.1 refer to the moichos who can be slain in the act without punishment, and may therefore have been part of Draco's homicide statute (Stroud 1968, 81). Plutarch, however, attributes this law to Solon. Paus. 9.36.8 does link a law on moicheia to Draco, but not to a homicide law. Lys. 1.49, the allegation that a moichos can be treated by the kurios in whatever way he wishes, is supposed to bolster Lys. 1.30-33. Cf. Ruiz 1994, 167. Ogden 1997, 27 and Cohen 1991b, 100 think that one can also speak of the law of adultery, seduction, and rape with reference to these passages. D. 23.22 explains the competences of the Areopagos. Ps.-D. 43.57 provides us with the provisions for pardon in cases of unintentional homicide and indicates which relatives of the victim were morally obliged to take action against a murderer; in more detail, Ps.-D. 47.68-73 (down to and including the degree of descent first cousin once removed). Indirectly on Athenian homicide law Pl. Euthphr. 3e7-5d6. Schmitz 2001 convincingly argues that Draco only regulated the blood feud and codified this new regulation. Similar are Hölkeskamp 1999, 267-268; Ruschenbusch 1960, 152. Euphiletus, the speaker of Lys. 1, represents his killing as justified homicide, especially at 1.30 and 1.34 . On the symbolic side of the dikê phonou, cf. Riess 2008. 
ever he liked, apart from killing her. ${ }^{69}$ The punishment for her disobedience was not only talion; it was almost boundless, unrestricted, absolute. Only her death was excluded as the ultimate boundary that could not be transgressed. Violating this threshold would have caused pollution and could have triggered civil strife.

Killing, except for self-defense and a very few other, qualified reasons, was taboo. This was the ideal. But reality might have been different. In a casual side-note, Lysias talks about the frequency of murders commissioned by enemies for money. ${ }^{70}$ The speaker of Lysias 3, defending himself against Simon, interprets the law in a strange way that leads to the assumption that at least the wounding rate must have been quite high in Athens: 'Clearly our lawgivers also did not think they should prescribe exile from the fatherland for people who happen to crack each other's heads while fighting — or else they would have exiled a considerable number. ${ }^{71}$

In the following paragraphs, I seek to explore the parameters by which homicides were morally assessed and adjudicated in court. Despite the unacceptability of homicide, it was not an objective, factual category of extremely violent misbehavior, understood by everyone alike as a serious crime. On the contrary, the relevance of a homicide hinged upon many factors, including the citizenship status of the victim, his political function, his or her legal and social rank, and sex. The number and kinds of boundaries that a violent action broke determined the societal relevance of the act. At the same time, the violation of these markers created the symbolism that was ascribed to a particular killing. Accordingly, subtle gradations in the assessment of the outrageousness of a homicide resulted. The reactions of the judges on the Areopagos or of legal interpreters (exêgêtai) ${ }^{72}$ and thus of the general public, were different on every occasion. We will concentrate first on the murderers par excellence, the Thirty Tyrants and to what extent they shaped-unknowingly—the

69 Ps.-D. 59.86-87; Aeschin. 1.183; cf. Arist. Ath. 59.3-4 (graphê moicheias). Cf. Omitowoju 2002, 113; Ogden 1997, 28-29. On the woman's punishment, cf. Schmitz 1997, 85-90; on the moichos' punishment, 91-106.

70 Lys. 1.44 .

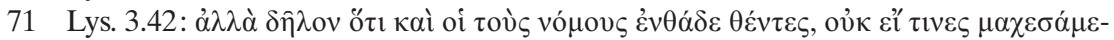

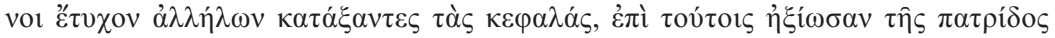

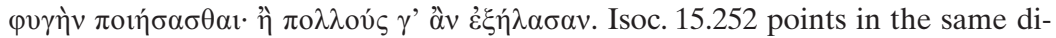
rection: many people use the skills they have acquired in the pankration against their fellow citizens.

72 Even these interpreters of Athenian religious matters were no legal experts. 
notion of homicide during the fourth century. An analysis of a few, wellattested homicide cases will show by example the markers involved (citizenship status, political function, legal and social rank, and sex). Special emphasis will be placed on the killing of relatives, followed by a section on "framing for homicide," an essential method of character denigration in the forensic speeches, and, finally, attempted homicide.

The tyranny of the Thirty provided the most powerful interpretive framework for judicial murder ever created in Athenian history. ${ }^{73}$ Allegedly, the tyrants killed 1,500 citizens without proper trial. ${ }^{74}$ They not only eliminated political opponents in 404/03 BCE, but also put to death rich citizens and metics, whose property they seized. Their greed is emphasized unanimously in the ancient sources. ${ }^{75}$ Among the victims was Polemarchus, Lysias' brother, a fact that prompted Lysias to write his twelfth speech (Against Eratosthenes, after 403/2 BCE), one of the most valuable sources for the dictatorship of the Thirty. Lys. 13 (Against Agoratus, 399 $\mathrm{BCE}$ or later) is also to be seen in this context. This speech tells about court proceedings against Menestratus and Agoratus, informers for the Thirty, who had caused the death of many democrats. Both were prosecuted via the summary procedure of the apagôgê and executed. This means that the restored democracy found legal loopholes to circumvent the stringent rules of the amnesty and to take revenge on people who had not killed with their own hands during the tyranny and who only belonged to the entourage of the Thirty. ${ }^{76}$ This procedure is revealing. The horrific regime of the Thirty became the foil against which many acts of violence against citizens, not just homicide, were gauged during the fourth

73 On the Thirty and their politics, cf. Wolpert 2002 (with older literature). Nemeth 2006 and Krentz 1982 provide an excellent overview of the sources on the Thirty Tyrants, most importantly D.S. 14.3-6, 32-33; Arist. Ath. 34-40; Lys. 12; 13; X. $H G$ 2.3-4; Just. Epit. 5.8.11-10.4.

74 Aeschin. 3.235. They did not even provide their victims with reasons why they would be executed. Most heinous of all, they denied them burial (Allen 2000, 237). On all aspects of violence committed by the Thirty, cf. Wolpert 2002, 15-24.

75 Cf. Nemeth 2006, who claims that the Thirty predominantly killed out of greed rather than for ideological or political reasons. Similar is Balot 2001, 219-224. On more tyrannical actions of the Thirty, cf. Jordović 2005, 194-202.

76 Cf. Phillips 2008 on these two speeches and their respective argumentation (153184 on Lysias 12; 185-235 on Lysias 13); Riess 2008 on the symbolic meaning of the apagôgê procedure. 
century. The Thirty Tyrants became the very embodiment of violence. ${ }^{77}$ As we will see, many negative interpretations of violence in the fourth century can ultimately be traced back to the traumatic experience of the suspended democracy.

Citizenship status. The oldest homicide case attested in Athenian oratory (dated between 422 and 413 BCE) is that of the Athenian klerouch Herodes, allegedly killed by Euxitheus, a rich Mytilenean citizen. ${ }^{78}$ Both were on a sea trip together from Mytilene to Aenus in Thrace, when a storm forced them to anchor in Methymna on Lesbos. During a night of drinking, Herodes disappeared. His corpse was never found. On the basis of a slave's report, forced by torture, Herodes' relatives indicted Euxitheus for homicide in Athens. The procedure to be expected was the dikê phonou, which would have given Euxitheus the possibility of going into exile after delivering his first speech in court. Trusting in his relative security, he went to Athens willing to face trial there. Upon his arrival, he was imprisoned and not even allowed to post sureties to prepare his trial. Since it took place before a dicastic court and not the Areopagos, there is good reason to assume that the nomos tôn kakourgôn involving the apagôgê procedure was expanded and used in a homicide case for the first time. ${ }^{79}$ If this was the case, Euxitheus' indignation and protest were justified, for the summary procedure of the apagôgê posed serious obstacles to his defense, whereas it greatly favored the prosecution. ${ }^{80}$ Considerations on why the extension of the kakourgos law came to include homicide reveal some of the prejudices the Athenians had against their foreign allies around 420 BCE. Given the conservatism of Athenian homicide law, the extension of the apagôgê kakourgôn procedure was a crucial innovation. Heightened anxieties about Athenians living abroad in times of war may have induced the Athenian dêmos to look for possibilities of bringing disobedient or unruly allies to justice at Athens. Summary arrest seemed to be the most convenient means of achieving this goal. If this is correct, a decisive change in Athenian homicide law would have resulted from Athens' growing fear that Athenian citizens "might be murdered as a form of

77 Although Isocrates 20 has nothing to do with tyranny, the prosecutor constructs his opponent as a tyrant, a paradigm that only became viable in this particular way after 404/03.

78 Antiphon 5. For an overview of all homicide cases attested in fourth-century records, cf. Riess 2008, 93-94.

79 Phillips 2008, 122-131. On all the procedural questions in detail, cf. Gagarin 1989.

80 Volonaki 2000, 153, 158-159 (with older literature). 
protest vote against Athenian imperialism." ${ }^{81}$ Athens' aggressive foreign policy would then have had serious repercussions on the administration of justice at home. ${ }^{82}$ It is revealing that a foreigner became the victim of these concerns first. ${ }^{83}$ In addition to its political relevance, the Herodes case also has social overtones. A rich ally lays hands on a poor and innocent Attic klerouch. The symbolic meaning on the political level, the fact that imperialism has domestic consequences, is cast in the conventional terminology of the social divide between rich and poor.

Political function. The killing of Nicodemus of Aphidna (348 BCE), friend of Eubulus and Meidias, also had strong political implications. He was brutally murdered, with his tongue cut off and his eyes put out. ${ }^{84}$ The killer was not found, but Nicodemus' relatives suspected Aristarchus, a young friend of Demosthenes. A motive was readily at hand: Nicodemus had slandered Demosthenes and wanted to sue him for desertion, and so it appeared to Nicodemus' family that Demosthenes might have commissioned this murder. According to the Athenian homicide law, it was the family's moral duty and prerogative to file charges of homicide on behalf of a killed relative. Instead, Meidias reacted first and brought Aristarchus before the Boulê, probably through ephêgêsis followed by apagôgê kakourgôn, which was a public suit that anyone who wished (ho boulomenos) could bring. ${ }^{85}$ Meidias' proposal, however, was rejected by the Boulê for reasons unknown to us. Unlike a dikê phonou, in which the accused could escape into exile before the end of the trial, the apagôgê procedure did not allow for this possibility. The accused was executed immediately after a verdict of guilt. To many councilors, this may have seemed an excessive penalty for someone like Aristarchus, who was only suspected of homicide. This is the only homicide case we know of in which two different procedures were used separately by different prosecutors, a fact that has been neglected in research so far. After the failure of the apagôgê procedure, Nicodemus' relatives filed a conventional dikê phonou. Even before the start of the trial, Aristarchus withdrew into exile, which, for his opponents, was a tacit confession of guilt.

81 Todd 1993, 331.

82 Erbse 1977, 224; Evjen 1970, 405, 412.

83 Cf. also the killing of Aesion on Ceos: IG II ${ }^{2} 111=$ Syll. I $^{3} 173=$ GHI II $142=$ Rhodes - Osborne 2003, $39=$ HGIÜ II $231=$ Hansen 1976, 133, no. 16.

84 D. 21.104-122 and scholia 21.102, 104, 116, 205; Aeschin. 1.171-172; 2.148, 166 and scholia; Din.1.30-31, 47; Rhet. Gr. VIII 48 (Sopat. Rh.); Idomeneus FGrHist 338 F 12.

85 Hansen 1976, 135-136, no. 23. 
What does the double prosecution mean? Both parties of prosecutors wanted to see Aristarchus convicted of homicide. Their intentions were different, however. The fact that Meidias tried his luck first with an uncommon apagôgê sent a powerful message to the politically well-informed. Although it was the moral obligation of Nicodemus' family to file a dikê phonou, Meidias went ahead of them and initiated the unusual apagôgê procedure, not only to ensure Aristarchus' death, but also to demonstrate that this was a political murder, with Demosthenes looming in the background and bearing joint responsibility. Through the procedure chosen, Meidias made it clear that this was a political affair with much more at stake than just ordinary homicide. The whole community of Athenian citizens was called upon to stop Demosthenes' machinations. It is not less revealing that the bouleutai did not share this view and rejected Meidias' bold proposal.

The murder of Nicodemus was politicized posthumously in order to attack a political opponent. The murder of Phrynichus (411 BCE), one of the leading members of the Four Hundred, was also politicized post factum, but with contrary goals in mind. The killers were portrayed as tyrant slayers to protect them from being brought to justice. The metics Thrasybulus from Calydon and Apollodorus from Megara killed Phrynichus in the Agora near the Boulê. ${ }^{86}$ Their motives are unclear and might have been of private nature, like those of Harmodius and Aristogeiton who had killed Hipparchus in 514 BCE. Right after the deed, with the Four Hundred still in power, the assassins absconded. When they disclosed themselves and claimed responsibility for the assassination after the restoration of the democracy, Phrynichus' relatives or friends felt compelled to react and file charges against the murderers. Since Phrynichus had been a staunch oligarch for all his life, the people of Athens, strongly endorsing the restored democracy, now wanted to protect the killers from being prosecuted. So they declared Phrynichus a traitor and portrayed his murderers as tyrannicides. They were not only not punished, but in fact honored for the rest of their lives. ${ }^{87}$ Hence, the prosecutors' plan to bring the killers to justice (410/09 BCE) failed.

86 Th. 8.90-92; Lys. 13.70-72; Lycurg. 1.112-115. Cf. Lys. 7.4; 20.9-11; 25.9. Hansen 1976, 125-126, no. 4-5.

87 IG I$^{2} 110=$ IG I $^{3} 102=$ Syll. I ${ }^{3} 108=$ GHI I $86=$ M/L $85=$ HGIÜ I 140: Thrasybulus was rewarded with a golden crown and citizenship. His fellow conspirators, among them Agoratus, were also honored as euergetai. They received lesser rights, most notably the right to own real estate in Attica as non-citizens (egktêsis). 
Legal and social rank. In all the cases mentioned above the victims were Athenian citizens; the latter two even had political functions. That is why their deaths were taken seriously. Very different were reactions when a non-citizen suffered a violent death. In Plato's fictional dialogue Euthyphro or on Holiness ${ }^{88}$ the father of the speaker, Euthyphro from Prospalta, had killed a dependent, a so-called pelatês, through negligence. ${ }^{89}$ This man had killed a house-slave and, in retaliation, Euthyphro's father had thrown him into a ditch without providing food or drink. $\mathrm{He}$ then sent a messenger to Athens to ask the exêgêtai for advice on what to do with the killer. Before the messenger returned, the pelatês had died in the ditch from hunger, thirst, and cold. Although Euthyphro, the interlocutor of Socrates in the dialogue, has the law on his side in suing his father for homicide, ${ }^{90}$ Socrates, first of all, is shocked to hear that his friend has filed a dikê phonou against his own father. Very clearly, Socrates assumes the attitude of an average Athenian; he seems to be highly concerned about Athenian social etiquette and family ties. It was inappropriate to sue one's own relatives in court, ${ }^{91}$ even more so for a son to indict his own father for homicide, let alone in a case where the victim at stake was a slave and a killer himself. Once more, we see that the notion of homicide was not independent of social norms. Values permeating Athenian society also pervaded Athenian law and contributed to determining the choice of legal procedure. ${ }^{92}$ The philosophical dialogue clearly delineates the discrepancy between some principles of Athenian law and social practice.

Sex. To what degree the assessment of homicide as a serious crime was dependent on the viewpoint of the accuser and the judges is also clear from the regulations concerning the honor of women. According to Demosthenes' interpretation of the lawful homicide statute (D. 23.53), every kurios under whose protection a woman lived was entitled

88 Although the case is fictional, it must be plausible within the parameters of Athenian law. Otherwise, there would be no effect on the readership (Kidd 1990, 213-214).

89 Pl. Euthphr. 3e-4e.

90 On the legal status of the pelatês and the father's liability, cf. Kidd 1990; Panagiotou 1974.

91 Cf. Phillips 2008, 85-88. Cf. also the trial for homicide initiated by a stepson against his own stepmother (Antiphon 1).

92 A prime example is the beginning of Ariston's speech against Conon (D. 54.1) and the aforementioned case of Nicodemus. 
to kill even friends if they tried to compromise female honor. ${ }^{93}$ Although this level of self-help had become problematic by the fourth century, the wide latitude of the kurios' prerogatives was still taken for granted after the restoration of democracy in 404/03 BCE. Hyperides, in his defense of Lycophron (Hyp. 1 [Lyc.]), the alleged seducer of a widow betrothed to another man, claims that the bride's brother Dioxippus, an Olympic victor in the pankration, and his friend, also a wrestler, would have killed Lycophron on the spot, if he had dared to approach the bride indecently during the wedding procession. This argument may be rhetorically distorted, because Hyperides has to show that his client did not make overtures to the woman at all, but Hyperides conveys the impression that killing under these circumstances would have been justified and even expected. This anecdote also casts some light on Lysias 1, Euphiletus' famous speech in his own defense for having killed Eratosthenes, the seducer of his wife. ${ }^{94}$ His excessively violent reaction to his wife's cheating on him was probably seen as problematic, ${ }^{95}$ but Lysias is able not only to justify Euphiletus' deed by Athenian law, but even to present it as having been necessitated by it. We will have to come back to Euphiletus' excessive act of revenge, but he could still cite three laws in his support, probably the nomos tôn kakourgôn (Lys. 1.28), ${ }^{96}$ the lawful homicide statute (Lys. 1.30), ${ }^{97}$ and probably the dikê biaion (Lys. 1.31). ${ }^{98}$ Although the first two laws may have given Euphiletus the right to kill the seducer whom he caught in the act, this extreme reaction had almost certainly become obsolete by the fourth century. ${ }^{99}$

93 D. 23.56.

94 From a gender perspective, cf. Omitowoju 2002, 72-115.

95 If we follow Roy 1997, 13-15, 18-19 in concluding that adultery must have been fairly frequent in Athens and was often condoned by the parties involved, Euphiletus' extreme measure must have been all the more shocking.

96 The nomos tôn kakourgôn is the most controversial of the three laws. Cf. the lists in Arist. Ath. 52.1 and Antiphon 5.9. Hansen 1976, 36-48 has the most detailed and sharpest analysis of the kakourgoi to date. Todd 2007, ad Lys. 1.28 discusses the possibility whether or not this law could also be that on moicheia.

97 Cf. above 36, n. 68.

98 On these three laws, cf. Omitowoju 2002, 98-105. Todd 2007, ad Lys. 1.31 discusses the possibility of a dikê blabês, but also leans toward a dikê biaiôn.

99 Carawan 1998, 135, 284, 291 reminds us that the amnesty's stipulation of $m \hat{e}$ mnêsikakein, not to recall past crimes, referred only to the atrocities committed during the civil war, but in reality had a tremendous impact not only on the conditions of justifiable killing, but also on the Athenians' understanding of retrib- 
These two instances may suffice as examples of how seriously female chastity was taken. And yet, the ambivalent position of women with regard to the homicide law is obvious. Whereas they were protected by their kurios from any outside intrusion, they were almost completely at the latter's mercy. An anecdote encapsulates the general Athenian notion. According to Aeschines, fathers had the full right of disposal over their daughters in the old days. When the Athenian king Hippomenes discovered that his daughter Leimone had lost her virginity before marriage, he sealed her up in a stable and had her killed by a horse. ${ }^{100}$ This brutal act of social control was obviously not regarded as punishable homicide, but as a justified paternal reaction to female misconduct. Sources from classical times confirm the impression that women were firmly subject to the powers of their kurioi. No one protested when Alcibiades dragged his wife Hipparete by the hair back home from the Agora, where she had filed for divorce from him with the archôn basileus. ${ }^{101}$ Two weeks later, she died under mysterious circumstances. ${ }^{102}$ It would have been the responsibility of the woman's relatives to investigate the case, and, if necessary, to bring charges against Alcibiades. Whether it was his high social status that prevented any action against him or the general notion that a wife was at the whim of her husband anyway, we cannot say.

Even more precarious was the status of women when they were slaves, freedwomen, or metics. When an old nurse, a former slave, died from the blows that she had received from Theophemus and Euergus, the prosecutor in Ps.-D. 47 was at a loss as to how to proceed. ${ }^{103}$ On the one hand, the woman had been a member of his household and thus a dependent. Therefore, he felt the responsibility to take legal action to avenge her death. On the other hand, she had been neither his relative nor his slave. Therefore, he did not dare file charges of homicide before the king archôn. In his dilemma, he asked the exêgêtai for advice. Their answer is one of the most debated passages in all of Athenian legal documents, ${ }^{104}$ but we can grasp the essentials. The exêgêtai emphasized that he should not bring a dikê phonou against the killers. It was enough for him

utive violence in general. Also for this reason, self-help killing had become problematic during the fourth century.

100 Aeschin. 1.182; D.S. 8.22; Heraclid. Lemb. Epit. Ath. Pol. 1.

101 Ps.-And. 4.14.

102 Plu. Alc. 8.4; indirectly Lys. 14.42; Ps.-And. 4.14; Antiphon fr. 67 (Thalheim Blass).

103 Ps.-D. 47.58-62, 67.

104 Ps.-D. 47.68-70. Cf. Hansen 1976, 110-111; Grace 1975. 
to make a proclamation against the killers in general terms. They advised him further to perform the appropriate rites to cleanse his house from pollution and to 'exact vengeance in some other way." ${ }^{, 05}$ The exêgêtai deliberately chose a vague formulation, which allowed for some kind of selfhelp within the latitude of Athenian law. We do not know how the prosecutor was supposed to go about this business, but whatever form of redress he would seek, his reaction should remain below the level of a dikê phonou, which would make him extremely unpopular, as the exêgêtai told him. Very clearly, the death of a former slave woman did not warrant any major ill feelings among Athenian citizens. To put it in other words: the well-known killers of a former slave woman got away scot-free on the advice of the city's interpreters of religious matters. More than any other example, this incident shows again that killings were not always treated in the same way. Beyond the question of procedural variety in how to deal with killings (depending on the likelihood of prosecution and the intent of the killer), the citizenship status and political function of the parties involved, as well as the legal and social rank and sex of the victims, were decisive in order for a killing to qualify as homicide. The judges and the exêgêtai interpreted a killing differently according to the circumstances and the outrage they felt.

Killing of relatives. After these remarks on the violent death of women, let us now treat a sort of homicide that was considered especially heinous. Opponents were not the only ones killed; the slaying of relatives is also attested. Because of their mythical dimensions, matricide, ${ }^{106}$ parricide, ${ }^{107}$ fratricide, ${ }^{108}$ and the killing of one's own husband or relative constituted the most horrible subcategories of homicide. It comes as no surprise that a stepmother accused of having poisoned her husband was compared to Clytemnestra by her stepson, the prosecutor. ${ }^{109}$ In Isaeus 8, Diocles is accused of having murdered one of his brothers-in-law. For this reason, Orestes is mentioned twice in the speech to give a mythical flavor to

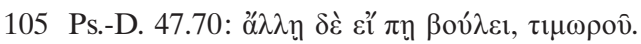

106 Cf. Orestes' trial for matricide in A. Eu. 566-777.

107 Diodorus allegedly killed his own father (D. 22.2).

108 Thudippus had killed his own brother Euthycrates. The eyewitnesses did not dare speak about it; since they were not relatives of the victim, they were in no position to file charges and so probably thought that this homicide was none of their business (Is. 9.16-19).

109 Antiphon 1.17. 
this reproach. ${ }^{110}$ In Ps.-Andocides 4.15, the character assassination of Alcibiades is driven to the extreme by insinuating that he was plotting the murder of his brother-in-law Callias.

Framing for homicide. Because homicide was the most extreme crossing of the ultimate threshold and the most blatant form of violence committed by the Thirty Tyrants, framing one's opponent for homicide became one of the most popular means of character assassination in fourth-century forensic oratory. ${ }^{111}$ In Apollodorus' speech against Stephanus and Neaera (Ps.-D. 59), ${ }^{112}$ Apollodorus relates how his long-time opponent Stephanus had tried to damage his reputation with a fabricated charge of homicide. Stephanus brought a dikê phonou against him, because he had allegedly slain a slave or foreign woman from Aphidna with his own hands. ${ }^{113}$ The woman was probably dead, but the accusation lacked every basis and was, in fact, false. Although he had no proof whatsoever to substantiate his charge, Stephanus was willing to swear the diomosia, calling down destruction upon himself and his household. Just in the hope that the reproach would somehow tarnish Apollodorus' reputation in the future, Stephanus risked coming out of this procedure as a perjurer. This is in fact what happened.

Isocrates transmits an even more blatant example of faked homicide. ${ }^{114}$ In the wake of a quarrel over a plot of land, Callimachus and his brother-in-law accused Cratinus of having killed a slave woman of theirs. Although the woman was alive-she was hidden away during the trial-Callimachus could muster fourteen witnesses on his behalf who backed him up in court by claiming that the woman was in fact dead. This incident tells us a lot about the role witnesses had to fulfill. Similar to the part sunêgoroi had to play in court, ${ }^{115}$ witnesses were- - seen from the litigants' partisan point of view—not necessarily supposed to tell

110 Is. 8.3, 44. Diocles of Phlya was nicknamed Orestes, cf. below 276, n. 130. Diocles was a frequent name and is also to be found on curse tablets, cf. below 163, n. 596 and 176, n. 55.

111 On framing for homicide, cf. Roisman 2006, 54-58.

112 On the speech as a whole, cf. Brodersen 2004; Hamel 2003; Kapparis 1999; Carey 1992. On Apollodorus in general, cf. Trevett 1992. Schuller 2008, 57-63 rightly notes that much of what Neaera is accused of might fall under diabolê, 'slander.'

113 Ps.-D. 59.9-10.

114 Isoc. $18.52-54$.

115 On their role, cf. Rubinstein 2000. 
the truth, but to endorse a particular litigant's claims. ${ }^{116}$ The more support a litigant could garner, the higher was his social prestige, and the more likely was his acquittal. Cratinus waited until Callimachus had sworn the oath of self-execration, went out to the farm, freed the slave woman, and presented her in court. Being a slave and a woman, she was certainly not allowed to speak in front of the judges. And yet, her presence was so powerful that Callimachus did not get one single vote and was thus unmasked as perjurer. Performance won the day.

In an inheritance case, Diocles was framed for having killed his brother-in-law, his sister's husband. ${ }^{117}$ Although the allegation of kinship murder clearly served the purpose of extreme character denigration-we do not hear anything about reactions on the part of the victim's familythere seems to have been more substance to it than in the cases mentioned above. At least the man was dead. It is interesting to note that Diocles may have employed mediated violence-he may have had the murder committed by a slave whom he smuggled out of the country-and put the blame for the homicide on his own sister, thus framing her with having killed her own husband. The strategy seems to have worked. As far as we know, Diocles got away with his plot; at least, the speaker of Isaeus 8 does not tell us that Diocles was ever indicted for homicide.

In order to harm Diodorus as much as possible, Androtion insinuated that Diodorus had killed his own father. Although parricide was an outrageous crime, Androtion did not file charges himself-as a non-relative he was not entitled to bring a dikê phonou outside his own family ${ }^{118}$ _ but contented himself with lodging a graphê asebeias against Euctemon, the brother of the victim. According to Androtion's interpretation, Euctemon had incurred pollution from associating with Diodorus, his nephew and

116 Todd 1990, 20, 23, 27; Humphreys 1985b, 313, 322-325. Mirhady 2002, 272, however, emphasizes that "systemic expectations" required witnesses to tell the truth. Ancient evidence itself speaks against Mirhady. A fragment of Aristophanes' Storks (F 452 [Henderson; K.-A.]) draws a rather negative picture of

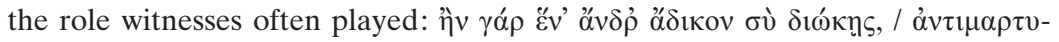
 of his hangers-on, equally bad, will bring a countersuit.' In his speech against Conon (D. 54.32-34), Ariston emphasizes the contrast between his witnesses and those of Conon. He, Ariston, did not even know his witnesses, but they were still willing to testify to what they saw on his behalf. Different are Conon's witnesses, according to Ariston: they put on Spartan airs of soberness during the day and went wild during the night.

117 Is. 8.41.

$118 \mathrm{He}$ still would have been entitled, however, to resort to the apagôgê procedure. 
alleged parricide. ${ }^{119}$ We do not know why Androtion chose this indirect form of attack, but to him at least the graphê asebeias against the victim's brother, Diodorus' uncle, was the appropriate form of framing Diodorus for parricide. ${ }^{120}$ Androtion failed with his strategy, but we cannot tell to what extent Diodorus' reputation was permanently damaged. A reproach as serious as parricide must have left its traces.

Framing for homicide, however, was not the only way one could denigrate one's opponent with regard to homicide. Falling short of social expectations in this context also entailed ill feelings among the community. Theocrines failed to prosecute Demochares and others, the murderers of his brother, although he was at least morally obliged to do so. Instead, he preferred a private settlement outside of court by accepting blood money, a kind of financial compensation. ${ }^{121}$ This was an archaic practice, but obviously frowned upon in fourth-century Athens. ${ }^{122}$ Not even taking judicial "revenge" for one's own brother might have been regarded as scandalous cowardice. ${ }^{123}$ Otherwise, the speaker could not have used this incident to denigrate Theocrines as thoroughly as he does.

Attempted homicide. Given the highly symbolic relevance of the homicide of an Athenian citizen, it comes as no surprise that attempted homicide weighed heavily in any court proceeding. Apollodorus was attacked late at night near a quarry outside Athens. Nicostratus hit him,

119 D. 22.2 .

120 In the long run, the graphê asebeias should create a "material and moral vacuum" around the killer (Glotz 1973, 436-437, 442).

121 Ps.-D. 58.28-29. There is debate about whether or not the relatives of a slain victim were obliged to file a dikê phonou. Against Gagarin 1979b, 322-323, Panagiotou 1974, 433-434, and MacDowell 1963, 10-11, 94, 133, Grace 1975, 175, Hansen 1981, 30, Hansen 1976, 111, and Tulin 1996, 105-106 have shown that only relatives of killed victims and masters of killed slaves were allowed and even expected to prosecute, but were not obliged to do so. MacDowell 1997 has adopted this opinion in his review of Tulin's book. Sanctions for not taking action were social and religious.

122 Glotz 1973, 439-440.

123 Through the ideology of self-control, masculinity became redefined. Restraining oneself and going to court instead of striking back were now also considered masculine; cf. Fisher 1998a, 81 contra Herman; also Roisman 2005, 177. Trials were emanations of masculinity; concomitantly, going to court was regarded as a kind of vengeance with different means (Fisher 1998a, 92; Cohen 1995, 23, 33, 72, 87; Gehrke 1987, esp. 140, 143). Cf. below 96, n. 327 and 137, n. 526. Bers 2009, esp. 69-76 demonstrates that maintaining one's composure in court, in a situation of stress and anxiety, was beneficial for the speaker. Not being able to keep one's emotions under control was considered unmanly. 
grabbed him around the waist, and tried to throw him down into the quarry. The plot was well prepared. Nicostratus and his men must have observed Apollodorus beforehand, because they knew that he was coming up from the Piraeus. The murder should have taken place outside the city and at night so as to avoid witnesses. But Apollodorus was lucky. Upon his shouting, passers-by rushed to his aid and foiled the plot. Several days later, he faced Nicostratus in court on grounds of other charges. Apollodorus told the judges all that had happened. They were so outraged that they demanded Nicostratus' death. In a pose of self-restraint, however, Apollodorus asked the judges during the timêsis, the assessment of the penalty, not to execute Nicostratus, but to exact a fine of one talent only. ${ }^{124}$ We do not know exactly what Apollodorus told the judges, but the attempted homicide was certainly a major factor in their willingness to vote for Nicostratus' death. ${ }^{125}$

It is communis opinio today that Athenians of the classical period did not go around armed. ${ }^{126}$ But it would be rash to conclude from this fact a high level of peacefulness. Although we do not hear about swords with regard to daily brawls, but only about potsherds (ostraka), the latter were obviously effective and also acknowledged as weapons dangerous enough to cause someone's death. ${ }^{127}$ Phillips has shown that intentional wounding (trauma ek pronoias) involved the use of weapons and that the infliction of serious wounds was tried as a graphê in front of the Areopagos, although it was differentiated from attempted homicide. ${ }^{128}$ Lysias 3 and 4 , in which litigants are suing each other for wounding with ostra$k a,{ }^{129}$ during their ongoing fights about lovers, are probably both graphai

124 Ps.-D. $53.17-18$.

125 Dillon 2004, 94-100 provides a good overview of the case.

126 Herman 2006, 206-215; 1994. Van Wees 1998 provides detail on the fundamental shift from the proud panoply of weapons as testifiers of manly prowess to the display of "conspicuous consumption and leisure" (369) in the form of, e. g., luxurious clothes and walking sticks. This paradigm shift happened during the archaic period and preceded the emergence of the city-state. Cf. also Gröschel 1989 from a different, rather antiquarian perspective.

127 Phillips 2007, 82-83, 98-99. Cf. the reasoning of the speakers in Lys. 3.28 and 4.6.

128 Phillips 2007 passim. On trauma, cf. Pl. Lg. 874e-879b; Arist. Rh. 1374a11-15, 1374a32-b1, 1375a6-7; EN 1135b24-27.

129 Todd 2007, 275-286, 347-353 provides excellent introductions to these two speeches. 
traumatos ek pronoias. ${ }^{130}$ In Lysias 3, the accused faces such a graphê traumatos ek pronoias in front of the Areopagos. He accuses the prosecutor, the young and poor Simon, of having resorted to wanton violence and hooliganism, whereas he, the speaker, did not injure anyone, he claims. ${ }^{131}$ The strategy of the accused is easily discernible. He claims that the prosecution far exaggerates the level of violence committed in these fisticuffs and passes over his own violence in almost complete silence. Whereas the speaker downplays his own aggressive behavior, ${ }^{132}$ he highlights that of his opponent. This is a standard pattern and can be found time and again in the orators. The prosecutor would always exaggerate the wounds, whereas the accused would play them down. Ariston anticipates the argumentation of Conon and his sons, according to which they did not cause serious wounds to their rivals; their actions were just youthful skirmishes typical of teenage clubs. ${ }^{133}$ The speaker of Isocrates 20 clearly trumps up the assault made on him by Lochites. He urges the judges to consider whether or not the law was broken rather than to look into how severe the beating was. ${ }^{134}$

It is highly unusual that Euphiletus as a defendant talks about his sidêrion, ${ }^{135}$ the dagger he used to kill Eratosthenes. This is the only incidence in the whole extant corpus of Attic oratory where a defendant implicitly talks about the weapon he used, and it can only be explained by the specific intention Euphiletus had in mind, to represent the murder he committed as a formal execution prescribed by Attic laws.

Wounds could be instrumentalized against one's opponent. We do not know if the story is true or to what extent it served the purpose of char-

130 Whether the charge was a graphê or a dikê has been contested. Whereas Hansen 1983 thinks that both procedures were possible, Phillips 2007, 93-98 makes a strong case for the existence of a graphe traumatos ek pronoias only. Important sources are D. 54.18 and Aeschin. 2.93; 3.51, 212. Most recently, Todd 2007, 284 favors a dikê traumatos ek pronoias for both speeches, without precluding the possibility that a graphê as well as a dikê was possible in these two cases.

131 Lys. 3.14.

132 Concerning Lys. 3.13 we should wonder why the defendant absconded right after the brawl if nothing serious had happened. Did he run away because he injured someone seriously, just as the prosecutor claims? Normally, defendants would belittle their violence as youthful skirmishes. Cf. also Lys. 4.9, where the defendant claims that his opponent is so insolent as to call a black eye a "wound" and to have himself carried around on a litter to display his terrible condition.

133 D. 54.20. On teenage violence in ancient Athens, cf. Van Looy 1990.

134 Isoc. 20.7

135 Lys. 1.42. 
acter denigration, but Aeschines reproached Demosthenes for having inflicted upon himself a serious cut on the head in order to indict for wounding his cousin, Demomeles of Paeania, with a graphê traumatos $e k$ pronoias in front of the Areopagos. ${ }^{136}$

\section{Public versus Hidden Violence}

In order for a violent act to be regarded as justified, it had to take place in public. ${ }^{137}$ It was the presence of bystanders and passers-by willing to join the fracas that constituted an audience and thus ensured the "proper" evolvement of a violent interaction. ${ }^{138}$ This means that the attendance of a third party not only enabled the litigants to summon witnesses in court later ${ }^{139}$ but also fulfilled vital functions within the violent action proper. The presence of a certain public often reduced the violence committed by forcing the opponents to restrain themselves and remain within the accepted boundaries of exerting violence. ${ }^{140}$ The bystanders also

136 Aeschin. 2.93; 3.51. A similar story is to be found in D. 40.32-33, 57: in the wake of a long-term quarrel between two half-brothers about the question of who would be allowed to carry the name of Mantitheus, Boeotus had the doctor Euthydicus inflict a cut on his head so as to enable him to bring Mantitheus before the Areopagos on charges of attempted homicide.

137 Cf. the telling dialogue between Aegisthus and Orestes (S. El.1491-1495).

138 On the active participation of bystanders and witnesses, cf. Sternberg 2006, $76-$ 103 (p. 77 lists bystander responses in oratory and historiography). Fisher 1998a, 88 with 96, n. 74 lists source passages; cf. Fisher 1998b, 67; Hunter 1994, 138.

139 Isoc. 20.1: Lochites struck the first blow in public. All who were present testified to this fact later in court. The speaker of Ps.-D. 47, an incoming trierarch, seeks to retrieve the naval equipment from his predecessor, Theophemus, who was not willing to hand it over to him. In order to be authorized to exact what was due to him, the speaker obtained a decree and took witnesses with him so as to constitute a public (Ps.-D. 47.34). Obviously, exacting this naval equipment from a trierarch reluctant to do so was a tricky business. The context alone suggested probable verbal abuse, the escalation of the argument, and finally the use of violence.

140 Passers-by save Apollodorus from Nicostratus' attempted homicide (Ps.-D. 53.17). Although the neighbors would sometimes keep aloof when witnessing violence (cf. Plato's Euthyphro and the homicide of Euthycrates as described in Is. 9.16-19), they intervene in Ps.-D. 47.60-61 and prevent the incoming trierarch's son from being led away like a slave. Similarly, even grasping a slave boy violently was considered disgraceful and caused many people to congregate (Lys. 3.16). The presence of a public clearly had a corrective function. In Isoc. 18.6 we see that people rushing to the scene could actually prevent the out- 
served as the first judges on the scene. Their opinion was key in labeling the violence of one party legitimate.

Performing violence in public also facilitates the communication about it. Many violence mongers, therefore, deliberately sought the public scene to dramatize their actions in a theatrical-like frame and endow them with a certain meaning. They felt they were in the right and wanted to display their good conscience to the public, which was called upon to legitimize that particular act. By going public, the aggressor put up his behavior for scrutiny. And through making violence public, it was democratized. Examples of this performative aspect of violence abound in the Attic orators. In the following survey of violent acts committed in public, I will focus on their symbolic meanings. The order in which the cases are presented is descending, from homicide in the political and private sphere, to violence in choregic competition involving death and blows, and finally to daily-life brawls.

The political assassination of Phrynichus (411 BCE) was carried out in plain view, in the Agora, thus following the unwritten code or semantic rules of tyrannicide. The phenomenological difference between tyrannicide and dynastic murder was constructed along constitutional lines. ${ }^{141}$ Whereas in the constitutional hoplite polis, where the culture of public display held uncontested sway ${ }^{142}$ and political murder had to be committed before the eyes of onlookers in order to qualify as a legitimate tyrannicide, dynastic murder mostly took place behind closed doors in tyrannies or monarchies, as in Sicily, Thessaly, and Macedonia. There, the aspect of publicity was of minor importance, since the citizenry was not involved in the moral assessment of the murder the way it was in a constitutional polis. As a rule, citizens killed tyrants in public as a civic act on behalf of the city; family members killed monarchs in their bedchambers for dynastic reasons. Both patterns of standardized killings conveyed specific, culturally coded messages. Through the public killing, a victim was con-

break of open violence. Patrocles and Callimachus were in a heated argument that came close to escalating. Among the passers-by who came running up was Rhinon, one of the Ten, who arrested both of them, when Patrocles denounced Callimachus for illegally holding on to state money (phasis).

141 Cf. Riess 2006 passim.

142 Cf., e.g., Bonanno 1997, 112 ("culture of performance par excellence"); Gentili 1997, 125 ("culture of spectacle"). Cartledge 1997, 6 calls Athens a "performance culture" (with older literature). Even the tension between civic obligations and individual liberty was negotiated and performed in public: Liddel 2007 passim. 
structed as a tyrant who had overthrown or was about to overthrow the democracy and had thus earned his due punishment. The assassins displayed their personal courage and superior power openly for all to see by killing their victim in public, who was thus represented as defenseless and weak. The two metics who carried out the plot on Phrynichus had an instinctive understanding of the symbolic language of Greek assassinations. They were bold enough to face the "tyrant" in public and strike him down in front of eyewitnesses, whose task was to adjudicate the deed. In hoplite poleis the citizenry wanted to be involved in the process of defining the legitimacy of an assassination. Phrynichus died helplessly in front of an audience. The circumspect choreography and careful staging of this assassination resembled an execution or religious sacrifice, making the bloody deed seem necessary to purge the city of tyranny. The dramatic effect of the public killing underscored the success of the city's saviors. Since the standard pattern of tyrannicide in hoplite poleis was fulfilled, the murderers' self-presentation as tyrant slayers in the tradition of Harmodius and Aristogeiton worked and was publicly recognized. The plot was legitimized post factum, the prosecution by Phrynichus' relatives was thwarted, and the killers honored as tyrannicides. ${ }^{143}$

If a violent act was supposed to make sense by transmitting a message, it had to be public. This even holds true in the private sphere. One of our best sources is Lysias 1, where Euphiletus stands trial for having killed the seducer of his wife, Eratosthenes. When Euphiletus learned about the moicheia going on in his house, he created a public by calling upon friends and neighbors to accompany him into his house and catch the adulterer in flagrante delicto. ${ }^{144}$ Although he had many other options for seeking redress at his disposal, ${ }^{145}$ he took a dagger with him, which tes-

143 Cf. above 41, n. 87.

144 Lys. $1.23-24$.

145 Ransom money, the painful and humiliating radish-and-ash treatment (rhaphanidôsis: Ar. Nu. 1083-84; Lucianus, Peregr. 9; X. Mem.2.1.5; cf. Omitowoju 2002, 108; skeptical is Kapparis 1996, 65), apagôgê (since Eratosthenes admitted his guilt [Lys. 1.25, 29], the Eleven could have executed him on the spot), graphê moicheias, and graphê hubreôs. In theory, also an eisangelia and a dikê biaiôn (in case of rape) could be brought against a moichos; cf. Riess 2008, nn. 106-111; Phillips 2006 passim; Omitowoju 2002, 68-71, 112; Ogden 1997, 27; Carey 1995a, 410 on the different possibilities of punishing a moichos. Let us not forget, however, that executions without trials even in cases of apagôgê and endeixis had become obsolete by the second half of the fourth century (Carawan 1984, 120 121). Lysias 1 is earlier, of course, but the development away from executions without trials had started as a consequence of the tyranny of the Thirty. This 
tifies already to his intention to kill the rival. How could Euphiletus possibly legitimize the most serious transgression that Athenian society knew, the killing of another citizen? It was not enough to cite three laws on his behalf later. ${ }^{146}$ The act itself had to appear as being within an acceptable framework. In order to stage this killing as a kind of legitimate execution, prescribed by the laws of Athens, Euphiletus needed accomplices in the act. In pre-modern times, most formal executions were carried out in public. Euphiletus' posse provided the ritual frame which transformed the actual killing into an acceptable act of public vengeance, at least in Euphiletus' and his friends' eyes. We see again that the participants not only fulfilled the function of witnesses later in court, but also had the role of forming an audience that was part of a spectacular ritual. They witnessed the "execution" and by attending the scene and not intervening they validated the killing as such. Beyond these legal considerations, this extreme form of self-help sent an additional message to the bystanders. Euphiletus proved that he was a real man, taking revenge for his wife's and his own compromised honor. Whatever his argumentation in court was, his actual behavior was in line with the old archaic ideology of revenge. ${ }^{147}$ Euphiletus flaunted his physical prowess. He bound the moichos, spoke briefly to him, and defended his oikos by spilling the blood of the victim. This almost religious form of taking revenge worked like a purifying sacrifice. The spilt blood cleansed the house from pollution by washing off the stain of dishonor. Euphiletus did not talk about this underlying message in court. There, he played the modern, rational, and law-abiding citizen by quoting three laws in his support, and could well have been acquitted. ${ }^{148}$ The discrepancy between ideology and dis-

means that Euphiletus' self-justice, although theoretically in compliance with the letter of the law, may have been frowned upon. A case of graphê moicheias is attested among the fragments of Lysias: Against Autocrates for Seduction: Lys. fr. XXVII 58-61 (Carey). Henceforth, I will stick to Carey's numbering of the fragments in his OCT edition of 2007.

146 Probably the nomos tôn kakourgôn (Lys. 1.28), the lawful homicide statute (Lys. 1.30), and the dikê biaiôn (Lys. 1.31). Cf. above 36, n. 68 and 43, nn. 96-98.

147 From a ritual perspective, we could say with Kertzer 1988, 68 that, "socially and politically speaking, we are what we do, not what we think."

148 It is an idle question why Euphiletus probably could go home scot-free. To Herman 2006, 175 the civic discourse was what the dikastai wanted to hear and they believed in this version. In my opinion, the judges did not convict him because, in the end, they approved of Euphiletus' old-fashioned actions. The judges were not called upon to judge a discourse, but Euphiletus' excessive violence. In the three archaic laws he cites he found sufficient support to justify his deed. 
course on the one hand and actual practice on the other could not be more blatant.

Alcibiades' violent behavior toward his wife was also carefully staged and enacted in public. When she filed for divorce with the archôn basileus in the Agora, Alcibiades called his friends so as to have an audience and 'carried his wife off from the Agora by force, making clear to everyone his contempt for the Archons, the laws, and the other citizens. ${ }^{149}$ The dramatization of violence again transmitted a symbolic message to the bystanders. Alcibiades did not acknowledge his wife's actions in filing for divorce. Like the archaic father who killed his debauched daughter, Alcibiades displayed that he was fully entitled to wield his boundless power as a kurios over his wife, whose subordinate status was thus fully re-established. ${ }^{150}$ Alcibiades' insistence on being in charge worked at the expense of the authority of the archôn basileus, whose task it was to provide a minimum of protection to Athenian wives. It lies in the logic of the power of performance that no one intervened to stop Alcibiades from committing this unlawful act. The woman died only two weeks later under mysterious circumstances. ${ }^{151}$

In the realm of choregic competition we see that political commitment and involvement in this high-pitched liturgy were inextricably intertwined. Any activity in this field belonged in the public domain and enticed the participants to resort to harsh measures. Political, social, and economic rivalries between elite members of Athenian society were also expressed through the competition of the choruses. ${ }^{152}$

A rich and politically active Athenian citizen equipped a chorus and had the boys practice in his house. In his absence, one of the boys, Diodotus, was given a potion, drank it, and died in front of all the other trainees. The boy's brother, Philocrates, brought a dikê phonou for unintentional homicide or a dikê phonou for bouleusis (normally 'planning,' 'plotting') of unintentional homicide against the chorêgos before the Palladion. ${ }^{153}$

149 Ps.-And. 4.14. Cf. above 44, nn. 101 and 102.

150 Plutarch reports many more instances of Alcibiades' exerting violence against social inferiors. He slaps his teacher, for example, because he does not have the Homeric texts available: Plu. Alc. 7.1.

151 Cf. above 44, n. 102. Influential biographies on Alcibiades are De Romilly 1995; Ellis 1989; Hatzfeld 1940. On the literary presentation of Alcibiades in the major sources, cf. Gribble 1999.

152 D. 21.5-6.

153 Antiphon 6.16. On the meaning of bouleusis in this specific context (negligent homicide or involuntary manslaughter through failure to do something), cf. 
Although all parties agreed that Diodotus' death was accidental, the question remained how liable someone was for actions taken by his subordinates. The accused was especially enraged about the homicide charge, because Philocrates had reconciled with him some time after the deadly accident but now resumed the prosecution of this incident. This re-opening of the case happened for political reasons, according to the speaker, for he was about to bring an eisangelia against Philocrates' friends. They might have bribed Philocrates into indicting him for homicide again. This was a clever move on their part, because as a suspect of homicide he would be banned from the Agora and would thus not be able to plead his cases. What might the intentions of the opponents have been in rendering the chorêgos silent through a trial for homicide? The speaker insinuates that his political adversaries cooperated with Philocrates so as to frame him for homicide through negligence. The actual death occurred in public, ${ }^{154}$ which means that the opponents benefitted from the publicity of the accident. Since it happened in front of many people, the weakness of the chorêgos became blatantly clear. He was not able to protect the boys who trained on his behalf in order to embellish his chore $\hat{e}$ geia. His lack of power was fully revealed and his whole social standing and political status were thus undermined. If he could not take care of young boys, he was even less suited to serve as chorêgos for the city. The death of the boy in public dramatized the chorêgos' lack of power. The ensuing dramatization of the case in court may have had long-term effects by severely damaging the reputation of the chorêgos, even in the event of his acquittal. ${ }^{155}$

In the realm of choregic competition, there were other, far less harmful, but still effective means of knocking out your competitor. In front of the assembled citizenry and foreigners attending the Great Dionysia, Alcibiades punched Taureas, a rival chorêgos and/or one of his chorus boys in the face and drove them out of the theater of Dionysus while the performance was under way. ${ }^{156}$ Such disrespect for the religious character of the festival was prohibited under any circumstances: concerns about the

Heitsch 1984, 95-98 and below 94, nn. 320, 322, and 95, n. 324. On the Palladion, cf. Carawan 1998, 391; Todd 1993, 274, n. 17; Osborne 1985, 57; MacDowell 1978,$116 ;{ }^{2} 1966,63-64$.

154 Antiphon 6.19.

155 Wilson 2000, 116-120 places the incident within the whole context of choregic competition at Athens.

156 Ps.-And. 4.20-21; D. 21.147; Plu. Alc. 16.5-8; cf. Th. 6.15-16 (indirectly); Wilson $2000,148-155$. 
citizenship status of chorus participants had to be voiced before the performance. This incident shows once more that Alcibiades deliberately and self-indulgently trampled on democratic rules. The audience was well aware of this. They were shocked at the outrageous act, felt pity for Taureas, and sided with his chorus by not wanting to listen to Alcibiades' chorus. Are we to imagine a tumultuous scene here? Did the audience render an informal verdict on the chorêgos' social behavior by hissing, shouting, gesticulating, and not listening? It is equally telling that the judges, influenced and intimidated by Alcibiades' social and political power, wealth, and personal charisma, awarded the prize to Alcibiades despite the unanimously hostile reaction of the public toward Alcibiades' flagrant transgressions. Did Meidias imitate Alcibiades around sixty years later?

Taureas was, indeed, not the only chorêgos to suffer from his opponents' mischief. During the long-term conflict between Demosthenes and Meidias, the latter saw his chance coming when Demosthenes became chorêgos and was responsible for a chorus and its performance at the Great Dionysia in 348 BCE. ${ }^{157}$ Meidias wanted to undermine Demosthenes' commitment in any way he could, so he bribed the teachers of the chorus to prevent the chorus boys from completing their training. ${ }^{158}$ The result would have been a bad performance and Demosthenes' complete embarrassment in the theater of Dionysus. It is clear that Meidias aimed at the loss of face for the chorus and its chorêgos. ${ }^{159}$ When these attempts failed, Meidias broke into a goldsmith's factory in order to destroy Demosthenes' crown and robe so as to hinder him from actually performing in public. It was only because the shop owner arrived at the scene that Meidias' plot failed. ${ }^{160}$ He now planned a direct, physical attack upon his opponent as a last resort, in and through which the conflict between the two rivals should culminate. Like Alcibiades, Meidias had a good feel for the semantics of violence at Athens and intentionally sought the most public frame imaginable for punching Demosthenes: the stage

157 Dillon 2004, 87-94 provides a good overview of the case. On the problematic nature of hubris in this case, cf. Fisher 1992, 44-49.

158 This means that Meidias tried to disturb the rehearsals. To Schechner $(1985,18-$ 21; 1977, 132-136), rehearsals as well as the cooling-off and aftermath phase after the performance of a play are integral parts of theatrical production. From this perspective, Meidias' attack on the rehearsals of Demosthenes' chorus can be equated with an attack on the actual performance of the chorus.

159 D. 21.15-17. Cf. Versnel 1999, 137-155 on malicious joy (Schadenfreude).

160 D. 21.22. 
of the theater of Dionysus. ${ }^{161}$ With citizens and foreign visitors assembled there to celebrate the Great Dionysia, the choreographic staging was perfect with the theater as an ideal setting for the showdown. In this festive context, Meidias wanted to make it clear to everyone that Demosthenes deserved to be punched in the open. Why did Meidias not want to attack Demosthenes behind closed doors? Had he done so, he could not have transmitted the symbolic message he wanted to send to the dêmos. Instead, Meidias preferred to stage his corporal insult within the Dionysiac frame, within the theater, so that everyone could see and experience what he dared to do. Meidias counted on Demosthenes' not striking back. Thus, he could portray him as a coward, a weakling who could not defend his honor in public and would therefore lose face. Since every dramatization is open to interpretation, Demosthenes could charge this act, which was so humiliating to him, with a completely different meaning. In his speech against Meidias, one of his masterpieces, he was at ease portraying himself as the innocent victim living up to the democratic ideal of appealing to the courts, whereas his opponent had resorted to barbaric, tyrannical, and anti-democratic bullying. Meidias' physical attack within a sacred sphere-this is how Demosthenes characterizes the theater of Dionysuswas unheard of. ${ }^{162}$ Previous chorêgoi were also in competition with each other, but always refrained from direct violence (apart from Alcibiades) ${ }^{163}$ Meidias was brazen enough to break the laws and disrespect the religious feelings of the Athenians. Demosthenes here speaks the new democratic polis-discourse of self-restraint and peaceful conflict resolution. It cannot have constituted the whole truth. Meidias must have felt he was in the right and therefore justified to exert violence openly. Given the highly symbolic setting of the showdown, it is very unlikely that Meidias did not plan this coup carefully in advance. If it had not been a strategic move, Meidias would not have enjoyed Eubulus' backing. Why Meidias thought he was in the right, we do not know. Demosthenes may have previously violated crucial rules of the upper-class game of competition and thus provoked Meidias in a way that warranted the high risk of challenging a chorêgos in public. It lies in the nature of things that we do not hear anything about Demosthenes' transgressions in his

161 Cf. Wilson 2000, 156-168 on the whole incident from a theatrical and performative point of view.

162 D. 21.74.

163 D. 21.61. 
own speech. ${ }^{164}$ How difficult it was for both contenders to gauge public opinion is obvious from the aftermath of the incident. First of all, the people supported Demosthenes' version in a probole , a preliminary verdict against Meidias, who, with his punch, had disturbed the peace of a religious festival. Nevertheless, it is uncertain whether Demosthenes actually went to court at all. He might have written the speech without intending to deliver it, bribed by Meidias not to bring charges against him. ${ }^{165}$ If this is true, Meidias was afraid of a court sentence and Demosthenes might have welcomed this deal, because he could not predict the opinion of the judges either, and might have run the risk of losing face once again in public, had the judges voted against him. From this perspective, acquiescence might have been beneficial for both sides. But another scenario is also conceivable. If the trial took place, Demosthenes may have won the case. Since this lawsuit was an agôn timêtos, the judges decided upon the penalty and may have condemned Meidias to pay a small fine. ${ }^{166}$ At any rate, he must have come out of these troubles almost unharmed. Notwithstanding public opinion as expressed in the probole, the judges (if the trial took place) did not come to a sweeping agreement on how to assess this incident. ${ }^{167}$ Whatever scenario one might prefer, one thing is certain: there was uneasiness on all sides about how to deal with open violence.

On a less official level, we see that the public aspect of violence was also paramount in daily-life situations. Conon's son Ctesias gathered his father and his drinking mates to attack Ariston in the Agora. ${ }^{168}$ Although the incident happened at night, there were still many people in the Agora and its vicinity. Ctesias acted on the spur of the moment. He probably did

164 MacDowell 1990, 8.

165 Aeschin. 3.52; Plu. Dem. 12. Most recently, Harris $(1992,75 ; 1989)$ has argued in favor of the speech's delivery. Lehmann 2004, 120-125, Dreyer 2000, Wilson 1991/92, 187, and Fisher 1990, 136, however, adduce good reasons why Demosthenes did not deliver the speech. MacDowell 1990, 24-27 is careful and rather assumes that Demosthenes did not deliver the speech, at least not in the form we have it preserved today. Even more agnostic is MacDowell 2009, 246. The question remains irresolvable.

166 Harris 1989. MacDowell 1990, 28 thinks that Meidias paid 30 mnai either to the fisc or privately to Demosthenes.

167 Herman 2006, 173 is right in saying that a Corse in pre-modern times would have found Demosthenes' dodging behavior dishonorable. Many Athenian dikastai must have felt similar, hence Demosthenes' uncertainty.

168 D. 54.7-8. We must keep in mind that a lot of what Ariston tells us is character assassination. On Demosthenes' strategy in detail, cf. MacDowell 2009, $242-$ 245. 
not think about potential witnesses he might need in court to defend himself. Ctesias called on his friends to help him in beating Ariston to a pulp and to constitute a witnessing public. They were eager to teach Ariston a lesson in plain view of other citizens. Other arguments and frictions had preceded this incident and we can be sure that Ariston does not tell us his responsibility for the escalation of the conflict. The ensuing paragraphs of the speech show that the thugs desired to have an audience and deliberately created one. Conon abused the seriously injured Ariston verbally and danced like a rooster over the victim as he lay on the ground. ${ }^{169}$ This ritual of humiliation served the purpose of enacting hubris and brutally mocking Ariston. This performative sort of taunting was supposed to be visible and almost tangible to the bystanders. Ariston's loss of face was complete. All that could be done was for the onlookers to carry him home. There, the neighbors showed deep concern and wanted to know what had happened. ${ }^{170}$ It was important to Ariston and his family that the neighbors fully saw the state he was in. Suffering had to be visible to arouse sympathy for the victim. Injuring an Athenian citizen like this was beyond the acceptable threshold of violence. The outrage caused to Ariston's family and friends would be highly useful in the ongoing conflict with the other party.

After the detention and whipping that Archippus suffered from Teisis and his friends, Archippus' brothers laid him, unable to walk by himself, on a litter, carried him to the samples market, and showed him to many Athenians. ${ }^{171}$ One might suppose that, similar to Ariston's fate, this public demonstration of Archippus' terrible state contributed to his loss of face, but instead it highlighted the injustice and hubris of the perpetrators. Seeing what an innocent Athenian from the higher echelons of society had endured during his entrapment should stir up emotions and mobilize the public against Teisis and his reckless friends. The place of the samples market was certainly chosen deliberately. Archippus was just an example

169 Cf. Hoffmann 1974 on the iconography of the rooster in Athenian culture. Fisher 2004, esp. 71; 1998a, 69 and Csapo 1993, esp. 13, 15, 124 have worked out the symbolic significance of the rooster in Greek society, embodying the ideal of a "real man" and an agonistic, almost martial mentality. Csapo does not mention the Conon episode. Cf. in a similar vein, Winkler 1990, 49. Herman 2006, 282 287 tries to belittle the symbolic value of cockfights and offers no explanation of the phenomenon.

170 D. 54.20 .

171 Lys. fr. CXXIX 279.6. 
of Teisis' hybristic attitude and wanton insolence. ${ }^{172}$ The performative aspect of suffering fulfilled a strategic function in the next spat against the opponent.

Although the victims of violence clearly suffered under its public aspect-they must have felt the humiliation even more painfully under the gaze of curious onlookers - they might have preferred the exchange of blows taking place in public to violence committed out of the public limelight. Violence committed in the dark of night or in a closed room was not accessible to public scrutiny and assessment, and was likely apt to be considered excessive and illegitimate. Someone who resorted to violence without granting a sufficient level of observability was suspect in the eyes of the victim and the public. The notion was that he had something to hide or had a bad conscience for using violence at all. For this reason, many users of violence preferred striking in public. Not dramatizing one's own violence had another drawback. In the absence of an audience, one could not convey a symbolic message to the citizenry, a serious defect when it became necessary to defend one's actions in court.

Athenian citizens would readily resort to violence in the dark or behind closed doors, however, when they simply wanted to avoid detection or when there was no symbolic message to be transmitted. In the first case, things were more complex than it seems. If someone deliberately used violence outside the public gaze, he removed it from the controllable sphere. Since the public insisted, however, on the assessment of violence against Athenian citizens, this breach of the rules was charged with a negative symbolism and deemed outrageous and illegitimate. In the second case, the violence was directed against subordinates, like slaves ${ }^{173}$ and wives. This kind of coercive power was understood in paternalistic terms and taken for granted. It did not have to be adjudicated by fellow citizens, because it was unproblematic in their eyes.

Thus, violence against another citizen was ideologically not permitted inside the house or outside the city. Archippus' neighbors and the people in the samples market were outraged when they learned what he had endured at the hands of Teisis and his friends. Since the body of an Athenian citizen was inviolable and could not be bound except under special cir-

172 Todd 2000, 348.

173 Klees $1998,176-217$ on the punishments that slaves had to fear. On the ideology of the sacrosanct body of the citizen and its implications for penalties meted out to slaves, cf. Hunter 1992. 
cumstances, ${ }^{174}$ Archippus' detention for a whole night within Teisis' house and his whipping by a slave during a festival constituted multiple transgressions of socially accepted boundaries. Whereas Teisis did not want to convey any symbolic message and therefore wanted to hide this maltreatment of an Athenian citizen, the public immediately charged this incident with a high level of negative meaning. Archippus and all good citizens now regarded Teisis as a hubristês. Even his friend Antimachus was shocked to see what had happened and demanded the immediate release of Archippus.

We also know the judges' reaction when Apollodorus told them about Nicostratus' attempt to kill him outside the city by throwing him into a quarry late at night. ${ }^{175}$ Nicostratus was keen to avoid any witnesses. Since homicide was almost always beyond the acceptable level of violence, any adjudication would have resulted in a negative outcome and was therefore to be avoided outright. All that Nicostratus was striving for was the silent disappearance of Apollodorus. If his corpse had been found in the quarry, it might have looked like an accident. To the judges, Nicostratus' treatment of Apollodorus was a shocking act that required the death sentence.

In Antiphon 1, the stepmother did not want to be caught in her plot to poison her husband (if this was her intention). Therefore, the fatal act was not dramatized like the probable poisoning of the chorus boy in Antiphon 6 . But it was precisely this hidden homicide that was deemed highly offensive and led to her prosecution years later by her stepson.

However fictional Antiphon's tetralogies may be, they are valuable documents for the Athenian canon of values. In Antiphon 2.1 we learn

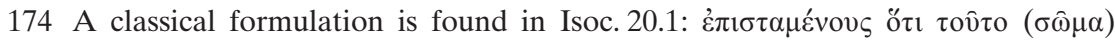

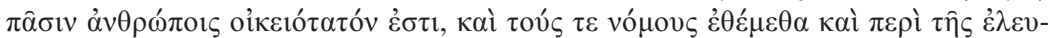

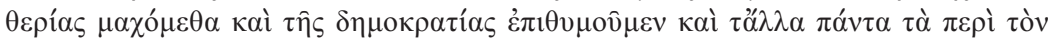

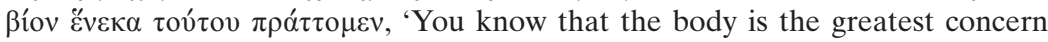
for all people: we have established laws and we do battle over its freedom; we desire democracy and we do everything else in life for its sake.' Even a killer could not be detained in a private home, and no one was allowed to do him any harm. Instead, one had to inform the state authorities (D. 23.28). For exceptions in the apagôgê procedure, cf. Riess 2008; Volonaki 2000; Hansen 1976. On the inviolability of the Athenian citizen's body, cf. Ruiz 1994, 16-20. Illuminating on the Athenians' obsessiveness with the male body is Fisher 2005, 77-78, including aspects such as military value, nudity, aesthetics, and morals. On D. 22.55-56 (Androtion treated free men like slaves), cf. Cohen 2005b, 170. Cf. below 126, n. 461.

175 Ps.-D. 53.17-18. 
about a rich man who was killed in the street at night together with two slaves. We do not hear much about the relationship between the victim and his killer, only that the two were long-time enemies and had fought against each other in court multiple times. On these occasions, the victim had always carried the victory. Finally, the defeated man was so frustrated that he was ready to transgress the ultimate boundary and kill his opponent. The killer again had no symbolic message to convey, but probably sought to satisfy his lust for revenge by getting rid of his opponent physically: from his side, then, publicity was neither required nor desired. Going to court multiple times did not prevent this killing. On the contrary, the various defeats that the man who later turned murderer had suffered accumulated to such a degree of frustration and helplessness that he saw no other way out than to kill his archenemy under the protection of darkness. In this case, the court system was not able to settle a longterm conflict for good, but even contributed to its fatal escalation.

It is important to note that committing violence in public could sometimes be judged negatively when it meant the transgression of a threshold. Religious festivals were not to be disturbed, and violence committed in this context was regarded as disruptive, at least by the victim. Demosthenes is outraged at the punch he suffered in open daylight in fulfilling his religious duty as a chorêgos. ${ }^{176} \mathrm{He}$ initiated a probolê against Meidias, a public suit for having committed a crime during a religious festival. The Assembly of the People held a preliminary hearing and voted against Meidias. This verdict of guilt, however, was only a recommendation and did not bind the dicastic court, in front of which the case was to be tried later. The fact that Meidias certainly interpreted the incident differently shows once more that the boundary between legitimate and illegitimate violence was flexible and could shift continuously around its "defining" semantic markers according to the viewpoint of the speakers.

Beside these serious aspects, elements of play must not be overlooked in the discussion of the public side of violence. The skirmishes of the upper classes must have been entertaining for the lower ranks of society. ${ }^{177}$ One gains the impression that passers-by sometimes engaged in brawls just for the fun of it. Lysias 3 is one of our best sources for repetitive brawls in public. They seem to have been frequent and to have followed specific conventions. One indispensable part of the social norms in

176 D. 21.217.

177 Cf. below 286 on Philocleon's lawcourt addiction in Aristophanes' Wasps. 
place were the many people rushing to the scene, providing comments, and even engaging in the mêlée by lending a helping hand to one party. Perhaps we can explain the active participation of onlookers in these scuffles by a certain lust for violent rivalry. Some of this entertainment aspect is clearly preserved on the level of representing violence in court as well. In order for a speech to be successful, it had not only to persuade the judges, but also to entertain them. The speaker of Lysias 3 gives an ironic cast to his description of the fisticuffs $;{ }^{178}$ in a similar vein, Euphiletus plays the naive and gullible simpleton easily duped by his wife; ${ }^{179}$ the handicapped man in Lysias 24 (For the Disabled Man) aptly parodies upper-class discourses. Earnestness and ironic play, seriousness and cheerful entertainment pervaded daily life and its discursive representations. ${ }^{180}$

To summarize. Most conflicts attested in the forensic speeches concern male Athenian citizens, mostly from the upper echelons of society, ${ }^{181}$ worrying about their honor and public status. This may be one of the reasons why the parties involved in a conflict nearly always called for witnesses. Violence should ideally take place in the open, so that everyone could see what was going on. As long as violence took place in public, it remained subject to observation and checking. A "felicitous" act of violence depended on its performative aspect. Violent clashes for which the contestants sought the public limelight were understood as performances. The publicity of the violent act was crucial in channeling violence, restricting its degree, and conveying symbolic messages. Only the existence of a symbolic meaning, a certain intersubjective significance, ensured that a violent act made sense. From this perspective, Alcibiades was subjectively right in dragging his wife across the Agora in broad daylight. Meidias was subjectively right in punching Demosthenes in plain view of all. Danger was imminent, however, when violence was committed in a secret place, hidden behind closed doors, or at night. Such an act signaled to the citizenry that there was something wrong, that the norms of committing violence had not been observed, that the perpetrator had something to hide, had a bad conscience, and did not want to expose his violent behav-

178 Lys. $3.15-18$.

179 Porter 1997 and Perotti 1989/90 even go so far as to doubt the historicity of the speech. Opposed to this view are Wolpert 2001, 420, n. 15 and Gagarin 2003b, 2, who argue that the employment of literary elements does not necessarily mean that speeches were mere literary exercises.

180 Cf. Bonner 1922.

181 Fisher 1998b, 61 emphasizes the contrast between upper-class trials of strength and lower-class petty crime. 
ior to public scrutiny. As a result, this kind of hidden violence was outside the boundary of acceptable violence: it was problematic in its anti-democratic character and was thus tyrannical (cf. the charts below). After all, the tyranny of the Thirty (as well as the blasphemous mutilation of the Herms) was based on secret conspiracies at night. Also with regard to violence, Athenian culture was bound to publicity. The staging of social interactions took place in every domain of life, so that one can speak of a culture of public display. ${ }^{182}$ The upshot of this theatricality of life was that some political figures, who were exposed to publicity more than other citizens, voluntarily subjected themselves to constant public screening by living in the open and giving up most of their private sphere. Demosthenes and Agesilaus, for example, lived through a permanent dokimasia, so to speak, thus making the social control of their lives all-pervasive. Thriving in this pressure-cooker atmosphere, they were proud of their accomplishments, which were immediately open to the gaze and admiration of all. ${ }^{183}$

\section{Day versus Night}

Like the dichotomy between the public and the non-public aspects of violence, the time of its commitment, either day or night, could also be used to advantage post factum by the litigants. ${ }^{184}$ Murdering a man and his two slaves in the open street by night was judged as the ultimate withdrawal of the atrocious deed from public gaze and assessment. ${ }^{185}$ Apollodorus barely escaped from attempted homicide near the quarries late at night, ${ }^{186}$ but even before this most heinous attack, Nicostratus had invaded Apollodorus' property at night, cut down the vines and fruit-trees, and destroyed olive groves ${ }^{187}$ the worst sort of vandalism. Since bystanders would not have condoned this level of destruction, Nicostratus chose to avoid the public gaze.

A certain Simon had invaded the house of the accused by night, beat him up, and insulted the women inside by his sheer presence. To the ac-

182 Cf. above 52, n. 142.

183 D. 18.10.

184 Cf. Phillips 2000, 197-198.

185 Antiphon 2.1.

186 Ps.-D. 53.17.

187 Ps.-D. 53.15. 
cused this behavior was the utmost hubris. ${ }^{188}$ A similar fate, if not worse, befell the public slave Pittalacus. In the wake of his quarrel with $\mathrm{He}$ gesander about the young male prostitute Timarchus, Hegesander and Timarchus broke into Pittalacus' house late at night, destroyed his furniture, killed his fighting cocks, bound him to a pillar, and flogged him severely. All this happened only because Pittalacus had become jealous after Timarchus' leaving him for Hegesander and continued pestering the new couple. ${ }^{189}$ Teisis invited Archippus to come to his party after dinner and thus lured him into his house. Just after his arrival, Teisis seized his guest and fastened him to a pillar, where his ordeal would continue throughout the night. Meidias had broken into the goldsmith's den at night to destroy Demosthenes' crown and robe. ${ }^{190}$ And we should not forget that one was allowed to kill a thief at night, however small the sum of money was which he was going to steal, if one could catch him in the act. ${ }^{191}$ Committing a crime at night created aggravating circumstances. It was for this reason that Euphiletus took friends and neighbors with him to confront the moichos Eratosthenes at night.

Nevertheless, a victim could also instrumentalize the daytime in his favor by making the violent act committed during the day appear worse and more brazen than one committed at night. Teisis' second maltreatment of Archippus with the whip took place during the day. ${ }^{192} \mathrm{Ar}$ chippus' friend, who pleads for him in court, mentions this detail because it is supposed to shock the judges. Demosthenes is more explicit about the seriousness of a daytime attack. He was outraged to have been assaulted by Meidias in the theater of Dionysus early in the day. According to him, it was bad enough to suffer bodily harm at night from a drunken rascal, but it was even worse when the assailant did not shun the bright sunlight and was sober, implying a special audacity on his part and the deliberate breach of boundaries. ${ }^{193}$

188 Lys. 3.23.

189 Aeschin. 1.58-59.

190 D. 21.16.

191 D. 24.113-114 (law on theft). Cf. Cohen 1983, 58, 92. Cf. the similar regulation on the Roman Twelve Tables 8.12-13; cf. Dig. 4.2.7.1 (Ulpian); 9.2.4.1 (Gaius); 47.17.1 (Ulpian).

192 Lys. fr. CXXIX 279.4.

193 D. 21.74. 


\section{Inebriation versus Sobriety}

Just as in the rhetorical treatment of the daytime-versus-nighttime dichotomy, we observe a similarly contradictory evaluation when it comes to the influence of alcohol in violent interactions. ${ }^{194}$ According to the circumstances and the viewpoint of the speaker, the use of alcohol could be judged negatively or positively and thus manipulated to serve one's own purpose in court. The defendant often used drunkenness as a kind of excuse to justify a certain reckless behavior. In most cases, however, the consumption of alcohol was criticized when it led to the outbreak of violence. The relevant passages in the orators are numerous and clearly show that violence often had its roots in drunkenness. ${ }^{195}$ At times, drunkenness and anger were almost equated as blurring the perpetrators' states of mind and leading to violence. ${ }^{196}$ Rhetorically, it was also effective to build up the opponent as an intoxicated transgressor of multiple boundaries and to construct one's self-image in contrast to this foil. Conon's sons were constantly drunk, whereas their victim, Ariston, was always sober. ${ }^{197}$ The consumption of alcohol, however, is not consistently seen negatively. The question is not only whether or not drunkenness is a morally reprehensible state, but also if, under certain circumstances, soberness is not even worse than drunkenness. From Antiphon's Third Tetralogy (Antiphon 4), we can deduce that drunken brawls were quite normal events. A young man had killed an old man in a fistfight. Both were drunk. In order to accuse the young man effectively, the prosecutor passes over in silence the inebriation of the killed victim and makes use of a stereotype: young men are more prone to violence because they are strong, proud of their noble birth, and not used to alcohol, while at the same time they drink more than old men, who are more self-restrained. ${ }^{198}$ There may have been an ideological age limit for drunkenness. It was inappropriate for an old man to become drunk and get carried away to such

194 Cf. Phillips 2000, 199-201.

195 E.g., Lys. 3.11-12, 18-19; Aeschin. 1.58; D. 21.38-40, 180; D. 22.63. A connection between drinking and brawls is also drawn, for example, by a fragment of Middle Comedy, preserved from Alexis' play Trophonius: Alexis F 239 (K.-A.). The close connection between violence and alcohol is culturally determined and variable. In Japanese culture, for example, alcohol is associated with leisure, relaxation, and peacefulness. Cf. Riches 1986, 16.

196 E.g., D. 54.25 .

197 D. $54.3-4,7-8,16$.

198 Antiphon 4.3.2. 
a degree that he engaged in a fistfight with a youngster. ${ }^{199}$ The accused, however, tears apart this ideological construct. According to him, 'many young men act with restraint, and many of the elderly become violent when drunk. ${ }^{200}$ Since the prosecutor's argument cuts both ways, it is more important, according to the accused, to ask who actually started the fight. In this scenario, the reproach of drunkenness does not work and the defense takes full advantage of the prosecutor's logical inconsistency. Since both men were drunk, guilt could not be assessed along these lines. The negative power of alcohol is thus neutralized in this case. Drinking was not an inappropriate activity for the young man, nor should it be held against him in the evaluation of his deed. An almost positive evaluation of drunkenness is given by the accused in Lysias 3; when drunk, he argues, one cannot wound in premeditation. After all, one regrets one's deed after recovering from the effects of alcohol. ${ }^{201}$ The accused in Lysias 4 takes exactly the same line of argumentation: 'We admit we were going after boys and flute girls, and that we had been drinking; so how can this be premeditation? I certainly do not think it can. ${ }^{202}$ It is fascinating to see that one and the same defendant can give two opposite interpretations of the almost stereotypical consumption of alcohol within only a few lines of his defense speech. Applied to one's own violent behavior, drunkenness serves as an excuse and even justification. ${ }^{203}$ Turned against one's opponent, it fulfills the purpose of character denigration: 'He has been aroused by the slave girl, he is prone to drunken violence and too quick with his fists, and one has to defend oneself. ${ }^{204}$

Demosthenes is able to phrase the dialectic between drunkenness and sobriety even more sharply. In his speech against Meidias, the latter's so-

199 But cf. Philocleon's rowdy misbehavior in Ar. V. 1322-1449. If this ideological construct existed, the defendant could also have argued that the old man should not have been drunk, that in fact, he had violated a rule of social interaction, whereas it was normal for the young man to drink. This line of argumentation, however, seemed too bold to the defendant, especially in light of the old man's death.

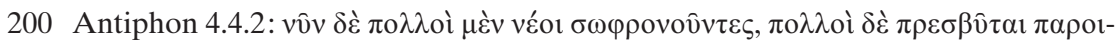

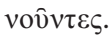

201 Lys. 3.43.

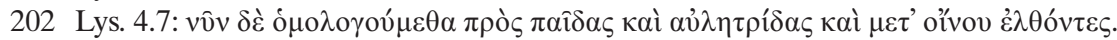

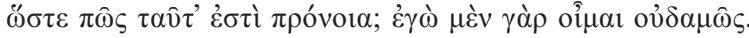

203 In a fragment of New Comedy, a father does not accept the drunkenness of his son (?) as an excuse: Philippides F 27 (K.-A.).

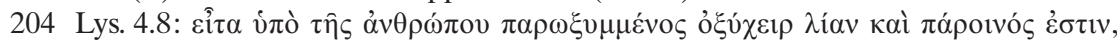

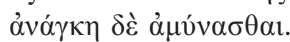


berness is characterized as being worse than any state of drunkenness, because it testifies to his deliberate hubris. In comparing the deadly conflict between Euaeon and Boeotus, the latter of whom was drunk when he struck Euaeon and was in turn killed by him, with the insult Demosthenes suffered by the hands of Meidias, alcohol is represented as something negative, ${ }^{205}$ but soberness on the part of the hubristês is something far worse: 'I, on the other hand, was the victim of outrage at the hands of an enemy who was sober, in the morning, acting to humiliate me not under the influence of wine. ${ }^{206}$ The masterful manipulation of the dichotomy of drunkenness versus soberness was staged successfully, working to the detriment of the opponent and to Demosthenes' favor. It is equally striking that Demosthenes makes full use of the culturally entrenched, double-edged sense of the drunkenness-versus-soberness metaphor to create the palpable discrepancy between the devastating portrayal of his opponent and his own self-representation. The ideological construct of the drunkenness-versus-soberness dichotomy unfolds in only two consecutive sentences. This condensation is typical of Demosthenes' supreme rhetorical skills and highlights the degree to which this pair of opposites was open to interpretation.

As if Demosthenes' negative characterization of soberness were not enough, Antiphon, two generations earlier, employed the reproach of soberness as a powerful weapon to indict someone for homicide in his First Tetralogy (Antiphon 2). It is not clear who the fictional prosecutor is, but he claims that the victim was neither killed by a drunken man nor in a quarrel on the spur of the moment. ${ }^{207}$ This murder was carefully prepared and therefore deliberate. In this argumentation, soberness serves as a thoroughly negative quality, to be equated with intent and even premeditation. To conclude, the topic of drunkenness and soberness could be exculpatory or condemnatory, depending on the viewpoint and the argumentative strategy of the speaker. ${ }^{208}$

205 D. 21.73. In the same passage (D. 21.71), Demosthenes gives a second example and relates the story of Euthynus the wrestler, who engaged in a fistfight with the prizefighter Sophilus at a private party. The passage is so vexed that it is unclear who actually killed whom.

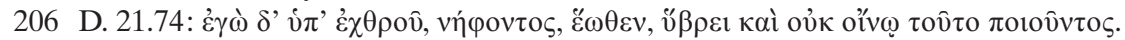

207 Antiphon 2.1.4.

208 Menander takes this dichotomy to an ethical level in one of his comedies: oủ $\gamma \grave{\alpha} \rho$

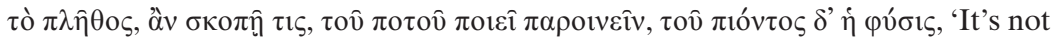
the number of glasses, if you'll think, accounts for brawls, but what they're like who drink,' transl. in Menander F 627 (Edmonds). 


\section{Old Age versus Young Age}

Prosecutors and defendants could also instrumentalize their ages in favor of their own causes and to the detriment of their opponents. Like the daytime-nighttime and the drunkenness-soberness dichotomies, age-related arguments, too, could cut both ways, and the litigants were apt to manipulate and thus instrumentalize their own ages and those of their opponents. The prosecutor in Antiphon's Third Tetralogy, who accuses a young man of having killed an old man, plays this game in close connection with the drunk-sober dichotomy and does so in a manner that is not altogether convincing. Young men are by nature bolder and more aggressive, because they can rely on their physical strength when it comes to fights with older men. Old men, in contrast, are weaker and better at self-control. ${ }^{209}$ Very clearly, old age is a positive argument in this setting, but it is easily refuted by the young murderer's friend who speaks on his behalf. ${ }^{210} \mathrm{He}$ implies that it was inappropriate for the old man to become drunk at all, whereas it was quite normal for the young man to indulge in alcoholic excesses from time to time. The more advanced maturity of the elderly man should have prevented him from breaking this rule of interaction. It was irresponsible of him to pick a fight with the young man, who was superior in strength. Because of his recklessness, the old man had in fact deserved to die. ${ }^{211}$

In his speech of prosecution, Ariston argues along similar lines when he states that, whereas the abuse committed by young men is somehow understandable, but should still be punished, violence on the part of an elderly man-Ariston defines "elderly" as being above the age of fifty-is inexcusable. Conon should have checked his sons' behavior and stopped their abusive actions. Instead, he not only condoned their maltreatment of Ariston, but even took an active part in it. According to Ariston, an old man's inclination toward violence and, even more so, actual misbehavior is socially unacceptable. Therefore, Conon actually deserved death. ${ }^{212}$ Given these age-related rules of interaction, one wonders how elderly men reacted when facing charges of battery or even at-

209 Antiphon 4.3.2.

210 Antiphon 4.4.2.

211 On the concept of old age in antiquity, cf. the contributions to Gutsfeld Schmitz 2003, esp. Baltrusch's disillusioning piece on Athens ("An den Rand gedrängt. Altersbilder im Klassischen Athen," 57-86) and Brandt 2002, 41-85 on old age in Classical Greece in general.

212 D. 54.21-22. 
tempted homicide. How would they defend their problematic behavior, which was supposedly inappropriate at their age? A prime example is the mature speaker in Lysias 3, who has to refute a graphê traumatos ek pronoias brought by the younger Simon against him. From the outset of the speech, the older man admits his foolishness with regard to the boy Theodotus, given his age, and thus undermines the most serious attacks of the prosecutor. He coyly tries to win the sympathy of the judges by portraying himself as having succumbed to the charms of the young boy. Spellbound by Theodotus' beauty, he acted irrationally. ${ }^{213}$ This admission of his own weaknesses creates subtle irony and is supposed to excuse his ensuing violent actions as being committed under the influence of erotic passion. But the accused is clever enough not to rely solely on the judges' goodwill and understanding for his amour. Self-confidently, he also puts his old age to strategic use by emphasizing the responsible role he plays in the city. ${ }^{214}$ Without saying so explicitly, he is latching onto the discourse on liturgies that were expected from the rich on behalf of the city. Speaking about his accomplishments in this field implies the positive side of his advanced age: self-restraint and civic commitment. The older you are, the more you can have done for Athens. The judges are thus called upon to weigh his considerable merits against his slight misbehavior in a trifling love affair. In the context of liturgies, it is interesting to note that the civic contribution of a community member was measured by the largesse of his donations in relation to his age. In his speech against Meidias, Demosthenes renders himself younger in order to make his liturgies appear even more generous, especially when compared to Meidias' stinginess in this respect. ${ }^{215}$

Youth could also be instrumentalized as an excuse not to speak for oneself in court, thereby stressing one's innocence and naiveté in matters of law and the court system. The young and seriously injured Archippus does not assume the role of the prosecutor. A friend is pleading the case in court on his behalf, suing Teisis for battery. ${ }^{216}$ This strategy of non-performance is supposed to emphasize Archippus' youth and inexperience, thus calling for additional sympathy from the judges.

\section{Lys. 3.4.}

214 Lys. 3.9.

215 Demosthenes must have been thirty-seven or thirty-eight years old in 347/6, not thirty-two, as he claims (MacDowell 1990, 370-371).

216 Lys. fr. CXXIX 279. 


\section{Thresholds \\ (invasion of homes versus protection of oikos)}

The violation of the threshold of someone's home was always charged with a highly negative symbolism by the victim and defended by the perpetrator. Most recently, Schmitz has offered a compelling interpretation of this intrusive behavior from an anthropological perspective. ${ }^{217}$ In a society where a tight social control held people firmly in its grip, ${ }^{218}$ the performance of abusive songs in front of a house, accompanied by hissing, drumming, and banging of metal implements ("rough music," charivari), the battering of doors, the partial destruction of the house owner's belongings, ${ }^{219}$ and beating him up outside the house can be understood as a ritual form of social coercion and popular justice (Rügebrauch). ${ }^{220}$

Two basic settings are to be distinguished. The first involves the community's stance on the illicit sexual relationship of a house owner. If an elderly man was living together with too young a woman or a prostitute or even a young boy, this relationship was deemed inappropriate. Young revelers would come to the house in a carnivalesque procession after a symposion (kômos). ${ }^{221}$ In most cases, they were drunk, noisy, and deliberately challenged the kurios to come out of the house to be taught a lesson. If he refused, they would smash the door (Өטроколєî) and drag him out onto the street. ${ }^{222}$ Normally it was the rule that the komasts would not

217 Schmitz 2004, 287-300. Cohen 1991b, 70-97 differentiates between the public sphere of the Agora and the "private" sphere of the oikos. These spheres were gendered and fraught with social expectations and norms. Similar is Dover 1974, 95-98.

218 On neighbors as agents of social control, cf. Schmitz 2004, 464. A fragment of New Comedy, preserved in Stobaeus' Physical Extracts, neatly expresses the

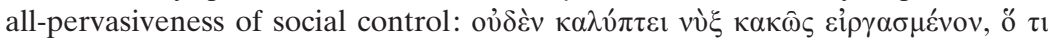

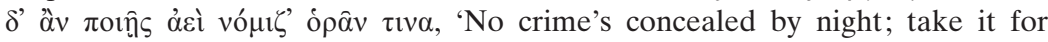
true, someone will see whatever you may do,' transl. in F 148 (Edmonds). Cf. also the anonymous New Comedy fragment on neighbors' eyes being as sharp as those of foxes: F 435 (Edmonds).

219 An extreme form was the razing of the whole house (Connor 1985).

220 Forsdyke 2008 convincingly shows that collective rituals of humiliating offenders, especially in the context of festivals, were inextricably linked to the more formal aspects of bringing about justice.

221 On violent kômoi with partial destruction of the furniture or house and its function as charivari, cf. Schmitz 2004, 280-287.

222 This is what happened to Pittalacus (Aeschin. 1.59): he was penalized for pestering the new couple Hegesander and Timarchus. He was not only beaten, but his 
enter the house, ${ }^{223}$ but sometimes it was unavoidable to do so, and in the ensuing mêlée, furniture would be broken and the women present at the scene verbally insulted. The goal of this social coercion was to shatter the honor of the victim and his household. ${ }^{224}$ The public humiliation was supposed to work as a social corrective and force the attacked to better his mores by either marrying the woman in question, if she was an Athenian, giving up the improper relationship, or even leaving the country. An excellent example for this Rügebrauch is Lysias $3 .^{225}$ The mature speaker, suffering from the constant protests by the younger Simon against his relationship with Theodotus-Simon wanted the boy for himself-left Athens temporarily after the first charivari. ${ }^{226}$

The second setting was not associated with illicit erotic affairs, but with a legal relationship, the exaction of money or equipment that a debtor owed to a creditor. ${ }^{227}$ The conflict could be economically or politically motivated, such as the choregic agôn between Meidias and Demosthenes. Unlike in the first setting, there were neither youngsters nor alcohol involved, and most intrusions were committed during the daytime. ${ }^{228}$ In this second, more official context, the transgression of the door can be re-

furniture was dragged out into the street, and his fighting cocks and quails were killed. For more sources concerning the battering of doors, cf. Schmitz 2004, 297.

223 It was equally forbidden to detain a komast within the house. What happened to Archippus at the hands of Teisis was serious misconduct and did not correspond at all to the unwritten but stringent rules of the Rügebrauch (cf. Schmitz 2004, 295). Teisis, who is familiar with the semantics of housebreaking, accuses Archippus in turn of having intruded violently and having verbally abused the women present (Lys. fr. CXXIX 279.4-6). Thus, Teisis aptly plays with threshold arguments to cover his own misdeed.

224 Huizinga ${ }^{4} 1964,86$ puts the Haferfeldtreiben, a Bavarian form of charivari, into the context of play, thus adding a comic note to the serious meaning of measures of popular justice. We certainly sense a comic undertone in Lysias 3 and 4.

225 According to Schmitz 2004, 290, the Rügebrauch comes close to personal revenge in this case as in many others.

226 Lys. 3.10. Cf. Schmitz 2004, 291-293, 300. Cf. also Lys. 4; Is. 3 and Schmitz 2004, 294-296.

227 D. 37: Pantaenetus owed Euergus 105 mnai; the payment of his installments was in arrears. Therefore Euergus invaded Pantaenetus' home and threatened his mother and daughters. As punishment, Euergus had to pay two talents. Encouraged by this success, Pantaenetus now also indicted Nicobulus, his co-creditor, and accused him of having violated his door threshold. Cf. Schmitz 2004, $298-$ 299. The most famous case is Ps.-D. 47; cf. Schmitz 2004, 299.

228 Schmitz 2004, 300. The speaker in Ps.-D. 47.19 neatly draws the line between his task of securing the naval equipment from his predecessor and the motivations of other house intruders, i.e., drunken revel (kômos) and amorous passion. 
garded even more as a kind of self-help than in the first setting. Christ has worked out the conflicting claims in these cases of trespass against the backdrop of relatively inefficient law-enforcement agencies in pre-modern societies. ${ }^{229}$

On the one hand, private individuals normally could not rely on the state's help in confiscating property, the value of which they could legally claim. With the help of friends ${ }^{230}$ or, only under very special circumstances, a magistrate from the city, ${ }^{231}$ they could invade private property, violate thresholds, and seize what they thought was owed them. They felt they were in the right and normally claimed that state authorities backed them. ${ }^{232}$ The state had to condone this aggressive behavior, because it did not have the means to intervene; it had to enable individual citizens to lay hands on private property in its stead, to prevent or stop the abuse of the owner. ${ }^{233}$

On the other hand, it was the prerogative of the kurios to defend his oikos from any intrusion from outside. ${ }^{234}$ The polis was only allowed to violate the seclusion of the oikos under very special circumstances. ${ }^{235}$ These exceptions were hotly contested, and so it comes as no surprise

229 Christ 1998b.

230 On the help of friends one could enlist, cf. Christ 1998b, 531.

231 For example, if the creditor thought himself too weak, he could apply for officials appointed by the state to help him or carry out the confiscation of property for him (dikê exoulês): Christ 1998b, 531-533; MacDowell 1990, 261; 1978, 153 154; Harrison 1971, 186-189. Wolff 1961, 36 aptly characterizes the dikê exoulês as "Schutz der berechtigten Selbsthilfe." Similar is Wolff 1961, 5, 38.

232 Ps.-D. 53.15: Nicostratus had registered a fine of 610 drachmas against Apollodorus. Since he did not pay, Nicostratus invaded Apollodorus' property and carried off all his furniture, worth more than 20 mnai, according to Apollodorus' report. The trierarchic speaker in Ps.-D. 47.19-48 explains that he was authorized by an official decree either to confiscate the naval equipment owed to him or to seize some of Theophemus' property in compensation.

233 Because of a lack of law enforcement agencies, the self-regulating society of Athens was dependent to a large degree on self-help (Riess 2008, 1-4; Allen 2000, e.g., 202; Hunter 1994, 120-153). Rhodes 1998, 149-150, 160 hits the nail on the head in pointing out that private prosecution and law enforcement had their share in continuing and aggravating quarrels. Similar is Todd 1998. This is important for a balanced assessment of the functions of Athenian courts, which will be treated in more detail below.

234 Christ 1998b, esp. 541 works out this tension between defensive self-help and state control most persuasively.

235 Even agents of the state should not enter private homes without a decree: D. 18.132-133 (reporting and refuting a slanderous comment by Aeschines). 
that the tension between state control and the private sphere remained strong throughout the fourth century and was also symbolically expressed through threshold violations. In the heated atmosphere of these hostile encounters charged with aggressive feelings, the conflicting claims often found their outlet in the use of violence. The moral and judicial assessment of these expected outbreaks of violence was as ambivalent as the reasons that had led to the violent showdowns in the first place. Therefore, both parties could feel offended and file, for example, a dikê aikeias, a dikê biaiôn, a dikê blabês, or a graphê hubreôs in the wake of such an incident. Schmitz rightly interprets these legal procedures as the refinement of popular justice by the lawgiver. ${ }^{236}$ These measures actually protected the house owner from private self-help and state intervention in the form of individual self-help. Schmitz regards the threshold transgressions attested for the classical era as later differentiations of the original popular ritual of humiliation. ${ }^{237}$ They had partly lost their original, communal function and had rather degenerated into serving the purpose of private vengeance. ${ }^{238} \mathrm{We}$ will have to come back in more detail to the symbolic implications of threshold breaches in the context of exacting money or equipment.

In the ensuing analysis, I am less concerned with the historical development of this custom than with its actual phenomenology and functions during the fourth century. In spite of their differences, both contexts in which threshold violations were exercised have many features in common. In fact, a law that prohibits the exaction of debts during religious holidays links the two spheres. ${ }^{239}$ Apparently, creditors had taken advantage of the licentious atmosphere during festivals and had demanded the money owed to them by posing as reveling komasts. In the carnivalesque

236 Schmitz 2004, 306-307.

237 Schmitz 2004, 467-492.

238 Schmitz 2004, 402-403, 409, 483 offers an evolutionary model that is convincing, owing to its rooting in anthropology: rituals of popular justice supplanted personal revenge as taken during the archaic times. These Rügebräuche finally became sanctioned by the community and regarded as law (humiliating punishments like the rhaphanidôsis, humiliating parades, apagôgê). Finally these Schandstrafen gave way to more rational, lawful, and sophisticated procedures, such as fines. Social control had itself become the subject of control (Schmitz 2004, 491). Forsdyke 2008 shows the simultaneity of extra-legal forms of ritualized popular justice and more formal modes of law enforcement in classical Greece. Both forms were inextricably intertwined.

239 D. 21.10. 
atmosphere of drinking and consequent violence, the use of force was supposed to appear excusable, if not legitimate.

Sexual and monetary or political motives in trespassing were similar, in so far as they always involved public bystanders. ${ }^{240}$ An attack on an opponent's private sphere was designed to reveal his misbehavior to an audience. ${ }^{241}$ On a physical as well as metaphorical level, the overstepping of boundaries (parabainein) was deliberately and visibly performed. The aggressor was conscious of the fact that what he performed was an intrusion, an encroachment upon his opponent, which, in his view, was fully justified because of his rival's misconduct. The culture of public display lured the supposedly stronger party into enacting a controversy over a hetaira, a boy, or a sum of money around an opponent's doorstep. If one was victorious, one would gain the respect of the bystanders and the defeated rival would be humiliated even more in the ongoing contest for honor and power.

At the same time, penetration into a house always had a sexual connotation, ${ }^{242}$ even if women were not present and the struggle was not about a woman or boy. Why were women who were present at the scene verbally abused, even if they had nothing to do with the men's quarrels? In Athenian ideology, the act of entering a house by force was equated with sexual intercourse and, as such, a display of masculine prowess (thumos). ${ }^{243}$ From this perspective, the adultery described in Lysias 1, as well as Lycurgus' speech against Lycophron and his defense by Hyperides, encapsulate the most extreme level of violating an oikos. The gendering of the threshold metaphor glorified the victory of the intruder and lasting-

240 On the publicity of popular justice, cf. Schmitz 2004, 403.

241 The house owner accepted the violation more easily when he realized that his behavior was not beyond reproach. Cf. Is. 3.13-14; Schmitz 2004, 295-296.

242 According to Christ 1998b, 525 violating the threshold of a door was symbolically equated with rape. Perotti 1989/90, 47-48 gives a political interpretation of the sexual metaphor of Lysias 1: Euphiletus embodies the democracy. He is married to the polis. Eratosthenes, one of the Thirty Tyrants, besmirches the honor of the polis by penetrating her and duping democracy. Even though the equation of the Eratosthenes of Lys. 1 with the tyrant of the same name is highly problematic, this interpretation is compelling. Regardless of the identity of the man Euphiletus killed, the speech charges the action with political connotations.

243 Cf. Viano 2003, 93-94 on thumos in Aristotle; Winkler 1990, 78 on self-control and the need to suppress thumos; Faraone 2003, esp. 162 on thumos in curse tablets and its later equation with orgê, which in this and similar contexts may also denote what we mean by "machismo"; more general is Cohen 1995, 83. On masculinity, cf. Rosen - Sluiter 2003; Foxhall - Salmon 1998. 
ly devastated the reputation of a kurios, whose lack of protective power had been "visualized." The sexualization of the transgressive act catered to the heightened lust of the aggressor precisely because it meant the extreme humiliation of the male house owner. Heaping insults on women who ideally led a secluded life within the oikos, hidden away from the gaze of men who were not family members, intrinsically belonged to the stock of motifs of sexual humiliation. ${ }^{244}$ Since the abuse was uttered within a concrete, pragmatic context, the insults had the power of valid illocutionary speech acts, meaning that if the intruder called the opponent's wife a 'whore,' for example, she may have been a whore in the eyes of some of the people involved. ${ }^{245}$ The kurios had to take immediate action to refute this statement, often by striking back physically. How easily emotions got out of control and the situation of conflict could escalate, is attested by the fact that intrusions into homes often exacerbated conflicts considerably because of the sexual implications involved.

There was one ideological figure who, by wielding extreme power, could take possession of every woman he desired: the tyrant. ${ }^{246}$ The tyrant derived satisfaction not only from the opportunity to have sex whenever, wherever, and with whomever he wanted, but also from the joy of humiliating the kurioi of his sexual partners. The tyrant was the embodiment of the hubristês. ${ }^{247} \mathrm{He}$ was not necessarily driven by sexual passion, which would mitigate the impression of hubris, but by his desire to humiliate his subjects. ${ }^{248}$ In Athenian and Greek mentality in general, the tyrant became an ambivalent cipher standing for complete abhorrence and hidden dreams. ${ }^{249}$ It comes as no surprise that the victims of door-threshold transgressions would often establish a link between the intruders whose attacks they suffered and the Thirty Tyrants, thus modeling their enemies after the most extreme hubristai Athenian history had ever seen. ${ }^{250}$ The

244 D. 21.78-79: Meidias had burst into Demosthenes' house and insulted his mother and sister, who was still a virgin, in such a way that Demosthenes felt he could not repeat the words in court.

245 For a definition of an illocutionary speech act, cf. below 184, n. 94.

246 On the tyrant taking every liberty to rape free women, cf. Wohl 2002, 221-222; Doblhofer 1994, 34-40. Against this backdrop, self-control in all matters sexual was of prime importance for the upkeep of the polis (Isoc. 3.39).

247 On this complex, cf. below 126-127.

248 Cohen 1995, 145-146; 1993, 9; 1991a, 174 based on Arist. Pol.1311b18$1315 \mathrm{a} 28$.

249 Lewis 2009; 2006; Wohl 2002, 215-269; McGlew 1993, 183-212.

250 D. $24.164,197$ portrays Timocrates and his companions as worse than the Thirty Tyrants. To substantiate this reproach, Demosthenes even goes so far as to bend 
tyrant metaphor of hubris was the appropriate, retaliatory answer to the sexual metaphor of intrusion. ${ }^{251}$ In Lycurgus' prosecution speech against Lycophron, the actual and the metaphoric, sexual meaning of housebreaking are blended. Lycophron is said to have undermined the walls of a house to penetrate inside and commit adultery with another man's wife. It lies in the logic of this accusation that Lycurgus may have compared Lycophron to the tyrant Hipparchus, the son of Peisistratus, who also violated a woman's honor. ${ }^{252}$

Our best example of the second context (intrusion into homes on grounds of reclaiming debts) is Ps.-D. 47. The conflict between the incoming trierarch and the ex-trierarch Theophemus materializes a supra-personal tension that must have occupied Athenians throughout the history of their democracy. How much individual self-help was acceptable on both sides - that of the intruder and that of the kurios - in a state that, according to Demosthenes, officially claimed the monopoly on violence and the rational rule of law ${ }^{253}$ A highly inconsistent policy testifies to the wavering of the state in this question. Whereas the law protected the house owner by granting him the possibility to file various lawsuits against any intrusion he suffered from outside, ${ }^{254}$ it also encouraged the creditor, sometimes even authorized him with decrees to gather some friends, and, in rare cases, had him even accompanied (and thus supported) by a magistrate, to go to his debtor's home and demand what was due to him. This is exactly what happened in the case of the trierarch. ${ }^{255} \mathrm{Al}$ though backed by the presence of a state official, the speaker was beaten by Theophemus, who would neither hand over the equipment nor pay for

historical facts. According to the speech, the Thirty Tyrants arrested people only in the Agora and led them away to jail, whereas Timocrates and his friends invaded private homes by bringing magistrates into oikoi. Timocrates, in contrast, certainly interpreted the presence of officials as necessary to preclude all tyrannical presumptions.

251 In D. 54.37 Conon, his sons, and their friends are said to have broken into houses without good reason. Thus, they are closely associated with tyrants.

252 Lycurg. frr. 10-11.6 (Against Lycophron). Hyp. Lyc. Speech B, fr. 1.1 argues that the reproach of Lycophron digging through the wall of a house is completely absurd. Cf., however, the many instances of undermining walls in Egypt, attested in papyri, e.g., P. Ryl. II 127; P. Oxy. IL 3467; P. Mich. Inv. no. $3267=$ SB XX 14679; P. Abinn. 45 = P. Lond. II 245. Cf. Meidias' nocturnal raid on the goldsmith's house (D. 21.16).

253 D. 21.45, 76; 23.69; 54.18-19. On this tension, cf. Cohen 2005c, 226.

254 Schmitz 2004, 406.

255 Ps.-D. 47.19-48. 
it. The speaker complained to the Boulê, and the bouleutai were outraged at the fact that an incoming trierarch was insulted like this while on official duty. Theophemus' punch was considered a violation of the Boulê itself, the laws, and thus the whole Athenian dêmos, because the speaker's action had been commissioned by the council of the city. But all the speaker could do was file charges for battery against Theophemus. The latter delayed the action by going abroad, and sued the speaker in turn after his arrival back home. Euergus and Mnesibulus, Theophemus' friends, gave false evidence, and so the speaker was convicted to pay a fine of eleven hundred drachmas. The preserved speech is the action for false testimony against Euergus and Mnesibulus. Since the prosecutor could not pay the full sum right away, Euergus and Mnesibulus went to his farm and plundered it in his absence. ${ }^{256}$ They took fifty sheep, a shepherd, a serving boy with a bronze pitcher, some slaves, and furniture. They had no qualms whatsoever about doing all this in the presence of the prosecutor's wife, his children, and an old nurse, who later died as a result of the blows she received on this occasion. The worth of the goods seized surpassed the sum owed by far, so the prosecutor's wife protested vehemently against the perpetrators. In addition, she claimed some of the seized property as her dowry. ${ }^{257}$ Even after the prosecutor had paid the sum he owed, the friends came back one more time for a second pillaging. There was no motive any more; this second raid was an act of pure revenge and further intimidation. ${ }^{258}$

The semantics of breaking into houses had exacerbated the conflict. Finally, the situation got out of hand and escalated to a degree that cost one woman's life. Both the prosecutor and the accused could trace back their actions to original legal claims. Both parties argued that their actions were validated by state authorities. The judges must have found it difficult to disentangle the complex adversarial relationships between the litigants. The fundamental question posed above also arose for the judges: How much self-help did the Athenian state condone, although it badly needed it? Any Athenian would have been at a loss to give a logical answer. The boundary ritual of violent doorstep transgression dynam-

256 The speaker claims to have deposited the sum owed to Theophemus at a bank in the Piraeus. Hence, the seizures at his farm were of questionable legality.

257 Ps.-D. 47.52-57. Cohen 1998 draws attention to the relative importance of women in legal transactions. Gagarin 1998, 50 contrasts the "physical invisibility" of women in the courtroom with their "forensic presence ... in the public discourse of the litigants."

258 Ps.-D. 47.63-64. Cf. Schmitz 2004, 299 on this episode. 
ically expressed this ambivalent state and performatively negotiated this crucial question again and again on a symbolic level. Moreover, this tension between necessary and even partly institutionalized self-help and the claim to power that every state makes was visually enacted in the court proceedings dealing with this case. The corporeal performance of this clash on the two levels of interaction and representation made it tangible to the participants in the game so that they could start playing with the ambiguous discourse on trespass. Threshold rituals thus fulfilled a highly communicative function that allowed Athenian citizens to stage, often subconsciously, a supra-personal conflict on a personal level.

In most cases, we only hear the voice of the humiliated house owner. How would a transgressor justify his intrusion? The following strategies were supposed to render a doorstep transgression acceptable. A trespasser could be sent by someone else, a weak argument that the speaker in Lys. 4 glosses over quickly, because he cannot deny his raid on the house, but insists that his opponent struck the first blow. ${ }^{259}$ Normally, the entrance into a house was only deemed legitimate, and the intruder considered authorized, with a decree issued by the Boulê. ${ }^{260}$ In addition, it was recommended to take witnesses to the scene, as in any other situation that might arouse violent conflict. A circumspect intruder would not enter a house, if women were present. Thus, he showed his respect for old age and women and conveyed the impression that he was not out to seek the sexual humiliation of the household's women and their kurios. His intentions were restricted to the money or equipment due to him; they did not include damaging his rival's reputation. Disinterested in his opponent's honor, he wanted neither to involve him in a troublesome zerosum game for social prestige and power nor to contribute to his loss of face. ${ }^{261}$ His strategy was one of cooling off the conflict rather than escalating it by avoiding the metaphorical undertones of sexual abuse. In order to be in full compliance with socially accepted rules, the intruder had to make sure that the kurios was present before he entered his house to

259 Lys. 4.15.

260 Ps.-D. 47.19-21. Aeschines reproaches Demosthenes for violating (without proper decree) the home of Antiphon, who wanted to burn down the Piraeus. Demosthenes thinks that Aeschines should be put on the rack, like the traitor himself, for this terrible slander (D. 18.132-133).

261 Dover 1974, 231 on the zero-sum game in classical diction. The precautions that were taken neatly demonstrate the strict rules according to which the game for social reputation had to be played. Burckhardt 1999 emphasizes the channeling of the agôn and thus relativizes it. 
seize some of his property or money. ${ }^{262}$ Only under these strictly defined circumstances was a non-family member allowed to enter an oikos with the intention of exacting money or other goods. Were these circumstances not given, the breach of actual and metaphoric boundaries was clearly expressed. ${ }^{263}$ If these circumstances were given, the victim could still try to interpret them away. These strict regulations led to Callicles' house not being searched in the wake of the Harpalus scandal, because Callicles was recently married and his wife was inside the house. ${ }^{264}$

The transgression of door thresholds was by far the most conspicuous breach of boundaries. There are many more that, in their sum, formed the dividing line between unacceptable violence and acceptable force, which Athenian citizens did not necessarily perceive as violence at all. It lies in the nature of forensic dispute that the perpetrators did not acknowledge their own violation of thresholds, but claimed that their actions were within the range of accepted norms. They reached this goal by manipulating the line and expanding the realm of accepted violence to their benefit. When they admitted to breaking interactionist rules, they claimed to have had good reasons for doing so (cf. the chart below).

Trespassing was, as we have seen, bad enough, but sometimes the aggressors chose to overstep even more limits, what could be called aggravated trespassing. After a first invasion of Apollodorus' estate, marked by the habitual battering of doors and carrying away of furniture, Nicostratus came back at night and cut down fruit trees and vines and damaged olive groves. ${ }^{265}$ With this action Nicostratus deliberately evoked the symbolism of siege warfare, a powerful message aimed at Apollodorus with the goal of intimidating him. ${ }^{266}$ Given the private nature of the dispute and the 610 drachmas that were at stake, this was a severe transgression. Since the showdown took place among citizens, this disproportionate

262 Ps.-D. 47.79-80: The unknown pleader against Euergus and Mnesibulus had allegedly even called for the kurios before he entered his house.

263 D. 21.16 refers to Meidias' breaking into the goldsmithy as $v \pi \varepsilon \rho \beta o \lambda \eta$. At various instances (D. 21.30, 92, 147), Meidias' breaking the law is expressed by $\pi \alpha \rho \alpha \beta \alpha$ í-

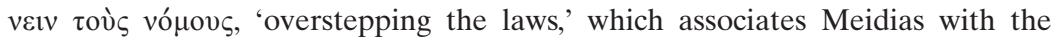
loathsome figure of a tyrant. Cf. Lys. 1.26 and passim, where Euphiletus pursues a similar strategy by representing Eratosthenes as a potential tyrant.

264 Plu. Dem. 25.7-8.

265 Ps.-D. 53.15.

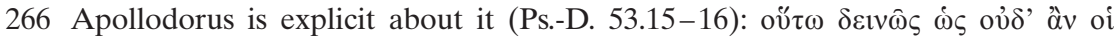
$\pi \mathrm{o} \lambda \varepsilon \dot{\mu} \mu \mathrm{or} \delta 1 \alpha \theta \varepsilon \hat{\varepsilon} \varepsilon v$, 'they acted with a ferocity worse than enemies in wartime would have done.' 
measure was reminiscent of civil war, an image that was supposed to arouse the judges' wrath against Nicostratus. The traumatic experience of the Thirty was constantly looming in the background and could be instrumentalized at any time by a forensic speaker. In the ensuing paragraphs, we will concentrate on the most significant breaches of norms and focus on their underlying messages.

\section{Disturbance of Public Duty versus Maintenance of Public Order}

Victims reacted vehemently to violence when they were assaulted during the performance of public duty. Demosthenes was less shocked about the punch he received by Meidias, than about the fact that Meidias attacked him while he was serving as chorêgos. In this position, Demosthenes fulfilled high religious, cultural, and civic functions. ${ }^{267}$ Meidias' punch not only dishonored him, but was also a blow to the citizenry as a whole and a shameful act in front of all the allies and foreigners who visited Athens at this time to participate in the Great Dionysia. With a physical attack on a chorêgos, Meidias treated the most important festival of Dionysus with utter disrespect by disturbing its solemn atmosphere. The prosecutor in Ps.-D. 47 uses a similar argument. When he tried to exact the naval equipment from his predecessor Theophemus, he acted as incoming trierarch on behalf of the city. He was even authorized by a decree from the Boulê. In his opinion, Theophemus' punch not only compromised the honor of one private individual, but also constituted an attack on the authority of the laws themselves and thus the state. ${ }^{268}$ The speaker corroborated his actions by giving examples from the past. He was not the only one to demand naval equipment from a predecessor; previous trierarchs also exacted what was due them in the same manner, backed by a decree. ${ }^{269}$ This argumentation should make us suspicious. Was this a kind of excuse? Was it unusual for a trierarch to invade another trierarch's home to confiscate some of his property? We do not know.

267 D. 21.189.

268 Ps.-D. 47.41-42, 48.

269 Ps.-D. 47.48. 


\section{Perversion of Religious Customs}

Another major transgression was the breach or perversion of religious customs, rituals, and institutions. Alcibiades' punching of his choregic rival Taureas ${ }^{270}$ and Meidias' punching of Demosthenes disrupted the Great Dionysia. To emphasize the audacity of the physical attack, Demosthenes portrayed the theater of Dionysus as a temple. ${ }^{271}$ Any crime committed in a holy precinct was a sacrilege and therefore worse than an ordinary offense. We can glean Conon's contempt for religious matters from the fact that he and his friends allegedly violated holy rituals that were of highly symbolic value for the community. This means they treated the community itself with scorn and endangered its wellbeing by perverting religious rites. The passage deserves to be quoted in full: ${ }^{272}$

These men would regularly gather offerings to Hecate and also pig testicles, the ones used for purification when there is going to be a public meeting, and dine on them every time they got together, and they swore oaths and perjured themselves as casually as can be.

These men's willingness to pervert religious rites affected values that were holy to the community. This reproach harks back indirectly to the profanation of the Mysteries and the mutilation of the Herms in 415 $\mathrm{BCE}$, a powerful and decidedly effective way of slandering Conon and his friends.

In Antiphon's first speech, the prosecutor accuses his stepmother of having plotted his father's and his friend's deaths by poison. He characterizes her as having no respect for gods, heroes, and men. ${ }^{273}$ The speaker represents the homicide itself as the perversion of a libation ritual. ${ }^{274}$ The prosecutor's father sacrificed to Zeus Ctesius after dinner. Both he and his friend Philoneus poured out libations and prayed to the gods for the former to have a safe sailing trip to Naxos. In the middle of these libations and prayers, Philoneus' mistress poured libations too, and added the deadly poison to both cups. Philoneus died on the spot after drinking, the prosecutor's father some twenty days later. The pur-

270 Ps.-And. 4.20.

271 D. 21.74.

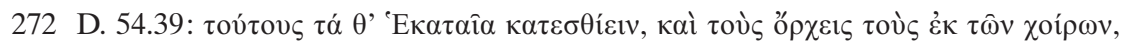

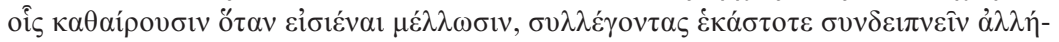

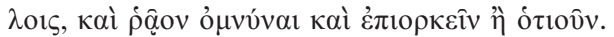

273 Antiphon 1.27.

274 Antiphon 1.17-19. 
pose of this passage is to show how these cunning women perverted a religious sacrifice in order to kill two innocent men: a context of sacrifice was turned into the context for homicide. The holy act was blatantly perverted, according to the prosecutor. ${ }^{275}$

Within the religious sphere, violating the bonds of hospitality was an impious act and a horrible crime. Aeschines accused Demosthenes of having his host, Anaxinus of Oreus, tortured and executed. ${ }^{276}$ Demosthenes felt compelled to reply to this reproach by claiming that Anaxinus had been a spy and Aeschines was involved in the affair. ${ }^{277}$ Teisis lured Archippus inside his house to celebrate a party with him and his friends on the occasion of a horse race, in a festive, perhaps even religious context. Once trapped, his ensuing detention, binding, and whipping was a patent violation of hospitality that would have been even more offensive, had it in fact happened in a religious context.

\section{Perversion of Gender, Citizenship Status, Social Rank and Role}

Violence was a serious matter when it happened among male Athenian citizens. Where the boundaries of gender, however, were transgressed or the gender relationship even reversed-men could maltreat women but not the other way round-the adversarial situation was deemed more serious and the male victim felt even more humiliated. ${ }^{278}$ In the Greek imagination, the victorious soldier could justifiably drag a woman away by her hair after the fall of a city. In doing so, he displayed his status as superior warrior and his undisputed right to take possession of the defeated enemy's wife, sister, mother, or daughter, and lead her away into captivity. ${ }^{279}$ In the archetypal representation of the Amazono-

275 We do not know the outcome of this trial, which, as a case of poisoning, was to be held before the Areopagos (D. 23.22, 24; Arist. Ath. 57.3). Arist. $M M$ 1188b31-37 may or may not allude to this case, but shows that such a trial could also result in an acquittal. The woman Aristotle refers to was not found guilty because she meant to give her husband a love potion and thus acted unintentionally. On homicide through poisoning, cf. also Voutiras 1998, 55-56.

276 Aeschin. 3.224.

277 D. 18.137.

278 Tragedy is obsessed with female violence against men. Ruiz 1994 offers a collection of sources, including instances from outside Athens.

279 In ancient belief, someone who pulled his opponent by the hair exerted power over him (B. Kötting, s.v. "Haar," RAC XIII, Stuttgart 1986, col.177-203, col. 179). 
machy, male dominance and female submissiveness are visibly expressed. ${ }^{280}$ Greek men or heroes like Theseus or Heracles kill Amazons. ${ }^{281}$ If an Athenian man applied the same treatment to a citizen woman, as in the case of Alcibiades' wife, bystanders might have frowned upon the extreme action the kurios had taken, but in the end, his authority over his wife was not questioned. ${ }^{282}$ If, however, this ritual of submission, normally reserved for women only, ${ }^{283}$ was used to humiliate a male citizen, the lim-

280 On Amazons and their iconographic representation, cf. Fornasier 2007. On the construction of hierarchies in the Amazonomachy and Centauromachy, cf. DuBois 1982, 129-152.

281 Cf. P. Devamblez - A. Kauffmann-Samaras, s.v. "Amazones," LIMC I 2, 1981, e.g., no. 101 (p. 454), 104a (p. 455), 104 f (p. 456). The pictorial representations of hair-pulling preserved in vase paintings, sculptures, reliefs, sarcophagi, and mosaics all stem from mythological contexts.

282 Cf. above 44, nn. 101 and 102. D. 25.1.56-57 relates a similar incident: Aristogeiton had lived together with the metic woman Zenobia, who had supported him financially after his escape from prison. When she demanded recompense, he cast her out of his house. As she complained, he dragged her by force to the auction house of the metics' registry. If her metic tax had not been paid, she would have been sold as a slave. Even though the woman was a metic, the act was deemed morally questionable. That is why Demosthenes uses it to denigrate Aristogeiton.

283 Normally, only men drag women by their hair. Exceptions confirm the rule and deserve an analysis in their own right. The Gigantes are godlike men whom gods or goddesses pull by their hair as a sign of their defeat (F. Vian - M. Moore, s.v. “Gigantes," LIMC IV 2, 1988, e.g., no. 24 [p. 112], 60 [p. 115], 322 [p. 144]). In the Gigantomachy as presented on the Pergamon altar, Nereus, Doris, and Oceanus fight against a giant by pulling his hair. The moirai strike the giants Agrius and Thoas by grabbing their hair first. In the Centauromachy, only centaurs are pulled by their hair. They are thus represented as the defeated party. Theseus grabs a fleeing centaur by his hair (C. Weber-Lehmann, s.v. "Kentauroi et Kentaurides," LIMC VIII 2, 1997, e. g., no. 181 [p. 427; L. Palaiokrassa], 212 [p. 434; I. Petrocheilos]). Heracles pulls a centaur by his hair and drags him down (C. Weber-Lehmann, s.v. "Kentauroi et Kentaurides," LIMC VIII 2, 1997, e.g., no. 271 [p. 449; S. Drogou], 285 [p. 450; I. Touratsoglou]). In the Trojan cycle, Achilles' dragging of Troilus by his hair before killing him is among the most famous representations of hair pulling (A. Kossatz-Deissmann, s.v. "Achilleus," LIMC I 2, 1981, e.g., no. 344 [p. 91], 349a [p. 91], 354 [p. 92], 355 [p. 92], 356 [p. 92], 372 [p. 95], 373 [p. 95], 374 [p. 95]). Similarly important is the depiction of Neoptolemus' pulling of Priam by his hair before brutally killing the old king (J. Neils, s.v. "Priamos," LIMC VII 2, 1994, e. g., no. 99 [p. 407], 100 [p. 407], 102 [p. 407], 104 [p. 408]). The Ilioupersis represents more Trojans defenselessly exposed to the furious rage of the Greek victors, who grab their victims by their hair before they slaughter them (M. Pipili, s.v. "Ilioupersis," LIMC VIII 2, 1997, e.g., no. 7 [p. 400], 11 [p. 401], 16 [p. 404], 30a [p. 405], 31 [p. 406]). 
its of good taste were definitely overstepped. To suffer this ritual of humiliation was regarded as weak, cowardly behavior and stigmatized the victim as effeminate. This breach of gender rules is attested in a fragment attributed to Hyperides, in which Dorotheus was indicted for battery or hubris (dikê aikeias or graphê hubreôs). The context is difficult to reconstruct, but it seems that several citizens were quarreling over a plot of land. The contestants insulted and hit each other, and spat in each other's faces. The speaker complains that a man dragged him by the hair and hit him in the face. ${ }^{284}$ The aggressor thus wanted to express his superior power over his opponent. From Isaeus' ninth speech (On the Estate of Astyphilus), we know that these quarrels could escalate and even lead to a man's death.

The ultimate reversal of gender roles was achieved when a woman killed a man. The fact that a stepmother had her husband poisoned turned the established hierarchies in the oikos upside down. ${ }^{285}$ Instead of enduring maltreatment by her husband, ${ }^{286}$ this woman took action against him. This idea of a woman becoming active against her kurios was highly worrisome for Athenian men. The mythological example of Clytemnestra and her murder of Agamemnon is well chosen by the prosecutor, ${ }^{287}$ because it evoked deep-rooted fears in the judges, who were all men, most of them married. The mythological dimension revealed the atrocity of this homicide and the enormous degree of pollution caused by it. The ultimate limit, the attack on the life of a citizen, had been violated. In addition, the transgression had happened within the oikos itself. The wife, whose role had always been to pamper her husband with loving care, had acted against him. If the judges did not punish this crime accordingly, husbands would no longer be safe in their own oikoi. This, at least, is the message that the prosecutor wants to convey to the judges.

284 Hyp. fr. 21 (97-99) (Against Dorotheus). It is interesting that the speaker obviously wore his hair long in contrast to the short haircut fashion (Athletenfrisur) that had prevailed with democracy by the middle of the fifth century. Did he have oligarchical leanings that gave a political note to the quarrel? On haircut fashions, cf. W. Bremer, s.v. "Haartracht und Haarschmuck, Griechenland," RE VII 2, Stuttgart 1912, col. 2109-2135, esp. col. 2112; R. Hurschmann, s.v. "Haartracht. Griechenland. Etrurien. Rom," Der Neue Pauly V, Stuttgart - Weimar 1998, col. 39-45, esp. col. 41 (with older literature).

285 Antiphon 1.17.

286 The prosecutor passes over in almost complete silence the wrongdoings of his father in relation to his stepmother (Antiphon 1.15).

287 Antiphon 1.17. 
Citizenship status, social rank and role. Since the notion of violence was based on the idea of multiple transgressions, we need to take a closer look at the Athenian social system to discern more dichotomies, semantic markers "defining" violence. Many breaches of interactionist rules were closely tied to social factors, such as citizenship status and social rank and role. A citizen's body was inviolable, because he represented the democracy on a micro-level. Any physical assault on a citizen was equated with an attack on the state and its constitution. A free citizen, even if he were a murderer, could not be detained by anyone (unless the apagôgê procedure was employed or a moichos was detained in the act), ${ }^{288}$ let alone be slapped in the face or beaten. Archippus' suffering was deemed so outrageous because, as a citizen, he was not supposed to suffer any harm at all. The whip was reserved for slaves only. ${ }^{289}$ As Flaig states, citizens also defined their status negatively by knowing that they were exempt from corporal punishment. The lashes of the whip made the slave victims who were tortured near the Hephaisteion in the Agora cry out loudly. Their screams acoustically categorized the attendees of the Agora by separating slaves from free citizens. ${ }^{290}$ In violation of his citizenship status, Archippus was detained and whipped like a slave. ${ }^{291}$ Ironically and for the sake of further humiliation, Teisis had a slave carry out the actual whipping of Archippus, a blatant reversal of social roles. The fact that a slave turned the established order upside down under the orders of his own master must have struck the judges as shocking.

As far as the detention of slaves is concerned, Apollodorus reports a valuable anecdote. His neighbor and enemy Nicostratus sent a free Athenian boy to his estate to pluck the blossoms off his rose bush. The strategy was designed to entice Apollodorus into laying hands on the boy, to either strike or detain him, on the assumption that the boy was a slave. Apollodorus' opponents could then have brought a graphê hubrês against him. ${ }^{292}$ By contrast, it was perfectly fine to carry away a slave when one

288 D. 23.28. Cf. above 62, n. 174.

289 Hunter 1994, 181-184.

290 Flaig 2006, 32-33.

291 Note the close parallel to Aeschin. 1.59, where Pittalacus is whipped by Hegesander and Timarchus. It is unclear whether Pittalacus was a slave. It almost seems as if his enemies used this kind of violence deliberately to make it clear that Pittalacus was indeed a slave.

292 Ps.-D. 53.16. This is what happened to Diocles in Isaeus' eighth speech. He had locked up his half-sister's husband, an Athenian citizen, to prevent him from fulfilling public duties. The man lost his citizenship, but Diocles was indicted via a 
was about to confiscate an opponent's property. Euergus and Mnesibulus snatched away a shepherd and a servant boy from the prosecutor's farm when they plundered it, ${ }^{293}$ and if the incoming trierarch's neighbors had not intervened, they would have abducted the estate owner's son like a slave. ${ }^{294}$ The fact that they refrained from doing so shows that they did not want to transgress this boundary. These incidents alone-the examples could be multiplied-show that free citizens could strike or detain a slave as long as they did not inflict longer-lasting injuries on him or her and thus permanently damage another citizen's property. ${ }^{295}$

This policy stands in stark contrast to statements by Aeschines, the Old Oligarch, and Demosthenes, according to whom even slaves could not be beaten in Athens, and were further protected from any kind of hubris. $^{296}$ In light of evidence for slave torture, ${ }^{297}$ this legal protection of slaves is hard to explain. ${ }^{298}$ Flaig has found a solution to resolve this ap-

graphê hubreôs. We do not know the verdict, however (Is. 8.41; fr. 5). Cf. Ps.-D. 59.66, where Stephanus unjustly detains Epaenetus for having illicit sex with Neaera's daughter. In order to be released he paid 30 mnai. As soon as he was free and realized that the woman he had had sex with was not a citizen woman, he brought an action against Stephanus for having unduly restrained him as a seducer (graphê adikôs eirchthênai hôs moichos; Ps.-D. 59.66) Cf. below 125, n. 459.

293 Ps.-D. 47.52.

294 Ps.-D. 47.61.

295 Other instances of violence committed by masters against their slaves are collected in Ruiz 1994, 113.

296 Aeschin. 1.15-16 and D. 21.47-48 mentioning the law of hubris that also protects slaves; Ps.-X. Ath. 1.10 (indirectly). Cf. also Antiphon 5.47-48, but contrary Ps.-D. 53.16. Cf. below 124, n. 450.

297 E.g., in Ps.-D. 48.14-19. Sternberg 2006, 146-173 paints a dark picture of slave torture with the slaves not having deserved the pity of free persons, when the court case was about an Athenian citizen (p. 148 contains a list of instances of torture of free persons and slaves in classical Athens). Cf. Mirhady 1996 and the response of Thür 1996; DuBois 1991; Carey 1988; Bushala 1968. Foreigners and metics were also subject to torture: Ruiz 1994, 223-224; DuBois 1991, 50 62, 125-1265; Bushala 1968; contra Carey 1988. Gagarin 1996, esp. 1, 17 regards the basanos as a rhetorical strategy rather than a real social practice. Herman 2006, 301 thinks that slave torture never occurred in practice. This is false. Slaves were tortured and executed, e.g., in the case Against the Stepmother (Antiphon 1.20) and On the Murder of Herodes (Antiphon 5.29-56).

298 The Old Oligarch, of course, regards the protection of slaves as another negative feature of Athenian democracy. Ruiz 1994, 109-110 calls the theoretical protection of slaves from blows a principle of Athenian law that was not consistently 
parent contradiction: it was not humanistic ideals that lay at the ground of pro-slave regulations, but the protection of the slave-owner's interests. ${ }^{299}$ Slaves were protected in their capacity as a citizen's property. Nonetheless, some slaves had to endure considerable hardships, as the text of a sensational private letter, written on lead and found in the Agora, has recently confirmed. In this letter, the slave boy Lesis writes to his mother, who is either a slave or a freedwoman, and her owner or prostatês, Xenocles, and implores them to free him from a smithy, where his master (despotês) brutally hits him every day. He cannot stand the blows any more. Full of emphasis, he depicts his sufferings: 'I am perishing from being whipped; I am tied up; I am treated like dirt-more and more!'300 This is the first extant example of the voice of a slave from classical Athens. He was defenselessly exposed to utter abuse at the hands of his master, an Athenian citizen.

With citizenship status came the privilege of being exempt from the infliction of bodily harm. This prerogative also extended to freeborn citizen women. The exception was the woman's subordination to the coercive power of her kurios. But although women and slaves stood under the authority of a man, citizen women were far better off than slaves. They were highly respected as mothers, sisters, and daughters, and, after all, citizen women were responsible for the procreation of legitimate children, future Athenian citizens. A telling anecdote, rendered by Demosthenes to heap slander on Aeschines, makes this difference abundantly clear. After the fall of Olynthus, many Olynthian women fell into Macedonian captivity. Being prisoners of war, they were formally regarded as slaves at the mercy of their masters. A certain Xenophron, not by accident the son of one of the Thirty Tyrants, celebrated a party in Macedon with Aeschines in attendance. When the symposiasts were drunk, they brought in an Olynthian girl and asked her to sing for them. When she replied that she did not know how to sing, Aeschines became outraged and demanded a whip to castigate the girl for her insolence. And indeed, a slave brought a whip, tore off the girl's garment, and gave her some lashes on the back. She cried and rushed to one of the guests to protect

put into practice. Morrow 1937, 227 is more optimistic and claims that the Athenians treated their slaves as subjects and not as mere property.

299 Flaig 2006, 34-35, n. 16.

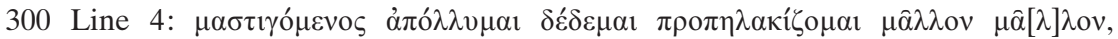
transl. Jordan 2000, 95 in his edition of the text. Cf. Harris 2006, 271-279 with corrections regarding the family relationships. 
her, which he did. Otherwise, she would have been killed by the drunken rascals, according to Demosthenes. The news of this incident spread like a wildfire all across Greece. ${ }^{301}$ Aeschines took this reproach so seriously that he felt he had to come back to it twice to refute it. ${ }^{302}$ Obviously, female prisoners of war enjoyed some minimal protection, if they had been freeborn. Aeschines seems to have violated this Greek norm blatantly. Otherwise, the widespread outcry would not make any sense.

Although Athenian society was politically egalitarian, Athenians were class-conscious and took any violation of social or legal status seriously. As is typical of any hierarchical society, violence that social or legal superiors inflicted on lower-ranking people, especially slaves, was deemed insignificant, if not normal. Violence among social equals was frowned upon. ${ }^{303}$ Violence that people of lesser status exerted on members of the upper classes was labeled perverse. The perpetrators were considered outrageous and were liable to severe punishment. It comes as no surprise that litigants instrumentalized social ranks in court for their own sake and played with the respective notions attached to them. A few instances exemplifying each scenario shall suffice in this context.

The violent conflict between the two trierarchs as described in Ps.-D. 47 was significant, because it symbolized the tension between state control and the private sphere. The Boulê did not condone Theophemus' use of violence, but government authorities did not do anything to prevent the conflict from escalating. When the old nurse died at Euergus' and Mnesibulus' hands, the exêgêtai, referring to the homicide law of Draco, advised the trierarch not to go to court, but to find another way of taking revenge within the framework of accepted social rules. One may read this as an encouragement to exercise self-help within the structures of Athenian law, or to ask for financial compensation. At any rate, it is hard to imagine what steps the offended party should have taken. It seems as though the majority of Athenian citizens (in accordance with the sense of the law) valued the nurse's life less than her prostatês did. Her death was not worth major turmoil among citizens, not even court proceedings, which might have heated up the atmosphere between the enemies even more. The community seems to have waited for the conflict between the trierarchs to subside on its own. It is also imaginable that

301 D. $19.196-198$.

302 Aeschin. 2.4, 153-155.

303 E.g., Arist. EN 1160a3-8. 
Theophemus backed off after the deadly incident and finally gave the naval equipment to the prosecutor.

In Lysias' fragment Against Teisis, the opposing parties enjoy the same social status. We get a glimpse into the world of rich young men and their leisure-time activities. They exercise in the palaistra and celebrate symposia, where they drink, ${ }^{304}$ mock, and taunt each other. In these social circles, hubris was frequent as a way of demonstrating one's own power and entering into a long-term agôn with a social equal to measure strength. Although the violence inflicted upon Archippus by Teisis was excessive and not at all condoned by relatives, friends, and bystanders, the common notion was that outbreaks of violence were to be expected in these contexts, especially among rich and daring youngsters of the same social class.

Things became more complicated when the litigants belonged to two different social classes. If skillful enough, they could take advantage of their own social rank and denigrate their opponent by ascribing negative attributes to his social status.

If the rival was socially inferior, one emphasized his social and economic weakness, moral baseness, and civic uselessness. ${ }^{305}$ In Lysias' third speech, the accused speaker is rich and mature, whereas the prosecutor, Simon, is poorer and young. The speaker treats his opponent with utmost scorn. While he stresses time and again the prosecutor's audacity, arrogance, and insolence in having physically attacked him, ${ }^{306}$ a member of the elite circles, he emphasizes his own benefactions to the city. ${ }^{307}$ Clearly, the under-class attacker had transgressed a boundary in assaulting an upper-class citizen. Conon and his sons, likewise, may have been of low birth - at least Ariston compares his and his father's status of trierarch to their alleged uselessness-but nevertheless they laid hands on Ar-

304 On the connection between drinking and hubris, cf. in detail Fisher 1992, 99101.

305 If the social imbalance between the two contestants was too noticeable, however, the social superior had to be careful not to overdo his attacks. Nothing could be gained by crushing someone who was far from being socially equal. A fragment

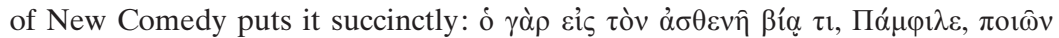

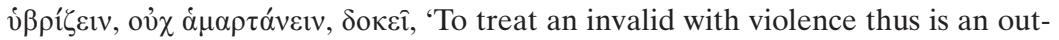
rage not an error, Pamphilus' (Philippides F 27 [K.-A.]; transl. in Philippides F 26 [Edmonds]).

306 E.g., Lys. 3.1, 5, 7, 9, 25-26, 45.

307 Lys. 3.9. 
iston ${ }^{308}$ Belonging to the upper echelons of Athenian society, Ariston and his family had earned merits for their services to the city, whereas Conon and his sons had done nothing for Athens. Ariston, in his argumentation, suggests the perversity of a social nobody attacking a high-ranking civic benefactor. In this quarrel between Conon and his sons on the one side, and Ariston on the other side, the gulf between different social strata is clearly expressed. It is for this reason that Ariston feels especially humiliated, because he was beaten up by lesser men. The social hierarchy was thus turned upside down, when Conon and his sons had blatantly broken social thresholds and codes. Since most of the judges were rather poor themselves, however, especially rich litigants had to be careful not to offend the dikastai with biting and derogatory remarks against the lower classes in general. ${ }^{309}$

If the opponent was socially superior, one emphasized one's own weakness and moderation and stressed the bullying hubris of the upperclass enemy. Our best examples come from Demosthenes' speech against Meidias, in which he characterizes his long-term rival as a hubristês par excellence. ${ }^{310}$ Through his wealth and social connections, Meidias wielded a great deal of power and could intimidate many people. His whole habitus contributed to his superior position, which also allowed him to influence court decisions in his favor. Without saying so directly, Demosthenes insinuates that judges can be bribed, ${ }^{311}$ because money can accomplish anything. But instead of blaming the judges, Demosthenes, in a rhetorically brilliant stroke, takes the poor citizens' side and establishes a front against Meidias' anti-democratic potential: ${ }^{312}$

in comparison to the wealthy, the rest of us do not share equal rights and access to the laws, men of Athens; we do not share them, no. These men are given the dates to stand trial that they want, and their crimes come before you stale and cold, but if anything happens to the rest of us, each has his case served up fresh.

308 D. 54.44.

309 On the dialectical negotiation of class differences in Athenian rhetoric, cf. in great detail Ober 1989.

310 E.g., D. 21.20, 69, 96.

311 D. 21.98.

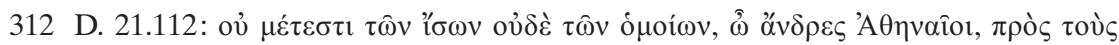

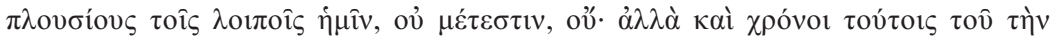

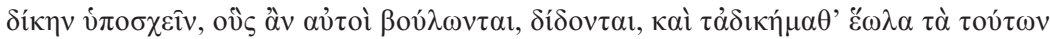

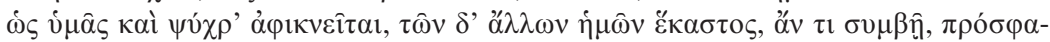

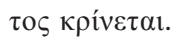


In spite of all the state's efforts to guarantee the same rights to everyone, Athenians did not manage to close the gap between rich and poor. The shortcomings of the Athenian social structure had concrete repercussions on the political and judicial systems. The weak and poor, according to Demosthenes, were endangered by tyrannical types like Meidias. ${ }^{313}$ Demosthenes drives his message home successfully: if the judges do not punish Meidias for his constant transgressions and thus stop him from further hybristic misconduct, even democracy will not be able to provide the poor with protection against the rich. ${ }^{314}$

In Isocrates' speech against Lochites, the prosecutor is allegedly a poor man who suffered hubris from a young and rich citizen. The situation could not be more archetypal. In fact, we will see that this speech almost works like a school speech, containing all semantic markers that "define" violence. The speaker condenses the notion of class justice, obviously not unknown to Athenians, in one powerful sentence: 'It is unjust ... to think that the impoverished are worse than those who have much. ${ }^{315}$

Closely connected to social rank was the social role of all parties involved. The reversal and hence perversion of social roles through an act of violence was considered reprehensible behavior, as long as it did not take place within a festive context, in which the carnivalesque questioning of the existing social order was part of the religious ritual and provided an outlet for potential societal tensions. ${ }^{316}$ It was a wife's function to look after her husband, not to kill him. It was the citizen's prerogative to whip a slave, not the other way around. ${ }^{317}$ Simon even went so far as to strike his military commander, an extreme form of military disobedi-

313 D. $21.123-124$.

314 D. $21.138,143,183,207$. Cf. Plu. Dem. 12.2-6. We find similar complaints in the papyri from Roman Egypt, where widows and orphans especially feel threatened and overpowered by local strongmen: E.g., P. Mich. IX 525; PSI VIII 883; P. Oxy. VIII 1120; P. Oxy. XVI 1837; P. Sakaon 36; P. Ryl. II 114; SB XIV 11904; BGU II 522. On the deplorable status of widows, cf. Krause 1994, $220-$ 255.

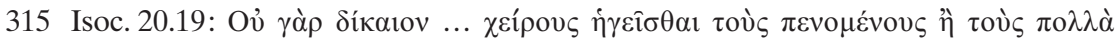

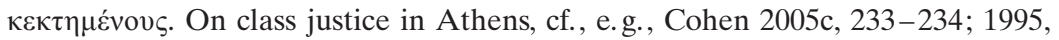
64; Ruiz 1994, 111.

316 E.g., the City Dionysia.

317 Breaches of this rule were considered scandalous; cf., e. g., Antiphon 1 (wife kills husband) and Lys. fr. CXXIX 279 (Teisis' slave whips Archippus). 
ence. ${ }^{318}$ In Athenian eyes, all these reversals of social roles endangered the public order and could not be tolerated.

\section{Mediated (Sanctioned) versus Direct Violence}

Another major factor in the assessment of violence was its direct or mediated character. Direct violence, especially against citizens, was considered unacceptable. Mediated violence, especially aiming for an opponent's death, was only acceptable if sanctioned by a collective of judging authorities and carried out by state officials. The following examples will show that, in cases of homicide, having someone killed through a third party (without obtaining a majority verdict) did not excuse the instigator.

Nicodemus' killing was mediated, but of course not considered acceptable. Demosthenes' opponents tried to implicate him in hiring the hit men. ${ }^{319}$ We are informed that the Areopagos sent the father of a priestess at Brauron into exile for having encouraged an assailant to strike another man, who died as a consequence of the blows. ${ }^{320}$

Although, according to Athenian law, the instigator of a homicide was as guilty as the killer himself, ${ }^{321}$ the stepmother in Antiphon's first speech had, for a long time, gotten away with putting the blame for her husband's death on her slave maiden, who had given the poisonous potion to the two drinking men. The slave woman was tortured and executed shortly after the incident. Whereas the sons of the accused woman probably insisted on their mother's complete innocence, the prosecutor, the dead man's son, stressed the bouleusis, the intent to kill, of his stepmother, which can be interpreted in different ways, but was always seen negatively by contemporaries. ${ }^{322}$ We do not know the outcome of Antiphon's first speech.

318 Lys. 3.45 .

319 Aeschin. 1.171-172; 2.148, 166 with scholia. Cf. above 25, n. 16.

320 D. 54.25. It is unclear whether the trial was held on charges of bouleusis ('planning') of homicide, homicide proper (dikê phonou), attempted homicide, or intentional wounding (graphê traumatos ek pronoias). Cf. Bers 2003, 74, n. 22; Osborne $1985,57$.

321 Harris 2006, 396; Gagarin 2002, 140; 1990, 98; Loomis 1972, 94.

322 Harris 2006, 398-399 and Gagarin 1990, 94-95 make a strong case for the charge being a dikê phonou for intentional homicide (phonos ek pronoias). The latter emphasizes the non-technical meaning of the term bouleusis. In contrast, Carawan 1998, 390, Thür 1991, 65, Wallace 1989, 101, Heitsch 1984, 32, and 
We are likewise uninformed about the result of Antiphon's sixth speech on the accidental death of a chorus boy. A rich and politically active Athenian assumed the liturgy of equipping and training a chorus of young boys. In his absence, one of the boys, Diodotus, was given a potion and died on the spot. The boy's brother, Philocrates, brought a dikê phonou on grounds of unintentional homicide ${ }^{323}$ or a dikê phonou for bouleusis of unintentional homicide against the chorêgos. In this case, the alleged violence was so mediated that the chorêgos could hardly be held liable for what had happened. Since his opponents, however, wanted to sue him anyway, probably for political reasons, as he himself claims, the prosecution, according to Heitsch, extended the meaning of bouleuein ('planning') and used bouleusis in a new sense ('negligent homicide' or 'involuntary manslaughter' through failure to do something). ${ }^{324}$ If this is true, the high degree of mediation in this case might have led to a subtler category of homicide. Given the conservative nature of Athenian homicide law, ${ }^{325}$ this new interpretation would have been a remarkable innovation.

From Isaeus' speech on the estate of Ciron, we learn that Diocles had his half-sister's husband killed by one of his slaves. He smuggled the slave out of the country and put the blame for the murder on his sister, a severe approach, because she would then have been liable for killing her own husband. We do not know what happened to her, but Diocles was not convicted for homicide. ${ }^{326}$ This report need not be more than framing an opponent for murder, but the essential facts remain valid. Diocles' brother-in-law was killed by one of Diocles' slaves, who absconded abroad. Since Diocles was eager to appropriate his brother-in-law's fortune, rumors connected Diocles to this homicide, regardless of the fact that he was not indicted.

In sum: aiming for one's opponent's death was only acceptable if approved of by a community of authorized agents (judges). If we take the idea of mediated and sanctioned violence to a higher level and regard

MacDowell 1978, 115-116; 1963, 62-63 assume a charge of bouleusis of intentional homicide.

323 Antiphon 6.16. Harris 2006, 399-400; Gagarin 1990, 95-96.

324 Heitsch 1984, 95-97; similarly, Gagarin 2002, 140; Carawan 1998, 391; Loomis 1972, 94. Nevertheless, Gagarin 2002, 140; 1990, 95-96 and Harris 2006, 399400 think that the charge was not bouleusis, but one of unintentional homicide (phonos akousios). MacDowell (1978, 116; 1963, 62-64), however, assumes a charge of bouleusis ('plotting') of unintentional homicide. Cf. above 55, n. 153.

325 Hansen 1976, 118-119.

326 Is. 8.41 and fr. 5 . 
court sentences, especially capital punishments, as acts of mediated violence, we could regard court verdicts as accepted, because sanctioned, violence carried out by state officials instead of private individuals. ${ }^{327} \mathrm{We}$ will encounter the same idea when analyzing the curse tablets. Committing violence, including death via the courts or magical curses, was permissible because it was sanctioned by a community verdict, in court by the judges, in the realm of magic by the gods of the underworld.

\section{Escalation versus De-escalation}

Athenian society viewed any form of escalation negatively, because escalation broke the rules of democratic self-restraint and moderation. Any speaker would always claim to have done his utmost to avoid escalation. The prosecutor in Isocrates' speech Against Lochites, for example, uses different grades of escalation in order to demonstrate to the judges how dangerous even blows are, for 'because of those who dared to strike blows in the past, some people have become so angry that they have resorted to assaults, killings, exiles, and the greatest misfortunes. ${ }^{328}$ The

327 On courts as instruments of "vengeance" and violence sanctioned by the state, cf. e.g., D. 21.182; in general, Gehrke 1987. Borg 2006, 234-235 speaks of a new kind of revenge, legitimized by the collectivity of the polis from the Peisistratids on. On Din. 2.4 and 2.20, where the speaker pleads for the death penalty against Aristogeiton without further ado, cf. Cohen 2005b, 179, who speaks of the "confusion of judicial retribution and private revenge." Courts were used, for example, as a tool of punitive violence against stratêgoi (X. HG 1.7.2223). Revenge and law should not be pitched against each other (Scheid 2005, 402-403; Fisher 1998a, 81, 92). McHardy 2008 presents the most refined view on vengeance in the Greek world so far. Instead of speaking of revenge in absolute terms as research has done so far, she demonstrates that individuals, in the case of being wronged, carefully considered the options they had and made their decision on which kind of redress to seek dependent on the specific situation and circumstances. Surprisingly enough, the killing of a relative called for revenge the least (9-44). The violation of female honor (45-64), however, as well as the encroachment upon one's property $(65-84)$ and damage to one's reputation (85-102), were far more likely to trigger an act of revenge in the ancient Greek world. Cf. above 48, n. 123 and below 137, n. 526.

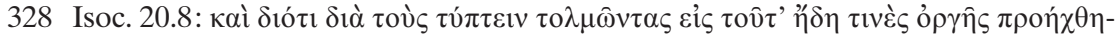

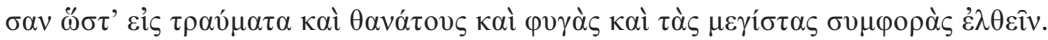
A similar escalation scheme is rendered by Hyp. fr. 21 (97-99). Rivals fight over a piece of land. They insult and spit, and finally they hit each other in the face. As we know from Isaeus, such violent showdowns could even lead to homicide 
enumeration of blows, physical attacks, killings, and exiles in one sentence is meaningful. In the contemporary view, there was a direct connection between blows and homicide. Once struck, the rules of honor and shame required the victim to strike back, which, in turn, further inflamed the conflict. As Forsdyke has shown, exile through ostracism served the purpose of replacing the blood feud with more peaceful means of fighting against each other. ${ }^{329}$ By the fourth century, ostracism had fallen out of use. Its role was taken over by court verdicts that could sentence people to death or exile. Thus, going to court and pleading for an opponent's death or exile was understood as the continuation of a vendetta by different means, a process that had already begun in archaic times. ${ }^{330}$ In other words, the archaic-looking and at least ideologically obsolete exchange of blows, ${ }^{331}$ which, however, was often resorted to in practice, could aggravate and prolong a situation of conflict that was still perceived as a kind of "feud" by contemporaries. "Feuding" was all right in the Athenian perception of agonistic behavior as long as it was carried out according to "modern" standards, which means by appealing to the courts. Ariston uses the escalation brought about by Conon's sons to cause his own selfcontrol and the de-escalating measures he took to stand out in sharp relief. ${ }^{332}$ Conon's sons started out by insulting Ariston in the military camp. Then they hit him and caused so much turmoil that other men came to his rescue. This was good, because he was so angry that he might have retaliated in a similar fashion, had he not been restrained by the taxiarchai and other men. Back in Athens, he did not sue his opponents, but instead kept

(Is. 9.16-19). Arist. Pol. 1302b5-21 widens the focus even more and claims that revolutions (staseis) can stem from petty causes. Slander and verbal abuse can lead to blows (D. 40.32). Blows can easily lead to revenge. On the close connection between revenge and stasis and the Athenians' obsessiveness with civil war, cf. Flaig 2006, 50. On the close connection between hubris and stasis, cf. Fisher 2000, esp. 112, who emphasizes the important role personal motives and hatred played in engendering civil unrest. On stasis in the Greek world of the fifth and fourth centuries in detail, cf. Gehrke 1985.

329 Forsdyke 2005, esp. 143, 204, 278-280.

330 Cf. above 48, n. 123 and 96, n. 327; below 137, n. 526.

331 Conon and his sons did not think that they acted according to an outdated modus operandi. To them, the notion of carrying out quarrels physically was very well alive. We have to keep in mind that we extrapolate the discourse on moderation and self-restraint from a couple of speeches only, mainly D. 21 and 54 as well as Isoc. 20.

332 Herman 2006, 123-124, 132, 156-159, 166, 199, 213, 283-285, 286. On the rhetoric of self-control in general, cf. Bers 2009 passim; Roisman 2005, 176-185. 
away from them to avoid any trouble in the future. ${ }^{333}$ The prosecutor in Isocrates' Against Lochites argues along the same lines. Only because of his self-restraint and moderation did the situation not get out of hand. ${ }^{334}$ Ideally, however, it was only the laws that could prevent a conflict from escalating. For every stage of the showdown, the lawgiver had taken precautions by giving the assaulted party the right to sue its malefactor. Demosthenes' passage on behalf of Ariston is clear enough:335

there is provision for the least important of these acts, verbal abuse, to avoid the final and worst, homicide, from happening and to prevent the escalation by small steps from verbal abuse to blows, from blows to wounds, and from wounds to death; instead, the laws provide a legal action for each of these, instead of letting these actions be decided by the individual's anger or desire.

This passage is to convince the judges that they have to crack down on Conon and his sons because they trample on the laws and the constitution of the city. ${ }^{336}$ It is worth defending these very laws of the city, since they are the only bulwark against hybristic rascals like Conon and his sons, and are thus the mainstay of democracy.

All of the semantic markers mentioned above were grouped in dichotomies and instrumentalized by the perpetrators and the victims of violence (first blow vs. self-defense; murder vs. lawful homicide; public vs. hidden violence; day vs. night; inebriation vs. sobriety; old vs. young age; invasion of homes vs. protection of oikos; disturbance of public duty vs. maintenance of public order; perversion of religious customs; perversion of gender, citizenship status, social rank and role; sanctioned vs. direct violence; escalation vs. de-escalation). Taken together, these semantic markers constitute the flexible line between unacceptable (victim's viewpoint) and acceptable violence (perpetrator's viewpoint).

The most famous speeches today are those that tell us about high-profile citizens who broke many social norms simultaneously. Ps.-Andocides'

333 D. $54.5-6$.

334 Isoc. 20.8.

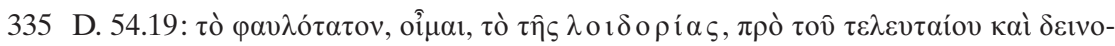

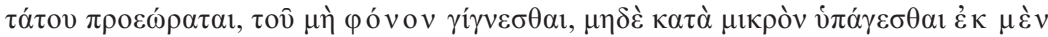

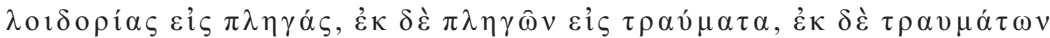

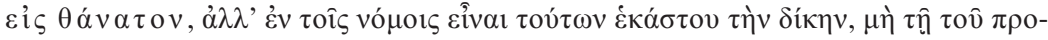

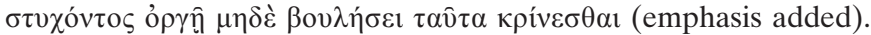

336 A similar list ranging from calling another man names to backtalk, assault, and brawls is preserved in a fragment of Middle Comedy, taken from Alexis' Odysseus at the Loom (Alexis F 160 [K.-A.]). 
speech Against Alcibiades (Ps.-And. 4), Lysias' speech Against Simon (Lys. 3), Lysias' fragment Against Teisis (Lys. fr. CXXIX 279), Isocrates' plea Against Callimachus (Isoc. 18), his speech Against Lochites (Isoc. 20), and Demosthenes' speeches Against Meidias (D. 21) and Against Conon (D. 54) have the character of school speeches, because they call on almost all semantic units of violent interaction and thus "define" paradigmatically what Athenians meant by "violence."

To single out only two examples. At least four semantic markers "defining" violence are to be found in Against Teisis. Archippus was a free citizen, but detained during the night. The abuse of his body took place within Teisis' house and not in public. ${ }^{337}$ A slave lashed him with a whip, an instrument reserved for slave torture, thus reversing the social roles attributed to certain social classes. Since there was no control by an audience, the violence was regarded as excessive, even by Teisis' friend Antimachus. The multitude of norms broken increased the victim's shame. Archippus' brothers established an audience only after the fact by presenting their badly injured brother on a litter in the marketplace. In this way, they dramatized Archippus' atrocious mistreatment and displayed its significance to bystanders.

Allegedly, Andocides delivered a speech against Alcibiades on the occasion of the last ostracism at Athens (417-415 BCE) in order to sue him for multiple breaches of the democratic order. This oration is almost certainly not authentic. Andocides cannot be the author, nor can the speech be dated to this time period. ${ }^{338}$ These reservations do not detract from our argument, however. Whoever the author was, he had a very good understanding of the Athenian semantics of violence. The speech was preserved because it appeared plausible and convincing to its readers. If it is a rhetorical exercise, it is even more valuable as a source for us, because we can extract from it the general notion of violence. Alcibiades, as portrayed in this literary piece, is thoroughly familiar with the way violence works in his hometown. As a staunch oligarch, he deliberately lives in accordance with old aristocratic ideals and discourses. His flamboyant lifestyle makes him break democratic rules of interaction in a self-indulgent and tyrannical way. He does so ostentatiously and with great relish. When his wife initiated her divorce from him with the archôn basileus, an action to which she was fully entitled, Alcibiades dragged her

337 It is true that some friends were present to witness the abuse, but not a broader public.

338 Heftner 2001 (with older literature). 
home by force, thus reasserting his authority as her kurios and trampling on the democratic order of Athens. Alcibiades literally dramatized the physical attack on his rival chorêgos, Taureas, by punching him in the face in the theater of Dionysus. By establishing publicity for his breaches of democratic ideals, norms, and rules, he performed his contempt for Athenian democracy. There was no better way of flaunting his emotional and mental detachment from Athens' constitution than staging these violent violations of democratic expectations.

We should always bear in mind that the players attested in the sources are all male citizens, whose actions and words were taken seriously, for they could appeal to an audience of peers. If a slave beat up another slave, the incident was not reported and did not leave any trace in our records. In most cases, violence committed by male citizens against metics, ${ }^{339}$ or their own wives and slaves, is not reflected in our sources either. ${ }^{340}$ To the male agents, this behavior was normal, not even worth discussion. This does not mean that these persons were not protected by any laws. A metic could enlist legal support from his prostatês, the killing of a metic was brought before the Palladion, women abused by their husbands could ask for help from their kin or file a divorce, and slaves could seek asylum at the altar of the Mother of the Gods as Pittalacus did. ${ }^{341}$ Nevertheless, all these groups were less well protected than male citizens.

The situation was entirely different when citizens were affected by violence. In that case, a boundary had been violated, and the act was significant enough to be debated. If committed publicly, the incident would unfold in front of an audience, whose members could then determine its appropriateness. Even if a societally relevant form of violence was not committed in public, people could still hear about it in court.

Citizens played their games of violence not only with their fists on the streets of Athens, but also with their bodies, gestures, and voices on the stage of the courts. There, ideology and rhetoric allowed them to shift the line between unacceptable and acceptable violence according to

339 Exceptions are, of course, large-scale crimes against metics as conducted by the Thirty (X. HG 2.3.21; D.S. 14.5.6; Lys. 12). According to Ruiz 1994, 205, metics were better off than women and slaves. Cf. her chart on p. 231 visualizing in descending order citizens, metics, women, and slaves and their opportunities to protect themselves against encroachments upon their bodies.

340 The archaeological evidence, too, points in this direction. As Morris 1998, 218 220 points out, women and slaves are hard to find in Athenian material culture. They remain invisible, because Athenian men wanted it that way.

341 Aeschin. 1.60. 
Summary of Semantic Markers in Table Form

(Dichotomies constituting flexible line; cf. table below 139):

\begin{tabular}{|c|c|c|}
\hline & $\begin{array}{l}\text { Unacceptable Violence (outside } \\
\text { accepted norms, always } \\
\text { relevant, committed by } \\
\text { opponent, as characterized by } \\
\text { speaker) }\end{array}$ & $\begin{array}{l}\text { Acceptable "Violence" } \\
\text { (inside accepted norms, } \\
\text { sometimes relevant, } \\
\text { committed by speaker, as } \\
\text { characterized by him) }\end{array}$ \\
\hline $\begin{array}{l}\text { Discursive } \\
\text { Level of } \\
\text { Interaction }\end{array}$ & $\begin{array}{l}\text { Serious wounds } \\
\text { (Attempted) homicide } \\
\text { Non-public, hidden } \\
\text { Night } \\
\text { Day } \\
\text { Drunk } \\
\text { Sober } \\
\text { Young } \\
\text { Old } \\
\text { Unauthorized transgression of } \\
\text { door threshold } \\
\\
\text { Victim on public duty } \\
\text { Perversion of religious customs } \\
\text { Perversion of gender, citizenship } \\
\text { status, social rank and role } \\
\text { Direct } \\
\text { Escalating } \\
\text { Disruptive }\end{array}$ & $\begin{array}{l}\text { No wounds/light wounds } \\
\text { Lawful homicide } \\
\text { Public } \\
\text { Day } \\
\text { Night } \\
\text { Sober } \\
\text { Drunk } \\
\text { Old } \\
\text { Young } \\
\text { Authorized transgression of } \\
\text { door threshold (decree, no } \\
\text { women inside, owner home, } \\
\text { witnesses); justified } \\
\text { enforcement of } \\
\text { governmental or personal } \\
\text { claims } \\
\text { Victim not on public duty } \\
\text { Following religious customs } \\
\text { Respecting gender, } \\
\text { citizenship status, social rank } \\
\text { and role } \\
\text { Sanctioned by community of } \\
\text { judging authorities } \\
\text { De-escalating } \\
\text { Integrative (under certain } \\
\text { circumstances) }\end{array}$ \\
\hline
\end{tabular}

their needs. The law courts would then, through their verdicts, transform unacceptable and acceptable violence into illegitimate and legitimate violence. Most of the above mentioned dichotomies structuring daily-life violence (see chart above) were interpreted, manipulated, and instrumentalized on the level of representation. 


\section{Images of Violence: Discursive Rules of Violence II (Mental and Cultural Representation)}

Violence was verbally represented in three settings: courtroom proceedings, magic, and theater. All three media were characterized by a high degree of performance. What we grasp in forensic oratory is the discourse on the observable breaches of socially coded norms as mentioned above. Since the dikastêria were ritual communities, a courtroom trial was ritual theater that narratively staged an ongoing conflict between two parties. Since, on this level of discourse, the discussion about violence was ritually staged, we can also speak of the ritualistic representation of the violence discourse. Not only was the setting of the trial highly ritualistic on the macro-level, but the speeches themselves also show a high degree of ritualization on the micro-level of language. They are less bound by poetic diction and formulas than magical spells and less poetic than tragedies and comedies, but we do find standard motifs and stereotypical patterns in rhetorical language. ${ }^{342}$ These repetitive elements-for example, the rhetoric of character denigration-allow us to speak of ritualized language. The skillful orator would lend his voice, body, and gestures to the effective performance of the speech. Therefore, it is legitimate in this case to equate the process of narration with that of ritualization and theatricalization. In other words, ritualization and theatricalization engendered narrativity, and vice versa. ${ }^{343}$ The litigants transformed everyday occurrences into partly fictional tales (and not just because they presented themselves in a favorable light and demeaned their opponents). That is the reason why speeches cannot be faithful mirrors of reality. The frequent allusion in secondary literature to the "rhetorical distortion" of many facts does not render sufficient justice to the vexed problem. But even though speeches do fictionalize events, they at the same

342 Cf. Gänszle 2000, 37 on the different degrees of formalized or ritualized speaking. Harth 2004, 108-109 enumerates the appropriate figures of speech that create the ritual frame that marks this speaking as distinct from ordinary, daily-life speech: e.g., repetitions, anaphoras, transmutations, doublets, inversions, parallelisms, and formulas. This ritualized language is situated within the liminal sphere of the courtroom, and thus contributes to its creativity and ceremoniousness.

343 According to Davis 1987, 121 the creativity of the ritual transforms the purely empirical coexistence of occurrences into stories. Cf. Gagarin 2003b, 4 on the narrative aspect of oratory. 
time reflect the cultural perception of violence and the way it was represented.

Since we know that human beings construct meaning via rituals, ${ }^{344}$ the best way for us to extract the symbolic significance of violence from court speeches is to regard their narrative structure as ritualistic and performative. It is in the liminal phase of the courtroom speech that the significance of a violent act emerged. The orators not only spoke about breaches of social norms, but also implicitly and explicitly invested these transgressions with symbolism by embedding them in larger discursive horizons and thus interpreting and evaluating them. The process of narration charged individual actions with meaning. ${ }^{345}$ If some violent acts already were highly symbolic, such as instances of charivari, threshold transgressions, and Conon's rooster dance over Ariston, they acquired even more meaning through being told and narrated to an audience. The meaningful construction of a violent event happened, to a large degree, post factum on the narrative level, which gave explanations for and interpretations of it from the speaker's point of view. Through this process of narration within a ritual and theatrical context, future actions in daily life also gained symbolic significance. Since these actions were mainly charged with meaning in the courts, and the courtroom drama had repercussions on reality, the violent interactions of real life began to adopt a symbolic meaning. ${ }^{346}$

A discourse analysis taking into consideration the ritual and performative quality of the speeches will help us decipher the symbolic meaning of violence further. This technique will necessarily go far beyond the traditional examination of rhetorical structures. Rules of representation constructed the symbolic meaning of a violent act even more explicitly than rules of violent interaction. On the ritual macro- and micro-level of the speeches, the representation of violence enabled contemporaries to interpret a specific violent act. On this level of discourse, the moral, judicial, and socio-political assessment of violence was easier than on the level of daily interaction. If we gain access to these parameters of interpretation, we will be able to give answers to the questions raised above.

344 De Coppet 1992, 4, 14, e.g., insists that rituals not only express messages, but also do something and have effects on the world.

345 It was only the law court that turned the conflicting parties into litigants (Johnstone 2003, 6; 1999, 127, 131-132).

346 Schechner's braid model (cf. above 16, n. 77) is again of high heuristic value. 
How did Athenians perceive violence? How was an act of violence verbally represented and commented upon in the ritual framework of a court speech? Prosecutor and accused ascribed sense to violence from their respective perspectives and interpreted it. What does this mean on a larger scale? How did the public negotiation of what violence signified help create an Athenian identity? What consequences, finally, did the construction of community have for the victim and the perpetrator of violence? The far-ranging dialogue on violence did not take place in a societal vacuum. It was never abstract, but was concrete in the sense that real people committed and suffered violence, and that their narrations were inextricably intertwined with many other discourses. This semantic polyvalence of the violence discourse explains its flexibility and paramount importance to Athenian society. Before we can tackle these questions, however, we have to understand how, in general, Athenians verbalized violence in court.

\section{The Depiction of Violence}

As a rule of thumb, we can say that the speaker rarely depicted his own violence. ${ }^{347} \mathrm{I}$ am speaking here of the rhetorical zero-performance of the violence committed by the speaker. One might suppose that he represented his opponent's violence graphically, but this is not the case. Although any speaker had to exaggerate his rival's misconduct to a degree, he refrained from detailed descriptions of his opponent's violence. Instead, he talked about it in relatively vague terms, sometimes only hinting at the violence proper. We will come back to this strategy, the underlying reasons for and the consequences of it shortly. So the speaker also mitigated the violence committed by his opponent.

The most blatant example of toning down one's own violence is Euphiletus' rendering of his "execution" of Eratosthenes. To Euphiletus, this homicide was justifiable; therefore he could talk about his own extreme form of violence. But it takes him only one sentence, expressed with a euphemism, to circumscribe his killing: 'So it was, gentlemen, that this man met the fate which the laws prescribe for those who behave like that. ${ }^{348}$ The whole killing is presented as a rational act on behalf of the polis. Eu-

347 Gagarin 2005, 366, 371.

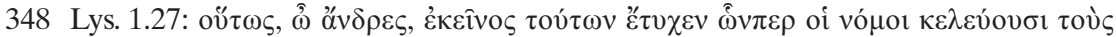

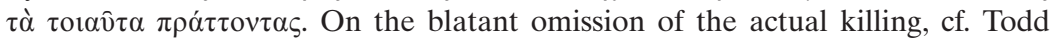
2007, ad loc. 
philetus plays down his emotions for precisely this purpose. Not talking about one's own violence was essential in portraying oneself as innocent. In Isocrates' speech Against Lochites, the speaker does not spell out his own violence at all, whereas he characterizes his opponent's actions as prime examples of hubris. The rich chorêgos who was accused of having caused the death of Diodotus, one of his chorus boys, through neglect, did not articulate the boy's actual death so as not to arouse negative emotions against himself. ${ }^{349}$

In general, speakers hardly ever talk about their own problematic behavior with which they have contributed to exacerbating a conflict. Oftentimes, they deliberately pass over in silence the whole background that has led to the outburst of violence. The prosecutor suing his stepmother for the homicide of his own father only hints at the bad marriage his parents had and from which the wife, especially, suffered. ${ }^{350}$ Knowing these circumstances, however, would be crucial to understanding the woman's motives for killing her husband. Apollodorus does not speak a single word about the reason for Nicostratus' change of mind, how and why he turned from neighbor and friend to fierce enemy. ${ }^{351}$ Demosthenes does not tell us why Meidias punched him in the face. The punch was charged with too great a degree of semantics and was too significant for it to have been "unpremeditated," as MacDowell thinks. ${ }^{352}$ Demosthenes does illuminate the background of this lingering conflict, ${ }^{353}$ but with an exclusive focus on Meidias' misdeeds. What was the motivation for Meidias' risky step? There must have been a recent incident that finally induced Meidias to weigh all risks, go ahead, and hit Demosthenes in public. It should also make us suspicious that Eubulus supported Meidias in this case. Similarly to Demosthenes, the defendant against Simon in Lysias' third speech omits his part in the story. He does not explain why Simon and his friends behaved so outrageously; they employed charivari rituals against him, which the speaker talks about in detail. His strategy is easy to discern. He only represents his opponent's violence in court to conceal his own. We should wonder whether Simon exaggerated the de-

349 Antiphon 6.

350 Antiphon 1.15.

351 Ps.-D. 53.

352 MacDowell 1990, 8. J. Vince's characterization of the event as a "trivial occasion of the action" (introduction to Loeb volume Demosthenes III, Cambridge/MA 1956, p. 4) and Ober's "relative slightness of the offence" $(1994,93)$ miss the dramatic setting, which Demosthenes understood full well.

353 On the longevity of this conflict, cf. Yunis 2005, 206. 
fendant's violent behavior, and the answer is probably yes, but the speaker had nonetheless been aggressive enough for Simon to indict him. ${ }^{354}$ The defendant, who is the speaker in Lysias' fourth speech, relentlessly plays down his own violence, ${ }^{355}$ although the reader gains the impression that he was the actual aggressor. Concomitantly, he enhances his claim to innocence by effectively appealing for pity, ${ }^{356}$ for, according to ancient belief, only the innocent man deserved pity. ${ }^{357}$ The best way to arouse pity and visualize the rival's unheard of degree of violence was to stage one's suffering. Pittalacus sought the public gaze and thus a performative aspect and demonstratively sat down as a suppliant at the altar of the Mother of the Gods after Timarchus and his new sexual partner, Hegesander, had killed his fighting cocks ${ }^{358}$ and severely whipped him. ${ }^{359}$ In order to make his wounds visible to the public, Pittalacus did not wear a garment. This highly performative kind of self-exposure drove home a powerful message, which the bystanders and the perpetrators fully understood. Pittalacus' citizenship status was in doubt, ${ }^{360}$ but his whipping in the middle of the night was certainly beyond the threshold of acceptable behavior. A crowd gathered immediately around Pittalacus, curious to find out what had happened. Timarchus and Hegesander were panic-stricken and implored Pittalacus to leave the altar. ${ }^{361}$ They were afraid of formal and informal social control. The performance of suffering put heavy blame on the aggressors. In a similar vein, Archippus' brothers achieved the same goal by going public and carrying their seriously injured brother around the samples market. ${ }^{362}$

Too open a display of the victim's suffering, however, could also have negative side effects. This brings us to the ambivalent requirements for representing the opponent's violence. How could the perpetrator's guilt be aggravated? How could he be demonized without at the same time

354 Another strategy to cope with the accusation of violent behavior was to ironize it (Lys. 3.15-18).

355 Lys. 4.9-10.

356 Lys. 4.18. On the effective enactment of pity as spectacle, cf. Johnstone 1999, 110, 125.

357 Konstan 2006, 201-218; 2000 passim. Since one could not trust pity, it was not a virtue (Sternberg 2005, 40-43).

358 On the Pittalacus story and the geographical location of the cock fights and dicing games, cf. Fisher 2004, 71-76.

359 Aeschin. 1.59-60.

360 Fisher 2004, 67; Carey 2000, 43, n. 62.

361 Aeschin. 1.60-61.

362 Lys. fr. CXXIX 279. 
damaging the reputation of the victim? If the victim came across as defenseless, having to endure the opponent's bullying behavior without reacting to it, the assaulted person could lose face for a second time, appearing as a cowardly weakling in court. The protection of the powerless victim's honor is one of the main reasons for also representing an opponent's violence only in a mitigated form. In this process it made no difference whether the speaker himself or another person was the victim. The prosecutor, for whom it would have made a lot of sense to plead for pity on his status as a victim by highlighting his opponent's abuse, sought instead to prevent his further humiliation.

Exceptions confirm the rule. In Ps.-D. 47, the speaker renders the maltreatment of the old nurse and her death graphically and in great detail. This is one of the most vivid representations of violence we have from classical oratory: $:^{363}$

then the men-Theophemus and Evergus his brother-caught sight of her and treated her so brutally as they were wrenching the small cup away from her that her arms and wrists were all bloodied from having her hands twisted and pulled this way and that by them as they wrenched the cup away, and she had bruises on her throat from being strangled by them, and her chest was black and blue. Indeed, their meanness was such that they didn't stop throttling and striking the old woman until they had yanked the cup free from her bosom.

The concrete elaboration of a violent scene always depended on the temperament of the individual speaker. Whereas the grand orators thought to achieve more by restraint, the speaker in Ps.-D. 47 chose a different strategy by displaying the excessive degree of his opponents' violence. The victim was already dead and, as such, was not in need of being protected further. Her under-class status might have helped the speaker in not observing the rules of decency in the representation of violence. A definite answer, however, is difficult to give. In the speech Against Conon, Ariston is explicit about the wounds he received at the hands of Conon and his sons. ${ }^{364}$ Why did he go to such detail in describing his own utter humiliation? Was he not afraid of losing face a second time, in court? Demos-

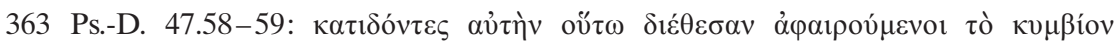

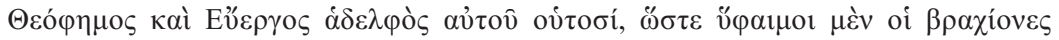

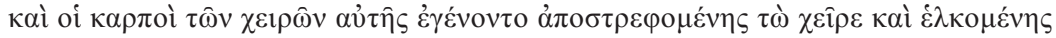

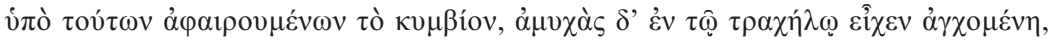

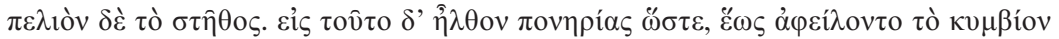

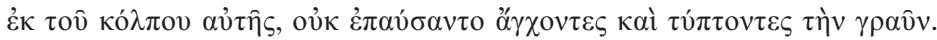

364 D. $54.7-8$. 
thenes, it seems, deliberately deviated from the standard norm and charged the performative situation with special significance. The speaker was the victim himself and a young aristocrat. Since he was outnumbered, his inability to defend himself was excusable. He had to persuade the judges that what he suffered was more than the habitual wrestling among youths eager to test their strength. Ariston and his logographer were prepared to break the convention in order to drive home a powerful message.

More typical was the case of Demosthenes. It is revealing that he did not explicitly mention in his speech Against Meidias the punch he had received. ${ }^{365}$ This low-key reaction on the discursive level can only be understood against the backdrop of the performative court culture. Meidias had displayed his social, economic, and political superiority by demonstratively punching Demosthenes in the face. Demosthenes did not want to grant him another, indirect stage performance by verbally re-enacting this humiliating incident. Once was enough. The people knew well what had happened and did not need a reminder. To elaborate on the punch again might have seemed obsessive to many and would only have shown hurt feelings. Talking about the actual occurrence in detail might even have appeared ridiculous and shaken Demosthenes' position to its foundations, ${ }^{366}$ at least in the eyes of those audience members who favored the archaic ideology of an "eye for an eye." Similarly, the speaker against Lochites does not dwell on the violence he received from the latter. Although he insists that Lochites did strike the first blow and does not mention his own violence, he describes Lochites' hubris only mildly. We do not hear more than the weak 'Lochites did indeed strike me. ${ }^{367}$

On a more serious note, even killings are not represented in detail. The prosecutor in Antiphon's First Tetralogy does not directly describe the killing of the victim, whose posthumous honor remains protected in all decency. ${ }^{368}$ In Isaeus 9, two brothers, Thudippus and Euthycrates, could not come to an agreement concerning the ownership of a piece

365 D. 21.13-18; cf. MacDowell 1990, 32.

366 Meidias might have played down the violence he had exerted like the defendant in Lys. 4.9, who claims that the prosecutor is so brazen as to call a black eye a wound.

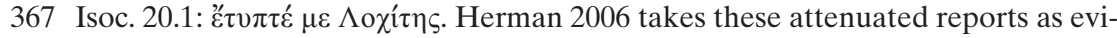
dence for the mild temperament of the Athenians. He is right in stating (21-22) that appeals for under-reaction pervade the whole corpus of Attic oratory, but this is a reflection of ideology rather than social practice.

368 Antiphon 2.1.4. 
of land. An ensuing fistfight resulted in Thudippus' killing of Euthycrates. From then on, the families of the two brothers would not talk to each other. Euthycrates, dying, had given an order that no one of Thudippus' family should ever come near his tomb. ${ }^{369}$ The speaker, who is the halfbrother of Astyphilus, the son of Euthycrates, questions the authenticity of Astyphilus' will, in which he allegedly named Cleon, Thudippus' grandson, as heir. Although the graphic description of Euthycrates' violent death would have made a lot of sense in the context of this speech, it is presented in weak, almost neutral terms, probably to protect the honor of Euthycrates. Many people had witnessed the fratricide, among them Hierocles, Euthycrates' brother-in-law. The speaker even insists that a number of Araphenians, who had been tilling the land at the time, would testify for him. The presence of so many witnesses would have facilitated the prosecution of Thudippus for homicide and would have made it even more unlikely that Astyphilus would have adopted the grandson of his father's killer. Nevertheless, the speaker does not take advantage of this opportunity to depict the killing graphically. Likewise, the cruel murder of Nicodemus of Aphidna, presumably committed by Aristarchus, a friend of Demosthenes', is represented only in mitigated form, although it is well attested in the sources. ${ }^{370}$ Only once does Aeschines become more explicit: "with both his eyes gouged out, poor wretch, and the tongue cut out. ${ }^{371}$ The mitigation of even the opponent's violence is in stark contrast to the broad spectrum of violent language the Greeks had at their disposal.

This does not mean that the omission of details is not used to good effect. At times, a lacuna in the narrative emphasizes the unspeakable. The aposiopesis-everyone knew what the gap stood for-was ritually staged in front of the judges. I speak of the performance of a semantically

369 A low-level reaction, indeed, as Herman 2006, 161-162 points out, but only at first glance. Phillips 2008, 91-96 explains the implications of this mitigated dying injunction. First of all, Euthycrates might not have wished to trigger a dikê phonou against his own brother. Secondly, his own son was too young to prosecute Thudippus. At the same time, barring Thudippus and his direct descendants from participating in the funeral rites, Euthycrates severed all kinship ties with this branch of the family. In an act of piety, Euthycrates' direct descendants followed the dying injunction and thus carried the enmity between the two branches of the family into the next generation. On other, more aggressive dying injunctions, cf. Phillips 2008, 64-68, 77-78, 205-207, 221-222.

370 Cf. above 40, n. 84.

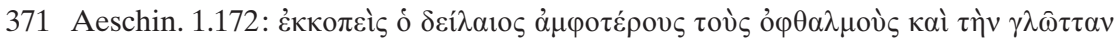

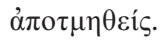


highly charged narrative vacancy, or simply of the performance of aposiopesis. In accusing Timarchus, Aeschines conceals his lack of proof by claiming that he cannot verbally render Timarchus' moral debasement. ${ }^{372}$ Conon insulted the severely beaten Ariston, who was lying in the mud, with such foul language that Ariston felt he could not repeat it in court. ${ }^{373}$ A verbal rendering would be another humiliation for Ariston because of the speech-act qualities of these abusive remarks. Because the power of an illocutionary speech act constituted verbal violence, Demosthenes does not want to repeat Meidias' and his brothers' vulgar talk in the presence of Demosthenes' womenfolk that led to a dikê kakêgorias against Meidias. ${ }^{374}$ Ps.-Demosthenes uses a similar rhetorical trick for the sake of character denigration. Nicostratus' and his friends' misdeeds are so numerous that even twice the time of a court session would not be enough to inform the judges about them. ${ }^{375}$ Through this performance of aposiopesis, the vile character of the perpetrators' actions and words could be stressed without doing the victim further harm.

The best orators went one step further. If possible, they enacted aposiopesis in a corporeal performance. Meidias had Straton disenfranchised because, in his capacity as arbitrator, he had rendered a verdict against Meidias. As a result of his disenfranchisement, Straton had become atimos and was no longer allowed to speak in court or in the Assembly. Demosthenes wanted to visualize Meidias' meanness by narrating its most horrible consequence. An innocent Athenian citizen had lost his citizen rights merely because he had rightly intervened against the strongman Meidias. The crowd should see this unheard of crime and be emotionally roused. Demosthenes here had a stroke of genius. He called upon Straton as a witness. It was clear that he would not be able to speak up. He came forward to the stage and stood there, silent, in front of the judges, and displayed what Meidias had done to him. ${ }^{376}$ Straton's muteness in public embodied Meidias' outrageous transgression, the undeserved exclusion of an Athenian citizen from the citizen body. The theatrical performance of this aposiopesis could not have been more symbolically charged. In his first

372 Aeschin. 1.38.

373 D. 54.9.

374 D. 21.79. MacDowell 1990, 3.

375 Ps.-D. 53.3; similarly, D. 21.129.

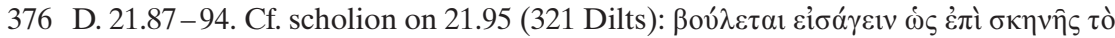

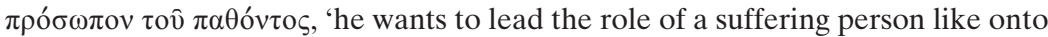
a stage.' Ober 1994, 97-98 and MacDowell 1990, 35-36 hint at the stage character of this incidence. 
speech against Aristogeiton, Demosthenes employed the same dramaturgical technique. Imprisoned for a long time, Aristogeiton had bitten off the nose of an inmate from Tanagra. To display this atrocity in public, Demosthenes had the mutilated man enter the dicastic stage. ${ }^{377}$ Like the arbitrator Straton, he was a silent witness testifying to the cruelty of the accused. ${ }^{378}$

To conclude: The fact that the verbal representation, even of the opponent's violence, did not stand in the foreground does not mean that his violence was not expressed adequately. Other means, in line with the amnesty and medial conventions, may have been even more effective. Not speaking about a violent act in court could work like an aposiopesis, which could even be performed onstage in brilliant strokes by the best orators. It put the questionable behavior into relief; emphasis was achieved by not mentioning the misconduct. It was the power of omission that stressed the outrageousness of a physical attack. Hence, mitigating the opponent's violence did not just protect the honor of the victim; it could, especially through the performance of an aposiopesis, be part of the attack strategy. The performative lacunae must have had immense repercussions similar to those of classical tragedy, where the act of killing was not displayed onstage, ${ }^{379}$ but was even more impressive and horrifying precisely because it was not openly demonstrated, ${ }^{380}$ but only brought to the spectators' minds through a messenger's report or an ecce-scene, for example. ${ }^{381}$

377 D. $25.60-62$.

378 Another famous incident of bodily representation is the anecdote according to which Hyperides uncovered Phryne's breasts in public so as to display her beauty (Hyp. fr. 60; Ath. 13.590d-591f). Naked truths told more than a thousand words, and Phryne was released from the politically motivated accusation of asebeia. Not only did Phryne's beauty save her, but it also exposed the adversaries' foolish plan to condemn both her person and her beauty. Cooper 1995 doubts the historicity of this incidence. Cf. Schuller 2008, 64-66 on her alleged relationships with Hyperides, Praxiteles, and Apelles, as well as her statuary representations.

379 Seidensticker 2006, 105 adduces causes of reception and production for the nonrepresentation of fatal violence on the tragic stage. There are notable exceptions, to which Herman 2006, 290, n. 78 draws our attention: Ajax commits suicide on stage in Sophocles' Ajax, Agave brandishes her son's head in Euripides' Bacchae. These shocking scenes deserve special treatment.

380 Goldhill 2006, 164, 168; Seidensticker 2006, 122.

381 For the methods of representing violence in tragedy, cf. Seidensticker 2006, $106-$ 121. Brutal violence was graphically depicted in tragedy (and epic). Tragedy was 
The verbal and performative representation of violence in court was a complicated matter. The speaker not only did not represent his own violence, but also mitigated the violence he had suffered at his opponent's hands. Exceptions confirm the rule, as we have seen. In addition to the reasons mentioned above, socially coded rules of decency regarding the medial representation of violence also account for the mitigated portrayal of the opponent's violence. While Athenians espoused a culture of public display, Athenian society did not appreciate the open display of negative affections. The graphic rendering of real-life violence (and other troublesome behavior and emotions such as mourning and grief) did no longer correspond to the code of behavior of fifth- and fourth-century Athenians. ${ }^{382}$ The temperate citizen was now the ideal. Against this ideological backdrop, it seems unlikely that all punches and slaps in public were spontaneous outbursts of violence. Rather, they may often have been calculated, carefully planned, and staged spectacles with symbolic significance attached to them. ${ }^{383}$ Although archaic discourses persisted and were often enough put into practice during the classical era, they were, as far as one's own person was concerned, negated in court, where the official, democratic set of values was constantly being enacted. Many bits of information that are not verbally preserved in the speeches must have been represented by the speaker through the medium of performance. The texts we have are only the skeletons of the original performances. It was the act of performance itself that was the lifeblood of the speech, and endowed a text with vividness by filling its semantic gaps. The spectators understood how violent an act really had been, even in the absence of a precise textual rendering.

able to re-enact the violence for the audience via verbal description, because, unlike in forensic speeches, which had consequences for the real litigants involved, the social status of the speakers was not at stake in fictional genres.

382 The archaeologist Bergemann 1997, 67, 151-156 has discovered that death and mourning are almost completely suppressed on grave reliefs. According to Bergemann 1997, 67, only a few gestures show emotions on Athenian grave reliefs of the classical period: "Dieser Befund findet seine Erklärung in den aus den Textquellen erschlossenen Vorbehalten der athenischen Gesellschaft gegen offen zur Schau getragene Emotionen. Die Äußerung von Emotionen in der Öffentlichkeit entsprach im 5. und 4. Jh. ganz und gar nicht gutem Benehmen." Cf. below 162, n. 592.

383 Also from this perspective, I think it a likely hypothesis that Meidias was not carried away when punching Demosthenes in the face, but that he acted deliberately and with premeditation. Cf. above 105, n. 352. 
Neglecting the performance aspect and the conventions of how to portray, or rather not to portray, violence in the media has misled generations of modern researchers into fabricating an all too rosy Athenian reality. As will become clear, these idealizing assumptions are skewed and have resulted in the scholarly fantasy of a highly pacified Athens. ${ }^{384}$

The rules of representing violence are structured in dichotomies that are based on the dichotomic, semantic markers of violent interaction. Like the latter, the rules guiding the representation of violence are dependent on the speaker's viewpoint. What we have observed in our treatment of interactionist rules is also valid for the principles of representation. One and the same occurrence could be interpreted very differently, if not in completely contradictory ways. Thus the evidence from ancient Athens calls for a constructivist approach. A specific action was not automatically considered "violence"; only its interpretation as such rendered an act "violent." What constituted "violence" was not determined by the deed itself, as violent as it may have been, but by the ensuing discursive treatment of it. This holds true even for homicide. Under certain circumstances and with the appropriate reasoning, homicide could be considered lawful. The perpetrator would insist that he did not break any rules of interaction, but, on the contrary, that his measures, all of which lay within the sphere of acceptable behavior, were legitimate, if not required by the polis to help maintain law and order. In contrast, any speaker would claim that his opponent had violated certain rules of interaction and that his deeds, therefore, deviated strikingly from socially accepted norms. This strategy of legitimizing one's own behavior and delegitimizing the opponent's behavior entailed downplaying one's own violence and exaggerating the rival's violence, albeit indirectly. Almost no bounds were set for the negative construction of the opposed party. Whether the opponent was finally stigmatized as a danger to the polis who had to be done away with lay in the logic of exaggerating the charges. The constructions of a positive and harmless self-image and of a negative and highly detrimental view of "the other" reinforced each other.

384 Herman 2006 passim; Harris 2005; to a lesser extent also Gagarin 2005, 366, who deduces from the low number of incidences of violence found in the orators a relatively peaceful society. Cf. Faraone (especially 1991a and b; 1988), with regard to the malicious intent of curse tablets. We should consider Schmitt Pantel's observation $(1998,45)$ that ancient historians in general have forgotten about Greek violence or have played it down. Exceptions confirm the rule, as, e.g., Bernand 1999, who offers an anthropological view of Greek violence without idealizing historical reality. 


\section{Selfless Motives versus Selfishness}

Whereas a speaker typically portrays himself as driven by selfless motives - in the end, his actions help uphold the polis ${ }^{385}$ - he often presents his opponent as motivated by personal greed and selfishness. ${ }^{386}$ In such cases, the opponent is often portrayed as even supported by foreign powers such as Persia or Macedon, ${ }^{387}$ which constitutes an inappropriate interference with Athenian affairs. Euphiletus, for example, portrayed himself as good-natured, naïve, and gullible. For a long time he had no clue as to what was going on in his house. The self-image of a simpleton stands in stark contrast to the cunning of the notorious adulterer Eratosthenes.

Through verbal representation and its enactment on the stage of the courts, the viciousness of the opponent was performed and thus exposed to the judges and the bystanders in court. The convention of not fully representing violence, not even that exerted by the opponent, led to extreme character denigration instead, serving as a contrasting foil against which one could positively present oneself. The negative characterizations of Timarchus and Meidias, as well as Conon and his sons, belong to the most famous examples in Attic oratory. At the same time, these reproaches had to engage the audience emotionally. This goal was achieved by various means; for example, through a performative act, ${ }^{388}$ by stirring up the feelings of the audience through exuberant rhetoric, or by heaping ridicule on the opponent so as to fulfill the entertainment aspect that was required of a good speaker. In this context, this last point deserves further treatment. In his accusation of Timarchus, Aeschines has preserved a supreme example of situational humor at the expense of his opponent. ${ }^{389}$ Autolycus, a member of the Areopagos, spoke in front of the Ekklêsia to discuss and reject a proposal by Timarchus. In doing so, Autolycus unknowingly played with sexual metaphors. The audience found the double meanings so amusing that they could not control themselves and burst into laughter. In retelling the story, Aeschines re-enacted the comic situation and exposed Timarchus to ridicule for a second time. This was no harmless thing. According to Versnel, it was only rarely that laughing had purely positive connotations in the Greek world. Mockery and laughter, on

385 E.g., Lys. 1.4, 34, 36, 47-49.

386 E.g., Din. 1.

387 Aeschin. 2 and 3.

388 Cf. above 110, n. 376 on Straton and 111, n. 378 on Phryne.

389 Aeschin. 1.81-84. 
the contrary, excluded the persons laughed at by alienating them from their communities. Derision, especially if performed in public, could lead to the victim's losing face. ${ }^{390}$ A few examples may suffice. Demosthenes scolded the people for taking delight in seeing orators taunted. ${ }^{391}$ In his speech against Meidias, Demosthenes amuses his audience by graphically describing Meidias' lack of qualifications for serving as a cavalry commander. The allegation that Meidias cannot even sit on a horse is biting slander that comes across as a joke. ${ }^{392}$ Demosthenes further arouses hatred against Meidias by insinuating that Meidias had offered him more money in compensation for the blow than he would ordinarily have paid to the city in the form of liturgies. In doing so, Meidias would have made Demosthenes a laughingstock in the society of onlookers. Hence, Demosthenes' indignation is understandable. ${ }^{393}$ To what extent derision could come close to hubris, or could even be regarded as hubris, can be deduced from Ariston's speech against Conon, whose sons maltreated Ariston's slaves first and thereby displayed their contempt for him. Conon's sons topped this deliberate provocation of Ariston by mocking him and his messmates. ${ }^{394}$ These insults finally resulted in the beating of Ariston and Conon's hybristic rooster dance above Ariston's seriously injured body.

In order to come to terms with the broad concept of hubris, an analysis of two complexes that are closely related to it-anger and the transgression of boundaries-shall serve as a means of approaching the performative character of hubris. The two complexes help explain how outbursts of emotion, especially fits of anger, were treated and how transgressions of norms were perceived.

\section{Anger}

The notion of anger ( orgê) had become problematic by the $450 \mathrm{~s} \mathrm{BCE} .^{395}$ In Herodotus, anger became the attribute of the "other," mainly the bar-

390 Versnel 1999, 137-155.

391 D. 18.138.

392 D. 21.171. Cf. Harding 1994, 210, who demonstrates that Demosthenes comes closest to Old Comedy in his choice of "techniques, themes, and vocabulary."

393 D. 21.151.

394 D. 54.4.

395 W. Harris 2001, 164. 
barian. ${ }^{396}$ Thucydides sharply criticizes decisions that the fickle masses had made in anger. ${ }^{397}$ By the end of the fifth century, the leading circles regarded orgê as jeopardizing the agonistic culture of the polis. ${ }^{398}$ Isocrates argued that anger should be strictly controlled. ${ }^{399}$ To Plato, anger had become separate from reason. ${ }^{400}$ Orgê, cholos, and thumos ${ }^{401}$ were now often linked to mania, madness. ${ }^{402}$ Orgê found its negative expression in an excessive fit of anger, which stemmed from a lack of self-control, ${ }^{403}$ and characterized the transgressive nature of the perpetrator. The Areopagos sent the father of a priestess of Brauron into exile because he had enticed an assailant to strike another man, who died as a consequence. ${ }^{404}$ In his accusation of Meidias, Demosthenes adduces a highly interesting case. During a symposion, Euaeon suffered a slight from his drinking mate Boeotus. ${ }^{405} \mathrm{He}$ felt so offended that he could not restrain himself and killed the offender. Thus, he exercised exaggerated revenge and was condemned by a single vote. Demosthenes even explains what the almost-split vote meant. While almost half of the judges felt Euaeon was right in retaliating even at the risk of killing the aggressor, a minimal ma-

396 E.g., Hdt. 3.1, 25, 32-36; Hdt. 7.11, 39; Hdt. 9.111; W. Harris 2001, 171-176.

397 E.g., Th. 2.21.3-22.2; 3.36-49; W. Harris 2001, 179.

398 W. Harris 2001, 181, 187, 200.

399 E.g., Isoc. 1.21. On the containment and channeling of anger in classical Athens, cf. Borg 2006, 237.

400 Allen 2000, 255-257.

401 Orgê is closely related to thumos. According to Viano 2003, 93-94, the originally broad semantic range of the term thumos was narrowed down by Aristotle in particular, who sees thumos as "source of anger and courage," "impulsive desire," and the "irrational faculty or passion of the soul." Faraone 2003 discerns the same semantic development of the term in magical spells. It came to denote a kind of masculine orgê in later curses that comes close to the Mediterranean "machismo." Winkler 1990, 78 works out well the official ideology requiring one to restrain one's thumos. On the representation of these emotions in Old and New Comedy, cf. below 254-260; 319-331.

402 Borg 2006, 253.

403 Konstan 2006, 58.

404 D. 54.25. This means that the courts decided on the question of how much anger was acceptable (Allen 2003, 77).

405 D. 21.71-75. Konstan 2006, 45 translates the Greek word oligôria ('lessening,' 'belittlement') as 'slight.' Demosthenes does not speak about oligôria in this passage, but about the atimia that Euaeon suffered. Atimia is the stronger word and explains even better Euaeon's entitlement to orgê. The passage fits into the larger context of showing that Demosthenes had even better reasons to be angry at Meidias, but that he chose to go to court rather than strike back personally. Thus, Demosthenes demonstrates his exemplary ability to control anger. 
jority of judges did not have qualms about the revenge, but about its extreme form of killing the assailant. ${ }^{406}$

Orgê as the "desire for revenge" 407 became problematic at the time when physical revenge fell out of use and was supplanted by court proceedings. With lawsuits becoming acceptable means of revenge, going to court did not do away with anger, but kept it under control. ${ }^{408}$

If the anger remained within certain limits, it could be regarded as justified and even righteous. ${ }^{409}$ In a world where a person's social status depended on his honor and good reputation, any insult necessarily aroused the anger of the offended party. ${ }^{410}$ Aristotle even goes so far as to characterize a man as stupid and servile if he does not grow angry at the abuse of his person. ${ }^{411}$ This positive assessment of anger explains the orators' frequent use of the concept in their own behalf ${ }^{412}$ and shows that a fit of anger was as open to interpretation as any other semantic marker of violence.

Dwelling on one's anger in a speech was not only a convenient rhetorical device to stir up the feelings of the audience, ${ }^{413}$ but also a way to justify one's own problematic behavior. In the eyes of the speaker

406 Demosthenes thus presents the underlying assumption that anger should be proportionate to the offense. Cf. Konstan 2006, 67 and above 35, n. 67. The search for the right measure of violence (as of erotics) also becomes a motif in vase painting: Borg 2006, 242-243, 257.

407 Konstan 2006, 56.

408 Konstan 2006, 69. The orators often play with the concept of orgê, a phenomenon that warrants a more in-depth study than can be accomplished here.

409 Konstan 2006, 70-72 on anger as a legitimate response to wrongdoing, also in foreign politics.

410 Konstan 2006, 58, 75-76 regards anger as obligatory in the Athenian social system.

411 Arist. EN 1126a4-8.

412 Allen 2003, 76.

413 It is important to note, however, that recourse to anger is mainly reserved to graphai, where the polis as a political entity was at stake, not just money, as in the dikai. In dikai, the suing parties generally avoided the language of anger and punishment. Since dikai were often brought between kin and aimed for viable dispute settlements, an excessive use of the orgê motif could even be counterproductive (Rubinstein 2005b, 129-134). Especially in inheritance and maritime cases, cooperative values counted more than intransigence. On the strict focus on relevance and the high level of consistency reached in the dikai emporikai, cf. now Lanni 2006, 149-174. Kurihara 2003 shows that, on the level of ideology at least, personal enmity should only motivate private, but not public, suits. On the close connection between $\operatorname{org} \hat{e}$ and law and its treatment in tragedy, cf. Allen 2005, 385-392. 
who instrumentalized orgê for his own sake, anger was a passion and, unlike in cases of hubris, his spontaneous outburst of violence happened only in response to an insult received. ${ }^{414}$ According to Demosthenes, Meidias could not argue that he was carried away by a fit of anger, because he was enmeshed in a long history of transgressions: ${ }^{415}$

What kind of pretext, what human or reasonable excuse will emerge clearly from his actions? Anger, by Zeus: yes, perhaps this is what he will say. When someone is carried away and acts on the spur of the moment before having a chance to think, one would say that his actions, even if performed in an insulting manner, have been done because of anger. On the other hand, if someone is detected doing something for a long time, repeatedly over many days, and in violation of the laws, his actions are certainly far removed from those done in anger, but it is clear that such a person is deliberately committing outrage.

Hence, Meidias' misconduct was worse than $\operatorname{org} \hat{e}$, because it was not a spontaneous fit of anger, but a deliberate and planned attack on Demosthenes' honor. Demosthenes does not talk about his provocation of Meidias, but implies that Meidias did not suffer a slight from his part. Demosthenes argues that he was innocent and therefore all the more entitled to justifiable anger. ${ }^{416}$ And because Meidias had insulted him in his capacity as an Athenian citizen and in his function as a chorêgos, Meidias deserved the anger of the whole citizenry. ${ }^{417}$

Euphiletus could have argued that he was driven by passion when he killed Eratosthenes. And indeed, he does speak about the outrage he suffered and his entitlement to revenge. ${ }^{418}$ But, since his careful planning and staging of Eratosthenes' "execution" was incompatible with a fit of anger, he had to think about another motivation for his deed, which he found in the fulfillment of a civic duty. ${ }^{419}$ This strategy explains his emotionally detached description of the murder, which seems strange to a modern read-

414 Faraone 2003, 161 works out how closely linked masculine, righteous anger and passion (proper male behavior) were.

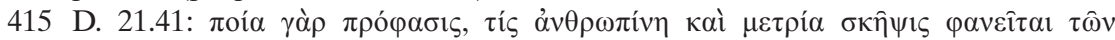

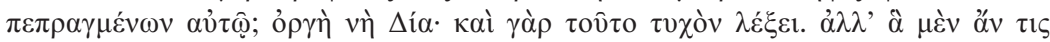

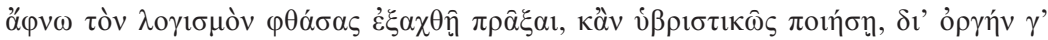

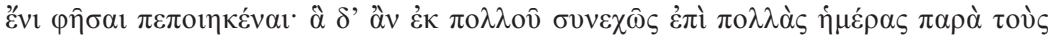

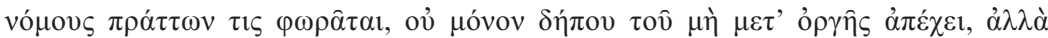

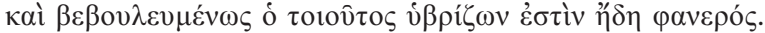

416 On anger being justified under particular circumstances, cf. W. Harris 2001, 185.

417 D. 21.73, 123, 127, 175, 196, 215, 226.

418 Lys. 1.2 .

419 Lys. $1.45-50$. 
er. In the end, the decision about whether or not a fit of anger was appropriate involved the assessment of its transgressive nature. An angry response to an insult suffered should ideally be in proportion to the abuse. But even retaliating on a harsher note was acceptable as long as the action taken did not entail homicide.

\section{Transgression of Boundaries}

Understanding the implications of threshold transgressions, in a literal and metaphoric sense, is a further prerequisite for the analysis of hubris. When Isocrates, for example, expresses the idea of breaking the law, he uses the standard formula 'they transgressed the law. ${ }^{420}$ In this and similar contexts, ${ }^{421}$ the orators also speak of hubris, indicating that there is more at stake than just the violation of a law. The negative symbolism of the violent act increased with the number of boundaries transgressed. If, in this process, violence took on symbolic significance, the threshold metaphor can even be expanded in its spatial dimensions. The best example, again, is probably Meidias' striking of Demosthenes. Meidias' punch deeply hurt Demosthenes' personal honor, not only as a private citizen, but also as chorêgos failing to fulfill his religious, cultural, and political functions. Since multiple threshold transgressions occurred in public, communication with the spectators took place on a symbolic level. The audience had in mind the social rules that chorêgoi had to observe in interactions with each other at high religious festivals. They understood well Meidias' multiple deviations from the model in their symbolic implications.

A perpetrator would argue along different lines. Either he would downplay the violence he had exerted or he would ascribe a positive value to it, if he could not deny the transgression of laws and social conventions. In the first case, he would claim that he had violated only a few thresholds, if any at all. His violence was justified because it was either self-defense or directed against a non-citizen or someone who could no longer be regarded as a citizen. From this perspective, his action was irrelevant and did not carry a special symbolic meaning. In the latter case, his argumentation was similar, but he would go on the offensive by charging his actions with positive meaning. In both cases, he would portray his own

420 Isoc. 20.7: $\tau$ òv vó $\mu$ ov $\pi \alpha \rho \varepsilon_{\beta} \eta \sigma \alpha v$ (transl. Riess).

421 E.g., Isoc. 20.4; Lys. 3.5-8, 37. 
violence as being in the interest of the Athenian state and the upkeep of its social and political order.

The ambivalent notion of anger and, above all, the threshold metaphor, help us to understand better the notion of hubris. The more thresholds that were violated, the more the victim suffered from hubris and felt orgê at the outrageous act. While the victim would characterize his opponent with hubris-words, ${ }^{422}$ he would emphasize his own self-restraint and insist that his actions were all located within the boundary of acceptable behavior. Far from exercising hubris himself, he was provoked by his hybristic opponent to resort to legitimate counter-measures to fend off aggressions.

\section{Hubris}

For generations, scholars have tried to pin down the definition of hubris, but so far they have not come to an agreement. ${ }^{423}$ Demosthenes and Aeschines do cite the law of hubris, ${ }^{424}$ but the underlying meaning is taken for granted by the Athenian lawgiver, who saw no need for spelling it out. Hundreds of passages scattered all across Greek literature mention hubris in manifold contexts. Aristotle analyzes the phenomenon of hubris in detail and strives for consistency, ${ }^{425}$ and yet the exact meaning of hubris

422 Good examples: Lys. 3; Isoc. 20; D. 21; 54. Cf. also Antiphon 4.1.6.

423 Todd 1993, 270-271; Garner 1987,34. A good summary of the discussion is MacDowell 1990, 17-21.

424 D. 21.47-48; Aeschin. 1.15-16. I quote Aeschines' paraphrase (1.15), not the

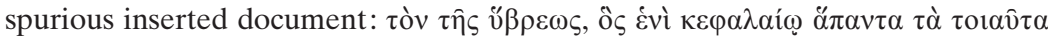

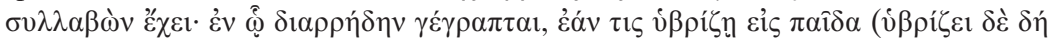

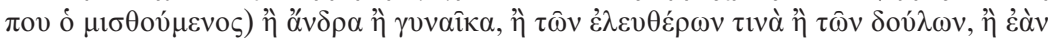

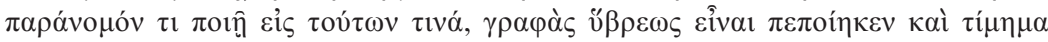

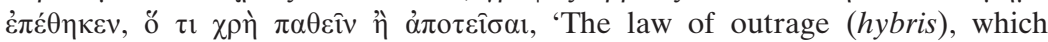
sums up in a single statement all such acts. In this law is written explicitly that if anyone commits outrage against a boy (and anyone who hires him commits outrage, I imagine) or man or woman, whether free or slave, or if he does anything contrary to law to any of these, it has allowed for an indictment (graphê) for outrage and prescribed assessment of the penalty he is to suffer or pay.' On this law as issued by Solon, cf. Fisher 1992, 81-82.

425 Arist. Rh. 1373a35; 1373b38-1374a15; 1378a31-33; 1378b13-30; 1379a30, 32; 1380a29; 1380b5; 1382b35-1383a3; 1384a16-19; 1385b19-24, 31; 1389b7, 12; 1390a19; 1390b32-34; 1391a14-19; 1395a1; 1398a25; 1402a1-2; 1408a16. Phillips 2000, 276-278 provides an English translation of some of these passages. 
remains elusive and has given rise to various scholarly debates. ${ }^{426}$ While no one would question Cohen's catch-all definition encompassing physical violence, verbal insult, and sexual outrage including rape, adultery, and seduction, ${ }^{427}$ the term has even wider implications and the discussion has centered upon the question of whether the commitment of hubris always required a victim, or if excessive self-assertion ("thinking big") was already enough to account for hubris. The first position is vehemently represented by Fisher, who has provided a seminal study of all instances of hubris in Greek literature. ${ }^{428}$ According to him, hubris is "the committing of acts of intentional insult, of acts which deliberately inflict shame and dishonor on others." ${ }^{429}$ Thus, hubris is unthinkable without an object. Cantarella and Gagarin have basically followed Fisher. ${ }^{430}$ This view is disputed by Cairns, ${ }^{431}$ Dickie, ${ }^{432}$ Michelini, ${ }^{433}$ MacDowell, ${ }^{434}$ and Hooker. ${ }^{435}$ They all emphasize the importance of dispositional factors on the side of the hubristês. Hubris is an over-confident state of mind and excess energy, based mainly on youth ${ }^{436}$ and wealth, which drives a man to use his abundant power self-indulgently. Cairns even goes so far as to equate $h u-$ bris with "thinking big," 437 suggesting that this kind of arrogant attitude alone constituted hubris and did not necessarily involve the infliction of dishonor upon a victim. It can, however, find its outlet in different actions, for example, in beatings and killings. ${ }^{438}$ Thus, an insult is recognizable in most cases, "but the insult consists not in an act or an intention to act, but

426 MacDowell 1990, 18-23 provides a good overview of the history of research. The debate on the time of origin of the hubris law is irrelevant in the context of this book.

427 Cohen 1991a, 185. Cf. his detailed observations in Cohen 1995, 121-126, 143 162.

428 Fisher 1992.

429 Fisher 1992, 148; similar Fisher 1992, 1, 25, 56, 493 et al. Cf. Fisher 1990, 126 and 1976, 185-187, where he even goes so far as to claim that his definition fits all occurrences of hubris in Greek literature; cf. also 1979, 44-45, where he manages also to fit problematic passages into his concept.

430 Cantarella 1983; Gagarin 1979a, 230.

431 Cairns 1996, 1; 1994 (review of Fisher 1992).

432 Dickie 1984.

433 Michelini 1978.

434 MacDowell 1990, 18-23 (most explicitly); 1978, 129-132; 1976, 23.

435 Hooker 1975.

436 On the connection between youth and hubris, cf. in detail Fisher 1992, 97-99.

437 Cairns 1994, 78.

438 MacDowell 1990, 19, 21-22; 1978, 129. Cairns 1996, 1 summarizes the debate. 
in the impression created by a disposition of excessive self-assertion." ${ }^{439}$ Although Cairns has indeed managed to bridge the divergent opinions as much as possible with this and similarly subtle formulations, ${ }^{400}$ and although there is much common ground among scholars today concerning our understanding of hubris, a fundamental uncertainty remains in the absence of any contemporary definition.

A performative interpretation of the phenomenon of hubris can further reconcile the different views. The Athenians deliberately avoided precise definitions. On the contrary, on the basis of cultural preconceptions, they insisted on "defining" the meaning of hubris every day afresh in the law courts. This is common knowledge, ${ }^{441}$ but needs to be expanded. The Athenians were able to do so because they saw and sensed what hubris was. Whether or not there was a victim involved, hybristic behavior had to be displayed on the interactionist level and was coined as such on the representational level, where litigants and judges ascribed the sense of hubris to certain transgressive acts. Research has taken the famous passage in D. 21.72 as one of the best descriptions of dispositional factors, here with a victim involved: ${ }^{442}$

It was not the blow that aroused his anger, but the humiliation. Being beaten is not what is terrible for free men (although it is terrible), but being beaten with the intent to insult. A man who strikes may do many things, men of Athens, but the victim may not be able to describe to someone else even one of these things: the way he stands, the way he looks, his

439 Cairns 1994, 78.

440 Cairns 1996, 32: "Self-aggrandisement constitutes an incursion into the sphere of others' honour, because the concept of honour is necessarily comparative. Thus the reason why MacDowell, Dickie, and others ought to recognize that their accounts of hybris should be firmly located within the concept of honour is also the reason why Fisher should accept that the essential relationship between hybris and dishonour can accommodate purely dispositional, apparently victimless forms of self-assertion." Harris 1992, 74 also thinks that the different standpoints are not irreconcilable.

441 E.g., Cohen 1995, 152-153; MacDowell 1990, 22.

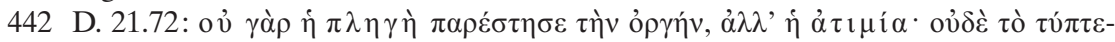

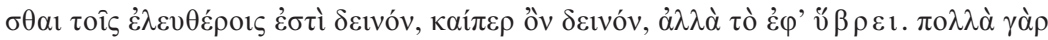

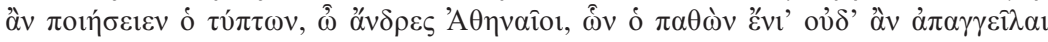

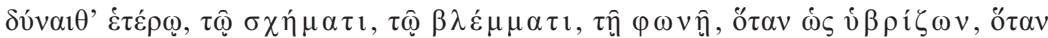


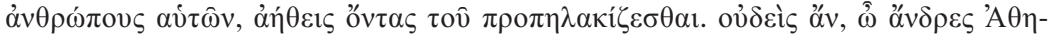

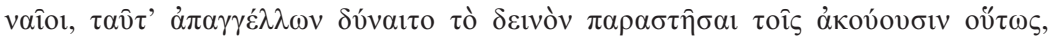

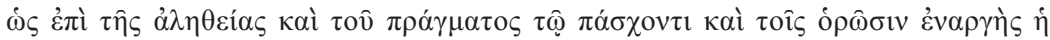

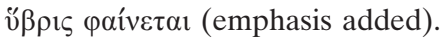


tone of voice, when he strikes to insult, when he acts like an enemy, when he punches, when he strikes him in the face. When men are not used to being insulted, this is what stirs them up, this is what drives them to distraction. No one, men of Athens, could by reporting these actions convey to his audience the terrible effect of outrage in the exact way that it really and truly appears to the victim and those who witness it.

While I do not want to deny the presence of dispositional factors in this passage, I would like to emphasize rather the performative side of this presumptuous state of mind. The 'humiliation' and 'intent to insult' must be seen or felt to count as hubris; otherwise it is not tangible. In most cases, as in the above-quoted example, and here Fisher is right, the contemptuous behavior has a target. Conon's rooster dance above Ariston as he lay on the ground, ${ }^{443}$ and the maltreatment of Pittalacus, the demolition of his furniture, and the killing of his fighting cocks ${ }^{444}$ are further prime examples, to name just a few. In other cases, and here MacDowell and his supporters are right, hybristic behavior can do without a concrete victim: $:^{445}$

Will you be the only person in the world who has the greatest reputation for being stuffed with so much arrogance toward everyone that even those who have nothing to do with you get irritated when they see your pushiness, your shouting, the way you strut around with your entourage, your wealth, and your abuse-and then find yourself pitied the minute that you are on trial?

What both quoted passages have in common is that the hubristês displays his self-indulgent state of mind, with or without a victim. A tone, a look, a gesture, a deed is symbolically charged with the notion of hubris, because it is performed in front of an audience. Thus, a performative analysis of hubris cases can help us understand better the complex phenomenon and bridge gaps in research. ${ }^{446}$

Besides its performative nature, the second major component of hubris is its transgressive nature. ${ }^{447}$ Since the body of an Athenian citizen

443 D. 54.9.

444 Aeschin. 1.53-62. Cf. Fisher 2004.

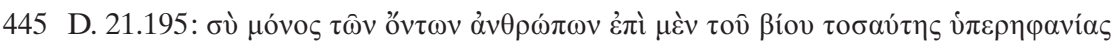

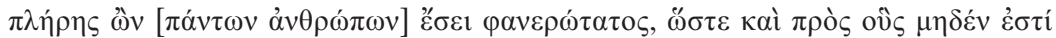

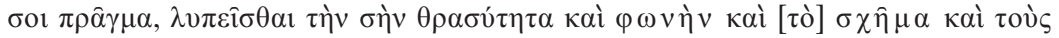

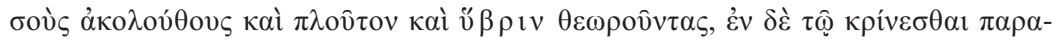
$\chi \rho \hat{\eta} \mu$ ' $\dot{\lambda} \lambda \varepsilon \eta \theta \dot{\mid} \sigma \varepsilon 1$; (emphasis added).

446 Cf. the very similar passage at Isoc. 20.5-6.

447 Fisher 1979, 44-45 stresses the transgressive nature of hubris. 
was inviolable, ${ }^{448}$ any infringement upon a citizen's body could be regarded as hubris. Nicostratus sent a free Athenian boy onto Apollodorus' property to pluck some of his rose blossoms, in hopes that Apollodorus would assume the boy was a slave, tie him up, and beat him. Nicostratus could then have indicted him for hubris. The passage implies, contrary to the above-mentioned law of hubris, ${ }^{449}$ that tying up and hitting a slave was not hubris. ${ }^{450}$ Themistius of Aphidna raped a Rhodian lyre player at the Eleusinia and was executed as a consequence. ${ }^{451} \mathrm{We}$ may hypothesize that she was a free woman; otherwise her rape would not have warranted the death penalty for the rapist. That freeborn Greek women enjoyed a minimal protection of their bodies, even as prisoners of war, is shown by the incident of Aeschines' maltreatment of an Olynthian captive woman at a banquet in Macedon. ${ }^{452}$ Euthymachus, too, suffered the death penalty, because he had put an Olynthian girl, presumably a prisoner of war, in his brothel. ${ }^{453}$ In this last case, we see that the detention of a free man or woman was a serious crime and was considered hubris, because a citizen's body had been violated. We have more and ample evidence. Teisis' binding of Archippus to a pillar and his whipping throughout the night is a prime example of outrageous, hybristic behavior. ${ }^{454}$ Menon, the miller, was executed because he had retained a free boy from Pallene in his mill. ${ }^{455}$ Pancleon claimed to hail from Plataea and therefore to be an Athenian citizen, but Nicomedes and the speaker of Lysias 23 contested this allegation. The former even tried to seize Pancleon by claiming that he was his slave. After a brawl, Pancleon was car-

448 According to Demosthenes, the laws protected the Athenian citizen's body and encouraged disputants to handle conflicts in a noncorporal manner: D. 21.178 181; D. 22.53-56. There is also epigraphic evidence, mainly honorary decrees that protect the foreign honoree like an Athenian citizen, e.g., IG $\mathrm{II}^{2} 72,73=$ IG I $^{3}$ 179; IG I3 164, 228; AG XVI 20; SEG XXXIII 96; StV II $268=$ SEG XXXI $67=$ SEG XLV 47 (Second Athenian League); IG II ${ }^{2} 46=$ StV II 235 = AG XVI 35 (agreement between Athens and Troizen).

449 Cf. above 120, n. 424.

450 Ps.-D. 53.16. Cf. on this passage Bers 2003, 62, n. 30 and above 88, n. 296.

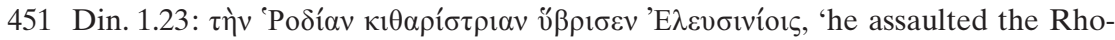
dian lyre player at the Eleusinia.'

452 D. 19.196-198; Aeschin. 2.4, 153-155. Cf. above 89-90.

453 Din. 1.23

454 Lys. fr. CXXIX 279.

455 Din. 1.23. Cf. Phillips 2000, 205 on slave labor. Lesis' master, however, can subject his apprentice boy to any kind of torments because of his slave status. Cf. above 89 , n. 300. 
ried off by force, which caused turmoil in light of his unclear citizenship status. ${ }^{456}$ In Lysias 3, the citizenship status of Theodotus, a male prostitute, was unclear, although he undoubtedly came from Plataea. He was an object of desire for both Simon and the speaker. Whereas Simon felt entitled to drag him off by force several times because he regarded him as a slave, the speaker rather treats these raids as hybristic abductions of a free citizen. ${ }^{457}$ In one instance, the detention of an Athenian citizen definitely led to a graphê hubreôs. This is the only securely attested case of this legal procedure. ${ }^{458}$ Diocles had locked up his brother-in-law and prevented him from fulfilling some civic duties, as a result of which he lost his civic rights (atimia). This outrage caused someone to file a graphê hubreôs against Diocles, but we do not know the verdict. It is telling that Alcibiades' detention of the painter Agatharchus in his house for three months caused considerable ill feelings, but did not have legal consequences. $^{459}$

In brief, hubris was the open and performative display of an excessive attitude that transgressed the flexibly defined domain of good behavior. The way in which this arrogance was performed, with or without a victim, was secondary to the definition. It comes as no surprise that the rich and young were especially prone to hubris, because they were eager to show off their superiority (cf. Arist. Rh. 1389a).

456 Lys. 23.

457 Lys. 3.11-12, 15, 37. Cf. the similar anecdote about Phrynion, Stephanus, and Neaera (Ps.-D. 59.40).

458 Is. 8.41 and fr. 5. Other cases: The graphê hubreôs brought by Apollodorus against Phormio was dropped (Ps.-D. 45.3-5). Further possible cases are Arist. Rh. 1374b35-1375a2; D. 21.36-40, 71-76, 175-181 (possibly probolê cases); Lys. fr. CXXIX 279 (maybe dikê aikeias) and more dubious cases, historical and fictional (Ps.-D. 53.16; Din. 1.23; Ar. V. 1417-49; Nu. 1297-1302; Av. 1035-57; Pl. 886-936). Cf. Fisher 1990, 125-126; Osborne 1985, 56. Five more graphai hubreôs that are only attested by speech title are listed at Fisher 1990, 133, n. 29.

459 Ps.-And. 4.17 relates that Alcibiades treated Agatharchus like a slave. D. 21.147 claims that Alcibiades caught Agatharchus in an act of trespass and was therefore entitled to detain him for a while. The scholiast explains the trespass: allegedly, Alcibiades had found the painter having intercourse with his concubine (506 Dilts). Plu. Alc. 16.4 reports that Alcibiades released the painter with a nice gift after he had embellished his house with paintings. Unlike in all other cases, where it was strictly forbidden to detain a citizen, it was obviously permissible to do so with a moichos (Christ 1998b, 523). Cf. above 87, n. 292. 


\section{Tyrants}

Laying hold of an Athenian citizen's body illegally links the notion of $h u$ bris to that of tyranny. ${ }^{460}$ In his character denigration of Androtion, Demosthenes had recourse to the Thirty Tyrants and their illegal arrests of citizens in the Agora. Androtion was worse than the tyrants, Demosthenes contends, because he sent the Eleven into citizens' homes. ${ }^{461}$ With this biting remark, Demosthenes makes the metaphorical threshold transgression, so typical of hubris, literal and concrete. In 22.68 he widens the reproach of binding and arresting aliens and citizens alike to the more general portrait of a hybristic man, who yells in the Ekklêsia because of his lack of self-control and calls free men slaves and slave-born.

Isocrates, in his speech Against Lochites, has the speaker equate his opponent, Lochites, with one of the Thirty Tyrants just because of his $h u$ bris. ${ }^{462}$ Given the young age of the accused, this reproach was absurd. The offense at stake was a blow. The speaker, however, trumps up the charge and connects Lochites' hubris to the one exercised by the Thirty Tyrants, who 'betrayed our empire to the enemy, razed the walls of our homeland, and executed fifteen hundred of our citizens without trial. ${ }^{463}$ Once more we see that the tyranny of the Thirty casts a long shadow over fourth-century discourses on violence. The arch-hubristês was a tyrant, and vice versa. Hubris and tyranny became interchangeable constructs, mainly designed and represented in court. ${ }^{464}$

The tyrant is the embodiment of hubris. ${ }^{465}$ The founding myth of Athenian democracy was based on the elimination of tyrannical hubris

460 On the semantic development of the word, originally having the positive sense of "king," to the later negative meaning of "tyrant," cf. Parker 1998. According to Parker, the sharp semantic distinction between tyranny and kingship is Attic (170-172). Cf. above 75-78 on hubris and tyranny in the context of threshold violations.

461 D. 22.52 and D. 24.164 seem to be a doublet. But the Thirty, too, violated the protected sphere of the oikos; cf., e.g., Lys. 12.8; X. HG 2.4.14.

462 Isoc. $20.10-11$.

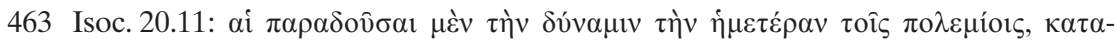

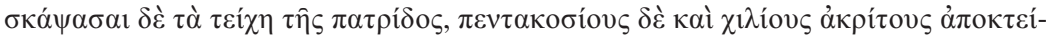

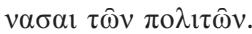

464 The first equation is to be found in S. OT 873; cf. Parker 1998, 161.

465 The tyrant remains a highly ambiguous figure in the imagination of the Greeks. Cf. above 77-78. When Athenians spoke about violence, they barely attributed positive traits to a tyrant-like figure, unless the perpetrator himself played with the image of an omnipotent tyrant and thought he could get away unpunished 
by Harmodius and Aristogeiton. ${ }^{466}$ In Girard's terminology, their killing of Hipparchus was an act of founding violence, ${ }^{467}$ which created something new: democracy. Tyrants operate outside the norms, transgress thresholds, violate $o i k o i,{ }^{468}$ disrespect the inviolability of the Athenian citizen's body by executing citizens without trial, and appropriate the laws of the city. Thus, they trample on the democratic constitution and overthrow the public order of the polis in order to seize power illegally. Through these hybristic actions, they incur pollution and need to be driven out of the city like the Peisistratids and the Thirty Tyrants. ${ }^{469}$ When Aeschines demands that Demosthenes be cast beyond the borders of Attica, ${ }^{470}$ he widens the notion of the polluted scapegoat in the religious sense, charges it with political meaning, and applies it as a strong metaphor to his political opponent in order to crush him. ${ }^{471}$ It is designed to evoke negative connotations by characterizing Demosthenes as an outsider and associating him with tyranny. Aeschines, in his speech, heaps the sins of the city upon Demosthenes. Only the driving out of the tyrant as a founding victim would enable a fresh start of democracy. In the speech against Timarchus, Demosthenes is likewise represented as a ty-

after committing violence in brazen self-confidence. D.Chr. 47.24 characterizes the tyrant as a breacher of taboos. On the characteristics of the hybristic tyrant, cf. Borg 2006, 233; with particular emphasis on Athens, cf. Rosivach 1988. On the traditional tyrant as painted by Aristotle in the fifth book of his Politics, cf. Blomqvist 1998, esp. 15-24.

466 Wohl 2002, 266.

467 Girard 1972.

468 Ariston and Lycurgus, in his function as logographer and sunêgoros for Ariston, brought an eisangelia against the adulterer Lycophron (Lycurg. frr. 10-11), who allegedly had undermined a house to seduce a married woman (Hyp. Lyc. Speech B, fr. 1.1). Cf. above 78, n. 252. Lycurgus compares him to a pirate, a robber, and maybe to Hipparchus, who also compromised the honor of a woman. With this possible reference to Hipparchus, Lycurgus directly represents Lycophron as a tyrant. Cf. Hyp. 1 in Lycophron's defense. On the procedure of eisangelia, cf. in detail Hansen 1975, 106-107, no. 119 (on this particular case) and Phillips 2006 passim.

469 On the exclusion of polluting elements, cf. Nijhawan 2005, 273.

470 Aeschin. 3.131.

471 The notion of driving out the scapegoat is deeply ingrained in Greek thought and is of tenacious longevity in terms of the exclusion of a malefactor from the community: e.g., Pl. Lg. 853d-855a; 862d-e; 871d; 873a-b; 874a-b; 877a-b; 880e-882c; 936c; Arist. EN 1180a5-14; 1 Cor. 5:11-13. Lys. 6.50-53 regards Andocides as a scapegoat who must be driven out of the community. On the concept, cf. Bremmer 1983; Burkert 1982. Cf. below 221, n. 268 on the concept of the scapegoat in malign magic. 
rant for considering himself above the law. ${ }^{472}$ It is only through stigmatizing him as a tyrant that one can commit violence against him without a guilty conscience. ${ }^{473}$

The atrocities committed by the Thirty Tyrants provided a foil against which illegitimate violence was "defined" during the fourth century. Hence, a litigant could always put the violence of his opponent, however trivial it was (cf. Isocrates' allegations against Lochites), into the context of the Thirty by alluding to some of their measures, using hubris-words, ${ }^{474}$ or making direct allusions to tyrannical behavior. Thus, he would aggravate his charges by claiming that his opponent's actions not only hurt him, but also endangered the existence of the polis as a whole. Aeschines indirectly constructs Timarchus as a tyrant-like figure through the attribution of multiple instances of hubris. ${ }^{475}$ Ps.-Andocides and Plutarch in his rendering of Alcibiades' life pointedly describe Alcibiades as not caring about democracy and flaunting tyrannical traits. ${ }^{476}$

The prime example of a constructed tyrant, however, is Meidias, ${ }^{477}$ whom Demosthenes models after Alcibiades. ${ }^{478}$ Demosthenes charges Meidias' punch, his previous actions, and his whole habitus with a great deal of symbolism. The threshold metaphor is used vividly: Meidias 'over-

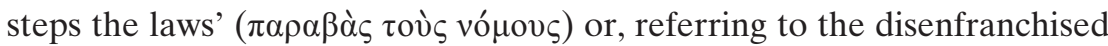
Straton, wreaks havoc on them. ${ }^{479}$ In order to gain control over the state, he tries to bribe state officials and intimidates them. ${ }^{480}$ But Demosthenes aligns Meidias with tyranny even more directly. Philippides, Mnesarchides, Diotimus, and Neoptolemus, all rich trierarchs, supported him and

472 Aeschin. 1.173.

473 Cf. Davis 1975, 181-182.

474 In his speech Against Simon, the unknown speaker in Lys. 3 makes almost excessive use of hubris-words. He also characterizes Simon as a sycophant and thus as anti-democratic (Lys. 3.44).

475 E.g., Aeschin. 1.62, 107-108 (including excessive lust for married women), 137, 141.

476 On Alcibiades the tyrant, cf. Jordović 2005, 131-168.

477 Wilson 1991/92 comes closest to my argumentation.

478 Demosthenes 21.66-67 alludes to Alcibiades; in 21.143-150 he names Alcibiades and directly compares Meidias to him. The similar contexts in which Alcibiades' and Meidias' attacks took place almost imposed this comparison. Cf. MacDowell 1990, 36.

479 D. $21.91,96$. Cf. also D. 21.26 .

480 D. $21.85-86$. 
aimed at getting control of the state, according to Demosthenes. ${ }^{481}$ Painting Meidias as an arch-hubristês throughout the speech further bolstered Demosthenes' claim that Meidias was a ruthless would-be tyrant bullying the whole citizenry. ${ }^{482}$ Meidias also threatens the population, especially the weak and poor, with his unrestrained arrogance. ${ }^{483}$ D. $21.193-195$ provides a perfect characterization of the tyrant through a textbook description of hubris. ${ }^{484}$ Other passages give the impression of an Athenian mafia, ${ }^{485}$ within which Meidias, according to Demosthenes, seems to have been a major player. ${ }^{486}$ All these reproaches culminate in a universal accusation: by attacking the laws, Meidias assaults the city of Athens and the gods. $^{487}$

The commitment of violence and the discourse on it were shaped by the image of the tyrant. When opponents were slandered as hubristai in court, they came close to being portrayed as tyrants and thus demonized. In this way, the conflict was exacerbated and dramatized onstage, in front of the people's courts. Gross exaggerations were the result. Neither Simon nor Lochites, neither Conon nor Meidias, neither Timarchus nor the adulterer Eratosthenes were tyrants. But hubris pointed to tyranny. When reading the orators we have to keep these semantics in mind. The conversation on violence followed the conversation on tyrants. The performance of the courtroom ritual created identity through the exclusion of the "other," in this case the tyrant. ${ }^{488}$ What other concept of an enemy was more readily at hand than the haunting specter of the tyrant who had to be repelled or cast out like the Peisistratids or the Thirty? Or-

481 D. 21.209. If this Philippides is identical to the one Hyperides accused, we know that he was an oligarch (MacDowell 1990, 12), so that Demosthenes' insinuation makes sense. On the convergence of personal and political enmity, cf. Rhodes 1996.

482 On the characterization of Meidias as the archenemy of the citizenry, cf. Ober 1994, 93-94; on Meidias as the archetypal tyrant and barbarian, cf. Wilson $1991 / 92$.

483 D. $21.123-124,131,135,204$.

484 Cf. the characteristics of a tyrant as described by Hdt. 3.80.5.

485 Cf. Fisher's (1998b) nuanced answer to the question whether or not we can speak of organized crime in Athens. There were organized gangs of muggers and thieves (Fisher 1998b, 54, 59, 83), but they were not a common phenomenon.

486 D. $21.201,207,209,213$. On Meidias' aspiring to tyranny, cf. the scholion on D. 21.200 (666 Dilts), cited by Phillips 2000, 230.

487 D. 21.127.

488 Johnstone 1999, 132 claims that litigation in general "created, reinforced, and reproduced" group identities. Cf. Farenga 2006, 6-7. 
ators took delight in mobilizing this motif and instrumentalizing it. In dramatic form, they appealed to their fellow citizens to stand together in solidarity so as to fend off the imminent threat posed by a hybristic tyrant. The performance of a court speech enacted the community-creating function of the tyrant/hubris discourse. . $^{49}$

Violence was assessed within political parameters, abhorrence expressed in political terminology. Violence involved the polis on a fundamental level, because the physical attack on a citizen's body was an assault on the community as a whole. Democracy could only be upheld if the inviolability of every individual citizen was guaranteed. The violence discourse was inextricably linked to the discourse on democracy. As a consequence, the violence discourse was extremely politicized. Any speaker would adhere to these discursive patterns by also representing his own violence in political vocabulary. He was driven by democratic virtues. His measures were lawful, anti-tyrannical, and amounted to civic duty. From this perspective, his violence could even be called democratic. The fending off or expulsion of the would-be tyrant was a personal duty as well as a political necessity. ${ }^{490}$

\section{Barbarians}

If the politicization of the perception of violence is expressed in an ethnocultural fashion, the hubristês becomes a barbarian. ${ }^{491}$ All of the above-

489 It is telling that Plato constructs the tyrant along the same line of dichotomies as the orators. Excessive democracy ultimately generates its opposite, tyranny (Pl. $R$. 564a). Famous is Plato's description of the tyrant and its soul at the beginning of $R$. 9. He cannot check his excessive passions, mainly his mad desires for drinking and sex $(R .573 \mathrm{c})$. He does not even refrain from beating his mother and father $(R .574 \mathrm{~b}-\mathrm{c})$. Cf. below 273-274; 305-306 on father-beating committed by the comic type of the hybristic tyrant.

490 This connection helps explain the graphê hubreôs as a public suit. Anyone who was concerned (ho boulomenos) about the state could bring this serious charge, also to knock out a potential tyrant and save the city. A dikê aikeias did not carry these associations. When the prosecutor brought a dikê aikeias, he would not imply the reproach of tyrannical hubris. In some cases (e.g., D. 54.1. explicitly; Isoc. 20.5. implicitly), the speaker would claim that he was entitled to a graphê hubreôs, but that, for reasons of self-restraint, he had chosen the milder procedure of the dikê aikeias.

491 Cf. Fisher 1992, 500-504. On the Greek perception of barbarians in general, cf. Mitchell 2007; Harrison 2002, especially the contributions by Lissarague and 
mentioned semantic markers "defining" the hubristês and the tyrant also apply to the barbarian, albeit with slightly different undertones. ${ }^{492}$ The barbarian comes from outside and is oblivious to Greek cultural values and norms; he self-indulgently breaks rules and violates not only Athenian citizens' bodies, but also those of his own subjects. Barbarians transgress boundaries in general. Meidias is a barbarian because he cannot comply with Athenian law and hates religion. ${ }^{493}$ Against the contrasting foil of the barbarian, speakers build up positive self-images as cultivated Athenians. By rendering Aristogeiton 'tactless' and 'un-Greek, ${ }^{, 44}$ the speaker implies that Greeks are tactful. This passage bears witness to Athenian self-awareness and the strategy of litigants to represent their own violence as civilized because squarely located within the established norms of democratic behavior.

Insight into the politicization of the expression of violence sheds light on the scholarly debate between Hansen and Ober, who stand, respectively, for a political and social historical approach to ancient Athens. The Athenians could not but express social issues, among them violence, in political terms. Thus, Hansen's insistence on political history and the history of institutions and Ober's plea for a social and ideological history of Athens are two sides of the same coin and supplement each other. ${ }^{495}$

\section{Old versus New Discourse Strategies}

The overall strategy of each speaker was to portray his own actions in a positive light and make them appear in conformity with the new, pacifying discourse of the democratic polis that emphasized moderation and self-restraint, cooperative virtues that were broadly discussed in philosophy, where they figure as enkrateia ('self-control') and sôphrosunê

Nippel. Cf. also Nippel 2001. On the barbarian as constructed on the Athenian dramatic stage, cf. Hall 2006, 184-224. On the Greek-barbarian dichotomy and its contribution to the formation of Athenian self-identity, especially in tragedy, cf. Hall 1989a.

492 Since barbarians (foreigners) could ideologically be equated with slaves, they were also subject to torture: DuBois 1991, 125-126. Cf. above 88, n. 297.

493 D. 21.150.

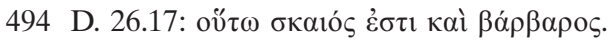

495 E.g., Hansen 2002; 1989a; 1989b; Ober 2005; 1996; 1989, 35, 42. Hunter 1994, 185-189 is succinct on this debate. Similar to Hansen is Herman 2006, 228, who sees the statehood of Athens as beyond doubt. 
('soundness of mind,' 'temperance'). ${ }^{496}$ The orators instead use the word praotês ('mildness,' 'gentleness') to express the new set of values. ${ }^{497}$ The reasons for this fundamental shift from the archaic and aristocratic discourse on revenge and violent self-assertion to much more peaceful forms of conflict resolution are still unclear, ${ }^{498}$ but by the fourth century, the new concepts had prevailed, at least on the discursive level. That is why some litigants strove hard to appear to be in line with these "modern" expectations. Euphiletus, who had so blatantly violated them, re-interpreted his murder of Eratosthenes as a civic duty to protect his oikos and, in so doing, to maintain the order of the state. The elderly speaker in Lysias 3 withdrew from the city together with the male prostitute Theo-

496 It has to be noted that enkrateia and sôphrosunê were originally aristocratic concepts that people appropriated for themselves more and more under the democracy. By the fourth century, these values had become thoroughly "democratized." Enkrateia is an important topic in Plato, who often links the term to sôphrosunê. Aristotle frequently contrasts enkrateia to akrasia ('want of self-control,' 'incontinence'), which also figures prominently in Plato. On akrasia, cf. now Bobonich - Destrée 2007, esp. 119-138 (on enkrateia in Plato) and Pakaluk 2005, 233-256. Plato emphasizes the closeness between sôphrosunê and dikaiosunê ('righteousness,' 'justice'). On sôphrosunê in Plato, cf. Rademaker 2005, 1-7, 251-356. Sôphrosunê is often contrasted with orgê (Borg 2006, 253254). Aristotle also contrasts sôphrosunê and akolasia ('licentiousness,' 'intemperance'). It is interesting to note that the Old Oligarch ascribes social connotations to this negative term. According to him, slaves and metics, above all, indulge in akolasia (Ps.-X. Ath.1.5.). Aristotle equates akolasia with huperbolê ('superiority,' 'excess'). In Arist. EN 1145a15-1152a36, esp. 1146b27-1147a18 and 1151b32-1152a6 enkrateia and sôphrosunê are opposed to akrasia and akolasia. Cf. Rademaker 2005; Roisman 2005, 176-185; North 1966 on sôphrosunê.

497 Especially Demosthenes and Isocrates. Cf. Arist. EN 1125b26-1126a1 on praotês. On sôphrosunê in the orators, cf. Rademaker 2005, 233-247. While Isocrates aligns himself with philosophical discourses by using praotês, Demosthenes charges the term with a distinct political meaning by putting it in the context of democracy, philanthropy, and the laws. He constructs a strict opposition between this term and aselgeia ('licentiousness,' 'wanton violence'), which he attributes to his archenemy Meidias.

498 Herman 2006, 266, who attributes the utmost importance to the shift from statelessness to statehood, regards "the driving force behind the transition itself" as an "enigma." Ideally, one could speak of a civilizing process, as paradigmatically described by Elias ${ }^{5} 1978$. Cf., however, the sharp criticism of Elias by Dinges 1998, 187. Sofsky 1996, 209-226 is reminiscent of Elias, but he stresses the self-regulating capacities of the individual more. Culture is based on the repression of violence. The domestication of instincts and passions is the precondition for every kind of culture. This comes close to Plato's and Aristotle's understanding, as pointed out above. 
dotus, probably because he could no longer endure Simon's Rügebrauch harassments, but he represents his dodging as a conciliatory contribution to the cooling off of the conflict. ${ }^{499}$ According to Demosthenes, Meidias has no 'human or reasonable excuse' for his misdeeds. ${ }^{500}$ And, what is more, Meidias never exerted self-control, so demanding his execution is justified. ${ }^{501}$ In a grand captatio benevolentiae, Demosthenes hails his audience as responsible citizens who abstain from violence and verbal abuse. Other chorêgoi, though competing against each other, did refrain from physical attacks. ${ }^{502}$ The contrast between the judges' role as ideal representatives of democratic values and Meidias' outrageous behavior highlights his outsider position as an evildoer opposing mainstream attitudes. Ariston characterizes himself as peaceful and inoffensive, always eager to de-escalate the conflict with Conon and his sons. ${ }^{503}$ Since they were $h u$ bristai and clothes-snatchers (lôpodutai), Ariston could have brought a graphê hubreôs against them or led them away as kakourgoi in an apagôgê procedure. The fact that he did not resort to these public suits, which could have resulted in their execution, underscores his low-key reaction and self-restraint. ${ }^{504}$ The whole demeanor of a speaker should comply with and exude the democratic virtues of moderation and decency. Aeschines contrasts Timarchus' inappropriate behavior in the Assembly with Solon's elegance as enshrined in the statue of Solon on Salamis. ${ }^{505}$ Demosthenes exposes Androtion's misconduct in the Ekklêsia in similar terms. ${ }^{506}$

In stark contrast to Euphiletus' action and argumentation, Demosthenes persuasively invokes the concept of a monopoly on violence held by the state and finds powerful words to formulate a political understanding of state control that sounds surprisingly modern to us. It is not the victim's prerogative to strike back when wronged, he says, but the task of the state to seek redress for the victim. ${ }^{507}$ In this way, retaliation is immensely curtailed. Notwithstanding Demosthenes' argumentation in his own favor, Athens did go further than any other ancient community

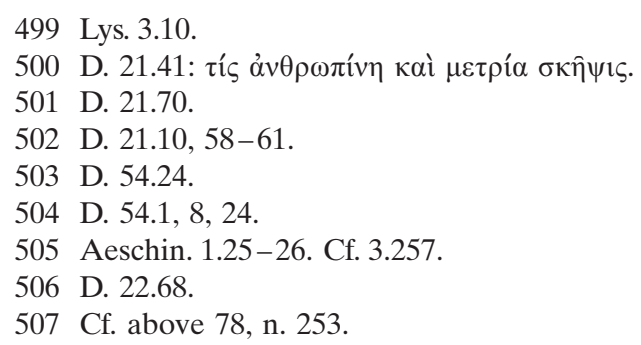


we know of in its endeavor to restrain the private use of violence. But whether or not it was successful is an entirely different matter. In the absence of a functioning police apparatus in our sense, of state prosecutors, and of a consistent substantive law, the state had to rely on a considerable amount of self-help. Paradoxically, it was only the citizens' commitment and their willingness to engage directly in a quarrel that guaranteed the observance of the laws. The laws in themselves were powerless. ${ }^{508}$ Here lies the problem of the pre-modern state, even of a community as politically and philosophically advanced and refined as that of classical Athens. If the citizens fall short of the high expectations the lawgiver has vested in them, the validity of the laws is at stake, the monopoly on violence being nothing more than a theoretical postulate based on wishful thinking. In practice, the state's claim to the monopoly on power was always doubtful. Not even the elites cared about state representatives when they wanted to push through their own claims or avert state interference. The trierarch Theophemus immediately struck the incoming trierarch who demanded the return of some naval equipment. Theophemus paid no regard to the presence of a servant of the magistrates who backed the repossession of the equipment. ${ }^{509}$ This lack of law enforcement and the individual's need to exert self-help brings us to the longevity of the Homeric violence discourse, which continued to advocate retaliation and the infliction of shame upon a rival in the never-ending game for power and wealth, as channeled and regulated as it may have been.

Many instances show that archaic values had a long afterlife. Three examples shall suffice in this context. In quoting the lawful homicide statute, Demosthenes presents the killing even of one's friends as still permitted in his own time, if the honor of one's womenfolk was at stake. ${ }^{510}$ Isocrates' famous description of how escalation works makes sense only if we accept that one aggressive act responds to a previous one. ${ }^{511}$ The fact that this cycle of revenge actions, including homicide, existed demonstrates that the fighting parties did not always go to court, but sometimes took personal revenge for the harm they had suffered. The second pillaging of the speaker's farm in Ps.-D. 47.63-66, for example, was an act of pure revenge. ${ }^{512}$

508 D. $21.224-225$.

509 Ps.-D. $47.35-38$.

510 D. 23.56.

511 Isoc. $20.8-9$.

512 Another locus classicus for the escalation of violence is D. 54.17-19. 
Prosecutors went to great lengths to ascribe unfashionable, because outdated, behavior to their opponents. Antiphon's tetralogies often breathe pre-polis discourses. ${ }^{513}$ In the First Tetralogy, the prosecutor accuses the defendant of defying the new canon of values and taking pride in sticking to the old concept, even at the cost of his life: for the killer, it was apparently better to kill his enemy and be executed than to be a coward. ${ }^{514}$ In this formulation, the friction between the old and new ethics is neatly expressed. Because the killer had suffered multiple defeats in court by his long-term enemy, he finally decided to kill him. As fictional as this speech may be, it shows that the apparent settlement of a conflict in court did not preclude further violence, but, in this case, generated even more violence on an increased scale.

Meidias is the prime example of a man who allegedly lacked every kind of self-control. ${ }^{515}$ At first glance, Demosthenes sympathizes with people who act in accordance with the old violence discourse and take revenge after being insulted. But Demosthenes pretends to approve of such problematic behavior only to show how much more reason he had to strike back after Meidias' blow and to highlight instead his temperance in going to court. ${ }^{516}$ The contrast between the obsolete aristocratic discourse on honor and shame and the new, moderate polis-discourse aptly characterizes the opponent and the speaker. ${ }^{517}$ Meidias and Euphiletus deliberately chose archaic practices to damage or knock out opponents, although more peaceful means stood at their disposal. Their cases are particularly interesting because of the clash between discourse and practice. In Euphiletus' case, at least, we see that it was possible to argue in blatant contradiction to the facts. ${ }^{518}$

It is true that the new democratic discourse problematized the old one, but it never supplanted it. As has become clear from the discussion above, both coexisted side by side in uneasy tension, overlapping and at times clashing. ${ }^{519}$ To the extent that a speaker would portray himself as

513 According to Gagarin 2005, 367-368 they are steeped in Homeric values and seek the proximity to tragedy and myth.

514 Antiphon 2.1.8.

515 Cf. also the negative characterization of Aristogeiton at, e.g., D. 25.32.

516 D. $21.71-74$.

517 Cf. Roisman 2003, 136-141 on the two diametrically opposed ideologies in the Meidias speech that nonetheless do not preclude each other.

518 Cf. above 53-55.

519 As powerfully described, e.g., by Cohen 2005c, 220; 1995, 66-68; Roisman 2005, 76; Scheid 2005, 410; Adkins 1972, 112-119 (new cooperative values as aretê). 
adhering to the new concept of moderation, he would ascribe unrestrained, brutal, and anti-democratic behavior to his opponent. The enemy would embrace the old discourse of revenge and would cling to a completely outdated model of social interaction. Instead of appealing to the law courts, the hybristic rival believed in his bodily strength and felt entitled to strike citizens at whim. These reproaches evoked highly negative associations: the Thirty Tyrants had killed 1,500 citizens without proper trial. ${ }^{520}$ In the face of a powerful bully, the weak were defenseless, ${ }^{521}$ and the courts turned a blind eye to his misdeeds. ${ }^{522}$ In fact, the fear of the judges to convict such a rascal left considerable scope of action for all those who thought themselves superior to others. If one was rich and powerful enough, one could afford to exact private vengeance, because some were more equal than others-so the rhetorical argumentation went. In contrast to his tyrannical opponent, the speaker would endorse the state monopoly on violence. In relying on the laws, he would appeal to the law courts and renounce the exertion of private violence.

What almost all speakers, however, pass over in silence while claiming to espouse the new violence discourse is their use of the court system as a means of "vengeance." Through its thrust, the performance of verbal abuse constituted character assassination. In this domain, the implications of speech-act theory still need to be exploited in full. ${ }^{523}$ Trials continued violence by different means, and time and again we see that going to court was just a phase in an ongoing long-term conflict. Two examples shall suffice here. Theomnestus and Apollodorus brought the graphê xenias against Neaera to attack Stephanus for private and political reasons that dated back a number of years. ${ }^{524}$ The quarrel between Apollodorus and Nicostratus preceding the court case continued after the trial. ${ }^{525}$ In addition, many speakers, especially in political trials, were eager to get rid of their rivals permanently and made a plea for the death sentence. The fact that "vengeance" was often carried out by the courts and no lon-

Flaig 2006, 39 differentiates the Homeric agonistic discourse from the discourse of justice.

520 E.g., Aeschin. 3.235.

521 D. $21.20,30,66,85-86,91,96-98,112-113,123-124,131-132,135,138,143$, 183, 193-195, 201, 207-213; Ps.-And. 4.36.

522 Ps.-And. 4.23.

523 A start has been made by Butler 1998 and Kelly 1994. Cf. below 152, n. 569.

524 Ps.-D. 59.

525 Ps.-D. 53. 
ger by the individual does not mean that the spirit of vengeance had disappeared. ${ }^{526}$

Weighing all this evidence, we can say that there was a wide gap between discourse and practice. While the ideology of democratic moderation was widely accepted and proclaimed in court, people continued archaic practices, which had theoretically fallen out of use. ${ }^{527}$ We have to keep in mind that for every Ariston there was a Conon and for every Demosthenes there was a Meidias. Even though they may have done so less than in previous centuries, ${ }^{528}$ and the courts may have mediated violence that had been perpetrated in earlier times, people still engaged in brawls, fought against each other, and exerted private "vengeance," albeit often in ways different from before. This is not to deny the qualitative jump

526 Gehrke 1987, 143. On enmity and revenge as motivations for prosecution, cf. Rubinstein 2005b, 138, n. 20 (listing all passages in the orators); Cohen 1995, 83; Hunter 1994, 128-129. On litigation as a form of feuding behavior, cf. Phillips 2008 passim, with 13-32 esp.; Cohen 1995, 104, 138-139. Cohen (1991a; 1990) uses, among other cases, the Meidias case in anticipation of the theses of his 1995 book. In light of this evidence, one can speak of a non-militant ideology, as Herman 1994 does, but one has to differentiate between this civil discourse and the brutal practice. Herman 1998, 610-611 vehemently argues against the allegedly inappropriate extension of the term "feud" by Cohen that also encompasses litigant behavior. Cohen 1995, e.g., 20, however, makes it clear that feud is more than merely blood feud: "feuding behavior should not be identified solely with blood feud, but should be seen as an enduring long-term relationship of conflict following a retaliatory logic." Black-Michaud 1975, 27-28 offers a broad and minimalistic definition of "feud" that comes close to Cohen's understanding and can also be applied to ancient Athens. In light of this broad definition of "feud," taking vengeance and going to court do not exclude each other, as Herman, e.g., 1996, 22 thinks. Cf. above 48, n. 123 and 96, n. 327.

527 One of the best examples is Ps.-D. 47, where we gain insight into archaic practices and the official, democratically minded, and peaceful discourse that is spoken in court.

528 It is an idle undertaking to try to measure the amount of violence. The scant evidence does not lend itself to quantifying. Commissioned murders and dangerous brawls, especially related to lovers' quarrels, seem to have been relatively frequent (Lys. 1.44; 3.39, 42). Demosthenes speaks explicitly about the frequency

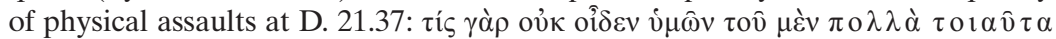

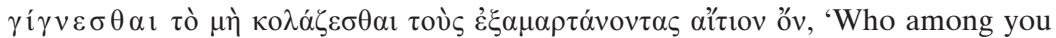
does not realize that the reason why many crimes of this sort occur is the failure to punish offenders?' (emphasis added). Although these statements may be dismissed as stemming from the rhetorical strategy of downplaying one's own violence, they have to be taken somewhat seriously. In order for them to be effective, they had to be plausible for the audience. 
in the development of Athenian civilization from archaic to classical times, partly brought about by the emergence of the lawcourt system. But we have to bear in mind that even mediated violence is still violence and that the irrationality of the Athenian legal system, the unpredictability of the trial's outcome, ${ }^{529}$ as well as the understanding of court proceedings as another form of revenge, ${ }^{530}$ make Athenian trials fundamentally different from those of modern Western courts. In addition, the courts could only punish exemplarily, so that their function was highly symbolic. Concomitantly, law enforcement was highly selective and socially biased. All these factors contribute to the impression that the law courts were far from being perfect means of conflict resolution. ${ }^{531}$

529 As can be seen, e.g., from the trials against Socrates, Phocion, the admirals of the battle of Arginusae, as well as the Harpalus scandal, there was almost no legal certainty.

530 Here I am leaning toward Cohen's view, which is vehemently rejected, e.g., by Herman 1998, 614. Steering a middle way between the disputants, my emphasis lies on "another form of." In contrast to Calhoun 1927, who idealizes the development of Athenian law, Hansen 1976, 121 paints a pessimistic picture of the Athenian system of law: "To the modern reader it seems striking that the driving forces behind private prosecution in public actions ostensibly were personal hatred or desire to get rid of a political opponent rather than public spirit and good citizenship. Severe penalties combined with accidental prosecution must have created a very unstable administration of justice where petty offenders were sometimes sentenced to death and executed as a deterrent whereas criminals might go unpunished if nobody would take it upon himself to initiate proceedings."

531 Harris and Herman overstate the pacifying functions of the law courts; e. g., Harris 2005; Herman 1994, 116. Cohen 2005c, 234-235 summarizes the opposing standpoints succinctly, trying to give justice to both views: "As we have seen, on the one hand, prosecutions for public offenses in Athens were informed by ideas about crime, punishment, and the rule of law that are clearly familiar to modern readers in their adherence to notions of impartial judgments dispensed in the name of the law to vindicate and prevent harms to the community as a whole. On the other hand, the incorporation of elements of self-help, summary procedures, execution without trial, and judgments based on the character, wealth, political clout, and public benefactions of the parties challenges us to understand why the understanding of crime and punishment in democratic Athens could differ so sharply from that of today. And differ not because their legal system was corrupt, primitive, or incompetent, but because the Athenian understanding of concepts of justice, democracy, and the rule of law in important ways differed fundamentally from our own." W. Harris 1997, esp. 365-366 attacks Herman for presenting a one-sided, black-and-white picture and pleads for a more nuanced view of things, situating Athens midway between a civilized society and archaic societies that indeed countenanced the blood feud for a long 
Since the new discourse came to be an integral part of the democratic value system, the violence discourse was closely linked to the discourse on democracy. A violence monger was a tyrannical and barbarian hubristês who endangered the cosmos of the city. ${ }^{532}$ The democratic polis could only exist if conflicts were settled by peaceful means. The courtroom ritual transmitted the new ideology to the citizenry and thus contributed to stabilizing Athens' social and political systems.

The rules of representation have shown once more that one and the same occurrence could be interpreted differently, that the line between acceptable and unacceptable behavior was dependent on the speaker's perspective and was therefore shiftable. As in the case of the rules of in-

Summary of Rules of Representing Violence in Table Form

(Dichotomies constituting flexible line; cf. table above 101):

\begin{tabular}{|c|c|c|}
\hline & $\begin{array}{l}\text { Unacceptable Violence (outside } \\
\text { accepted norms, always } \\
\text { relevant, committed by } \\
\text { opponent, as characterized by } \\
\text { speaker) }\end{array}$ & $\begin{array}{l}\text { Acceptable "Violence" (inside } \\
\text { accepted norms, sometimes } \\
\text { relevant, committed by speaker, } \\
\text { as characterized by him) }\end{array}$ \\
\hline $\begin{array}{l}\text { Discursive } \\
\text { Level of } \\
\text { Represen- } \\
\text { tation }\end{array}$ & $\begin{array}{l}\text { excessive, escalating } \\
\text { impermissible } \\
\text { unacceptable, transgressive } \\
\text { tyrannical } \\
\text { barbarian } \\
\text { hybristic } \\
\text { dysfunctional } \\
\text { senseless or negative sense } \\
\text { symbolic message/significance, } \\
\text { not accepted by victim } \\
\text { always relevant } \\
\text { illegitimate } \\
\text { anti-democratic }\end{array}$ & $\begin{array}{l}\text { restrained } \\
\text { permissible } \\
\text { accepted } \\
\text { anti-tyrannical } \\
\text { anti-barbarian } \\
\text { anti-hybristic } \\
\text { functional } \\
\text { sensible, meaningful, positive } \\
\text { sometimes symbolic message/ } \\
\text { significance } \\
\text { relevant vs. irrelevant = } \\
\text { dramatization vs. normalcy } \\
\text { legitimate } \\
\text { democratic }\end{array}$ \\
\hline
\end{tabular}

time, like that of the Pentateuch or of traditional Albania. Cohen's view is also supported by Fisher 1998a, 80.

532 It is telling that Conon, in his younger years, belonged to a group of young people who engaged in deviant religious behavior. They were nicknamed "Triballoi" after a Thracian tribe (D. 54.39). 
teraction, semantic units grouped in opposites make up the representation of a violent act. We can also talk about semes of violence structured in dichotomies on the interactionist and representational levels, the latter morally assessing and interpreting the first.

\section{Functions of Ritualization}

Most Athenians did not regard the recourse to violence as something negative per se. Some deemed the use of violence indispensable in certain situations simply in order to construct and represent a web of social hierarchies and power relationships. But Athenians were wary of excesses. To avoid them, Athenians gave themselves rules, normative codes of behavior that regulated the game. It is in the nature of a vibrant political community characterized by a culture of public display that these regulations were subject to discussion and manipulation. We distinguish two kinds of norms.

Semantic markers constituted rules of violent interaction that structured and limited the actual use of violence. They helped the actors to orient themselves in confused situations of conflict. ${ }^{533}$ Rules of representing violence imposed a certain order on the assessment and interpretation of violence. Both sets of rules can be understood as forms of social control and exertion of power. ${ }^{534}$ At the same time, both fulfilled functions on two different levels. The first level concerns the relationship between contemporaries. I refer here to the direct function of interactionist and representational rules of violence, which allowed the perpetrators to convey a certain message to the victim and the audience. The second level concerns supra-individual, societal functions. Contemporaries may not have been fully aware of these indirect functions that rules of violence also fulfilled.

Rules of violent interaction play their immediate role in transmitting a symbolic meaning to all people involved in a brawl. By following or violating a pattern, the perpetrator more or less consciously ascribed sense and significance to a violent act, thus expressing a view that the victim normally did not share. The aggressor either reasserted his social status or challenged existing hierarchies. In the first case, we can speak of affirmative violence that secured the status quo in society. In the second case, the aggressor strove to alter social positions. This violent behavior was

533 Cf. Schomburg-Scherff 1986.

534 Cf. Bell 1992, 8. 
potentially innovative. This breach of thresholds visualized the opponents' vying for power. Although violence could always lead to escalation, most of the time rules of interaction helped restrain violence by making it controllable. In their pacifying function, rules of violent interaction supplemented the stabilizing functions of the courts.

This inherent quality of interactionist rules takes us to their supra-individual, societal function. In Ps.-D. 47, for example, the trierarchs perform their struggle for status and reputation in a ritual way by mutually violating the thresholds of their homes. Speaking of the societal function of these skirmishes, we could say that this showdown between two members of the elite negotiated and symbolically represented the conflict between personal autonomy and the state's prerogative to intervene.

Rules of interaction charged violent actions with a certain sense and made violence possible within strict limits. Thus, the exertion of meaningful violence helped negotiate and sometimes overcome the tensions underlying the political, social, economic, and cultural conditions of fourth-century Athens. From this perspective, most outbreaks of violence "made sense" in the Athenian system. This is not the sense perpetrators ascribed to their actions and by no means the viewpoint of the victim, but the function of violence on the societal level. In this regard, violence is functional or productive if there is a concrete outcome, if we can grasp the alteration or further advancement of social conflicts. Violence becomes societally dysfunctional and unproductive if there are no tangible consequences and/or the perpetrator acts far outside the accepted norms. In the latter case, violence was also senseless to contemporaries, because it took place beyond the boundary of accepted norms. According to Hyperides, fear and shame prevented people from committing crimes, ${ }^{535}$ but clearly not always and not everywhere. Only if the offense was performed within a certain frame of accepted norms was the violence reined in and potentially legitimized. Contemporaries could understand and make sense of this particular act of violence, because it followed established rules and catered to routine patterns of perception. The structures underlying the violent act were clear to all players of the game and made its specific unfolding more or less expected. The creation and transmission of sense through these rules of violent interaction greatly facilitated communication about violence. ${ }^{536}$

535 Hyp. fr. 210.

536 With regard to sacrificial violence, Henrichs 2006, 87 quotes Blome 1998, 94-95:

"Dichter wie Künstler, aber vor allem eben auch die zuhörenden bzw. betrach- 
Rituals of representing violence shaped and performed the violence discourse within the ritual frameworks of court sessions, depositions of curse tablets, and theater performances. If a trial resolved a conflict for good, if the performance of a play led to catharsis, we can speak of the immediate pacifying function of representational rituals. In the open society of Athens, the notion of violence was negotiable and citizens were actively involved in discussing ideologemes, "defining" the meaning of violence, searching for the right measure to exert it, and issuing laws. The citizens even determined the contents of the ongoing dialogue.

The direct functions of representational rituals are best described by their performative character. The outcome of a trial had a very concrete effect on the ensuing life of the litigants. One defeated the other by successfully selling his own interpretation of events to the judges. Furthermore, the open performance of the violence discourse in public meant that elite circles could not monopolize the use of violence for themselves, as they could in other pre-modern societies. What is more, the ritual frame for representing violence had strong repercussions on violent occurrences in daily life by providing interactionist rules for "properly" conducting conflicts. The ritualized form of communication in court and theater disseminated the pacifying violence discourse to the whole citizenry.

As in the case of the interactionist rules, the overarching societal function of rituals of representation lies in the containment of violence, and we might put forward the hypothesis that Athens' rhetorical culture made it more peaceful and stable than other Greek societies, which lacked this very culture of carrying on a dynamic dialogue on violence and its excesses. ${ }^{537}$ Athenians talked intensively about violence, discussed values, and performed their violence discourse in courtroom trials. At the same time, the holding of a trial can itself be regarded as a ritual process. The speeches of prosecution and defense were conducted between rites of separation and rites of reaggregation. The performance of the orations themselves constituted the liminal phase of this specific ritual process. As is typical of a liminal phase, the courtroom session could temporarily reverse social hierarchies, which redefined and, in fact, enhanced them.

tenden Konsumenten können offenbar gar nicht anders, als sich das Schreckliche sakralisiert und ritualisiert zu denken. Sie lenken es damit in eine vertraute, weil fast stereotyp genormte Bahn und schieben so zwischen sich und das Geschehen wie einen Filter das Opferritual." The same can be said of violent actions, which evolved, in many cases, into a ritualized form.

537 Cf. Riess 2006 passim. 
Anti-structural elements are clearly discernible in courtroom performances. In court, ordinary people held supreme power over the powerful. The mighty humbled themselves and their quarrels before the judges and vied for the favor of the common people, an almost carnivalesque situation in Bakhtin's sense. Anything was possible. At the Delphinion, Euphiletus, the murderer, for example, constructed himself as a victim.

To appreciate fully the function of the law courts, a new understanding of them as ritual, symbolic communities is quite helpful. They did not necessarily operate rationally, ${ }^{538}$ but fulfilled the functions of ritual performances. The dialectic communication between masses and elites and the enormous scope for reflexivity and creativity provided by the theatrical framework of the courts allowed for the discussion of old and new concepts and values. In correspondence with the flexibility of rule-breaking in daily life, everything in court was a matter of interpretation and standpoint. The judicial assessment of an offense by the court happened on the basis of laws that were often vague, ideological constructions. Given the absence of legal experts, it could not have been otherwise.

This observation also holds true for the "definition" of violence. Athenians negotiated its notion anew every day in the courts. We can only aim at the "fair market value" of the "definition" in cases where we know the verdict, but, unfortunately, in most cases we do not know the outcome of a court case. That is why it is so hard, for example, to reconstruct the meaning of hubris or to decide whether seduction was worse than rape. ${ }^{539}$ Legal historians have spilled much ink on these topics without fully taking into account the possibility that Athenians might also have found these questions to be unanswerable. There was not and

538 Cf. above 138 , n. 529.

539 Seduction worse than rape: Manthe 2000, 222; Carey 1995a; MacDowell 1978, 124-126. Rape worse than seduction: Brown 1991, on the basis of Menander; Harris 1990 (with older literature). No difference between seduction and rape: Cantarella 2005, 240-244; Omitowoju 2002, 131; Ogden 1997, 32-33; Cohen 1993, 7 (on the basis of D. 23.53-57). Schmitz 2004, 476-477 offers an intriguing explanation that accounts for the confusion in the classical authors as well as in modern research: originally, the abduction of a woman was deemed less problematic than seduction or adultery, if her father agreed on a subsequent marriage (abduction marriage). So Draco penalized it less severely than seduction/adultery. Later, with the custom of abduction marriage having fallen out of use, this law was re-interpreted as the law on rape. On sanctions against sexual assault in general, cf. Cole 1984. Whether or not a prosecutor regarded seduction as worse than rape was also signaled to the community by the choice of legal procedure; cf. on this topic above 53, n. 145. 
could not be a stable definition of concepts like violence, hubris, and rape. As a result, there was no such thing as legal certainty in Athens. ${ }^{540}$ The judges were juridical laymen who were drawn by lot every day. People believed in daily dialogue and negotiation on these topics via performance. The whole culture did not only rely on rationality in our terms, but also ascribed the utmost importance to the magic of rhetoric, playful theatricality, and the public stage, in having disputes decided by the people of Athens in a simple majority vote. Everyone knew that the people could err. There were, therefore, strict laws to punish anyone who deliberately swayed the people to their disadvantage. ${ }^{541}$ The deep-rooted distrust of any kind of rhetorical professionalism stemmed from this problem. Athenians were not naive and did perceive the pitfalls of the democratic system, but to them these drawbacks did not outweigh the obvious advantages of democracy. These observations not only corroborate Cohen's view of the Attic law courts as being fundamentally different from modern Western courts, ${ }^{542}$ but go even further: the dynamic of the Athenian law of violent offenses in general was not only based on the ritual form of lawgiving and rendering verdict by fickle masses, but was even the precondition for the smooth running of democracy in Athenian eyes. The judges, who understood themselves as a representative sample of the dêmos, reserved for themselves the prerogative to "define" the semantics of each and every criminal offense. Therefore, the introduction of the nomothesia at the end of the fifth century did not change anything about the fluidity of Athenian substantive law. ${ }^{543}$

Without referring to the specific case of Athens, Huizinga insists on the irrationality of pre-modern systems of justice and postulates their similarity to magic. The data from ancient Athens fully corroborates his theo-

540 Cf. Lanni 2006, esp. 115-148 on the whole complex of the highly discretionary decision-making process in Athenian courts. In two realms only, homicide (75-114) and, above all, maritime cases (149-174), the Athenians preferred consistency and predictability to flexibility.

541 Harris 1999, 126-129, 138 shows that litigants who did not get one-fifth of the votes or were unsuccessful in carrying through a graphê not only had to pay a fine of one thousand drachmas, but were also always subject to atimia.

542 Herman 2006, e.g., 196 overemphasizes their likeness to modern courts.

543 Exempt from this fluidity are homicide and maritime cases, as mentioned above n. 540. But in general Gordon 1999b, 248 is correct: "a law had today whatever meaning a speaker at a trial could successfully convince the judges that it had and tomorrow perhaps something different. Indeed none of the words used in Athenian laws had legal definitions: for the most part, law was simply the written form of custom." 
ry. Resorting to trials and magic was meant to have the same result. The outcome of a trial was always unpredictable, similar to the result of enlisting the help of a sorcerer. In going to court or depositing a curse tablet, one had to rely on fickle fortune. In Athenian belief, a lot was determined by fate. A litigant could prepare himself by hiring a logographer and a professional magician, but he had no guarantee of success. The courts were not about deciding who was right or wrong; the whole agôn was about winning. The winner determined the acceptable contexts for violence, which became the "definition" of violence for that particular day. This notion, which is so fundamentally different from our understanding of how a legal system should work, also explains the completely different function of witnesses, which has been often observed in recent years. ${ }^{544}$

The dikasteria rendered the use of violence legitimate or illegitimate. This fact is fundamental, because it means that the laws had to be flexible enough to allow this desired discursive negotiability of legitimacy in court. The laws were not even permitted to interfere with the great discretion the judges enjoyed. The lay judges insisted that they themselves create the boundary circumscribing what constituted violence. ${ }^{545}$ This was only possible if this line could shift and was flexible enough to be open to interpretation.

It was this openness of the free ritual play in the courtroom that ensured the "open texture" ${ }^{546}$ of Athenian law and the staging of manifold discourses to resolve problems. The multiple possibilities for "defining" concepts and constructing meanings in a lively atmosphere enormously contributed to the stability of the system by containing violence.

By the end of a court session, the courtroom ritual had reconstituted the social order, but on a different level. Changes of status had been put to debate and were decided upon. Social hierarchies were overthrown or the status quo upheld. The litigants were transformed into winners and

544 Cf. above $46-47$.

545 Rubinstein 2005b, 143 speaks of the judges' "shaping the behavioral norms of the community as a whole." Of course Athenians also valued continuity, legal principles, and precedents. But within this framework, they were free to decide on an ad hoc basis.

546 Both in Osborne's sense of procedural flexibility (Osborne 1985, 43-44; now Carey 2004, esp. 112 with 132, n. 2) and in Harris' sense of the flexible application of generally acknowledged substantive law (Harris 2000, 30, n. 8). Cohen 1991a, 179 speaks of the "institutionalized ambiguity of concepts." 
losers. ${ }^{547}$ The participants in the ritual had wielded power for the short moment of rendering justice. ${ }^{548}$ The courtroom ritual confirmed once more the definitory power of the dêmos and enacted its supremacy almost every day. The highly political function of this mass ritual revealed political hierarchies and power structures. ${ }^{549}$

The ritual character of the courtroom system helps us now to understand better the prime role the law courts played. To Aristotle, they were the cornerstone of democracy and upheld the state ${ }^{550}$ One might ask why this was the case. J. Assmann distinguishes between book religions and cult or ritual religions. In the latter, the proper performance of rituals, not the adherence to dogmas borrowed from books, ensures the continuity of the cosmos. ${ }^{551}$ Athenian democracy was characterized not only by a ritual religion, but also by the secular ritual of the law courts. The speeches performed in this context were as vital to the maintenance of the Athenian cosmos as the exact performance of the appropriate religious rituals. Without law courts, there was tyranny, anarchy, chaos. With this ritual understanding of the law courts one comes closer to the importance that Athenians ascribed to their courts. From the courts' ritual functions stems the trauma caused by the Thirty Tyrants, who, for a short time (404/03 BCE), had circumvented the law courts and thus breached fundamental rituals of the Athenian state.

It is not enough to trust the courts' legal function as recipients and arbitrators of pleas from victims who were afflicted by violence. Only a minority of cases reached the courts, and when they did there was no guarantee that the offended party would be compensated. It is true that the courtroom system had replaced the blood feud by giving the injured family the right to indict a culprit in court, but the court system was not effective enough to deal with all cases and to resolve them to the full sat-

547 Even before the actual court proceedings, the decision to litigate had transformed the disputants into "specifically defined legal roles": Johnstone 2003, 6; 1999, 131-132.

548 There are only rare glimpses into the judges' behavior. On the occasion of Demosthenes' probole to the people with the goal of achieving a preliminary verdict against Meidias, we learn that the people booed Meidias for his offense at the Great Dionysia (D. 21.226).

549 As Allen 2000, 9 rightly points out, punishment is an act of power.

550 Arist. Ath. 41.1-2; Pol. 1275a22-33;1275b13-21. In Aristotle's eyes the dêmos ruled everything through decrees and courts.

551 J. Assmann 2000, 148, 162. He speaks of the "In-Gang-Haltungs-Bedürftigkeit der Welt" (152-153). Cf. above 28, n. 35. 
isfaction of the aggrieved parties. Our evidence is clear enough. Too many quarrels lingered on after a trial had taken place, or were even exacerbated through a verdict reached in court. ${ }^{552}$ In the long-term conflict between the trierarch and his opponents we see that going to court was only one way of carrying on rivalry. ${ }^{553}$ As in many other cases, the court session was situated within a continuum of more or less violent actions and counter-actions. ${ }^{554}$ One could appeal to the court any time, but was not obliged to do so. By no means did a court verdict necessarily mark the end of a struggle. Since a conflict could be pursued by many different means, the courts were only an optional and transient phase in the continuation of the conflict that could sometimes continue to smolder for generations. ${ }^{555}$ These few examples show that the pacifying function of the courts did not lie in the final settlement of conflicts.

Given these shortcomings of the Athenian legal system, one wonders wherein the pacifying functions of the courts lay. And, related to this first question, we may ask why they were so dear to the Athenians. The answer to the first question is to be found in yet another ritual function of the lawcourt system-its capacity to negotiate contradictory social demands. The second answer is to be found on a purely practical level, the perception of the courts as still another opportunity to exert legitimate violence against an opponent.

By fulfilling ritual functions, the court system met indirect, societal needs that had nothing, or not much to do, with settling cases. This indirect purpose of the courts contributed crucially to the containment of violence and the coherence of the citizenry. The courtroom provided a forum for discussing the clash between the old, pre-polis, Homeric, aris-

552 E.g., Antiphon 2.1.6-7: a man killed an opponent out of revenge for having lost against him in several trials. Cf. Bernand 1999, 424, fully endorsing Cohen's view.

553 Ps.-D. 47.

554 The same is true, e.g., for Ps.-D. 53, Apollodorus' speech against Nicostratus. The trial allows us to catch a glimpse of an ongoing argument among neighbors. The private fight between Theomnestus and Apollodorus on the one side and Stephanus and Neaera on the other side is connected to questions of citizenship policy and thus elevated to a political level that is put to discussion before the people's court (Ps.-D. 59). In Isocrates' eighteenth speech (Against Callimachus) we also gain insight into a long-term conflict. The speaker's opponent had brought a countersuit with charges of (faked) homicide, aimed at stopping the legal settlement of a former violent conflict.

555 E.g., D. 57; Ps.-D. 58; Is. 9.20; Lys. 13.42; 14.2; 32.22. The quarrel about the estate of Hagnias lasted for more than thirty years (cf. Is. 11; Ps.-D. 43). The examples could be multiplied. 
tocratic violence discourse, characterized by the values of honor and shame, and the modern, polis-, egalitarian discourse on self-control and moderation. ${ }^{556}$ The overlap of these two discourses with their contradictory claims neatly reflects the remarkable discrepancy between actual behavior and the ideology voiced in the courtroom speeches. According to the old set of values, an offended man had to strike back immediately so as not to lose face. It was only by sticking to this "eye-for-an-eye" ideal that a man could live up to the expectations of his family and friends. Masculine prowess was acquired and displayed on the battlefield, by hunting, and by defending one's honor and oikos. The embodiment of these ideals was the Homeric heroes. These epic warriors did not need courts, for they were able to seek redress by themselves. They were not bound by communitarian codes of behavior, but were, rather, spurred on by the community's expectations to excel in all the aforementioned domains. ${ }^{557}$ This ideology had slowly faded away with the development of the polis and the hoplite phalanx, but had never been completely lost. The hoplite citizen had to comply with new standards of living together. The politês could not do without his fellow citizens. New models of cooperation and conflict resolution were found. Court procedures had replaced the earlier blood feud. The violence threshold was higher than before. Retaliation was not a thoroughly positive value any more, but was problematized. The good citizen was now the temperate citizen who could keep his emotions under control. Modern research has described all these developments in detail. But it is wrong to assume that one ideology completely replaced the other. Rather, values shifted gradually, and competing if not conflicting ideologemes coexisted in a fairly uneasy tension with each other. During the fourth century these contradictory values clashed, more so than in the fifth century. The fourth century was an era of turmoil, strife, and uncertainties. The democracy had been restored internally, but how were the allies to be treated in the Second Naval Alliance? What was the Athenian stance toward the old powers of Sparta and Persia, let alone the rising state of Macedon? How were social, economic, and educational gaps to be reconciled with an egalitarian understanding of politics? What were the individual's position and leeway with regard to the community of citizens? How could the ideal patrios politeia, installed by Solon according to Athenian belief, be pre-

556 Cf. above 135.

557 Roisman 2005, 106-109 and Van Wees 2004, 37-40 masterfully describe the warrior ideal. 
served under the modern circumstances? All these questions, among many others, vexed fourth-century Athenians, and there were no clearcut answers. All Athenians could do was find discursive strategies to come to terms with these conflicting demands and challenges. Breaks and inconsistencies in the discourses are the logical consequence of this difficult situation. The perpetration and representation of violence is but one major field of controversy during the fourth century. In no other domain is the overlap between an old and a new discourse so tangible as in the case of violence. And this overlap also found its echo in concrete, everyday behavior.

On the one hand, our evidence indicates that brawls must have been quite common in Athens. Because of the bias of the sources and their concentration on elite members of society, upper-class people are overrepresented among the violence mongers. Trierarchs and chorêgoi beat one another, landowners and rich youths fought over hetairai and young boys. These were no outlaws, but honorable citizens. ${ }^{558}$ Although Athenians no longer practiced blood feud and people walked around unarmed, they must have been always ready to resort to violence. ${ }^{59}$ Otherwise, the fear of escalation would not be comprehensible. In light of the outbreaks of violence we know of, the violence threshold must have been lower than in today's Western societies. Members of the lower classes were probably even more prone to violence, given the absence of sophisticated means of conflict resolution and a restricted code of expressing themselves in these social strata. ${ }^{560}$ All these deliberations suggest that the cases of violence we find attested are only the tip of the iceberg. What we know about the authors of our sources, male citizens from the upper echelons of society, further corroborates the impression that the majority of violence was not reported in our sources. ${ }^{561}$

On the other hand, many if not most people deliberately refrained from violence. Aristides kept a tight control over his emotions, especially anger and hatred. ${ }^{562}$ Pericles did not react to the constant insults he suffered from a humble citizen for a whole day, but even had men escort

558 Many Athenian men flaunted their male assertiveness in forms of military prowess, physical aggression, and hiring prostitutes. Keuls 1993 passim subsumes these behavioral patterns under the term "reign of the phallus."

559 Cf. above 49.

560 Schmitz 2005, 103, 126.

561 Scant evidence, like Lys. 3.42, points in the same direction.

562 Plu. Arist. 4.1. 
the fellow back home after sunset. ${ }^{563}$ Taureas and Demosthenes did not strike back when publicly assaulted in the theater of Dionysus. Demosthenes especially is the prime representative of the new discourse on self-control and the state monopoly on violence. Divergent interpretations, however, remained possible, and are discernible for us. Alcibiades and Meidias deliberately sought the public limelight to attack their opponents physically. They acted in line with the old discourse on violence, honor, and shame. If Taureas and Demosthenes would not strike back in public, they would lose face, whereas Alcibiades and Meidias would reassert their superior positions in the zero-sum game for power and social prestige. If Demosthenes did not deliver his speech in court, he might have been afraid that the judges could interpret the case the way Meidias did. It might have been beneficial for him to speak the new discourse in court, but it was by no means beyond question which view would prevail. It was the courts' extraordinary prerogative to negotiate daily between these two different sets of values, represent this ongoing discussion, and transmit the new ideology more or less with success by communicating it to the common people. Since the violence discourse, with its anti-tyrannical character, was an integral part of the discourse on democracy, the court system, in providing the parameters and preconditions for the public staging and dissemination of this dialogue, decisively contributed to the stabilization of the Athenian political, social, and economic systems.

Our best example of the overlap and clash between archaic and modern notions of violence is Euphiletus' murder of Eratosthenes and his speech in self-defense, which vividly illustrates how wide the gulf could be between conservative practice and progressive discourse. The sharp tension between the preceding deed and the ensuing narration in court perverted the courtroom ritual. The man who was prosecuted for homicide starred in the role of the victim: his oikos had been intruded, his wife corrupted, his honor besmirched. In light of what had happened, Lysias chose a bold strategy for his client. Through acting in full accordance with the old violence discourse and retaliating on the harshest note possible by killing the seducer of his wife, Euphiletus had blatantly violated the new polis-discourse of non-retaliation. In complete contradiction to the facts, Lysias had Euphiletus reinterpret and distort the self-help killing as execution and speak the modern discourse perfectly well. This is thoroughly sophistic argumentation. The speaker even took full advantage of this clash of values by manipulating them in his favor. In his

563 Plu. Per. 5.1-3; cf. also 7.5. 
speech, Euphiletus completely negated the Homeric ideal, according to which he had in fact acted. The argumentation is so brilliant that even modern scholars have been swayed by it. ${ }^{564}$ If we heed Kertzer's famous dictum that we are what we do, not what we think or say, ${ }^{565}$ it is the social practice that counts, not Euphiletus' denials and claims in court. Euphiletus was a conservative Attic farmer, who, enraged and deeply offended by his wife's infidelity, took the law into his own hands and killed the moichos in accordance with the law of Draco, thus reasserting his authority as a kurios. ${ }^{566}$ At the scene of the killing, he was already confronted with the new realities of polis-life. Eratosthenes offered him money in compensation. What is more, Euphiletus had many more options of seeking redress at his disposal, granted by the legal system of the polis. ${ }^{567} \mathrm{But}$ he chose none of them. It seems he did not care about democratic ideals. In court, however, he was well advised by Lysias to speak the new polisdiscourse of moderation; how reluctantly he did so, we do not know. We do not know, either, whether he got away with it. If Euphiletus was released, we learn once more about the power of discourse, but also about the tenacity of traditions, customs, and old-fashioned laws, which still sanctioned acts of brutal violence.

On a more practical level, beyond all ritual functions, courts were popular precisely because they were regarded as a suitable mechanism for fighting against opponents. Verbal insults uttered in court as slander were a powerful weapon. According to speech-act theory, the impact of the character denigration performed in court was enormous, and ultimately constituted reality. This means that trials not only depicted past violence (Schechner's famous "there and then"), but also exerted mediated violence in and through their actual performances ("here and now" in Schechner's terminology). ${ }^{568}$ Because of the implications of speech-act

564 Most recently Herman 2006, 175-183, who overemphasizes the discourse spoken in court and neglects the actual deed, the murder of Eratosthenes. Better is Herman 1993, where he admits that Euphiletus spoke in blatant contradiction to the facts, which he, as a consequence, radically distorted in his favor.

565 Cf. above 54, n. 147.

566 In addition to the diachronic overlap between the archaic and the polis-centered violence discourse, we should also investigate the synchronic, i.e., spatial differentiation between the two contradictory sets of values. Behavioral norms in the countryside may have differed considerably from those in the city: Schmitz 2004, 466 speaks of a "Stadt-Land-Gefälle." Cf. also Dover 1974, 112-114 on the dichotomy between town and countryside.

567 Cf. above 53, n. 145.

568 Schechner 1977, 87. 
theory, these instances of verbal violence deserve a study in their own right. ${ }^{569}$ The courts were understood as the continuation of violence through different means. The death sentence was common, ${ }^{570}$ and even if the prosecutors did not plead for the death penalty, they often emphasized their entitlement to do so.

The violence exercised by the courts was acceptable because it was mediated, state-sanctioned violence. The prosecutor used peithô to persuade the judges of his innocence and the opponent's guilt. He did not himself kill, but implored the judges to mete out the death penalty to his rival. The judges did not kill the guilty man themselves either, but gave orders to the Eleven to execute the condemned. In cases of execution by hemlock, the condemned man actually executed himself, yet another level of mediation. Hence, the court's rendering judgment mediated violence on several levels. Violence mediated this way was checked violence, because its degree and application were subject to a social control that took place in court. This mediated form of violence is a great cultural achievement. It did away with the blood feud and lifted Athenian culture up to a higher level of civilization. At the same time, this mediation of

569 Butler 1998, 14, 21-23 explains the concrete somatic dimensions of hate speech. Cf. also Kelly 1994 with an attempt to transfer the results of speech-act theory to Athenian hate speech as performed in the trials. Significantly enough, Arist. $E N$ 1131a9 and Pol.1262a27 include defamation and abuse in a list of acts of violence, together with assault, murder, and robbery. The delivery of a courtroom speech was as performative as the deposition of a curse tablet. Lindenberger 1993, 6 claims that physical violence in early modern Europe was not necessarily the aggravation of verbal injuries. Rather, verbal and corporeal abuse were interchangeable and equally damaging and harmful to the victims. Cf. above 136, n. 523.

570 Todd 1993, 302-303; Hansen 1976, 118-121; Barkan 1936, 1. People do not seem to have taken offense at the cruel punishments and the high number of executions (Fisher 1998b, 83). On the contrary, Leontius could not get enough of staring at the corpses of the executed near the city gates (Pl. R. 439e-440a). Demosthenes even achieved the execution of a priestess, who had allegedly taught slaves how to deceive (Plu. Dem. 14.6). Gernet 1981, 241-247 emphasizes the public and hence highly symbolic character of all forms of executions at Athens. On the different forms of execution, still useful are Gernet 1981, 265-267; Cantarella 1991a, 41-46 (apotumpanismos), 73-87 (stoning), 96-105 (barathron), 106-116 (hemlock); Barkan 1936, 41-53 (stoning), 54-62 (barathron), 63-72 (apotumpanismos), 73-78 (hemlock). Rosivach 1987 has shown that stoning was hardly ever used in Athens. It was reserved for treason and perceived as brutal and barbaric. 
violence, as we will see, stands in striking analogy to the way curse tablets were believed to work.

But let us not forget that mediated violence was still violence. Numerous passages in Antiphon show that this fact was never forgotten. He talks, for example, about having one's opponent killed by the courts, ${ }^{571}$ and mentions that litigants sought revenge in court. ${ }^{572}$ Accordingly, it seems that people appealed to the courts not because they appreciated the mediation of violence, but the possibility of exerting violence at all. Combing the whole corpus of Attic oratory, one does gain the impression that there is, nonetheless, a shift away from the focus on revenge in Antiphon. It is true that fourth-century orators emphasize the law as the basis for any action against opponents, which could testify to a growing problematization of violence after the tyranny of the Thirty. ${ }^{573}$ Mediated forms of violence indeed gained importance, but the violence remained, disguised by intermediary agents and hidden underneath ambiguous vocabulary.

These various strategies of covering up violence have had serious consequences for modern scholarship. Athenian cultural practices of hiding violence, or at least not expressing it openly, led to the misconception of a peaceful Athens. This idea catered to the desires of eighteenthand nineteenth-century scholars and poets who wished to design an idealized portrait of "classical" Athenian culture, one that excelled in democracy, freedom of speech, domestic peace, and the production of unsurpassed works of art in literature, philosophy, architecture, sculpture, and vase painting. Any blemishes that might taint this picture were deliberately passed over in silence or explained away. The endurance of this all too flattering model into the present time deserves to be the subject of further study.

Festivals, ${ }^{574}$ theater, wars, ${ }^{575}$ and court systems ${ }^{576}$ created communities by ritual means. These ritual activities constructed solidarity and identity

571 E.g., Antiphon 1.25, 27; 2.4.11.

572 Antiphon $1.3,21,24 ; 2.2 .2 ; 3.3 .9 ; 4.3 .1$. On killing one's opponent via the court system, cf., e.g., Cohen 1995, 104.

573 This finding is in line with the great shift from Aristophanes to Menander concerning the dramatic treatment of violence, and can also explain the popularity of curse tablets during the fourth century.

574 Burkert 1987, esp. 28.

575 On ritual wars in archaic times, cf. Connor 1988a.

576 From a ritualistic perspective, trials can also be understood as a kind of festival, as the celebration of carnivalesque anti-structures. 
by sometimes excluding or even eliminating "the other," who was defined as "evil.." zons were their mythical enemies. Very soon, "real" threats were found: Persians (barbarians), Spartans, Macedonians, and other enemies of democracy. These discursive patterns, which were derived from the foreign realm, had an enormous impact on the domestic violence discourse. Political witch-hunts could also be conducted against fellow Athenians suspected of collaboration with the enemy. ${ }^{578}$ If the opponent who had resorted to violence lacked this negative quality, he could still be labeled as a hybristic tyrant and barbarian against whom the community of good citizens should take action. As a "tyrant" or "barbarian," he had practically lost his citizenship and all privileges derived from it. Accusations, trials, imprisonment, ${ }^{579}$ ostracism, exile, and various forms of execution were strategies of exclusion that eventually strengthened the community, ${ }^{580}$ because the community had decided upon them. This ritual creation and representation of community and the sense of belonging together was a consequential factor in containing violence and ensuring the stability of the system. Athenian citizens were status conscious, and became so accustomed to drawing lines between themselves and other human beings that they not only excluded foreigners and political opponents from the community of citizens, but also, to a lesser degree, people of a lower status. The ritual performance of the violence discourse in the law courts, during the deposition of curse tablets, and in the theater defined social, gender, and political status, as well as the question of whether or not any given violent act was actually problematic and, as such, constituted "violence." Perpetration of violence within the norms set up for it, and the verbal insistence on interactionist rules as well as their representation and reinforcement through repetition in the courts and theater, helped create and maintain the Athenian social structure to the detriment of the under-

577 On the integrative effect of violence, cf. Dinges 1998, 174-175.

578 Cf. Nijhawan 2005, 273 on the exclusion of polluting elements; Bergesen 1977.

579 Cf. Allen 1997 on the development of imprisonment as a punishment, arguing against the mainstream of research, which does not believe in the retributive, penal function of prison in ancient Athens.

580 Let us not forget that not the violence itself strengthened the community and reinforced a particular identity, but the ensuing discursive treatment that charged the violent act with a symbolic sense. Chaniotis 2006, 214, 228-229 emphasizes the role of "rituals as emotional experiences of togetherness." Cf. Forsdyke 2005, esp. 143, 204, 278-279 on ostracism as a ritual that re-enacted the origins of Athenian democracy and symbolized the power of the people. 
privileged. The flexible line concerning violence that Athenian citizens drew for themselves was even more flexible, or should we rather say selective, regarding those groups that Athenian men felt were within their right of coercion. Since these dependents were not regarded as independent citizen agents, their bodies were only more or less included in the hedged-in sphere that protected the bodies of Athenian men. In descending order, the violation of the bodies of metics, women, and slaves was less and less perceived as violence by the male offenders. ${ }^{581}$ Only the violation of the oikos was perceived by kurioi as undue intrusion into their private sphere. It was only in this context that rape was taken seriously at all. It was not the sufferings of the victim that stood in the foreground, but the offended honor of her kurios. ${ }^{582}$ This focus on the man's condition brought it about that rape and seduction amounted to almost the same thing in the eyes of Athenian men. ${ }^{583}$

A ritual understanding of violence can also help us understand the selection process underlying the sources we have. Only the transgression of boundaries, the deviation from norms of violent behavior, was relevant, and charged a violent act with meaning. The infringement upon a citizen's body, especially if it happened in public, was worth being talked and written about. Its dramatization sometimes left a record in our evidence. There can be no doubt that these incidences constituted only a fraction of the cases of violence actually committed. If a violent act took place behind closed doors, especially if a kurios used his authority to exert paternalistic coercion against his dependents, neither he nor the almost defenseless victims talked about it in public. ${ }^{584}$ The kurios' action was

581 Cf. above 100, n. 339 on the findings of Ruiz on the rights of these underprivileged people.

582 Omitowoju 2002, esp. 5, 27-28, 39, 47-48, 65, 93-95.

583 Omitowoju 2002 passim.

584 Bänninger 1991, 458 depicts from a sociological point of view defenseless victims and the fact that the perpetrators do not perceive their own actions as violence. From this perspective, Lesis' letter to his mother and her prostatês is sensational (cf. above 89, n. 300). Note, however, that Lesis did not go public, but turned to his mother to find some relief from his torments. In Aristophanes' play Lysistrata, Myrrhine asks Lysistrata what the women should do in case their husbands

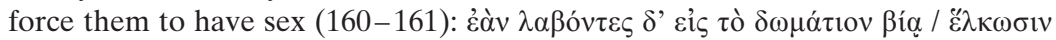
$\eta \mu \hat{\alpha} \varsigma ;$ 'And what if they grab us and drag us into the bedroom by force?'; 162: غ̇àv $\delta \grave{\varepsilon} \tau u ́ \pi \tau \omega \sigma ı v$; 'And what if they beat us?' Cf. also Ar. Lys. 225-227. Concerning the beating of wives in comedy, cf. also Aristophanes F 9 (K.-A.) = F 10 (Edmonds) and below 275, nn. 124 and 125. These passages give us a rare insight into domestic violence. Exact figures are shrouded in darkness. Cf. Alcibiades' 
deemed normal, and consequently did not find its expression in the sources. We could say that the fewer the thresholds that were violated-beating slaves, for example, did not constitute the transgression of a boundary, because their bodies were outside the sphere that protected male citizens' bodies - the more normal an action was deemed, and the less it was perceived as violence and reported in the sources. Even the violence that found its entrance into the historical record was either not described at all or only represented in a mitigated form according to the cultural convention of not displaying violence and emotions too openly. Victims barely had a forum to turn to and complain about their sufferings. Athenian citizens, in contrast, appropriated for themselves the right to "define" the notion of violence, exert violence as they pleased against "lesser" people, and not call it by name, whereas they protected themselves from any encroachment upon their bodies and lives.

In a politically egalitarian and, at the same time, highly competitive society, violence was one indispensible tool with which to construct social boundaries and superiority. Some people were more equal than others, and the publicly legitimized use of violence against an opponent made it abundantly clear to everyone which people enjoyed a superior position, from which they could commit physical and verbal violence without being punished. This is true for many similarly structured societies across history. Typical of Athens was the discursive representation of violence by oppositional pairs. This highly stylized, discursive treatment of violence deserves further scrutiny in rhetorical, literary, and media studies. One fundamental question poses itself: Why did the Athenians need such a high degree of ritualization for the negotiation of violence? One possible answer may lie in the fact that every society needs to define the difference between acceptable and unacceptable violence, but in a democratic culture of public display, the theatricality of life required this ongoing and dynamic dialogue to be carried out in public venues as well. ${ }^{585}$ In the absence of a written constitution, in a society where the line between politics and law was not clear-cut, where people from various social strata

violent treatment of his wife (cf. above 44, nn. 101 and 102) and Dicaeopolis' raping of his Thracian slave girl as a punishment (Ar. Ach.271-275).

585 With regard to religion, J. Assmann 2000, 166 ties the phenomena of de-ritualization (Entritualisierung) and de-theatricalization (Enttheatralisierung) closely to the process of writing. If we want to apply this concept to the explanation of the high degree of ritualization and theatricalization of violence in Athens, we could postulate a semi-oral society in which the culture of public display had to make up for a lack of literalization in many areas of life. 
Direct and Indirect Functions of Interactionist and Representational Rules of Violence in Table Form

\begin{tabular}{|c|c|c|}
\hline & Interactionist Rules of Violence & Representational Rules of Violence \\
\hline $\begin{array}{l}\text { Level of } \\
\text { contemporary } \\
\text { individuals, } \\
\text { Direct Functions }\end{array}$ & $\begin{array}{l}\text { Construction or challenging of } \\
\text { social hierarchies and power } \\
\text { relationships } \\
\text { Structuring and limiting of actual } \\
\text { violence (pacifying function) } \\
\text { Making violence expectable, } \\
\text { controllable } \\
\text { Creation and transmission of } \\
\text { symbolic message / significance / } \\
\text { sense } \\
\text { Facilitating communication about } \\
\text { violence } \\
\text { CONTAINMENT OF } \\
\text { VIOLENCE }\end{array}$ & $\begin{array}{l}\text { Representation of social } \\
\text { hierarchies and power relationships } \\
\text { Replacement of blood feud by } \\
\text { court system (pacifying function, if } \\
\text { conflict resolved for good, catharsis } \\
\text { in drama) } \\
\text { Imposing order onto the } \\
\text { assessment and interpretation of } \\
\text { violence } \\
\text { Keeping violence negotiable, } \\
\text { democratization of discourse } \\
\text { Performing and Shaping of violence } \\
\text { discourse, dissemination of } \\
\text { pacifying discourse } \\
\text { Providing interactionist rules } \\
\text { CONTAINMENT OF } \\
\text { VIOLENCE }\end{array}$ \\
\hline $\begin{array}{l}\text { Supra-individual, } \\
\text { Societal Functions, } \\
\text { Indirect Functions }\end{array}$ & $\begin{array}{l}\text { Negotiation and overcoming of } \\
\text { societal and political tensions } \\
\text { Functional/productive if tangible } \\
\text { outcome: alteration, improvement, } \\
\text { or advancement of social conflict } \\
\text { Dysfunctional/unproductive if no } \\
\text { tangible outcome or violence far } \\
\text { outside accepted norms } \\
\text { VIOLENCE }\end{array}$ & $\begin{array}{l}\text { Symbolic representation of societal } \\
\text { tensions } \\
\text { Open forum, full of reflexivity, } \\
\text { creativity, entertainment, staging of } \\
\text { sophisticated dialogue on: } \\
\text { (1) dialectic communication } \\
\text { between masses and elite, } \\
\text { (2) drawing the flexible line } \\
\text { between illegitimate and legitimate } \\
\text { violence (daily negotiation and } \\
\text { "definition" of violence), } \\
\text { (3) creation and representation of } \\
\text { community solidarity and identity } \\
\text { through exclusion of "the other" (= } \\
\text { evil): Persians, barbarians, } \\
\text { Macedonians, tyrants, hubristai, } \\
\text { underprivileged people (metics, } \\
\text { women, slaves) = maintenance of } \\
\text { Athenian social and political } \\
\text { structure, } \\
\text { (4) overlapping and contradictory } \\
\text { discourses on violence, } \\
\text { (5) dissemination of new polis- } \\
\text { ideology } \\
\text { Pacifying function by mediating } \\
\text { violence } \\
\text { CONTAINMENT OF } \\
\text { VIOLENCE }\end{array}$ \\
\hline
\end{tabular}


actively participated in the process of opinion- and decision-making, this communication had to take place on a symbolic level. ${ }^{586}$ This was best achieved through rituals. That is why we can speak of a highly flexible "definition" of violence through the ritualistic representation of every single defining factor. These semantic units were structured in dichotomies along the ritually constructed line between acceptable and unacceptable violence. Majority votes in rituals constructed the legitimacy of a violent act in Athens, not the law. The consequences are far-ranging.

\section{How to Plead in Court - A Conclusion}

During the liminal phase of the court session, litigants and, indirectly, judges formulated the violence discourse according to the dichotomies as fleshed out above. It is now possible to reconstruct the argumentation of the accuser, the victim of violence, as well as of the defendant, the perpetrator. While the victim claimed the illegitimacy of the act suffered, the perpetrator postulated its legitimacy. Since both concepts were elusive, because they were open to interpretation, it was the success of the litigants' performances alone that decided this thorny question. ${ }^{587}$ In order to be successful, however, the orator had to be an actor, an artist to help his audience make many logical jumps, to disguise his own violence as democratic, and emphasize that of his opponent by indirect means. ${ }^{588}$ The ritual staging of the forensic speech constructed the innocent and guilty parties, and thus revealed the transformative power of the courtroom ritual.

586 Schwedler 2005, 171-174 finds felicitous formulations concerning early modern rituals. These observations also hold true for ancient Athens. Complex relationships between persons, like social boundaries and hierarchies, are visualized best in a three-dimensional space via rituals. The paramount importance of space for rituals is also attested in Athens. The law courts, the theatrical stage in the theater of Dionysus, and tombs at which cursers could perform their magical rites provided spatial settings for enacting the violence discourse.

587 MacDowell 1990,13-22 hits the nail on the head by saying that offenses like asebeia and hubris are not clearly defined by the law. Instead, the definition is left to the discretion of the judges.

588 Occasionally, we get hints at the power of rhetoric and performance. Demosthenes was visibly irritated at Aeschines' forceful voice and formidable declamatory skills, so much so that he implored his audience toward the end of his speech not to heed Aeschines' opinions and advice (D. 19.337-338). Cf. Easterling 1999. 
Narrativity especially engendered the ritualization of violence on the discursive level. This discursive ritualization, in turn, charged the violent act itself with symbolic meanings that were transmitted by the performance of the violent act and its ensuing representation in court. Hence, violence was in most cases not a senseless act, but a meaningful social practice. Not only did the perpetrator regard his violent action as positive, productive, functional, and meaningful, but we can also discern these qualities on a higher, supra-individual level, as long as the violence committed remained within strict limits. When the violence challenged the status quo, expressed underlying societal tensions, led to a tangible outcome or improvement of the situation, or caused social forces to develop further, we can also discern some positive, productive, innovative, or functional traits for this kind of violence. ${ }^{589}$ This is not, of course, the perspective of the victim. If the violence took place outside the accepted sphere of action, if it only affirmed the status quo, if the perpetrator was reintegrated into society, and if the violence had no consequences, we can regard it as dysfunctional and unproductive.

Trials were all about de-legitimizing the behavior of one's opponent. A speaker would always label his rival's actions as having taken place far outside the constructed boundaries of accepted interaction. The speaker would either deprive his enemy's actions of all sense or charge them with negative symbolism by highlighting the breach of multiple rules of interaction or taboos. Only a barbarian or anti-democratic tyrant would behave that way, full of hubris and wanton insolence, appropriating the laws of the polis and using them for his own interests. This aggression was not justified, but unlawful in the extreme. The opponent was driven by a disproportionate fit of anger to transgress massively socially coded thresholds. Full of bloodthirstiness, he sought archaic revenge and committed excessive violence outside the parameters of democracy. From the speaker's point of view, the publicity of the violent act was problematic. The symbolic message transmitted by the opponent was put in doubt or negated outright; the speaker emphasized the transgressive and negative symbolism of the public act, because, for him, the staging of the vio-

589 That conflicts can have positive sides and integrative effects is a well-established fact in the sociology of conflict. Simmel 1908 exerted great influence, e.g., on Dahrendorf 1973; Coser 1967; ${ }^{2} 1966$; 1964; Rex 1961. Coser discerns realistic from unrealistic conflicts. Whereas the first unleashes productive forces by furthering social change, the latter form of conflict is not intended to solve the problem, but only aims at annihilating the opponent. 
lence he had suffered was always unseemly. If the incident took place outside the public gaze, it was even more outrageous. The lack of witnesses who could have adjudicated what was going on and prevented the worst was scandalous. The opponent's conduct was always disruptive, dysfunctional, unproductive, highly problematic, and therefore illegitimate. In a word, it was blind violence. This stigmatization of the opponent's violence aptly latched onto the discourses concerning tyrants and barbarians.

The perpetrator, in contrast, used various strategies to portray his own behavior as legitimate. He either did not talk about his violence at all or else played it down as far as possible. In order to convince the judges of the legitimacy of his actions, the perpetrator claimed that they had taken place inside the rhetorically delineated boundary of acceptable interaction. To prove this claim, he did not shrink from manipulating this line and shifting it to his favor, and to the detriment of his opponent. A convenient reproach was that the latter had practically lost his citizenship status because of his hybristic behavior, which had assimilated him to a tyrant or barbarian. The stigmatization along these lines was a popular strategy of exclusion from the protected sphere of citizens. It allowed the perpetrator to treat his rival like an outcast or foreign enemy. In addition, the aggressor emphasized his authorization by the government in the form of decrees, if any were relevant, and the meticulous observance of social codes, like waiting for the absence of a homeowner's father, wife, other female relatives, and children before entering a house. Thus, the incident made sense and was positive because it was not only justified, but lawful, non-excessive behavior.

If boundaries were transgressed, the perpetrator claimed that it had been unavoidable to do so and that he had met with the consent of the bystanders. He would then give a rationale for his behavior. Reconciling the conscious violation of normative rules with the simultaneous presentation of it as neither hybristic nor tyrannical behavior, but on the contrary as goodwill and even naivety, was a bold high-wire act that only members of the elite could dare to try. Only strongmen like Meidias or Alcibiades who enjoyed enough symbolic capital consisting of high social status, economic wealth, powerful relationships, and a good reputation were in a position to afford such a risky undertaking. The speaker would then admit that he had indeed been driven by a fit of anger, but rightly so, in order to exert self-help or legitimate revenge within the parameters of democracy. Yes, he committed violence deliberately, but for the sake of the city, driven by selfless motives and full of self-restraint. In this sense, his actions were civilized, anti-barbarian, anti-tyrannical, and democratic in 
the sense that the act was even required by democracy. As such, they were excusable. Thus, his measures were replete with positive sense and actually helped maintain the polis. From this perspective, violence appeared as a sensible, meaningful social action, which only failed to make sense at first glance. One's own conduct was always functional, productive, unproblematic, and therefore legitimate. In a word, it was self-defense that actually did not call for a trial at all.

On his side, the mostly upper-class perpetrator differentiated further between societally relevant and irrelevant violent behavior. He was rich, powerful, and daring enough to stage relevant violent behavior before the eyes of all citizens in order to unmask the wrongful twists and turns of the opponent and to protect himself. Quite often, some entertainment value was even attached to such an action. In this situation, the perpetrator was eager to convey a message to an audience, who should judge his action as legitimate. Only the violation of social codes charged an act semantically and made it memorable, thus increasing its chance of being recorded. Here we can speak of dramatization. It is mostly dramatized acts of violence that are reflected in the forensic speeches. The more influential and bolder the violence monger was, the more breaches he could afford. For the elites, these violent showdowns with their peers in public and their ensuing negotiation in court were part of their performative self-representation. Full of youthful self-confidence-their rivals would have spoken of arrogance and hubris - they wanted to test their bodily, societal, and institutional strength and see how far they could go in intimidating their rivals. The courts provided the appropriate stage for the legal continuation of the physical trial of strength.

Whenever the perpetrator found his violent behavior irrelevant, because it was not necessary for the citizens to assess it, or he did not want the citizens to know about it at all, he committed it behind closed doors or hid it under a cloak of silence. If he coerced the people in his power, it was unproblematic for him and his fellow citizens. When a kurios committed violence against them, he broke no taboos and he did not need onlookers to serve as corrective forces. In fact, he did not consider his conduct as "violence" at all. These acts hardly found an echo in the sources. Here we can speak of "normalcy." 590

The zero-performance of the speaker's violence and the mitigated representation of the opponent's violence in the speeches, as well as

590 Applied to modern nation states, especially the USA, in a different sense, cf. Von Trotha 1997, 34-35. 
the omission of fatal violence on vases ${ }^{591}$ show that Athenians were highly conscious of the destructive potential of violence. Athenians, especially from the upper echelons of society, problematized violence more and more, at least on the discursive level. Yet violence, at the same time, was ubiquitous in daily life, for the potential of violence was probably as high or low as during the archaic or Hellenistic periods. But the changed political circumstances of the fourth-century democracy necessitated the institutional and ritual containment of violence to enable Athenians to remain in line with the stringent rules of the amnesty. The avoidance of violence and, most of all, the avoidance of its open expression were more and more defined as cultural goals of prime importance, however unrealistic these goals were. All media, even grave stelai, ${ }^{592}$ omitted or glossed over negative emotions and conduct, such as violence or grief. How can we account for the suppression of violence in all media in the face of violence that pervaded all social strata? Brutality lay under the surface of relatively tame discourses that were spoken in forensic oratory, ${ }^{593}$ curse tablets, ${ }^{594}$ and partly also in stage drama. ${ }^{595}$ The tragedians, Aristophanes, and Menander are most explicit about the disruptive force of violence and the need to contain it as much as possible to ensure the maintenance of the state. The ideology of a violence-free space and society was obviously dear to Athenians, and many modern researchers have mistaken the ancients' ideal as reality. As will have to be shown in another study, the suppression of internal violence and "problematic" emotions (such as anger and excessive grief) rendered Athens a pressure cooker, at least for the elites. This pressure-cooker atmosphere was in need of a

591 Borg 2006, 248 on the disappearance of violent motifs from vase paintings after $480 \mathrm{BCE}$. It is interesting to note which scenes of violence are still depicted, i.e., sacrileges and the punishment of hubris (250). Muth 2006, 270 remarks that the violence that is depicted after $470 \mathrm{BCE}$ is always indirect; cf. also Kunze 2005; Muth 2005; Stähli 2005; Von den Hoff 2005. Henrichs 2006, 82-83 stresses that only three vase paintings directly depict the slaughter of a sacrificial animal.

592 With the change of values accompanying the introduction of oligarchy, many democratic features broke away around 320 BCE. Grave stelai, for example, so typical of democracy, disappeared. This phenomenon is to be seen against the backdrop of Demetrius of Phaleron's burial laws, which were supposed to curb funeral luxury. Cf. O’Sullivan 2009, 47-66; Engels 1998, 121-154, esp. 153. Cf. above 112, n. 382.

593 Herman 2006 passim; Gagarin 2005.

594 Cf. chapter III on the curse tablets.

595 Bohrer 2006; Goldhill 2006; Seidensticker 2006; Ercolani 2005. 
safety valve: suppressed violence in the domestic realm contributed to unleashing fatal forces in an aggressive and imperialistic foreign policy.

In the following chapter, we will see that the forensic speeches are not alone in their ultimate goal of damaging or even eliminating an opponent, who is to be understood as a tyrant or barbarian and is therefore to be excluded from the community of Athenian citizens. By the fourth century, the court system, with the curse tablets as its corollary, had taken over the function of fifth-century ostracism. It thus comes as no surprise that some of the persons mentioned in the forensic speeches also show up on curse tablets. ${ }^{596}$ The courtroom speeches, with their insistence on slander and character assassination, had an enormous performative force and can be regarded as a kind of public cursing. How private cursing worked in a ritualized context will be the subject of the next chapter.

596 D. 21.59 mentions The ozotides, an ancestor of whom is cursed in Gager no. 41 $=$ Trumpf 1958, 94-102 = BE 1963, 125, no. $32=$ SGD $9=$ Jordan 1988, $275-$ 276 = López 9 = Guarducci 1978, 244-245, fig. 68.69 = SEG XXI 1093 = SEG XXXVIII 31. Cf. also Lysias' mention of a certain Theozotides in fr. LXIV 129130; LXV 151. In D. 21.62, we encounter Diocles, who may be cursed in DTA 94 and López 55 = Willemsen 1990, 142-143, no. 1 = López 1992, 201-202 = SEG XLII $217=$ NGCT 1 . Most spectacular is a curse against Andocides and some of his followers who were involved with him in sea trading: Costabile 2004/5, 137-169. On another tablet, found in 1964 and dating to about $400 \mathrm{BCE}$, Menecles, Telestes, and Pythodorus are cursed; on the other side of the tablet, among other names, appears Leptines (Costabile 2004/5, 182-192), for whom Lysias may have written a speech (Lys. fr. XLVII 103 [Carey prefers "Elpinês" over "Leptines" and thinks "Leptines" got into some manuscripts because of the influence of D. 20]; cf. Carey 2007, 430). Cf. Jordan 1988 on the connections between curse tablets and the Lysianic corpus. 


\title{
III. Curse Tablets
}

\author{
Und sie laufen! Nass und nässer \\ wird's im Saal und auf den Stufen, \\ Welch entsetzliches Gewässer! \\ Herr und Meister, hör' mich rufen! \\ Ach, da kommt der Meister! \\ Herr, die Not ist groß! \\ Die ich rief, die Geister, \\ werd' ich nun nicht los. \\ (Johann Wolfgang von Goethe, \\ Der Zauberlehrling)
}

In addition to forensic speeches, curse tablets also served as a means for Athenians to talk about and exert violence in a ritual frame. The deposition of a curse tablet was a highly performative act, and the various magic formulas invoked were often viewed as a means of conflict resolution, regardless of the fact that malign magic could potentially exacerbate a conflict. What we know about binding-spells in ancient Athens, the so-called defixiones (Greek: katadesmoi), confirms this picture. The defixiones, "more commonly known as curse tablets, are inscribed pieces of lead, usually in the form of small, thin sheets, intended to influence, by supernatural means, the actions or welfare of persons or animals against their will." " People deposited curse tablets in order to help cope successfully with crises. ${ }^{2}$ Current evidence suggests that the Greek practice of depositing these tablets arose in Sicily during the sixth century BCE and was in use well into the late Byzantine and Ottoman periods. The use of this kind of ritual magic in Western Europe for over two thousand years suggests that its practitioners must have believed in its efficacy. The apparent importance of magic practices in the cultural context of conflict resolution provides the primary reason why it is necessary to examine the phenomenon here, despite the otherwise narrow definition of violence underlying this book.

In order to understand magic, one has to take into consideration the entire social context of a society, for magic can only work under special

1 SGD p. 151.

2 Graf 1996, 117, 139, 142. 
circumstances. In order for magic to work effectively, it has to be deeply engraved in a culture's way of thinking, and notions of a magical worldview have to permeate that culture's social, economic, and psychological fabrics. ${ }^{3}$ This worldview is not only rooted in play, its outcome being as contingent and unpredictable as that of an Athenian trial, ${ }^{4}$ but is also characterized by a combination of integrative and logical thinking. It is inappropriate to judge magic in scientific terms only. ${ }^{5}$ It is true that both magic and science operate on analogical thought and action, but magic embraces "persuasive analogy," whereas science is based on "empirical analogy." Tambiah's far-reaching finding that magical speech acts are marked by two types of figurative speech, metaphor and metonymy, ${ }^{7}$ helps to explain, for example, the enumeration of body parts in ancient curse tablets.

Cross-cultural evidence suggests that the preconditions sketched above are also valid in the case of ancient Athens. The economy of ubiquitous sorcery in contemporary West Africa is strikingly similar to what we know about Athens. ${ }^{8}$ In Africa, envy and the resulting evil eye are the driving factors behind magic. In order to avoid these dangers, the rich give part of their wealth to the poor so as not to be cursed. Did rich Athenians not feel compelled to engage in euergesia and give to the poor in form of donations and leitourgiai also in order to be spared from phthonos and baskania (envy and the evil eye), and katadesmoi? In antiquity, many well-to-do made a virtue out of this necessity and strove to outdo each other with lavish gifts to the dêmos of the Athenians.

3 Mauss 1972, 9, 122 establishes magic as a "collective idea," a "social phenomenon," which is the main theme of his book. I am aware of how problematic the notion of a "magical worldview" is, but nevertheless use the term for heuristic reasons to describe Athens as a society for which magic seems to have worked. Cf. in addition Wax 1962 on the magical worldview.

4 Huizinga ${ }^{4} 1964,76-88$. Cf. above 138 , n. 529 on the irrationality of the Athenian law court system.

5 Tambiah 1985a, 60.

6 Tambiah 1985a, 72.

7 Tambiah 1985b, 41-43.

8 Signer 2005. 

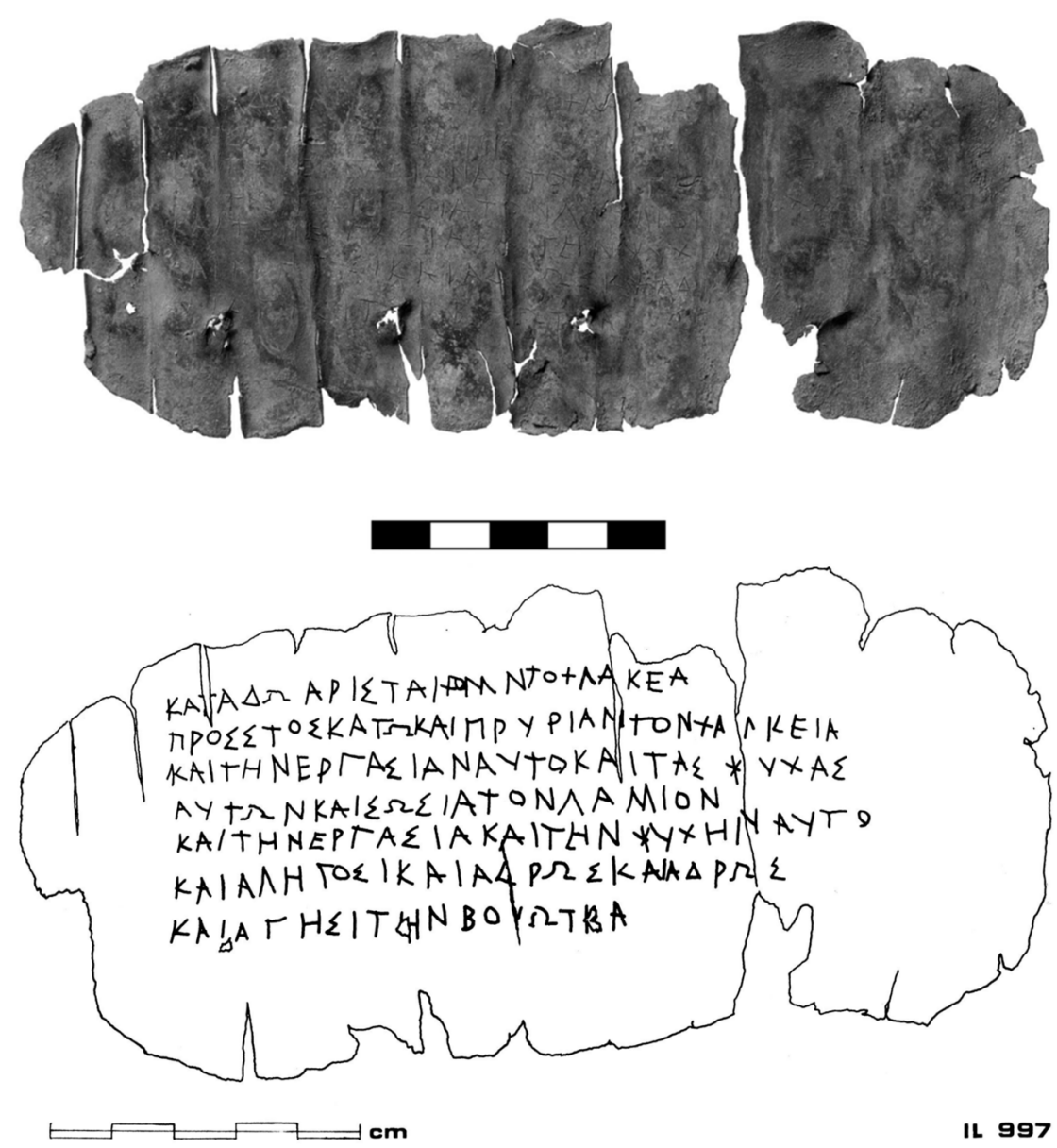

Both images are taken from J. B. Curbera - D. R. Jordan, "A Curse Tablet from the Industrial District near the Athenian Agora," Hesperia 67, 1998, 215-218. On the ensuing page (unnumbered), plate 32 shows a photo and drawing of this curse tablet (Agora Inv. no. IL 997). Reproduction is courtesy of the Trustees of the American School of Classical Studies at Athens.

Transcription (p. 216):

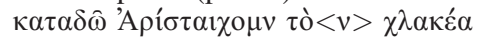

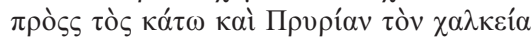

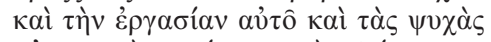

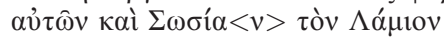

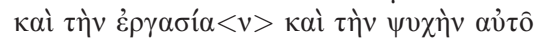

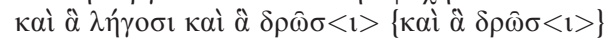

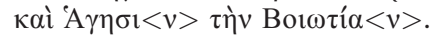

Translation (p. 217):

'I bind down Aristaichmos the smith before those below and Pyrrhias the smith and his work and their souls and Sosias of Lamia and his work and soul and what they say and what they do \{and what they do\} and Hagesis of Boiotia.' 
Numerous scholars have categorized the curse tablets in various ways. ${ }^{9}$ Today, we distinguish five categories: $:^{10}$

(1) Judicial or so-called "litigation curses." These include political curses, but whether there is a separate and distinct category of political $d e-$ fixiones is a matter of debate. ${ }^{11}$

(2) Defixiones agonisticae, concerning competitions. In classical Athens, these curses refer to theatrical rather than sporting events; during the Roman Empire, they deal with athletes, charioteers, and gladiators. $^{12}$

(3) Trade curses or business/commercial spells, concerning the world of small-scale craftsmen and merchants. ${ }^{13}$ These open a window onto social strata that are otherwise almost unattested in the literary sources.

(4) Erotic curses. These can be divided along chronological lines into the earlier separation (or separative) love spells (diakopoi) ${ }^{14}$ and the later attraction spells (agôgai). ${ }^{15}$

(5) "Prayers for justice." These do not have much in common with conventional binding spells $;{ }^{16}$ rather, their goal is the restitution of stolen goods and the punishment of the thieves. They are primarily a later phenomenon.

Given the chronological distribution of the different categories, this chapter will be mainly concerned with litigation and business spells preserved from fourth-century BCE Athens.

A few words on the situation of the sources may be appropriate. Approximately three hundred curse tablets have been excavated in Athens over the past hundred years, about two hundred seventy of which date

9 Graf 1996, 110, superseding Audollent 1904, lxxxix and, based on him, Trumpf 1958, 101; Gager 1992, 42-199; Faraone 1991a, 10, 16; Versnel 1991a, 62; Faraone 1985, 151; Preisendanz 1972, 9-10, 22; Kagarow 1929, 50.

10 I follow Ogden 1999, 31.

11 Gager 1992, 119.

12 Cf. Tremel 2004.

13 Ogden 1999, 33-35 in detail.

14 The best definition is given by Faraone 1991a, 13-14: “'lover's triangle,' where two individuals were competing for the affections of a third."

15 More subdivisions in Gager 1992, 79-80. Winkler 1990 has become a classic on attraction spells. Erotic spells must have been practiced at an earlier time in Athens, too (Lucianus, DMeretr. 4.4-5; S. Tr. 555-587, 1138-1142; Antiphon 1).

16 Versnel 1991a has established this category. Gager 1992, 175-199 speaks of pleas for justice and revenge. 
back to the fourth century BCE.$^{17}$ Whereas literary sources are easily accessible in manifold editions and in most cases also in translation, the state of the edition of curse tablets is still deplorable. A reliable, comprehensive edition of Athenian curse tablets corresponding to modern standards is lacking. ${ }^{18}$ This unfortunate situation is the reason for the curse tablets' being under-researched for their socio-historical value.

This chapter pursues two goals. A first thesis questions the communis opinio, which holds that the degree of violence expressed in these tablets was low. My own reading challenges this assumption by elucidating the highly ritualized form of violence exerted by these tablets, which are themselves imbued with the language of socially prevalent civil discourses on violence. I will demonstrate that, underneath the tame linguistic surface, quite a few curses may have been designed to kill the victim; moreover, further deliberations suggest that the potential of violence contained in binding magic was generally higher than scholarship has so far surmised.

A second thesis focuses on curse tablets in their role as an invaluable source for the study of Athenian culture. Because the texts preserved on these tablets display precise linguistic rules and discursive practices, and performance and theatricality play an important role in this genre, applying ritual and performance theory will add much to the current understanding of the curse texts. It is my goal to illuminate the discursive practices demonstrable in the extant body of curse tablets through a close reading of select texts. In doing so, I will explore the relationship between binding magic and Athenian democratic principles and procedures, with the goal of demonstrating that some assumptions underlying magic ritual reflect cultural practices of the Athenian democracy and can even be shown to be analogous to some aspects of Athenian lawcourt procedures.

17 Rabehl 1906 and Wilhelm 1904 could date most extant tablets to the fourth century BCE on grounds of prosopographical criteria.

18 Cf. the brief overview of research in Brodersen 2001, 57-59 and Ogden 1999, 86-90. The point of departure for every work on the Attic tablets is still the appendix of DTA. DT offers a few Attic curse tablets but deliberately excludes the pieces in DTA in order to publish all curse tablets known by 1904 in the Mediterranean basin. Indispensable are the overviews by Jordan (SGD and NGCT). Nevertheless, anyone working on this material is forced to consult the original publications. 


\section{Proportions - Social Origins of Cursers - Functions of Tablets}

As in West Africa, magic in ancient Athens had to do with envy (phtho$n o s)^{19}$ and the evil eye (baskania). ${ }^{20}$ Although these phenomena occur in practically every human community, they are especially prevalent in societies that place a great deal of emphasis on competition and the values of honor and shame. ${ }^{21}$ Officially, envy was regarded as a base, destructive, and shameful emotion and thus not as a legitimate motivation for litigation in Athens, whereas enmity and revenge were acceptable reasons for taking someone to court. ${ }^{22}$ In reality, however, many forensic speeches in Athens must have been motivated by envy as well, among other reasons, for we will see that many orators and those who commissioned magicians shared the same motives and, in fact, are sometimes even one and the same person. But although envy could not be openly expressed in court and was literally driven underground through the use of curse tablets, it still lingered in the background of many lawsuits.

Approximately two hundred seventy curse tablets have been preserved from the fourth century; of these, one hundred forty are barely readable. About one hundred thirty offer an insight into violent language and the Athenian understanding of conflicts. The bulk is made up of judicial spells (ca. eighty instances) cast on adversaries before crucial trials, ${ }^{23}$ approximately half of which were written or commissioned by, or

19 Konstan - Rutter 2003; Versnel 1999; Bernand 1991, 85-105 and passim; Gehrke 1987; Walcot 1978, 77-90. Cf. the early verses of Hes. Op. 25-26: кai

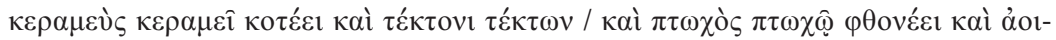
$\delta$ ò $\alpha_{\alpha} 01 \delta \hat{\omega}$, 'and potter is angry with potter, and builder with builder, and beggar begrudges beggar, and poet poet.' Cf. Hom. Epigr. 14, the "Potter's Hymn" and Plin. Nat. 28.4.19 on the potters. Phthonos is explicitly mentioned in NGCT $24=$ SEG XLIX 320, an early fourth-century Athenian tablet (side A). To Eidinow 2007a, 204 and 231, envy, jealousy, gossip, suspicion, and rivalry are always at the core of malign magic.

20 Accordinig to Rakoczy 1996, 271, the evil eye was already in existence in early Greek society. Pl. Phd. 95b connects the evil eye to malign magic. Later, baskania and phthonos became synonymous (Rakoczy 1996, 127-128). On the evil eye, cf. also Schlesier 1994; Dundes 1992; Dionisopoulos-Mass 1976; Arnaud 1912. To Luck ${ }^{2} 2006$, 19, baskania is an indo-european concept. The earliest Greek text that describes the evil eye in detail is A.R. 4.1635-1690.

21 Cf. Cairns' 1993 comprehensive study of the fifth century BCE.

22 Cohen 1995, 69, 81, 83.

23 The judicial context is mostly recognizable because the cursed victims are often designated as antidikoi or sundikoi (Boegehold 1995, 55). Faraone 1991a, 16, however, thinks that these terms are not necessarily connected to the judicial 
deal with, members of the upper classes, the political elite. ${ }^{24}$ Since the litigation curses were often involved in political conflicts, there is some degree of overlap with political curses. ${ }^{25}$ In the complex procedures of Athenian democracy, many political issues were addressed and negotiated in the law courts. Conversely, the Assembly of the People sometimes had to conduct judicial business. The Boulê also fulfilled judicial functions. To the Athenians, there was no clear differentiation between politics and law. It is important to note that political trials were not an agôn between two persons only, but between two rival teams consisting not just of several supporting speakers on the sides of prosecution and defense (sunegoroi), but also of their entire social entourage. ${ }^{26}$ In this theatrical setting, the witnesses, in the end, performed functions different from those in modern courts. Although they were supposed to help reveal the truth, they often flaunted the social prestige of the main litigant more than they contributed to seeking the truth. The more influential supporters someone could muster on his behalf, the more weight he carried with the judges. ${ }^{27}$ This special function of witnesses explains the long lists of names on many political/judicial curse tablets. ${ }^{28}$ The entire opposing

sphere. They could simply mean 'enemies' and 'friends.' More precise is the term sunêgoros, which is to be translated as 'supporting speaker' (cf. Rubinstein 2000). On the older debate about whether the tablets were deposited before or after trials, cf. the summaries in Gager 1992, 117 and Faraone 1991a, 15. For a detailed and nuanced treatment of informers, judges, witnesses, supporting speakers, sundikoi, and antidikoi, cf. Eidinow 2007a, 173-183.

24 Faraone 1991a, 30, n. 76; 1989a, 156, n. 20 gives the first listings of politicians on the tablets.

25 Faraone 1991a, 16: "such a category [i.e., political] would be difficult-if-not-impossible to separate from the category of judicial curses." Cf. also Eidinow 2007a, 168. A typical example is the spell against Andocides and his seafaring companions (Costabile 2004/5, 137-169). The defigens wrote this curse probably between 399 and 392 BCE, but we do not know his motives.

26 Rubinstein 2000.

27 Humphreys 1985b understands the law court proceedings as Social Dramas and fully recognizes the ritual function of the witnesses. On witnesses in general, cf. Rubinstein 2005a; Thür 2005; Mirhady 2002. Cf. above 46-47.

28 With 77 names cursed, no. 1 is the longest list: 1. Gager no. $56=$ Ziebarth 1934a, pp. 1023-1027, no. 1 A-B = Robert 1936, 13-14 = SGD $48=$ López $30=$ Eitrem 1936, $558=$ Peek 1942, 166-167 = Ziebarth 1934b, 132-136; 2. Gager no. 38 = DTA $103=$ Wilhelm 1904, 122-25 = SEG XXXVII 220; 3. Gager no. $41=$ Trumpf $1958=$ BE 1963, p. 125, no. $32=$ SGD $9=$ Jordan 1988 , 275-276 = López 9 = Guarducci 1978, 244-245, fig. 68, $69=$ SEG XXI 1093 $=$ SEG XXXVIII 31; 4. Gager no. $42=$ Wünsch 1900, p. 63 , no. $6=$ DT $60=$ Ziebarth 1899, p. 108, no. 6; 5. Gager no. $57=$ Braun 1970, 197-198 = Jordan 
party, including wives and prostitutes, was often lumped together in one single spell in order to break its power. ${ }^{29}$

Competition and business spells rank second, with about forty tablets. $^{30}$ Among them we also find competition between chorêgoi expressed. ${ }^{31}$ Separative love spells are rare (only nine examples are known from fourth-century Attica so far, some of them probably written by women). ${ }^{32}$

It comes as no surprise that most Attic judicial curses date to the fourth century $\mathrm{BCE},{ }^{33}$ the heyday of Attic democracy. In many ways,

1980a, 229-236 = SGD 14 = López $14=$ SEG XXX $325.2=$ SEG XXXV $211=$ SEG XXXIX 293 = Costabile 2004/5, 176-182; 6. Gager no. $102=$ Wilhelm 1904, 120-122 = SGD $18=$ López $18=$ Stryd 1903, col. 59-60, no. 5; 7. Gager no. $105=$ Peek 1941, pp. 91-93, no. $3=$ Jeffery 1955, p. 75 , no. $19=$ SGD 1 = López $1=$ Ziebarth 1942, 19; 8. López $5=$ SGD $5=$ Peek 1941, p. 96 , no. $7=$ Jeffery 1955 , p. 75 , no. 25 ; 9. López $6=$ SGD $6=$ Peek 1941 , pp. 93-94, no. $4=$ Jeffery 1955 , p. 75 , no. 23 ; 10. López $7=$ SGD $7=$ Peek 1941, pp. $94-95$, no. $5=$ Jeffery 1955 , p. 75 , no. 24 ; 11. López $8=$ SGD $8=$ Peek 1941, p. 97, no. 8; 12. López $24=$ SGD $42=$ Robert 1936, pp. 12-13, no. 11 = SEG XXXVII 214; cf. Bravo 1987, pp. 195 with 213, nn. 19 and 20; 13. López $55=$ Willemsen 1990, 142-143 = López 1992, 201-202 = SEG XLII $217=$ NGCT 1; 14. López $59=$ Willemsen 1990, 148-149 = NGCT 5; 15. DTA 10; 16. DTA 11; 17. DTA $57=$ Wilhelm 1904, 115; 18. DTA 65.

29 Eidinow 2007a, 189 rightly points out that entire social networks, i.e., inside and outside of the courts, were cursed. With regard to businessmen, Eidinow 2007a, 199 suggests that the people mentioned in long lists might have been cursed for varying reasons, but that someone commissioning a curse would have wanted to go to the effort of doing so only once.

30 Good examples are DTA 12, 30, 55 = Gager no. 64 = Wilhelm 1904, 107-108; DTA $69-71=$ Gager no. 63; DTA $75=$ Gager no. 65 ; DTA $86=$ Gager no. 67 ; DTA 97 = Gager no. 66; DT 52 = SEG XLIX 321 = Ziebarth 1899, pp. 118 120 , no. $20=$ Wünsch 1900, p. 67, no. 20; cf., similarly, DTA 96; Gager no. 71 $=$ Young 1951, 221-223 = SGD $20=$ López $20=$ SEG XL 273; SGD 3, 48, 52, 72. Cf. Curbera - Jordan 1998, 215-218.

31 E.g., 1. Gager no. 1 = DTA 34; 2. DTA 33 (Gager 1992, 49, n. 1); 3. DTA 45 is directed against an actor; SGD 91 (Gela) against producers.

32 1. Gager no. 22 = DT 68 = Petropoulos 1988, 219-20 = Ziebarth 1899, pp. $114-$ 116 , no. $16=$ Wünsch 1900 , p. 65 , no. 16. Cf. the detailed discussion of this curse in Eidinow 2007a, 218; 2. DT $69=$ Ziebarth 1899, pp. 116-117, no. $17=$ Wünsch 1900, pp. 65-66, no. 17; 3. Gager no. $23=$ DTA $78=$ Wilhelm 1904, 113 (with impotence as malevolent wish); 4. Gager no. $24=$ DTA 77 (with impotence as malevolent wish); 5. Gager no. $104=$ DTA $102=$ Wilhelm 1904, 112-113= SEG XXXVII 219; 6. López 57 = Willemsen 1990, 145-147 = NGCT 3, 7. DTA 89; 8. DTA 90; 9. DTA 92/93.

33 Faraone 1991a, 16. 
the judicial tablets are a welcome supplement to the court speeches. The rich, especially, could afford to hire skilled logographers (and/or professional magicians, so-called goêtes $^{34}$ ), and, as a result, often resorted to the courts to seek redress in quarrels. They also tended to regard the courts as viable institutions for conflict management and sometimes conflict resolution..$^{35}$

Since members of the upper classes were primarily the ones to make use of the courts, they were also the writers or commissioners of most of the preserved judicial tablets. ${ }^{36}$ In the highly public and competitive society of ancient Athens, the rich had more to lose, in social terms, by going to court, even on grounds of trifling charges, than did the lower classes. The culture of public display made trials vital for litigants, and being confronted with the danger of losing face in front of many people might cause a wealthy defendant to resort to all means available to win this contest in public. ${ }^{37}$ These considerations suggest that the upper classes might have been at least as prone to violence as the lower classes, because they felt their stakes were higher than those of the humble.

Suing one's opponent and cursing him were parallel, complementary social practices. Both defendants and prosecutors resorted to magical practices in dikai and graphai alike. ${ }^{38}$ Hiring a skilled logographer and a professional magician simultaneously were two sides of the same coin. ${ }^{39}$ The elites vying for social prestige had at least two modes of expressing their aggression in the game for power: $:^{40}$ a public one on the

34 Johnston 1999a, 103-116 on their functions.

35 The caveat is necessary, because court proceedings could also "provide an arena for ... exacerbating long-term feuds" (Faraone 1999a, 102). With this formulation, Faraone is perfectly in line with Cohen's terminology.

36 On the phenomenon in general, cf. Faraone 1985, 153.

37 Binding one's opponent's tongue was the easiest way to expose him to public ridicule: cf., e.g., 1. Gager no. $40=$ DTA $107=$ Wilhelm 1904, $112=$ SEG XXXVII 221; 2. Gager no. $59=$ DTA $47-50$ (a-d) = Wilhelm 1904, 114-115; 3. DTA 58; 4. DTA $88 ;$ 5. DT $66=$ Wünsch 1900 , p. 72, no. 4; 6. Gager no. $66=$ DTA 97; 7 . Gager no. 39 = DTA 95 = Wilhelm 1904, 119-120. Cf. Versnel 1999, 148-152; Cic. Brut. 60.217; Orat. 37.129.

38 Eidinow 2007a, 187-190; Faraone 1999a, 116. Gager 1992, 117 only thinks of prospective defendants using curse tablets.

39 Faraone 1999a, 116, 118.

40 We must not forget that most conflicts were settled outside of court through mediation and arbitration. Cf. Manley-Tannis 1998; Steinwenter ${ }^{2} 1971$; Harrell 1936. Going to court was just one of many options for dealing with a conflict. The decision to take a dispute to court, thus transforming it into a legal case 
stage of the courts, and a more reclusive one in the sphere of malign magic. This is not to say that the wishes inscribed on the tablets could not be uttered in public. In a fictional speech by Antiphon, the speaker goes so far as to threaten the judges with language that strikingly reminds us of the idiom used in curse tablets: if the judges do not fulfill the speaker's wish, he warns, he will set the wrathful spirits of the premature dead upon them. ${ }^{41}$

The co-existence of these two different outlets for violence-the courtroom and magic curses-is revealing at yet another level. According to Turner's theory, malign magic is one method of overcoming conflicts. ${ }^{42}$ If the trial did not result in the conviction of the opponent, the curse would function as a fall-back option to make certain of a negative outcome for the opponent. This idea, however, is a modern supposition and may be inapplicable within the cosmos of the magical worldview. Since many people were not only concerned with causal and logical, but also with integrative thinking, it may be possible that a curse promised more success to many Athenians than a trial. Given that both forms of conflict resolution worked side by side, having recourse to the court system may not have constituted the primary method of dealing with a conflict. Many, perhaps even most people may have relied on magic rather than the court system. In addition, the curse was definitely much cheaper and less daunting than going to court.

Binding spells must have fulfilled vital functions for the cursers, by allowing them "to deal with the nonlegal side, the emotional dimension, of lawsuits and public trials." ${ }^{43}$ In a situation of crisis and extreme angst, the litigants could express their anxieties and could give a pre-moulded form to their aggressions and feelings of insecurity. Therefore, the formulaic character of the spells is easy to explain. It was not necessary to search for individual, personal phrases to tailor a spell to a particular person, because formulas already existed that promised instant help. Since the rich had the resources to resort to all means available in vying for power, itin-

and dichotomizing the involved parties, was made by the prosecutor. Cf. Johnstone 2003.

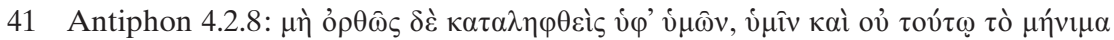

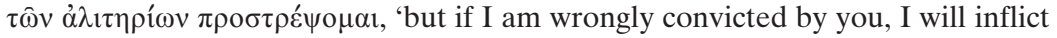
the wrath of his avenging spirits on you, not on him [i.e., the prosecutor]' (addition added).

42 Turner 1989b, 173.

43 Gager 1992, 116-117. 
erant magicians knocked on their doors to offer their services. ${ }^{44}$ The fact that professional sorcerers did offer such services leads us to the vexed question as to what degree people sought professional help at various stages of casting a binding spell, and to what degree they did it on their own. ${ }^{45}$

On the one hand, we have ample evidence for the employment of ritual experts. Sometimes the handwriting on the tablets is skilled and we can safely assume that not everyone knew the pertinent rites and formulas. ${ }^{46}$ In one Athenian well, not only were the same formulas found on many tablets, but the same handwriting is discernable. ${ }^{47}$ Moreover, it must have been unpleasant and highly dangerous to go to the Kerameikos at night, dig up a grave, and ideally place the curse tablet into the right hand of a corpse. ${ }^{48}$ From the later collection of the Papyri Graecae Magicae, we know of the existence of standard models for curse tablets and instructions for their manufacture and deposition. ${ }^{49}$ On the other hand, amateurs must have been active at all times. ${ }^{50}$ On most tablets, the handwriting is not more than a scribble. Some tablets are barely literate. There is also evidence that many different writers deposited tablets at one find spot. $^{51}$

Whereas many curse tablets appear to have been written or commissioned by members of the upper classes in the context of lawsuits, it is also likely that most disputes, especially among the lower strata of society, never reached the court level at all. Many less well-to-do people must have relied solely on curses to harm their enemies. A typical example of a curse tablet dealing with a quarrel that one party tried to set aside extra-judicially gives us a glimpse of the world of small-scale businessmen

44 Pl. R. 364b-c = Gager no. 140. Some experts of magic, however, must have been sedentary (Voutiras 1998, 49).

45 Ogden 1999, 54-55 differentiates four phases of a binding spell, where the expertise of a professional magician was almost certainly required: the drawing up of the curse text, the manufacture, inscription, and deposition of the tablet.

46 Bernand 1991, 20. DTA 55 = Gager no. 64 = Wilhelm 1904, 107-108 = SEG XXXVII 215 "resembles a public monument in the fineness of its lettering" (Ogden 1999, 58). Cf. Dickie 2003, 48; Ogden 1999, 54-55; Gordon 1999a, 256.

47 Graf 1996, 133; Wünsch 1900, 68.

48 Ogden 1999, 16, 60; Gager 1992, 20; Peek 1941, 89.

49 Ogden 1999, 56.

50 Although individuals were always at work, the number of professionals was on the rise during the Roman Empire.

51 Ogden 1999, 58. 
and tavern keepers. ${ }^{52}$ It is only in rare cases that these humble people resorted to the courts, like the rich, and used binding spells as preparatory measures for their lawsuits. In fact, there are only three cases of business spells in which the vocabulary used (sundikos, dikastês) or the persons cursed hint with relative certainty at court proceedings. ${ }^{53}$ This minimal overlap between business and judicial spells suggests that in most business matters curses were regarded as the most effective means of exerting violence against a rival. Thus, the use of binding spells was different in the upper and lower echelons of Athenian society. Whereas the upper classes considered the use of magical spells as a welcome, additional option of harming their enemies alongside other measures, to the underprivileged, curse tablets may have been the only method readily at hand to ward off an opponent. Hence, members of the lower classes primarily understood the curses as an extra-judicial means of conflict resolution. This result confirms the picture established so far. Most judicial spells were used by the upper classes and quite often had a political slant. Commercial spells only try to harm business rivals and rarely try to affect court proceedings. Their reach seems to have been more limited in its goals. The lower classes did not bring many business quarrels to the public stage of the dikasteria, for they only had access to the courts theoretically. Even if they had had the funds to hire logographers, they might have felt insufficiently eloquent to enter the public stage. Instead, they struck at home and in their neighborhoods, a pre-polis behavior that had not yet been altered by the new civil discourse of post-amnesty democracy. This rude behavior, however, was ridiculed and despised by the leading circles as rustic (cf. Menander's Dyskolos, e.g., 328-335; 890-905). ${ }^{54}$ But although the elite had engendered and shaped the new discourse of civic

52 DTA $87=$ Gager no. $62=$ SEG XXXVII 216.

53 1. Gager no. $70=$ Peek 1941, pp. $97-100$, no. $9=$ SGD $44=$ López $26=$ Ziebarth 1942, 19-20 (Nicias the politician cursed); 2. López $31=$ SGD $49=$ Abt 1911, pp. 155-158, no. $5=$ Ziebarth 1934a, pp. 1030-1031, no. $4=$ Eitrem 1936, 558; 3. López $45=$ SGD $72=$ Ziebarth 1934a, pp. 1033-1034, no. 7. Cf. Boegehold 1995, 55. There is one important caveat: in most cases it is not recognizable whether or not a business spell was written prior to a trial, but the rarity of the judicial terms just mentioned is revealing.

54 Schmitz 2005, 103, 126 adds that the lower strata of society generally had less access to legally sanctioned means of conflict resolution than the elites. That is why members of the under classes had fewer qualms about assaulting others. 
peacefulness, its members were not less aggressive than those of the lower classes. Violence was distributed evenly among all social classes. ${ }^{55}$

Although judicial spells make up the bulk of the fourth-century evidence, the use of binding magic cut across all social classes. Underprivileged groups, especially slaves, metics, and women, also embraced magic. ${ }^{56}$ We know a good deal about women who were active in magic. Their exact role, however, is a matter of debate. Women certainly commissioned curse tablets, but there is no evidence that they wrote or deposited the tablets themselves, though it is likely that they did so. ${ }^{57}$ On the level of literary discourse, witches were always female, but most tablets were probably produced by men. Women are underrepresented on the

55 A few tablets mentioning prominent members of the elite may suffice as examples in this context: 1. Gager no. 38 = DTA 103 (seventeen readable names, among them seven trierarchs of 325-322 BCE, an overseer of the docks in $333 / 2 \mathrm{BCE}$, and one treasurer for the building of the fleet in $323 / 2 \mathrm{BCE}$ ); 2 . In Gager no. $56=$ Ziebarth 1934a, pp. 1023-1027, no. $1 \mathrm{~A}-\mathrm{B}=$ Robert 1936, 13-14 = SGD $48=$ López $30=$ Eitrem 1936, $558=$ Peek 1942, 166-167 = Ziebarth 1934b, 132-136, there were originally more than a hundred names inscribed, seventy-seven of them readable today, among them Demosthenes (doubtfully the great orator), Demeas of Paeania, Demophilus and Lysicles of Acharnae, Xenocles and Polyeuctus of Sphettus, Strombichus and Strombichides of Euonymon, Phocion, Democrates, and Calliphanes; 3. Gager no. $57=$ Braun 1970, 197-198= Jordan 1980a, 229$236=$ SGD $14=$ López $14=$ SEG XXX $325.2=$ SEG XXXV $211=$ SEG XXXIX $293=$ Costabile 2004/05, 176-182 (the diadoch Cass ander, his brother Pleistarchus, his general Eupolemus and Demetrius of Phaleron); 4. Gager no. $42=$ DT $60=$ Wünsch 1900 , p. 63 , no. $6=$ Ziebarth 1899 , p. 108 , no. 6 (Lycurgus and Demosthenes); 5. Willemsen 1990, 148-149= López $59=$ NGCT 5 (Lycurgus, Hyperides, Callisthenes); 6. SGD $42=$ López $24=$ Robert 1936, pp. 12-13, no. 11 (Aristophon of Azenia, Chaerestratus of Collytus); 7. Ziebarth 1934a, p. 1027, no. 2 (Callistratus of Aphidna). 7. Gager no. $58=$ DTA $24=$ Wilhelm 1904, 115-122 (Phocion, Eupherus, and Aristocrates, brothers of Callistratus); 8. Gager no. 41 $=$ Trumpf $1958=$ BE 1963, p. 125, no. $32=$ SGD $9=$ Jordan 1988, 275-276 = López 9 = Guarducci 1978, 244-245, figs. 68, $69=$ SEG XXI $1093=$ SEG XXXVIII 31 (Mnesimachus, Theozotides); 9. DTA 94 (Diocles); 10. López 55 = Willemsen 1990, 142-143 = López 1992, 201-202 = SEG XLII $217=$ NGCT 1 (Diocles); 11. Costabile 2004/5, 137-169 (Andocides and some of his sea-faring followers); 12. Costabile 2004/5, 182-192 (Leptines); 13. DTA 65 (Callias; Hipponicus); 14. SGD $6=$ NGCT 9 (Smindyrides, possibly one of the profaners of the Mysteries, cf. And. 1.15).

56 Ogden 1999, 67; Bernand 1991, 30-34, 160. Among prostitutes magic seems to have been widespread (Voutiras 1998, 85-87).

57 Johnston 1999a, 112-113; Voutiras 1998, 94-95. 
tablets, especially as authors of curses. ${ }^{58}$ They had to consult professional male sorcerers or knowledgeable "wise women," often prostitutes, to make the tablets for them. ${ }^{59}$ In this process, we may detect one reason why women were underrepresented in this business: they were subject to tight social control and might have it found difficult to approach a male sorcerer and to pay him the fee. ${ }^{60}$ From this perspective, it might be a bit too optimistic to assume (with regard to attraction spells), as some have, that "it is precisely through defixiones that women emerge from their stereotyped seclusion and passivity in aggressive pursuit of their own erotic dreams." ${ }^{\prime 1}$ But whatever leeway women could enjoy, whether they wrote curse tablets themselves or commissioned professionals, they did find an outlet for their aggressions and wishes in the world of magic. Before shifting the focus of traditional interpretations of magic away from religious-historical aspects to a sociological and cultural historical analysis, I shall briefly address the ritual character of binding magic, for the deposition of a curse tablet was always a ritualized form of indirect, that is, mediated violence.

\section{Ritual Framing}

In Greek society, people believed that evil thoughts alone, especially when motivated by envy, can cause harm. ${ }^{62}$ Envy itself is bred and disseminated by gossip, and its personification is the Evil Eye. If evil thoughts alone already had some destructive power, how much more effective must a ritual be that conveys form and meaning to negative feelings like envy, spite, and vengeance? Although we know a lot about the ritual framing of binding spells, its significance has been underestimated. This

58 Ogden 1999, 63-64. Cf. above 171 the love spells quoted in n. 32.

59 In Antiphon 1, the wealthy citizen woman prepares the potion for her husband and his friend herself, but has it administered via her maidservant. It is interesting to see that the wife could put the blame for the botched drink-both men die-on the slave woman, who was executed immediately without trial. Antiphon's case was not about malign magic, but about homicide. Homicide by poison (pharmakon in its double sense as poison and magic) was treated before the Areopagos (D. 23.22, 24; Arist. Ath. 57.3). On Antiphon 1 as example of a love philter and deadly magic, cf. Voutiras 1998, 55, 89. On the "wise women," cf. Gordon 1999b, 182-185.

60 Ogden 1999, 64-65.

61 Gager 1992, 80-81. Similar, but more cautious, is Ogden 1999, 62.

62 Versnel 1999, 134-135. 
chapter, therefore, argues that curse tablets were not as harmless as hitherto thought, but were considered serious attacks on the well-being of others. The violence committed through curse tablets was carefully calculated, followed specific rules, and was deliberately orchestrated in order to achieve full malicious force.

Although depositing a curse tablet was very different from conducting a lawsuit or staging a drama, not least because of the lack of an audience, the person cursing an opponent followed many ritual patterns. In the elaborate process of casting a binding spell, rituals are discernable on a macro- as well as micro-level, like in the delivery of a forensic speech. The macro-level involves the ritual actions that the curser or professional sorcerer performed with his body, ${ }^{63}$ while the micro-level involves specific ritual language-words spoken, sung, and written-during the performance of the ritual. Ritual actions (drômena) and ritual language (legomena) are bound inextricably together; one is inconceivable without the other. ${ }^{64}$

\section{Ritual Actions (drômena)}

From later evidence, especially from the Greek magical papyri, we can glean evidence for rites of separation. Fasting, abstinence from sexual intercourse, ritual cleansing, the wearing of special clothes, and most of all the production of the tablet itself and sometimes the "voodoo doll" 65 dissociated the curser or the professional sorcerer from everyday life. At the same time, these separative rites prepared him for the core of the ritual, the final deposition of the curse tablet. In order for the ritual to work, preliminary steps were of vital importance. ${ }^{66}$

63 Rituals live by and through performance only: "Magical acts are ritual acts, and ritual acts are in turn performative acts" (Tambiah 1985, 60).

64 Cf. Tambiah 1985b, 29; similarly, Tambiah 1985a, 80. With regard to Athenian binding rituals, cf. Faraone 1991a, 5; similarly, Versnel 2002, 107. It might be assumed that, historically, actions and spoken words came first and the emergence of longer written texts was a phenomenon of later antiquity. But even with the longer and more elaborate curses written down from Hellenistic times on, the actions and the oral components of spells did not lose any of their vital importance. On the ritualistic macro- and micro-level in oratory, cf. above e.g. 102.

65 Faraone 1991b.

66 Gager 1992, 20: "the client's attempt to prepare a defixio, from the initial decision to its actual commission, must be located in a series of actions, a total flow 
The most important stage was the liminal phase that followed the preparation of a tablet. Deposition took place outside the boundaries of daily life and ordinary society, in precincts dedicated to chthonic gods or goddesses, such as the Kerameikos, the burial field outside the city walls, at Athens. ${ }^{67}$ Places of deposition included, in descending order of importance (calculated on the basis of extant tablets), tombs, shrines for chthonic deities, wells, places relevant to the victim (house, workshop), or other sanctuaries, especially in the case of prayers for justice. ${ }^{68}$ As to time, the ritual had to take place outside of ordinary daylight hours, at dusk or at night so that the curser or magician could not be observed. Some of these patterns of action were perhaps en vogue in classical Athens, but the lack of evidence for the fourth century prevents us from making any definitive conclusions. ${ }^{69}$

During the liminal act of depositing the tablet, anti-structural features became visible on multiple levels. ${ }^{70}$ Whereas "normal" rituals required an audience, the sorcerer or curser performed the ritual alone and invoked a sinister, topsy-turvy world. He was actor and spectator at the same time, a dual function that made the sender and recipient of the message identi$\mathrm{cal}^{71}$ (unless we take into consideration the vertical axis of communication, suggested by Graf, with the gods thought to be present as invisible partners of communication). ${ }^{72}$ The ritual of deposition was both a ritual of interaction (with the chthonic gods and the dead) and a ritual of representation that marked the extraordinary significance of the magical act.

During the ritual itself, three types of "restless dead," believed to be full of spite and easy to mobilize against opponents, could be invoked: the unburied (ataphoi), the untimely or prematurely dead (âoroi), and those

of events rather than a single isolated act. It is a serious mistake to focus attention solely on the innocuous piece of corroded lead and not to perceive other actions that accompanied its commission." Cf. in detail Mauss 1972, 48-49, who speaks of "entry rites."

67 Mauss 1972, 45, speaks about a "lonely place." Detailed, also with regard to special times, is Mauss 1972, 46-47.

68 Ogden 1999, 15.

69 PGM V 304-369 = GMP pp. 106-107 gives a detailed instruction for depositing a tablet. Cf. Trumpf 1958, 95.

70 Graf 1996, 203-204 speaks about reversals, the deliberate turning upside down of a common ritual practice.

71 Graf 1996, 189, 191.

72 Graf 1996, 191-192. Cf. below 187, n. 110. 
who had died a violent death, the so-called biaiothanatoi ${ }^{73}$ It was recommended to place the tablet in the graves of members of the last two groups, and ideally in the right hand of a corpse. Two new beliefs that gradually emerged in the late archaic period were the basis of these magical practices. First, the dead themselves were perceived as potential threats to the living. ${ }^{74}$ They no longer needed agents like the Erinyes to become active. Second, the living were able to mobilize the deceased and call them back into action. The underlying notion that rituals had an impact on the dead ${ }^{75}$ demonstrates that people firmly believed in rituals and ascribed extraordinary power to them and all those who knew how to handle them, like the goêtes.

In carrying out the ritual proper, the conjurer or curser used magic materials and tools. ${ }^{76}$ The material vestiges that remain are the curse tablets themselves and, in some cases, wax, clay, or wooden effigies that have rightly been called voodoo dolls. To my knowledge, there are nine examples extant from Attica. ${ }^{77}$ In Theocritus' second Idyll, which dates to the third century BCE, the girl Simaetha tries to win back her lover Delphis with love magic. She uses barley groats, crimson flower, bay leaves, a waxen puppet, some bran, the herb hippomanes (thorn-apple), liquids,

73 Gordon 1999b, 187; Johnston 1999a, 127 (both with a variety of source materials). Tablets were indeed found in graves of young persons, but this evidence is scanty overall (SGD pp. 152-153). Maggidis 2000, 89 reports that the archaeological evidence confirms this hypothesis. SGD 54 (Athens), 109 (Sicily) and 173 (Olbia) speak of offering gifts to someone. The context is always unclear; is it a gift for the dead or the gods of the underworld to activate the spell? Cf. below 216, n. 251 on the interaction among the agent of the curse, the gods, and the dead as expressed by Plato. In X. Eph. 5.7.7-8, one of the dead, not a god, strikes Anthia with epilepsy. Cf. also Hom. Il. 22.358-360; Od. 11.72-73; Hes. Op. $124=254$; A. Pers. $618-80$; Ch. 129-130, 456, 489-509; E. Alc. $1003-$ 1004; Pl. Lg. 865e, 926e-927b. Cf. also passages in the much later magical handbook PGM IV 296-466 = GMP pp. 44-47; PGM IV 1416-1431 = GMP p. 65; PGM IV 1460-1495 = GMP p. 66; PGM IV 2725-2739= GMP p. 89; PGM IV $2943-2966=$ GMP p. 94. Although these passages clearly evince the syncretism of Graeco-Roman magic as practiced in Egypt, some features, among them the mentioning of the traditional chthonic deities, must go back to much older notions of magic.

74 This is why cemeteries were placed outside the cities from late archaic times on. In Athens this shift probably occurred around 500 BCE (Felton 2007, 88).

75 Johnston 1999a, 31, 37. Cf. also the summarizing article Johnston 1999b.

76 Mauss 1972, 47.

77 Faraone 1991b, 200-201. Ogden 2008, 140 speaks of thirty-eight voodoo dolls from antiquity all together. 
a piece of her lover's cloak, pulverized lizard, a bronze gong, a bull roarer, and a four-spoked magical wheel of brass. We cannot gauge the level of fictionality in Theocritus' intense description of magical practice. ${ }^{78} \mathrm{~A}$ spectacular, still unpublished find from Athens gives us more insight into magical materials. A chytra, a common form of cooking vessel, was found in a commercial building near the Agora. Dated to 325-270 BCE, the vessel contained the head and feet of a chicken, was inscribed with at least twenty-two names, and was pierced with an iron spike attached to the underside of an iron disk. The transfixion of the container and its gloomy contents was so forceful that the nail punched a hole in the bottom of the container. After performing this magical action, the curser(s) hid the vessel in a hole dug along the back wall of a workshop. The use of a dismembered chicken is unique so far in our evidence. ${ }^{79}$ According to the later magical recipes preserved, we know that people sometimes put a bit of the victim's hair or clothing into the grave with a corpse in the hope that "what is effected upon part of the victim may be effected upon the whole of him (pars pro toto magic) ... [This practice] might have a 'deadening' or restraining effect upon the rest of him." ${ }^{80} \mathrm{Be}-$ yond the words spoken or sung, the practitioner's entire body was perhaps involved in the ceremony. A song performed during the ritual might have been accompanied by dance. ${ }^{81}$ We have no way of telling whether or not practitioners of magic aimed for a state of trance or rev-

78 Cf. Theoc. Ep. 2 passim. Verg. Ecl. 8.64-109 closely follows Theoc. Ep. 2.

79 I am greatly indebted to Marcie Handler and John Camp for their permission to mention this find in this context. I draw here on her unpublished paper delivered at the annual meeting of the Archaeological Institute of America at Philadelphia in 2009.

80 Ogden 1999, 14 (addition by author); cf. also Gager 1992, 16-18. More recipes from PGM are cited by Faraone 1985, 153, n. 21. Although the magical papyri stem from later eras, they enshrine magical traditions that emerged centuries earlier. Luck ${ }^{2} 2006,16,47$ assumes that they reflect at least Hellenistic traditions. As to rituals, Theoc. Ep. 2 exactly conforms to practices as described in the later magical papyri (Luck ${ }^{2} 2006,45-46$ ). Cf. also Lucianus, DMeretr. 4.4-5. Archaeological evidence (SGD p. 251) has confirmed the magical recipes. Four curse tablets from Roman Egypt and one tablet from third-century CE Athens show traces of human hair and other organic material. To Mauss 1972, 50-54 sympathetic or symbolic magic mainly consists of non-verbal rites. Tambiah 1985a, 72 calls the act of "influencing certain objects by manipulating other objects which resemble them" the "homeopathic act." Cf. below 198-199 on the problematic use of the term "sympathetic magic."

81 Johnston 1999a, 222; 1999b, 97-98 specifies the goêteia/mysteries/music triangle in the tradition of Orpheus, who is psuchopompos, initiator, and singer. 
erie, but often participants in liminal states are eager to experience psychologically and physically the transformative power of rituals. ${ }^{82}$ After performing the rites, the practitioners had to be released back into the normal world. Rites of reaggregation, "exit rites," 83 helped achieve this goal. Not only the rites performed during the liminal act, but indeed all actions framing the deposition were highly meaningful to the cursers.

Despite the reclusive character of the depositio, some evidence suggests that the magical act cannot have been completely hidden. Some cursers may have deliberately put up with a certain kind of publicity. Their deeds were not meant to be completely anonymous; it is possible that the efficacy of the spell depended on psychology ${ }^{84}$ its becoming known, especially to the victim of the curse. ${ }^{85}$ If someone went out to the Kerameikos at dawn or dusk to dig up a grave, place a tablet into the hand of a corpse, mutter formulae, and sing and dance around the grave, he may well have been observed. ${ }^{86}$ The entire preparatory sequence, the hiring of a professional magician, and all the activities involved during the cursing ritual could probably not be completely hidden from society. ${ }^{87}$ When the relatives of a deceased person visited a grave, at the least, they would have discovered that someone had tampered with the integrity of the tomb. That is the reason why I speak of the semi-secret sphere of malign magic. It is even possible that news of the casting of a binding spell spread like wildfire through gossip and could thus achieve its desired effect through the victim's becoming aware of the existence of a curse. ${ }^{88}$

\section{Ritual Words (legomena)}

Actions and words, treated separately here, intrinsically belonged together, for magical acts were not thinkable without magical words. ${ }^{89}$ Together, they show a highly performative character during the illocutionary speech

82 Mauss 1972, 49.

83 Mauss 1972, 49-50.

84 Johnston 1999a, 121.

85 This is especially true for attraction spells. Cf. Gager 1992, 21, 82-83, who lists five good reasons to assume the relative publicity of the magical act.

86 Ogden 1999, 17.

87 Kiernan 2004, 102.

88 Cf. Parker 2005, 124; Versnel 1999, 139.

89 Mauss 1972, 54-60 speaks of verbal rites. 
act of binding another person..$^{90}$ The oral and written language used during the depositio concerns the micro-level of the magical act itself. Only a careful consideration of specific linguistic features will enable us to gauge the specific form of violence expressed in these tablets. One important caveat must be made, however: the language on the tablets is highly formulaic and metaphoric. ${ }^{91}$ It is extremely difficult to ascertain emotional engagement in the tablets because the texts cannot be taken literally. Moreover, the individual did not speak extemporaneously, but rather resorted to preexisting formulas. The purpose of every ritual is its efficacy, not the expression of individual emotions and feelings. Magic was a common practice in Athens, and the magician had to make use of pre-moulded formulas to achieve a certain goal for his client. Both magician and client believed in the success of the binding spell, provided that the ritual was conducted properly. ${ }^{92}$ On a psychological level, the ritual was a means of coping with feelings like helplessness, fear, despondence, spite, and even revenge. On this level, the healing function of ritual lay in its capacity to restrain anger and wrath by giving these feelings a special form, thus hedging them in. The un-individualized texts were able to check orgê (wrath), a major theme throughout fourth-century discourses. Whether Demosthenes contained his orgê against Meidias by suing him instead of beating him, or Menander pleaded again and again in his comedies to exert self-control and engage in dialogue to resolve conflicts, in many instances in fourth-century discourse, we encounter the central topic of anger control making society function. From this perspective, binding magic was an intrinsic part of Athenian life and cultural discourse rather than a bizarre superstition at the margin of society.

Notwithstanding these remarks, the binding formulas do display a considerable amount of violence under the surface of relatively tame language. Before tackling this crucial aspect, it is first necessary to come to a thorough understanding of how magical language works. Malinowski's dictum of "verbal missiles" adequately renders the enormous force and thrust of magical utterances. ${ }^{93}$ The basic idea is that the speech act on the micro-level, which is powerful per se, is firmly embedded in a macro-ritual structure that charges the speech act with additional symbol-

90 Cf. Thomassen 1999, 60-61.

91 Gager 1992, 22.

92 Faraone 1991a, 19.

93 Based on Malinowski 1935, 248-249, Tambiah 1985c, 142 also speaks of "verbal missiles" in this context. 
ic meaning. The speech act derives its power from its performative character. Basing his argument on Austin's How to Do Things with Words, Tambiah renders the relevance of the illocutionary speech act as follows:

utterance which has a certain conventional force, a performative act which does something ... Usually the explicit illocutionary utterance is reducible or analyzable into a form with a verb in the first person singular present indicative active ... These statements cannot be subject to the true-false test, but are normatively judged. ${ }^{94}$

Thus interpreted, the utterance katado (I bind) is the real action, and the target truly is bound in the eyes of the speaker. From the importance of the speech act we can deduce that the oral curse existed prior to its written form. The first written binding spells accompanied the ritual action and the performative speech act. ${ }^{95}$ What we find written on the early tablets may just be a small portion of the words actually uttered aloud at a depositio. ${ }^{96}$

Gradually, the texts of curses became more elaborate and longer. The written word was regarded as less transient than the spoken word, and the written spell was thus viewed as more permanent. ${ }^{97}$ Nevertheless, the oral curse never lost its primary significance. ${ }^{98}$ Why were these formulas so successful on the psychological level, if they could not express individual feelings? The magical word had always been regarded as special, persuasive, seductive, and even coercive. ${ }^{99}$ As such, it had to be different from ordinary speech. It had to be poetic. The similarity between magic and rhetoric has long been recognized. ${ }^{100}$ The Greeks realized that the skillful use of words in speeches and spells alike charmed their audiences. Early medicine, which was inseparable from magic, relied heavily on incanta-

94 Tambiah 1985a, 79.

95 Ogden 1999, 9: "So perhaps the earliest tablets should be seen as simplified voodoo dolls and vestigial physical accompaniments to verbal curses."

96 The inscriptions on the tablets do not necessarily give a one-to-one rendering of the actual words spoken, as Wünsch 1902, 29 thinks. On the utterance of incantations, cf. Johnston 1999a, 92; Ogden 1999, 82; Gager 1992, 7.

97 Ogden 1999, 10.

98 During the Roman imperial period, some illiterates at Bath threw their curse tablets uninscribed into the sacred spring of the Temple of Sulis Minerva, relying solely on the oral performance of their curses (cf. Ogden 1999, 60).

99 On the coercive power of words, cf. Gager 1992, 120-121.

100 Eidinow 2007a, 189; De Romilly 1975, 3-22. The most important literary documents testifying to the supernatural power of rhetoric are Gorgias' treatise Helen as well as Pl. Men. 80a-b; Euthd.303a (indirectly). Cf. above 29, nn. $40-43$. 
tions. Consequently, all ritually framed and enacted speech was carefully shaped. But there are different degrees of ritualized language. The three genres addressed in this book reveal different levels of linguistic ritualization. Rhetorical prose in forensic speeches was meticulously formed. It abounds in stylistic devices and avoids hiatus. According to circumstances, the orator adjusted the level of style to the respective occasion and audience. He was always aware, however, that he spoke in a ritually defined arena and that his language could not be that of the ordinary Athenian on the street. ${ }^{101}$ Dramatic language in comedy, and especially in tragedy, was even further removed from everyday language. New Comedy did excel in the natural flow of an easy-to-grasp Attic, but it still clung to iambic trimeter in large portions of the plays. The strictest linguistic ritual, however, ritually bound language, was performed in the world of magic. In magical spells language had to be more operational than in any other ritual genre. We can visualize the different grades of formalization in a kind of continuum according to the cultural context of the event: forensic speeches are ritualized on a relatively low level, followed by dramatic plays, which are characterized by an increased degree of ritualization. The curse tablets record what is by far the most ritualized language; hence their formulaic character. From very early on, some spells worked like prayers and incantations, seeking direct contact with the supernatural powers of chthonic gods and the spirits of the dead. A solemn, poetically bound language was especially appropriate for this specific purpose. ${ }^{102}$

Magical language has been intensively studied. ${ }^{103}$ In the case of Athenian curse tablets, three basic formulas are discernable: (1) the "direct

101 Cf. Gänszle 2000, 37. Gänszle 2000, 41 offers a definition of performance that is strictly bound to a specific context: "Unter einer Performanz verstehe ich hierbei ... eine Handlung, die durch einen bestimmten Rahmen (frame) gekennzeichnet ist, welcher sie von der alltäglichen Ebene des Handelns abhebt."

102 The following observation (Gänszle 2000, 39) refers to ritualistic language as exercised by the Mewahang Rai in Eastern Nepal, but it may also hold true for ancient Athens: "Am stärksten ausgeprägt ist der formulaische Sprachstil bei den Texten der initiierten Ritualspezialisten, die im höchsten Maße ritualisiert sind. Schon die Vortragsweise hat mehr musikalische Qualitäten, und die Sprache ist besonders reich an idiomatischen Wendungen, poetischen Formen und Figuren: Sie hat also einen ausgeprägten ästhetischen Wert. Gleichzeitig eröffnet sie jedoch ein eigenes - wie ich es nenne - diskursives Universum, d.h. eine Welt, die nur im Ritual erfahrbar wird." Cf. DTA 108, perhaps dating to the third century $\mathrm{BCE}$; it is composed in dactylic hexameters and even comprises an elegiac couplet.

103 Tambiah 1985b, 30-32 offers an overview of theories of magical language. 
binding formula" in the form of a "performative utterance," (2) the "prayer formula" directed to the gods of the underworld to carry out the binding, and (3) the so-called "similia similibus formula" that is based on the principle of "persuasive analogy" in Tambiah's sense. ${ }^{104}$

The language used is highly rhetorical. Repetitions are frequent and produce a certain rhythm that facilitated the oral performance and thus the ritualization of the text. ${ }^{105}$ In addition, pleonasm, personification, exaggeration, threats, promises, prayers, formal appeals, metaphors, and similes are popular stylistic devices. ${ }^{106}$ Tambiah stresses above all the metaphoric and metonymic use of language that engenders the similia similibus effect. ${ }^{107}$ In brief, metaphors generate similarity-the principle being imitative ${ }^{108}$ - whereas metonymy (in a more narrow sense pars pro toto) is based on the principle of contiguity. From this perspective, the enumeration of body parts to be bound, like hands, feet, tongue, and psyche, makes perfect sense. The individual parts are standing for the whole body of the victim. Ritual actions involving substances that represent the victim, such as hair, nails, or voodoo dolls, accompany and enhance both linguistic procedures. What is true for the magic Malinowski observed with the Trobriands also applies to Athens:

Malinowski's characterization of this process as a "rubbing" effect is felicitous, for indeed in Trobriand magic the verbal creation of force is made more realistic and operational by using substances (which themselves have metaphorical associations named in the spell) metonymically, so that a transfer of effect is made through blowing, rubbing, smoking, and various

104 Faraone 1991a, 10; cf. Gager 1992, 13.

105 Gordon 1999a, passim; Ogden 1999, 9; Faraone 1985, 152, n. 13; Kagarow 1929, $34,37-38$.

106 Gager 1992, 13-14. Although Versnel 2002, 110 concentrates on the poetics of the magical aspects of incantations and charms, not curse tablets, many of his findings are applicable to some of the more elaborate curse tablets as well, especially given his definition of magic (Versnel 2002, 155-156), which certainly also comprises the curse tablets. Beside "persuasive analogy" the "poetics of magical formulas" is a second important concept in magic according to Versnel 2002, 151.

107 Tambiah 1985b, 35-37, 41, 43-44.

108 E.g., Gager no. $40=$ DTA $107=$ Wilhelm, p. $112=$ Faraone 1991a, $15=$ SEG

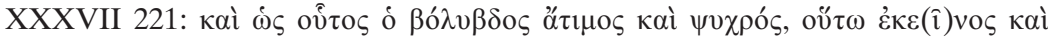

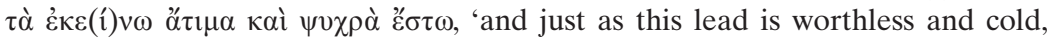
so let the man and his property be worthless and cold.' The similia similibus formula is also well expressed, e.g., in DTA 67, 96-97, 105-106. 
tactile manipulations. The cross-linkages in this art are manifold, and combine to produce an arrow-like thrust. ${ }^{109}$

Rituals typically require an audience in order to be effective; thus, at first glance, the lack of observers seems to be a defining feature of magic. Indeed, the audience of a magical ritual is often thought to be identical with its performer, making the performer and the recipient of a magic ritual one and the same person. On this view, the message of a collective ritual is directed at an entire group, but the message of a magician is relevant only to himself. Given the information we have today, however, this can hardly be true. ${ }^{110}$ The magician and his client, or the individual casting a spell, exerted so much effort in preparing the binding curse that it does not seem likely that he should have designed the whole procedure just for himself. Many tablets were written in haste and are not clearly legible. They were not destined for human recipients. The tablets were buried and ideally put into the right hand of a corpse. From these details, we can infer that the intended readers were the chthonic gods and goddesses as well as the dead themselves. ${ }^{111}$ If true, the ritual words spoken and the actions carried out during a depositio had a very concrete communicative function which was in no way different from that of any other ritual setting. In the eyes of the practitioners, there were spectators attending the ritual of depositing a katadesmos, ${ }^{112}$ for gods, demons, and the ghosts of the dead were the addressees of the rituals in question. Some tablets even name the gods as direct recipients of the messages. ${ }^{113}$ We speak of letters to the underworld. ${ }^{114}$ A curse tablet dating to the third century

109 Tambiah 1985c, 143; Tambiah 1985b, 36, 43 (similar). Versnel 2002, 155 characterizes "the relationship of text and reality as one of synecdoche."

110 Cf. above 179, n. 72. Graf 1996, 189-192, especially 189 on the vertical axis of communication.

111 Bernand 1991, 406.

112 Cf. Faraone 1999a, 103, who seems to hint at this belief. Cf. Theoc. Ep. 2.

113 Brodersen 2001, 67-68.

114 1. Gager no. $104=$ DTA $102=$ Wilhelm 1904, 112-113 = Versnel 1991a, $65=$

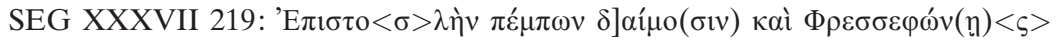
[sic], 'sending the letter to the demons and Persephone.' 2. Gager no. $38=$ DTA 103 = Wilhelm 1904, 122-25 = SEG XXXVII 220: 'Е $\mu[\hat{n}] \kappa \alpha i ̀ ~ Ф \varepsilon \rho-$

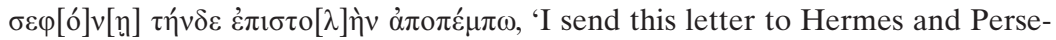
phone.' 3. DT 43 and 44 (Arcadia, third century BCE). 4. Bravo 1987, 206 (Olbia, 4th/3rd century BCE, reference to unpublished piece). 5. López 1990, pp. 134-144, no. $27=$ SGD 109 (Lilybaion, late Hellenistic). According to Graf 1996, 118, these letters to the underworld are rare. 
BCE mentions the names of gods as addressees, as if in a letter, on the exterior side of the folded tablet. ${ }^{115}$

In accordance with the anti-structural features that characterize the liminal phase of enacting a curse, there are inversions on numerous levels. ${ }^{116}$ Magical rites were not performed in open daylight, but at night. The Olympic gods were not called upon, but instead the gods of the underworld: Hermes, Hecate, Kore, Persephone, Hades/Pluto, Ge/Gaia, and Demeter. ${ }^{117}$ In many cases, the writing appears in reverse (with the letters running from right to left, but still facing right) ${ }^{118}$ and occasionally even in retrograde (with the letters running from right to left, with the letters facing left) $;{ }^{119}$ cases of "boustrophedon" form are also known, with the letters alternately running from left to right and right to left. ${ }^{120}$ This latter peculiarity, mainly attested in archaic inscriptions, created an archaic patina deliberately sought by sorcerers and their clients. The typical foldings and nail piercings of the tablets themselves, as well as the distortions of the dolls, also serve the purpose of inversion. ${ }^{121}$ The names of the victims are often scrambled or jumbled in various ways. All these forms of "twisting" have an inherent metaphorical meaning, ${ }^{122}$ for the victims were to be confused and distorted like the letters on the tablets. From the second century $\mathrm{CE}$ on, the targets were often identified via matronymics. ${ }^{123} \mathrm{Ev}$ erything speaks in favor of the magical ritual being a full-scale ritual on the macro- (non-verbal rites) and micro-level (verbal rites), endowed with enormous power. To the Athenians the intent to perpetrate violence was already regarded as violence. Harming someone via energetic rituals certainly went beyond intending to do so; it was a violent action in its own right.

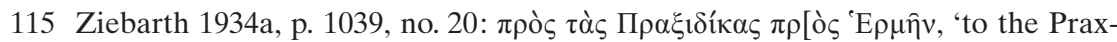
idikai, to Hermes.'

116 Ankarloo - Clark 1999, xii speak of a "countercultural cloak."

117 Cf. Ogden 1999, 45 (with older literature); Gager 1992, 12. On Hecate now in detail Zografou 2010.

118 E.g., Gager no. $42=$ Wünsch 1900, p. 63, no. $6=$ DT $60=$ Ziebarth 1899, p. 108, no. 6 .

119 E.g., 1. DTA 26; 2. DTA 33; 3. NGCT $15=$ Shear 1973, 127-128= Boegehold 1995, 55-57; 4. Gager no. 68 = DTA 68.

120 E.g., DTA 33-34. Cf. Ogden 1999, 29.

121 Ogden 1999, 29-30.

122 Gager 1992, 5.

123 Ogden 1999, 9, 61; Gager 1992, 14. An early example is DTA $102=$ Gager no. 104 = Wilhelm 1904, 112-113 = SEG XXXVII 219 (fourth century BCE). 


\section{Degree of Violence}

The level of violence that such curse tablets were intended to exert is debatable. Only ancient cursers could tell us how violent they meant their tablets to be. According to Faraone, the spells were merely protective. They did not aim at killing the victim, but fulfilled defensive functions with the goal only of impeding the victim by damaging his success. ${ }^{124}$ Since murderous intentions are hardly ever mentioned in the tablets, indeed, Faraone's claim is the communis opinio today. ${ }^{125}$ But research in general tends to underestimate the violent force of ritual speech and action. Reading sentences such as "The earlier curse tablets did not usually seek to kill their victims, even when wishfully comparing them to a corpse. But in the later tablets this aim is more frequently expressed," one wonders what made Athenians apparently more peaceful in earlier stages of their history and more aggressive in later times.

A re-evaluation of the evidence challenges the current view that all early tablets were intended only to restrain the victim and not to maim or kill by showing that some of them were indeed meant to be lethal, and many of them may have been more malicious in their intent than hitherto thought. Is it not possible that the early spells were meant to be as malicious as the later tablets, thus standing in a line of unbroken continuity? Could the different phrasing of earlier and later spells stem from changed practices of discourse rather than changes in the underlying notions and intentions of the cursers? Since the ritual actions were accompanied by verbal rites that were not necessarily inscribed on the tablets, we cannot automatically infer harmless intentions from the brief texts we have. They may constitute only the smallest part of the formulas originally uttered. Conversely, one cannot make argumenta ex silentio and postulate malevolence in those parts of the curse that were only spoken. We must work with what we have and probe deeply into the semantic meaning of the words actually preserved in order to come to more substantial conclusions with regard to violence in binding spells. One more caveat may be permissible here: the prefabricated formulas did not express individualized sentiments in most cases; the ritualistic texts were highly metaphoric and cannot be taken literally. And yet, these formulas

124 Faraone 1999b, 81-82; 1992, 133-134; 1991a, 3, 8, 9, 20; 1991b, 166, 193-194; 1988, 155-161, 171, 182-183.

125 E.g., Ogden 1999, 73.

126 Ogden 1999, 22. 
can also be subject to a careful analysis of their discourse. They were created in a broad cultural matrix that only becomes visible against the backdrop of the other genres dealt with in this book. Many reasons speak in favor of reconsidering and re-evaluating the potential of violence contained in the tablets. It will become clear that it is higher than currently assumed.

Whereas in most cases the malevolent meaning of the tablets has to be revealed via complex methodological deliberations, some tablets definitely display more violent language than others. A famous judicial spell that curses seventy-seven persons, represented in a long list, has an unusual formulation in its first line: 'I bind, I deeply bury, I cause to vanish from mankind. ${ }^{127}$ Again, it may well be that this formulation is not to be taken at face value, but its deviation from most other tablets should be noted. There are two more similar tablets. ${ }^{128}$ One dates to around $300 \mathrm{BCE}$ and deals with cooks and butchers, figures who recall the world of New Comedy: 'All of these I bind, I hide, I bury, I nail down. ${ }^{129}$ A further blatant example formulates: 'All of these I consign, [inscribed] in lead and in wax and in water [?] and to unemployment and to destruction and to bad reputation and to [military?] defeat and in tombs. ${ }^{130}$ Some tablets aim specifically at the life of their targets; for example: 'I bind Dionysius the helmet maker and his wife Artemis the goldworker and their household and their work and their products and their life-and Kallip[pos

127 Gager no. 56 = Ziebarth 1934a, pp. 1023-1027, no. 1 A-B = Robert 1936, $13-14$ $=$ SGD $48=$ López $30=$ Eitrem 1936, $558=$ Peek 1942, 166-167 = Ziebarth

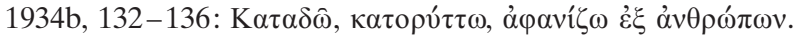

128 1. López $31=$ SGD $49=$ Abt 1911, pp. 155-158, no. $5=$ Ziebarth 1934a,

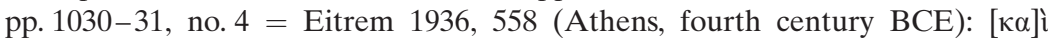

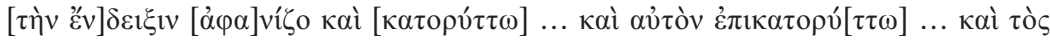

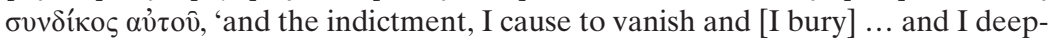
ly bury him ... and his lawyers.' 2. SGD 115 (Sicily, first century CE?): ’̀v

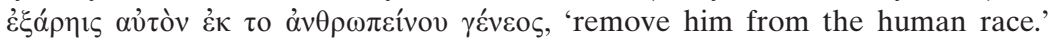

129 Gager no. 44 = Ziebarth 1899, pp. 109-110, no. 10 = Wünsch 1900, pp. 63-64,

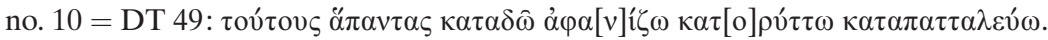
Graf 1996, 111-112 emphasizes that binding a victim "down" is no harmless thing. Cf. also Ogden 1999, 26.

130 Gager no. 64 = DTA 55 = Wilhelm 1904, 107-108 = SEG XXXVII 215: Toú-

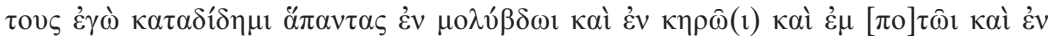

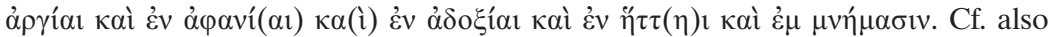

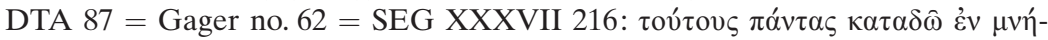
$\mu \alpha \sigma 1$, 'I bind them all down in tombs.' 
...]. ${ }^{131}$ This is a classical binding spell. The expression kai ton bion is unusual enough to deserve mention. Similar formulations can be found. ${ }^{132}$

The text of one tablet is structured in four paragraphs that all show the same formula: 'Until he goes down into Hades.' ${ }^{133}$ This is a rare and ambivalent formula that has two meanings: either the curse will be in force throughout the victim's life, implying that the curse is not lethal, or the curse is meant to kill the victim and will work effectively until this goal is achieved. Since all binding spells are in effect without time limits, the second possibility is more likely. Consumption, called down upon the victim in this particular spell, was lethal in pre-modern times. Hermes and Persephone are addressed with imperatives here in their functions as re-

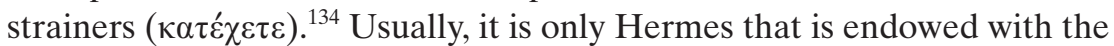
epithet katochos. ${ }^{135}$ In another tablet the "earth" is understood in a chthonic sense: 'I send as a gift to the underworld. ${ }^{136}$ There are also cases where the dead are used in their similia similibus function; for example: 'I hand him over to Ge and to Hermes Chthonios, and he shall be as useless as this corpse lies useless. ${ }^{137}$ In one business spell, even the hope for an afterlife is destroyed. ${ }^{138}$

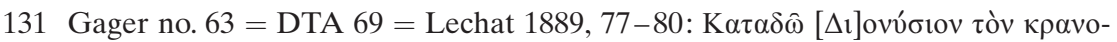

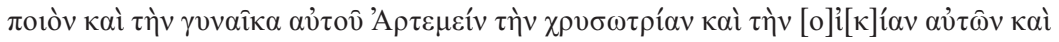

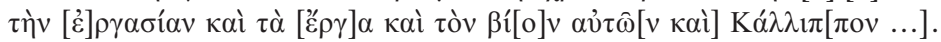

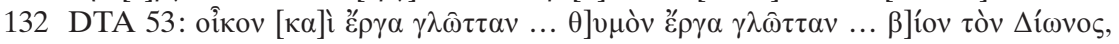
'the house and products, the tongue ... the courage, the products, the tongue, ...

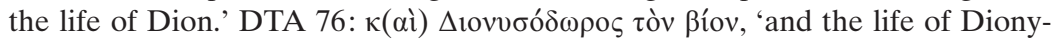
sodorus.' Gager no. 65 = DTA 75 intends to make someone perish. Cf. the similar spells SGD 89 (Sicily, second century BCE) and DT 92 (third-century tablet from the Black Sea). A later Attic spell (DT $51=$ Ziebarth 1899, p. 133, no. $2=$ Wünsch 1900, pp. 70-71, no. 2) wishes to burn to death Gameta, the daughter of Hygia.

133 DT 50 (p. 86 with commentary) = Ziebarth 1899, pp. 113-114, no. $15=$ Wünsch

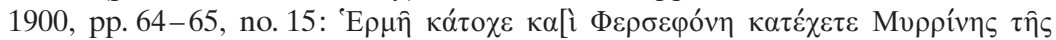

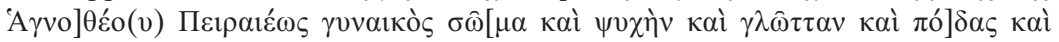

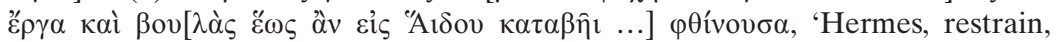
and Persephone, both restrain the body of Myrrhine, wife of Hagnotheus from the Peiraeus, and her soul and tongue and feet and deeds and plans, until she goes down into Hades, she who is being consumed.'

134 Further examples from Attica are, e. g., López 48 = SGD $75=$ Ziebarth 1934a, p. 1036 , no. 13 and DT $50=$ Ziebarth 1899 , pp. $113-114$, no. $15=$ Wünsch 1900 , pp. $64-65$, no. 15 .

135 On Hermes katochos, cf. Graf 1996, 130-131. Cf. below 209, n. 228; 211, n. 234.

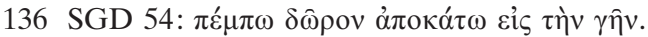

137 López $51=$ SGD $78=$ Ziebarth 1934a, p. 1038, no. $17=$ Ziebarth 1899, pp. 116-

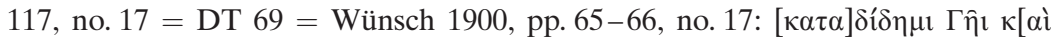


It should be noted that none of the fourth-century examples mentioned above is a prayer for justice, a valuable heuristic category that Versnel has successfully established in the study of ancient religion and magic. In these prayers for justice the explicit expression of violence was more common than in other spells. ${ }^{139}$ Prayers for justice gradually emerged during the fourth century BCE, but they were most frequent during the third and fourth centuries CE. The evidence is clustered in Great Britain, mainly at Bath. They are primarily concerned with the restitution of stolen property; sometimes they also envision revenge. Most of them were nailed to temple walls so that the thieves could read them, be rebuked by their consciences, and return the stolen property. According to Versnel, these prayers for justice are so different from the traditional curse tablets that they should not be categorized together at all, ${ }^{140}$ a view that, in my opinion, is questionable for the fourth-century Athenian tablets. Versnel summarizes the distinctive features of prayers for justice in nine aspects: (1) All hoards of tablets of this type were found in the sanctuary of a respectable deity, not in a grave. (2) These deities, even if sometimes chthonic, are different from those mentioned on binding spells, because they are called 'great' or 'superior.' They are worshipped in an officially acknowledged cult. (3) These gods are addressed with flattering

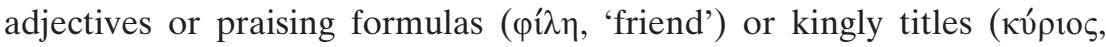

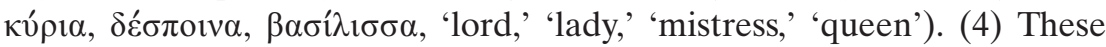

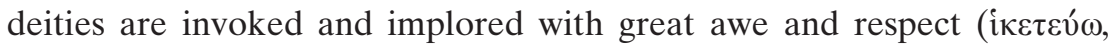

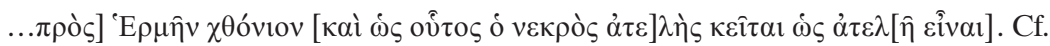
also DT 85 = Gager no. $20=$ Wünsch 1900, p. 70, no. $1=$ Ziebarth 1934a, pp. 1040-1042, no. 23 = Ziebarth 1899, pp. 132-133, no. 1 from Boeotia. On the multiple meanings of atelês, cf. Graf 1996, 136-137, 245, n. 106; Jordan 1993, 129-131: atelestoi are either people who have to go down into Hades without being initiated in some kind of mystery cult, or unmarried people who have not yet fulfilled their purpose in life (i. e., procreation), or corpses that have not yet received proper burial rites and have therefore incurred miasma. Graf discusses in detail Gager no. 22 = DT $68=$ Petropoulos 1988, 219-220 = Ziebarth 1899, pp. 114-116, no. 16 = Wünsch 1900, p. 65, no. 16. Jordan 1993, 129-131 discusses a curse tablet from Selinous. Cf. Pl. Phd. 69c (atelês as uninitiated). Cf., summarizing, Maggidis 2000, 89, n. 26; Johnston 1999b, 87, n. 12.

138 Gager no. $74=$ DT $72=$ Abt 1911, pp. 143-149, no. $1=$ Robert 1936, pp. 14-16, no. $12=$ Wünsch 1900 , p. 66, no. 18 and $19=$ Ziebarth 1899, pp. 117-118, no 18:

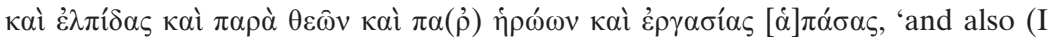
bind) the hopes \{of those men and women\} from the gods and the heroes, and all their business' (angled brackets addition by author).

139 Versnel 1991a.

140 Versnel 1991a, 61, 68-75. 


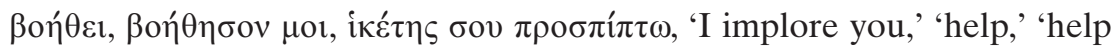
me,' 'I bow before you as a suppliant'). (5) These tablets were exposed publicly. (6) The cursers regard themselves as victims and often give

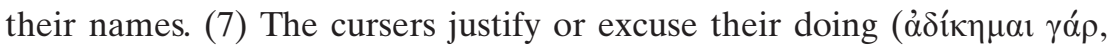
'for I suffered injustice'). (8) Terminology and names that refer to (in)jus-

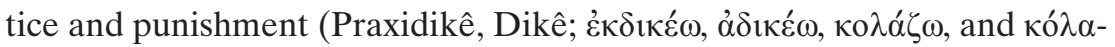
$\sigma ı \varsigma$, 'I mete out punishment,' 'I commit injustice,' 'I punish,' 'chastisement'). (9) The tone is often emotional, as attested by long enumerations of body parts, the cursing of which does not fulfill a direct purpose. ${ }^{141}$

Although these differences from the binding spells are undeniable, this categorization has not remained unchallenged. Ogden lists striking similarities between prayers for justice and traditional curse tablets:

Both are usually written on lead, rolled and transfixed by nails. Prayers for justice conform to the latter part of Jordan's definition of curse tablets: “... intended to influence, by supernatural means, the actions or welfare of persons or animals against their will." ... Prayers for justice are typically deposited in sanctuaries or sacred springs, as are many curse tablets. A significant number of cross-over cases, which share elements both of traditional curses and prayers for justice, prevents categorical differentiation between the two groups. ${ }^{142}$

Prayers for justice sometimes transfer the victims, the suspected culprits, to the gods for punishment. ${ }^{143}$ This fact demonstrates already the rather close connection between prayers for justice and the Athenian curse tablets, in which the victims are also handed over to the gods.

Versnel rightly stresses that some tablets show features typical of both traditional curse tablets and prayers for justice and thus create a so-called

141 Versnel 2009, 22-24. Similarly, Versnel 2010, 279-280, referring to Versnel 1991a, 68. In these latter two instances, he speaks of seven characteristic features. I would like to add three more criteria that Ogden 1999, 38-39 mentions and that Versnel 2010, 327 summarizes: "Not binding language, voces magicae etc., but prayer language ... The target is generally unknown ... Whereas other curses are supposed to be permanently effective, prayers for justice tend to be conditional and of finite duration." Note that points five and six in the above-mentioned list of nine criteria make these prayers more like curses in court orations and less like the clandestine deposition of curse tablets.

142 Ogden 1999, 38; similarly Graf 1997, 159-161. Graf adds that people wrote both prayers for justice and curse tablets in times of crisis, out of preoccupation with the past and the future. Moreover, thieves were also subject to binding spells. Versnel 2010, 324-327 discusses the various points in detail and tries to refute them one by one.

143 Ogden 1999, 40. 
border area between the two distinct groups. ${ }^{144}$ This construction allows him to discern a whole gamut of forms ranging from one end (curse tablets) to the other (prayers for justice) ${ }^{145}$ Only a few Attic tablets from the fourth century seem to belong to this border area. Because of the violent language they employ, they deserve special attention. Versnel has established seven "alien elements" that characterize the zone between defixiones proper and prayers for justice. Not all of them need to appear on a tablet; they are almost identical to the criteria of prayers of justice as mentioned above:

(1) The name of the author. (2) an argument defending the action. (3) a request that the act be excused. (4) the appearance of gods other than the usual chthonic deities. (5) address of these gods ... either with a flattering adjective $\ldots$ or with a superior title. (6) expression of supplication ... added to personal and direct invocations of the deity. (7) terms and names that refer to (in)justice and punishment. ${ }^{146}$

One of the earliest Attic examples of a piece belonging to the border zone is dated to the fourth or third century BCE. ${ }^{147}$ It fulfills requirements five, six, and seven. At the same time, the curse is a traditional binding spell:

Euruptolemos of Agrulê I bind Euruptolemos and Xenophôn \{Xenophôn\} who is with Euruptolemos, and their tongues and words and deeds; and if they are planning or doing anything, let it be in vain. Beloved Earth, restrain Euruptolemos and Xenophôn and make them powerless and useless; and let Euruptolemos and Xenophôn waste away. Beloved Earth, help me; and since I have been wronged by Euruptolemos and Xenophôn I bind them.

144 Versnel 2010, 281, 324-342 is the most detailed discussion and defense of the concept to date, developed originally by Versnel 1991a, 61, 64-68. Versnel 2009, 43 assumes that these border curses developed out of the "pure" form of defixio.

145 Versnel 1991a, 92: "it seems better to see prayer and defixio as two opposites on the extreme ends of a whole spectrum of more or less hybrid forms."

146 Versnel 1991a, 68.

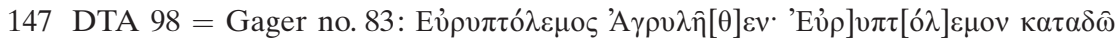

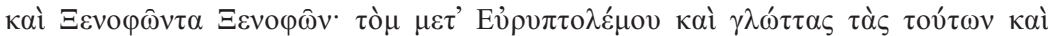

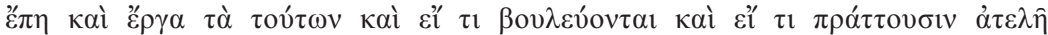

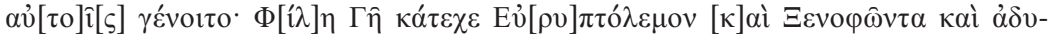

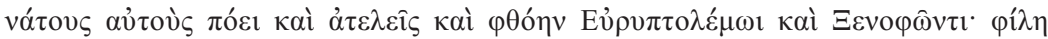

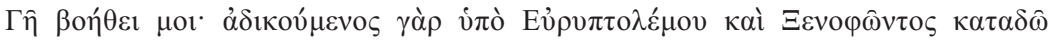

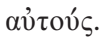


Another example of an early border case ${ }^{148}$ shows criteria six ('Hermes and Ge, I beg you') ${ }^{149}$ and seven ('to take care of all this and punish them, but save her who has 'struck' the lead') ${ }^{150}$ alongside characteristic features of classical binding spells. Hermes is called again 'Restrainer' (katochos). In another piece, Hermes, Gaia, and Persephone are simultaneously invoked (criterion six) to restrain the victim. ${ }^{151}$ Because of its formula, another tablet may date to the third century or later. Line 12 of this

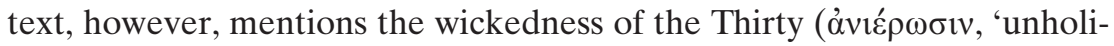
ness'), indicating that the tablet could date to the end of the fifth century. This tablet is interesting, because the victim is explicitly dedicated to the gods of the underworld (theoi epitumbioi). ${ }^{152}$ The fact that they are invoked (criterion six) suggests that this tablet belongs to the border area. ${ }^{153}$ Another border-area spell was indeed found in an Athenian sanctuary, that of Palaemon Pancrates. ${ }^{154}$

All these examples show that border cases may be understood as traditional binding spells. It seems rather artificial to separate very few specimens from the genre to which they belong, on grounds of two or three deviations from the main pattern. These abnormalities can be readily explained if one keeps in mind the different occasions for which people wrote curses. The formulas had to be flexible enough to adjust to dif-

148 DTA $100=$ SEG XXXVII $217=$ Versnel 1991a, 65-66. It is of special interest that a woman, Onesime, prays for the preservation of the one who actually struck the lead tablet. Did she manufacture the tablet herself or did she commission the tablet and therefore prays for the magician's safety? Cf. Ogden 1999, 59.

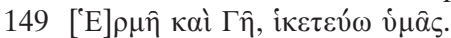

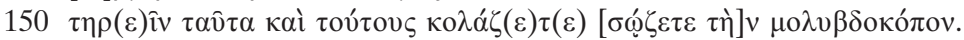

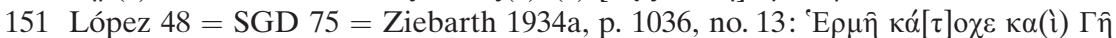

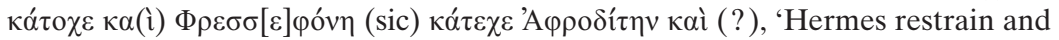
Gaia restrain and Persephone restrain Aphrodite and (?).'

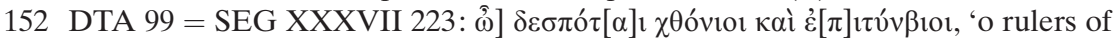
the underworld and of the tombs.'

153 A full-scale Athenian prayer for justice dating to the first century CE is Gager no. $84=$ López $63=$ SGD $21=$ Elderkin 1937, 389-395 = Jordan 1980b, $62-65$ $=$ SEG XXX $326=$ SEG XXXIX $1847=$ Versnel 1991a, 66-67 = BE 1938, $23=$ Aubert 1989, p. 435, no. 23. Two further instances (both probably dating to the fourth or third century BCE) need to be mentioned in this context (DTA 120 and DTA 158), because they allude to the wrong that the target of the spell has committed.

154 NGCT 14; cf. on this spell in detail Versnel 2010, 311-312. Other border-area cases from the fourth-century BCE are DTA 102, 109, and NGCT 3, which all fulfill criterion seven. NGCT 24 = SEG XLIX 320 is also a "borderland" case. 
ferent circumstances and individual needs. ${ }^{155}$ In addition, it is doubtful that the Greeks really thought in neatly separated compartments and assumed they were allowed to exert massive violence in judicial prayers, but they could not do so in binding spells. These categories are modern constructions. If one had the permission to be violent in judicial prayers, then it was also allowed to be so in binding spells. At least with fourth-century Athenian spells, this strict categorization does not work well, which suggests that the border-area cases of classical Athens are just examples of more openly malicious binding spells. If we accept that prayers for justice are indeed probably closer to the other spells than hitherto surmised and if prayers for justice are more violent than other curses, we can assume that the traditional Attic tablets were also meant to be more malevolent than has been usually believed. One could express his malicious intentions more or less directly. Even if the specific rules of the fourth-century democratic discourse did not allow one to call down violence on victims openly, strong feelings must often have loomed in the background. The fact that they were in most cases not inscribed on the tablets expressis verbis does not mean that the cursers had harmless intentions. ${ }^{156}$

In a later article, Versnel undertakes to differentiate groups of binding spells. ${ }^{157}$ As far as body parts are concerned, he separates the earlier competitive/agonistic or instrumental spells from the later anatomical spells. The former group consists of the early tablets, mainly from fourth-century Athens. According to Versnel, they are laconic, show no real intent to do serious harm, and enumerate a few body parts in a quite functional way. Only the body parts mentioned on the tablets are to be bound. The tablets in the latter group, by contrast, are more elaborate and therefore also more emotional. The relationship between the longer lists of body parts in these tablets and the human body is one of synecdoche. Since the parts listed stand for the whole body, there is intent to harm the entire person. These later anatomical spells fall into two subgroups: prayers for justice and love spells.

This categorization of instrumental versus anatomical spells seems problematic. First, the body parts enumerated in the early spells may

155 Also Versnel 2009, 43 concedes a high degree of spontaneity and individuality on the part of the cursers.

156 In my opinion, Versnel 2010, 337 draws too sharp a distinction between binding/ paralyzing and punishing/torturing/killing. As we will see, the semantics of binding is broad. It can even encompass death, and certainly includes the desire to torture or punish someone after having suffered injustice.

157 Versnel 1998a. 
also stand for the whole body. Second, some early spells were meant to be harmful, too. The sharp division between early harmless curses and later malevolent spells is artificial. Third, we cannot deduce a lack of emotion or aggression merely from the brevity of a text. The words accompanying the ritual of deposition may have been more brutal than the written curses. Perhaps a formulaic language was to be found and formulated. This evolutionary process took time. Gradually, the verbal formulas came to be written down as well. Furthermore, we do not have access to the cursers' state of mind.

Sometimes it is not the preserved text but the archaeological evidence that suggests the fatal character of a spell. One of the most famous Athenian "voodoo dolls" represents Mnesimachus, who was cursed along with some other more prominent Athenians of the late fifth century BCE. ${ }^{158}$ The lead figurine was found in situ in the Kerameikos. The name Mnesimachus is scratched on the doll's right leg. Two small lead plates formed a little coffin for the figurine, one of them bearing the curse. The similia similibus function is clear enough. This kind of magic plays with the notion of a coffin: the cursed person is to suffer the fate of his leaden representation through the force of magic. He is to lie in his grave, powerless and destroyed. ${ }^{159}$ Fortunately, the objects were found in situ. The skeleton at whose pelvis they were found was slightly disturbed. ${ }^{160}$ Perhaps the person had been murdered, for it was common practice to deposit curse tablets in the graves of biaiothanatoi, persons who had died a violent death.

The assessment of the potential violence enshrined in the curses requires an investigation into the core of magical practices, the similia similibus function. Research agrees that the tertium comparationis (' $\mathrm{X}$ is to become

158 Gager no. $41=$ Trumpf $1958,97-101=$ BE 1963 , p. 125 , no. $32=$ SGD $9=$ Jordan 1988, 275-276 = López $9=$ Guarducci 1978, 244-245, figs. 68, $69=$ SEG XXI 1093 = SEG XXXVIII 31 = Faraone 1991b, p. 201, no. $5=1991$ a, 156, n. 20. Mnesimachus counted among Lysias' enemies. Other opponents of the orator were Nicomachus and Theozotides, who are also attested on curse tablets (cf. above 176, n. 55), the latter's name also inscribed on a little voodoo doll (Parker 2005, 129). Cf. above 163, n. 596. Another spell from Lysias' environment is analyzed by Costabile 2001; 1998.

159 Trumpf 1958, 98.

160 The archaeological context is not clear. Previous scholars liked to see a murdered person whose corpse had been seriously mutilated (maschalismos). Cf. Graf 1996, 153-154, 248-249, n. 174. 
like lead') is an attribute that the victim lacks. Through magical, metaphoric practices, the quality lacking is to be transferred to the target. ${ }^{161}$ But how exactly this worked and to what degree the various verbal and material representations of the victim and the similia similibus actions were thought to be "real" is a matter of debate. As a point of departure, we should remember that the Greeks themselves regarded the magical act as an act of violence. To Malinowski, it was the psychological dimension that enabled the agent of the curse to experience a "real" action. Malinowski stressed the paramount importance of the "emotional setting" during the performance of the magical rite. For example, the destruction of the doll is, to him, a "clear expression of hatred and anger." $162 \mathrm{He}$ concludes: "The substitute action in which the passion finds its vent, and which is due to impotence, has subjectively all the value of a real action, to which emotion would, if not impeded, naturally have led." ${ }^{163}$

This emotionalist approach has been harshly criticized by Graf and Faraone. ${ }^{164}$ According to Graf, the psychological interpretation does not work, because the rituals were too complicated to allow the curser to vent aggressions spontaneously, and, in many cases, professional magicians performed the rites themselves. These goêtes were not necessarily emotionally engaged in a certain cause; they merely conducted business on behalf of a client. ${ }^{165}$ Speaking of the "sympathetic action" proper, Graf takes a radical stance. The "sympathetic action," according to him, is redundant because it is dispensable. Voodoo dolls were not employed every time and many curses could do without them. Graf even goes so far as to claim that there is no homology between ritual and goal, and argues that this is the reason why we should not speak any more of "sympathetic magic." 166

161 Cf. Kropp 2004, 93. A good example is López $51=$ SGD $78=$ Ziebarth 1934a, p. 1038, no. 17 = Ziebarth 1899, pp. 116-117, no. $17=$ DT $69=$ Wünsch 1900,

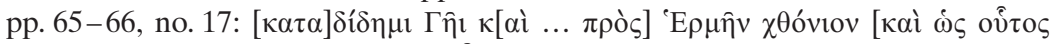

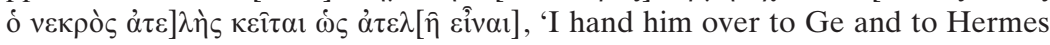
Chthonios, and he shall be as useless as this corpse lies useless.' If the victim really will lie like a corpse, the wish expressed is lethal. Since formulas like this are quite frequent, they are of prime importance for the assessment of violence in the tablets.

162 Malinowski 1974, 71.

163 Malinowski 1974, 80-81.

164 It was partly resumed, however, by Tambiah 1990 and Winkler 1990, but with different, more anthropological slants.

165 Graf 1996, 132.

166 Graf 1996, 131. 
Taking a stance in this discussion requires considering the different notions of depositing voodoo dolls, the similia similibus action par excellence. In popular belief, figurines and victims were probably equated. Graf concedes that the effigies somehow represent the victims whose names they bear, but the emphasis is on "somehow," for effigy and victim cannot be identical. Figurines were not direct portraits of their targets, but rather ideograms or symbols of them. ${ }^{167}$ Some dolls are inscribed with more than one name. ${ }^{168}$ Most curses did not require any pictorial representations, meaning that the use of a figurine was only optional. From this perspective, the transfixion of a doll with needles cannot be interpreted any more as a "sympathetic act." Moreover, many historians of religion, including Graf, think that the term "sympathetic magic" has become untenable anyway. It carries too much problematic baggage and evokes Sir J. Frazer with his colonial belief, derived from the Enlightenment period, of a constant upward movement of mankind, from primitive, magic beginnings to religion and finally science, culminating in the rationalism of the British Empire. Leaving the question of "sympathetic magic" aside, the question remains as to what use the dolls actually had. If they had no goal, as Graf poses, the magical rite of transfixion can no longer be understood as violent act, which seems odd.

In stark contrast to Graf's and Faraone's assumptions is Collins' radical stance. In a provocative article, he also rejects the notion of "sympathetic magic," but for reasons opposite to those of Graf. Basing his argument on theories of ancient Greek agency in general, he claims that the figurines do not represent the victims, but rather are the victims. Collins attempts to show that figures and statues were regarded not only as living creatures, ${ }^{169}$ but as social agents capable of causing events to happen in their vicinity. ${ }^{170}$ Thus, he states, "statues were bound not as an analogical gesture but to prevent them from moving." By this logic, "the binding of a figurine is the binding of its agency, not a symbolic or persuasive act." 171

If this notion is true, binding magic was incredibly brutal, at least as far as the maltreatment of voodoo dolls is concerned. And if the principles of symbolic or persuasive acts did not exist in Greek magic-in Collins' sense-all spells were meant to be direct and extremely violent. The

167 Graf 1996, 125-126. Similarly, Faraone 1991b, 190; 1988, 171.

168 Ogden 1999, 75.

169 Collins 2003, 39.

170 Collins 2003, 17, 38, 43.

171 Collins 2003, 43. 
question of how exactly the maltreated voodoo doll directs its aggressions onto the victim still remains. Frazer's term "sympathetic magic" has become obsolete, but Tambiah's less problematic "persuasive analogy" does not possess enough explanatory force either. What we need to comprehend in the following analyses is how the transfer of negative characteristics onto the victims via magical means was supposed to work. Without intending to do so, Collins makes a case for such a high degree of violence that it is not compatible with the evidence. His position is more extreme than what I am trying to demonstrate in this chapter. To recapitulate, Graf and Collins reject the idea of "sympathetic magic" for diametrically opposite reasons.

Johnston is less radical and takes a mediating position between Graf/ Faraone and Collins: "The Greeks used very small statues as magical dolls: by affecting the doll, one affected the individual whom the doll represented." ${ }^{\text {172 }}$ She concedes a representative function of the doll. In many cases, the doll was not needed, because writing the name of the victim on a tablet was already enough to bind him or her. This can only mean that the name itself stood for the person. Gaining control over the name on the tablet entailed control over the real person. ${ }^{173}$ That is why many tablets were pierced with nails. Taking this broad idea of representation seriously - even names on tablets can represent human beings-means allowing for a considerable degree of violence attached to binding spells. What might happen in malign magic has been explained in classical terms by the sociologist Mauss, who, like Malinowski, thought that the passion of violence has to be enacted. But in contrast to Malinowski, Mauss did not focus on the individual's soul, but firmly embedded the curser in his or her society, a collective that believes in magic. According to Mauss, three principal laws constitute magic: the law of contiguity (simultaneity, totum ex parte), the law of similarity (mimetic sympathy, even identity), and the law of opposition. The law of similarity can be characterized by two formulas: "like produces like, similia similibus evocantur; and like acts upon like, and, in particular, cures like, similia similibus $\mathrm{cu}$ rantur." The law of similarity may be equal to the one of contiguity. The third principle can be circumscribed by the phrases "opposite acts on opposite" or "like drives out like in order to produce the opposite." "Opposite drives away opposite" is also possible within this law of opposition. ${ }^{174}$

172 Johnston 1999a, 60; similarly 158 and passim.

173 Gager 1992, 14.

174 Mauss 1972, 64-73. Cf. the useful summary in Luck ${ }^{2} 2006,5$. 
The basic idea is that, in the magical worldview, which is not primitive, everything is connected with everything else and has multiple repercussions. No action stands isolated; every action refers to and reflects countless other actions, which in turn trigger other events. ${ }^{175}$ These assumptions are discussed today by chaos and coincidence theorists and their opponents. So, if one is violent toward an effigy or a tablet (or the name inscribed on it), there is a certain possibility that a human victim is affected too.

At this point, the defixiones should be put into the larger context to which they belong, and the connection between binding magic and public arai, which are often meant to be deadly, has to be more closely examined. Ara is the personification of a curse and almost synonymous to the Erinyes. ${ }^{176}$ It heaps the state of being cursed, the Fluchzustand onto an accursed victim. In his book on curse poetry in antiquity, Watson has proposed a useful categorization of curses. To him, ara is an overarching term that comprises four sub-categories: ${ }^{177}$ (1) Revenge curses, which we nowadays call prayers for justice, according to Versnel's terminology, or vindicative curses, if we want to follow Gordon's suggestion. ${ }^{178}$ (2) Provisional curses, which were often publicly proclaimed and set up in stone in a public place, visible for all to deter potential treacherous behavior and wrongdoings. They are arai in the more narrow sense, as the term is often employed in secondary literature. They protect cities, ${ }^{179}$ assemblies, ${ }^{180}$ consti-

175 Cf. above Tambiah's very similar linguistic categories. Luck ${ }^{2} 2006$, 5, 33-34 speaks of "cosmic sympathy."

176 K. Wernicke, s.v. "Ara," RE II, Stuttgart 1896, col. 337-338.

177 Watson 1991, 6-12.

178 Gordon 1999b, 167, 246. Apart from the Bath tablets, the lead tablets of Cnidus are famous (Audollent 1904, 1-13; I. Knidos 147-159; 300 BCE-100 CE). They were often put up in public. Cf. Versnel 2010, 281. Watson 1991, 6-7 lists literary sources.

179 Syll. $\mathrm{I}^{3} 37-38=$ GHI I $23=$ M/L $30=$ HGIÜ I 47 (Dirae Teiorum). The curse hits all those who may exert malign magic against Teos or some of its citizens, endanger the import of grain, may be disobedient to the magistrates, commit treason while being magistrates, engage in banditry or piracy, or support the enemies of Teos. Cf. Latte 1920, 70-73 with more sources. Note that some curses try to harm enemies of the city. The Athenians, e.g., cursed Alcibiades (Plu. Alc. 22; 33), Philip V of Macedon (Liv. 31.44.4-6), and those who were guilty of profaning the mysteries in $415 \mathrm{BCE}$ (Lys. 6.51). These curses transfer the offenders over to the infernal gods and are thus meant to be deadly. And since gods of the underworld are also mentioned on most curse tablets, their deadly character should impose itself on the modern interpreter. 
tutions, ${ }^{181}$ treaties, laws, decrees, ${ }^{182}$ tombs, ${ }^{183}$ private corporations, and phratries, ${ }^{184}$ as well as wills and possessions, ${ }^{185}$ and are therefore regarded as legitimate Rechtsschutz. (3) Self-imprecations (Selbstverwünschungen) overlap with arai in the more circumscribed sense of (2). Within this third category, I differentiate between provisional self-imprecations as parts of oaths, ${ }^{186}$ and unconditional imprecations, ${ }^{187}$ which comprise the devotiones mentioned below. ${ }^{188}$ Watson's last category (4) are unprovoked curses, that is, binding spells. Although Watson clearly differentiates between these very different forms of curses, it is telling that all of them

180 Din. 2.16; Andoc. 1.31; D. 19.70-71; 20.107; 23.97; Lyc. 1.31. Ar. Th. 295-371 parodies the entrance prayer of the Assembly of the People, which puts friends of the Persians, tyrants, and all enemies of the people under a spell.

181 The five thousand put their novel order under the guarantee of an ara (Th. 8.97). Many arai are directed against tyrants and enemies of the people (Latte 1920, 73-74).

182 Cf. Watson 1991, 9, 19, 22 (with sources); Latte 1920, 74-76. Cf. Pl. Lg. 871b; Criti.119e; D. 20.107 on the intricate connection between law and curse. The curse proclaimed by the Amphictyones against potential settlers of the plain of Cirrha is fully spelled out by Aeschin. 3.110-111. Cf. OGIS I 55.30-33, “a sanction ... attached to a decree of Lycian Telmessus setting up a cult for Ptolemy son of Lysimachus" (Watson 1991, 19-20).

183 Famous are the imprecations against tomb violators from Asia Minor, most of which hail from third century CE Phrygia (Strubbe 1997). Although normally grouped with arai- "they belong to the domain of justice and were socially accepted" (Strubbe 1997, XI) - they do show some traits of defixiones. If they invoke deities, these are the gods of the underworld that are also mentioned in binding magic (Strubbe 1997, XVI).

184 Ziebarth 1895, 69.

185 D. 36.52.

186 Most famously the oath of Plataiai (GHI II $204=$ HGIÜ I 40; Plu. Arist. 10.6; D.S. 11.29.2-3; Lyc. 1.80-81) and the decree of Cyrene (HGIÜ I $6=\mathrm{M} / \mathrm{L} 5.40$ 51), which is enhanced by a ritual practice of malign magic, i.e., the melting of waxen statues. Cf. Stengel 1898, 78 on curses as parts of oaths. Latte 1920, 73: "Die Exekration gehört ja zur griechischen Eidesformel." Watson 1991, 8-9

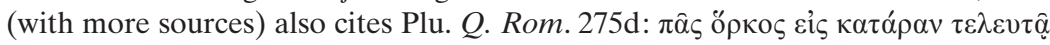

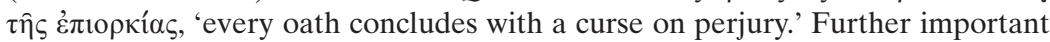
examples are Syll. $\mathrm{I}^{3}$ 527.78-94 (Dreriorum ius iurandum) and the oath of the Lacedaemonians before the war against the Messenians (Str. 6.3c279; Plb. 12.6b9). Cf. Parker 1983, 186, nn. 234 and 235 with numerous literary and epigraphical sources.

187 Cf., e.g., Oedipus' curse on all those who do not actively search for Laius' murderer (S. OT 269-275). Further literary sources appear in Watson 1991, 9-10.

188 Cf. below 207-208. 
are, in the end, arai. ${ }^{189}$ For older continental research this fact was selfevident. To Stengel, Ziebarth, and Nilsson the defixiones were a private form of the public arai. ${ }^{190}$ I do not mean to play down the fundamental differences between arai in the narrow sense and the defixiones. Arai are public, defixiones secret. The first often name the agent of the curse, the latter do not. ${ }^{191}$ The first cannot name the victim, because she or he is only potential - that is, the person is only cursed if he breaches an oath or does some harm to the community that protects itself with the curse. The latter explicitly name the victims, who are supposed to suffer harm, even if they did not do any wrong. Arai are socially accepted, a religious and legitimate form of self-help that is intrinsically tied to dike (justice), which the ara is supposed to implement more firmly, ${ }^{192}$ whereas binding curses were laid down in a clandestine way because they were socially unacceptable. Most arai are specific in their ill wishes and clearly express the desire for destruction in contrast to most binding spells, at least those from Athens. But are the differences really so great ${ }^{193}$ The author of a binding spell often sought to redress justice in his own sense, a form of justice that the institutions of the city had not or may not have provided for him. ${ }^{194}$ From this perspective, even binding spells can be considered as working alongside the courts and, in this sense, are similar to prayers for justice. The grave inscriptions, normally grouped

189 Watson 1991, 22 makes this abundantly clear: "ג̊oxí were quite as widespread in the private sphere. Some of the relevant types have already been noted - $\alpha \rho \alpha i$ í from the worlds of poetry and myth, curses against grave-violators, and defixiones."

190 Stengel 1898, 75 mentions that arai also bind, thus almost equating them with the defixiones. Cf. E. Ziebarth, s.v. “Fluch,” RE VI 2, Stuttgart 1909, col. 2771-2773, 2772 and Nilsson ${ }^{4} 1976,802$ stating that the curse tablets stem from the tradition of the arai. Cf. also Nilsson ${ }^{4} 1976,803-804$, where he explicitly mentions death as one possible aim of a binding curse.

191 There are some rare exceptions, however. SGD 54 (Athens, fourth century?) and SGD 91 (Sicily, fifth century BCE) name the curser.

192 On the connection between arai and justice, cf. Watson 1991, 38-42.

193 Voutiras 1998, 37-38 follows Audollent 1904, XXXII, XXXVI-XXXVII, XL in strictly separating binding spells from arai. Although Maggidis 2000 regards binding curses as relatively harmless, thus following Faraone and others, he comes to a conclusion that brings defixiones nearer to arai: "The binding spell on the curse tablet is in effect nothing but a ritualized, thus more powerful and efficient, 'borderline' prayer ( $\varepsilon \dot{\chi} \chi \alpha$, SGD 91)."

194 NGCT 14, 23, 24, 66; DTA 98, 100, 102, 103, 120, 158. SGD 58 speaks about some kind of injustice suffered. All of these tablets belong to Versnel's category of border-area curses. Cf. Eidinow 2007a, 229-230. 
with the arai, invoke the same infernal gods that can be found on the curse tablets. Most of all, in both forms of cursing, a Fluchzustand, a certain kind of contagious pollution (miasma) is called down on the victim. ${ }^{195}$ The Greeks had a precise word for this state of being accursed-loimos, which might be incurred either because of personal misdeeds, especially in the case of sacrilege (agos) ${ }^{196}$ or as a result of an ara or binding spell. The person who incurred loimos was then considered enagês, 'held in the agos. ${ }^{197}$ In contrast to the defixiones, arai often spell out the dire implications of loimos expressively: pestilence, crop failures and ensuing famines, infertility of women and cattle, or abnormal children and young cattle, as well as the destruction of the whole family. ${ }^{198}$ Hesiod, in his Works and Days, gives an almost classical definition of loimos: $:^{199}$

But to those who care only for evil outrageousness and cruel deeds, far-seeing Zeus, Cronus' son, marks out justice. Often even a whole city suffers because of an evil man who sins and devises wicked deeds. Upon them, Cronus' son brings forth woe from the sky, famine together with pestilence, and the people die away; the women do not give birth, and the households are diminished by the plans of Olympian Zeus. And at another time Cronus'

195 On the pollution of the accursed victim, cf. Versnel 2009, 16, n. 21.

196 Parker 1983, 180. Agos is a subcategory of miasma, i. e., every agos is a miasma, but not every miasma is an agos. It must be noted that, originally, the concept of agos (sacrilege) and that of miasma (pollution) were unrelated. Soon, these two terms became indistinguishable, i.e., by the classical period, an agos was also perceived as a state of pollution (Parker 1983, 144-147; Moulinier 1952, $247-$ 259). For Latte 1920, 77 it is self-evident that sacrilege pollutes.

197 Parker 1983, 192. This also means that diseases and other misfortunes could be washed off by purifiers (Parker 1983, 224, 232, 246, 251).

198 All of the above-mentioned curses (nn. 178-187) contain several of these ill wishes. Cf. Watson 1991, 31-34 with more sources on the infertility and destruction-of-the-genos motif.

199 Hes. Op. 238-247:

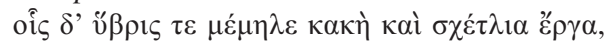

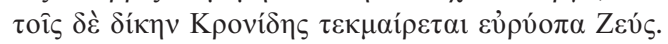

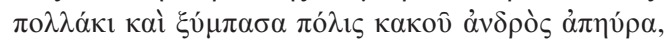
ő $\kappa \varepsilon v \dot{\alpha} \lambda ı \tau \rho \alpha i v \eta n ~ \kappa \alpha i ̀ ~ \alpha ́ \tau \alpha ́ \sigma \theta \alpha \lambda \alpha \mu \eta \chi \alpha v \alpha ́ \alpha \tau \alpha 1$.

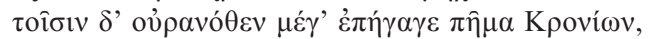

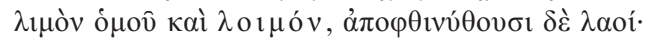

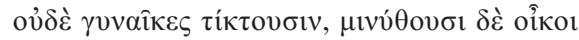

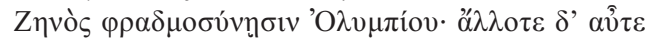

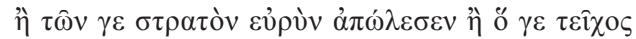

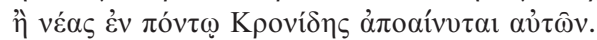
Similarly S. $O T 22-30$. 
son destroys their broad army or their wall, or he takes vengeance upon their ships on the sea.

A preserved oracle of Apollo at Clarus gives advice to the city of Sardis that was beleaguered by plague under Marcus Aurelius (after $165 \mathrm{CE}$; SEG XLI 981). It mentions loimos and malign magic in one breath. As a remedy, a procession in honor of Artemis of Ephesus was supposed to be introduced, and wax maumets, probably found by chance, were to be destroyed in a ritual. Thus, people believed that the magical spell caused by voodoo dolls could be unbound by destroying them. ${ }^{200}$ Very clearly, defixiones and loimos, and, consequently, arai, belong together in the imagination of ancient believers. ${ }^{201}$

Why are the Athenian curse tablets more silent on the harm they inflict? Apart from discursive restrictions, which I will address below, much was a matter of proportion. It would have been senseless for a potter to call down crop failure and ensuing famine on a neighbor. What the polis could do on a large scale was often not applicable on the small scale of a local businessman or a prostitute. But the thought-worlds underlying public arai and private defixiones were quite similar: both kinds of curses involved incapacitating a victim by various means for various reasons. It was the firm belief in both cases that pollution could be heaped upon a target by supernatural means, thus transferring him or her into the state of loimos. It goes without saying that the ritual practice of depositing a curse tablet was supposed to pollute the victim. By burying the tablet in a grave, sometimes even putting it into the hand of a corpse, the sorcerer came into contact with the dead, who were always thought to be polluting. And since the name on the tablet could represent the actual victim, as we have seen, a real person was thought to have been exposed to immediate miasma, or, in other words, to a certain kind of loimos, similar to the one called down on targets by public arai. ${ }^{202}$ What kind of misfortunes

200 I quote the translation of Gordon 1999b, 209: 'She [Artemis of Ephesus] will be distressed at the calamity $<$ which has befallen the city $>$, and by her fiery torches unbind man-destroying magic of plague (loimoio ... pharma $[k] a$ ) by melting with her night-flame (the) maumets of wax, the wicked signs of a magician's art (magou ... symbola technês)' (lines 6-9).

201 Rubinstein 2007 passim emphasizes the continuous deterrence arai exercised through Hellenistic and Roman times. Despite changes in the formulas, she cannot detect a trivialization of this kind of cursing.

202 Cf. Jordan 1993, 129-131 on the pollution caused by the dead in defixiones, especially with regard to the atelestoi. A good example of atelestoi in Athens is found in Audollent 1904, 68. Theophrastus' superstitious man (Thphr. 
this loimos, enshrined in the binding curse, entailed is encapsulated in the broad semantics of the binding word katado ${ }^{203}$ but is sometimes spelled out more drastically, as we have seen above. Imprecations against desecrators of a grave, as preserved from Asia Minor, which, in my opinion, stand between arai and binding curses, call down four different categories of punishments on all those who might violate the tomb: death (as the most frequent form of punishment), physical sufferings of all kinds, the situation of being accursed, and even punishments after death. ${ }^{204}$ These ill wishes fully confirm the picture established so far. Number 40 in Strubbe's corpus speaks about the air, which is supposed not to be pure and healthy for the culprit and his family $;^{205}$ Number 146 may speak of pestilence. ${ }^{206}$ The underlying assumption of contagious pollution and loimos is clear. Without speaking about loimos, Strubbe gives a definition of it under the rubric "The situation of being accursed":

death, especially death by drowning, burning, starvation or falling down and all strange and cruel ends of life; diseases, especially blindness, mental disorder and epidemics; infertility of women and the birth of abnormal children; all natural disasters and disruptions of the normal order, like drought and flood, hail and storm, crop failure and famine. ${ }^{207}$

When depositing binding spells, the cursers certainly also had some of these very same polluting ill wishes in the back of their minds. ${ }^{208}$ This means that bad luck and pollution were inextricably intertwined. Whoever suffered from bad luck had to be polluted in the eyes of his or her con-

Char. 16) feels compelled to purify his house all the time, because he assumes that Hecate has been activated against it. Her power was thought to be impure (Parker 1983, 222-223). Hecate appears on many curse tablets from fourth-century Athens, obviously because her power was also supposed to pollute the victim.

203 See below 214-216.

204 Strubbe 1997, XVII-XIX.

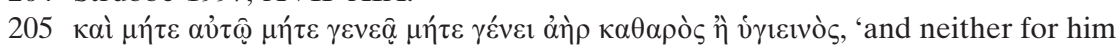
nor for his family and offspring shall the air be pure and healthy.'

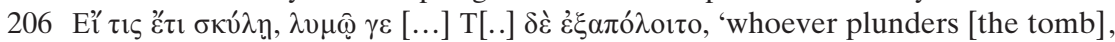

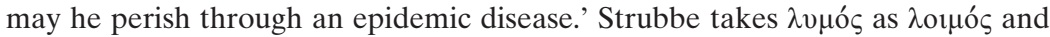
translates the term with 'epidemic disease.' L. Robert could not make sense of the word (REA 42, 1940, 309).

207 Strubbe 1997, XVIII. Cf. a similar listing in Watson 1991, 35-36. An inscription from Chalcis (IG XII 9 1179) provides an omnibus malediction (Watson 1991, $31-32)$.

208 Cf. Moulinier 1952, 296. 
temporaries. Consequently, wishing someone bad luck entailed polluting him or her in one way or another.

If a public ara could already be lethal, how deadly then was the clandestine devotion of a victim to the gods of the underworld meant to be? In the liminal act of a depositio, the downward movement to chthonic deities is a reversal of the official cult of the polis, which addressed the Olympian gods. $^{209}$ This important anti-structural stance is often enhanced by reverse writing. Such inversion was deemed appropriate for the gods of the underworld, who were thought to be opposite to the Olympians. The verbs of "writing" or "binding down" have a kinetic component, underscored by the preposition pros, with the inherent dynamic of establishing contact between target and chthonic deity. ${ }^{210}$ The victim is handed over, transferred, or dedicated to the gods of the underworld. The act of dedicating or devoting someone to these gods is expressed by katadô ('I bind down'), katagraphô ('I write down'), katatithêmi ('I put down'), and katadidômi ('I give down'), ${ }^{211}$ verbs that correspond to devotio in Latin. The devotio in Roman culture, however, always meant death by transferring a person to the gods for the sake of his or her destruction. ${ }^{212}$ Military commanders like P. Decius Mus devoted themselves to the gods in hopeless situations on the battlefield. ${ }^{213}$ The unconditional sacrifice of their lives was meant to avert defeat and secure the survival of the Roman troops. In conditional self-execrations, which are often found as parts of oaths, people called down destruction upon themselves. Such execrations had a long tradition in ancient cultures as dirae and were typically meant to be lethal. ${ }^{214}$ In Latin the word "curse" is also rendered as devotio, ${ }^{215}$

209 Graf 1996, 116.

210 Kropp 2004, 94.

211 Eidinow 2007a, 145 rightly translates the derivatives of tithêmi and didômi with 'to consign.'

212 H. Versnel, s.v. “devotio," Der Neue Pauly 3, Stuttgart - Weimar 1997, col. 493 494.

213 Allegedly, Decius Mus won the battle of Sentinum in this way in 295 BCE (Duris FGrHist 76 F 56; Liv. 10.26-30). His father is also reported to have sought death in the same way in a battle against the Latins in 340 BCE (Liv. 8.6; 8.9-11). This may be a projection from the son to the father (K.-L. Elvers, s.v. "Decius," Der Neue Pauly 3, Stuttgart - Weimar 1997, col. 347).

214 Cf. the famous Dirae Teorum (Syll. I $37-38=$ GHI I $23=$ M/L $30=$ HGIÜ I 47), the curse of the city of Teos against some miscreants, and the oath of Plataiai (GHI II 204 = HGIÜ I 40; cf. Plu. Arist. 10.6; Lyc. 1.80-81; D.S. 11.29.2-3). Cf. Graf 1996, 117. Cf. above 201, n. 179 and 202, n. 186 in the context of arai. 
showing that, for native speakers of Latin, the connection between death and curse was self-evident. Among modern scholars, Bernand goes so far as to equate the defixio with the devotio: for him, the defixio is just the process through which the devotio is achieved. ${ }^{216}$ Undoubtedly the Attic curse tablets are to be seen in this larger context as well. But did the Greeks, like the Romans, seek the reason for unexpected deaths in malign magic? Yes, indeed. Graf has presented a list of more than thirty inscriptions that demand revenge for the sudden, premature, and inexplicable deaths of close relatives through magic. The earliest inscription dates to the second century BCE. ${ }^{217}$ Through these inscriptions, we see that every misfortune and calamity, ranging from broken pots in one's kiln to loss of memory in court ${ }^{218}$ to the death of one's child, could be explained through the malicious force of malign magic.

On the tablets, devotions to the gods of the underworld clearly suggest the direction into which the dead were supposed to drag the victims, but further evidence must be considered. It is the communis opinio that the chthonic gods invoked-in most Attic cases, Hermes, Persephone, and Hecate-served as witnesses who oversaw the magical act. ${ }^{219}$ Terms used on the tablets, such as katagraphô ('I write down'), apographô ('I write away'), ${ }^{220}$ and paradidômi ('I hand over'), normally appear in judicial contexts to validate business transactions. It is all the more likely that the chthonic gods are envisioned as witnesses in the magical act if, in the tablets, the preposition pros is used to mean 'in the presence of,' a meaning typical in legal contexts. A good example is the curse against Litias: 'I bind Litias in the presence of Hermes the Restrainer and Persephone' (line 1); 'in the presence of Hermes the Restrainer, Persephone, and Hades' (line 17). ${ }^{221}$ The repetitive, mantra-like character of the preposi-

215 S.v. "devotio," OLD 1982, 534. Devotio is also the word used to designate the accusation of binding magic in Tacitus (Graf 1996, 116). Versnel 2010, 351 reminds us that the Latin term for curse tablet is not defixio, but devotio.

216 Bernand 1991, 110: "La 'défixion' n'est que le procédé par lequel s'exerce la dévotion." Cf. Bernand 1991, 108-110 on the whole complex.

217 Graf 2007b.

218 Ar. Scholia V. 946-948; Cic. Brut. 60.217; Orat. 37.129.

219 Faraone 1991a, 5.

220 I thank David Phillips (UCLA) for alerting me to the fact that apographô is also the technical term for registering a person as a debtor to the state (e.g., SEG XII 100; Lys. 29.1; D. 53.1-6, 19, 23, 28).

221 Gager no. $70=$ SGD $44=$ Peek 1941, pp. 97-100, no. $9=$ López $26=$ Ziebarth

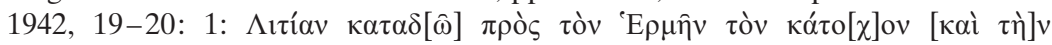


tional phrase is well shown in another piece: 'in the presence of Hermes, in the presence of Hermes, in the presence of Hermes. ${ }^{222}$ The business sphere evoked in these curse tablets suggests that the victims were registered with the gods or in their presence, ${ }^{223}$ with the deities thus serving as witnesses. The victim was bound in the deities' presence in the sense that the gods passed the curse on to the corpse, which would then put it into action. $^{224}$

But the gods are not just witnesses. In legal contexts, the accusative case is regularly used to refer to the magistrate who has jurisdiction over a case. This means that the agent of the curse renders the accursed person subject to the jurisdiction of the chthonic powers named. As we will see, this kind of registering of the victim with the gods endowed the dead with extraordinary functions. ${ }^{225}$ Curbera and Jordan have added that pros has a more geographical meaning as well, for it can denote the sanctuary of the god or the cemetery where the curse tablet is deposited. ${ }^{226}$ I would like to expand on the semantic range of this preposition, which is so crucial in the context of curse tablets. Pros in its basic meaning also signifies the direction of an action in the sense of 'to,' 'toward,' 'in the direction of.' ${ }^{, 27}$ Verbs of motion like katadô, katagraphô, and katatithêmi all denote a downward movement, and the chthonic gods addressed were thought to dwell in the underworld. ${ }^{228}$ Hence, this meaning of pros makes a great deal of sense, since the dead were supposed to drag the cursed person down into the underworld. In this con-

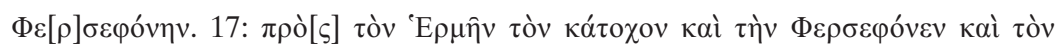
"Aı $\delta \eta v$.

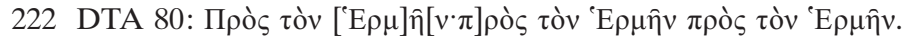

223 Graf 1996, 112. Curbera - Jordan 1998 translate pros as 'before.' Carastro 2006, 173 sees a connection between binding magic and civic life: "les katádesmoi étaient calqués sur des procédures courantes de la vie administrative en Grèce." Decidedly also Gordon 1999a.

224 Johnston 1999a, 73-74, n. 112 summarizes the discussion. Cf. Ogden 1999, 26 (with older literature).

225 Johnston 1999a, 74 in contrast to Parker 2005, 127-128, esp. n. 48, who emphasizes the importance of the dead's immobility.

226 Curbera - Jordan 1998. Cf. Johnston 1999a, 73-74, n. 112.

227 S.v. "pros," Liddell - Scott 1968, 1496-1497: "Prep., expressing directions, on the side of, in the direction of, hence c. gen., dat., and acc., from, at, to." In the curse tablets, the case used is accusative throughout; hence the definition on 1497: "WITH ACCUS., it expresses motion or direction towards an object."

228 Cf. Parker 2005, 126. In DTA 91 Hermes is characterized by two adjectives simultaneously, chthonios and katochos - that is, in his earthly, underworld, and restraining qualities. 
text, pros does not only mean 'in the presence of,' as exclusively rendered in the secondary literature; rather, in addition to its legal connotation, pros is used in the curse tablets in its very basic meaning denoting a downward direction. The translation offered by Gager-'I hand over X before/to the presence of Hermes ${ }^{229}$ — should thus be complemented by 'I write X down to/in a downward direction to Hermes.' Curbera and Jordan report that formulas with pros or para "followed by names of chthonians ... or by collective terms of them" are attested twenty-six times in the extant corpus of fourth-century Attic tablets; ${ }^{230}$ this amounts to roughly 10 percent. We can assume that pros has the same connotation in all instances where it is used. If this is the case, many tablets aim at sending their victims down to the underworld rather than merely registering them with the deities of the underworld. If this is true, the malevolent and morbid character of many early tablets is once more firmly established.

In the few "letters to the underworld," the preposition pros is unnecessary; the context is abundantly clear. The gods appear in the dative, for example, in the following judicial spell, where the letter is addressed to Hermes and Persephone: $:^{231}$

I am sending this letter to Hermes and Persephone, since I am presenting wicked people to them, for it is fitting for them to obtain the final penalty, O Justice/Dikê: Kallikratês son of Anaxikratês, Eudidaktos, Olympiodôros ... Theophilos ... Zôpuros Pasiôn Charinos, Kallenikos, Kineias ... Apollodôrus, Lusimachos, Philoklês, Dêmophilos and their associates and any other friend of theirs. Dêmokratês, the one going to court for the case: Mnêsimachos, Antiphilos.

The whole mental context of devoting one's victim to the underworld is not a uniquely Greek phenomenon. A parallel can be found in Mesopotamian curses, in which the dead also had the task of taking victims down to the underworld. ${ }^{232}$ Greece is not Mesopotamia, but the oriental evi-

229 Gager 1992, 20.

230 Curbera - Jordan 1998, 215.

231 DTA $103=$ Gager no. $38=$ Wilhelm 1904, 122-125 = SEG XXXVII $220=$

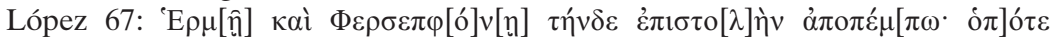

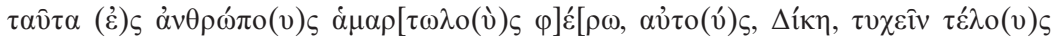

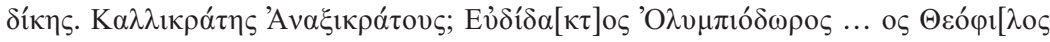

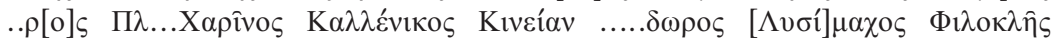

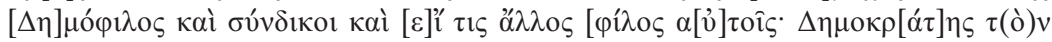

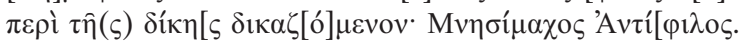

232 Johnston 1999a, 89. 
dence is valuable, for it shows that such an idea was not uncommon in the ancient world. It is likely that the Greeks borrowed this notion from the East. The epithet katochos, with which Hermes is often characterized on the tablets, ${ }^{233}$ offers an additional hint. Hermes katochos presses down, holds back, prevents the return of the dead. Katochos also means tombstone. $^{234}$

Regarding the magical act as a devotio often meant to be lethal, and considering the consequences of the spatial dimensions as expressed on the tablets, leads to a better understanding of who the agents involved, real and imaginary, actually were. In what follows, I would like to propose that the human and supra-human agents of magic rituals reflect some cultural practices of the Athenian judicial system and can even be regarded as being analogous to it.

Admittedly, the agents are not always specified on the tablets, or are unclear. The dead play a crucial role, although they are in most cases not directly invoked. The following pattern is, however, discernible: the early tablets were almost without exception buried in graves; the preferred dead were those who had been murdered (biaiothanatoi) or who had died prematurely (aôroi) before reaching life's major goals, mainly marriage and/or procreation. In the eyes of those surviving, these dead were deprived of social esteem and would, consequently, feel dishonored. Not having successfully completed the course of their lives, they were denied access to the underworld. Belonging neither to the upper nor to the underworld, they were doomed to hover in the liminal sphere between the world of the living and the world of the dead until a relative performed the appropriate rites on their behalf. ${ }^{235}$ What do these unhappy souls have to do with the chthonic deities invoked on the tablets? Some scholars have imagined the corpse to be a kind of postman, taking the tablet down to the gods and goddesses of the underworld. ${ }^{236}$ But why then would the agents of the curses invoke these deities? The ritual experts, the goêtes, manipulated the dead through addressing the gods. These professional sorcerers, often marginalized figures from out of

233 E.g., DTA 85; DTA $86=$ Gager no. 67; DTA $87=$ Gager no. $62=$ SEG XXXVII 216; DTA 88-91; DTA 93; DTA $100=$ SEG XXXVII $217=$ Versnel 1991a, 65-66; DTA $109=$ Gager no. 61; DTA 161.

234 L. Ganschinietz, s.v. "katochos," RE X, Stuttgart 1919, col. 2526-2534, 2533. To Eidinow 2007a, 147 Hermes katochos is basically an immobilizer.

235 Johnston 1999a, 127, 149-152 and passim.

236 Graf 1996, 115, 119. 
town, ${ }^{237}$ would have been responsible for handling the complicated verbal and non-verbal rites. These specialists knew how to deal with demons, gods, and the dead, which was especially uncomfortable. ${ }^{238}$

New theories of agency as developed by Johnston and Collins, which are based on a variety of source materials, elucidate these connections and confirm that psychopompic figures like Hecate and Hermes were supposed to trigger the chain of action and get the dead going against the victims of curses. ${ }^{239}$ Hermes was considered especially powerful, able to wake up a dead body and activate it. ${ }^{240}$ The dead were thus forced into action by the gods. ${ }^{241}$ These gods did not have to carry out the curse themselves, but had to register it and make sure that the restless spirits of the dead, often longing for revenge, would enact the spell. ${ }^{242}$ The task of the chthonic gods and daimones was one of mobilization and supervision.

237 According to Johnston 1999b, 99, goêteia came from the East. This fact and the circumstance that these foreign practitioners worked with the dead made them despicable. Similarly, Gordon 1999b, 231. Cf. below 222-223 on the unclear origins of Greek magic.

238 Johnston 2008, 14, 19-20; 1999a, 53-54, 83, 99, 103-120; 1999b, 84, 98-99 with the definition of the goês as a communicator between the living and the dead. Goêtes could also perform initiations into mystery cults and protect citiesi.e., they could also be hired by entire poleis (Johnston 1999b, 94). Voutiras 1998, 72 supposes that, by the middle of the fourth century, professionals must have been at work who collected formulas and materials and passed them on to the next generations.

239 According to Felton 2007, 90-92, Hecate especially is responsible for the restless dead.

240 I thank Bärbel Kramer (Trier) for drawing my attention to a new papyrus find, a fragment of Aeschylus' tragedy Psuchagôgoi (P. Köln III 125 = TGF III fr. 273a; cf. also TGF III fr. 273, 275), in which thirteen verses of a choral song hint at Odysseus' necromancy as described in Hom. Od.11.12-224, where the aôroi are also mentioned. The chorus of the psuchagôgoi, the servants of the oracle, descending from Hermes, help Odysseus in conjuring up Teiresias. Johnston 1999b, 84-85 also refers to Aeschylus' Psuchagôgoi. A similar scene is to be found in A. Pers. 623-651. It does not come as a surprise that in the new papyrus Hermes Chthonios and Zeus Chthonios (= Hades) are invoked (cf. also A. Ch. 727; S. Aj. 832; E. Alc. 743). Thus, the papyrus provides a direct literary link to similar invocations on Attic curse tablets. Cf. the psuchagôgoi in Plato below 216, n. 251. They lead the souls with the help of the gods.

241 Johnston 2008, 17; Johnston 1999a, 72-73 and passim; 1999b, 86-87. Similar Maggidis 2000, 90; Gager 1992, 118.

242 Felton 2007, 98 is convinced that ghosts were supposed to be able to kill. Parker 2005, 127 rightly emphasizes that the tablets were still deposited in graves, even if they do not mention chthonic powers. 
Consequently, it makes sense that only the gods are mentioned on the tablets, but not the dead. ${ }^{243}$

Sometimes the tablet was placed into the right hand of the corpse. ${ }^{244}$ If the dead person is not the transmitter of the tablet, but rather the executor of the spell, and if we assume that the curse tablet alone can represent the victim, we may hypothesize that the dead person is supposed to take the tablet, representing the victim, down with him into Hades, the final resting place of the ấros, where he or she was eager to go. From the texts alone we could only surmise that corpses were supposed to drag living people down into the underworld. The non-verbal ritual act, hinted at in the archaeological context, may have had priority over the written spell.

Is there additional proof that the transference of victims to the gods of the underworld implies death? Semantic considerations sustain the thesis presented so far. In an influential article on imprisonment in Athens, Hunter has investigated the semantics of binding in general without mentioning the connection to curse tablets. In the absence of a formal jail, Athenians relied on putting a suspect into chains and keeping him in a primitive building for several days until the judgment was rendered or the penalty executed, the most famous example being Socrates. Forcible

243 There are a few notable exceptions where the dead are mentioned: Gager no. 64 = DTA 55 = SGD 105 (indirectly); Gager no. 62 = DTA 87 (indirectly); DTA 99, 100, 102 = Gager no. 104; DTA 103; Ziebarth 1934a, pp. 1040-1042, no. 23; DT 52 = SEG XLIX 321 = Ziebarth 1899, pp. 118-120, no. $20=$ Wünsch 1900, p. 67 , no. 20 (third/second century BCE Attica); Gager no. $22=$ DT $68=$ Ziebarth 1899 , pp. $114-116$, no. $16=$ Wünsch 1900, p. 65 , no. 16; DT $69=$ Ziebarth 1899, pp. 116-117, no. 17 = Wünsch 1900, pp. 65-66, no. 17 (both from fourthcentury BCE Attica); SEG XXXVII 673 (from fourth/third century BCE Olbia); DT 43, 44 (Arcadia, third century BCE). Cf. Johnston 1999b, 87. Bravo 1987 passim overemphasizes the difference between the notions of the dead as immobile and those endowed with power and agency (a minority in the evidence). The Greeks did not have clear-cut notions of the dead. The fact that the accursed victim should become as motionless as the corpse in whose grave the curse tablet was buried does not preclude some agency on the part of the soul of the deceased. Bravo does not explain the exceptions away, where the dead show up as powerful figures (DTA 99, 100, 102, 103 [indirectly]), but attributes too much importance to quantifying considerations.

244 E.g., 1. Gager no. 105 = Peek 1941, pp. 91-93, no. 3 = Jeffery 1955, p. 75, no. 19 $=$ SGD $1=$ López $1=$ Ziebarth 1942, 19 (fifth century BCE); 2. López $2=$ SGD $2=$ Peek 1941, pp. 95-96, no. $6=$ Ziebarth 1942, 19-20 = Jeffery 1955, p. 75, no. 20 (fifth century BCE). Cf. Graf 1996, 119; Jordan 1988, 273-74. 
restraint as a systematic long-term punishment was not yet established. ${ }^{245}$ Hunter shows that the semantics of binding and imprisonment are mostly one and the same, with desmos, the action of binding, also meaning imprisonment. Consequently, the verb dein or katadein can mean both to bind and to put in prison. The most common word for prison, desmôtêrion, means nothing other than a place for binding. ${ }^{246}$

Who was bound in Athens and for what purpose? Most of the time, those who suffered being bound were debtors and criminals (kakourgoi) who had been given over to the Eleven (who also served as executioners), or had been summarily arrested by them (mostly killers, robbers, housebreakers, burglars, thieves, kidnappers, and clothes-snatchers). ${ }^{247}$ They awaited their trial or imminent execution. If a trial took place, the death penalty was often the verdict rendered. Binding by the Eleven, in fact, often preceded execution. This cultural practice of binding recurs on the curse tablets with the same semantics. This finding gives rise to several all-important questions: Why do the curses use the binding metaphor at all? What is its purpose? Why did Athenians not resort to different semantic fields, different forms of wishing adverse conditions and expressing harm, such as hanging, stoning, drowning, or burning? To begin with, verbs of binding evoked certain associations. They were supposed to put someone into fetters metaphorically. On the one hand, the metaphorical chains did not in themselves kill the target; on the other hand, applying them was only meant to be a preliminary step. Did the cursed victims await trial? Yes, in a twofold sense. Most curses were judicial spells and

245 Cf. the discussion in Harrison 1971, 241-244.

246 Hunter 1997, 308. Cf. s.v. "katadeô," Liddell - Scott 1968, 889. Athens seems to have been the first city to employ the binding metaphor in malign magic, which corroborates the thesis presented here. Not one of the earlier Sicilian curse tablets uses derivatives of binding, but of writing (e.g., katagraphô, engkatagraphô; cf. the corpora López Jimeno 1991; Arena 1989; Dubois 1989). The second oldest tablets hail from Athens. The fact that the famous Macedonian tablet from the fourth century refers to the writing metaphor further corroborates my thesis.

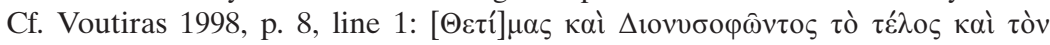

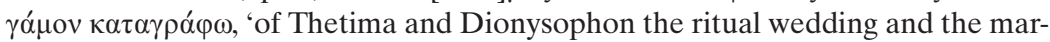
riage $\{$ I write down $\}$ by a written spell.' I have changed Voutiras' 'I bind' to 'I write down' because this is what the text actually says. That other cities followed the lead of Athens and later used the binding metaphor is only to be expected. A thorough geographical and chronological analysis of all verbs used in binding spells is a blatant gap in existing research.

247 Cf. Lys. 10.10; D. 24.204; Arist. Ath. 52.1. Cf. Ruiz 1994, 57 and Hansen 1976 on the various groups of kakourgoi. 
were deposited before real trials took place. The agent of the curse hoped for the most negative possible judgment against the opposing litigant. If the deposition did not refer to a lawsuit, the victim was to be bound metaphorically to face trial in front of the gods, first in front of the psychopompic figures of Hermes katochos, Hecate, and Persephone, and perhaps secondly before the judges in the underworld, typically Minos (who can be replaced by Triptolemus), Rhadamanthys, and Aeacus. ${ }^{248}$ Unlike in the courts of Athens, the juridical function in the realm of magic was split up between the psychopompic gods and the underworld judges, with the former deciding the fate of the accursed person in general. In accordance with the concept of loimos, the gods defined what katadô meant in each individual case and mobilized the dead to impose all kinds of adverse conditions on the intended targets of spells. If the psychopompic gods rendered a final verdict of death, they ordered the dead to lead the victims down into Hades, where the above-mentioned judges would decide further about the future of the newly deceased in the underworld. Like the Eleven, the dead fulfilled the executioner's function. From this perspective, the broad semantics of katadein not only means binding in the narrow sense of restraining or hindering someone by foiling his plans or business, but also evokes associations linked to imprisonment and preparation for execution. Consequently, verbs of binding may also point to imminent death. ${ }^{249}$ Thus we could say that the metaphorical binding by the curser is the preliminary action before the psychopompic gods convict the victim, and, if the verdict rendered is death, the dead carry out the execution. It was crucial that the person casting the spell did not perform the killing himself. Mediation of violence through intermediary agents was all-important. Hermes, Persephone, He-

248 Hom. Od.11.568; Pl. Ap.41a; Grg. 523e-524a. On Hades as judge, cf. A. Supp. 228-231; Eu. 273-275. Pl. Phd.107c-108b, 113d-114d takes a trial in the underworld for granted, which punishes the wicked and rewards the good. On the Totengericht, cf. Nilsson ${ }^{3} 1974,231,233 ;{ }^{4} 1976,821-822$. In prayers for justice, councils of judging gods are regularly mentioned (Versnel 2009, 29-30).

249 It must not be forgotten that the binding metaphor occurs in many more contexts, especially in Greek mythology with regard to the gods. They cannot be killed, but bound (cf. Collins 2008, 67-69; Carastro 2006, 178 with examples). Note that what is bound can also be loosened (Lib. 1.245-250; Eidinow 2007a, 151152; Carastro 2006, 180-181). The curser of SGD 18 (Athens, fourth century BCE) emphasizes that he does not intend to loosen his spell: $\kappa \alpha \tau \alpha \delta \hat{\omega} \ldots \kappa \alpha i$

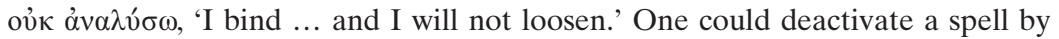
digging it up and unraveling it (Ogden 2008, 141). Arai could also be loosened (Versnel 2009, 33). 
cate, and their like stood in an intermediate and mediating position between the cursers and the executioners. Asking a panel of superior magistrates, in this case the psychopompic gods, for someone's execution was not the same thing as killing him personally or ordering an executioner to do the actual work. The dead fulfilled the function of the Eleven and conducted the victim off into the underworld, a grand metaphor for killing him on the command of the mighty psychopompic gods. The kata-verbs in combination with the preposition pros on some tablets (to hand someone down and over to someone else) are neatly parallel to the process of handing over the convicted person to the Eleven, whose task it was to lead the condemned away to their ultimate punishment. ${ }^{250}$

Which came first? Did the dead derive their function in curse tablets from the Eleven, or were the Eleven as executionary organs of the courts created after the model of the obedient dead who could not resist their godlike masters' cruel orders? With the agent of the curse representing the speaker in court, the accursed victim the opponent (curses were used by prosecutors and defendants alike), the psychopompic gods and underworld judges standing for the Athenian jurors, and the dead symbolizing the subordinate position and functions of the Eleven, the whole process of cursing stood in a certain analogy to the Athenian system of law. It is significant that the curse tablets originated from the judicial sphere. What peithô, the forceful persuasion of judges, was in the courtroom, verbal and non-verbal magical rites were in the process of cursing; the infernal gods had to be convinced of the opponent's wrongdoings. ${ }^{251}$ The incantations used were deeply embedded in rhetorical

250 This finding is in full accordance with what Johnston has demonstrated in her book (1999a): it is not the gods of the underworld themselves, but the corpse who takes the accused person down into Hades, upon the order of the chthonic deities who are invoked by the curser.

251 It is telling that $\mathrm{Pl}$. R. 364b-c uses the word peithô in characterizing the activities

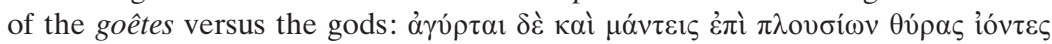

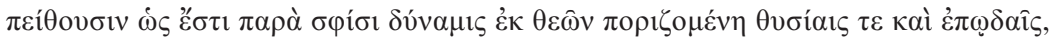

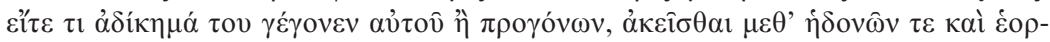

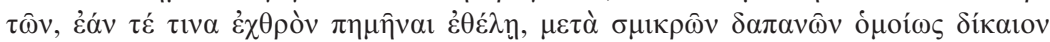

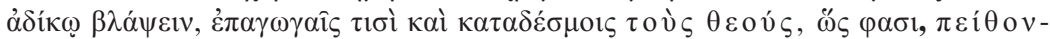
$\tau \dot{\varepsilon} \varsigma \sigma \varphi \imath \sigma \imath v \dot{v} \pi \eta \rho \varepsilon \tau \varepsilon \hat{\imath} v$, 'and begging priests and soothsayers go to rich men's doors and make them believe that they by means of sacrifices and incantations have accumulated a treasure of power from the gods that can expiate and cure with pleasurable festivals any misdeed of a man or his ancestors, and that if a man wishes to harm an enemy, at slight cost he will be enabled to injure just and unjust alike, since they are masters of spells and enchantments that fper- 
tropes and images. The notion of malign magic, created to hide one's own violent aggressions, worked effectively on the aggressors' behalf. By this cultural construction paradoxically, the violence performed was brought into line with the stringent rules of post-amnesty discourse. Forensic speeches and curse tablets are more akin to each other than hitherto thought. They are, in fact, two sides of the same coin.

The analogy between court and curse does not stop here, however. In many trials between the Athenian elite, the prosecutor pled for the death sentence or exile in order to get rid of his opponent. If many political trials could lead to the death penalty, and the same people who went to court also made use of curse tablets, we can assume that the cursers at least tolerated the potential death of the victims as a result of the spells, even if they did not explicitly call for the rivals' death. If the opposing litigant died before the trial, all the better. Much more likely, however, was his conviction in court. If the ultimate penalty was inflicted on the opponent, this "success" could be easily attributed to the curse. If the adversary was not killed via court sentence, the curser probably hoped that the spell would unleash its fatal power later on.

suade\} the gods to serve their end' (the verb 'constrain' in Shorey's translation is too strong). The goêtes have the power to persuade the gods to help them. We must not forget that the verb used here (ij $\pi \rho \varepsilon \tau \varepsilon i v)$ is related to $\dot{v} \pi \varepsilon$ $\rho \varepsilon^{\prime} \eta \varsigma$, which denotes the executioner in Attic legal language. Similarly clear is

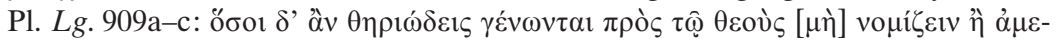

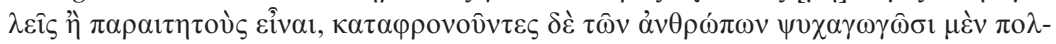

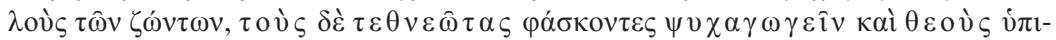

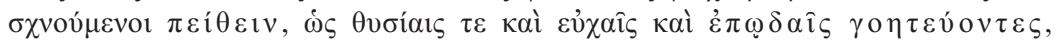

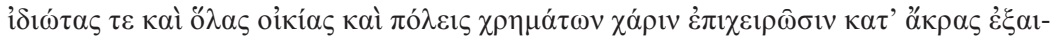

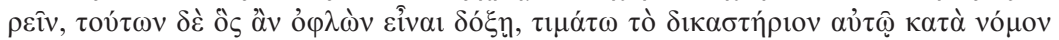

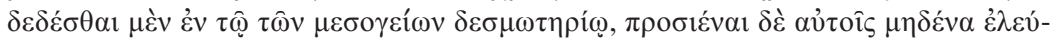

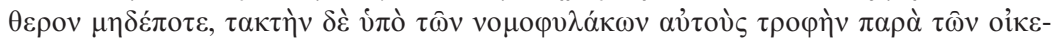

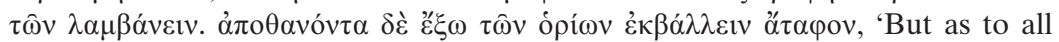
those who have become like ravening beasts, and who, besides holding that the gods are negligent or open to bribes, despise men, charming the souls of many of the living, and claiming that they charm the souls of the dead, and promising to persuade the gods by bewitching them, as it were, with sacrifices, prayers, and incantations, and who try thus to wreck utterly not only individuals, but whole families and States for the sake of money,if any of these men be pronounced guilty, the court shall order him to be imprisoned according to law in the mid-country gaol, and shall order that no free man shall approach such criminals at any time, and that they shall receive from the servants a ration of food as fixed by the Law-wardens. And he that dies shall be cast outside the borders without burial.' Pi. P. 4.219 explicitly mentions peithô in close connection to magic, too. 
It must be admitted that the analogy does not always work. The main divergence lies in the differing capabilities of a courtroom defendant and a cursed person to defend themselves. The accused could defend himself in court; the victim of a curse could not (in most cases, unless he resorted to a counter curse). Perhaps a person under a curse was thought to be able to defend himself in the presence of the judges of the underworld, but then it was already too late; he was already in Hades. In spite of this and other limitations of this model, the similarities seem to outweigh the discrepancies. In both forms of "accusation," violence was not exerted directly, a great advance in civilization to be sure, but rather was applied through intermediary stages. Dragging one's opponent to court and having him metaphorically dragged down to the underworld are both indirect forms of violence.

The notion of pollution corroborates the thesis presented so far. Faraone presupposes that people shrank away from killing opponents via curses because they wanted to avoid pollution (miasma), and therefore contented themselves with inhibiting their opponents by "binding." This assumption stands in stark contrast to Versnel's categorization of judicial prayers. Why was it permissible to curse someone to death through a prayer for justice, if miasma was so feared? By holding onto the traditional distinction between magic and religion, Versnel puts the curse tablets into the category of "magic" and the prayers for justice into the category of "religion." 52 At least with regard to violence, this strict dichotomy does not work. It does not seem logical that violence was permitted in religion, but was avoided in the realm of magic. If violence exerted via judicial prayers did not pollute, why should pollution have been a concern in binding spells? If pollution did not even constitute a problem in the religious sphere of prayers for justice, miasma for the commissioner of a curse was apparently a negligible concern in fourth-century binding magic.

Moreover, the agent of the curse did not kill in person but indirectly, by asking the psychopompic deities to order the dead to carry the victim away into the underworld. If the dead person took the victim down into his realm, there was no pollution for the curser. The different stages of casting a spell shielded him from the pollution that the accursed victim was supposed to incur through contact with the dead. Again, the analogy to the court system is striking. The curser was polluted as little as the

252 Versnel 1991b, 192 and now decidedly Versnel 2010, 337 (implicitly); 2009, 46 (explicitly). 
prosecutor who, pleading for the death penalty for his opponent, asked the judges to order the Eleven to execute the defendant. These two parallel social practices suggest that curse tablets mediated violence in ways that mirrored execution in the legal sphere. Mediated violence was still violence, and one wonders how it was integrated into the ideologically pacified polis. According to the archaic discourse on honor and shame, the offended party had to take revenge (timôria). Such discourses had a long life, as we have seen in chapter II, and Athenians were slow to give up their deep-rooted notions, some of them dating back to the pre-polis era. But at least officially they were willing to transfer the right of taking revenge to the state, which was the community of Athenian citizens assembled in the courts. ${ }^{253}$ It was not pollution that was at stake, but the avoidance of stasis to ensure the successful perpetuation of democracy after the amnesty of 404/03 BCE. Violence still existed under these restrained circumstances, and the aggrieved parties were eager to exert it, but it was only tolerable in its mediated form through courts or the deities of the underworld and the dead. Ideally, the perpetration of violence became inextricably tied to the consent of the majority of judges, the dikastai, or the gods of the underworld. The suppression of violence on the level of interaction was not without consequences for the level of representation, the level of discourses. Athenians were careful not to portray violence in its most open and brutal forms. Exceptions confirm the rule and bear special significance.

Other ancient evidence suggests that magic was often held responsible for failure in the business world or in court, unexpected illnesses, and, most of all, inexplicable deaths. ${ }^{254}$ In the Roman world, the famous passing away of Germanicus was readily ascribed to the fatal impact of binding magic. ${ }^{255}$ A Roman soldier mourning for his wife in third-century CE Africa explained her fatal illness beginning with muteness and her sudden death by considering malign magic only. ${ }^{256}$ There is a huge chronological and cultural gap between fourth-century BCE Athens and the late Roman Empire, but it is at least possible that death could also be ex-

253 Fisher 1998a, 92.

254 Graf 2007b; Graf 1996, 129, 147-152. Cf., e.g., Cic. Brut. 60.217; Orat. 37.129; Hieronymus, Vita S. Hilarionis eremitae 12.9; 21.

255 Tac. Ann. 2.69.3; D.C. 57.18.9. Cf. Graf 1996, 148, 247, n. 153 (with more sources).

256 CIL VIII $2756=$ Gager no. 136. CIL VI $19747=$ ILS 8522 reports the death of a girl through magic. 
plained by spells in ancient Greece at the dawn of Western magic. If true, curse tablets were always thought to be potentially destructive and lethal in their effects.

Athenian literary texts confirm the thesis as laid out so far. In a famous passage in his Laws, Plato talks explicitly about the nefarious effects of magic, and uses a highly differentiated vocabulary ${ }^{257}$ to put magic into the context of violence and murder. ${ }^{258}$ In ancient Greek, pharmakon can mean medicine, poison, enchanted potion, philter, or magical spell. ${ }^{259}$ Plato carefully separates and parallels these different meanings. He postulates a law about pharmaka: ${ }^{260}$ if a doctor kills someone with a pharmakon, he will be executed. If the same accident happens to a layman, he will pay a fine or be punished otherwise. The same holds true for malign magic: professional sorcerers are supposed to suffer the death penalty; unprofessional people dabbling with magic get away with a fine. ${ }^{261}$ This is not a law against magic, and indeed, we do not know of any such law from classical Greece forbidding binding spells, ${ }^{262}$ but Plato at least condemned the social practice ${ }^{263}$ and wished for the lawgiver to crack down on those who made a living by instilling fear in other people. ${ }^{264}$ The explicit parallel between a lethal pharmakon in the form of medicine and a curse suggests that at least Plato thought about magic as potentially fatal. Just as in Rome, murder via magic was probably categorized as murder by poisoning in Athenian law. ${ }^{265}$ Plato could not prove the inefficacy of magic. There is even evidence that he (and also the authors of the Hippocratic corpus) did not question the premises on which magic was based; ${ }^{266}$ thus he partook of a magical worldview, but felt at least compelled to encourage the lawgiver to prohibit the practice in the law code.

257 Pl. Lg. 933a-e. = Gager no. 141. Plato uses three derivates of peithô in this paragraph. Although he does not use them in reference to the gods (as in 216, n. 251 above) but concerning the victims of spells, their commissioners, and the general public, we see again the importance of the concept of peithô in magic.

258 Cf. Ogden 1999, 72.

259 S.v. "pharmakon," Liddell - Scott 1968, 1917.

260 Pl. Lg. 933d-e.

261 Cf. Baroja 1982, 74.

262 Ogden 1999, 83.

263 Faraone 1989, 159.

264 Pl. Lg. 909a-c.

265 Cf. Parker 2005, 132-133.

266 Collins 2008, 33, 42-43. 
Plato was not against magic only because it disturbed the souls of superstitious people. Underneath his criticism, the notion of body and society as parallel entities was at work. This notion permeates all of classical Athenian literature. The body of the Athenian citizen symbolized society as a whole. In his microcosm he embodied the macrocosm of the polis. Since the citizen represented not only his oikos, but also the polis at large and its democratic principles, concern for his body reflected concern about society. If the body of a male citizen was attacked, the whole city was affected. Whoever violated the body of a citizen, and as such democracy itself, committed the hubris of a tyrant. It is no wonder that the relation of bodily symbolism to the social and political structure is typical of the magical worldview. From this perspective, even the mediated violence of magic was dangerous for the polis and therefore unacceptable to Plato. Thus, he makes the violent and destructive force of magic abundantly clear. $^{267}$

The commissioner of a binding spell, in contrast, might have regarded malign magic as the last or only resort in his struggle against an opponent. What if one could not come to terms, even in procedures of arbitration, with a neighbor whom he felt to be evil and ruthless and perhaps so powerful that he would assuredly win the case in court? In the eyes of the allegedly disadvantaged, damaged, and suffering person, this oppressive neighbor may have become a tyrant-like figure who, in a hybristic, barbarian, and anti-democratic way, had done him wrong and who therefore deserved to be cast out by a magical spell. In the opinion of the curser, the accursed target was to be "ostracized" by magic and driven out of the community, similar to a scapegoat, because of his wrongdoings. ${ }^{268}$ Once more the connection between binding magic and the law courts is clear. From the speaker's perspective, the images of the target in binding magic and that of the opponent in court were similar, and in the case of judicial spells the persons under attack in the two procedures were indeed one and the same.

267 It is interesting to note that the perception of binding magic as destructive and even lethal has a long tradition in older and continental research. Kagarow discerns three functions of transfixing the tablets and dolls with nails, one of them being "die Zufügung von Schmerz und Tod" (Kagarow 1929, 15). Bernand dedicates a whole chapter of his book to death inflicted by curse tablets (Bernand 1991, 315-317). Bernand 1991, 315: "les souhaits de mort abondent dans ces maledictions haineuses." Similar Baroja 1982, 73.

268 On the idea of the scapegoat in court, cf. above 127, n. 471. Parker 1983, 194 speaks of "social ostracism" as a consequence of a curse. 
In this chapter, I have argued that more curses than hitherto thought were meant to be brutal and destructive. In some cases, the cursers wished for the death of their victims. Nonetheless, there were many relatively harmless tablets that merely sought to reduce a rival to poverty by hampering his or her business. ${ }^{269}$ The curse tablets thus do not have one consistent meaning. According to circumstances and the individual temperaments of the cursers, the broad semantics of binding resulted in a wide spectrum of possible intentions, ranging from impeding one's opponent to wishing his ultimate demise. The destructive character of the spells is already discernable in the early spells.

\section{Diachronic Development}

The practice of depositing curse tablets fits so well into the Athenian cosmos that one wonders where binding magic originated. The Greeks themselves were convinced that the techniques of goêteia came from the East. ${ }^{270}$ And there is no doubt indeed that there were precursors in Eastern cultures. Numerous scholars have tried to track down the lines of cultural borrowings from East to West, but chronological details and lines of transmission have proven elusive. ${ }^{271}$ Scholars agree that many Eastern cultures (Hittites, ${ }^{272}$ Sumero-Accadians, ${ }^{273}$ Egyptians, Jews ${ }^{274}$ ) had an impact on Greek notions and practices of magic, but there are no precise models for curse tablets like those in Athens among these cultures. ${ }^{275}$

269 Trumpf 1958, 102.

270 Johnston 1999a, 118.

271 Faraone 1992, 85.

272 Cf. Ogden 1999, 81.

273 King 1975 has published prayers from Assurbanipal's archive (669-625 BCE) which go back to Babylonian models. Johnston 1999a, 89 mentions that cursing in Mesopotamia depended on the dead, who had the task of leading the victims down into the underworld, a belief very similar to Greek notions. On Babylonian and Assyrian influence, cf. Ogden 1999, 80; Graf 1996, 249, n. 178 (with bibliography on magic in Mesopotamia).

274 Cf. Ogden 1999, 81; Gager 1992, 26-27.

275 Johnston 1999a, 119. Luck 2000, 211-213 and Graf 1996, 154-157 succinctly describe the praeludium in the East. Faraone 1988, 155-222 bases a considerable part of his dissertation on Eastern (Mesopotamian and Egyptian) practices, without which Greek magic cannot be understood. The contributions to Meyer Mirecki 1995 firmly integrate oriental magic into the general picture of "ancient magic." 
With regard to Egypt, it is important to note that Egyptian magicians had a "working relationship" with the dead. ${ }^{276}$ The Greeks changed their attitude toward the dead during the late archaic period, when notions about the dead began to privilege the idea that they were capable of significant interaction with the living. The dead were therefore distanced from the living and secluded to cemeteries outside towns. The new belief that some ritual experts, the goêtes, could conjure them up and make them work on their clients' behalf paved the way for the binding spells. ${ }^{277} \mathrm{Nev}$ ertheless, the comparison especially between Greek and Egyptian letters to the dead is far-fetched, despite some common features. ${ }^{278}$ One can speak of a cultural "cross-fertilisation" and a "magical koinê," but the emergence of a kind of malign magic in other earlier cultures does not necessarily mean that the Greeks just adopted it. ${ }^{279}$ Before the fifth century, the political, social, economic, and mental conditions in mainland Greece were not yet conducive to this cultural practice. It is also possible that the defixiones were, first of all, a Greek invention. ${ }^{280}$ Some ritual practices must have been in use before magoi arrived from the East, to whom necromantic, magical, and purificatory activities could be ascribed in a complex process of acculturation. ${ }^{281}$

Around 400 BCE we suddenly obtain ample archaeological evidence for curse tablets in Athens, although the practice must have been known at least fifty years earlier. ${ }^{282}$ It is no mere accident that the curse tablets

276 Luck 2000, 212-213: "Egyptian spells are very similar to the ones found in the papyri of the Roman imperial period, and they reflect the same way of thinking, although perhaps on an earlier level."

277 Johnston 1999a, 31, 71, 80-83, 85, 95 and passim.

278 Johnston 1999a, 91-93. Gager 1992, 27 lays open differences between Eastern and Graeco-Roman magical practices.

279 Ogden 1999, 79.

280 According to Gordon 1987, 78, magic emerged in sixth-century BCE Ionia and had originally nothing to do with the Persians. To Versnel 2009, 27, 41, binding magic may have originated in Greece, but could have been influenced by oriental concepts in proto-historical times.

281 Carastro 2006, 188. Because many itinerant practitioners came from the East and, as foreigners, encountered mistrust, Gordon 1999b, 191-194 aptly characterizes magic as the "transgressive Other." Cf. also Gordon 1987, 72-73.

282 Cf. Aeschylus' binding song (hymnos desmios) in Eu. 305-396 (458 BCE) and Faraone 1985. Cf. Johnston 1999a, 71. The burgeoning mass production of curse tablets from around 400 BCE on was a new phenomenon. Stratton 2007, 39-69 connects the emergence of binding magic to Pericles' citizenship law issued 451 BCE. This law increased male anxieties about the legitimacy of children and put additional pressure on women who often may not have had re- 
became more widespread at the end of the fifth century. Apart from growing literacy, ${ }^{283}$ the revision and new codification of the laws and measures refining democratic procedures, like the introduction of the nomothesia, as well as the amnesty of 404/03 BCE, crucially altered the Athenian discourse on democracy. In this chapter, it has been my intention to show that the violence discourse was firmly embedded in the general discourse on democracy. Any change in the latter had a profound impact on the former. The modifications that the now more civil democratic discourse underwent at the end of the fifth century necessitated the existence of binding magic and curse tablets in the particular form we find them preserved-that is, with relatively tame language on the surface but great underlying aggressions. ${ }^{284}$ The curse tablets arose in close con-

course to any means of action other than magic. Similarly, Bernard 1991, 32. Nilsson ${ }^{4} 1976,801$ thinks that curse tablets existed prior to the fifth century. In Sicily they do, but for Athens we do not have any evidence. Eidinow 2007a, 231-232; 2007b passim neatly contextualizes the uncertainty the Athenians faced at the beginning of the fourth century, with the defeat in the Peloponnesian War, the plague, two failed oligarchic coups, etc. While these circumstances help explain the soaring number of tablets deposited around $400 \mathrm{BCE}$, they do not account for the use of malign magic during the fifth century and later in the fourth century.

283 E.g., Nilsson ${ }^{4} 1976,803$. That growing literacy cannot be the only reason for the increasing length of the tablets is clear once we look at other epigraphic genres. Whereas lengthy laws were codified in the archaic period (i. e., prior to the emergence of the curse tablets), we find short funeral inscriptions much later. Further evidence demonstrates that longer texts were firmly established by the fifth century and that, therefore, the curse tablets cannot be short merely because of a lack of literary culture. Solon's kurbeis stood in the Agora. The Ekklêsia's agenda was posted near the monument of the tribal heroes. Peisistratus had the Homeric epics recited at the Panathenaea. Alcibiades allegedly slapped his teacher because he did not have an edition of Homer available (Plu. Alc. 7.1). Antiphon wrote treatises in the style of the sophists and made rhetorical experiments in his tetralogies. Herodotus and Thucydides wrote historical master narratives. So, if the Athenians had wanted, they could have written long curse tablets in the fifth and fourth centuries. What is new in the fourth century, however, is the growing awareness of and reflection on literalization and its inherent problems, as evinced, e.g., by Plato's critique of rhetoric. On all these issues, cf. Pébarthe 2006.

284 This thesis helps explain the alleged clash between the civic democratic discourse and the malevolent wishes in binding magic. Bernand 1991, 77 is right in postulating a high level of violence in the defixiones, but cannot bring it together with the Athenian ideology of rationality, moderation, and self-restraint: "Pour lier, il faut déployer une force en quelque sorte surhumaine et montrer un acharnement qui n'a rien à voir avec la pondération, la modération qui sied au 
nection to the law courts. ${ }^{285}$ And we could add that the spells were not only used in parallel with court proceedings, but could also function as the introduction to and continuation of lawsuits by different means before and after the formal start and ending of a trial.

The early tablets from the fourth century exhibit laconic language, a verb of binding (mostly katadeô), and an accusative object. A lengthy enumeration of malicious harms was incompatible with the new civil violence discourse. Early tablets were so terse not merely because they stood at the beginning of a long evolution; their succinctness was partly owed to the new democratic discourse. Moderation and self-restraint (enkrateia) were the chief principles and demanded that the same pose be taken in daily life and in all media that expressed emotions. ${ }^{286}$ We see similar tendencies in vase painting, where German scholars speak of Dämpfung, ${ }^{287}$ and in tomb reliefs. ${ }^{28}$ As in the forensic speeches, where we have seen how tricky a business the verbalization of violence was, aggression is to be found beneath the surface. Some researchers have been deceived by the mild and moderate language in forensic speeches and curse tablets. Under the surface of these allegedly harmless texts, however, there are hidden structures of underlying aggression.

Later generations did not have to observe such restrictions, for they could give free rein to their aggressions. Under Macedonian rule, with competition among citizens subsiding, agonistic binding magic lost some of its cultural relevance. Enkrateia and sôphrosunê, the democratic virtues par excellence that had artificially restrained the language of the earlier tablets, lost their normative power. These virtues, at least on the surface, had permeated the language of the older tablets. Now these restraining principles gave way and allowed room for more explicitly brutal curse tablets. Thus the verbosity of later tablets may have less to do with a

citoyen policé. Cette sagessse, cette honnêteté, cette convivialité, cette mesure, cette modestie que les auteurs grecs reconnaissent à leur clients disparaissent au profit d'une brutalité quasi bestial."

285 Faraone 1985, 153-154 clearly sees a close connection between judicial spells, the court practice, and politics.

286 Cf. Parker 1983, 189 on the virtue of aidôs. On enkrateia, cf. above 132, n. 496.

287 Muth 2005 with a critique of the concept. Cf. above 162, n. 591.

288 Cf. above 112, n. 382. From 317-307 BCE Demetrius of Phaleron regulated Athenian private life more than ever before by introducing gunaikonomoi and nomophulakes. Cf. O’Sullivan 2009, 66-86 and above 162, n. 592. 
"chatty" Hellenism ${ }^{289}$ than with flexible practices of discourse that changed under different political circumstances. An evolutionary model (from the early laconic tablets to the detailed Hellenistic tablets) does not work. ${ }^{290}$ It simplifies a complex development and may be inaccurate in its generalizations. ${ }^{291}$

If the restrained language on Attic tablets has to do with specific political circumstances in Athens and its discursive practices, a counterproof would be desirable. Are curse tablets from other poleis more explicitly violent? This question is difficult to answer, because many more tablets seem to have been written at Athens than anywhere else, or so at least the available evidence suggests. Research will have to continue, and the verbal usage of all tablets currently published will have to be scrutinized. What a first glance at the material can tell us is already promising, however. The majority of tablets from outside Athens follow Athens' lead in restraining violent language, which does not contradict the hypothesis proposed here, because Athens always served as a model for other poleis and was imitated in many ways. Moreover, some tablets from Athens are also quite brutal, as we have seen. Apart from these, we do have some explicitly violent tablets from outside Athens. DT 92 from the third-century BCE Chersonese, for example, and SGD 104 from fifth-century BCE Selinous use traditional curse formulas, which demonstrate once more how closely related arai and defixiones are. The famous fourth-century marriage spell from Macedonia employs such unabashedly open and detailed language that one may doubt that an Athenian of the fifth or fourth century BCE would have used a similarly individualized manner of expression. ${ }^{292}$ Despite its explicitness, the Macedonian spell does not use the binding formula, but a derivate of 'writing'

289 Faraone 1991a, 5 seeks the reason for the increasing verbosity in the "gradual spread of literacy in the classical period." This is correct, but does not wholly explain the complex phenomenon. On the alleged trend toward growing literacy, cf. above 224, n. 283.

290 Ankarloo - Clark 1999, xv do not take into account the changed practices of discourse. They trace the development in almost teleological terms.

291 Parker 2005, 131-132 remains agnostic about the chronological development.

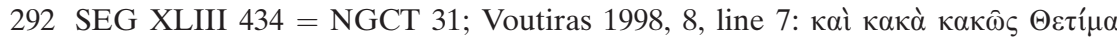
ג̇ó́ $\eta \tau \alpha$, 'and wretched Thetima perishes miserably.' It does not come as a surprise that in Hor. Epod. 5 the boy who is supposed to be killed by witches curses Canidia and her colleagues in a most brutal way. Lucan's witch Erichtho may be the most horrible figure of ancient literature (Luc. 6.413-830). These texts could not be further removed from Attic restraint. Cf. also Sen. Med. 6-23, 670-843. 
(katagraphô), which corroborates my thesis that the idea of binding in cursing is originally Athenian and evoked Athenian legal procedures.

Although ritual actions and the spoken word never lost their crucial function for the successful performance of the spell, a remarkable shift is recognizable over time, the literalization of magical language. ${ }^{293}$ At the beginning of the development, the performative aspect of the spell probably had priority over the written word. Since the performance itself lent power and thrust to the curse, written language could be restrained, regardless of any accompanying words or thoughts. So, agents of curses deliberately avoided language specifying violence in agreement with trends in prevalent civic discourse, at least as preserved in forensic oratory and at least as far as the written word in magic is concerned, which means that we cannot gauge the intensity of the curses just by examining the length of the texts. By Hellenistic and Roman times, longer texts promised to be more effective than the early laconic spells.

\section{Conclusion}

Depositing a curse tablet was the most ritualized form of perpetrating violence indirectly in ancient Athens. A correct assessment of how violent binding spells were could only be made by the ancient agents of curses themselves. Notwithstanding this caveat, the vocabulary of at least ten percent of the extant tablets suggests that, at the very least, these tablets are more violent and malicious than hitherto thought. It is also true, however, that most tablets did not aim at the death of the victim, but merely at incapacitating him or her. But even in these seemingly harmless cases, the destructive potential underneath the surface of the texts, with their broad semantics, should not be underestimated. The whole spectrum of malign intentions-from lethal curses to spells that are meant merely to impede a victim's activities - tells us a lot about Athenian society. Like in the forensic speeches, we also find in the curse tablets the tension expressed between the old, Homeric violence discourse and the new, dem-

293 According to J. Assmann 2000, 166, the process of literalization leads to the deritualization (Entritualisierung) and de-theatricalization (Enttheatralisierung) of religion. Cf. above 28, n. 35 and 146, n. 551 with Assmann's findings in a different context. If we follow Carastro 2006, 180, who understands writing itself as a performative act, the line between spoken and written language should not be drawn that sharply. 
ocratic one. The fact that a range of violent feelings was enacted in and through the tablets makes it clear that these two contradictory discourses overlapped. The tablets that wish to call down death and destruction on their victims embody the aristocratic pre-polis discourse. Most cursers, however, had already internalized the new ideology of self-restraint and moderation. They only spoke of 'binding,' whatever that may have entailed. Under the changed circumstances of post-amnesty Athens, living up to the Homeric warrior ideal was no longer possible. The good citizen was now the temperate citizen who embraced sôphrosunê and enkrateia, like Pericles and Demosthenes, two outstanding men who certainly shaped public opinion. Respecting the amnesty and its underlying notions of bloodless conflict resolution through the courts became the prime political agenda of the day. Old values and discourses, however, had a long life and continued to permeate the emotional world of most Athenians, upper and lower classes alike. In order to restore and maintain democracy, the elite-who, as the social centers of society, were always at the forefront in developing and disseminating new ideas and fashions-shaped the new civic and civil polis-discourse without being able to live in full accordance with it. Too powerful still were the traditional ideologemes of vengeance and brutal competition that were played out in court and curses.

Like the law courts, the curse tablets were one way of coming to terms with aggressions potentially dangerous to society. What the language of slander and character vilification was in the courtroom, metaphorically violent language was on the tablets. To us, both linguistic modes seem irrational and highly subjective, but to the Athenians, they were better than the uncontrolled, private, and direct use of violence. ${ }^{294}$ The new discourse on moderation and self-control had a profound impact on the language inscribed on the early tablets by making them sound tem-

294 In fact, the irrationality of the lawcourt system (cf. above 138, n. 529) explains the rationale that the Athenians obviously saw behind behind binding magic. Gordon 1999a, 262-263: "the judicial curse as a genre fits particularly well into the Athenian legal system prior to Demetrius of Phaleron. The object of this legal system was not to attain 'justice' in any abstract sense but to measure against one other before a mass public two theses or claims about a given situation or allegation, in order to judge which seemed more convincing or preferable (cf. Todd 1993: 88). In a system of this kind, in which there were no legal 'experts' let alone professional judges, and in which the law was whatever the judges decided it was, the outcome of a case was quite unpredictable ... In a word, it was the irrationality of the Athenian judicial system that underwrote the rationality of the curse." 
perate and restrained. In this way, they fit in well with the new civil discourse of the democratic polis that instilled in all the sources we have preserved a posture of self-restraint. But underneath the surface of an allegedly mild and moderate language lurked a high degree of aggression and inclination toward violence in the curses as well as forensic speeches. Deceived by the relatively calm language of fourth-century sources, many nineteenth-century scholars, and even some of today's classicists, have postulated a peaceful Athens, thus idealizing a historical period that was, in reality, much harsher.

As in the law courts, so in the realm of magic the final decision to exert violence was left to a higher authority. Even in their clandestine, treacherous character, from the contemporaries' point of view, the curse tablets were dedicated to the basic premise of democracy, that is, to surrender the ultimate decision about exerting violence to a sanctioning collective. Only a community - in court, the lay judges, in the realm of magic, the psychopompic gods of the underworld-could justify, authorize, and legitimize the use of violence in the democracy. We see again processes of performative negotiations. Like the Athenian jurors, who, on the basis of cultural presuppositions, decided what kind of behavior figured as hubris in a particular case, the psychopompic gods determined if and how katadeô was supposed to harm the victim in each individual situation. The semantics of violence was always open at first. It was only after performative, juridical entreaties and magical invocations that real and imaginary authorized agents negotiated and ultimately defined the exact significance, meaning, and applicability of violence in rituals, for which the Athenians provided public and semi-secret venues. Against this backdrop of leaving the power of definition to higher authorities, semantic openness no longer appears as vagueness, but as a strategy to persuade the judging powers of one's own legitimate cause for taking action against the opponent. By granting the human and divine judges considerable leeway, the speakers in court and the agents of curses respected the ultimate authority of superior collectives.

Curses and court procedures, to come full circle, were indeed the continuation of conflicts with different means. Both could be lethal in rare cases. Both mediated violence but remained based on the desire for revenge and pursuing one's enemies. Both involved pacifying rituals that could also exacerbate conflicts. Both could reduce violence or contribute to the escalation of a conflict, but, in the majority of the cases, they did the first, because we know that Athens was a stable society. And since both were more or less successful, we can say that both were highly am- 
biguous, even paradoxical, forms of exerting violence and resolving conflict. The potential of violence inscribed in binding magic was higher than that of forensic speeches. Since defixiones were semi-secret supplements to the law courts, one could at least wish in malign magic what one could not openly say in court. And since rich and poor resorted to binding spells, magic was socially more all-encompassing than the court culture. Semi-secret and institutionalized restraint of violence, in both cases ritualized, was necessary. Athens' uniqueness partly lies in the fact that its citizens put great trust and faith in the ritual practice of conflict resolution, and so Athens proceeded with great consequence on the path that it had entered with the introduction of ostracism in the fifth century. ${ }^{295}$

We see once again that the curse tablets were closely connected to the court system, and as such to democracy, since, to the Athenians, the courts embodied the democracy. In the superficially domesticated atmosphere of a refined democracy, especially after 404/03, the curse tablets pushed problematic emotions, mostly the desire for revenge, away from the public limelight into the realm of magic, thereby becoming a political, social, and psychological necessity. Psychological interpretations like that of Malinowski, however, have been criticized in research, because they hypothesize about ancient individuals' minds, to which we do not have access. ${ }^{296}$ If we understand the deposition of a curse tablet as a full-fledged ritual, however, our knowledge of what rituals can do might shed some light on an ancient curser's mindset.

The healing function of binding rituals for the agent of the curse lay in the expression of anger, wrath, and envy in formulaic form. Binding spells probably functioned as outlets for aggression and were thus an efficacious means of anger control. Since the individual and the polis were so closely connected, with the one defining itself through the other, the tablets may have played their role in hedging in troublesome emotions, an action that

295 Further research will have to show if there is a connection between ostracism falling out of use by $418 \mathrm{BCE}$ and the emergence of the curse tablets at around the same time. The similarities between inscribing a lead plate for deposition in a grave and inscribing a shard for deposition in an urn deserve more detailed treatment.

296 Malinowski 1974 has emphasized the emotional stress that an individual is keen to overcome by magic. This psychological interpretation has been fiercely criticized, mainly by sociologists. Winkler 1990 worked out the psychological dimensions of attraction spells that were, according to him, a projection of the tormented lover's desires. Cf. above 198, n. 164. 
contributed to maintaining the stability of the Athenian social and political fabric.

In addition, rituals draw invisible boundaries. In the case of binding magic, the agents of a curse drew a sharp line between themselves and their victims, who were to be devoted to the gods of the underworld and cast out of human society. Inclusion and exclusion were clearly expressed. The curser invoked and enacted his own alliance with the gods and the dead, whereas the victim was assigned to the wrath of the aôroi and the chthonic deities. Thus, the victim was removed or at least distanced from the world of the living. It was precisely through excluding one's opponent that the cursers could feel safer and more integrated into their own community. We have seen that the ritualistic performance of forensic speeches fulfilled similar functions. But how exactly might these strategies of exclusion have worked in the case of magic?

In the realm of magic, everything depended on one's point of view. As we have seen, Athenians differentiated between their own use of violence, deemed legitimate, and that of their opponent, regarded as illegitimate. Curse tablets, if detected or known to have been deposited, would have been removed immediately from the tomb of a family member. The fact that someone had abused the tomb of a relative for magical purposes must have caused deep resentment and anger. Moreover, anthropological evidence suggests that if the victim got to know that he or she was cursed, serious disturbance might have followed, which was part of the spell's envisioned effect. The agent of the curse, in contrast, might have felt relief after depositing a tablet, and, even more so, if his or her curse became known and was showing some effect. Thus, the curser successfully exerted power over his opponent and felt himself to be the stronger party in the never-ending contest for social prestige. If the spell worked, regardless of how long it might take, one knew that the aôroi and at least some of the psychopompic gods had supported one's cause and punished the opponent. One not only felt safely embedded in one's community, but also in harmony with supra-human forces. The ritual had worked; the cosmos was in order. For the successful agent of a curse, personal pride and a feeling of strength must have resulted from this ritual, and may explain, in part, why the magical rites of binding spells were performed for many centuries.

Behind the individual's personal wish to bring about an opponent's demise or harm lay the collective's intention to maintain or restore social equilibrium: no one, it was thought, should be able to rise above the rest of the community. In the highly egalitarian society of democratic Athens, 
anti-social malign magic, ${ }^{297}$ a form of cheating, ${ }^{298}$ was still social and accepted in the sense that a curser who thought of himself as disadvantaged and bullied by an opponent could seek to redress justice in his sense parallel to and outside of the existing court system by resorting to magic. Although magic is by default non-normative, no law forbade a person to resort to magic in classical Athens, mainly because, ultimately, a sanctioning of the aggressive act by higher powers was built into the process. Moreover, spell and counter-spell, like prosecution and defense, ensured the reciprocity of resentment and ill-feelings. ${ }^{299}$ In the end, magical spells did not endanger the maintenance of society, a feature that is in line with the stabilizing function of other rituals of conflict resolution.

Especially if one does not subscribe to this admittedly speculative reconstruction of the curser's feelings, one should take the ritual approach one step further: binding spells may not only have been safety valves for disconcerted individual temperaments, but, in the case of democratic Athens, for a whole society under the pressure of avoiding open, especially retaliatory, violence after the amnesty of 404/03BCE. ${ }^{300}$ Although the deposition of a curse tablet was a form of violence, it was deemed better than attacking one's opponent physically, because it was a mediated, indirect form of violence (like going to court). Hiring a goês to do the actual work was an additional level of mediation. The consequence is paradoxical. According to the official ideology, citizens should cope with their aggressions in a non-violent manner. The curse tablets strove for mediated violence, and although even mediated violence is violence in both our and the ancient Athenians' understanding, the mediation of violence achieved through magic was permissible and obviously in the interest of the polis community. Notwithstanding Plato's recommendation to punish profes-

297 Maggidis 2000, 99 lists literary sources that all sharply criticize the use of magic: Heraclitus of Ephesus (Clem. Al. Protr. 2.22); Gorgias (Diels ${ }^{9} 1959,82$ B 11, 10); Pl. R. 364b-c; Lg. 932e-933e; Men. 80b2-7; Hp. Morb.Sacr. 2. To Versnel 2009, 12-13, 42 and Gordon 1987, 73 binding magic was predominantly anti-social.

298 Cf. Gordon 1999b, 211 with many literary sources that firmly establish the link between goêteia and deceit.

299 A good example from fourth-century Attica is to be found in Jordan 1999, 117, side A. Amulets and charms can of course also be protective and healing (cf., e.g., Plu. Per. 38; Pl. Chrm. 155e-156c). NGCT 24 = SEG XLIX 320 curses back ( $\alpha \tau \tau \iota \kappa \alpha \tau \alpha \delta \varepsilon \sigma \mu \varepsilon v ́ \omega)$.

300 Carawan 1998, 135, 284. 
sional sorcerers, Athenian democracy, unlike Rome, ${ }^{301}$ never passed laws to prohibit magical practices. ${ }^{302}$ The mere façade of not exerting violence oneself was enough to be in line with the stipulations of the amnesty.

In sum, what we get out of the curse tablets deepens and crucially alters our understanding of classical Athens by offering new avenues of interpretation that challenge traditional views-for example, the opinion held by some legal historians that Athens was a relatively familiar, rational society, in which the rule of law held uncontested sway. Yes, Athenians were rational and mostly law-abiding, and tried to deal with violence primarily through a sophisticated system of laws and arbitration in which they relied on evidence and persuasive argumentation, but at the same time they looked not only upward to the Olympian gods, but also downward to the gods of the underworld. They believed not only in freedom within the citizen class, but also in transferring fellow citizens to the gods of Hades, alongside, but also beyond, the judicial sphere. Binding magic can thus be regarded as a supplement, but also as an antithesis to the emerging lawcourt system. The transition from a blood-feud society to one that refers vengeance to the courts of law is enshrined in one of the greatest tragedies of world literature, the Oresteia. Furies haunt the kin-killer Orestes in curse language, but through Athena's creation of the Areopagos the Furies are transformed into benign spirits. The acquittal of the kin-killer through the gods paves the way for the institutional

301 As early as the XII tables, the Roman state persecuted the use of magic. During the Roman Republic, masses of veneficii were executed (Gordon 1999b, 254255). Nothing like this practice is known from the Greek world.

302 Possibly unlike other Greek city states, Athens did not crack down on magical practices. Cf. the humorous anecdote in Pl. Men. 80b5-7, according to which Socrates would have been expelled as a magician (goês) in any other city but Athens, if he had been a metic. Athens' leniency toward magic might explain the high number of curse tablets from Athens (Maggidis 2000, 100). Thus, Plato's harsh stance might be more in line with the attitude in other poleis than with that of Athens. At the same time however, the city of Teos did not put cursing the city by means of pharmaka under a legal prohibition, but under the protection of an ara (Gordon 1999b, 245). There was no Athenian law specifically directed against magic (Voutiras 1998, 58), but if an Athenian wanted to file charges on grounds of having been impaired by magic, he could probably opt for either a dikê blabês, a graphê asebeias, or, in the case of a dead relative or attempted murder, a dikê phonou (Gordon 1999b, 248-250; Voutiras 1998, 49-58 with sources). Theoris of Lemnos, allegedly a witch, was found guilty in a graphê asebeias and was executed (D. 25.79-80; Plu. Dem. 14; Philochorus FGrHist 328 F 60 ; cf. Collins 2001). The priestess of Sabazius, Nino, probably faced trial under the same charge and was also executed (D. 19.281). 
renunciation of retaliatory violence. Is it mere coincidence that the curse tablets spring up at precisely the time when the new aetiological myth of the Areopagos explains the much older reform of this very law court and the replacement of deadly vengeance with a vengeance that consisted of state-issued punishment ${ }^{303}$ Does this convergence suggest that the awareness of a crucial judicial reform drove private revenge underground, literally? Read this way, the tablets shed light, however indirectly, on a core text of Greek literature, but most of all, they also open up new perspectives on the process of civilization at Athens, a process that remained highly complex and ambiguous.

303 This is not the place to discuss the chronology of when the Areopagos was entrusted with homicide jurisdiction and when the state-issued death penalty came into being, but it seems fair to assume that some of the Areopagos' competences, especially hearing homicide cases, predate the archonship of Solon (594/93 BCE; Plu. Sol. 19.3-4) and that Solon may have introduced the idea of capital punishment meted out by the state. Cf. the discussions in Schmitz 2001; Carawan 1998, 133-135; Wallace 1985, 3-69; Gagarin 1981, 5-29, 70, 125-132, 135-137; Ruschenbusch 1960. 


\title{
IV. Old and New Comedy
}

\author{
Aristophanes' books, divine \\ production, \\ over which green Acharnian ivy waves, \\ how much Dionysus your page holds! \\ How your tales echo, filled with fearful \\ graces! \\ O comic writer, o far best in spirit, \\ your hate, your laughter, matched the \\ ways of Hellas. \\ (-Antipater of Thessalonike, Anth. \\ Pal. 9.186, transl. Reckford 1987, 437)
}

Athenians enacted discourses on violence in the performative genres of forensic speeches, curse tablets, and drama. Although comedy lacked the consequentiality of the law courts and binding magic-that is, it did not commit mediated violence against an opponent-it nevertheless performed violence on stage and therefore gives us invaluable insight into Athenian perceptions of violence. Comedy also needs to be treated in detail, regardless of the fact that its speech acts are fictional in contrast to those of lawcourt speeches and binding curses.

The staging of a drama in the holy precinct of Dionysus was as sacred as the performance of a ritual of binding magic ${ }^{1}$ and as worldly as the performance of a speech in the courtroom or in the Assembly of the People. The ancients already recognized this tension, or rather this interdependence, between the cultic functions of theater and its role as entertainment. The characterization of Attic drama as 'having nothing to do

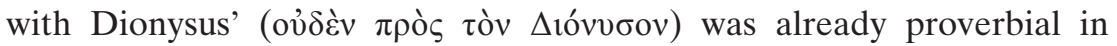
late antiquity, though the origin of the proverb is unknown. ${ }^{2}$ Csapo and Miller see Attic drama as situated between two poles: on the one hand

1 Murray 1943, 46 speaks of a ludus sacer even with reference to New Comedy.

2 Zen. 5.40 (Paroem. Gr. I 137.10; Suda o 806); cf. Diogenian. 7.18 (289.11). Cf. Pickard-Cambridge 1927, 166-168 on the unclear provenance of the proverb. The Athenians realized that their dramatic performances were quite detached from Dionysiac contents; the profane side of the theater emerged more and more during the late fifth century. Exceptions like Euripides' Bacchae confirm the rule. On the dionysiac or un-dionysiac character of tragedy, cf. Bierl 1991, $4-8$. 
there is ritual proper with its efficacy-we will come back to the meaning of "efficacy" in this context shortly-on the other hand there is theater "as we know it" with its almost exclusive focus on entertainment. In order to characterize Attic drama appropriately in its peculiar position between these extremes, Csapo and Miller opt for the felicitous expression "ritual-drama," as created by anthropology. ${ }^{3}$ Schechner and Turner have stressed time and again this peculiar interconnectedness as being typical of "real-life" Social Dramas and cultural performances (stage dramas). ${ }^{4}$ The relationship of drama to forensic speeches is thus clear. Whereas drama emphasizes the entertainment aspect without giving up the ritual aspect, deliberative speeches are more concerned with ritual efficacy without giving up their position as entertainment. ${ }^{5}$ Following Csapo's and Miller's terminology, we could also speak of the speeches as "dramatic rituals." This is not to deny the fundamental difference between the fictional speech acts as uttered in Athenian tragedies and comedies and those uttered in forensic speeches with their claim to truthfulness, but both forms of expression performed discourses on violence within ritual frames and thus lend themselves to comparison.

In contrast to tragedy, which used heroic myth to comment on societal problems, Old and New Comedy reflected contemporary Athenian life in however distorted a form and dramatized corporeal violence onstage. For this reason, this chapter focuses on the representation of violence on the comic stage and examines how violence is to be seen in the perform-

3 Csapo - Miller 2007b, 4. Balme 1998, 29 rightly remarks that the labeling of a performance as ritual or theater mainly depends on its functions and context.

4 MacDowell 1995, 2 identifies four parts that make up a successful ancient theatrical performance: "tone of voice" (speaking of words), "stage action," theatrical equipment in the form of costumes and scenery, and music, including the singing and dancing of the chorus. Cf. Gänszle 2000, 41-42 with a concise definition of performance; Turner 1989b, 141-42. Turner 1984, 25 talks about the convergence of Social and aesthetic drama. The evolution of Social Dramas is contained in aesthetic dramas; conversely, the rhetoric of Social Dramas is taken from cultural dramas. Cf. also Schechner 1977, 75-77. On the notion of the Social Drama, cf. above 14, n. 70.

5 The fundamental similarities between speeches and drama have frequently been pointed out. Cf., e.g., above 22, n. 2 and 31, n. 49. Harris - Leão - Rhodes 2010 emphasize the interconnectedness of law courts and drama. As Harris points out in his introductory chapter, the Athenian citizens had ample experience in both; the law courts and theater influenced each other. Burckhardt 1924 has already emphasized the close connection between comedy and the genre of dêmêgoria regarding vocabulary, style, and thoughts. 
ative context of comedy. Having explored in the previous chapters how rituals restrained violence and ascribed sense to it, thus making it comprehensible in forensic speeches and binding magic, I will further analyze, in this section, the functions that violence fulfilled in comedy, and how and what kind of meaning violence assumed through the ritual context of performance. The comedies of Aristophanes and Menander have often been compared on general levels, beginning in antiquity, but have not yet been examined in terms of their representations of violence. ${ }^{6}$ This chapter seeks to overcome the narrow concentration on the rape motif, especially in the case of New Comedy, ${ }^{7}$ and to interpret all major forms of violence in Old and New Comedy. I intend to explore whether or not violence on the comic stage follows the discursive rules as established in chapter II. This undertaking entails the phenomenological interpretation of anti-structural elements, as they are typical of the liminal phase of a ritual process, in this case slapstick scenes, rape, and violence as perpetrated in the context of kômoi (festive processions). Anger and hubris need to be considered first, for they often precede and accompany acts of violence in real life and comic fiction. In the case of Aristophanes, Wasps, Birds, and Clouds showcase violence more intensively than any of his other comedies. These three plays will thus serve as case studies.

All eleven Aristophanic comedies, Menander's completely preserved Dyscolus (316 BCE), his Samia (314 BCE?), and the following larger fragments dealing with violence will be subjected to scrutiny: Epitrepontes, Periceiromene, Misoumenos, Perinthia, Georgos, Heros, Colax, and Phasma. The numerous fragments of the later Old, Middle, and early New Comedy will also be considered, but to a minor extent, owing to the lack of context. In the restricted frame of this chapter, it is not possible to address every instance of violence in these plays; rather, a more overarching and broad survey will set up Old Comedy as a foil against which to analyze New Comedy, and so to demonstrate the profound change in the dramatic treatment of violence that occurred between Aristophanes and Menander.

6 Cf. above 111-113 on the representation of violence.

7 But cf. also Sommerstein 1998a, 105-109 with a list of all rape scenes in Aristophanes. 


\section{Ritual Framing}

When speaking of theater as a ritual, scholars hold widely different concepts, which we have to address briefly, one by one, before tackling the topic of violence on the Athenian comic stage. Unlike in the case of forensic speeches, comedy might have some of its roots in ritual origins, harking back to primordial times with animal-like heroes who disguised themselves with masks and made it their practice to insult people, especially high-ranking individuals (aischrologia). ${ }^{8}$ This question of ritual origins has only tangential bearing on the topic of this book. Nevertheless, it needs to be briefly addressed in any chapter dealing with theater and ritual (ritual origins). The second big issue is the interpretation of theatrical performance, as a whole, as ritual. Through the embeddedness of the performance in religious rites, the hypothesis that theater works like a largescale ritual (i.e., theater production as ritual process) is relatively easy to show. The question of what kind of efficacy (i. e., ritual efficacy) this specific ritual might have had needs to be addressed separately. The assumption that certain plot motifs could be ritualistic, as hypothesized by the adherents of ritual poetics, a new trend in Classics, is plausible, but need not concern us in the context of this book, because it does not contribute to the overall understanding of violence on the comic stage.

\section{Ritual Origins}

The relationship between Greek drama and ritual is highly complex and hotly debated. Although the following interpretation of violence performed on the comic stage will be concerned with the ritual functions

8 In Aristophanes, the most famous example is the attacks on Cleon in Knights, directed against Paphlagon in the play: Ar. Eq. 247-254 (chorus with exhortation to use violence), 304-312 (chorus), and 285-302, 367-374, 691-725, and 902-940, where the Sausage Seller and Paphlagon heap insults on each other with extremely violent language. The debate whether or not this abusive language is derived from the iambographic tradition cannot be reiterated here. Suffice it to say that Bowie 2002 is skeptical about this link (abuse took place in many different contexts, public and private), whereas Degani 1993; 1987 and Rosen 1988 see a clear affinity between comedy's invective and that of the iambographic tradition, a connection that the audience, too, must have acknowledged. Zanetto 2001 is more careful and takes up a position between that of Bowie and Degani/Rosen. 
of comedy as a whole on a synchronic level, a brief overview of ritual studies as far as they pertain to the origins of Greek drama may be appropriate here to contextualize the ensuing outline of other ritual layers contained in comedy. The historic origins of tragedy and comedy are shrouded in darkness and have given rise to many theories and speculations. ${ }^{9}$ The point of departure for any investigation are Corinthian and Attic vase paintings depicting Dionysiac scenes with maenads, satyrs, and the so-called padded dancers, ${ }^{10}$ and, especially, Aristotle's vague statements in his Poetics. Although Aristotle traces the origins of tragedy to dithyrambs, and comedy to phallic songs ${ }^{11}$ — both ritual cult events in the honor of Dionysus-many questions remain unanswered. How must we envision the transition from cult action to full-fledged drama with a sophisticated fictional plot ? $^{12}$ The picture is even more complicated because Aristotle offers competing theories on the origins of theater. In his time already, Greeks did not remember them any longer, so various regions and cities claimed to have invented tragedy and comedy. The Dorians of the Peloponnese derived the word "comedy" not from the Athenian kômos, kômazein (reveling in Dionysiac processions), but from the word kômai (villages). Hence, "comic" actors got their name from wandering through villages. In addition, the Dorians pointed to dialectal differences. The Dorian word for acting is drân, whereas the Athenians used prattein. Hence, according to the Dorians, the word "drama" must have evolved from the Doric form. Megarians claimed that drama developed

9 Stark 2004, 46-65 gives an overview of German theories on the emergence of Greek comedy.

10 Stark 2004, 66-88, 97-102; 1995 passim interprets the padded dancers as beggars and sees comedy as derived from the derision of these beggars during symposia. Her denial that comedy might have had any Dionysiac origins (esp. 2004, 29-30) is untenable (cf. Bierl 2011a). More careful on the unknown identity of the padded dancers is Breitholtz 1960, 127-81. Cf. now, on a broad archaeological basis, the contributions to Csapo - Miller 2007a, esp. Smith 2007; Green 2007; Hedreen 2007.

11 Arist. Po. 1449a5-12.

12 Brask - Morgan 1988 have suggested an explanation for the quantum leap from primitive ritual to sophisticated theater from an anthropological perspective. It would be no coincidence that theater emerged simultaneously with the birth of democracy (i.e., a refined state society). Theater would have evolved out of prior communal rituals and conveyed to the public a canon of values from the state's perspective. Thus, theater served as a means of social control and thought-conditioning, with the goal of maintaining the social order. As intriguing as this theory might seem, it cannot be overlooked that Old Comedy does not communicate consistent patterns of sense. 
during their democracy, whereas Sicilians built their claim on the early poet Epicharmus. ${ }^{13}$

The first systematic investigation into the ritual origins of drama was done by a group of British researchers, later called the "Cambridge ritualists." Based on Sir James Frazer's monumental book The Golden Bough, the team around Jane Harrison, Gilbert Murray, and others made extensive use of cross-cultural material to explore in greater depth than ever before the complex relationship between myth and ritual. ${ }^{14}$ Within this context, the study of Greek drama, too, and above all the vexed question of its ritual origins, was of paramount interest to these classicists. ${ }^{15}$ The results of the enormous amount of research conducted by the ritualists at the beginning of the twentieth century were well received by the general public, but regarded with suspicion by many of their colleagues in Classical Studies. Connecting and even embedding Greek culture in "primitive" and tribal rituals of other, often non-European peoples, dethroned the Greeks from the unique, lofty position they had held in contemporary idealism. Criticism was sharp. As early as 1927, Pickard-Cambridge formulated the most negative response to the group's theories in his magisterial Dithyramb, Tragedy, and Com$e d y$. The Greeks, he claimed, have to be understood in Greek terms, within their own culture; their achievements cannot be explained by gleaning evidence from other cultures. The debate subsided during World War II, but from the 1960s on there has been a renewed interest in the relationship between Attic drama and rituals. After the traumatic experiences of two World Wars, the Vietnam War, and racism shattering the United States, an ever more painfully felt alienation of the individual from the collectivity led many people, and especially academics (mainly anthropologists, sociologists, and dramatists), to search for new communal experiences and their appropriate forms of expression. A growing awareness

13 Arist. Po. 1448a25-1448b3. On these origins in detail, cf. Storey 2010, 179-184. Csapo - Miller 2007a have brought the historical dimension of comedy's ritual origins to the forefront again. Kerkhof 2001 confirms Aristotle's report that Epicharmus did in fact exert decisive influence on Attic comedy.

14 Versnel 1993, 20-48 provides an excellent overview of the Cambridge school, including the criticism they received. Ackermann 1991 gives an intellectual history of the main players of the group. Calder III 1991 offers a good introduction to the works of the Cambridge group in his edited volume. Arlen 1990 provides a useful bibliographical overview of the work of Harrison, Murray, Cornford, and Cook.

15 Most eminently Cornford ${ }^{2} 1961$. 
of an exaggerated rationality stemming from the growing degree of industrialization and technocracy in the Western world added to this phenomenon. Whether or not these intellectuals found satisfaction for these yearnings in the environmentalist movement or New Age groups, what all these endeavors had in common was the underlying quest for a new romanticism and a happier life more in tune with one's instincts, communal feelings, and corporeality. From the distance of more than a generation after the upheavals of the late 1960s, the so-called '68-movement, with all its exaggerations and unfulfilled claims, its successes and failures, can be assessed more rationally, and its approaches compared and even combined with intellectual movements from previous periods. Some assumptions of the Cambridge ritualists seem outdated today-not everything can be traced back to rituals-but many tenets have remained valid, most of all that we are still far from fully understanding the ritual implications of Greek drama. ${ }^{16}$ Although the Cambridge ritualists' alleged Euro- and Hellenocentrism are incompatible with the theoretical demands of post-colonial studies for a more just world order, and although the old ritualists' narrowing of the gap between Greek and other ancient cultures does not seem narrow enough today, ${ }^{17}$ the time has come for a more unbiased re-evaluation of the British scholars' endeavors. Since ancient literature is steeped in ritual and mythical patterns, scholars adhering to "New Ritualism" find these very patterns the appropriate heuristic tools for coming to a deeper understanding of literary works that were originally designed for performance on the occasion of religious festivals in semi-oral societies. ${ }^{18} \mathrm{New}$ Ritualism has turned its at-

16 Schechner 1988, 1-5, 15 rejects the Cambridge ritualists' basic theses outright and argues that drama has less to do with rituals than with performance. Therefore, he maintains, the origins of drama cannot be derived from rituals. Nevertheless, Schechner did not tire of pointing out, time and again, the inseparable relationship between performance and ritual on a synchronic level. Both belong to the binary system consisting of efficacy (ritual) and entertainment (theater). He calls the continuum of this system "performance." Since ritual has the inherent tendency to become theater, and theater has the inherent tendency to become ritual, theater can be understood as the interconnection of efficacy and entertainment. Cf. Schechner 1990, 96, 102; 1977, 68, 76-90 with his description of the relationship between efficacy and entertainment as a "braid": "wherever we look, and no matter how far back, theatre is a mixture, a braid of entertainment and ritual" (93). Köpping 2003 gives a concise overview of the current communis opinio on the relationship between ritual and theater.

17 On the history of the scholarship, cf. Csapo - Miller 2007b, 1-8.

18 Bierl 2007a, 5, 51-53. 
tention away from the unanswerable questions of the origins of theater, ${ }^{19}$ and has instead sought to reveal ritual structures within tragedy and comedy on a synchronic level. In the foreground now are questions as to what extent, how, and to what purpose the playwrights incorporated and transformed mythical and ritual material into tragedies and comedies. The variety of approaches is dazzling: whole ritual sequences can underlie plays, and rituals or parts of rituals can be staged and distorted, parodied, or only alluded to. ${ }^{20}$ Whereas scholars working on these phenomena speak of the ritualization on the micro-level (i.e., internal structure) of the plays, ${ }^{21}$ I will not be concerned with the inherent ritual structure of comedy, but will rather regard theater performance, as a whole, as a ritual, and probe into the question of what this means for the violence discourse.

The fruits of this new surge in ritual studies have been so great that some scholars today discern a new sub-field in Classical Studies: ritual poetics. $^{22}$ Most recently, even the vexed question of the ritual origins of Greek drama has been revived, ${ }^{23}$ not without incurring the fierce resist-

19 Cf., e.g., Krummen 1998, 325, who argues that the analysis of ritual actions in tragedy is to be separated from the question of origins.

20 On ritual and mythical patterns in comedy, cf., e. g., Scholten 2006; Kotini 2005; Goff 2004, esp. 359-370; Sfyroeras 2004; 1992; Bierl 2002b; 2001; 1994; LadaRichards 1999; Riu 1999; Nesselrath 1995; Bowie 1993; Marianetti 1993; Aronen 1992; Versnel 1993; 1992; Henderson 1991; R. Hoffman 1989; Craik 1987; Martin 1987; Paradiso 1987; Reckford 1987; Zannini Quirini 1987; Auger 1979; Hofmann 1976. Paradigmatic, but with all generalizations typical of the Cambridge ritualists, is Murray 1943, who claims that the old Dionysiac fertility cult remains alive in Menander in the form of the weddings (gamoi) celebrated at the ends of the plays.

21 Bierl 2009a, 14, 254-261, 337 speaks of the whole synesthetic event comprising rhythmic movements, rhythmic-metric texts characterized by metaphors, metonymies, alliterations, and metaphors that render the text poetic and ritualistic (I refer to the English translation of Bierl's German original from 2001). Cf. Gänszle 2000, 37-39 and above 182-188 on the ritualized language (microstructure) as used in curse tablets and orations.

22 Explicitly Bierl 2007a, 51-53; Bierl - Lämmle - Wesselmann 2007 passim; Yatromanolakis - Roilos 2003 and 2004.

23 Csapo - Miller 2007a; indirectly, Rothwell 2007, who argues that animal choruses originally stemmed from the context of aristocratic, symposiastic kômoi, but soon adopted civilizing functions. A good point of departure for the study of the archaeological evidence for animal choruses is still Sifakis 1971, 73-93. Stark 2004 describes in detail the development of the political comedy of types as practiced in Athens as the exception to the more common social comedy of types, as typical elsewhere in the Greek world. Graf 1998b gives a succinct overview of the research on the origins of theater, including a discussion of the relevant lit- 
ance of scholars who attempt to refute altogether the ritualistic approach to clarifying the origins of theater. ${ }^{24}$ The debate is ongoing and livelier than ever.

\section{Theater Production as Ritual Process}

Within the Dionysiac festivals of the Lenaea and the Great Dionysia, the theater performance as a whole can indeed be understood as a civic ritual. ${ }^{25}$ The demarcation of a certain space and time was key in defining a certain action as ritual. This holds true for meetings of the Assembly, the Council, and the law courts, for the deposition of a curse tablet, as well as for the performance of a stage drama. The festive context of the Lenaea and the City Dionysia, during which and only during which comedies were performed, does not have to be rehearsed here. ${ }^{26}$

Rites of separation insulated the spectators from their daily lives in terms of space and time. The theater of Dionysus on the south slope of the Acropolis is surrounded by sanctuaries on the north and south. ${ }^{27}$ This sacral-topographical embeddedness meant for the Athenians that,

erary sources. He parallels drama and ritual in a way similar to that of Schechner. Now, from an even broader perspective, cf. Graf 2007a. In his magisterial study, Adrados 1975 dared to raise the question of origins again, and has tried to give a universal answer encompassing the origins of tragedy, comedy, and satyr play as all stemming from agricultural rites. Following Pickard-Cambridge, Adrados does not believe in the usefulness of cross-cultural material to illuminate the Greek case. It is only after establishing his theories that he is willing to put his findings into the larger context of ritual and theater outside of Greece (369-450).

24 Stark 2004, 97-102; Rozik 2002; Friedrich 1983.

25 Riu 1999; Goldhill 1990.

26 Cf. the extensive coverage of the Athenian festivals by, e.g., Bierl 2011b, 37-57; Parker 2005, 155-384; von Möllendorff 2002, 49-53; Pickard-Cambridge ${ }^{3} 1988$, 25-42, 57-101; Parke 1977, 104-106, 125-135; Deubner ${ }^{3} 1969,124-131$, 139142. Goldhill 1990 points out in detail three civic rituals that were also part of the Great Dionysia: the allies' tributes were brought onto the stage for display, the honors for those who had benefited the city were read aloud, and the young adult orphans, whose fathers had died in war and whom the state had brought up at its own expense, marched into the orchêstra clad in full hoplite armor. This expression of civic ideology and hegemonic power could not have been more ritualized.

27 Nielsen 2002 scrutinizes all known sanctuaries that comprised theaters, which she rightly calls "cultic theatres," where ritual dramas were also performed. On the theater of Dionysus as cultic theater, cf. Nielsen 2002, 112-120. 
coming from the Agora and flocking into the theater, they left behind the profane area of their routine business and entered a sacred space-at least during the festivals-in which a spectacle in honor of Dionysus would take place. The staging of the plays was partly understood as cult action, and participation in them as a kind of religious service to the god Dionysus, thought present in the form of a cult statue, which may have been put up in the holy precinct south of the orchêstra, if not in the theater itself. ${ }^{28}$ In addition, special seats were reserved for the priests of Dionysus in the prohedria, that is, in the front row of the koilon, especially for the priest of Dionysus Eleuthereus in the center of the front row. ${ }^{29}$ Perhaps it is not inappropriate to speak paradoxically of a secularized service. The performances took place on the occasion of the aforementioned festivals, which were marked off from daily life. The sacrifice of bulls before the beginning of the dithyrambs on the first day of the Dionysia separated, in a way visible to all, the festive realm of the theater from the secular world of daily life in terms of space and time. Even before this large-scale ritual slaughter, a peristiarch may have purified the theater by sacrificing a piglet and carrying it around, thus drawing a ritual frame around the holy and, through the ritual act, sacralized precinct. ${ }^{30}$ In the ensuing liminal phase, during the performance of the plays, the Athenians became witnesses of extraordinary spectacles. Detached from their ordinary lives, the spectators felt like parts of a larger whole, a cultural communitas. The plays themselves surrounded spectators with anti-structural and ludic elements, the so-called Other World (Ital. il mondo alla rovescia), in which daily life configurations were no longer valid, or were even turned upside down. In the realm of fiction, alternative actions were tried out, social values were problematized, anti-worlds constructed and discussed, a comic hero's rise and downfall depicted. ${ }^{31}$ Thus, the limi-

28 Pickard-Cambridge ${ }^{3} 1988,60,67$ (with discussion of the sources).

29 Ar. R. 297; Pickard Cambridge ${ }^{3} 1988,268$; 1946, 141-143.

30 Moulinier 1952, 101 (with discussion of the sources). On the same practice before meetings of the Ekklêsia, cf. Bers 1994, 176 and above 23-24, nn. 3-9. Cole 2004, 48 stresses the sociological function of this circumambulatory ritual. It created order and drew a visual boundary indicating who belonged to the ingroup and who did not. Wiles 2000, 43 combines the idea of ritual purification with the catharsis that was to be achieved in attending the performance of a dramatic spectacle. Schechner 1977, 110-11, 119 has a sharp eye for the religious edifices, altars, purification rituals, and sacrifices that converted a secular and profane area into a sacral space.

31 Cf. Turner 1988, 24, 76, 82, 92-94; 1984, 25-26, 40. Cf. on this aspect especially Zimmermann ${ }^{2} 2006,34$ and Kenner 1970, 97-98 on the topsy-turvy world as en- 
nal phase created by the performances enabled reflection on the highest level possible. Theater was a medium of reflection and, hence, also reflection about violence. From a methodological point of view, however, it must be noted that, in comedy, we primarily grasp aesthetically motivated mechanisms. Because of their fictional character, comedies can be read as historical documents only with great care and a considerable caveat; we will have to come back to the partly anti-mimetic and non-referential character of comedy. Nevertheless, the comedies of Aristophanes, with their strong elements of theatrical self-awareness, today called metatheatricality, ${ }^{32}$ and their references to the polis, however indirect, and those of Menander, with their explicit references to Athenian daily life, are closer to "reality" than tragedy, which, as a mimetic art form with a much more closed fictional world to display, is firmly anchored in Greek heroic

visioned in Frogs. In the topsy-turvy world of the theater, enabled by Dionysiac license, escapist fantasies and utopias could be tried out. On utopias in Aristophanes, cf. Farioli 2001; Zeitlin 1999; Versnel 1998b; Dobrov 1997; Hubbard 1997; Konstan 1997; 1995, 15-90; Rösler - Zimmermann 1991; Corsini 1987; Bertelli 1983; Heberlein 1980, 117-82; Zimmermann 1983 (repr. 1991), with a poignant critique of Schwinge 1977. Cf. also Cartledge 1990, 54-62 on e(u)topias and outopias, and Auger 1979 with regard to utopia and female figures in Aristophanes. On the highly sophisticated discourse on utopias also in other playwrights of Old Comedy, cf. Ruffell 2000. Important Athenian festivals staging the "otherworldliness" were the Anthesteria, Kronia, Haloa, Thesmophoria, and Skira (cf. Bierl 2004, 6). Cf. Versnel 1993, 90-135 on the Kronia, 229-288 on the Thesmophoria and the Roman festival for Bona Dea (extended version of Versnel 1992; cf. also Versnel 2006, 322 speaking of the Thesmophoria as a "ritual of exception and of role reversal"), and 136-227 on the Roman Saturnalia. On the Thesmophoria as ritual background for the chorus in Aristophanes' Thesmophoriazusae, cf. Bierl 2009a, esp. 249-254. By taking Thesmophoriazusae as a case study, Tzanetou 2002 explicates that Athenians were more aware of the close affinity between ritual and theatrical performance than we are.

32 Good points of departure for metatheatricality in Aristophanes are still Muecke 1977 and Dover 1972, 55-59. Chapman 1983 describes the means by which Aristophanes frequently ruptures the dramatic illusion of his plays. N. Slater 2002, 236-239 emphasizes the pre-eminent role that metatheatricality plays in teaching the Athenian dêmos the staginess in all areas of life, especially politics. On the reciprocal communication between Aristophanes and his audience, cf. N. Slater 1999. For the purpose of this study, Slater's consideration is valuable in so far as we can postulate that the same metatheatrical features also help the spectators to penetrate the intricacies of violence. Cf. Bierl 2009a, 220-223; 1991, 172-176 on the metatheatrical Dionysus in Aristophanes' parody of Euripides' Helena in Thesmophoriazusae; cf. Gutzwiller 2000 for Menander. 
myth. ${ }^{33}$ Just as in the dicastic courts and in the Assembly, the central role of the dêmos is also recognizable in theater: it watched its own hopes and anxieties, joys and worries, re-created and transformed onstage in invented plots. The comedies are thus indispensable sources for a comprehensive study of cultural phenomena, mentalities, and discourses, not least those about violence.

If we accept the basic premise that the performance of Attic drama as a whole operated like a ritual, we can deduce that it also fulfilled many of the functions of a ritual, especially that of opening up room for reflection within its liminal sphere. The violence discourse is embedded within the ritual macro-structure of the theatrical performance. Thus, the spectators, by watching a play and its performed discourses, simultaneously participated in the overarching civic ritual of the Lenaea and Great Dionysia. With the non-fictive theater performance as a whole encompassing the fictive stage action, symbolic meaning was ascribed to all actions onstage, including scenes of violence. ${ }^{34}$ As a result, the condensed situation of social communication onstage was charged with a high amount of expressiveness. $^{35}$

Many of the citizens attending theatrical performances served as judges in court. Through the appellative character of theater, they were indirectly called upon to adjudicate the fictive happenings on stage and decipher the symbolic meaning of violence and conflict that the theatrical performance negotiated on a kind of meta-level, ${ }^{36}$ not unlike the "real" occurrences that were negotiated in court. In both courtroom speeches

33 Cf. above 3, n. 14.

34 Turner 1989b, 174 speaks about ritual as the orchestralization of symbolic actions.

35 Cf. Köpping - Rao 2000, 7 summarizing Turner and Geertz.

36 Dramas were performed in the context of a theatrical contest. As with every competition, judges were required. For the dramatic agônes the procedure worked as follows: several men represented each of the ten tribes (how this first selection process worked is unknown); their names were put in ten urns; before the first performance, the archon drew one name out of each urn so that ten men represented each of the ten tribes; these ten men drawn by lot were called to judge the quality of the plays, and each inscribed his decision on a tablet, which was again placed in an urn; the archon then randomly picked out five tablets, on the basis of which the victor was determined and the awards granted (cf. Pickard-Cambridge 1953, 96-100 on the complex procedure). In voting, the judges certainly also took into consideration the reaction of the audience to the various plays. As a consequence, the playwrights' work had to appeal to the whole dêmos. 
and drama, the reception was guided by rhetoric and the orator's, logographer's, or playwright's intentions underlying the more or less fictional plot. As modern readers of the texts, we are equally called upon to make sense of the scenes of violence. We are at a crucial disadvantage, however, in so far as we no longer have access to the Athenian repertoire of cultural images and meanings, and the performance context is lost to us. I think that the discursive line, as established in chapter II of this book, can be applied as a heuristic tool to explain the violent drômena and legomena as performed on the comic stage. Exit rites must have signaled to the audience when the play was over so that they could reintegrate into society (re-aggregation).

\section{Ritual Efficacy}

If we follow the thesis that the staging of a comedy was similar to a ritual process, and if we take comedy seriously in its embeddedness in the contemporary world, not least because of its metatheatrical elements reaching out into the "real" world of the spectators, we cannot rule out that some dramas could also fulfill the function of a catalyst for pointing out social, political, and ideological conflicts, for mediating between divergent opinions, and reducing or mitigating tensions by bringing about a playful release of pent-up feelings and emotions without, ${ }^{37}$ however, being able to suggest a viable and permanent solution. From this perspective, theatrical space could adopt the function of trying out a ludic and temporary cure for social upheavals. Acharnians or Lysistrata, for example, can be understood against the background of a specific historical situation, an encumbered Athens that may indeed have perceived the burden of a protracted war as a crisis threatening to disrupt Athenian society. In this scenario, Aristophanes would have tried to address this societal

37 Cf. Bierl 2004, 19; 2002b, 19; Reckford 1987, 279. Turner 1976, 118 is optimistic about the potential power of cathartic effects "causing in some cases real transformations of character and social relationships." Sutton 1994 sees comedy, as a whole, as functioning like catharsis. Laughter purges spectators of bad feelings, which is not only beneficial for them but also for society at large. Sutton 1980, 69-82 sees the comic catharsis as brought about by the mocking of authorities. MacDowell 1988, 8 briefly discusses catharsis as brought about by slapstick violence. Skeptical of the cathartic impulse is von Möllendorff 1995, 21-22. 
conflict onstage with his comic ritual drama. ${ }^{38}$ This would be an idealistic view of the power of theater, however. Can the staging of a drama really have an impact by reaching out into the world to affect human beings and generate change $?^{39}$ As far as ancient drama is concerned, the evidence is scant and ambivalent, but worth considering for two reasons. First, aesthetics and politics were interwoven in a way that is unimaginable for us. Second, theater worked like a ritual and rituals always show a certain degree of efficacy. It is exactly this efficacy of ritual, or the lack thereof, that is at stake here. Three examples demonstrating the very indirect or even non-existent relationship between comedy and reality shall suffice in this context.

However fictional, anti-mimetic, and non-referential Old Comedy was, Aristophanes must have produced Knights with Cleon in mind, if only to welcome him to his new office by heaping insults on him. ${ }^{40}$ In

38 This does not mean that Aristophanes directly voices in his Acharnians a plea to end the war. As Carey 1993 has convincingly shown, things are more complicated, with comedy only articulating one strand of opinions among the Athenian people. On the ritual effect that Lysistrata might have had, cf. Bierl 2007b.

39 E.g., Heath 1987 passim denies outright that Aristophanic comedy has political intentions: "Politics was the material of comedy, but comedy did not in turn aspire to be a political force" (42). On the vexed question of the relationship between comedy and politics, cf. below 257, n. 75 .

40 As suggested by Riu 1999, 235-239. On Cleon's alleged reaction, as addressed in Ar. Ach. 377-382 and 502-505, cf. also fr. 24 in Henderson's Loeb edition of Acharnians. To Wiles 2000, 33, the freedom to insult and slander individuals was central to classical comedy and epitomized the parrhêsia of Athenian democracy. In a similar vein, Henderson 1998a regards parrhêsia and isêgoria, as exercised in oratory and comedy, as the cornerstones of politically engaged art forms. Sommerstein 2004b; 2002, however, clearly denotes the boundaries of free speech. According to him, comedy was not above the law. Therefore, Pericles and Cleon could try to silence the poets; it was only popular opinion and the cultural understanding of comedy that protected comedy de facto. Sommerstein 2004b, 167-172 lists all ancient sources on the alleged prosecutions Aristophanes had to face. To Sommerstein 1986, the decree of Syracosius (in force between 415 and $411 \mathrm{BCE}$ ) is historical. It might have prohibited the onomasti kômôdein of persons condemned of impiety in the wake of the mutilation of the herms and the celebration of mock mysteries. In stark contrast to Sommerstein, Halliwell 2008, 244, 259-262; 2004, 139-140; 1991b passim claims that Old Comedy's satirizing was exempt from the law of slander. This was only possible because the exuberant kind of comic aischrologia was confined by the strictly defined boundaries of ritual license within the context of the Dionysiac festivals. By a similar token, Wallace 2005, 361-363, 365-368 could convincingly show 
this case, the efficacy of ritual amounted to nothing. Shortly after the performance, the Athenian dêmos, roughly the same people who watched the play, elected Cleon stratêgos. ${ }^{41}$ Cleon sued Aristophanes before the Council in the wake of his staging Babylonians (426 BCE), but there is no indication that this lawsuit had any effect on Aristophanes' further career.

In the Apology, Plato's fictive Socrates alludes to Aristophanes' Clouds as one reason for his standing trial. ${ }^{42}$ This passage, however, is complex and hardly proves the efficacy of Attic comedy in the sense of having an impact on daily life. Socrates rather refers to those people who spread rumors about him, not people who spoke up against him in public. It is very doubtful that a comedy staged twenty-four years prior to the trial of Socrates would have had any bearing on the prosecution of the philosopher. ${ }^{43}$ In addition, Plato's Symposium features Socrates and Aristophanes as interlocutors of equal standing in a friendly and highly intellectual conversation. At least the mature Plato does not seem to have borne any grudge against Aristophanes.

The year 405 saw the staging of Frogs. Aristophanes' success was overwhelming and he received the unprecedented honor of having his play restaged a second time. In this case, we seem to grasp a concrete outcome: what the chorus had demanded (the restoration of citizenship rights to those who had lost them in the wake of the oligarchic coup d'état of 411) ${ }^{44}$ came true with the decree of Patrocleides. These hints that the thrust of a dramatic performance could at times reach out into

that the freedom of comedy was only curtailed under special circumstances, and then only very briefly.

41 Cf. Ar. Nu. 587-594. Carey 1994, 75 discusses the ambivalent efficacy of comedy. In comedy and the Ekklêsia, different attitudes of the dêmos found expression. According to Carey 1994, 80-82 people could only choose between two options in the Assembly of the People. The art form of comedy, however, allowed for a more subtle and multi-layered articulation of political sentiments. This is exactly the function of a large-scale social ritual. Cf. Stark 2004, 218-316.

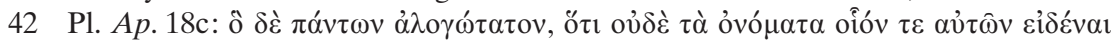

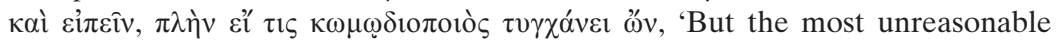
thing of all is this, that it is not even possible to know and speak their names, except when one of them happens to be a writer of comedies.' And Pl.

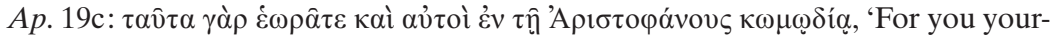
selves saw these things in Aristophanes' comedy.'

43 Whereas Halliwell 2008, 254-255 is very pessimistic about a connection between the performance of Clouds and Socrates' trial, Sommerstein 2007a, 3 is optimistic about the link.

44 Ar. Ra.686-705. Cf. And. 1.73-79; Sommerstein 1996, 21. 
the spectators' world notwithstanding ${ }^{45}$ we cannot claim that comedy alone was to be credited for bringing about this political decision. Many other factors, including discussions in the Assembly of the People, must have played a role as well, if not the decisive role.

Considering these tenuous ties between stage drama and reality, we cannot naively postulate a direct route between comedy and reality. Hence, comedy's efficacy is to be sought elsewhere. Athenian drama has to be acknowledged in its artistic, aesthetic, and open structure, but it is neither political satire nor l'art pour l'art taking place in a social vacuum without any pragmatic rooting in contemporary life. Athenians ascribed too much importance to theater to regard it solely as literature. ${ }^{46}$ After all, they decided to subsidize theater attendance with the theôrika. ${ }^{47}$ The fictional world on the comic stage was indeed connected to the "real" world of the audience via the manifold metatheatrical elements to be

45 For the theater anthropologist Schechner (cf. 1985, 18-21; Schechner - Appel 1990, 4-7), the power of theater to affect spectators on an emotional and cognitive level is a given because of the characteristics of a good performance: the "transformation of being or consciousness"; the "intensity of performance"; the inevitable "audience-performer interaction"; the whole "performance sequence," including rehearsal, actual performance, cool-down, and aftermath (Aristophanes frequently mentions the cooling-off phase during the revels and dinners following the performance); the "transmission of performance knowledge," an aspect that N. Slater 2002, 236-239 rightly puts into relief; and the stirring of an interest in "how performances are generated and evaluated." The last aspect is especially fascinating in the case of Athenian drama. The prizes awarded were enshrined in stone, the so-called victors' lists. In the dicastic courts, the winner who swayed the jury was the party who provided the best, most plausible, and authentic performance.

46 Wiles's sharp criticism (Wiles 1987) of Goldhill's Reading Greek Tragedy (1986) is revealing in this respect. To regard Athenian drama primarily as literature in the style of New Criticism is reductionist and does not do justice to its performative character (cf., however, Goldhill's response [1989]). Ritual theory, by contrast, is integrative and combines all dimensions of theater, the whole context, the performance sequence, the actors and the audience, and also, self-evidently, the text. In this sense, ritual theory can help bridge the gap between pragmatists and theater researchers like Wiles, on the one hand, and discourse analysts like Goldhill, on the other.

47 Pickard-Cambridge 1953, 270-273. Roselli 2009 illuminates the character of these subsidies in the fifth and fourth centuries. Although only formally introduced as state funds by Eubulus, precursors of the theorika were distributed occasionally to spectators already in the fifth century, probably on Pericles' suggestion. 
found mainly in Old but also in New Comedy. ${ }^{48}$ Rituals, especially in the form of the chorus in its function as "shifter" between the fictional "there-and-then" onstage and the "here-and-now" of the theatrical performance not only guaranteed communication between the fictional world of the characters onstage and the extra-fictional, pragmatic world of the spectators (and actors), ${ }^{49}$ but also kept the theatrical staging as such always transparent. The high level of metatheatricality is a characteristic feature of the Archaia and thus an integral part of Greek comedy. This deliberation brings us closer to the assumption that the performance of a comedy as a whole worked like a large-scale ritual, fulfilling ritual functions. Unlike forensic speeches and the deposition of curse tablets, the staging and viewing of a comedy did not really "do" something in a tangible sense. Rather, the generically open structure of comedy provided a space detached from the constraints of daily life where meanings could be freely reflected upon and negotiated; it provided a ludic space in which the downfall of the comic hero was depicted and, with it, the instability of all norms and values was laid bare. The "target" of derision constantly shifts and includes everyone, even the playwright. This space for reflection and negotiation was so dear to the Athenians that they made theater-going a citizen's duty. Herein must lie comedy's efficacy, beyond fostering a sense of belonging among the audience. ${ }^{50}$

\section{The Discursive Rules of Violence}

\section{Aristophanes}

One of the biggest differences between the tragic and the comic stage is that tragedy avoided, in most cases, the open display of acts of violence onstage,$^{51}$ whereas comedy needs violence onstage to be funny. ${ }^{52}$ An in-

48 Cf. above 245 , n. 32.

49 E.g., Bierl, 2007a, 21; 2001 passim. Sifakis 1971, 23-2 already saw this double existence of the chorus between the worlds.

50 Unless we are willing to follow Schechner and assume that rituals may affect emotions and the intellect alike, and, in so doing, can generate changes on the affective as well as cognitive level. For these far-reaching changes, potentially brought about by ancient drama, we do not, however, have any evidence.

51 Exceptions confirm the rule, e.g., Euripides' Orestes. Sommerstein 2004a has elucidated the conventions of performing violence in Attic drama. Killings can 
sight into these generic differences will facilitate the ensuing interpretation of violence in Old and New Comedy. The stage and the orchêstra in the theater of Dionysus were both fictional and non-fictional spaces. Old Comedy, with its partly non-referential, anti-mimetic, and anti-illusionist character, constantly reminded the audience of its constructedness. The high amount of metatheatricality ${ }^{53}$ kept a distance between stage action and real life at all times (unlike in tragedy). Since tragedy was a relatively closed poetic and performative system, rather mimetic and illusionist in its staging of a mythical plot,${ }^{54}$ it was bound to the stringent rules and conventions of representation that prevented the open display of violent actions, similar to oratory, where the depiction of graphic violence was, in most cases, avoided. ${ }^{55}$ Comedy can, however, display acts of violence, because it does not pretend to be reality. These remarks should alert us already to the possibility that violence on the comic stage cannot mean the same thing as violence in real life.

The poiêsis of a comedy can fruitfully be compared to work in a laboratory. The comic poet selects all kinds of elements from daily life and other literary texts-for example, names, family constellations, contemporary social and political problems, cultural specifics, historical events, literary motifs, and ideologemes, including ritual patterns-combines them in a new way, and joins them with additional elements. According to Iser and A. Assmann, these terms (selection, combination, and addition) make up the process of creating fiction, ${ }^{56}$ meaning that most ingredients are taken from the real world, but combined and contextualized differently. The result is a mock-mimesis of the real world, a fictional con-

be staged neither in tragedy nor in comedy. Blows cannot be performed in tragedy and possibly not even in satyr drama.

52 Goldhill 2006, 156-157.

53 Cf., e.g., Zeitlin 1999, 167. A prime example is Ar. Ach.377-384, 497-507, where the persona of Aristophanes blends with the character of Dicaeopolis, thus breaking the comic illusion. Sutton 1988 assumes that Dicaeopolis' part may have been played by Aristophanes himself.

54 Rosen 2005, 265: tragedy was "a relatively 'closed' system which, while it could mirror well enough contemporary Athenian values and ideologies and even occasionally call attention to its own theatricality, was not dynamic and freewheeling in the ways Old Comedy could be." On the different modes of speaking in tragedy and comedy respectively, cf. Taplin 1986.

55 Cf. above $104-113$.

56 Iser 1983, 125-126; ${ }^{2} 1979,300-307$; A. Assmann 1980, 14-17. Bierl 2002b emphasizes the experimental character of Old Comedy within the ritual-pragmatic boundaries of the genre. 
struct whose fictionality is always transparent to the spectator. As a consequence, we can hypothesize that violence and the discourse on it, which tend to converge in drama, might follow the discursive rules of violence as brought out in chapter II above. The obviously fictional world of comedy allows the comic poet to delineate and play with the boundaries of acceptable behavior on stage. ${ }^{57}$ The extreme delight and amusement the spectators enjoyed partly stemmed from three closely related factors: first, the oscillation of this kind of violence between reality and play, enforced by means of metatheatricality (meaning that the spectators did not have to take onstage violence seriously or at face value); second, the superior knowledge that this was all temporary pretend-play, make-believe, a fictional laboratory within a splendid civic festival, which allowed the spectators to question the behavior of others and themselves; and third and most importantly, the awareness that (a) the comic heroes can easily and playfully break the boundaries and constraints of real life without incurring any sort of punishment, ${ }^{58}$ and (b) that they themselves, as the audience of these heroes, can burst into unrestrained, shameless laughter without fearing any consequences. ${ }^{59}$

As in previous chapters, the methodology will be phenomenological again, taking into consideration and applying the flexible discursive line between acceptable and unacceptable violence as a heuristic explanatory tool, as fleshed out in chapter II of this book. Other approaches for coming to terms with the phenomenon of violence on the comic stage are equally possible; for example, Kaimio's valuable explanation of Aristophanic violence within the structural elements of Old Comedy, or the interpretation of many comic scenes via Aristophanes' method of parodying tragedy (paratragedy). ${ }^{60}$ These different approaches do not exclude

57 Schechner 1977, 66 rightly speaks of the "transformation of real behavior into symbolic behavior" onstage, which is the result of the specific context in which this kind of communication takes place.

58 Krummen 1998, 299 aptly characterizes the liminal situation of the spectators between reality and fiction.

59 Halliwell 2008, e.g., 245-248, 253 ("institutionalized shamelessness").

60 On Aristophanic paratragedy, cf. Rosen 2005, 255-261; Silk 2000, 42-97; 1993; and, still fundamental, Rau 1967. To what extent Aristophanes entered into a fruitful dialogue with Euripides on many different levels to enrich his own poetics, cf. the contributions in Calame 2004; Bierl 2009a, esp. 220-244 on paratragedy in Thesmophoriazusae, based on Euripides' Helena and Andromeda. Foley 1988 argues that, in Acharnians, Aristophanes not only parodies Euripides, but also puts allusions to tragedy into the service of comedy, not least in order to defend himself against Cleon. Harriot 1962 explicates that spectators attended the 
but complement each other. We are still far away from a thorough understanding of corporal violence in Attic comedy, especially in regard to its relationship to violence as represented on the tragic stage. It is my intention to sketch here only one way in which we can make sense of violence in the ritual context of comedy and in the framework of a book that also examines forensic speeches and curse tablets as other genres through which discourses on violence can be performed. It is three comedies above all, Wasps, Birds, and Clouds, in which violence figures most prominently and which therefore contain somber undertones. The material in these three plays is so abundant that they warrant separate treatments in their own rights as case studies.

\section{Anger}

The treatment of anger in comedy needs full consideration because anger was a frequent precedent to violence in daily life and is often invoked in forensic oratory. ${ }^{61}$ Aristophanes makes full use of the semantic field of anger in Greek, with terms approximately corresponding to anger, fury, rage, ire in English, although the cultural specificity of emotions must always be kept in mind. Aristophanes employs the terms orgê (natural impulse, propensity, temperament, disposition, mood, anger, wrath) ${ }^{62}$ thumos (soul, spirit as the principle of life, heart, mind, courage, fits of anger, passions) ${ }^{63}$ mania (fury, rage, frenzy), and cholos or cholê (gall, bile, bitter anger, wrath) ${ }^{64}$ and often interchangeably, despite their different shades of meaning. These terms can range in meaning from thoroughly positive, to the expression of some kind of ill-feeling toward a person or group, and yet further to the outright stigmatization of a particular behavior as socially disruptive and therefore negative. Ambivalent usage is also frequent. In this respect, the comic playwright is in line with the highly differentiated use of these terms in the orators. Anger was problematized from the 450 s on as a lack of self-control that ultimately endangered the

plays not just to be entertained; many of them had undergone rhetorical training or had at least acquired some rhetorical experience by listening to lawsuits. They did not read much, but were trained to listen carefully, concentrate, and thus memorize and recognize passages from other plays. This background explains why Aristophanes could allude to Euripides' tragedies years after their respective performances.

61 Cf. above 115-119.

62 Liddell - Scott 1968, s.v. "orgê."

63 Liddell - Scott 1968, s.v. "thumos."

64 Liddell - Scott 1968, s.v. "cholê." 
peaceful coexistence of members in a community. ${ }^{65}$ Simultaneously, the orators reserved for themselves the entitlement to justifiable anger, if they were affected by some kind of transgression on the part of their opponents. Anger could thus cut both ways. As we will see, this highly complex semantic field is even more multifaceted and open to interpretation in Aristophanes.

In Knights 41, Demosthenes characterizes the dêmos in endearing

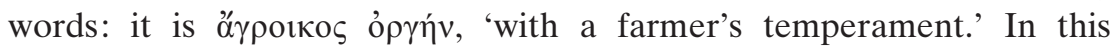
sense, orgê is a positive quality because it is down-to-earth. In the parabasis of Peace, the chorus-leader is commonly regarded as the playwright's mouthpiece. ${ }^{66}$ Aristophanes speaks out with Heraclean tempera-

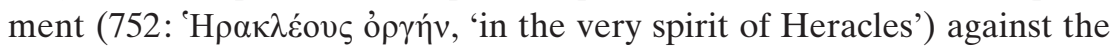
war-mongers, conjuring up the figure of Heracles in his function as monster-slayer, thus resuming almost verbatim a passage from Wasps, staged the year before, in 422 BCE.${ }^{67}$ In Clouds 610 , Selene claims to be angry

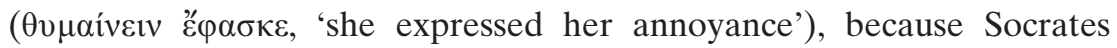
has treated her badly. Her wrath is completely justified. If orgê or thumos denote the fighting spirit of the Athenians of old, especially that of the Marathon fighters, the terms have positive connotations. Their anger at the Persian intruders was more than justified; Aeschylus' great merit was to have enhanced this martial attitude through his dramatic poetry

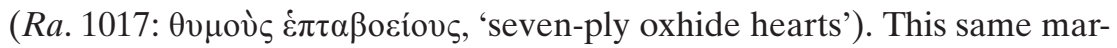

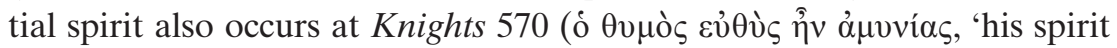
was defiant') and Wasps 1082/83, where the chorus of wasps speaks of biting their lips in battle out of thumos (sharp, bitter spirit) against the Persians. In Lysistrata, we also discern some positive features about anger. Lysistrata speaks with pride of the women's cholê (angry temper, sharp spirit) in chasing off the Scythian archers in a kind of battle (Lys. 464:

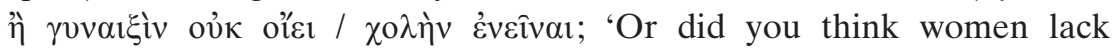
gall?'). ${ }^{68}$ In a comically touching scene, in which, in a great dialogue, the semi-chorus of old men is reconciled to the semi-chorus of old women. The men's leader indirectly confesses that they have suffered from the women's sex strike, the occupation of the Acropolis, and all the resultant turmoil. He also admits that, earlier, they took off their

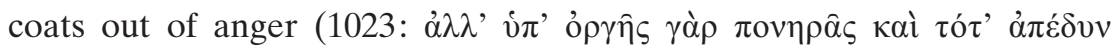

65 Cf. above $115-116$.

66 On this complex scene, cf. Hubbard 1991, 140-156.

67 A similar attack is to be found in Ar. Eq. 41.

68 Cf., similarly, Ar. V. 403; Thesm. 468; Ra. 4; Eubulus F 61 (K.-A.). 
$\dot{\varepsilon} \gamma \omega$, 'in fact, it was mean of me to take it off in anger before'), an indecent gesture because, in doing so, they revealed their enormous erections. The old women, however, have pity on the men. Because of their life experience, they know about men's urges and plights. The women's leader takes the old man by the hand and covers him with his cloak. The other women follow her example.

Frequently, the wrath of the comic hero or the chorus is directed against individuals. Aristophanes' primary target of ridicule is Euripides and his tragedies, followed by Cleon. Onstage, these two figures deserve to be criticized; in other words, the anger and spite they provoke is not only justified, but practically a comic necessity ${ }^{69}$ In Thesmophoriazusae, the women rail against Euripides (e.g., 466, 518), because he has done them harm in his tragedies, by uttering the most evil and offensive slanders imaginable against them. ${ }^{70}$ The In-law, disguised as a woman, and out to defend Euripides by confessing outright adultery in unabashed detail, tries to win the favor of the assembled women by claiming that their ire is

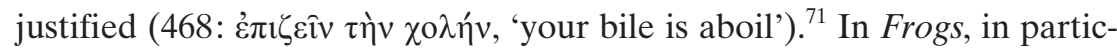
ular, laughter and ridicule are heaped upon Euripides. Dionysus admonishes Aeschylus again and again to control himself and suppress his anger

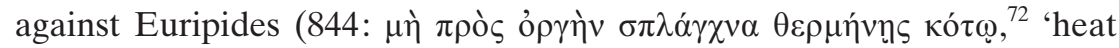

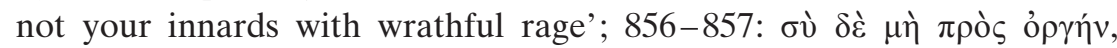

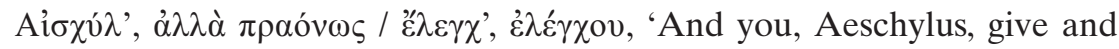
take arguments not angrily but calmly'), and the chorus, too, reminds Aeschylus: 'Yes, take care, good sir, that you don't reply in a rage' (997-998:

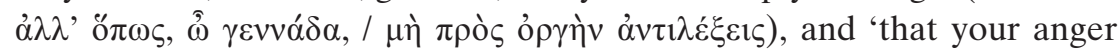

69 Aristophanes must have held Euripides in high esteem; otherwise he would not have taken him on in his comedies as frequently as he did. This can only mean that he considered him an equally gifted colleague.

70 Cf. Bierl 2009a, 172-74. Euripides' critical attitude toward women was often subjected to mockery in comedy, e.g., Diphilus F 74 (K.-A.)

71 The bile that boils over symbolizes anger and combativeness. It is a frequent motif in Aristophanes; e.g.: Ach.321-322 (Olson 2002, ad Ach. 321-322 with more sources), V. 403, and Lys. 464. Pax 66: confronted with the war, Trygaeus feels his bile (cholê) come up. To Olson 1998, ad Pax 66, cholê, the bile-sickness, signifies a kind of madness. He quotes many parallel examples, esp. $N u .833$ on "the lunatics Socrates and Chairephon." Cholê is an illness which can also affect the brain. Sommerstein 2007a, ad Nu. 833 calls this sickness a "form of insanity ... due to overheating of the brain through an excess of bile (Hippocr. On the Sacred Disease 18)." Cf. also Alexis F 150.5 (K.-A.); Eubulus F 93.9 (K.-A.).

72 This phrase is possibly a humorous quotation from E. Cyc. 424 (Dover 1993, ad Ra. 844). 


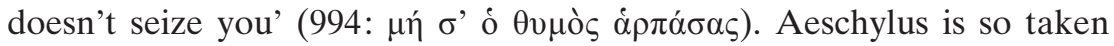

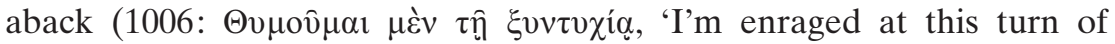
events') by Euripides' "impertinence" that he does not even want to converse with him. Even Zeus will be indignant: 'Surely fearful wrath will fill

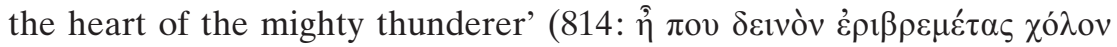

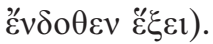

The second most common target of Aristophanes' mockery, after Euripides, is the politician Cleon. In Knights 993-994, Cleon's teacher grows so angry at him, because he insists on playing only Doric hymns,

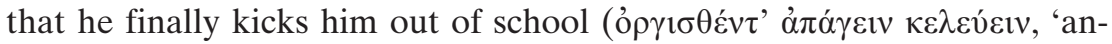
grily had him expelled'). The chorus-leader in Wasps speaks about 'three days' rations of rotten rage against that bloke' (243-244: $\dot{\eta} \mu \varepsilon \rho \hat{\omega} v$

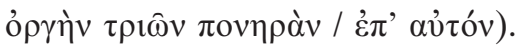

Only one more "real" person had to endure Aristophanes' wrath: his comic rival Crates, whose productions were cheap, according to Aristophanes, and who therefore incurred the rage of the audience against him

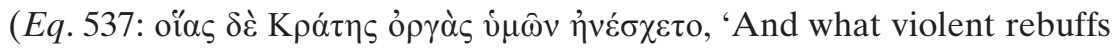
Crates had to endure at your hands'). It is to be noted that the onomasti kômôdein, the satirizing of living individuals by name, ${ }^{73}$ was part of the Dionysiac license ${ }^{74}$ and the literary and performative genre of comedy. Actors behind masks playing out fictional roles spoke these invectives, not recognizable individuals. As "real" as these mockeries might seem, the seriousness of their references to the persons targeted, who often stand in for a whole group, appears doubtful. ${ }^{75}$

73 A good example is a fragment from Ar. Triphales F 563 (Henderson), where Theramenes is credited with decreeing three penalties: imprisonment, drinking hemlock, and exile.

74 Cf. Bierl 2002a passim. Hoffman 1989 probes into the inseparable connections between ritual license and the cult of Dionysus. To come to a better understanding of this peculiar cult, he uses cross-cultural material and Turner's terminology of liminality and communitas.

75 Bierl 2002a and Stark 2002, to name just two, have shown that comedy derides types, not individuals. Similar is Heath 1987. Contrary is Koster 1980, 72, who postulates a direct relationship between comedic derision and actual politics. $\mathrm{He}$ is right that the artful diabole is a practice that oratory and comedy have in common (76), but Old Comedy instead plays with this rhetorical pose. More nuanced is Kraus 1985 (31-101 on Acharnians; 113-92 on Knights), because he fully considers the fictive aspects of Old Comedy. Gelzer 1999, $31-$ 37 rightly sees comedy as a playful form of popular justice (Rügebrauch) in the specific form of using masks. The question of whom the onomasti kômôdein is referring to is only one aspect of a larger complex, the notoriously vexed prob- 
In only a few instances is anger unquestionably negatively connotated. According to Dicaeopolis (Ach. 530), who is, admittedly, a highly problematic figure, morally speaking, Pericles' orgê caused the Peloponnesian War. The chorus-leader in Frogs exhorts his fellow-citizens to abandon their wrath against the disenfranchised citizens (700: $\dot{\alpha} \lambda \lambda \dot{\alpha} \tau \hat{\eta} \varsigma$

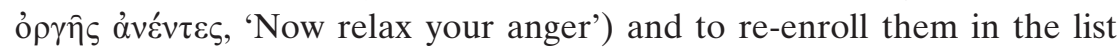
of citizens, because they and their fathers fought alongside the rest of

lem whether or not (and if so, to what extent) Old Comedy had political meaning and thrust. The literature on this topic is immense. I point to some trends: Gomme 1938, who denies that we can pin down Aristophanes' political opinion, because, as an artist, he was impartial, has set the tone for much of modern research. Wysocki 1988 has confirmed that Aristophanes' political utterances cannot be taken at face value; von Möllendorff 1995, who offers a Bakhtinian interpretation, and van Steen 2007, e.g., detect so much complexity and playfulness in the plays that one coherent opinion underlying the text becomes unattainable. According to Heath 1997, 236, Aristophanes does speak an oratorical, political discourse, but it is "exaggerated in the ... comic world." Contrary to this current communis opinio, there has always been a long tradition in Aristophanic scholarship to take the plays seriously as political statements. Researchers on this side base their opinion on Ps.-X. Ath. 2.18, where the Old Oligarch complains that comedy creates caricatures of members of the upper classes, but always spares the masses. Ehrenberg 1968 paradigmatically stands for the ancient historian's wish to elicit as much historical information as possible from Old Comedy. As far as I can see, De Ste. Croix 1972, 355-76 is the most decisive of this group of scholars, arguing, against Gomme 1938, that Aristophanes had not only a consistent political opinion, but also a serious message with which he wanted to influence his audience. Also MacDowell 1995, 355 thinks that Aristophanes meant to sway the Athenians and that his invectives mean exactly what they say. In a similar vain, Ercolani (2006 and 2002) and Henderson (2003, 1998a, 1998b, 1993) are willing to ascribe more direct functions to the comedic satirizing of public figures. According to Henderson 1993, the dêmos could not be mocked and ridiculed, only tyrannical individuals. Olson 1996 argues for a decidedly political view of Wasps, where Aristophanes makes a plea for an improved democracy, not for oligarchy. Recently, Brockmann 2003 takes the political impetus of Old Comedy more seriously again. Zimmermann 2006 even goes so far as to ascribe didactic intentions to the playwright. Most recently, Sidwell 2009 sees Aristophanes as an arch-democrat involved in extreme competition against his rivals, especially the oligarchically minded Eupolis. To Sidwell 2009, e.g., 299, the characters represent real individuals, with satire referring to Aristophanes' rivals. Mediating voices in this debate are Carey 1994, 74, who regards comic satire as a more general means of control, complementing the law courts, and Robson $2009,162-87$, who takes a stance between the extremes and acknowledges the fundamental ambiguity inscribed in the plays, which makes research on politics in Aristophanes inexhaustible. Cf. Olson 2010 with a thorough overview of the scholarship. 
the Athenians. The magistrate in Lysistrata orders the Scythian archers to march against the women as if in battle, since he cannot control himself

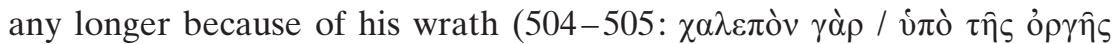

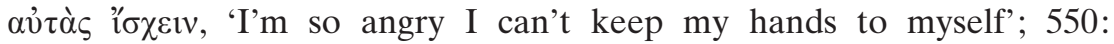

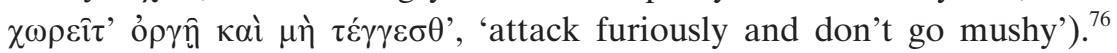
In Acharnians, almost all instances of thumos and orgê are negative. It is the negative energy of the conservative charcoal-burners who defend the continuation of the war and try to prevent Dicaeopolis from making a private truce with the enemy that is problematic. When the charcoalburners threaten the comic hero, their anger at him is the precedent to violence. Dicaeopolis screams (352-354): 'It's terrible that the temper of gentlemen should grow so vinegary that they throw stones, and

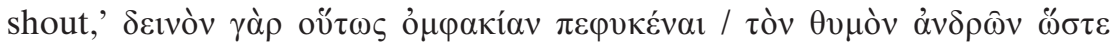

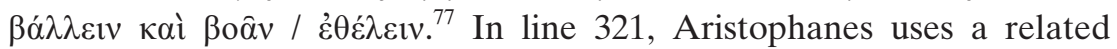
pun: thumalops means 'half-burnt piece of charcoal' but also reminds one of the charcoal-burners' unreasonable wrath (thumos).$^{78}$ In Peace, the Peloponnesian War is sometimes metaphorically circumscribed with orgê. Thus, the jars representing the Greek poleis were angry at each other and beat each other up, according to Hermes' speech to Trygaeus (613).

This metaphorical use of the semantic field of 'wrath/anger' paves the way for an ambivalent understanding of these problematic emotions. Again in Peace, the gods give free rein to their wrath against the Greeks (204: "Е $\lambda \lambda \eta \sigma ı$ o $\rho \gamma 1 \sigma \theta \varepsilon \dot{v} \tau \varepsilon \varsigma$, , They grew angry with the Greeks') by moving out and handing the Hellenes over to War. Likewise, Peace is angry at the Athenians because they have treated her so badly (659: ó $\rho \gamma \eta े v ~ \gamma \grave{\alpha} \rho$

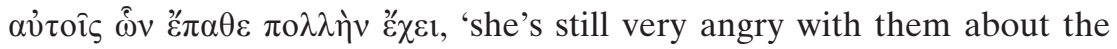
treatment she got'). While this kind of wrath is terrible for the Greeks and for the Athenians, respectively, it is understandable from a higher perspective. After all, the war among the Greeks is homemade and not the fault of the gods, whose anger is thus comprehensible. According to Praxagora's speech on appropriate behavior in the Assembly, Thrasybu-

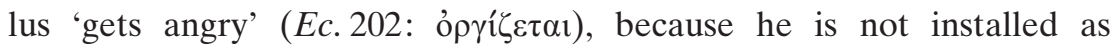
commander-in-chief. We see again how double-edged this kind of orgê is. Thrasybulus' anger is justified from his perspective, but not from

76 Cf. a similar wording in Th. 5.70.

77 Olson 2002, ad Ach. 352-356 equates thumos with 'wrath' in this case and cites $N u .1369$ and $V .383$ as other examples of this equation.

78 Cf. Olson 2002, ad Ach. 321 on the comic implications of this pun. 
that of the women or, perhaps, the audience. Often, moral values acquire a meaning onstage opposite to that held in daily life. We will return to this phenomenon later.

As may be expected, words for anger also occur within contexts that are not readily identifiable as positive or negative in connotation. In the opening scene of Frogs, for example, Dionysus declares that he is sick of

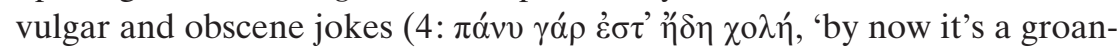
er').$^{79}$ Later, at line 584, Xanthias is angry at Dionysus, who, as a consequence, curses himself. In Birds, the birds are initially suspicious of Euelpides' and Peisetaerus' arrival in their realm, but they gradually give up

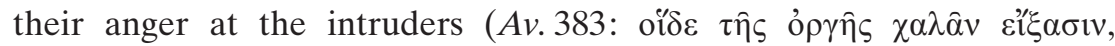

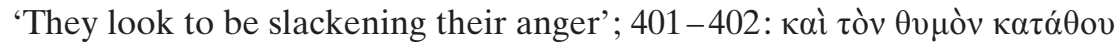

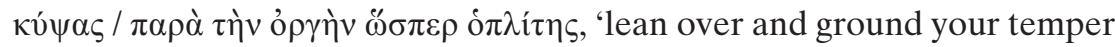
alongside your anger, like infantrymen'). ${ }^{80}$

The broad semantics of orgê can thus comprise many different meanings. It can be a good (and therefore justified), bad, or ambivalent emotion. The meaning of orgê and related words in this semantic field can range from the almost-endearing, ultra-democratic, wasp-like energy exuded by the old Marathon fighters in Wasps, to the hatred of Euripides and Cleon by the dêmos, or even to the fearsome anger of the gods. Whatever its semantics, however, 'wrath' is almost exclusively a characteristic of the citizenry as a whole, or another collectivity. If an individual indulges in wrath, he or she is rather the exception, or, most frequently, stands as an example for the body politic, with anger being the expression of a collective phenomenon played out through the body of one actor. Orgê is thus a communal experience, not yet an exclusively private feeling.

\section{Hubris}

The concept of hubris looms large in the orators. As to the broad semantics of hubris, Aristophanes' comedies are in line with the usage embraced by other authors and genres of Greek literature. Aristophanes uses hubris and related words in basically four meanings: wanton insolence, often expressed through physical violence; cases of sexual violence; offenses

79 On obscenity in Aristophanes, cf. Robson 2006, 70-94. The standard work on obscenity in Aristophanes remains Henderson 1991.

80 Sommerstein 1991, ad Av. 401-402 discerns a "parody of the military order." 
against the gods, treated in the section on Birds; and hubris in the form of mere insults. ${ }^{81}$

Wanton insolence is mainly characteristic of the rich and young. If their transgressive actions, which might include assault and battery, were deliberately aimed at humiliating a victim, this shocking behavior was liable to a graphê hubreôs. ${ }^{82}$ Aristophanes mirrors Athenian law correctly on the comic stage. In Wealth, Penia defends her existence by argu-

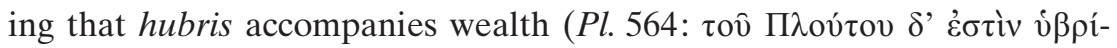
$\zeta \varepsilon i v$, 'and arrogance [dwells] with Wealth'). In Ecclesiazusae, Blepyrus raises several objections against Praxagora's communal utopia, among them the question of how, after the abolition of money, rowdies would pay the penalty for attacking people after a symposion (Ec. 663-664:

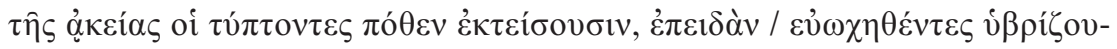
$\sigma i v$; 'when people act rowdy after a dinner party and get into fights, how will they pay their fines for assault?'). The vocabulary used corresponds exactly to the language of oratory and shows once more that occurrences like those described by Blepyrus must have been quite frequent. The outrageous behavior of the women in Lysistrata is repeatedly called hubris

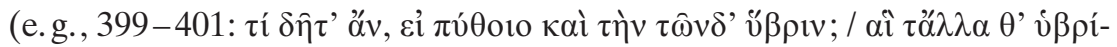

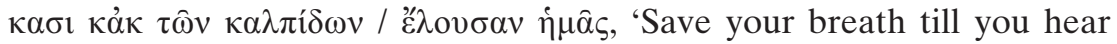
about their atrocities! They've committed every outrage, even doused us with those pitchers'). Not yielding to the sexual wishes of their husbands and occupying the Acropolis are regarded as severe transgressions of social norms and values that threaten to disrupt the social order and gender hierarchy. Therefore, a magistrate attempts to stop female inso-

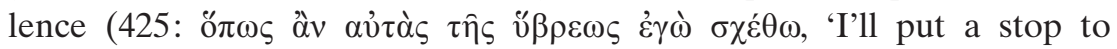
their arrogance'), but in vain. The leader of the women's chorus is even so bold as to threaten to kick the men's leader ${ }^{83}$ an outrage that the man rightly, from his perspective, calls hubris (658-660: $\tau \alpha \hat{\tau} \tau$ ' ơ̂v oủ $\chi$

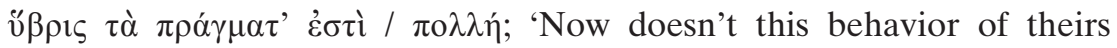
amount to extreme hubris?'). The chorus of women assembled at the Thesmophoria, in Aristophanes' play of the same title, are hunting for any man who might have intruded on their secret festival. Such a violation of religious rites, also a form of wanton insolence and even hubris

81 An important instance of hubris in the comic fragments is Eubulus F 93.6-7 (K.A.); cf. also Arist. Pr. 953b4, as cited by Sommerstein 2007b, ad Ec. 663-664.

82 Cf. above $120-125$.

83 Threatening gestures were popular in Old Comedy. Cratinus, in his Herdsmen, has one protagonist threaten another with his fists (Cratinus F 19 [K.-A.]). 
against the gods, is explicitly called hubris by the women (670-671:

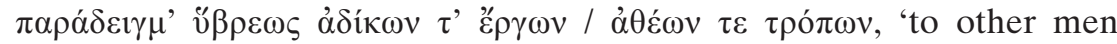
he'll be an example of outrageousness, of wrongdoing, of godless ways!'), who insist that a potential malefactor would have to pay the penalty. A horrible fate would befall such a man, who would then serve as an example to deter all other men. In this scene, the chorus could not fulfill better its function as mediator between the fiction on stage and the "real" audience. The male spectators must have relished watching the festival of the Thesmophoria, from which they were normally barred, unfold on stage. The search of the frantic women for more male intruders in the orchêstra (655-687), with the women looking around and maybe directing their gaze up to the koilon, the spectators' seats, with thousands of men in attendance, certainly could not fail to produce a special, comic effect. ${ }^{84}$

Closely connected to hubris in the sense of wanton insolence with the intent to inflict shame on a victim, is hubris in the sense of forced sex, because both forms of transgressive behavior are associated with the young and rich who cannot contain their surplus energy. In Thesmophoriazusae, the servant deduces from the In-law's vulgar address to him (59-62: of $\varsigma$

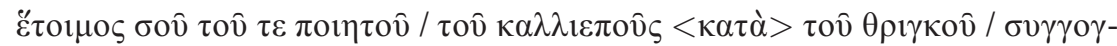

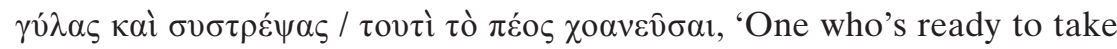
you and your mellifluous poet, and spin you around, and bend you over, and up your rampart funnel this cock of mine') that the In-law must have

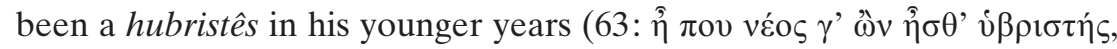
'I can't imagine what a rapist you were when you were a boy'). Further instances of hubris in the meaning of "rape" figure prominently in Birds and will be treated in the discussion of that play.

In everyday Attic speech, hubris could metaphorically mean 'insult' or 'offense,' and we encounter this usage in Aristophanes as well. Brief remarks shall suffice in this context. In Acharnians, hubris has no physical component. Euripides reproaches Dicaeopolis for having insulted him

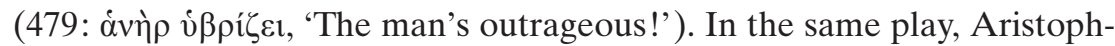
anes speaks through the chorus, complaining that he was criticized for hu-

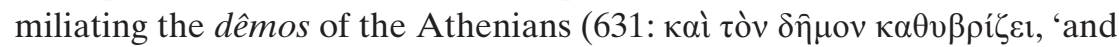
outrages the people'). Like Euripides before him, the general Lamachus

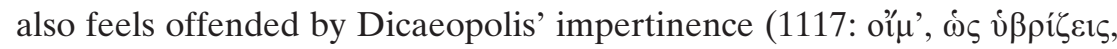
'Oh! What impudence!'). In Thesmophoriazusae, the chorus of women demands punishment for Euripides' slandering them in his tragedies

84 Cf. Bierl 2009a, 175-176 on the speech act that the chorus of women performs in this scene. 


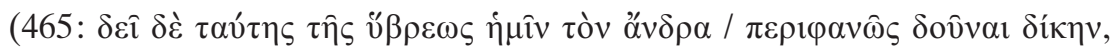
'For this outrage the man must pay us the penalty in no uncertain terms!'). Hubris assumes here a strong metaphorical note. ${ }^{85}$ In line 535 of the same play, we encounter a similar reproach, directed at the In-

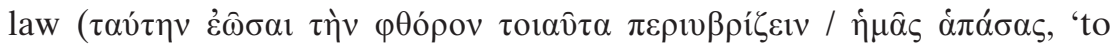
let this scum get away with slandering all of us so outrageously'). This scene derives its special comic effect from the fact that, a few verses before this remark, the women themselves wanted to strip the In-law and whip him, an act that would also constitute hubris. A magnificent instance of paratragedy and metatheater is the scene in which the In-law and Euripides engage in role-playing, the first impersonating Helen, the second pretending to be Menelaus. "Helen" unveils "her" face and blushes in

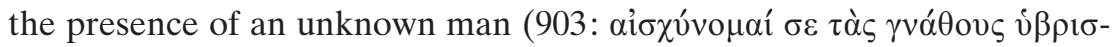
$\mu \varepsilon \dot{v \eta}$, 'I feel shame-for the violation of my jowls'). Within the pretendplay, the beautiful Helen feels insulted and uncomfortable after her cheeks have been revealed; on the actors' level, however, the actor refers to his shaved cheeks. As Austin and Olson remark, "this is thus a brief irruption of the 'real world' of the story into the parody of [Euripides'] Hel[ena], the effect of which is to stress, at the high point of the action, precisely how ludicrous everything going on on stage really is." ${ }^{86}$ In Peace, the arms-dealer complains about Trygaeus' denigrating his goods

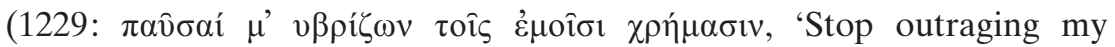
wares!'), and in line 1264 the arms-dealer and the spear-maker both claim to feel insulted (i $\beta \rho \imath \zeta o ́ \mu \varepsilon \theta \alpha$, 'That's an insult!'). In the slapsticklike opening scene of Frogs, Dionysus is shocked by Xanthias' insolent behavior. Sommerstein observes that Xanthias "does not know his place. Rather than grumble as he does, he ought to be grateful that his master has allowed him to ride instead of walking. ${ }^{~} 87$ In Wealth, more instances are to be found. A sycophant is mocked; he complains about the

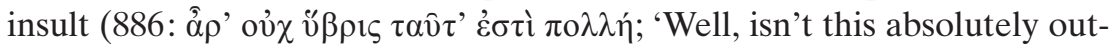

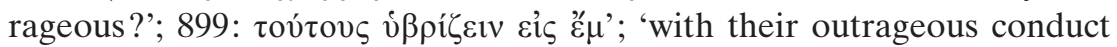
toward me?'). A young komast teases an old woman by making fun of

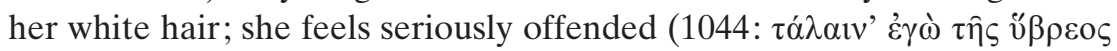

85 Austin - Olson 2004, ad Th. 465 remark that the language of hubris "adds an angry, emotional note."

86 Austin - Olson 2004, ad Th. 903; cf. on this scene also Rau 1967, 53-65.

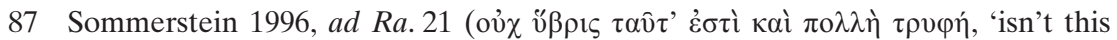
outrageous, the behavior of an utterly spoilt brat'). 


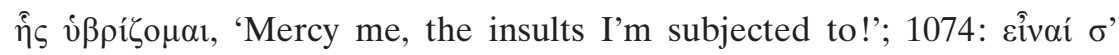

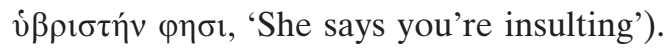

To sum up: The word hubris as used in the Aristophanic corpus shows the same spectrum of meanings as in oratory or other genres of Greek literature. It ranges from mere verbal insult to actual beatings, thus encompassing the broad notion of hubris in all its transgressiveness as circumscribed by Athenian law. As a pattern, we can discern that Aristophanes takes elements from daily life and puts them into different contexts. In most cases, supra-human comic heroes, ${ }^{88}$ figures marked as liminal through their boundless energy, ambivalent characters, and grotesque plans to establish problematic utopias, commit hubris. Since the main protagonists are somewhat doubtful figures, their actions are as well. It is striking that, unlike in tragedy or in the later New Comedy, hybristic behavior is often physically shown on the Aristophanic stage, only to evoke an immediate, negative response from another protagonist. The audience could probably laugh about these instances, but at least onstage the fictional order was endangered, as for example in Lysistrata or Wasps. At this point it is important to stress the openness and polyvalence of Aristophanes' ritual work of art.

According to Riu, insults in comedy mostly happen at thresholds, when people arrive or meet each other for the first time. That is, in certain speech acts framed by a specific, pragmatic context, insults can almost be taken as friendly welcomes. ${ }^{89}$ This is all the more true because, in Greek comedy, the actor's mask would have covered his individuality: the mask utters the insults; therefore the actor's utterances cannot necessarily be understood as personal statements aimed at particular historical persons. ${ }^{90}$ Since hybristic behavior is per definitionem insulting, Riu's observation is also true for the commitment of hubris in comedy. And indeed, a survey of all above-mentioned instances of hubris confirms the picture. Hybristic acts mark thresholds. They mark either the arrival of a protagonist or chorus, or a character's first encounter with an opponent or chorus. ${ }^{91}$ Thus, hubris defines a borderline situation and creates a boundary.

88 Cf. Whitman 1964, esp. 21-58 on Aristophanes' absurd comic hero and his or her interconnectedness with Aristophanic fantasy.

89 Riu 1999, 238-239. In a book-length study, Cottone 2005 establishes Aristophanes' practice of insulting as an intrinsic part of his dynamic poetics dealing and competing with the Euripidean model.

90 Cf. above 257 , n. 75.

91 On the aggressive nature of the chorus in Old Comedy, cf. Treu 1999; Carnicelli 1975. 
When the insult finally leads to blows in the play (as it often did in real life), the audience experiences violence in a liminal situation. Violence would then serve to define the thin borderline between acceptable and unacceptable behavior (the flexible line as established in chapter II), and the line of separation between the realm of laughter (within the range of acceptable behavior) and the realm of seriousness (outside the range of acceptable behavior, about which we cannot laugh any longer). The special delight of comedy is derived from the fact that the realm of seriousness (i.e., violence) is pulled onto the stage and is thus still laughable. Nevertheless, the flexible boundary is there and Aristophanes constantly plays with it (similar to the orators in court), thus deliberately blurring the line between the comic and the serious. In fact, he constructs and enacts this line through the actors' bodies on the comic stage. Since it is up to the individual spectator to determine where the line between fun and seriousness runs, it is partly from this process of definition that ancient spectators as well as modern readers of the plays have derived so much satisfaction and joy, delight and amusement. In what follows I shall verify whether the hypothesis that violence marks a threshold can serve as a heuristic model to reach a better understanding of the main instances of violence on the comic stage-i. e., slapstick violence.

\section{Slapstick}

Research has not yet made much of slapstick violence in Greek comedy. I use "slapstick" as defined by the Encyclopedia Britannica:

a type of physical comedy characterized by broad humour, absurd situations, and vigorous, usually violent action. The slapstick comic, more than a mere funnyman or buffoon, must often be an acrobat, a stuntman, and something of a magician - a master of uninhibited action and perfect timing ... The rough-and-tumble of slapstick has been a part of low comedy and farce since ancient times, having been a prominent feature of Greek and Roman mime, in which bald-pated, heavily padded clowns exchanged quips and beatings to the delight of the audience. ${ }^{92}$

Murphy sees Aristophanes as heavily influenced by popular entertainment and derogates this kind of banter to an under-class amusement: it is "likely that many scenes and bits of comic stage-business are directly imitated from a sub-literary, farcical type of performance known to the

92 Encyclopedia Britannica Online: http://www.search.eb.com/eb/article-9068154, s.v. "slapstick" (accessed March 29, 2011). 
Greeks of the fifth century B.C." 93 Aristophanes, then, in Murphy's view, is no better than his audience and indulges likewise in this unsophisticated, lowbrow humor:

There is certainly enough evidence to demonstrate the existence of popular entertainments which were familiar to Aristophanes and his audience, and from which he borrowed material to season, so to speak, his literary comedies and make them more acceptable to the 'groundlings' in his audience. The possibility, however, cannot be ruled out that he used this type of material because he himself enjoyed it and thought it funny. ${ }^{94}$

MacDowell rightly discerns jack-in-the-box-type clowning in Philocleon's futile attempts to break out of his own house (Wasps), prevented by his son Bdelycleon (see below), and custard-pie-type slapstick when the women pour water over the men in Lysistrata. But he does not offer an overarching model to come to terms with and explain the ubiquitous violence on the Aristophanic stage. Moreover, the blatant discrepancy between Aristophanes' claim to have freed comedy from coarse "Megarian" slapstick, ${ }^{95}$ and his simultaneous full use of rough-and-tumble scenes has not yet been sufficiently researched. ${ }^{96}$

Kaimio, in her convincing analysis of violence in specific parts of Aristophanic comedy, comes closest to making sense of most of the instances of slapstick in Old Comedy. She differentiates between two forms of violence: violence as happening at certain points in comedy (parodos, agôn, expulsion episodes in the second part of the comedy after the parabasis)

93 Murphy 1972, 189.

94 Murphy 1972, 169.

95 Ar. Ach. 655-656; Eq. 510; Nu. 537-562; Pax 729-774; V. 54-66; Ra. 1-24.

96 Cf. Dobrov 1988 with regard to the passages mentioned in n. 95. He postulates a specific comic muthopoiêsis which was not successful-unlike tragedy, with its heroic myth-in subduing the farcical elements of Dionysiac ritual. Arnott 1989 has shown that, in Athenian drama, performance was more important than a written text. Most recently, Russo 1994 and Thiercy 1986 have given full justice to Aristophanes as a stage author. A script, in Schechner's sense, was there, but drama "as we know it" (sticking closely to a written text) was not in the foreground as much as it is today. This fluidity allowed for a large amount of improvisation, including inconsistencies and logical breaks, as can be found in all classical dramatists. During the fifth and fourth centuries BCE we also observe in the development of drama the gradual transition from a basically oral to a fully literate society. Another way to explain the discrepancy between theoretical claim and theatrical practice is to take into consideration the degree to which comedy was bound by the parameters of the genre, and knew how to play with them to achieve innovation (Bierl 2002b; Zimmermann 1998 [non vidi]). This explanatory model could be combined with Dobrov's approach. 
and violence involving a typology of preferred victims who are prone to suffer violence at any point in comedy (slaves, officials, paratragic violence).$^{97}$ With regard to the beating of slaves, a stock motif in ancient comedy, she correctly observes that this use of violence always casts a negative light on the perpetrator. ${ }^{98}$ Thus, pure slapstick, devoid of any sense, is hardly ever found in Aristophanes, and in this respect Aristophanes may be accurate in his renunciation of coarse ribaldry and humor. ${ }^{99}$ Although I agree with this interpretation, I wonder if such a formal classification of the scenes of violence can do justice to the whole spectrum of violence as exhibited in Old Comedy. Kaimio, indeed, must confess that she cannot make much of the slapstick scenes at Lysistrata 1216-1224 and Birds 1323-1336.

Following Kaimio's thesis that all scenes of violence ultimately serve to characterize the persons who commit those acts of violence, I will be concerned, in what follows, with a fundamental question: how is the negative portrayal of the perpetrator brought about while, in the end, he is never held accountable for what he does? What makes the audience laugh and even identify with the hero, and, at the same time, laugh at and see his violent actions in a problematic light? The answer lies, I suggest, in the gelastic transgression of thresholds that were valid in real life. Violence as committed in comedy playfully questions these real-life boundaries and thus vaguely defines them in a way similar to the treatment of violence by the orators in the forensic speeches. This deliberate ambivalence, which accounts for a good part of the audience's amusement, is achieved because the acts of violence onstage, with their inherent breaching of regular societal norms, are embedded within a large-scale ritual: ${ }^{100}$ The two layers of ascribing sense to particular scenes, the fictive plot onstage and the space of the audience (koilon), are in tension with each other. Within the plot played out on the comic stage, conventions

97 Kaimio 1990, 53.

98 Slapstick cannot do without brawls and beatings. In Pherecrates' Petale (Pherecrates F 144 [K.-A.]), an exasperated victim encourages an assailant to $\pi \alpha i ́ \varepsilon v \nu \varepsilon$

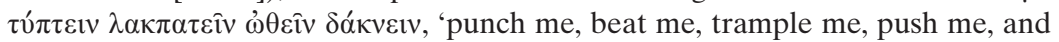
bite me,' transl. in Pherecrates F 136 (Edmonds). Biting and even chewing off a person's ear occur in Hermippus' Soldiers: Hermippus F 51 (K.-A.). Other slap-

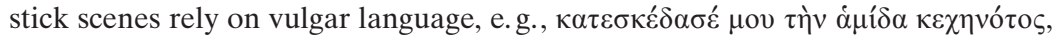
'as I was gaping he dumped the piss pot over me' (F 653 [Henderson]).

99 Kaimio 1990, 66-67, 71.

100 On Aristophanes' deliberate ambiguity with regard to his humor, cf. Jacquinod 2005. 
of daily life are more or less intact. But, at the same time, the plot is embedded within the larger, ritual framework of a Dionysiac festival. The comic license granted during these festivals provided for a different perspective and cast a special, humorous light on the actions onstage. Between these two levels, an incongruence arose in the assessment of staged violence. ${ }^{101}$ This friction generated, for the spectator, a layer of distance from the actions onstage, which allowed him to interpret what he saw onstage with a certain amount of irony. Since all dramatic actions derive symbolic sense from their embeddedness in ritual, scenes of violence and slapstick humor are also charged with a high level of expressive symbolism. The goal of the following pages is to flesh out this communicative aspect of slapstick scenes. I will concentrate on the beating of slaves; the expulsion of authorities; the parody of the judicial system; the reversal of family relationships and of gender roles and religious customs; father-beating scenes; and other scenes of violence, including the maltreatment of women (short of rape), metaphorical violence, mugging at night, and parodies of tragedies. Neither a mythological nor a structural analysis can do justice to the multiple meanings of slapstick scenes. It is my hypothesis that they follow the discursive rules of violence as laid out by the orators and are therefore to be interpreted against the backdrop of the customs and norms of Athenian daily life.

Although the beating of slaves, a stock motif in Old and New Comedy, was not a transgression of Athens' legal and moral codes-in chapter II it was shown that violence against slaves belonged to the realm of normalcy-it helped portray the master negatively. The following list gives only a few prime examples and does not claim to be exhaustive. In Wasps, the slave Xanthias, beaten black and blue by the drunken Philocleon, dashes onstage wailing about his sufferings (1292-1296) and thus anticipates his master's violent kômos (1326-1537). Just as in a tragic narrator's report, the spectator is informed about the hero's misdeeds. In Pax, the chorusleader criticizes the low humor of slave-beating scenes $(742-747)$ in the parabasis, while in the same comedy this motif is transposed onto an al-

101 I very much thank Peter von Möllendorff (Gießen) for corresponding with me in detail about this question. Following Warning 1976, he thinks that the ritual of comedy grants relief from daily life and allows the spectator not to assess the contents morally. In fact, being able and free to ignore moral judgments is key to achieving the immediate effect of comic laughter. Any serious pondering about the plot would be counterintuitive to the goal of comedy. While I agree in essence, I do think that reducing Aristophanes' comedy to mere entertainment does not do justice to this kind of sophisticated drama. 
legorical level: The master Polemos (War) beats the ears of his slave (Hubbub) and forces him to fetch the morsel with which he wants to crush the Greek cities (255-256). The play Knights opens with great tumult: Demosthenes and Nicias, Dêmos' slaves, come running out of the house after a severe beating by Paphlagon $(1-29){ }^{102}$ To Kaimio, this opening scene already characterizes the brutal rule of Paphlagon over Dêmos. ${ }^{103}$ But Paphlagon becomes a victim of violence himself, when the Sausage-Seller brutally beats him down in a brawl (451-456).

Apart from the extended scenes of expelling authorities in Birds, there are two hilarious scenes of informer-bashing in Acharnians. At lines 824828 , Dicaeopolis whips a sycophant offstage by metaphorically referring to his leather straps as agoranomoi. The task of the agoranomoi was the maintenance of law and order in the Agora. ${ }^{104}$ It is ironic that the sycophants, who pester many people but are integral to the Athenian court system, are driven out so as to re-establish order in Dicaeopolis' state. The ironic flavor is increased even further if we take into account that acting on behalf of the one-man polis ${ }^{105}$ can include the threatening of an Athenian citizen with a whip, an action that, in daily life, was a severe breach of a fundamental rule of interaction, that is, the inviolability of the Athenian citizen body. ${ }^{106}$ Onstage, this rule of interaction is reversed. One must beat a sycophant, even if he is an Athenian citizen, to render Dicaeopolis' problematic city safe. Seen from the perspective of the outer ritual, the scene even gains an additional layer of irony: the establishment of the hero's norms takes place in the middle of Dionysiac license and revelry. Operating far outside the norms, Dicaeopolis becomes the laughingstock of the dêmos. His unsocial behavior must have been clearly recognized by the spectators as a problem. One could not be $a$ polis in real life. Dicaeopolis, however, has the license and the power to do so within the festive frame of the Dionysia, and this very fact amused the audience. In lines 925-952, Dicaeopolis strikes a second informer, Nicarchus, packs him up, puts him into a vessel, and turns him

102 On their attempt to escape, cf. Dobrov 1988, 22-23, 25; Murphy 1972, 174, 188. On the slaves' flogging, cf. Ar. Eq. 64-72.

103 Kaimio 1990, 66, 71. Murphy 1972, 177-181 points to archaeological evidence in the form of vase paintings that depict farcical elements for the sake of popular entertainment.

104 Olson 2002, ad Ach. 824-825.

105 Dicaeopolis is actually an a-polis. To Pl. Lg. 928e, an a-polis is a criminal dropout.

106 Cf. above 62, n. $174 ; 87$, n. $288 ; 124$, n. 448. 
over to a Theban to be carried off to Thebes, a hilarious parody of the economic exchange between Athens and Thebes. ${ }^{107}$ Again we see that Aristophanes does not make use of slapstick scenes for the sake of slapstick alone, but pursues very concrete goals. His comedies are always physical and somatic, and their claims remain tangible throughout. The message of these scenes is clear enough: people who harm the city's well-being-in Dicaeopolis' eyes and world-deserve to be expelled.

Even more problematic, from the everyday perspective, is the resistance shown in Lysistrata 387-475 against the Scythian archers, an informal "police" force that was on duty until the end of the fifth century. The rebellious women, clad in hoplite armor, defeat a group of Scythian archers in a kind of battle under Lysistrata's command. ${ }^{108}$ This resilience against state power is all the more remarkable, since the fighters are not bold men daring to face the police, but male actors dressed as women who are disguised as men! The symbolism of this transvestism is clear. The reversal of gender roles is threatening to all men and undermines the order of the state. Ironically, however, the women's plan is to save the city from war and destruction. To this end, they do not even shrink away from meeting the archers in battle. ${ }^{109}$ Although women were not supposed to fight men, according to Athens' gendered understanding of battle and war, these citizen women derive some justification for their daring actions because they are fighting Scythian barbarians. Gender reversals as well ethnic and political considerations, combined with transvestism, make for a very complex scene.

On an allegorical level, in the play Wealth (lines 454-612), the comic hero Chremylus drives out Poverty (Penia). In a highly sophistic agôn, Penia defends herself. Chremylus tries to refute her, but words alone are not enough. He is not as mighty as the supra-real heroes of old, Dicaeopolis, Trygaeus, or Peisetaerus. Nevertheless, he pursues his utopian

107 Goldhill 2006, 157.

108 Cf. Goldhill 2006, 157. Sommerstein 2007c, ad loc. explicates the dense texture of this scene. Cf. also Hall 1989b, 46-47; Henderson 1987, ad loc.

109 Another famous scene involving this foreign "police" force is Ar. Th. 930-1225, where, for the first time in Attic literature, a foreigner speaks in broken Greek. On this scene, cf. now Willi 2003, 198-225 from a linguistic perspective and Hall 1989b passim. Like Hall, Willi 2003, 222 regards the foreigner's talk as "a literary expression of Greek ethnocentricity," but also concludes (225) that the Scythian's being immune to Euripides' poetry protects him from the traps of tragedy. Barbarian language is thus more honest than deceitful tragic language. In Ar. Ach. 40 the archers have only one short entrance onstage. 
goal: wealth for everyone. Although he cannot win by argumentation, he still "succeeds," which marks him as an ambivalent figure. He hustles Poverty offstage and manages to bring about a happy end.

Closely connected to the expulsion of authorities is parody of the judicial system. As far as I can see, there are two prime examples of this comic technique in Aristophanes, one of which is Philocleon's mock trial of a $\operatorname{dog}(V .894-1008)$, treated below; the other is concerned with slapstick beating. It is the magnificent pain-agôn between Dionysus and his slave Xanthias in Frogs. Aeacus whips them both to find out who the real god is (635-673) and both suffer tremendously under the blows. Each of them, however, tries his best to swallow the pain so as to prove that he is the god. The fun part in this scene is of course the fact that Dionysus himself, the god of theater, performs and is as vulnerable and whiny as the mortal. Aristophanes' metatheatrical game with the tension between theatrical illusion and reality is played out on the actors' bodies. ${ }^{110}$ The parody of the basanos, the judicial institution to discover the truth via torture, could not have been more sophisticated. Whereas the audience could certainly laugh about this scene onstage, bystanders who saw the grim proceedings of basanos in the Agora probably did not laugh about the plight of the tortured. The litigants in court, at least, tried hard to spare their slaves this lot. ${ }^{111}$

In other slapstick scenes, the reversal of family relationships, ${ }^{112}$ gender roles, and religious customs is even more systematic. Shortly before the young women engage with the Scythian archers in Lysistrata, the fight for the Acropolis reaches its peak. The semi-chorus of old women douses the semi-chorus of old men with water $(352-386),{ }^{113}$ a typical example of custard-pie-type slapstick, but here charged with more than one symbolic meaning. ${ }^{114}$ Perusino offers a psychoanalytical interpretation of this scene. Whereas the men want to smoke out the women from the Acropolis-the fire standing for phallic power-the women extinguish the fire with water, the symbol of femininity. The latter frustrates and defeats

110 Goldhill 2006, 158-160. Cf. Bierl 2011a on Dionysus' pivotal role in Old Comedy and 1991, $27-44$.

111 On torture, cf. above 88, n. 297.

112 The fact that Bdelycleon tries to educate his father, Philocleon, without success in Wasps, and that this failure leads to a violent kômos, epitomizes the generational conflict. The conflict between Pheidippides and Strepsiades in Clouds escalates into the notorious father-beating scene.

113 There are more vulgar dousing scenes in Aristophanes than this, cf. above 267, n. 98.

114 Perusino 1999, 74-78; MacDowell 1988, 10-11. 
male potency. One could also say that the women are rational and cool off masculine irascibility, which is raging like fire. Female violence again cuts both ways. It threatens male dominance but it is not an end in itself. The women resort to violence only to stop violence forever, to save the city from war, and re-establish the traditional, paternal world order. The happy end is thus masculine and an affirmation of the existing social order.

Whereas the topsy-turvy world of Lysistrata ends in the final affirmation of male dominance, the communal utopia in Ecclesiazusae presents a nightmare-like finale. ${ }^{115}$ The old woman wins the competition against the young woman for the right to sleep with poor, young Epigenes first. As if this were not enough for Epigenes, two more old hags appear onstage and quarrel with each other about the youth. He cannot escape, but is dragged by the three old women into the house to have sex with them (893-1111). This scenario, so horrible for the young man, of having to consummate a perverted gynecocracy, is mitigated, it is true, by a more conciliatory ending-Blepyrus dances off to dinner arm in arm with two young girls shortly before-but it is abundantly clear that a true communal life that entails sharing everything is not possible, not even-or, should we rather sayespecially not among women. Turning gender relations upside down is thus not a viable solution to resolve everyday problems. In the end, all Aristophanic utopias fail, because they are impossible to implement and would be even worse than reality. They fail not because of the violence involved, but because of the irrationality and lack of community spirit on the part of the individual. But since violence is inherent in these problematic utopias, it is discredited, too, alongside the utopias themselves.

How severely the breach of a religious taboo was punished is exemplified by Thesmophoriazusae. Euripides and Agathon shave Euripides' In-law, Mnesilochus, singe his bottom and crotch with a torch, and disguise him as a woman so that he will be able to participate unrecognized in the women's celebration of the Thesmophoria. There, it is his mission to defend Euripides' plays. The plan goes all wrong. The women discover the man behind the disguise, strip him naked, and have him nailed to a

115 According to Dettenhofer 1999, Aristophanes was not concerned with a communist utopia or an emancipatory movement, but brought a piece of anti-Spartan propaganda onstage, either to plead for the rejection of Sparta's peace offer or to welcome the rejection by the Assembly. 
wooden plank by a Scythian archer. ${ }^{116}$ Goldhill and Zeitlin have masterfully analyzed the game of transvestism on several planes. ${ }^{117}$ In contrast to those in Bacchae, the scenes of clothing and unclothing here all happen onstage. Even the In-law's punishment is imagined to have taken place in full view of the audience. The multiple humiliations that the In-law has to endure, and that are all seasoned by strong allusions to tragedy, largely result from his willingness to put his own gender at risk. This is funny to the audience but not to the fictional character onstage. The boundaries between the fiction of the enacted there-and-then and the here-and-now of the real-life frame are blurred when the raging women search the orchêstra for more male intruders. The difference in the perception of violence by the participants of the stage action and the spectators accounts for a good deal of the spectators' amusement.

Some of the most ambivalent scenes of violence in Old Comedy are probably the instances of father-beating. ${ }^{118}$ Because this type of scene is quite frequent in Aristophanic comedy, we can deduce that the violence of sons against their own fathers must have been a major preoccupation for Aristophanes. ${ }^{119}$ The existence of a graphê kakôseôs goneôn in Athenian law, a public procedure to punish the maltreatment of one's own parents, points to the atrocity of such a crime in the minds of the Athenians. ${ }^{120}$ Aristophanes' poetic metaphor in Frogs-according to Heracles, those who have struck their fathers or mothers lie in 'lots of mud and

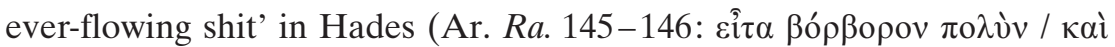

116 Hall 1989b, 52 dubs the Scythian archer in Thesmophoriazusae as "the comic counterpart of the barbarian villains in the Euripidean escape-dramas on which the plot is loosely based."

117 Goldhill 2006, 157-158; Zeitlin 1999; 1981.

118 On the generational conflict in Clouds and Wasps, cf. Zimmermann 2007; in Frogs, von Möllendorff 2007.

119 In Pherecrates' Ant-Men, a son curses his father: Pherecrates F 121 (K.-A.).

120 Todd 1993, 107-108. Appropriate civic behavior toward one's parents was part of the dokimasia procedure, a check of moral qualification that archontes and public speakers (rhêtores) had to undergo (Arist. Ath. 55.2-3; X. Mem. 2.2.13; Aeschin. 1.28). Aeschin. 1.28 explicitly mentions father- and mother-beating as a major offense. We may assume that the idea of treating one's parents well was an integral part of all types of dokimasia. Cf. on these passages in detail Feyel 2009, 25-27. 


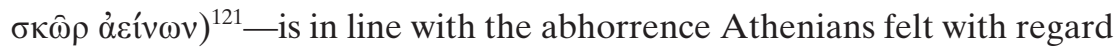
to this severe transgression of moral norms.

The most prominent scene of father-beating in Aristophanes is to be found in Clouds and will be treated below, in the context of that play. Another short instance, Blepyrus' objection to Praxagora's proposal of complete sexual community among men and women, does not shed favorable light on young Athenian men. Only the respect of their own fathers would make them abstain from father-beating, if at all. The pessimistic, certainly exaggerated passage deserves to be quoted in full: ${ }^{122}$

Then from now on won't sons methodically strangle each and every older man? Because even now they strangle their acknowledged father; what will happen when he's unacknowledged? Won't they'll shit on him as well?

Other instances of slapstick violence portray the maltreatment of women (short of rape), metaphorical violence, mugging at night, and parody of tragedy. All of these scenes make sense in the context of the respective comedies and are again ambivalent.

The magistrate in Lysistrata is so angry at the women's meddling with things that allegedly do not concern them that he threatens Lysistrata with a thorough beating (503). This menacing of a free Athenian woman must be seen against the background of all other scenes of violence directed against women in comedy. Sommerstein's comment deserves to be quoted in full:

The Magistrate, like Lysistrata's husband (520; cf. also 516), thinks it quite proper to strike a woman merely for talking about matters that ought not to concern her. This attitude is found in Ar. only in the present play; elsewhere physical violence against women is associated with drunkenness (cf. Wasps $1388 \mathrm{ff}$ ) or with moral corruption (cf. Clouds $1443 \mathrm{ff})$. Even female slaves, in marked contrast to male slaves, seem never to be beaten, though they are sometimes raped ... In view of Old Comedy's fondness for physical violence in general ... this taboo on such violence against women must be regarded

121 On the relationship between Euripides' Heracles in his Peirithous and Aristophanes' Heracles in Frogs from a metafictional standpoint, cf. Dobrov 2001, 133 156.

122 Ar. Ec. 638-640:

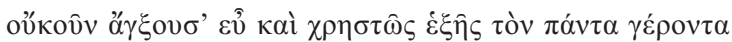

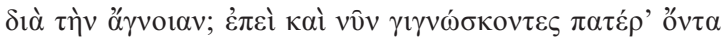

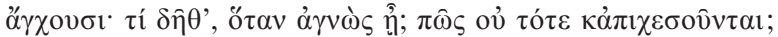

Cf. Sommerstein 2007b, ad Ec. 635-643 on Plato's solution to this problem as proposed in his communal utopia in $R$. 460c-d; 461c-e; 463c-d; 465a-b. 
as significant, and the breach of the taboo in the present scene highlights the arrogance and unreasonableness of Athenian males. ${ }^{123}$

The significance of this scene is neatly expressed in these words. Sommerstein's observations hold true even if we consider the background of the women's potential rape by their own husbands (Lys. 160-166 and 225227). Domestic violence, as we have seen, belonged to the realm of normality and would not have been perceived as anti-structural by the male theater audience. ${ }^{124}$ But the magistrate's behavior toward Lysistrata was certainly the transgression of a taboo, because he was not entitled to touch a free citizen woman. ${ }^{125}$

Even when violence is relegated to a metaphorical meaning only, it is still full of symbolic significance. By having the chorus-leader boast, 'I'm the one who hit Cleon in the belly when he was at the height of his power'

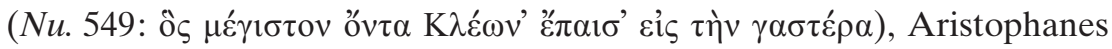
harks back to Knights, performed one year prior (424 BCE), and reminds the audience of his daring attack and his satirizing of the powerful politician.

Several times, night-time mugging is envisioned, frequently in combination with clothes-snatching. It was obviously all right to wish for an enemy to be assaulted by night and get his head broken by a drunkard (Ach.1165-1173). Frogs 715-716, for example, refers to Cleigenes' running the risk of being waylaid and stripped of his clothes when he walks around at night, drunk and without his stick. According to Sommerstein, Cleigenes is cast here in an unfavorable light. ${ }^{126} \mathrm{He}$ is not only an alcoholic, but is also characterized as aggressive by his wearing a weapon, which was no longer customary at Athens. ${ }^{127}$ This also presents him as a coward, since his life was not in danger in the streets of the city. In the utopian other-world of Ecclesiazusae, the danger of encountering footpads is banned forever, because, as Praxagora explains, once everyone has a share in

123 Sommerstein 2007c, ad Lys. 503.

124 In Aristophanes' fragmentary Aeolosicon, the women take it for granted that they are beaten black and blue (Aristophanes F 9 [K.-A.] = F 10 [Edmonds]). In an unattributed Aristophanic fragment, violence against a woman is clearly expressed (F 676 [Henderson]). Unfortunately, we do not know the context of this fragment. Cf. above 155, n. 584; below 283, n. 159.

125 If even female prisoners of war enjoyed a minimum degree of protection (cf. above $89-90 ; 124$, n. 451 ), the magistrate's threat to beat a free woman in the comedy is to be regarded as an anti-structural feature.

126 Sommerstein 1996, ad loc.

127 Cf. above 49, n. 126. 
everything there is no longer any need to steal and rob people of their clothes (668-670). Euelpides tells Peisetaerus in Birds how he was mugged and knocked down with a cudgel by a clothes-snatcher, when he had just left the city walls to go on a trip, ${ }^{128}$ having mistaken the dark of night for the early morning hours because of the aberrant crowing of a bird (495-498). Here again we can perceive a double standard in these scenes. Within the fictive plots, Athenian law holds sway, and clothes-snatchers are therefore kakourgoi and, as such, subject to the apagôgê procedure that could have led to their immediate execution, if they confessed their guilt. The audience could laugh about these scenes because they themselves were not the victims of the muggers and were safe in the seats of the theater of Dionysus. ${ }^{129}$

Old Comedy cannot be fully understood without considering its constant references to tragedy. Parody of tragedy (paratragedy) and its mythological plotlines is hence a major source of humor. A few examples shall suffice in this context. Birds 712 and 1482-1493, and Acharnians 1167-1168, have to be read together. It was not desirable to meet a hero at night. Orestes, in particular, the son of Agamemnon, had not only killed his mother, but was also accustomed to waylaying people and stripping them of their clothes. Orestes, as the archetypical footpad, provided the nickname for various miscreants in Athens, three of whom we know: the son of a certain Timocrates, Diocles of Phlya, and one of the adherents of Callias. ${ }^{130}$ These passages provide good illustration of how Old Comedy plays with mythology and jokingly refers to "real" people. In Birds 1565-692, Heracles is presented as a gluttonous brute with his diplomatic skills limited to threatening a Triballian with his club while on the gods' embassy. ${ }^{131}$

In two grand scenes, Aristophanes parodies Euripides' Telephus (from $438 \mathrm{BCE}$ ), in which Telephus escapes death by taking Agamemnon's young son hostage and threatening to kill him. In Acharnians, the chorus of the fanatical charcoal-burners wants to prevent Dicaeopolis from striking a private truce with the Spartans, by violent means if neces-

128 Also Middle Comedy makes use of the motif of mugging, in close connection to kidnapping: Antiphanes F 202 (K.-A.), a fragment from Antiphanes' Soldier or Tychon. On this scene, now with commentary, cf. Olson 2007, p. 187 (E3) with p. 440 (transl.).

129 MacDowell 1988, 12 sees the reason why the spectators could laugh about violence onstage in their feeling of superiority with regard to the victim onstage.

130 Sommerstein 1998b, ad Ach. 1167-1168 and 1991, ad Av. 712 and 1485-1493.

131 On this scene, cf. Kaimio 1990, 70. 
sary (204-236). They attack him and are about to stone him-the appropriate capital punishment for a traitor (280-283), although the violence is to be taken ironically - when the comic hero suddenly goes inside the house and comes back with a basket of coals, presents it as a hostage, and threatens to split it open if they advance any further (326-365). ${ }^{132}$ Under this pressure, the charcoalers back off and agree to listen to Dicaeopolis.

Aristophanes must have loved the tragic pathos of the Telephus scene, which lent itself so well to parody, because he used the motif again in Thesmophoriazusae, this time on an even grander scale than in Acharnians. ${ }^{133}$ When the In-law attending the Thesmophoria in the guise of a woman is discovered, unmasked, and threatened by the women, he takes Mica's baby hostage in order to save himself $(689-761) .{ }^{134}$ As it turns out, the baby is only a wineskin that the In-law finally cuts open, spilling the wine all over Mica. What started out as a dreadful scene ends in comic relief. In all these paratragic instances, violence is prescribed by myth and domesticated by the comic framing.

In her analysis, Kaimio cannot make any special sense out of Lysistrata 1216-1227 and Birds 1323-1336. To her, these scenes are pure slapstick for the sake of slapstick only. ${ }^{135}$ In the passage toward the end of $L y$ sistrata, two Athenians remove slave doorkeepers by force, thus allowing the celebrating Spartans to come out and join the Athenians. Sommerstein has pointed to the strong metatheatrical element of the phrase

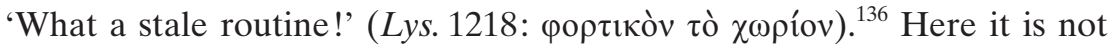
the fictive character but the very real actors who are speaking. Aristophanes does not want to fall back on the traditional, low humor of slapstick violence. This remark allows the audience to think about the violence normally used by Athenian citizens against slaves onstage. ${ }^{137}$ Moreover,

132 On this hostage-taking scene, borrowed from Euripides' Telephus, cf. Zimmermann 22006, 128-129; Sommerstein 1998b, ad loc.; Kaimio 1990, 68-69.

133 Rau 1975, 339 remarks that, for two-thirds of Thesmophoriazusae, tragedy forms the background, however parodied and comically reshaped. Cf. Rau 1967, 42-50 (Thesmophoriazusae), 19-42 (Acharnians); von Möllendorff 2002, 150 (Thesmophoriazusae), 67-69 (Acharnians). On the Telephus-motif in Acharnians and Thesmophoriazusae comparatively, cf. Platter 2007, 143-175; Scholten 2006 on Aristophanes' playing with the myth of Telephus in Acharnians.

134 Kaimio 1990, 69.

135 Kaimio 1990, 67.

136 Sommerstein 2007c, ad loc.

137 Revermann 2006b is willing to grant the Athenian audience a high theatrical competence that they acquired through their active participation in choruses 
in the preparation of the common feast shared by the Athenians and Spartans, these slaves are the last, though insignificant, obstacle to the final reconciliation with the Spartans. They are easy to overcome, yet their presence at a door marks a threshold separating the old animosities from the more peaceful, brighter future. Stepping over this threshold forcefully is a kind of retarding moment, able to enhance suspense and make the audience laugh once more. In this function, this kind of violence is no longer transgressive, not because Athenian citizens had every right to manhandle slaves, but because they act here onstage on behalf of a larger cause, bringing about peace between Athens and Sparta.

In Birds 1323-1336, Peisetaerus menaces his slave Manes with blows in accordance with the chorus of birds. This impatience and lack of selfcontrol characterize Peisetaerus neatly. He is a polupragmôn, a typically Athenian busybody who upholds traditional hierarchies. Cloudcuckooland does not change anything about the Athenians' unquenchable aspiration for power.

Aristophanes cannot do without slapstick, but, as I hope has become clear, each and every slapstick scene makes sense and conveys a message more important than mere lowbrow humor. Is Aristophanes, in the end, correct in claiming that he elevated comedy from ribald vaudeville theater to a self-reflective art form, or was it all self-referential and joking make-believe? In the magnificent metatheatrical self-praise of Peace, Aristophanes has the chorus-leader boastfully speak as his mouth-piece: $:^{138}$

In the first place, he [Aristophanes] was the only man on earth to stop his rivals from making jokes about rags and waging war on lice; ... and to cashier those slaves who run away or pull hoaxes or get a beating ... By getting

and their frequent attendance of theatrical performances. At the same time, he emphasizes the "stratified decoding" of the plays' sense by the spectators (99, 118-120). Not everyone understood the performances in the same way, but the playwrights made certain that their dramatic products could be understood on different levels and were entertaining to everyone in the audience.

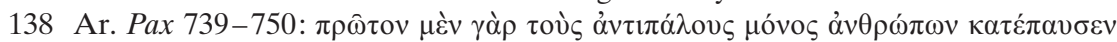

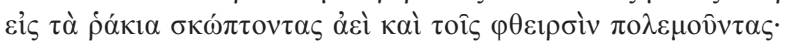

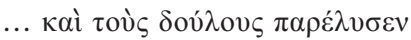

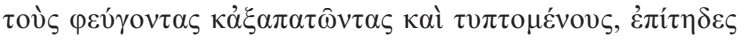
...

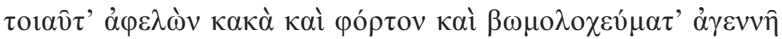

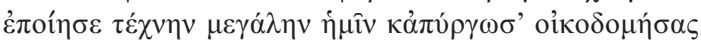

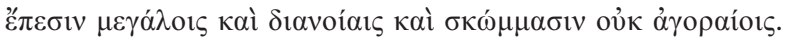


rid of such poor, lowbrow buffoonery, he's made our art great and built it up to towering size with impressive verses, conceptions, and uncommon jokes.

So although Aristophanes does make use of these very same motifs, he charges them with more than bawdy humor. ${ }^{139}$ The friction between stage action and Dionysiac frame allows Aristophanes to play with the boundaries delineating the meaning of violence. Everything that happens inside the confines of the Dionysiac festival, with its exuberant license, can be perceived as funny, as not being subject to everyday scrutiny and moral assessment. Only seen from within the fictional plot onstage, however, the flexible line of daily life between acceptable and unacceptable behavior is intact. There is also acceptable and unacceptable violence. Acceptable violence onstage is no problem, but the judgment of unacceptable violence onstage is quite different. Aristophanic comedy can make fun and, at the same time, indirectly problematize this kind of violence, not least because human beings tend to exclude and marginalize phenomena about which they laugh. Laughing itself draws a boundary similar to the one described in chapter II of this book. We can laugh about calamities as long as they do not affect us, happen within our cognitive horizon, and are somehow tolerable. Atrocities occurring outside this sphere are monstrous and more appropriate for tragedy than for comedy. This perspective explains the different layers of Aristophanic violence, slapstick in particular.

\section{Rape}

While the scholarly treatment of rape in Menander has developed into a subfield of Classical Studies, ${ }^{140}$ there is, to my knowledge, only one article on rape in Aristophanes (and Menander), by Sommerstein. While he underlines the "aggressive assertion of superiority" that is expressed in rape,${ }^{141}$ he does not miss the fundamental differences from New Comedy. In Old Comedy, rape is never "a present or past event; [it] is always threatened, anticipated or imagined." ${ }^{\text {142 }}$ The victim is almost always a

139 McLeish 1980, 94-95 differentiates among six types of bawdy: explicit bawdy, explicit bawdy prepared, explicit bawdy involving a third party, secondary bawdy, double entendre, and bawdy gesture.

140 Cf. above 5, n. 28. Although Fantham 1975 mentions rape only in passing, her article triggered research on women in Menander so that, from the 1970s on, we can see that women's studies have reached the realm of New Comedy.

141 Sommerstein 1998a, 109.

142 Sommerstein 1998a, 105. 
slave,${ }^{143}$ not a free citizen woman (with exceptions to be found only in $L y$ sistrata and Birds, and a fragment maybe from Thesmophoriazusae II). ${ }^{144}$ All rapists are mature men over thirty and married. ${ }^{145}$ These preliminary remarks alone suffice to show that Aristophanes sends an ambivalent message concerning rape. It can be both a "harmless" incident, designed to express the sexual abundance and fertility of a happy, utopian life, ${ }^{146}$ as well as a problematic occurrence. A close analysis of all instances of anticipated rape in Old Comedy will once more corroborate the discursive openness of the Aristophanic stage. ${ }^{147}$ I treat the comedies in chronological order.

As is often the case in Aristophanes, and as is typical of the male perception of sex in Athenian sources, the line between consensual sex and rape is blurred. In an extended pun playing with agricultural double-entendres, the chorus-leader in Acharnians envisions three sexual encounters with Reconciliation, thus stressing his still fully intact virility (994999). ${ }^{148}$ More open to interpretation is Dicaeopolis' prayer to Phales, a companion of Dionysus, to grant him the chance to rape a young and blooming girl (263-275) as a punishment for her stealing wood. The status of the girl is not directly expressed, but as she is occupied with fetching wood from the forest, it is safe to assume that she is a slave. ${ }^{149} \mathrm{Di}$ caeopolis regards her theft as a kind of excuse for the rape, but Olson is right in observing that the rape of another man's slave constituted hubris. ${ }^{150}$ What is the message of this scene? Hubris is not a concern for the egotist Dicaeopolis in his utopian wish to establish for himself, and just

143 A typical phrase from the fragments is Philyllius' statement in Cities that ö $\tau 1$ ’̀v

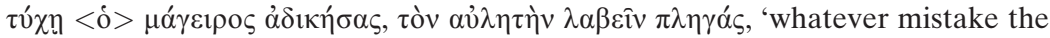
cook may make, the fluteplayer gets beaten' (Philyllius F 9 [K.-A.]; transl. in Philyllius F 10 [Edmonds]).

144 Sommerstein 1998a, 105; anonymous fragment of Old Comedy, Aristophanes' Thesmophoriazusae II? 5 A (Edmonds). Cf. Zeus' (?) remark that his wife has been forced in a fragment from Alcaeus' Endymion (?): Alcaeus F 31 (K.-A.).

145 Sommerstein 1998a, 109.

146 On the Schlaraffenland-motif, a characteristic feature of the world turned upside down, cf., from a broad anthropological perspective, Kenner 1970, 69-82.

147 Cf. the useful overview given by Sommerstein 1998a, 105-109.

148 Cf. Sommerstein 1998b, ad loc. The triple penetration is a frequent motif in Aristophanes. Cf. also Eq. 1388-1391; Av. 1256.

149 Olson 2002, ad Ach. 272-273; cf. Bierl 2009a, 314-325 on the phallic and private celebration of the rural Dionysia in the parodos of the play.

150 Olson 2002, ad Ach. 272-275. 
for himself, a kind of paradise. Similar to the slave-beating scenes that lay open the cruel nature of their masters, this imagined rape of another man's property characterizes the protagonist in all his ambivalence. He has no qualms about transgressing the boundaries that the community has drawn. This scene paradigmatically shows the tension between the luxurious and sexually abundant lifestyle that the comic hero demands for himself and his followers and the limits that society poses onto his complete and at times ruthless claim to self-fulfillment. ${ }^{151}$

In Knights, the Sausage-Seller tries to lure Dêmos over to his side and presents him with a slave boy carrying a camp stool. The Sausage-Seller encourages Dêmos to enjoy the boy sexually. This is the only scene in Aristophanes in which the rape of a boy is suggested (1384-1386). Immediately afterward (1387-1391), two allegorical Peace-terms (Spondai) enter the stage, in the form of two beautiful girls. The word spondai is feminine in Greek, and a vulgar wordplay ensues. Dêmos is fascinated by the beauty of the girls and asks the Sausage-Seller if he can 'satisfy [his] thirty-year

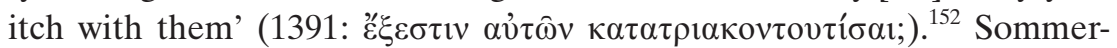

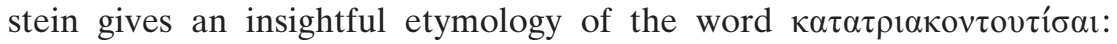
"to pierce them (outasai) three times (tria) with a long pole (kontos) from below (kata-)." 153 The suggestion of triple penetration proves again that the sexual potency of Dêmos is beyond doubt. Several more times in Aristophanes' comedies we will encounter silent women, whom the comic hero is allowed to rape or have consensual sex with. We do not know how these women were represented onstage. Were they, in accordance with stage conventions, men in the disguise of women, or is it imaginable that, for the purpose of titillating the male audience, female prostitutes appeared naked onstage ? ${ }^{154}$ It is interesting to

151 The final scene (Ach.1197-1231), in which Dicaeopolis dances off with erect phallus and two dancing girls by his side is a finale characteristic of Old Comedy. Rape and consensual sex are not distinguished. The "wonderful" conditions of peace that Dicaeopolis enjoys are explicitly contrasted to the dire calamities from which the general Lamachus suffers.

152 Translation taken from Sommerstein 1997 ad loc.

153 Sommerstein 1997, ad loc.

154 Sommerstein 2007c, ad Lys. 1114 follows Henderson and believes that male actors enacted female objects of desire: "it is certain, and in most of the other passages cited it is probable, that the girl(s) appeared nude (i.e. that they were impersonated by men wearing appropriately designed bodysuits and padding: see J. J. Henderson, YCS 26 [1980] 163-4)." While Zweig 1992 is careful enough not to answer the vexed question of whether mute nude female figures were represented by padded male actors or female prostitutes, she demonstrates convincingly 
see Dêmos' reaction to getting the chance of indulging in homo- and heterosexual activities. He is delighted and cannot wait to consummate the Peace-treaties. The members of the dêmos assembled as audience could surely laugh about their own sexual appetites as presented onstage, but laughter also creates a critical distance.

We find rape similarly represented in Peace. Trygaeus and his slave bring Theoria (Holiday, Show-time), a handmaid to Peace, onstage, make her strip in front of the audience, and entrust her to the councilor in the first row. During this long scene $(868-908,523-867$ as preparation), full of vulgar and unequivocal sexual language, the audience had to join in the game. ${ }^{155}$ Metatheater at its best potentially broke down the invisible barrier between plot and Dionysiac ritual. A truly sexual performance was now possible. Trygaeus makes it clear that the five hundred councilors can have sex with Theoria without further ado: 'you can lift her legs in the air right away and have a Liberation Feast! Just look at

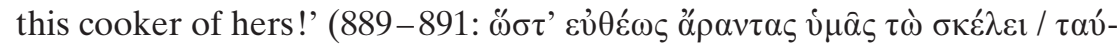

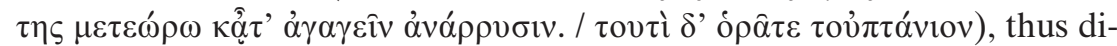
rectly suggesting gang rape. ${ }^{156}$ What probably occurred is that Trygaeus took her by the hand, led her across the orchêstra, where one prytanic officer, coached by the playwright, received her. She sat down among the prutaneis, naked and silent, until the play was over. ${ }^{157}$ It comes as no surprise that Trygaeus, in the exit scene, dances offstage together with the chorus-leader and the two semi-choruses, looking forward to having sex with Opora (Cornucopia), who is also a handmaid to Peace (13291340). We can only guess whether or not this kind of sexual intercourse was understood to be consensual, but we have to keep in mind that Theoria and Opora are allegorical figures standing for the blessings of peace, not real human beings, even though represented by (female?) actors on stage.

In Thesmophoriazusae, rape has an almost metaphorical sense in the verbal exchange between Agathon and Euripides' In-law. The latter threatens to rape the former (59-62), one of the rare instances of the rape of a man in Aristophanes. The scene is decidedly funny and has

that these scenes are pornography rather than the celebration of exuberant sexuality. They unmistakably show to what high degree male dominance over women was entrenched in Athenian culture.

155 On the whole scene, cf. Robson 2006, 132-186; Henderson 1991, 64-66, $169-$ 170.

156 Cf. Sommerstein 2005, ad loc. on all the sexual allusions and word-plays.

157 Olson 1998, ad Pax 905-906. 
strong slapstick qualities. At lines 157-158, the In-law again uses foul language, suggesting to Agathon that he will take him from behind when he is about to write a satyr-play. This is not even envisioned as rape, but is a meta-literary joke, since satyr-plays centered on racy, sexual humor. ${ }^{158}$

A different image of rape emerges in Lysistrata. When the heroine suggests the sex-strike to her companions, the women fear they might be raped by their own husbands $(160-166)$. Later, in their oath to the common cause, the women also take potential rape by their husbands into consideration (225-227). ${ }^{159}$ That this fear is not unfounded becomes clear from Cinesias' remarks after he has been titillated and duped by his wife, Myrrhine, who pretends she will seduce him but, to make him suffer more, suddenly disappears shortly before the sexual act. Cinesias is outraged by his wife's impertinence and wishes to rape her, with the help of Zeus (973-979). These scenes from Lysistrata are the only three passages in the whole of the Aristophanic corpus that allude to the rape of married women (i.e., female citizens). In the grand scene of reconciliation, staged by Lysistrata, between the Athenian and the Spartan envoy, Reconciliation herself (Diallage), in the guise of a naked and beautiful young woman, appears onstage $(1112-1189) .{ }^{160}$ The men, having suffered for quite some time from the plight caused by the sustained sex-strike, are now even harder pressed than before. They cannot divert their gazes from Reconciliation and are now ready to strike the truce to enjoy, finally, the fruits of peace. Unlike in Acharnians (990-999), Diallage appears onstage in Lysistrata, thus heightening the performative effect of the scene by underlining the men's sexual arousal right in front of the tangible object of sexual desire. On a concrete, physical level, the naked Diallage, whose erogenous zones are distributed as spheres of influence to the men contracting for peace, embodies the unity of Greece.

In Ecclesiazusae, the relationships of sexual power in Athenian society are laid open. A reversed world order, in which women reign, automatically entails women raping men. Whoever is in charge also has the

158 On both scenes, cf. Austin - Olson 2004, ad loc. The dancing-girl, Fawn, who sleeps with the Scythian archer for a drachma in order to distract him while Euripides releases the In-law from the plank (Th. 1172-1225) is not the victim of a rape. She is nevertheless a silent character.

159 From the perspective of Athenian men, forced sex with their wives was legitimate. But the women clearly express concern and are afraid of violence (bia), so that we can definitely speak of rape. Cf. above 155 , n. 584; 275, n. 124.

160 Cf. above 281 , n. 154 on the question of wether prostitutes played the roles of these silent and naked women. 
right to rape members of the other sex. Toward the end of the play, however, this gruesome prospect of a true gynecocracy is somehow mitigated. On the command of his wife Praxagora, Blepyrus is given two young girls before he goes off to dinner (1137-1138), a conciliatory gesture that heals the world again, at least for Blepyrus.

Like every other form of violence in Aristophanes, rape has a broad semantic range of meanings and is therefore open to interpretation. Rape is fundamentally ambivalent and can be either harmless or problematic, according to its circumstances and who its victims are. In eight out of eleven Aristophanic comedies, rape is mentioned as a fantasy or threat by a male protagonist; it never actually occurs on the comic stage. It is always imagined as something pleasant for the comic hero. In most cases, he longs for the rape of, or consensual sex with, subordinate women who are in no position to defend themselves. Legally, a man could do anything he liked with a slave, as long as he owned that slave. Molesting or maltreating one's own property was not violence in the eyes of Athenian men, because this kind of patriarchal behavior belonged to the realm of normalcy. Unlike in Menander, citizen women were, in most instances, not the targets of sexual violence in Old Comedy, and if Lysistrata and her female companions are afraid of being raped by their own husbands, this fear only underlines their unprecedented boldness in defying their husbands' sexual wishes. Often, sexual fulfillment has a metaphorical sense-the heroes want to sleep with Diallage in $L y$ sistrata, or with Cornucopia (Opora) and Holiday (Theoria) in Peacestanding for the fullness of life, the paradisal utopia of a golden and peaceful age revived by the comic hero. Rape in this sense, then, is the expression of exuberant happiness. On this surface level, forceful sex was not problematized; the male audience could certainly laugh. In this sense, Aristophanes was far less transgressive than Menander, who took the rape of a citizen girl (who was always impregnated by the sexual act) as the point of departure for the gradual resolution of troublesome complications. This does not mean, however, that rape is a harmless event throughout Old Comedy. Aristophanes sticks closely to Athenian law, which recognized rape as a threat to the established order if a woman under a man's kuria was the victim. ${ }^{161}$ Thus rape is cast in a critical light when the perpetrator does not respect social hierarchies. The threatened sexual violation of divine figures, like Iris and Basileia in Birds, is excessive misconduct (see below). Raping another man's slave

161 Cf. above 53, n. 145; 76, n. 242; 77, n. 246; 78, n. 252. 
(Acharnians) and stealing a flute-girl from a symposion to have sex with her (Wasps) are unacceptable, and characterize the comic hero negatively. In Athens, strict moral codes regulated homosexual behavior. The molestation of boys (Knights, Thesmophoriazusae), however funny it is meant to be, emphasizes the moral depravity of Dêmos and the In-law. Rape thus becomes a tool of negative characterization in the hands of the dramatist. Once more, we discern different layers within one type of violent behavior. The whole range of meanings attached to rape is in line with the polyvalence of all other kinds of violent behavior in Aristophanes. The comparison with Menander will be telling. One significant difference should be addressed at this point already. In contrast to Menandrian comedy, Aristophanic comedy graphically displays the sexual urge onstage through the actors' wearing of leather phalloi around their waists. Although sexual intercourse was not directly performed onstage, largerthan-life erections, obscene gestures, and the appearance of titillating figures like Diallage on the stage could not fail to create a highly sexualized atmosphere.

Three Case Studies:

Wasps, Birds, and Clouds

The ensuing inquiry follows the structure employed above, in examining anger, hubris, slapstick, and rape. The violent kômos in Wasps is of such paradigmatic importance to the genre of Old Comedy that a special subchapter will be dedicated to it.

\section{Wasps (422 BCE)}

Aristophanes has addressed in Wasps, more than in any other comedy, the theatricality and ritual character of the Athenian courtroom, and blended them with those of the theater. The generational conflict between Philocleon (Cleon-lover) and his son Bdelycleon (Cleon-hater) is embedded in a wider web of conflicts: whereas Philocleon stands for old age, poverty, democracy, the judicial system, and the Agora-that is, he embodies the qualities of a typical Athenian busybody driven by political activism-his son is the exact opposite. Bdelycleon stands for youth, wealth, aristocracy, the symposion culture, and the oikos, and thus epitomizes political passiv- 
ity. ${ }^{162}$ The two men symbolize these opposing views and are close relatives, with a certain amount of mutual understanding and a willingness to take responsibility for each other. Democratic energy, however, if exaggerated, is recognized as a fundamental problem. Philocleon is obsessed by his jury duty. Bdelycleon is concerned about his father's state of mind and is at first successful at hindering his father's comrades, the chorus of elderly jurymen (wasps), from dragging him along to the courtroom in the Agora. To find compensation for his father's favorite activity, Bdelycleon stages a private trial within the oikos of the dog Labes (8911008). The setting is absurd. The real-life situation of a courtroom trial is grotesquely distorted. The proceedings should be held in the Agora, not at home. There should be hundreds of judges, not one man. The whole ritual framing is lacking and this fact alone renders this parody of a trial unsuccessful. Bdelycleon dupes his father into releasing the defendant, an act of mercy that Philocleon has actually never before granted. This botched "courtroom" ritual leads to ever-increasing absurdity and chaos in the remainder of the comedy. If we regard the play within the play together with the scene of transvestism, in which Bdelycleon forces his father to change his old garb for new, symposiastic clothes (11221164), and the scenes in the street, in which Bdelycleon tries to mitigate his father's aggressiveness and uninhibited energy (1326-1387, 14421449), as a liminal phase (i.e., the stage between perverted democratic vigor and a calm, aristocratic culture), we may observe that all these attempts on the part of the son to (re-)educate his father fail in the end. Could theater itself be a form of redress, in Turner's terminology, an alternative space in which Philocleon's unchecked energy could find its outlet in a functioning form of liminality that provides a safety valve for disturbing, over-energetic, maniacal, and egotistic behavior ? ${ }^{163}$ We will see to what extent a closer look at the violence perpetrated in this play challenges this hypothesis.

Anger is the emotion that best characterizes Wasps, in a literal sense. In line 1082/83, where the chorus of wasps speaks about biting their lips in battle out of thumos (sharp, bitter spirit) against the Persians, this thumos is meant positively. At the same time, it is also obvious that their fighting spirit, in its gross exaggeration, is turning into a problem, as democratic energy goes more and more awry in the play. More here than in any

162 Von Möllendorff 2002, 98-104.

163 It is von Möllendorff's merit to have worked out the highly ritualistic dimension of this comedy. Cf. von Möllendorff 2002, 94-104 and especially his graph (103). 
other Aristophanic comedy, we see that drama is able to shed light on the same phenomenon from at least two different angles. To the wasps, who symbolize the Athenians of old who are passionate judges and uphold the lawcourt system that stands for democracy, their anger is positive, justified, even a manly virtue and moral obligation. The chorus of wasps

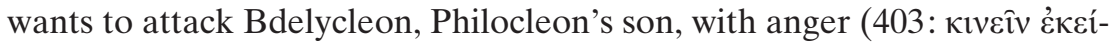

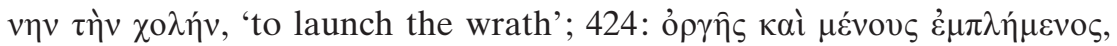
'full of rage and spirit') and with their stings in order to free Philocleon.

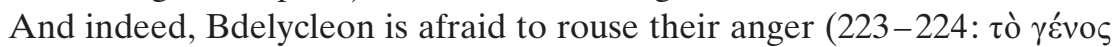

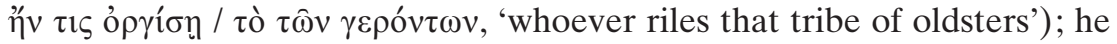
warns the servant Xanthias of their horrible stings. In lines 646-649 the

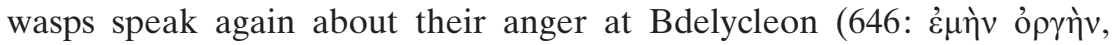
'my anger'). After asking Bdelycleon to give up his own anger at his father and them, the wasps finally abandon their ire and declare Bdelycleon winner of the argument (726). Thus, Bdelycleon has managed to appease the chorus. This can only mean that even the chorus of fervent democrats somehow acknowledges Bdelycleon's feelings. They implicitly grant that Bdelycleon's concern is justified to a certain extent. To Bdelycleon, his father's and his comrades' perverted energy is not only obsolete, but also menacing and threatening to become meddlesome and imperialistic. His father lost the juste milieu; democratic passion as expressed in his psychological dependence on the law courts became a dangerous addiction. Within the context of a trial, Philocleon's energy is directed against

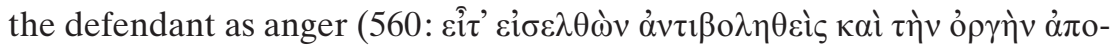
$\mu о \rho \chi \theta \varepsilon i ́ s$, 'Then after I've been supplicated and had my anger wiped away'), because more often than not the behavior of the accused was perceived as anti-democratic. ${ }^{164}$ Philocleon takes great delight in describing how the defendants implore him to lay down his wrath and have pity

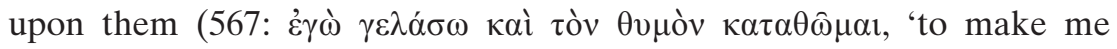
laugh and put away may anger'). It is only when he is invoked in this way that he shows moderation, might abandon his wrath (574: $\tau \hat{\jmath} \varsigma$

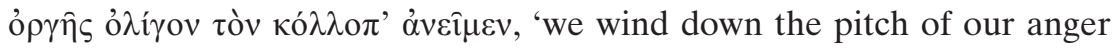
a little'), and may grant pardon. Shortly before the hilarious mock-trial scene staged by Bdelycleon for his father as an inner play within the outer play of the theater production, in which Philocleon holds court judging a dog (891-1008), Bdelycleon addresses the chorus and asks that his father let go exactly this hard-heartedness and wrath (883-885:

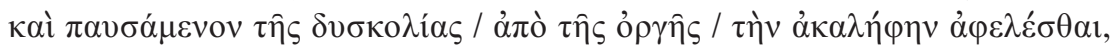

164 Cf. above 58; 92, n. $312 ; 128$, n. 474; 136; 139; 159. 
'and put away his bad temper, from his anger drawing the sting'). So, while a certain democratic anger is justified against a miscreant, Philocleon's exaggerated, perverted form of wrath is not. Anger becomes problematic at the point where the limits of usefulness are transgressed. ${ }^{165}$ Bdelycleon does his best to suppress his father's unchecked anger (risking the wrath of Philocleon's colleagues) or to find different outlets for it, but ultimately fails. As we will see time and again, Aristophanes shows both sides and demonstrates onstage to what extent a certain ill-feeling is still tolerable, and when it becomes excessive. As in the orators, the ritual of public performance draws boundaries and creates a discursive and flexible line between acceptable and unacceptable behavior.

The most famous instances of hubris in Aristophanic comedy are to be found in Wasps, where it mainly denotes battery of free citizens. As Bdelycleon invites his father to take part in a symposion at a friend's house, Philocleon at first wants to abstain from heavy drinking, because he well knows about the consequences of losing control of oneself. ${ }^{166}$ In the wake of the lavish feast, however, Philocleon cannot resist: he drinks too much, starts rampaging with his unquenchable energy, and hits innocent passers-by during his drunken revel. ${ }^{167}$ Of all the men in the compa-

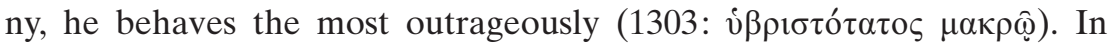
lines 1418-1419 we see to what extent the context of hubris is anchored in Athenian law. A beaten accuser enters the stage with a witness and declares that he will file charges of hubris against Philocleon. Bdelycleon knows what is at stake and immediately offers the wronged man compensation in any amount he wishes. Nevertheless, Philocleon rages on and strikes the accuser a second time, who leaves the stage, telling the hubristês to carry on with his outrageousness until he faces his judge (1441:

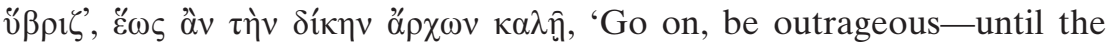
magistrate calls your case!'). In this play, we see that the unbridled, wasp-like energy of Philocleon transgresses the boundaries of acceptable behavior and is therefore no longer compatible with the judicial norms of

165 Cf. Olson 2002, ad Ach.352-356 referring to the heated dialogue between Dicaeopolis and the chorus: "although a certain amount of anger is understandable and expected in a situation such as this, utterly unreasonable anger is not."

166 V. 1252-1255. Epicharmus has a similar passage about the detrimental consequences of heavy drinking (Epicharmus F 146 [K.-A.]). Telling are also Alexis F 160 (K.-A.) and Eubulus F 93 (K.-A.) with lists of escalation.

167 V. 1299-1341, 1417-1441. At V. 1306, Philocleon is also compared to a donkey because of his gluttony and his enormous, supra-human sexual appetite. On the hubris of the donkey, cf. Fisher 1976, 189-190. 
Athens. Within the fictional, dramatic action played out onstage, this is certainly true. The exuberant energy of the larger-than-life individual that forces its way beyond the norms and conventions of society is problematic from a communal perspective. Another matter is to what extent the spectators may have regarded Philocleon's riotous conduct as problematic. On the surface level, they certainly did not. They knew well that it was all play and that Philocleon would dance offstage; therefore they could relish this playful breach of everyday boundaries. In fact, they saw their own hidden wishes fulfilled onstage. Again we see the openness of comedy. Although the actor's behavior was only outrageous onstage, and the bearer of Philocleon's mask was not expected to carry this kind of exuberant license into the civic realm outside the theater, it would have been a transgression had the actor tried to elide the permeable line between stage and civic ritual. Despite all festive, Dionysiac license, pelting other citizens was, in the eyes of the spectators, only permissible onstage. In addition, a closer look reveals that a ritual is violated here: the rite of passage that young Athenian males, the ephebes, had to undergo. In this ephebic rite, young men were transferred from a state of immaturity, in which they were granted a certain amount of license, to maturity, responsibility, and the right to carry arms. Philocleon reverses this ritual of becoming an adult: as an old man who should be temperate and circumspect, he is regressing into unbridled puberty, unheeding of social norms and expectations. ${ }^{168}$ To the Athenians, a violated ritual was always reason for concern.

The term "jack-in-the-box slapstick," as masterfully described by MacDowell, neatly describes the scene in Wasps in which Philocleon tries to break out of his own house to join the chorus of courtgoers but is held back by his own son, Bdelycleon, and his slave, Xanthias. The idea of a grown man's son, and even his slave, detaining him, in particular in his function as father and master, was unheard of. ${ }^{169}$ As if the violation of Philocleon's social status, as implied by his age, gender, citizenship, and role in the family, were not enough, another, fundamental boundary is transgressed here. As Philocleon is about to let himself down on a rope, Bdelycleon intervenes. He orders Xanthias to take a harvest wreath from the door and strike his father with it, which Xanthias actually does (397-402). Bdelycleon is well aware of the multiple transgressions this

168 Von Möllendorff 2002, 100; Bowie 1987.

169 Cf. above 62 , n. $174 ; 73$, n. $223 ; 87 ; 99 ; 124-125$ the cases of hubris regarding the detainment of a free Athenian citizen. 
act entails and has recourse to mediated violence. ${ }^{170}$ It is the slave, after all, who commits the atrocity, not he himself, the son. Nevertheless, this breach of social norms is blatant; it remains an indirect form of fatherbeating. What is more, under no circumstances could a slave hit his master, and especially not with olive or laurel branches that had been dedicated to Apollo on the occasion of the fall festival of the Pyanopsia. ${ }^{171}$ The wreath has a religious meaning and its misuse as a weapon certainly constitutes the transgression of a religious taboo as well. Philocleon's violent resistance is hence understandable and justified, and, later in the play, he strikes back. At lines 1382-1386 he knocks down his own son. And although the play's spectators would have deemed this aggressive act more socially acceptable than Bdelycleon's behavior toward his father, the frequent Aristophanic motif of father-beating is nonetheless humorously reversed in this scene.

In Wasps, there is only one instance of forced sex, when Bdelycleon asks Philocleon to stop judging in the Agora and judge instead at home, for example, in the case of their maidservant. These lines (768770) contain a pun with the double meaning of imposing only one fine, and having sex with the maid once at the door. ${ }^{172}$ Since the two men here are speaking of their own housemaid, they do not perceive her rape as transgressive; hence the act does not constitute hubris in their eyes. Bdelycleon makes this "harmless" suggestion to keep Philocleon in the house. Another matter is Philocleon's later appearance with the silent flute-girl Dardanis, whom he stole from a symposion to have sex with her $(1341-1381)$. This is a problematic variant of the sexually charged exit scenes so typical of Old Comedy. It comes as no surprise that Bdelycleon drives her offstage, especially after Philocleon has declared he will buy her freedom and make her his concubine (pallakê) after the death of his son (1351-1353). This statement is funny on two levels. First, it was a common notion in Athens that a son might wait for his father's death to install a woman of doubtful reputation in his oikos; Philocleon, feeling young and reinvigorated in the company of the young girl, thus reverses the natural order of things. Second, it was socially disreputable to live with a former prostitute, although this of course happened in real

170 On the mediation of violence and the mitigating circumstances it provided in some cases for the responsible party, cf. above 94-96.

171 Cf. Sommerstein 2004c, ad V. 398-399.

172 Sommerstein 2004c, ad loc. 
life. ${ }^{173}$ This double inversion of socially acceptable behavior leads directly to Philocleon's hybristic behavior (see above) and the frenzy of his violent kômos that concludes the play.

Violent kômos: Most Aristophanic plays conclude with kômoi symbolizing the start of a feast, or the celebration of a victory or wedding. ${ }^{174}$ From the point of view of genre, these final revelries have the function of opening up the stage action and smoothly leading into and merging with the festive atmosphere of the outer ritual, the Lenaea or Great Dionysia. In contrast to a pompê, a celebratory and official procession in the honor of a god, a kômos in the strict sense of the word is the festive, frolicsome, and rather uncontrolled marching around of revelers, often drunk, in the honor of Dionysus, especially after dramatic agônes. But kômoi were also held privately after dinner parties. Symposiastic elements are therefore crucial ingredients of any kômos: a cheerful atmosphere, alcohol, music, singing and dancing, cups, torches, garlands, and the presence of flute-players and other girls. Also typical of kômoi are the mockery of public figures and/or the derision of socially disreputable behavior. ${ }^{175}$ If it is true that comedy derived its origins from such kômoi, any comedy using this motif somehow harks back to these Dionysiac and ritual beginnings of the genre and tries to vary it. But there is more to comic kômoi: as Bierl demonstrates, ${ }^{176}$ the theatrical staging of a kômos (often choregic) was the re-enactment of a real-life kômos, which marked and was part of the liminal and initiatory sphere through which young aristocrats crossed the threshold between adolescence and adulthood. Within this puberty ritual, the young men were granted-often in symposiastic contexts-a considerable degree of "Dionysiac" license, which comic drama incorporated into its structure and brought to the stage. Although komastic mockery, the derision of particular persons (skômmata), and physical aggressiveness belong together, ${ }^{177}$ they normally followed certain

173 Cf. Ps.-Dem. 59 and Lys. 3 and 4 on living together with slaves as problematic behavior.

174 Pütz 2007 distinguishes between "cheerful, celebratory kômoi at the end of plays" (128-138), as exemplified by Acharnians, Frogs, Wealth, Birds, Peace, Ecclesiazusae; "religious kômoi" (138-142), as represented by Acharnians, Frogs, and Ecclesiazusae; and "violent kômoi" (142-146). Pütz admits that the categories overlap. Lysistrata does not meet any classification. For these reasons, her categorization is of limited heuristic value.

175 Cf. above $72-73$ on kômoi as elements of popular punishment.

176 Bierl 2009a, esp. 278-280.

177 Cf., e.g., Lys. 4 on the violence committed among rivals for hetairai. 
established rules in daily life. Some comedies, however, show excessive komastic behavior, perversions of this celebratory ritual, and thus the dangers inherent in any such comic license.

The most notorious test case in Aristophanic comedy is Philocleon's kômos, performed single-handedly at the end of Wasps. Special irony is created by Philocleon's resolution before the symposion not to indulge in alcohol too much. He claims to know about the troublesome outcome of such unrestrained behavior, which, he says, often ends in battered doors, assault, and battery (1252-1255), but his ensuing behavior ends in exactly these transgressions. Bdelycleon has tried to resolve the tension between himself and his father several times, but without success. All of Bdelycleon's attempts to educate, domesticate, and civilize his father have failed. The liminal situations of the oikos court, the scene of transvestism, and finally the scene in the streets of Athens do not lead to a satisfactory outcome, the taming of the arch-democrat Philocleon with his unquenchable, wasp-like energy. We will focus on the last scene, Philocleon's rioting on his way back home from the symposion. At line 1292 Xanthias, Philocleon's slave, runs onstage after receiving a severe beating from his master. Like a messenger in tragedy ${ }^{178}$ he reports his master's drunken and riotous behavior and thus paves the way for the latter's appearance on stage from line 1326 on. Philocleon has stolen a slave prostitute away from the party (1345-1381) and now menaces passers-by with blows $(1327-1331,1386)$; in fact, he strikes people indiscriminately without taking heed of their social class or rank (his own slave, 1296, 1307; everyone, 1323; his own son, 1386; the woman Myrtia, 1390; a citizen, 1422). This unacceptable misbehavior can rightly be called hubris $(1303,1319$, $1418,1441)$. When the wronged parties finally raise their voices against him and demand legal redress or extrajudicial compensation (13891391, 1406, 1417-1426), Philocleon drives them away by force. After Bdelycleon has dragged his father into the house at 1449, Philocleon bursts out again at 1484 with snorting nostrils, like a bull, the animal of Dionysus, after having danced all through the night. Xanthias characterizes this supra-human, god-like energy as the 'onset of madness' (1486:

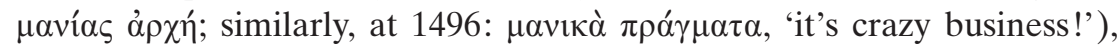
while Philocleon descends into the orchêstra, replies with vulgar remarks to Xanthias' warning that all the injured people might stone him in the end (1491), and takes on the tragedian Carcinus and his three sons in a

178 Rau 1967, 162-168 on Aristophanes' Botenszenen humorously shaped after Euripides' models. 
dancing contest, hinting at the possibility that he will beat these representatives of tragedy to a pulp (1503). In frenzied ecstasy, Philocleon maniacally dances offstage. ${ }^{179}$

How are we to understand this exuberant finale? It is not enough to state, with Pütz, that "Philocleon's rude conduct and excessive dancing overstep the boundaries of the usually accepted behavior on such an occasion." " Von Möllendorff ascribes a healing function to the ritual efficacy of theater in this case. Whereas the tensions between Philocleon and his son could not be resolved in the fictive plot onstage, these conflicts are now channeled through the orchêstra, with the theater building and representatives of tragedy being integrated into this final, and at last successful, attempt at coming to terms with Philocleon's extreme energy. According to von Möllendorff, theater addresses here its own theatricality and leaves fiction behind. In doing so, it becomes another space of the polis in its own right, equal to Agora, oikos, and street. In its capacity to bring about communitas, theater demonstrates the shortcomings of these other spaces and points to its own strengths. Finally, theater enables Philocleon to do what he could neither achieve at home nor in the Agora, living his tyrannical individualism in full. ${ }^{181}$ But is the outcome all that positive? Philocleon operates far outside the limits as drawn by Athenian law. His obnoxious bullying of Athenian citizens is permissible and funny onstage, but would be unbearable in real life. Unmistakably, this perverted kômos is supposed to demonstrate drastically the dangers of a democratic energy that has gotten out of control. If the integration of the heroic individual into democratic society - that is, the reconciliation of the aristocratic claim to egotistic self-realization with the final integration of the hero into the community of the polis-has been the overarching theme of all Greek literature since Homer, Aristophanes enacts the collapse of this reconciliatory endeavor in an almost depressing way. This breakdown is only bearable because it is made funny. The problematic traits of Philocleon's hypertrophic conduct that cannot be integrated are exposed to ridicule. ${ }^{182}$ Thus, violent kômoi test the limits, the tightrope

179 MacCary 1979 has demonstrated that Philocleon is an ithyphallos, dancing in the end to a mixture of tragic, satyr-like, and comic tunes, i. e., "proto-dramatic phallic performances in honor of Dionysos" (145).

180 Pütz 2007, 145.

181 Von Möllendorff 2002, 102 and in his correspondence with me on this scene.

182 Whitman 1964, 52 gives a most sympathetic characterization of the Aristophanic comic hero: "A desperate small fellow, inexcusably declaring himself for a social savior; an utterly self-centered rogue of poneria, representing a universal gesture 
walk between exuberant license during the Dionysiac ritual and violence that harms the community. Similar to the tragedians, Aristophanes enabled his spectators to look into the abyss.

A side-glance at one more, admittedly perverted and violent kômos may be permissible in this context. ${ }^{183}$ In Ecclesiazusae, Blepyrus only alludes to a violent kômos, trying to refute Praxagora's utopian plans. How will symposiasts pay compensation to people they have struck (664: $\varepsilon \dot{\omega} \omega-$

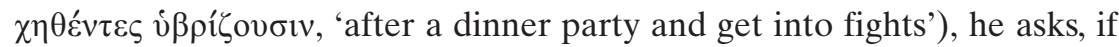
money has been abolished ? $^{184}$ The violent scene toward the end of the play, in which two old hags drag the young man Epigenes by force into a house, quarrelling with each other in an amorous contest and staking their claims on which of them gets to have sex with him first, has a distinct message. The reversal of gender roles has not brought about a blissful utopia as designed by Praxagora, not even for the women. The nightmare-for young men-of a complete gynecocracy and breakdown of the social order is mitigated by the final scene, in which Praxagora commissions her maid to bring two young girls to Blepyrus, her own husband, who dances offstage with them in the traditional way. This kômos, as prescribed by the genre, displays considerably less exuberant vitality and force than that in Wasps.

What happens in violent kômoi or conclusions to the plays? They breach the boundaries of the genre as well as boundaries of real-life interactions $^{185}$ (i.e., the thin line between boisterous license and violence), and

of thumb-to-nose unto all the high and mighty; a coward who runs away from his enemies for the moment, and then dances on their graves with godless cheer; a fast talker, a hoper-for-the-best and a believer-in-the-worst; a creature of infinite ambition, infinite responsiveness, and infinite appetite - the comic hero, as represented in Aristophanes, somehow makes up a figure of salvation, survival against odds; he is the self militant, and devil-take-the-means."

183 Ar. Lys. 306-403 (the women thwarting the attack of the men armed with torches by pouring water over them) is not really a kômos. The same is true for Lys. 1216-1222. The Athenians are about to celebrate a party with the Spartans and have a little scuffle with some slaves - the passage is unclear and suggests a variation of the doorkeeper motif (cf. Henderson 1987, ad loc.) —but the kômos itself can hardly be called violent. For an opposing view, cf. Pütz 2007, 142-143, $145-146$, who interprets both scenes as violent kômoi.

184 On assaults committed by drunken komasts on passers-by, cf. Olson 2002, ad Ach. 980 and 1166-1168 with the following sources (among others): V. $1253-$ 1254, 1322-1331, 1389-1391, 1476-1496; Ec. 663-664; Men. Dysc. 230-232; Epitr. 169-171; Eubulus F 93.8-10 (K.-A.); E. Cyc. 445-446, 507-509, 534537.

185 On the boundaries of the comedic genre, cf. Bierl 2002b. 
thus mark them more clearly. Violence at the end of a comedy is situated at the limen of a comic play that is still embedded within the liminal phase of a Dionysiac festival. Insulated or mediated by this festive layer, violence is kept at a sufficient distance from the audience. Spectators could laugh because this outer dramatic layer was intact and would thus prevent the violence onstage from coming near them, but they were also called upon to reflect on the violence depicted. The theater was a laboratory that allowed for such intellectual experiments. The "as-if" situation of fictional play enabled the spectators to judge violence on different levels. Within the fictional world, Athenian law was basically intact, and so hubris, for example, was outrageous. Through the distance of pretend-play, however, the spectators, safely embedded in the extrafictional world, could still laugh. The fact that the fictional contract between actors and audience to suspend disbelief could be broken at any time in Old Comedy prevented the creation and conveyance of a consistent message.

In addition, Aristophanic characters are complex and do not offer consistent models of identification. Dicaeopolis, ${ }^{186}$ Strepsiades, Philocleon, and Peisetaerus are as ambivalent as Lysistrata ${ }^{187}$ and Praxagora. As trickster figures they are endearing, but their actions are also doubtful, the premises of their great ideas and the concrete materialization of them not beyond reproach. The distance that was always maintained between stage characters and spectators empowered the latter to both like and dislike the characters simultaneously, to identify with them partly, disapprove of them, and criticize those characters' actions as well as question their own behavior and desires, which were critically mirrored and grotesquely distorted onstage. In the case of Philocleon, this multi-layered communication between the stage characters and the spectators might have worked as follows: yes, we all love law courts, so we sympathize with Philocleon's passion, but we should not overdo it as he does. Yes, he is a great hero of Marathon, but he could also adjust a bit more to the modern refinements of civilized culture. Yes, we find his raging fury at the end funny and we would like to join him in dancing offstage and having sex with slave women, as he does, but once the theater production is over and the "real" kômos begins, we cannot be as hybristic and disruptive of the komos as he is. The openness and polyvalence of Aristophanic

186 Cf., e.g., Platter 2007, 42-62 and Fisher 1993 on Dicaeopolis' ambivalent personality.

187 Cf., e.g., Faraone 2006 on Lysistrata as priestess and prostitute. 
comedy especially apply to violent kômoi, which, as endings to the plays, open them up to daily life and thus also enable reflection about violence.

\section{Birds (414 BCE)}

Birds may well be Aristophanes' gloomiest and most mysterious comedy. Its extraordinary length testifies already to the special status it enjoys within the Aristophanic corpus. As to form, the comedy imitates the closedness of tragedy, in itself an important hint for any interpretation of the play. The comic hero Peisetaerus, allegedly sick of Athenian court culture, aspires to the utopia of a polis apragmon $(40-41,44){ }^{188}$ Whereas, in Wasps, the exuberant Philocleon breaks away from societal conventions only in the very end, Peisetaerus is so full of himself that he transcends the narrow boundaries of his hometown in the very beginning of the play. Together with his friend Euelpides, he is right away on the lookout for a utopia that he could found by himself. In his endless ambition and unlimited energy, Peisetaerus even surpasses Philocleon and is, in fact, more of a busybody (polupragmôn) than his comic predecessor. Step by step, he carefully builds up his own empire, a castle in the air (Nephelokokkugia, Cloudcuckooland), located somewhere between man and the gods. In his larger-than-life capacities, he has the power to set aside the laws of nature and eventually even rival the gods by becoming ruler over the whole universe. ${ }^{189} \mathrm{I}$ have described, time and again, Aristophanic comedy as the attempt at delineating the line between acceptable and unacceptable behavior, but Peisetaerus transgresses that boundary from the outset: his self-confidence has long turned into unbearable arrogance and hybristic self-assertiveness. And yet, the play can be read from many different angles, though three main interpretations predominate: (1) understanding the play as a positive and escapist fantasy, ${ }^{190}$ quite detached from contemporary politics, (2) reading the play as political allegory, and (3) seeing the play as a parody of myth. ${ }^{191}$ The second

188 Also for Bierl 2004, 18-19 this utopia is regressive and harks back to a primordial, animal-like Otherworld.

189 Auffarth 1994 demonstrates to what extent the "sacrificial strike" that directly challenges the supremacy of the gods in Birds is anchored in oriental literature and the Homeric Hymn to Demeter.

190 Henderson 1998b passim and Sommerstein 1991, 5 do not see the dark sides of the "comic" hero Peisetaerus. To Henderson, Nephelokokkugia inspires hope as a superior alternative to Athens.

191 Von Möllendorff 2002, 108-115 gives a summary of the main interpretive trends. 
and third interpretations overlap and, in my opinion, allow us to discern a relatively coherent message. In what follows, I adhere to these latter two interpretive models.

In Birds, Peisetaerus is never angry, but calm and focused on his goals. His interlocutors, be they gods or men, are overwhelmed and duped by his masterful sophistic rhetoric and are not angry either. Anger, therefore, need not be addressed here. Hubris is quite a different matter, however. Two different meanings of hubris are clearly expressed within the play: battery and rape. Hubris as battery occurs, for example, when Peisetaerus beats up the decree-seller, ${ }^{192}$ who then wishes to take Peisetaerus to court on a charge of hubris (1046-1052). In so doing, he precisely follows Attic legal language. Hubris in its meaning of rape will be considered below under the category of rape.

Comic license during Dionysiac festivals is best expressed in the release of pent-up feelings and aggressions, mainly against state agencies. The playful expulsion of authorities is thus a central part of all carnivalesque occasions, and Aristophanes does not fail to make abundant use of this slapstick motif in Birds. Peisetaerus shows traits of a tyrant by chasing off nine successive intruders into his Cloudcuckooland. His first victim is a priest $(859-894),{ }^{193}$ the next a poet who would like to compose dithyrambs and other poems in honor of the new city (904-958), and next comes an oracle-monger (959-991). At line 992 the astronomer Meton enters the stage, wanting to take measurements of the airy city. Peisetaerus, upset by this plan, kicks him offstage shortly afterward (1016-1020). The next intruder to incur Peisetaerus' aggression is the inspector from Athens, who gets beaten and driven out even more quickly than his predecessor (1021-1034). Nevertheless, he shows up again and is repelled a second time, together with the decree-seller (1035-1057). The pinnacle of Peisetaerus' insolence, however, is his blasphemous insulting and chasing off of the goddess Iris, whom he sends to Zeus with a threatening message (1199-1261). In lines 1375-1409, Peisetaerus chases Cinesias, poet of dithyrambs, out of Nephelokokkugia. His whipping and expulsion of

192 An interesting variant of an expelled professional is the bookseller in the fragment Theopompus F 79 (K.-A.).

193 In Pax 1118-1126, Trygaeus has the priest and soothsayer Hierocles beaten and driven off by a slave. Hierocles later calls on witnesses to file charges of battery (dikê aikeias) against Trygaeus. Cf. below 304, n. 215 on other passages of calling on witnesses. Interestingly, and in line with the ritual of Dionysiac license, winning over the fictive plot onstage, the evil-doers nowhere have to face the consequences of their misdemeanors. 
the informer (1410-1469), a hereditary pest in Athens, ${ }^{194}$ shows how serious Peisetaerus is about severing all ties with Athenian democracy. In offending and striking people who are actually necessary for the founding and maintenance of a democratic polis, ${ }^{195}$ Peisetaerus demonstrates that he does not intend to establish a democracy, but, on the contrary, his own solitary rule. By not admitting or even eliminating the democratic professions from the new utopian polis, democracy itself is driven out. In claiming all power for himself and even eating some of his subject birds for a wedding meal, a horrifying scene (1688-1689, with 15791590 as preparation $){ }^{196}$ he makes it abundantly clear that he is, in fact,

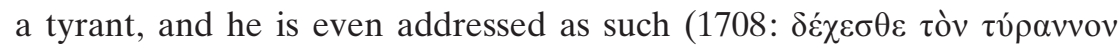

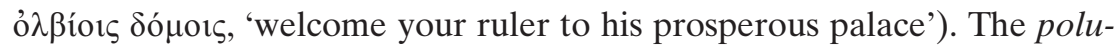
pragmôn (busybody) Peisetaerus, who cannot abstain from political maneuvering - and for whom Cloudcuckooland is not an escapist retreat from litigious Athens but a transient phase used as a means of establishing his tyranny over the entire cosmos-shares many features with the stereotypical Athenian: he is clever, if not cunning, suspicious of his fellow countrymen, restless in his pursuit of visionary dreams of power, and loves daring entrepreneurship even at the expense of turning over the natural world order.

In Birds, beating one's father is ostentatiously kept ambivalent. Whereas the chorus advocates the reversal of moral values by claiming that striking one's father is "good" in the birds' realm (757-758: દi rò $\rho$

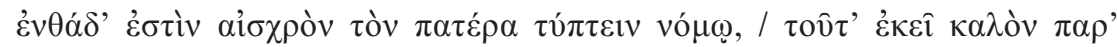

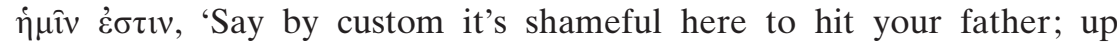
there it's admirable'), ${ }^{197}$ Peisetaerus rejects a young man seeking access to the new kingdom because he wants to get away with killing his father. Peisetaerus first cajoles the young man into disclosing his true intentions by saying, 'We do in fact consider a bird very manly who's beaten up his

194 Against the backdrop of these frequent and highly meaningful expulsions of authorities, Peisetaerus' threat to beat the slave Manes if he does not prepare more and more wings faster and faster (1313-1336), seems like a conventional and quite harmless comic occurrence.

195 Cf. MacDowell 1988, 7.

196 Previously, Peisetaerus had pointed out to the birds that human beings are so cruel as to eat them (531-538), a fact about which he expresses deep resentment. The contradiction in his utterances only underlines his sophistic rhetoric and opportunism.

197 On this complex scene, cf. Dunbar 1995, ad loc. with extended material on Athenian social norms regarding parents, esp. Xen. Mem. 4.4.20. 


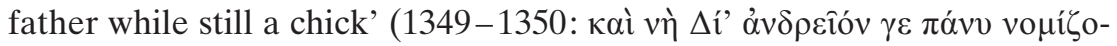

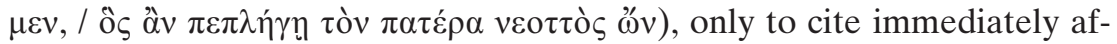
terward the old Solonian law, adapted to the birds' situation, according to which the young must sustain their parents, if they have brought them up $(1353-1357)$. It is remarkable to what extent Athenian law is still valid in the "other world" of Cloudcuckooland. Peisetaerus does not want to have criminals in his state and recommends to the young man that he let his father live, and instead get rid of his aggressions on the Thracian warfront (1360-1369). The birds' kingdom is not a safe haven for malefactors of all kinds. It is not a lawless, topsy-turvy world in which everyone can do what he pleases, to the detriment of others. The fact that not even the would-be tyrant Peisetaerus, who is entirely driven by his own imperialistic ambitions, tolerates violence against parents casts all previous and subsequent father-beating scenes in Aristophanic comedy in a highly problematic light, especially the most somber of these scenes: the blows that Strepsiades receives from his son Pheidippides in Clouds (see below). Aristophanes has taken great care to weave ambivalence into the very fiber of Birds.

During the optimistic and exhilarated atmosphere that prevailed in Athens immediately after the beginning of the Sicilian expedition, it might have been impossible for a comic playwright such as Aristophanes to speak his mind openly and raise a warning voice. Can we say, then, that Birds is an anti-imperialistic allegory, Aristophanes' coded criticism of megalomaniac imperialism, and that Peisetaerus stands for Alcibiades, who, through his mastery of sophistic rhetoric, dupes the birds/the Athenians into believing in Nephelokokkugia, a dream-like castle in the air that is founded only on empty words? The birds are as gullible as the Athenians, and the latter are as imperialistic as the former. Does Aristophanes want to say that in each Athenian lurks a potential tyrant who is unable to keep his democratic energy under control, and therefore ultimately aspires to sole rule? Scholars have read the play this way, ${ }^{198}$ and once more we see that slapstick scenes can indeed be highly meaningful.

198 Arrowsmith 1973 offers a cogent interpretation of the play from the American perspective during the Cold War, with Peisetaerus embodying the Athenian dêmos as assembled in the audience and driven by his boundless phallocratic and tyrannical imperialism. Most recently, Rosenbloom 2006, 270-271 continues to think along these lines, interprets Birds and Euripides' Trojan Women in close connection to each other, and states that both texts are subversive in yearning for the apragmôn polis. 
Scenes of rape, a subject far more problematized in Birds than in any other Aristophanic comedy, can also be shown to have meaningful significance. As Peisetaerus threatens to dethrone Zeus and incinerate his palace, the goddess Iris warns him in paratragic diction not to incur Zeus' wrath, cautioning that human arrogance will always be punished by the gods $(1238-1242)$. As a consequence, Peisetaerus is so brazen as to threaten to rape Iris three times, if she continues to annoy him (12531256). ${ }^{199}$ She is so baffled that she flies off, warning Peisetaerus that her father will stop such hybristic behavior before long (1259: $\eta \hat{\jmath} \mu \eta ์ v \sigma \varepsilon \pi \alpha v-$

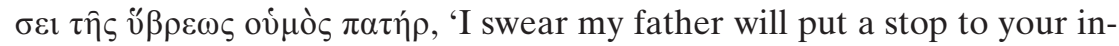
solence!').200

The protagonist's diabolic and violent nature is exposed even more through a gloomy mythical parallel. Indeed, one scene can be seen as a parody of the myth of the Thracian king Tereus, who raped Philomela, sister of Procne, his wife, and was later transformed into a bird after unknowingly consuming his own son, Itys. Aristophanes probably refers to the myth as shaped by Sophocles in his tragedy on Tereus. ${ }^{201}$ Humorously, in Birds, the traditionally chaste Procne appears naked (?) onstage 665673 and is not unwilling to be kissed by Euelpides, who actually wants to have sex with her. What is more, as von Möllendorff has worked out, Peisetaerus' career ladder turns the Sophoclean plot on its head. In the original myth, Tereus is a tyrant, rapes Philomela, eats his own son Itys unknowingly, and, as a punishment, is transformed into a bird. Aristophanes reverses this familiar order of events from the myth: Peisetaerus starts out as a fellow citizen of the birds, deliberately eats birds as a wedding meal (1688-1689), and gradually turns into a tyrant. But one step is missing. There is a narrative gap between Peisetaerus' (pseudo-)cannibalism

199 Cf. Ar. Ach. 994 on the triple penetration. Dunbar 1995, ad Av. 1253-1256 with reference to Ach.271-276 is right in pointing out that Peisetaerus does not threaten her with rape out of sexual desire, but to punish her. As Scharffenberger 1995 could demonstrate, several literary and pictorial models are in the background of this scene: Aeschylus' Prometheus Bound, satyr plays (in Euripides' Cyclops Helena is threatened with gang rape at lines 179-182), and vase paintings, where lustful satyrs are eager to molest unwilling nymphs. On the mythological grounding of the Iris figure and Aristophanes' adaptation, cf. Zannini Quirini 1987, 62-65; Hofmann 1976, 110-119.

200 Cf. Buis 2002 on the different layers of hubris in $A v$.

201 On the relationship between Sophocles' and Aristophanes' Tereus from a metafictional standpoint, cf. Dobrov 2001, 105-132. On Aristophanes' shaping of the myth of Tereus, cf. Zannini Quirini 1987, 23-44, and, still valuable, Hofmann 1976, $72-78$. 
and his becoming a tyrant. In this context Basileia, a godlike figure, plays a pivotal role. Does Peisetaerus ultimately rape her as Tereus has raped Philomela? The answer is not clear, but it is telling that Basileia is on stage from line 1720 on and, like all other female figures in Aristophanes that are envisioned as victims of rape, does not speak. ${ }^{202}$ We can compare this visual performance of an aposiopesis with the same technique as practiced by the orators. ${ }^{203}$ In Demosthenes' Against Meidias, for example, the deliberate performance of silence in the courtroom appearance of Straton, barred from speaking in public because he has been disenfranchised by Meidias, serves the purpose of denigrating Meidias as an evildoer. ${ }^{204}$ Is something similar going on in Aristophanes' play? Be that as it may, Peisetaerus' behavior is presented as highly problematic through the use of many motifs, among them his potential rape of Basileia (1720-1765). In its mythical dimension, this kind of rape is different from the frolicsome exit scenes starring drunken revelers at the brink of indulging in peace and all the joys it brings. Peisetaerus' tyrannical and supra-human egomania has transgressed all human boundaries and is frightening in its blasphemous threat to rape a divinity. ${ }^{205}$ Only his final marriage to Basileia might mitigate this impression (1536-1543, 1634-1693, 1720-1765), ${ }^{206}$ which does not detract, however, from the unsettling portrayal we get from the "comic" hero. And in general, Aristophanes' tone is more muted than in any other of his comedies: he makes fewer direct political allusions, does not use the comic technique of the onomasti kômôdein, and basically abstains from obscenities. ${ }^{207}$ The unusual humor throughout the play, supported by the specific meanings of violent words and deeds, underscores once more the tyrannical imperialism Peisetaerus is striving for and, with him, maybe most Athenians?

202 Von Möllendorff 2002, 114-115.

203 On Aristophanes' art as an orator, cf. Harriott 1986, $27-45$ (attack and defense); 46-67 (praise and blame).

204 Cf. above 110, n. 376.

205 Cf. Sommerstein 1991, ad Av. 1536-1543 on the identity of Basileia. Hose 1995a, 58-67 focuses on Peisetaerus' hubris.

206 On this kind of hieros gamos, cf. Hofmann 1976, 138-160.

207 Von Möllendorff 2002, 115. 


\section{Clouds (423 BCE)}

Where Birds is unsettling already, with its overly cruel and ruthless hero, Clouds is even more so. ${ }^{208}$ This play is concerned with the fundamental societal and cultural changes Athenians were exposed to from the mid fifth century BCE on. A new system of education, sophistic training in oratory, had destabilized the old canon of values and promised quick success in the public venues of Athens. The boorish farmer Strepsiades is deeply in debt because of his son's aristocratic lifestyle. Both realize that they have to get rid of their creditors by arguing away their debts. But where to learn good rhetoric? As it happens, their neighbor is Socrates, whom Aristophanes characterizes as an arch-sophist. Strepsiades takes lessons with him first, but to no avail, and later sends his son to Socrates' school. There, Pheidippides learns how to deceive and make the worse argument the better. Strepsiades is enthusiastic about his son's success but, soon afterward, learns the hard way that his son can turn his newly acquired "education" against him. Pheidippides beats up his father and threatens to do the same to his mother. Strepsiades' endeavor to dupe his creditors has, in fact, only aggravated the conflict between generations and turned his family life upside down. Fully aware of his big mistake, he is desperate and finds no other way out than to set Socrates' house on fire.

It must be remembered that what we now have preserved is the second version of Clouds, which was never performed. The original version, which we do not have, was not successful in the comic agôn. We do not know exactly what kind of changes Aristophanes made before producing the second version, but, according to an ancient plot summary (hypothesis), there are three major deviations from the original. ${ }^{209}$ (1) Aristophanes obviously replaced the parabasis with a new one (518-562) in which he bitterly complains about the first version's failure. He considers Clouds his best play, because it is intellectually far superior to the comedies of his rivals. (2) A long agôn (889-1104) between the better argument (also called 'just argument,' or logos dikaios) and the worse argument (also called 'unjust argument,' or logos adikos) epitomizes what the dramatic conflict is all about. (3) The burning down of Socrates' thinkery (phrontistêrion) was a completely new conclusion to the play

208 For an opposing viewpoint, cf. Fisher 1984, who does not see any serious elements in Clouds.

209 Coulon 1952, Hypothesis VII (p. 162) = Clouds I, Testimonia (ii) Hypothesis A7 (Henderson). 
$(1476-1511) .{ }^{210}$ Since Aristophanes must have regarded these major alterations as crucial means of improving the depth and quality of his play, ${ }^{211}$ they are key to our understanding of it. While the self-evident parabasis need not be analyzed in this context, and the incineration of the reflectory will be treated below in detail, we will look first at the agôn between the logos dikaios and the logos adikos, abstractions for the binary oppositions in which many Athenians felt themselves trapped.

The logos dikaios grounds his arguments in custom, tradition, and the law; that is, in the old value system. The logos adikos, by contrast, no longer accepts the stable normativity of old; for him, "good" is whatever one feels is advantageous. Ruthlessly and unscrupulously, he tramples on oldfashioned values and praises arbitrariness and irresponsibility. Through his arguments, ties to the past are severed and values become interchangeable. ${ }^{212}$ In the end, the disrespectful logos adikos wins the debate and takes on Pheidippides' education in Socrates' reflectory, which, in turn, leads to the ensuing disasters. The long agôn containing the debate between the two types of arguments, itself a grand satire on sophistic thinking, is thus pivotal in the play and also paves the way for an understanding of the role of the chorus of clouds. The topic of the comedy is rhetoric and, more broadly speaking, language, communication, and the questions of who is in command of language and what kind of power it can wield. ${ }^{213}$ The clouds are equivalent to language itself; in fact, they are a cipher for language, with all its chances and risks. Thus, they unite tradition and old values with new trends. In their constant state of flux, they are fundamentally open and flexible, adaptable to every new situation. ${ }^{214}$

210 On the three changes, cf. Marianetti 1997, 6. O'Regan 1992, 138 assumes that the second version of Clouds is a response to the first, failed version. This second version includes more vulgarity than the original, which, because of its sophistication, did not appeal to the audience. According to Hose 1995b, Aristophanes presented, in the figure of Socrates, a new type of comic hero who foreshadowed New Comedy. He was no longer the democratic hero who committed himself to the polis, but was a below-average figure who cared only about himself. This new type of comic hero did not yet appeal to the audience.

211 Sommerstein 2009, 176-191 (with older literature on the relationship between the first and the second versions of Clouds) is of the opinion that Aristophanes did not substantially rewrite the first version, but that some minor changes did indeed shift meanings considerably.

212 Marianetti 1997, 8-9 with more binary pairs.

213 Von Möllendorff 2002, 139.

214 Ambrosino 1983. 
Violence in this play can again be addressed under the heuristic categories as applied in all previous cases. Anger is consistently portrayed negatively in Clouds. Shortly before setting fire to Socrates' phrontistêrion, Strepsiades prays to Hermes not to be angry at him (1478: ڤ̉ pí $\lambda$ '

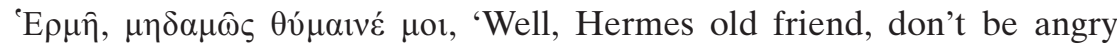
with me') for having questioned the gods' existence in the wake of Socrates' teachings. He chastises his own blasphemous thoughts as paranoia and mania (1476). From Strepsiades' perspective at least, Hermes' thu$m o s$ is justified and frightening. As we have seen multiple times, emotions onstage can acquire a meaning opposite to that held in daily life, or can be looked at from different perspectives that the theater provides. In the great agôn between Strepsiades and his son, Strepsiades chokes down

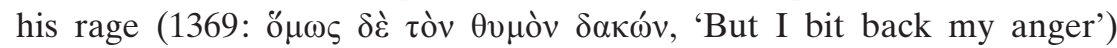
when Pheidippides insults Aeschylus and his archaic-sounding poetry. Slapstick scenes follow father and son's mutual insults and lead to the notorious father-beating scene, which we will treat in greater detail below. From Strepsiades' perspective, his anger is certainly more than justified; to his son, however, who is by now a cunning and ruthless sophos, and perhaps also to the audience, Strepsiades' anger is unwarranted. He is characterized as a boorish, backwards-looking, and uneducated citizen.

Hubris is not lacking in Clouds either. A first instance is closely connected to the motif of the expulsion of authorities. In lines 1214-1302, the bankrupt Strepsiades chases off two creditors and even threatens the second with a goad. The frightened creditor is shocked, labels Strepsiades' violent conduct hubris, and calls witnesses to help him (Nu.12971302), ${ }^{215}$ a frequent social practice, certainly familiar to every Athenian in the audience. The ambivalence of these scenes must have been recognizable to the audience: although there is good reason to get rid of sycophants and creditors, they are Athenian citizens, and the latter would be entitled to claim their property back from the debtor, Strepsiades. Another instance of hubris occurs in the context of "wanton" behavior. In a great parody of myth, the worse argument refutes the better argument by explaining that Thetis abandoned Peleus because he did not satisfy

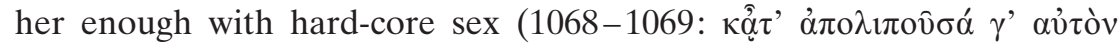

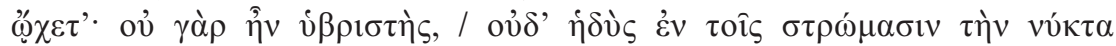

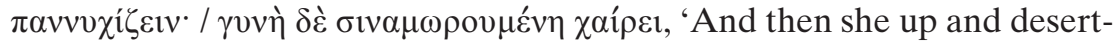

215 Calling on witnesses in threatening situations is a popular motif in Aristophanes (Nu. 495; Ach.926; V. 1436-1445; Av.990, 1019, 1031, 1466; Ra. 528-529; Pl. 932; Pax 1119). 
ed him because he wasn't a roughneck, and no fun to spend the night with between the sheets. A woman enjoys being lewdly used'). In addition, $h u$ bris also denotes offensive behavior toward the gods themselves. Shortly before setting Socrates' thinkery ablaze, for example, Strepsiades accuses

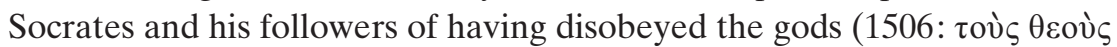
i $\beta$ pí $\varepsilon \tau \varepsilon$, 'outraging the gods'). ${ }^{216}$

As to slapstick, Aristophanes formulates the norms with which the characters onstage should comply. In lines 494-498 Socrates asks his new student Strepsiades what he would do if he were beaten. In full accordance with Athenian law and the new value system of the democratic polis, he replies that he would wait briefly, call on witnesses, and go to court. It is telling enough that Socrates does not give an answer to this perfectly legitimate proposal. In 57-59, Strepsiades threatens his slave with beatings and maltreatment. He is thus presented as an impatient and cruel bully. ${ }^{217}$

Before tackling the father-beating scene that leads up to the incineration of Socrates' thinkery, we have to consider again that we do not know Aristophanes' motivation in substantially altering the conclusion of the play: whether he sought to teach his audience a lesson for not understanding the play at its first production, as suggested by the parabasis, or whether he tried to be more amusing than before so as to win back the favor of his audience, or at least his readership. It is also possible that Aristophanes took license to overhaul the play, including putting in unusual, potentially off-putting scenes. Be that as it may, we must work with what we have and can safely assume that Aristophanes provided his readers with a more sophisticated play once he had the chance to rework it. Modern scholars, most notably Reckford, Revermann, and, in recent years, Riu, have emphasized time and again the peculiarity of Clouds. Reckford, in particular, has not ceased to emphasize that Clouds is a funny play, like all other Aristophanic comedies. ${ }^{218}$ Let us scrutinize the relevant scenes in chronological order. Aristophanes puts the first clue for interpreting the later father-beating scene in line 911, where the better argument uses the

216 Other slurs on Socrates are to be found, e. g., in Eupolis F 386 (K.-A.) and F 395 (K.-A.), which present him as a drunken glutton. Patzer 1994 examines the figure of Socrates in the fragments of Old Comedy. They concentrate on his ugliness and the rags he wears. Clouds offers much more, but also contains the stock motifs of intellectual-bashing.

217 Cf. Kaimio 1990, 67.

218 Cf. Reckford 1976, 94-97, 100, 106, 112-113, where he emphasizes the playful side of the theater performance. 
word 'father-beater' or 'father-slayer' ( $\pi \alpha \tau \rho \alpha \lambda o i ́ \alpha \varsigma)$ as a swearword denoting the worse argument. ${ }^{219}$ The foreshadowing is thus clear; after all, Adikos, the worse argument, will teach Pheidippides. In 1321, finally, Strepsiades dashes out of his house like the slaves at the beginning of Knights, wailing that he has been beaten by his own son and imploring his neighbors, kinsmen, and fellow demesmen to come to his aid (1321-1324). In the ensuing heated argument, in which Strepsiades calls his son a 'parri-

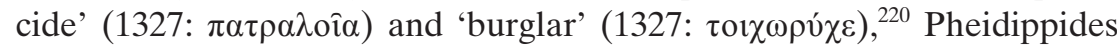
quite sophistically proves that he was in the right in striking his father. Strepsiades realizes that his son has learned this clever reasoning and twisting of words to his own advantage at Socrates' school. Naïve Strepsiades is finally forced to concede to the seemingly logical sophistry of his son and sounds the retreat, addressing the audience: 'In my opinion, you gentlemen of my own age out there, his argument is right, and we should concede that these youngsters have made a valid point. It's only fitting that we should wail if we misbehave. ${ }^{221}$

At this final point, Strepsiades has made a complete fool of himself. Because of his lack of intellectual capacity and rhetorical skills he must surrender to the whimsical arguments of his son. His failure is ridiculous and so pokes humorous fun at Strepsiades. The natural family order is turned upside down. ${ }^{222}$ To provoke his father even further, Pheidippides next proposes to beat up his mother too (1443). Strepsiades is now exasperated, furious, and desperate. He sees no way out other than to throw his son, together with Socrates and the worse argument, into the barathron (1447-1451), a ravine into which only criminals were cast for execution. As Strepsiades again bewails his fate, the chorus-leader makes it

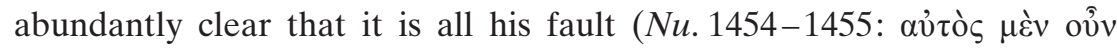

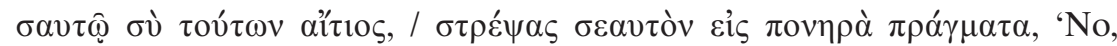
you've only yourself to blame, since you took the twisted path that leads to evildoing'). What he means is that Strepsiades went astray when he tried to evade payment to his creditors by sending Pheidippides

219 Juicy swearwords can be found, e.g., in Phrynichus' Muses: Phrynichus F 34 (K.-

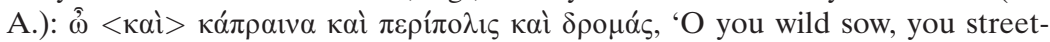
walker, you drab,' transl. in Phrynichus F 33 (Edmonds). On this play in detail, cf. Harvey 2000, 100-108.

220 My translation; Henderson's 'criminal' is not specific enough.

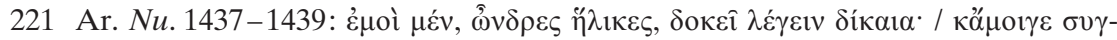

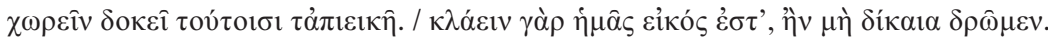

222 Cf. Arist. Pol. 1259b3, where Aristotle equates the authority of a father with that of a king. 
off to school so that he could learn how to outwit them. Strepsiades recognizes his mistake, but he is now enraged and takes revenge on the "real" evildoers, Socrates and his servant Chaerephon, whom he actually wants to murder (1465-1466). Pheidippides does not follow his father's call-he cannot attack his teachers-so Strepsiades burns the phrontistêrion to the ground, with the help of his slave, Xanthias. The father-beating scene thus blends into the final act of destruction, the incineration of a philosopher's house, unheard of on the comic stage.

The scene of arson (1484-1509), unique in Attic drama, poses even more interpretive problems, against which the father-beating scene must be assessed. The highly aggressive act is accompanied by words

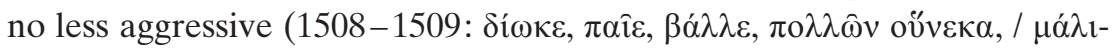

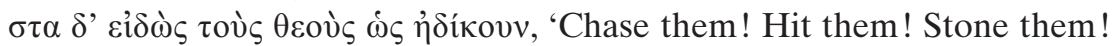
They've got it coming many times over, but most of all for wronging the gods') ${ }^{223}$ Within one and the same horrifying sentence, there is also another layer: in Strepsiades' eyes, Socrates and his pupils have offended the gods by denying their existence. We should not forget that Socrates was indeed accused of blasphemy (asebeia), among other charges, in 399 BCE, so Strepsiades' reproach must have been plausible to many in the audience. But the fact remains that this brutal and uncompromising exit scene is the sheer opposite of the frolicsome revels of the komoi that normally conclude comedies. Sommerstein sees three bases for the scene: (1) the torch-scenes of comedy, normally the "symbol of Dionysiac joy," but here perverted "into a weapon of destruction"; (2) "the smoking ruins of Troy" in tragedy (E. Hec. 823, Tr. 1256-83, and Supp. 980-1030); and (3) real-life events, such as the spiteful burning of the house of the Pythagoreans in the Italian city of Croton. Almost all of them died in the flames (Iamb. VP 249; D.L. 8.1.3). ${ }^{224}$ Because, in Clouds, the torch is only an accessory, and there is not even the remotest hint of Troy, only one conclusion remains: Aristophanes comes very close to representing the depressing reality of anti-intellectual sentiments in the Greek world.

Older research has wondered, on a concrete level, whether or not the character of Socrates was killed in the fire onstage. While Kopff, for example, argued that Socrates was indeed murdered, Harvey refuted this assumption as being implausible for a comedy. After all, people simply do

223 Cf., for similar exhortations, Ar. Ach. 280-283; E. Rh.675-676; X. An. 5.7.21.

224 Sommerstein 2007a, ad Nu. 1484-1485. Comedians heaped fun on Pythagoreans because of their poor way of living: Alexis F 223 (K.-A.); Aristophon F 10, 12 (K.-A.). 
not die in comedy, a claim repeated by Reckford, who tries to defend the hilarity of Clouds. ${ }^{225}$ In a similar vein, but on a grander scale, the debate about the play's final, violent scene has been resumed in recent years. Following in Reckford's footsteps, Revermann does not try to dismiss the high level of violence contained in this scene. He concedes that there is a complete deviation from the normal pattern, wherein a reconciliatory ending merges into the joyous revel of drunken komasts, the requirement of the genre. Nevertheless, Revermann cogently argues that this kind of violence is still comic violence, which is, to a certain extent, justified against Socrates. ${ }^{226}$ While Riu is in agreement with Revermann on the uniqueness of Clouds, he offers an interpretation that is diametrically opposed to Revermann's. Riu sees Aristophanes in an alliance with Socrates. After Aristophanes' failure with Clouds, he might have felt that he and Socrates were misunderstood by the Athenians and badly treated because of their reputation as intellectuals. If Strepsiades is representative of the Athenian dêmos in its rejection and even condemnation of Socrates and his wisdom, the portrayal of the dêmos as depicted via Strepsiades is not flattering. He is a boorish blockhead, unable to think for himself and

225 Reckford 1987, 388-402; Kopff 1977; Harvey 1981. Davies 1990 has convincingly shown that what happens at the end of Clouds is a method of legal self-help, the so-called Wüstung that has as its aim exile, not death. Marianetti 1992, $131-$ 132 thinks that Clouds draws a consistently negative image of Socrates. She substantiates her thesis by pointing out to what extent Aristophanes parodies the Eleusinian mysteries in Clouds (Marianetti 1993). More refined is Erbse 1954, 420 , who denies outright that we can move from the poetic figure of Socrates to his historical persona. An even balance between a more positive and a rather pessimistic assessment of Clouds' functions and Socrates' role can be found in Platter 2007, 84-107; O'Regan 1992; Gelzer 1956. Schmid 1948 adds a valuable diachronic perspective. What was originally meant to be a relatively harmless derision of an intellectual was turned into a biting attack by Socrates' enemies in 399 BCE, a time charged with mistrust and profound anguish after Athens' defeat in the Peloponnesian War and the recently overcome tyranny of the Thirty. According to Hubbard 1991, 112, Aristophanes mirrors himself in the figure of Socrates, questioning the very sense of artistic and intellectual endeavors in general.

226 Revermann 2006a, 226-235. Nussbaum 1980 reveals Socrates' mistakes and ambivalent depiction in Clouds, and can demonstrate similar traits in the "historical" Socrates. Aristophanes could exaggerate and distort the traits of a living person, but he could not completely falsify a living and widely known character. Whitehorne 2002 is more skeptical about the historical connection and claims that Aristophanes, in the figures of Socrates, Euripides, and Agathon, does not paint historically accurate characters, but uses stereotypes of contemporary intellectuals as stock motifs for his comedies. 
yet, at the same time, overtly cunning and acting for his own advantage. According to this interpretation, Socrates has done little wrong. Strepsiades sent his son to him to have him taught how to deceive creditors, and Socrates was successful at teaching Pheidippides, but cannot be held responsible for the ill use that the latter made of his newly acquired skills. ${ }^{227}$ If Aristophanes felt, as early as $423 \mathrm{BCE}$, that Socrates was as scorned by the Athenian people as he himself was, the playwright's sensitivity and insight would come close to a sinister foreboding of Socrates' fate twenty-four years later. If it was really Aristophanes' intention to speak on Socrates' behalf, to characterize him as innocent victim, and the dêmos, by contrast, as brutal, foolish, and incapable of understanding intellectuals, he did no good for Socrates. Unfortunately, Aristophanes would then have been misunderstood once more; Strepsiades would have been seen by the Athenians as a down-to-earth citizen repenting of his doubts about the gods and taking the law into his own hands to eradicate a modernist imposter and intellectual trickster. Regardless of the question as to what extent the fictive Socrates onstage mirrored the historical Socrates, Socrates' eventual trial and death may point to the reality of this latter interpretation, even though the connection between the performance of Clouds in $423 \mathrm{BCE}$ and the trial and execution of Socrates in $399 \mathrm{BCE}$ is tenuous. ${ }^{228}$ Aristophanes seems to have captured the general hostile atmosphere with regard to intellectuals pretty well, although we will never know the truth about his intentions and how he felt about Socrates before and after his failure in the dramatic contest.

Let us not forget, however, that Socrates is not the comic hero, but Strepsiades. In his gullible reliance on ponêria (badness) and the logos adikos, he eventually accelerates the break-up of his own family, an event he has tried to prevent since the beginning of the play. Thus, Strepsiades almost appears as a tragic figure. Further allusions to tragic motifs, ${ }^{22}$ especially Strepsiades' two victory hymns (1154-1166, 12061213), which precede both his final downfall and the parody of tragedy at the play's end, point in the same direction: the line between comedy and tragedy is blurred in this play. Plato's Socrates in the Symposium

227 Riu 1999, 261-270. We could still say, however, that Socrates is not careful enough in his selection of students: Strepsiades does not have the necessary intellectual capacities and deliberately tries to deceive, and Pheidippides lacks the moral qualities needed to deal with new insights in a humane and responsible way.

228 Cf. above 249, n. 43.

229 For more information, cf. Milanezi 2009, XXIV-XXV; O'Regan 1992, 109-111. 
at least deems it possible, and even demands, that one and the same person should be able to write comedy and tragedy alike. The famous end to the Symposium, set in 416 BCE, deserves to be quoted in full: ${ }^{230}$

and immediately he [Aristodemus] saw that all the company were either sleeping or gone, except Agathon, Aristophanes, and Socrates, who alone remained awake and were drinking out of a large vessel, from left to right; and Socrates was arguing with them ... but the substance of it was, he said, that Socrates was driving them to the admission that the same man could have the knowledge required for writing comedy and tragedy - that the fully skilled tragedian could be a comedian as well.

The tragedian Agathon and the comic playwright Aristophanes have to be compelled to believe what Socrates suggests, it is true, but Socrates' reasoning cannot be meant as a criticism of potential shortcomings on the part of the two dramatists; rather, it should be read as a compliment to their dramatic geniuses. We do not know what the historical Socrates and Aristophanes thought about the line between tragedy and comedy, but the fact that Plato portrays them freely discussing this topic seven years after the performance of Clouds-the dialogue itself was probably written around $380 \mathrm{BCE}$ - demonstrates that there was at least some feeling that comedy and tragedy belong together in the end.

It is fascinating to see how one and the same scene, the incineration of Socrates' house, has generated diametrically opposed interpretations. Semantic openness and polyvalence seem to have made some scenes inexhaustible. The polyphony of Clouds is more than spoudaiogeloion at its best. Aristophanes, in his frustration over the failure of his first Clouds, wrote a conclusion to the second Clouds that deviates so strikingly from the main patterns of how a comedy should end that it may not be wrong to say that Aristophanes, here, is pushing against the very boundaries of the genre. He appropriated for himself the carnivalesque license that he cherished so much. As a supreme master of the genre, he dared to become its transgressor and play with its limits, thus himself becoming

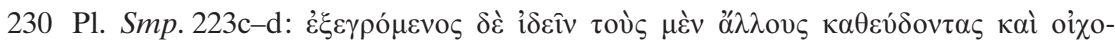

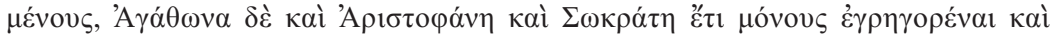

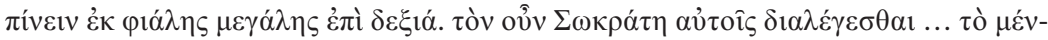

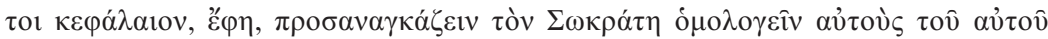

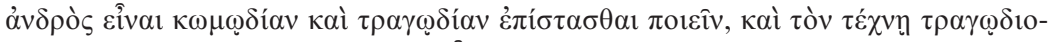

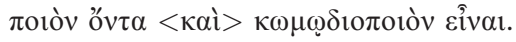


an ambivalent trickster figure plumbing the depths of the conditio humana. $^{231}$

\section{The Double-Layerdness of Violence}

We have to investigate further the perspectives from which violence was acceptable and unacceptable to the audience, and how Aristophanes both uses violence as entertainment and indirectly problematizes it at the same time.

At first glance, most scenes of violence in comedy are unproblematic. The spectators could (and did) laugh about the violence committed onstage, and they enjoyed the possibilities of identifying with the comic hero, often a brutal and tyrannical hubristês, and of getting carried away without having to take responsibility. Many of the scenes of violence within the plays involved actions that fell within the realm of acceptable behavior, and the Dionysiac license granted by the civic ritual of the theater performance sheltered the audience further. Indeed, violence and hubris were dangerous in the pragmatic, extra-fictional world of the audience, but the play performed onstage remained largely play. The spectators were conscious of this distance and experienced laughter in its more playful aspect. While comic laughter does have the capacity to stigmatize and exclude, it can also endear the comic hero to the audience and cause them to sympathize with him to a certain extent. And although I pointed out above that most Aristophanic comic heroes are ambivalent figures, the same also holds true for the violence each of them exerts. In as much as the comic hero happens to be likeable, his violent behavior may even seem acceptable. Riu's thesis that insults often happen at thresholds and mark them as such can be expanded. ${ }^{232}$ Since there is acceptable and unacceptable violence, violence performed onstage delin-

231 Edmunds 1986, 226-229 has discerned a sinister and destructive Aristophanes. The clouds stand for Socrates' daimonion and his irony, both of which are impossible to grasp. At the same time, the clouds also symbolize Aristophanes' own ability to create ever-new forms. And there are more links between the playwright and the philosopher to be observed in the play. What this amounts to is that Aristophanes, in mocking and criticizing Socrates, destroys his own position and comedic creation. On the basis of all eleven Aristophanic plays, but with special emphasis on Clouds, Strauss 1966 sees embodied in Aristophanes' dealing with Socrates and his philosophy the eternal tension between poetry and philosophy, here with Aristophanes' deeming poetry superior to philosophy.

232 Riu 1999, 238-241. 
eates the boundary between acceptable and unacceptable conduct. Consequently, comedy dramatizes this boundary by staging violence. If the comic performance as a whole serves as a ritual, a primary function of this ritual must be to define the limits of acceptable behavior in a similar way as the law courts constructed and represented them. ${ }^{233}$ In comedy, even more than in oratory, the limits of what is acceptable are in a constant state of flux, depending on what interpretive standpoint the observer chooses to adopt on the two layers of sense. This constant shifting of sense is also the product of Aristophanes' deliberate discursive and semantic openness. Every type of behavior that lies within the boundaries emphasized in a particular play is acceptable, and the play's spectators are thus enabled to laugh about violent stage actions that they regard as comprehensible and not too atrocious; any conduct that lies outside these boundaries, is off-color, barbarian, and not to be laughed about (at least in daily life). As became clear in the chapter on the orators, this line is highly culturally specific. Humor often remains untranslatable, and anyone who has traveled knows about the highly diverse notions of what constitutes a joke in different cultures. Twenty-five hundred years separate us from the Athenians, who might not have laughed at ideas we find funny today, and vice versa. Even within the same cultural horizon, every individual spectator, like a judge in court, had to define for himself what constituted acceptable and unacceptable violence by participating in the civic ritual of Old Comedy. One member of the audience might have laughed at seeing Socrates' phrontistêrion on fire; another might not. But one fact remains certain: Aristophanes' plays were comedies, and people attended them to laugh and experience a comic release from their daily sorrows and troubles.

At second glance, however, things are more complicated. Aristophanes indirectly charges each and every blow that he has his actors strike with some kind of negative sense. The evidence is abundant. The self-referential and meta-theatrical parabaseis, mostly spoken by the chorus in its function as mediator between the fictive world onstage and the pragmatic and extra-fictional world of the performance itself, pretend to be understood as authorial statements by the playwright. These statements, however ironically they might have been meant, explicitly criticize slapstick humor, ${ }^{234}$ although Aristophanes undermines his own tenets directly af-

233 Cf. above e.g., 142-146.

234 Ar. Ach.655-656; Eq. 510; Nu. 545-550, 560-562; Pax 748-753; V. 54-66, 1043-1045. 
terward, because violence remains an integral part of his comedies. This kind of criticism is more than the denigration of allegedly untalented and vulgar rivals who have to resort to low-brow humor because they lack comic ideas. We will come back shortly to the alleged tension between Aristophanes' claim to have purified comedy from "Megarian" jokes and his "failure" to do so.

It is true that the ritual of watching a play unfold onstage protects the spectator and keeps him safely ensconced in a superior position from which he can laugh about the events playing out before him; however, the very same distance that dissociates the violence onstage from the spectator and enables him to laugh also creates the capacity for the audience to judge critically the acts of brutality displayed in the course of the play. This consideration addresses the ambivalent nature of laughter itself. It is not always playful and meant in sympathy, but is often meant to be offensive and marginalizing. Laughter and biting mockery exclude people from a community that defines itself through precisely this kind of aggressive joking. Versnel even shows that laughing seldom had positive connotations in Greek culture, at least not for the victim, the person laughed about. ${ }^{235}$ Violence involves a perpetrator and a victim. At whom could the audience laugh? To the victims onstage, violence was not funny; neither was it so for the beaten slaves, the almost-raped women, the beaten father, Socrates, the expelled decree-seller, or the Scythian archers. Even if violence was confined to the stage, we cannot rule out that the audience at some point felt pity for the victims in Birds and perhaps also for Socrates and other injured characters. The question is: to what degree did the spectators relate to and identify with the widely different victim-figures represented onstage? In all probability they hardly did, and we can be quite positive that the Athenian audience laughed about these scenes. But the main protagonists are also laughed at; in most cases they are the dominant agents of violence, endowed with tyrannical, larger-than-life qualities that also defy an all-too-easy identification with them. The comic heroes were ambivalent figures and so the violence perpetrated by them was as well. As problematic and disagreeable as the

235 Versnel 1999, 138-139. An even more complicated picture is drawn by Halliwell 1991a passim, who argues that Old Comedy could combine harmful derision (aischrologia) with harmless, celebratory, and inconsequential laughter by combining ritual abuse with festive license. The integration of these contradictory concepts remained problematic and tested the limits of appropriate laughter and festivity. 
comic hero may have been, his violent misconduct was equally problematic and disagreeable.

A further consideration concerns Athenian law, which held almost uncontested sway within the fictional plot. ${ }^{236}$ According to the rule of law, many of the violent instances displayed were transgressive and at times endangered the social and political order onstage. We can deduce from Clouds, for example, that setting Socrates' house ablaze constituted arson and would have been tried before the Areopagos in real life. We can still say that this severe breach of law adopted a playful character within the atmosphere of comic license, but the basic fact remains that this deed would not have been condoned in democratic Athens. Does the text contain any clues about how to read this action? Yes, indeed. The arsonist Strepsiades is not presented as a positive character. He is naïve and untalented, and gets a thorough beating from his own son, against whom he cannot defend himself, either physically or verbally. His final and excessive outburst of violence against Socrates only demonstrates the depth of his own failure. In his helplessness he cannot communicate and express his problems adequately. His final, desperate action casts him, once and for all, in a negative light. The fact that evildoers and violence-mongers like Strepsiades get away scot-free in comedy and are never held accountable for their wickedness is indicative of how comedy works. In real life, condoning this type of behavior was impossible, as the spectators well knew. The audience could relish the funny and playful breaches of Athenian law as presented onstage, but was always aware of their inherently problematic nature.

Given the widely different meanings that onstage violence acquires through plot and performance as civic ritual it is possible to identify at least two layers of sense displayed by most violent scenes. As we have seen before, Riu shows that, in certain speech acts, insults can almost be meant as friendly greetings. ${ }^{237}$ The mask of the actor covers the individual behind it; insults uttered on the comic stage are therefore not to be understood as personal statements, and are not aimed at particular persons, but mark boundaries of various kinds. Insults are clustered around metaphoric thresholds, often when the comic hero meets another character or the chorus for the first time. Insults also often precede violence. Is it possible, then, that violent actions show traits similar to insults? When insults turn into blows, violence happens at a threshold

236 Cf., e.g., above 304, n. 215 on the calling of witnesses.

237 Riu 1999, 238-239. 
and thus defines a borderline, often the boundary between old and new, between the ordinary and utopian dreams or bizarre other worlds. Violence would then mark a frontier on multiple levels. From this perspective, we can discern even greater meanings in scenes of violence. The most obvious line drawn is the boundary between acceptable and unacceptable behavior, as discussed above. Again, the emphasis lies on unacceptable conduct. Through the embeddedness of violent behavior within the plot and the civic ritual of the theatrical performance, this boundary constantly shifts. A definitive interpretation of many violent scenes has thus been irrecoverable, for the ancient audience as well as for modern scholarship. To give just one example, Kopff and Harvey, Reckford and Revermann, as well as Riu, are all correct in their divergent viewing of Clouds as a funny or not-so-funny play. At the core of comedy lies a fundamental instability; everyone and everything is funny and problematic, somehow entitled to certain actions and at the same time not. Nothing is secure and definite; there is no sense-producing axis around which the plot can revolve. The possibility of constant shifts and changes of perspective enables a complex humor which forces the spectator to ponder seriously about what he is watching and hearing, including violence. Many figures, especially the comic heroes, invite the audience to identify with them, but also inhibit such identification because of their deep ambivalence.

Whereas judges in court had to come to a verdict and define, for example, the meaning of hubris in a concrete case, meanings in theater could remain open. This semantic polyvalence is to be explained not only via the fictional and artistic character of the plays, but also through the pragmatic conditions of staging them. The fictive plot and the outer ritual of the theater performance charged the deeds and words enacted onstage with different, sometimes even contradictory, meanings. These two layers generated, and continue to generate, tensions in the understanding of comedy as a holistic piece of art. ${ }^{238}$ Moreover, Aristophanes

238 My thesis on the double-layeredness of the sense of violence is in line with Halliwell's findings on the double-layeredness of aischrologia, which came to my knowledge only late in the production of this book. I quote from Halliwell 2008, 262 a passage that also addresses the vexed question of politics in Aristophanes: "The result [of the translation of grotesque shamelessness into theatrical artifice] is a sort of blurred focus between the world inside the plays and the phallicly costumed actors on display ... in the Dionysiac festival itself. As with the specific junctures (or transpositions) of 'ritual laughter' in Aristophanes ... so with aischrology in general Old Comedy seems able to endow it with a subtle 
and his colleagues wanted to win in the dramatic agôn and so had to convince a pluralistic audience of the quality of their work. Whereas, in the depositio of a curse tablet, the gods of the underworld decided what $\mathrm{ka}$ tadô meant in a particular case, and whereas, in court, several hundreds of judges rendered a verdict, five jurors drawn by lot decided success in the dramatic contests. But of course these five men tried to base their decision on the will of the audience as much as possible by paying special attention to the applause after the respective plays. This means that, in the end, works of Old Comedy had to pay respect to the pluralism of opinions at Athens and had to appeal to as many different views as possible in order to have a realistic chance of winning. A fundamental polyphony of meanings was the necessary consequence.

Aristophanes knew the discursive rules of violence in daily life well. He took, dramatized, and played with them, thus deconstructing them with the help of his fictional worlds. In this way, he enabled his audience to transgress the limits of their "normal" world and think deeply about what they saw and heard in the theater of Dionysus. With the rules of daily life temporarily suspended, and through the performance of actors disguised in whole-body masks, the spectators experienced breaches of customary behavior more intensely than in the forensic narrations performed in court. They enjoyed the ambiguous art of the playwright tremendously, but were aware of the fact that the violence displayed within the fictive plot onstage would not necessarily be something to laugh at, if it occurred in real life.

\section{Aristophanes' Discourse on Democracy - Summary}

There is more to the comic hero than we can discern today in the texts we have. The figure of the trickster, the notorious deceiver, goes back to primordial times. In his pre- and supra-human, even animal-like, existence, his violence is an intrinsic part of primitive, pre-polis behavior that throws into relief the modern, democratic, anti-revenge discourse that is spoken

double role: both as material for (distorted) representation of an imaginary world, and at the same time as the fulfilment of its own Dionysiac performance. This irreducible doubleness creates ... a sort of ambiguity and undecidability at the level of socio-political function." 
in the law courts. ${ }^{239}$ The comic hero's claim to have the right to go back to the golden age of full tables and boundless sexual satisfaction creates a regressive and therefore problematic utopia. ${ }^{240}$ Stage and reality clash. After the performance, the pre-Zeus time is over; now is the time of the well-ordered polis, the time of Zeus and Dikê. The comic hero, as an antipode to this new polis-discourse, struggles with these new forces and can found his problematic and actually untenable utopia only temporarily, during the carnivalesque license of the other-world permitted during the Lenaea and Dionysia. ${ }^{241}$ As soon as the performance, with its other-world, is over, the larger-than-life buffoon has to withdraw, surrender, abdicate. His power is broken until he is revived at the next Dionysiac festival. As long as he is active, however, the hero's existence is deeply sinister and frightening, as are his claims and actions. The ubiquity of violence, together with numerous metatheatrical elements, opens up the text and points toward problematic, topsy-turvy worlds and utopias made gloomy by the ambivalent comic hero, who often founds and maintains his own, respective utopia by violent means. But, either because all these utopias fail in the end, or because it is made clear to the audience that they are doomed to failure, their inherent violence is negatively charged and discredited. Violence on the comic stage is therefore largely negative when examined more closely. It is exaggerated and perverted democratic energy. Democracy, in the Athenian mindset, is good and great, but its surplus power can go awry in the theater. Here, the abuse of democracy often turns into violence and, as such, shows menacing traits. It jeopardizes the social and political order and tends toward tyranny. The Athenian dêmos itself was always prone to become a turannos toward its allies, slaves, women, and (horribile dictu) even against the gods themselves. The unpunishable delight that the spectators must have taken in watching these transgressions does not contradict the indirect problematization of such violence as tyrannical, hybristic, and barbarian. This negative characterization of violence is, in the end, as effective in Old Comedy (albeit at an indirect level) as the stigmatization of opponents in oratory. The same transgressions that are represented in forensic speeches

239 On the comic hero, cf. above 264, n. 88; 293, n. 182; below 368, n. 412. From a different angle, Halliwell 2008, 249-250 corroborates the view of an atavistic comic hero by speaking of comedy as a pre- or sub-democratic institution that allowed for shameless laughter about democratic institutions and representatives of the democracy (aischrologia, "agorafication").

240 According to Heberlein 1980, 177-182, the "great plan" is always ironized.

241 Cf. Versnel 1998b. 
are mutatis mutandis reflected on the comic stage. In other words, the transgressions enabled by the comic license of the carnivalesque Dionysiac festivals overstep the lines of real life. It is this breach, however, that visibly demarcates the realm of good behavior. In the speeches, this misconduct is rhetorically highlighted and brought to trial; on the comic stage, this violence, and with it the failed utopias and the violent heroes who strive for them, are also brought before a "judging" audience and ridiculed.

In Aristophanes, violence happens at the level of the polis and is therefore always highly politicized. It is interwoven with questions of gender and family relationships and, consequently, of power. These relationships do, therefore, affect the oikos-level, but are analyzed in their capacity of helping to maintain the polis. Hence, violence is less concerned with individual suffering than with the plight of the polis and its institutions as a whole.

Although this political kind of violence is mostly occasional and generic in Old Comedy, Aristophanes manages to individualize the violent motifs used, thus going far beyond comical farce and slapstick and creating something new, the charging of Dionysiac license with critical undertones, an extremely artful form of spoudaiogeloion, however rhetorical and ironic his claim might have been. While the performance itself of an individual play comes to a point of closure, the work of art, in all its dimensions, is always open in its meanings. In analogy to the open texture of Athenian law, we could also speak of the open texture of Old Comedy. In Aristophanic comedy, plot and ritualistic performance context overlap in their inherent functions of providing and ascribing sense and meaning to whatever happens onstage. The fictive plot that plays out on the stage and the outer ritual with its rooting in pragmatic, extra-fictional conditions shed different meanings on the actions (drômena) and words (legomena) performed onstage, and therefore generate tensions, if not incompatibilities, between the two layers. The ambivalence inscribed in scenes of violence accounts for our difficulties in discerning a consistent, valid meaning for violence on the Aristophanic stage. Since violent scenes are always polyvalent and offer various ways of seeing and assessing the violence staged within them, we cannot reach any single, definitive interpretation. What is to be done? We may compare this interpretive impasse with the view of violence constructed in and through lawcourt speeches, in which violence is not presented as a given fact, but as a ritual construct. This is true even more so in a decidedly open theater. More flexible interpretations might be appropriate if we take into account 
that the aesthetic mode of acting and speaking, in particular, recoils from simplification and easy solutions. From Old via Middle to New Comedy, Attic comedy shows a trend toward providing more closure and more definitive meanings for the violence represented onstage. That being said, it is now time to probe into Menander and the depiction of violence on the stage during his time.

\section{Menander}

Menander is the only author of New Comedy whose work survives in any semblance of lengthy passages. The earliest of his plays that we have preserved, Dyscolus, dates to $316 \mathrm{BCE}$ and is thus separated by seventy-two years from Aristophanes' last comedy, Wealth (388 BCE). To enable a comparison between Aristophanes and Menander, the Menandrian plays will now be subjected to the same scrutiny as the Aristophanic plays, using the interpretive categories of anger, hubris, slapstick scenes, rape, and violent komoi. The basic question is whether or not violence in Menander is as double-edged as it is in Aristophanes. As we shall see, the range of meanings contained in key concepts such as anger and hubris is massively curtailed when compared to that used in the Aristophanic equivalents. For this reason, the ensuing analysis will proceed play by play to elicit the exact semantics of the phenomena within the context of the respective plays.

\section{Anger}

Anger cannot be understood without also considering the means of its suppression, enkrateia and sôphrosunê. From the fifth century on, the ideology of enkrateia and sôphrosunê, originally aristocratic concepts, became more and more the hallmark of virtuous democratic behavior, mainly through the dissemination of Attic forensic speeches and the ever-ongoing process of democratization of elite values in Athens (i.e., the fact that the masses did not cease to appropriate upper-class behavior, gestures, and lifestyle). In response to Macedonian monarchy, democratic ideals were generalized even more and constructed as overarching Greek values and even universal humanitarian principles in contrast to Macedonian (i.e., barbarian) shortcomings. Thus, the democratic discourse of enkrateia and sôphrosunê merged into a broader discourse on Greekness, which in turn became more and more equated with civilization in general under Hellenistic rule. 
Anger looms large in almost all Menandrian plays, most of all in Samia. ${ }^{242}$ All negative actions and misunderstandings occur because of negative orgê. Based on external criteria, the play is usually dated to 314 BCE. The theme of the comedy is Athenian status-consciousness and the long way to a marriage that befits the rank of the bride and groom. The old, rich Demeas has adopted Moschion as his son. The cunning slave Parmenon supports his young master in all situations. Demeas lives with a young Samian hetaira, Chrysis, whom he impregnated, but the child died right after birth. Demeas, being abroad on a long business trip, is unaware of these happenings. Their neighbors are the "poor" 243 and elderly Niceratus and his wife, and their daughter, Plangon. When Niceratus accompanies Demeas on his business trip, Moschion helps the women of Niceratus' household and comes to know and love Plangon. Whether or not he rapes Plangon, we do not know, because, as is typical of New Comedy, the sexual act that occurs, in this case during the festival

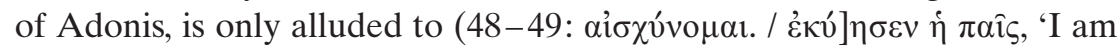
ashamed. The girl got [pregnant]'). After Moschion realizes that he has impregnated Plangon, he immediately asks her mother for permission to marry her. But things are not that easy; only virgins are allowed to marry. To conceal the unwelcome pregnancy and make Plangon still appear to be a virgin, Chrysis is willing to declare the baby her own and breastfeed him (77-86). Severe complications occur as a result. Moschion is afraid to tell his adoptive father the truth and fears that he will not grant him a wedding befitting his status. When Demeas sees Chrysis with the baby, he assumes that Moschion has had sex with her and has thus besmirched his bed. The final denouement resolves all problems and Moschion can marry Plangon, despite their difference in class status.

In anticipation of Demeas' reaction to Chrysis' having a baby, allegedly by Moschion, Chrysis describes him as a 'hot-tempered man' (83: $\tau$ òv ó $\rho(\lambda \omega ́ \tau \alpha \tau o v) .{ }^{244}$ We will see that all violent actions in this comedy are the result of a negative orgê. And in fact, Demeas is driven out of his mind when he sees Chrysis with the baby (206-282), because he thinks his

242 Menander's play Orgê is unfortunately not preserved.

243 We should keep in mind, however, that "poor" in Menander does not mean destitute or impoverished. Menander's personae live at the very top echelons of society, the three hundred richest citizens in town. The "poor" are those "some cuts below them" (Casson 1976, 57).

244 As a concubine, she can speak onstage. According to Henry 1985, Menander invented the good hetaira who has her share in the development of the plot and its final denouement. 
own adopted son is the father. Gradually regaining his temper, Demeas, in a great monologue, excuses his son on grounds of his youth and the influence of wine (339-342). He admits that, in his anger, he lost control of

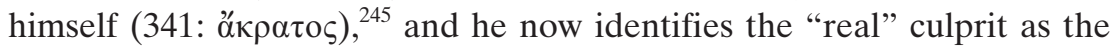
whore Chrysis, who (he supposes) must have seduced Moschion. Full of anger, he throws Chrysis out of his house (370-398), an unjustified action since she has borne him a child like a citizen woman, has not had sex with Moschion, and has helped her neighbor Plangon to conceal the baby's true identity by breastfeeding him herself. Thus, her behavior was impeccable, selfless, and generous. ${ }^{246}$ Observing the scene of Chrysis' cruel rejection, the cook speaks of Demeas as raging in a frenzied state of

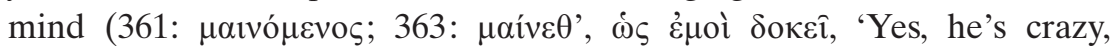
that's my view'). ${ }^{247}$ From the point of view of the history of mentalities, it is interesting to see that the adopted son is far more important and dear to the father than his own life partner. To Niceratus, Chrysis complains that Demeas is crazy (415: 'ُ $\mu \mu \alpha v \eta$ s, 'lunatic'), and the old man confirms the impression that Demeas must be out of his mind (416: $\Delta \eta \mu \varepsilon \dot{\alpha} \chi_{\varsigma} \chi 0 \lambda \hat{\alpha}$, 'Demeas is mad'). ${ }^{248}$ Finally, however, Demeas calms

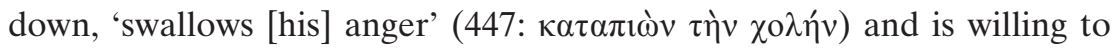
arrange the marriage between his adopted son and Plangon. ${ }^{249}$ Concerning his father's doubtful behavior toward Chrysis, Moschion reminds De-

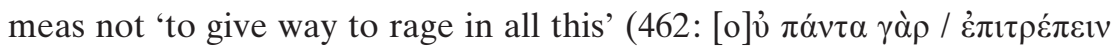
o $\rho \gamma \hat{n} \pi \rho \circ \sigma \eta ் \varepsilon 1)$, and the quarrel between father and son escalates in the ensuing verses. The conflict between the generations is archetypical. Unlike in Aristophanes' Clouds, where Pheidippides beats up his father, Strepsiades, Menander's characters are more tactful and better heed traditional Athenian rules of conduct. Moschion wants to speak and explain to his father what has really happened, but he does not get the chance to do so because his authoritarian father cuts him short. Even worse, Niceratus now enters the stage and reviles Moschion for what he has allegedly

245 On youth and drunkenness as mitigating factors, cf. Lamagna 1998, ad Sam. 341 (with more sources).

246 So Lape 2004, 166-167. But Chrysis also pursues her own interests. She needs a substitute for her own lost baby. We do not know if Demeas was ever supposed to be informed that the child was not his own.

247 These utterances are qualified in so far as the cook is traditionally a joke character.

248 Cf. Men. Dysc. 89; Epit. 393.

249 Gomme - Sandbach 1973, ad Sam. 447 add that this phrase recurs in Chrysippus, SVF ii. 891. 
done. Niceratus is on the brink of losing his mind (492-520). In a tragic pose, he claims that Moschion's sexual affair with Chrysis is worse than the three most shocking cases of incest and sexual abuse in Greek mythology: Thyestes' adultery with his brother's wife, Aerope, and incest with his own daughter, Pelopia; Oedipus' marriage to his own mother, Jocasta; and Tereus' rape of Philomela, his wife's sister (495-497). ${ }^{250}$ Given the circumstances, these comparisons are inappropriate and therefore ridiculous. Niceratus expands on the mythological metaphors by wondering why Demeas has not 'adopted ... Amyntor's wrath, and blinded [the evil-

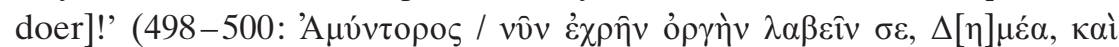

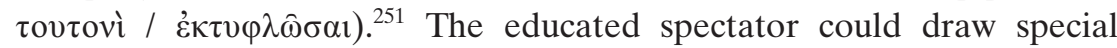
amusement from the fact that, in many versions of the myth, Phoenix was in fact innocent (as Moschion is). In a mutual reinforcement of the other's argument, the two old men become more and more exasperated (506-520). Finally, Moschion manages to get a word in to reveal that Plangon is the mother, not Chrysis (529). At this news, Niceratus rages in fury. His daughter has lost her virginity and is thus not fit for marriage under the strict Periclean laws. Niceratus, in his severe state of shock, rages like a victim in a Greek tragedy (533-540). Gomme and Sandbach remark on this scene: "the whole atmosphere and vocabulary are those of tragedy ... There is also a contrast ... between the confused rage of Niceratus on seeing his daughter suckling the baby, and the self-control of Demeas when he saw Chrysis." ${ }^{252}$ As angry as Demeas is at the possibility that his son has slept with his concubine, he is nonetheless able to pull

250 On these examples and their rooting in myth and literature, cf. Lamagna 1998, ad Sam. 495-496; Bain 1983, ad Sam. 495; Gomme - Sandbach 1973, ad Sam. 495 ff. Cf. Dedoussi 1970, 167-168. Cf. also above 86 on the stepson's denigration of his stepmother as Clytemnestra in Antiphon 1.17. Goldberg 1980, 102 argues already that this funny reference to mythology makes Samia appear to be a farce. On the degree to which Menandrian comedy is steeped in tragic patterns, cf. Hurst 1990 (with older literature). On paratragic motifs in Samia specifically, cf. Blume 1974, 80-81, 119, 175-176, 184, 196-197, 212, 230, 268. On the similarities between Menander and Euripides, cf. Fitton 1981 (Menander alludes to Euripides, in his late comedies above all) and Andrews 1924, who shows that Menander harks back to about twenty Euripidean tragedies. Menander is dependent on Euripides on many levels, such as plot construction and his general thought-world.

251 Gomme - Sandbach 1973, ad Sam. 498 connect this passage to Hom. Il. 9.448 463 and Euripides' Phoenix. Cf. also Bain 1983, ad Sam. 498. On the wrath of Amyntor in detail, cf. Lamagna 1998, ad Sam. 498-499.

252 Gomme - Sandbach 1973, ad Sam. 532-534. 
himself together and "swallow" his anger. Thus, furious rage stands in deliberate contrast to enkrateia-a pattern in Menander, as we will see. ${ }^{253}$ While Demeas and Moschion seem to be reconciling with each other (535-538), Niceratus rages on. Chrysis runs off with the baby because Niceratus pursues them with a club. Although this familiar kind of slapstick does not, as frightening as it looks, ${ }^{254}$ get out of hand-Niceratus refrains from touching his neighbor's property-Demeas and Chrysis rail against the senseless and unenlightened violence exerted by the simultaneously comic and tragic figure of Niceratus (550-585). Since Niceratus is eager to kill Chrysis and Plangon's baby_or so he says, at least (553$556,560-561,580)^{255}$ - Demeas wants to duel with him (570). This scene, too, is steeped in mythology and is thus funny. Ajax dueled with Diomedes (Hom. Il. 23.802-25), but contemporary associations are also conceivable: "Cassander held funeral games in 316/15 in honour of Philip,

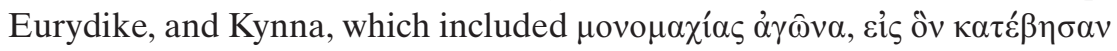
$\tau \dot{\varepsilon} \tau \tau \alpha \rho \varepsilon \varsigma \tau \hat{\omega} v \sigma \tau \rho \alpha \tau 1 \omega \tau \hat{\omega} v$, 'a contest of pair fighting, to which four soldiers stepped down' (Diyllos ap. Athen. 155a)." ${ }^{256}$ At the height of his frenzy, Niceratus finally physically attacks Demeas, an utterly inappropriate action since Demeas is socially superior to Niceratus (572-576). Demeas defends himself by striking the first blow, thus incurring the risk of committing injustice in order to protect Chrysis. ${ }^{257} \mathrm{~A}$ brief and slapstick-like scuffle ensues before the struggle continues verbally, with language borrowed from the Attic courtroom. ${ }^{258}$ Both men accuse each other of

253 Webster 1950, 201-204 makes out a lack of sôphrosunê that leads to physical passions like anger. If Menander has the characters of Demeas and Niceratus suffer from a deficit of sôphrosunê, he is in close affinity with Aristotle, as Quinn 2001 has shown in detail.

254 Keuls 1973, 18 cannot find this slapstick scene funny.

255 It is important to note that Niceratus, at this point in the plot, is fully aware that the baby is Plangon's child, his grandchild. His wish to wash off Plangon's stain of lost virginity is stronger than his willingness to accept his own grandchild (Keuls 1973, 14).

256 Gomme - Sandbach 1973, ad Sam. 570 (transl. by author). On the duel in Menander from a linguistic point of view, cf. Humpers 1922.

257 On the importance of who struck the first blow, cf. above 34-35. Cf., on this passage, Gomme - Sandbach 1973, ad Sam. 572-576 with Men. Dysc. 168; X. Cyr. 1.5.13; Lys. 4.11; Arist. Rh. 1402a.

258 Goldberg 1980, 103 stresses the comic contrast between Niceratus' language, which partly shows characteristics of high poetry, and his fits of rage, which are farcical from the very beginning. 
being sycophants (578) ${ }^{259}$ Finally, in a scene of comic relief, Demeas manages to calm down Niceratus by explaining to him with mythological examples how gods impregnated mortal women (589-595). The hilarious scene ironizes Niceratus' fury and presents the events as brought about by the gods. Since Moschion will marry Plangon, he will atone for his own sin and wash away Plangon's stain. In a calm and private conversation, Demeas and Moschion seem to reconcile with each other. Demeas does not blame Moschion for being angry (695), because he admits that he treated him unfairly. On the contrary, Demeas concedes that he

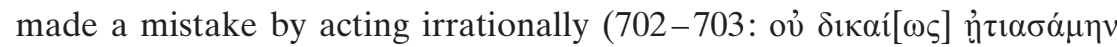

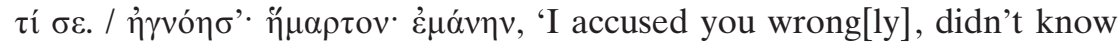
the facts, made an error. I was crazy'). ${ }^{260} \mathrm{He}$ asks for understanding, but deeply regrets that his son made his blunder public by wishing to go abroad as a mercenary $(707-708) .{ }^{261}$ In a final confusion, Niceratus is afraid of Moschion's alleged trying to evade marriage and wants to bind him as a moichos who has been caught in flagrante delicto and has even confessed his crime (717-718). As such, Moschion would be a $\mathrm{ka}$ kourgos and subject to the death penalty under Athenian law, but several other remedies were conceivable as well, among them marrying the injured girl. ${ }^{262}$ This is probably what Niceratus is supposed to have had in mind with this overreaction. ${ }^{263}$ Moschion, however, interprets this renewed physical attack on his person differently and draws his sword to defend himself against the ranting father of the girl.

From a broader perspective, we could say that Samia is about anger, justified and unjustified, and its ultimate inappropriateness. ${ }^{264}$ Violence and the anger preceding it are explicitly exposed to ridicule and criticized onstage. Violence in Menander stems from ignorance and misunderstand-

259 Lamagna 1998, ad Sam. 578; Bain 1983, ad Sam. 575 ff.

260 On the effective asyndetic list of three verbs, as typical of Greek prose style, cf. Lamagna 1998, ad Sam. 703.

261 According to Grant 1986, there is no real reconciliation between Demeas and Moschion. The father-son relationship remains problematic because Moschion tends to see Demeas as a friend, which does not work.

262 On the different possibilities, cf. above 53, n. 145.

263 Cf. Gomme - Sandbach 1973, ad Sam. 717-718.

264 Groton 1987 recognizes that anger is the driving force of the play-when it subsides, the plot is over-but does not see Menander's unequivocal criticism of orgê and mania. On Demeas' and Niceratus' outbursts of anger, cf. Lape 2004, 157-158, who emphasizes that Niceratus cannot control himself. Cf. also Scafuro 1997, 262-263. 
ings ${ }^{265}$ and is therefore irrational and ridiculous, as Blume has rightly observed. ${ }^{266}$ Threatening someone with violence is anachronistic, ${ }^{267}$ the pure burlesque useless. The father Niceratus exemplifies this view paradigmatically. $\mathrm{He}$ is coarse and rustic, endowed with all the traits of a boorish agroikos. ${ }^{268}$ This means that his propensity to violence is not urban but barbarian. As we shall see, this negative view of anger and violence pervades the whole Menandrian corpus, and that of New Comedy in general. ${ }^{269}$ This negative meaning is consistent and, unlike in Aristophanes, unambiguous.

If Old and New Comedy are based on tragedy and constantly engage with it, a short side-glance at Euripides may be permissible in this context. ${ }^{270}$ Euripides presents violence mythologically in manifold ways, but never fails to lay open its destructive character. The play Orestes, for example, performed in $408 \mathrm{BCE}$, has a distinct message for the Athenians. Every form of violence proves senseless in the play ${ }^{271}$ and Euripides builds in elements of parody and irony in order to push the boundaries of the description of graphic violence in the tragic mode. Violence thus becomes, at times, ridiculous. This ironization of violence creates a certain distance between stage action and spectator and enables the latter to reflect upon and finally dissociate himself from violence. If a historical

265 Stoessl 1973.

266 Blume 1998, 138.

267 Blume 1998, 139-140. In a way, Menander ironizes the wrath of Achilles. It is an outdated epic emotion, inappropriate for modern, bourgeois life. A fragment of

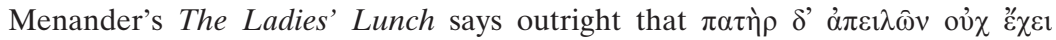
$\mu \varepsilon ́ \gamma \alpha v$ póßov, 'a threatening father can't inspire much fear' (Menander F 453 [Edmonds]).

268 Blume 1998, 141.

269 Numerous fragments of New Comedy deal with anger and cast it in a highly unfavorable light; e.g.: Philemon F 156-157 (K.-A.); Menander F 574, 629-630, 780, 1089 (Edmonds). Menander F 614 (Edmonds) speaks a different language

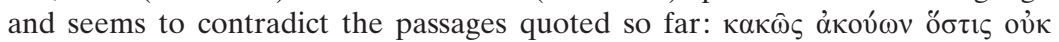

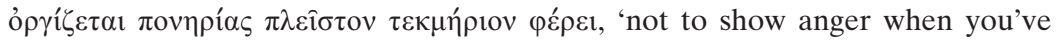
been maligned marks you as the owner of a wicked mind.' We do not know the context of this passage and it is possible that this exception confirms the rule established so far. It is also possible that Menander, in this particular instance, follows Arist. EN 1126a4-8 (cf. above 117, n. 411), because this rather uncompromising attitude fits the situation better.

270 On Menander's relationship to Euripides, cf. now Blanchard 2007, 63-70; still valuable is Katsouris 1975 on the influence of tragedy, esp. Euripides, on Menander.

271 Burkert 1974 passim calls the violence in this tragedy "absurd." 
reading is permissible, among the many other possibilities for understanding the play, one may say that brutality in the Orestes occurs as a consequence of imperialism. In such an interpretation, Euripides may be referring, how directly we do not know, to the senseless continuation of the Peloponnesian War: the Atrides want to perish in the burning palace, which they themselves have set on fire.

In Bacchae, performed after $406 \mathrm{BCE}$, violence is the consequence of religious delusion. ${ }^{272}$ The play may well be the most enigmatic of all Euripidean works, but one strand of interpretation concerns the criticism of religious zealots, who, nine years before, on the occasion of the mutilation of the herms, had instilled suspicion and fear into their fellow citizens and organized a witch-hunt for the parties responsible. ${ }^{273}$ Rational sophists, like Euripides, or philosophers, like Socrates, put up intellectual resistance but did not prevail. Seven years after the performance of Bacchae, under different political circumstances, Socrates was executed, allegedly for committing asebeia and corrupting the Athenian youth. An ironical undertone is also discernible in Bacchae. But if violence is already partly ironized in tragedy, and Attic comedy, in turn, ironizes tragedy on various levels, violence in a play like Menander's Samia is ironized on at least two levels simultaneously. The message is clear: violence, anger, and furious rage are outdated and inappropriate means of conflict resolution. The adherence to and propagation of the new, civilized discourse of the polis, as seen in tragedy in the fifth century, is taken up by New Comedy and related to society in general.

Other Menandrian comedies confirm this picture. In Epitrepontes, Charisius rapes Pamphile while he is drunk, and later marries her without knowing that it was she whom he raped. As a consequence of the rape, Pamphile becomes pregnant and bears a child only five months into her marriage. To save her marriage and reputation, she exposes the baby while Charisius is on a trip abroad, but a slave informs him about all these happenings. Charisius is shocked about the alleged infidelity of his wife, moves in with his friend Chaerestratus, and hires the hetaira Habrotonon to distract himself from his sorrow. Because he loves his wife, Pamphile, he does not touch the prostitute. Pamphile's father, Smicrines, is more exasperated about his son-in-law's prodigality than about his public infidelity (128-131). In the meantime, the shepherd Daus has found Pamphile's child, a son, and has passed him on to Syrus, a slave and

272 On Bacchae, cf., e.g., Seaford 1996; Segal 1985; 1982.

273 Cf. Th. 6.27-29, 53, 60-61; And. 1. 
charcoal-burner belonging to Chaerestratus. A bitter quarrel breaks out between Syrus and Daus about the recognition tokens that were found with the baby: Daus wants to keep them for himself because he found the baby; Syrus argues that they belong to the child. The men appeal to Smicrines to serve as arbitrator in their case, and he decides in favor of Syrus, unwittingly becoming, in the process, judge of his own grandchild's fate. Later, with the help of the selfless Habrotonon, the truth comes to light; everyone is happy that Charisius himself is the father of the child, and the married couple is reunited.

In the second act of the play, the quarrel over the abandoned baby's recognition tokens introduces the idea of madness. During the quarrel, Syrus accuses Onesimus, Charisius' slave, of being 'mad' (393: $\chi 0 \lambda \hat{\alpha} \varsigma) .{ }^{274}$ And, later, Onesimus himself complains that his master is 'quite madyes, by Apollo, mad! He's really crazy. Yes, he's mad, by heaven!'

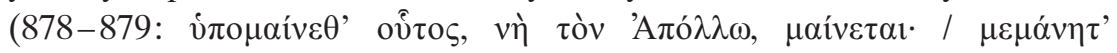

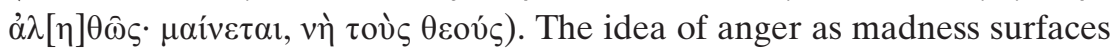
when Smicrines threatens to crack his old slave Sophrone's head (1026)

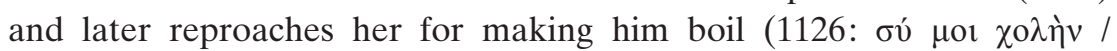
א]ıvî́, 'Your antics make me boil'). Gomme and Sandbach explain the metaphor: contemporary Greek medical theory espoused that excessive amounts of black bile could boil over and drive people mad. ${ }^{275}$ Excessive anger was thus considered madness, something to be afraid of and to be treated. Smicrines' anger and violent language are comparable to that of Niceratus in the Samia. His fury against his daughter, who, in his eyes, has conceived a child out of wedlock, is presented as boorish, and he, as punishment, is exposed to ridicule. ${ }^{276}$ In this play, Smicrines menaces a slave, Sophrone, with blows in the traditional fashion of masters in Old Comedy, but he also rages against his own daughter. Angry at what is, essentially, his own lack of information, Smicrines threatens to crack Pamphile's skull and drown her in a pond. All of his threats are inappropriate and out of date. ${ }^{277}$ In the liminal phase of the stage action, the world is turned upside down, in so far as Onesimus, Charisius' slave, feels superior to Smicrines, his master's father-in-law, in his attitude to violence, because he, the slave, knows more than the old citizen. ${ }^{278}$ In a reversal of social

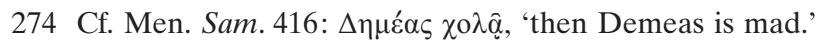

275 Gomme - Sandbach 1973, ad Epit. 393 and 880-881 (cf. Sam. 416; Dysc. 89).

276 Blume 1998, 122.

277 Blume 1998, 123.

278 Blume 1998, 124. 
roles, Onesimus feels sovereign, because the threat of violence fails completely. Smicrines stands isolated onstage. He is the last to know the truth, because he is such a violent character. ${ }^{279}$

In the fragmentary Aspis, a report of the soldier Cleostratus' death leaves his two uncles, Smicrines and Chaerestratus, divided over the fate of Cleostratus' young sister. Smicrines, the older of the two brothers, claims the right to marry her himself, under the law of the epiklêros ("heiress"), which required that the property of an heiress remain within the family. The greedy Smicrines grows angry with the resistant Chaerestratus, who decides to fake his own death, with the help of the good slave Daus, in the hope that Smicrines will forget about the young girl because of the prospect of getting an even greater inheritance from Chaerestratus himself by marrying his daughter. Ultimately, the report of Cleostratus' death turns out to be false, but it is unknown how the play ended.

When the wretch Smicrines realizes that his brother Chaerestratus intends to marry the epiklêros off to someone else, he becomes angry (180-

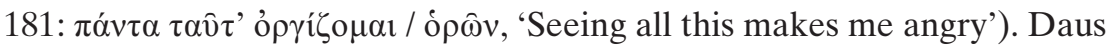
pretends to Smicrines that Chaerestratus is dying of 'bile, anguish, loss of

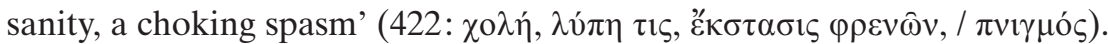
This vocabulary is generally used as a metaphor to characterize severe states of fury. Insanity is a disease that requires medical treatment, and orgê and mania are its symptoms. In fact, the doctor whose help is enlisted

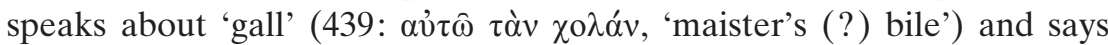

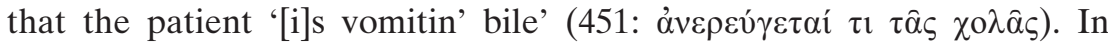
the doctor's opinion, this illness will be fatal.

In Periceiromene, Moschion embraces and kisses Glycera, who is the property of the Corinthian soldier Polemon, unaware that the object of

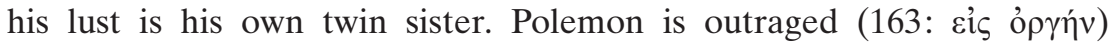
when he hears about Glycera's lack of resistance to Moschion's hugging and kissing, and, to humiliate her, cuts her hair short, a punishment typically reserved for convicted adulteresses. This brutal act results directly from Polemon's ignorance and lack of self-control. ${ }^{280}$ Glycera did not re-

279 Blume 1998, 125-126.

280 Compare Polemon's irascible character to Thrasonides' exemplary self-restraint in Misoumenos, as fleshed out in detail by Lape 2004, 190-201. In imitating the shearing of an adulterer's pubic hair when caught in the act, Polemon cuts off Glycera's hair after the alleged seduction, which never actually took place. Thus, Polemon is in the wrong, his violence uncivilized. In the course of the play he learns how to behave like a civilian. Lape 2004, 174-188 reads the whole play as a grand metaphor, with Polemon standing for the Hellenistic 
sist the kiss because she knew that Moschion was, in fact, her brother. Further complications ensue, which need not concern us here. Instead, let us turn to the quarrel between Polemon's slave, Sosias, and Moschion's slave, Daus, whose verbal bickering might easily have led to a scuffle or brawl. In a heated dialogue, Daus characterizes Sosias as

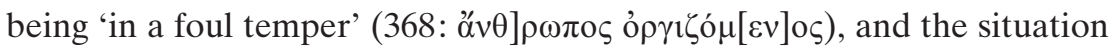
threatens to get out of hand when Daus calls Sosias a 'filthy liar' (378:

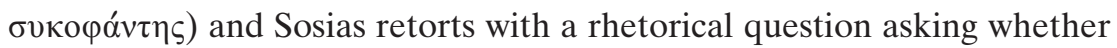
Daus thinks they (i.e., Sosias and his master) are 'not [hot-blooded], or

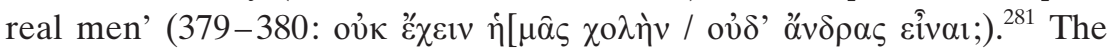
old Corinthian Pataecus, father of Glycera and Moschion, mediates the conflict between Polemon and Moschion and calms down their heated emotions. In doing so, he speaks the new discourse of moderation: he has the courage to ask his daughter's master, Polemon, 'not to shout' (489: $\mu \grave{\eta} \beta$ ó $\alpha$ ), and, shortly afterward, explains to Polemon that using violence is senseless. Rather than exacting physical punishment, Pataecus advises, he should go to court to file a complaint against Moschion (500503): 'He's wronged you, so lodge a complaint, if you can meet and talk. Use force, though, and you'll lose your case! This wrong doesn't call for a reprisal, but a complaint. ${ }^{282}$ Thus, Gomme and Sandbach see the legal implications of Pataecus' advice: "if Polemon uses force to recover Glykera he will be acting illegally and be condemned when brought to trial." 283 The norms of Greek civilization, derived from Attic judicial culture, have become so strong that they serve as a deterrent for every deviation from them.

In the play Dis exapaton, Sostratus pities his friend Moschus but is, at

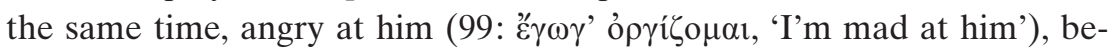
cause he believes that Moschus is in love with his hetaira. Sostratus does

kings and Glycera symbolizing the Greek city-states striving to maintain their independence. The goal is the "complete reciprocity between the participants" (Lape 2004, 188). This enhanced equality within balanced gender relations suggests, as Lape contends, on the political level, a greater equilibrium between the Geek poleis and Hellenistic kingdoms. This interpretation is insightful, but seems reductionist. Further research needs to be done to ascertain whether or not this analogy is valid on every level.

281 Gomme - Sandbach 1973, ad Pk. 379 explain the semantics of "gall, bile" again, and give numerous examples from Greek literature.

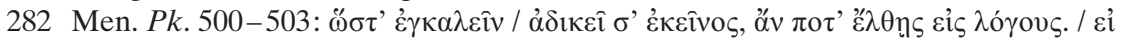

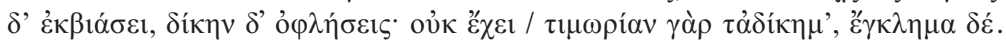

283 Gomme - Sandbach 1973, ad Pk. 499-503. 
not yet know that his friend, instead, loves the girl's sister, Bacchis. Again we see that orgê is a result of ignorance, a state that needs to be mended.

Like Aristophanes, Menander uses the terms orgê, thumos, and cholê almost interchangeably. At the same time, however, their meaning in Menandrian comedy is much narrower and less ambiguous than in Aristophanes. The concept of anger pertains exclusively to family relationships, which, from the viewpoint of a male protagonist, have gone wrong. But since all obstacles can be overcome in comedy-most typically the rapist always marries the rape victim-orgê is always unjustified, a false and futile means of conflict resolution because it prevents communication. Menander consistently portrays anger and, with it, the loss of moderation, negatively, as rustic, barbarian, tyrannical, and even un-Greek qualities, not worthy of free Athenian citizens. This concept of anger shows close affinity to the ideology of the forensic speeches. After the onset of, and mainly on grounds of, the Macedonian rule over Athens, the democratic violence discourse, thoroughly democratized through forensic speeches, had become even more generalized on an essentially human level by the time of Menander. Since folly and the violence resulting from it are inappropriate means of conflict resolution, the playwright ironizes wrathful raging, most notably in Samia. This critical stance becomes possible because orgê is no longer a collective phenomenon, as, for example, in Aristophanes' Acharnians, where the old but glorious fighters of Marathon embody wrath in its most positive shade of meaning, the fierce willingness to resist foreign intruders. Orgê is no longer the perverted democratic energy exuded by Philocleon and his companions in Wasps, but has turned into a personal defect. If generalization is permissible in this context, one could put forward the following hypothesis: whereas the individual defines himself via the polis in Aristophanes, it is the other way around in Menander, where the sum of individual citizens makes up society. This fundamental difference accounts for the very different use of the concept of orgê in both playwrights. In Aristophanes, it is the expression of a communal feeling: the body politic is angry at Euripides or Cleon; the charcoal-burners or the wasps as a collective are angry at deviant individuals. Orgê is not yet a private emotion. In Menander things are different: wrath is the private shortcoming of an individual within an oikos. But since society is made up of the sum of all individuals, their respective private feelings do matter on a political level, because they ultimately affect society as a whole. It is thus necessary to quench and eliminate wrath from every single household. If exercised on a grand and uncontrolled scale, loss of one's temper has the potential to harm society. Private emo- 
tions and their control are thus as important as ever for the proper running of the polis. Once again we see the affinities among forensic speeches, curse tablets, comedy, and other media that this study does not treat (e.g., grave stelai and vase paintings). Emotions that are possibly problematic for society must be suppressed. In this respect Menander is as close to a fifth-century understanding of emotions as Aristophanes. Only the perspective has shifted, which makes for a new kind of comedy. But why did this shift occur? Why did the concept of anger undergo this profound change, which seriously narrowed the range of meanings that the concept had in Aristophanes? We can only speculate. In an age of uncertainties, when Athenian democratic identity was constantly under question by Macedonian oligarchy, theater may have served to provide the citizens of Athens with definiteness, a portrait of stable values, couched in traditional terms, in order to enhance citizenship ideology and discourses about Greek identity. ${ }^{284}$ Athenians, it seems, no longer appreciated the semantic openness of Old Comedy. Comedy had to adjust to new circumstances and cater to new expectations and tastes. Plutarch's rant against Aristophanes is a late but telling testimony of how Greeks under the Roman Empire did not understand Aristophanes and his poetic and political program. ${ }^{285}$ The Athenians of the late fourth century BCE might not have thought much differently. ${ }^{286}$

\section{Hubris}

Whereas the concept of hubris is frequent in Aristophanes, it only plays a minor role in Menander. When it appears, it refers exclusively to illicit sex, including rape. In Samia, for example, Niceratus tells Demeas that he would not have let Moschion commit 'outrage' by having sex with an-

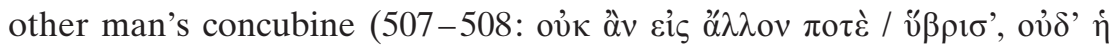
$\sigma v \gamma[\kappa \lambda]_{1} \theta \varepsilon i \sigma \alpha$, 'never would he or his mate have outraged another!'). Instead, he would have sold the guilty hetaira and his son into slavery. And, in Periceiromene, Glycera, in a conversation with her father, Pataecus, re-

284 Herein lies Menander's political impetus, as Lape 2004 suggests (passim).

285 Plu. Mor. 10.853-854. A compiler gave this summary-a comparison between Aristophanes and Menander-of one of Plutarch's lost essays. Plutarch condemns Aristophanes outright and praises Menander without taking any notice of the different historical and social circumstances, as well as the different poetics and intentions of the playwrights.

286 Most famously Aristotle, who probably never saw a performance of Old Comedy (Arist. EN 1128a15-19; Rh. 1419b8). 
fers to her master, Polemon, and his potential rape of another girl as $h u$ -

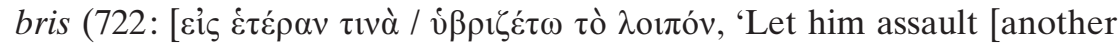
girl] in future').

One of the most famous instances of hubris in Menander is to be found in Gorgias' dialogue with Sostratus in the play Dyscolus. Since this play will be of major importance in the following subchapters, I include the outline of its plot here, although only one scene explicitly pertains to hubris. Menander's best-preserved play, awarded the first prize at the Lenaea of 316 BCE, Dyscolus is about class barriers and the misanthrope Cnemon's difficult and antisocial character-he shuns human society out of conviction. ${ }^{287}$ Cnemon has an unmarried daughter, with whom he lives in isolation. The girl's mother, Cnemon's estranged wife, Myrrhine, lives next door with the poor farmer Gorgias, her son from a previous marriage. The rich town-dweller Callipides has two grown-up children, a son named Sostratus and a beautiful daughter, Plangon. The former owns two slaves, Pyrrhias and Getas; the cook Sicon is also part of the family. Sostratus falls in love with Cnemon's daughter, but wooing her turns out to be difficult because of Cnemon's unapproachable character. Chaereas, Sostratus' close friend, offers to lend the would-be lover a helping hand; he says he would even be willing to burn down doors and help him kidnap the girl, a clear ironization of scenes of violent kômoi and abduction marriage. ${ }^{288}$ Sostratus first speaks to Gorgias, the halfbrother of his beloved girl. From line 285 on, the deep suspicion that the honorable young farmer feels toward the rich city-dweller Sostratus is evident: he fears that the rich young man might seduce his half-sister. Gorgias' suspicions encapsulate the social tensions between rich and poor, town and countryside. ${ }^{289}$ And Gorgias is frank about his reserva-

287 Zagagi 1994, 105 speaks of a "character study of the misanthrope." On the comedic type of the misanthrope, often called "Timon," cf. Olson 2007, p. 92-93 (B21) with p. 425 (transl.) and more sources. Schäfer 1965, 91-95 discerns the beginnings of psychological character-painting with regard to Cnemon. Especially in the fourth act, Cnemon transgresses the narrow boundaries of the type and becomes a person, but then Menander, who may not have been aware of his own literary boldness, subjugates the figure of Cnemon under the predominance of the plot again. Anderson 1970 contends that Menander unites Aristotle's theory of hamartia with his own aesthetic and moral theories.

288 Menander certainly plays with traditional door-breaking scenes as a slapstick motif derived from Old Comedy. Cf., e.g., Heracles' smashing a front door in a fragment of Aristophanes' plays (Aristophanes F 300 [K.-A.]).

289 Ramage 1966 sees the divide between town and countryside vividly described in this scene. It is overcome in the end through philanthrôpia. According to Arnott 
tions. He reminds Sostratus that a poor man, when outraged, becomes the bitterest enemy of a rich offender. In this context, Gorgias talks-in all probability-about hubris, meaning an extreme form of insult and humiliation stemming from Sostratus' having had illicit sex with his (i.e., Gorgias') unmarried half-sister: 'When a poor man's injured, he's the bitterest foe of all, for sure. At first, he's just pathetic; later, he takes all his tribulations as a [personal] [insult], not just as mischief!'290 Finally, Gorgias recognizes Sostratus' honorable intentions after he has sworn to marry the girl (315).

In Menander, hubris mostly denotes rape. This means a massive curtailment of the broad semantic range of the word as we encounter it in Aristophanes. There is no more hubris against the gods in Menander, no more hubris in the kômoi concluding the plays, with one notable exception that we will deal with shortly. Transgressions in general are hardly depicted by Menander, and since rape had never been openly displayed on stage, there was no room whatsoever left for the representation of $h u$ bris in Menandrian comedy. Unlike on the Aristophanic stage, where $h u$ bris occurred in many different shapes and grades, the stage of New Comedy was no longer the place for the expression of hubris.

\section{Slapstick}

Aristophanic comedy is unthinkable without slapstick, however elaborate its implied meaning is. What about Menander? Not even New Comedy can do without the rumble and tumble, as rare as it is. Although slapstick scenes are much less frequent in Menander than in Old Comedy, they have specific meanings that are different from those in Aristophanes. Because they are anchored in anger, they present an explicit discourse about civilized conduct by showing what human behavior is not supposed to look like. I proceed again play by play, according to the importance of the slapstick scenes, to discern their functions in the context of the respective plays.

1964, Menander reveals all his dramaturgical craft in this scene. He fleshes out the social nuances very well. Gorgias' railing against the innocuous city-dweller testifies to his own narrow-mindedness.

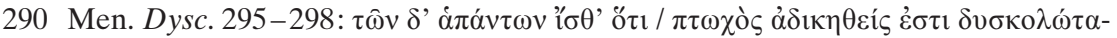

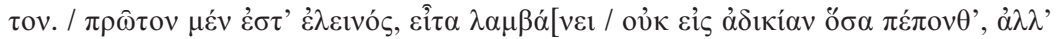

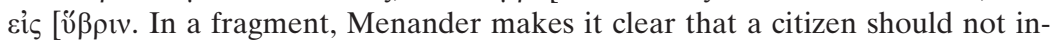
dulge in a pleasure that is based on hubris: Menander F 728 (Edmonds). 
In Dyscolus, Sostratus sends his slave, Pyrrhias, to Cnemon's door to make investigations for him, but Pyrrhias later runs onstage complaining that Cnemon has driven him away after pelting him with clods of earth, pears, and stones $(81-123)$. The threatened man echoes tragic diction: $\alpha \dot{\alpha} \hat{\lambda} \lambda \omega \lambda \alpha$, 'I'm all in' (83). For a slave to run onstage after receiving a beating from a free man, is a standard scene in Old Comedy. ${ }^{291}$ Pyrrhias' wailing description of what has happened to him characterizes Cnemon's rude character and is at the same time a fitting way to ridicule and discredit the kind of violence Cnemon uses. Already in this scene, Menander presents the misanthrope and his actions as 'mad.' The peevish Cnemon confirms this picture over and over again with his own words. When his usual isolation is disturbed, he rants and raves about the way people intrude on his property (153-178). He mocks the Attic lawcourt system, criticizes civilization in general (176-178), and finally loses his temper when Sostratus' entire family shows up to sacrifice at the altar of Pan (430-455). When Getas, one of Sostratus' slaves, knocks on Cnemon's door to borrow something, Cnemon heaps insults upon him (466-486). The cook Sicon does not believe Getas and thinks that, with more subtlety and diplomacy, they can get what they want from the old man. The result is a wonderful scene of slapstick comedy that can be regarded as a doublet of the one mentioned above (Cnemon's pelting of Pyrrhias with stones at lines 80-123): Cnemon threatens Sicon with a strap and gives him a thorough hiding with it (500-503). Sicon breaks free but, understandably enough, bears a grudge against the fierce and brutal man. When Cnemon later falls into a well and Gorgias and Sostratus are about to rescue him, Sicon recommends that they instead throw a huge rock down the well to make Cnemon stay down there forever (631632). After his rescue, Cnemon explains to Gorgias and Myrrhine why he withdrew from human society $(711-723)$ : he was disappointed by mankind and strove to live an independent life, fully autonomous and self-contained. This questionable ideal as formulated by Cnemon mirrors the concept of autarkeia, as defined by Aristotle. ${ }^{292}$ It stands in stark contrast to the Greek practice of neighborliness, ${ }^{293}$ as worked out by

291 Cf., e.g., Ar. Ach. 176-177.

292 Arist. Pol.1253a1; EN 1177a28-36. According to Zagagi 1994, 107, Cnemon's "deliberation reflects contemporary arguments about the relation between the individual and society."

293 Zagagi 1994, 104. 
Schmitz. ${ }^{294}$ Cnemon now admits that he was wrong and is deeply moved that Gorgias, whom he did not even greet before, has saved his life (722729). Cnemon now transfers to Gorgias all the powers of a kurios and commissions him to find a suitable husband for his daughter (730-747). Gorgias knows what he has to do. He unites his half-sister with Sostratus and speaks the betrothal formula in lines 761-763. Callipides then speaks the betrothal formula for Gorgias and Plangon (842-844), a scene that leads to the double wedding that concludes the play. Although Cnemon makes concessions and shows some kind of insight, he does not undergo a real change (729-747). He just accepts help within the family and is not interested in how life goes on; he wants to continue his stubborn routine and live on in solitude. This loose end is the prerequisite for the final scene, which I will treat in more detail below. The servants Sicon and Getas, both previously beaten by Cnemon, take revenge in a funny way (893-960). They carry the old man out of his house while he is asleep and lay him down on the bare ground. Cnemon wakes up and is exasperated. The slaves finally help him up, force him to dance, and carry him into the neighboring house, where the wedding feast is in full swing. In other words, the Athenian citizen Cnemon has to endure a violent reintegration into human society (hubris) at the hands of two slaves. Menander presents Cnemon's own violence as rustic and uncivilized throughout the play. ${ }^{295}$ His barbarian behavior can be compared to Niceratus' senseless and ridiculous fury in Samia. Menander has internalized the discourse on Greek civilization. No one can live without the help of other human beings. ${ }^{296}$ Self-restraint and moderation are key to maintaining good relations with one's fellow citizens and neighbors. Cnemon has to learn this fact the hard way, but actually fails to do so. ${ }^{297}$

We get a similar picture in Samia. After Demeas discovers Chrysis with a baby, he wrongly assumes that his son Moschion has slept with his hetaira. He is so furious that he wants to cast Chrysis out of his house, together with the baby $(130-136,370-398)$. If the child were in fact his son's child, Demeas here would be on the brink of exposing his own grandchild. ${ }^{298}$ He cannot believe that his son has betrayed him,

294 Schmitz 2004, 423-431.

295 Blume 1998, 89-90.

296 Cf. Blume 1998, 93.

297 The old form of the kômôdein, to poke fun at someone through masks, is well preserved in this play. Cf. Gelzer 1999, 12.

298 Cf. Keuls 1973, 13-14 on this kind of child exposure. 
and asks the slave Parmenon about what has been going on (302-324). But when Parmenon can only give limited information, Demeas becomes furious about his slave's supposed obstinacy. He threatens to thrash him (305-306), strike him with a strap (320-322), and brand him. All of these threats belong to the typical arsenal of problematic master-slave relationships in Old and New Comedy. Toward the end of the play, the same slave suffers bodily harm, ${ }^{299}$ this time from his master's son, Moschion. Although Moschion's marriage has already been arranged, he still intends to take revenge on his father for having accused him of such a serious misdeed as having impregnated his hetaira. Moschion pretends that he is going abroad as a mercenary so that his father will ask him for understanding and implore him to stay at home. To carry out the scheme, Moschion asks Parmenon to bring him his cloak and sword (660). Parmenon does not understand and is unwilling to carry out the order. Moschion threatens him with a whip (663), but now explains to him what he is up to. Parmenon goes inside and realizes that the wedding preparations are already in full swing. He comes out again, without cloak and sword, and tries to convince his master that the scheme is unnecessary. Moschion, in a rage, hits Parmenon in the face (678). The blow is so strong that it splits the slave's lip (679). This is violence beyond slapstick. Masters could, legally, treat their slaves in this way, but in this case the punch is overly brutal and Menander depicts it as problematic.

All these outbreaks of violence in Menander result from preceding anger and an inability to keep it under control. The slapstick scenes ridicule violence and present their agents as immature and unenlightened. Thorough argumentation informs the unknowing and does away with their ignorance as well as the irrational emotions that stem from it. Seen from the angle of the ideal of self-restraint, we could say that rustic stupidity and ignorance may lead to un-Greek violence that dissociates its perpetrator from society. Whereas Demeas in Samia and Gorgias and Callipides in Dyscolus embody the values of a refined Hellenistic civilization, Niceratus in Samia is as misanthropic, rustic, and crude as Cnemon is in Dyscolus. The final pacification at the end of each and every Menandrian play testifies to violence that has become problematic. Without the problematization of violence there would be no Happy End. In political terms, we could say that the civic and civil violence discourse was equated with the ideology of Hellenistic urban culture. The vocabulary of the Me-

299 Zagagi 1994, 129 rightly argues that Samia resembles farce because of the multiple "repetition[s] or reversal[s] of situations and motifs." 
nandrian as well as Aristophanic stages reflected that of contemporary ideology and discourse, albeit in different guises. The fragments of the play Colax and Perinthia confirm the picture established so far.

In Colax, two men love a beautiful hetaira who is the property of a pimp. One of the lovers is Pheidias, a young man who is accompanied by his slave, named Daus, and a fawner. The other man is Bias, a rich specimen of the braggart-soldier type. He, too, has a "parasite" in his entourage. In excerpt E $225-237,{ }^{300}$ the pimp reports, terrified, that Pheidias and his sixty poor friends have cudgels in their hands and might use them to try to steal the prostitute from him. Since she makes more money than ten other prostitutes together, he is afraid that they might kidnap or sell her to another suitor or pimp. In this scenario, he would have to go to court to sue them, and he is frightened by this prospect. ${ }^{301}$

We do not know the exact plot of the play Perinthia, which is only preserved in a few fragments. The old, married man Laches has one son and owns many slaves, among them Daus. The main protagonist, the girl Perinthia, may not even have appeared onstage. For whatever reason, Daus is to be punished by his master. He seeks asylum at the stage altar. To force him away from the altar, people start piling a pyre up around him. The same kind of threat is found in Aristophanes' Thesmophoriazusae $(726-727,749)$, where "the angry women threaten to burn Euripides' kinsman at the altar." ${ }^{302}$ As normal as violence against slaves was deemed in the Greek world, it is equally certain that Daus was saved in the end. People do not die in comedies. Menander's dramatic technique in this particular instance consists of driving the violence against a slave to the extreme, only to have the slave rescued in the end, thereby proving the futility of the violence exerted on him.

When we compare slapstick violence in Menander to that in Aristophanes, we see a fundamental discrepancy. Menander cannot do without traditional slapstick, but it is not as much in the forefront as in Aristophanes. The latter's claim-if it is not just a highly ironic, rhetorical pose- to have civilized comedy by subduing vulgar violence was only fulfilled by Menander and probably other authors of New Comedy. Just as in Aristophanes, violence in Menander serves the goal of characterizing the violence-monger in a bad light. But it lacks typically Aristophanic multi-

300 As in Arnott's 1996 Loeb edition (p. 183) = F 109-121 (Kö.) = F 126-138 (Pernerstorfer).

301 On this scene, cf. Gomme - Sandbach 1973, ad Kol. 120-132.

302 Cf. Gomme - Sandbach 1973, ad Per. 1 ff. 
dimensionality. Menander consistently presents slapstick violence as primitive and outdated, and he always subjects it to ridicule. In contrast to Aristophanes, only a few stock motifs of slapstick are even extant in what is preserved from New Comedy. Slave beatings are frequent, but we search in vain for the expulsion of authorities, father-beating scenes, arson, or the parody of the judicial system, apart from Cnemon's brief critical remarks about the Athenian law courts. Gender roles and religious customs are discussed and challenged-the mercenaries in Periceiromene and Misoumenos are, in the end, sensible young men $;{ }^{303}$ Chrysis in Samia is as reproductive and nurturing as a citizen woman ${ }^{304}$-but never really reversed, and family relationships are not turned upside down. Chrysis and Habrotonon are impressive stage characters, to be sure, but they do not have the utopian format of a Lysistrata or Praxagora. Aristophanes' larger-than-life male heroes, endowed with boundless energy, like Dicaeopolis, Trygaeus, Philocleon, or Peisetaerus, have given way in New Comedy to human-sized men, young and old, with their strengths and weaknesses. This is not to say that New Comedy is not political or visionary, but that its tone is milder and gentler than in Old Comedy. Violence is less transgressive on the Menandrian than on the Aristophanic stage. Masters still beat slaves, but this is normal. Only once does a father threaten his own daughter (Smicrines against Pamphile in Epitrepontes). No son hits his father, and gods are certainly never struck, like Dionysus in Frogs. Has New Comedy become tame? Within the frame of the oikos, certainly not, but the polis is no longer the point of reference, because it had lost its political functions by the time Menander was writing his comedies. Referring to the polis now meant referring to society as a whole, which was deprived of its former political ambitions and preoccupations. In order for a playwright to reach this kind of audience, he no longer had to be political. The authors of Old Comedy liked breaking rules of interaction on a grand scale to open drama up to utopia. New Comedy mainly follows social norms, but is still no less reflective. The obligatory Happy Ends after myriad complications also serve to create an ideal world. How realistic was it for siblings to find each other again after decades apart, or for female slaves to bring about reconciliation in a household?

In Menandrian plays, plot and ritual frame are less in tension with each other than in Aristophanes, because the action onstage is less fantas-

303 Lape 2004, 171-201.

304 Lape 2004, 166-167. 
tic than in Old Comedy. It is, after all, more likely (from a Greek perspective) that a man would marry his rape victim than that someone would conclude a separate peace with Sparta, or that women would go on a collective sex-strike or set up a full-fledged gynecocracy. With the difference between stage action and festive ambiance during the Dionysiac festivals massively reduced, the spectators of New Comedy essentially watched their own lives unfolding onstage. They could identify more with the human-sized stage personae than with Aristophanes' fantastic, animallike creations. Thus, the outer frame lost much of its original functionthat is, to check what happened onstage by providing a different perspective that added more layers of meaning to the action performed. With the stage action more and more resembling the world of the audience and vice versa, theater became, paradoxically enough, a closed system. ${ }^{305}$ New Comedy appealed to the spectators by making them ponder many issues, but it did not involve them so actively and physically as did the anti-illusionist plays of Old Comedy. The immediate ritual of Old Comedy, which did not yet know a strict barrier between actor and audience and could never decide between the fictional there-and-then onstage and the here-and-now of the performance, gave way to the gradual evolution of the Guckkastenbühne, which drew the line firmly between the two worlds and scarcely broke the illusion of the fictional plot. Stage and koilon were forever separated. The reduced role of the chorus in Menander is symptomatic of this fundamental change. It does not oscillate any longer (as it did in Aristophanes) between fictional role and actual performance, but has been reduced to the function of a mere divider between acts. ${ }^{306}$

In Aristophanes, other instances of slapstick violence concerned the maltreatment of women, metaphorical violence, mugging at night, and the parody of tragedy. What is the situation like in Menander? In Periceiromene, the excited dialogue between Sosias, Polemon's slave, and Daus ironizes a form of popular justice, the Rügebrauch of shattering the doors of a wrongdoer and calling him out, ${ }^{307}$ especially if he maintains a socially

305 On the reasons for the growing comic illusion in fourth-century comedy that finally led to Menandrian comedy, cf. N. Slater 1995.

306 Cf., e.g., Lape 2006. Pöhlmann 1988 demonstrated already that the chorus sings on the empty stage, never intervenes in the plot, and enters and leaves the stage for every one of its performances, thus underscoring the five-act structure of the plays. On the continuity and change of the comic chorus during the fourth century, cf. Rothwell 1995.

307 On the motif of door-breaking scenes, cf. above 332, n. 288. 
inappropriate love affair. Glycera flees from her master, Polemon, to the house of her neighbors, Myrrhine and Moschion. She does so by her own free will, but Sosias implies that Moschion and his people are detaining a free woman against her will, a woman whose kurios is his master, Polemon. If true, this accusation would constitute a severe case of hubris. Anticipating a housebreaking scene, Sosias warns Daus that Polemon will come with his own men, break the door open, and free the girl (375393). Before line 467, Polemon does indeed show up with his "army," probably only consisting of Sosias, the flute-player Habrotonon, and a few men, to drag Glycera back to his own house, with violence. Pataecus is now onstage, ready to intervene (469-471). He addresses the more sensible Polemon, because he seems to be less drunk than Sosias. At first, Pataecus' mediation seems to be only half successful. Sosias encourages Habrotonon to sound the attack (476); the whole scene, however, is ridiculous. A flute-girl is supposed to support a sham attack with only a few men? The occasion is totally inappropriate. The quite civilized mercenary is ready to talk to Pataecus anyway and just sends Sosias offstage (481).

The action of the fragmentary play Sicyonioi unfolds after four-yearold Philumene is kidnapped and sold into slavery. ${ }^{308}$ The main theme of the play is Athenian citizenship and how Philumene and the young man Stratophanes come together in the end. Because of the fragmentary state of this play, as with many other works of New Comedy, it is hard to come to more general conclusions, but, as far as we can tell from extant fragments, the scenes discernible as slapstick, do not alter the picture we can glean from the larger pieces.

\section{Rape}

In contrast to Aristophanic comedy, most forms of violence have a consistently negative meaning in Menander. There is only one notable exception: rape. The issue of rape is deeply ambivalent in New Comedy and is more complex than in Aristophanes. Modern research is divided on how to assess the open meaning of forced sex in Menander. The striking diversity of modern opinions suggests that ancient spectators and readers might also have been at odds to come to terms with the frequent phenomenon of sexual violence in Menandrian plays. Here is a summary of the

308 The fickleness of fate, a popular motif in New Comedy, is already used in Middle Comedy, with explicit regard to kidnapping in a fragment of Antiphanes' Soldier or Tychon (Antiphanes F 202 [K.-A.]). 
main contradictory viewpoints, presented in comparison with the motif of rape in Aristophanes.

On the one hand, Menander's plays confirm the thesis derived from the evidence of the forensic speeches. If a man raped his own wife or slave, the act belonged to the realm of normalcy. In Menander's plays, rape does not take place in public, does not need spectators to assess it as "rape," and is not even verbally dramatized in most cases. Rather, it is only hinted at, with the exception of the rapes in Epitrepontes and the Eunuch of the later Roman playwright Terence, who used Epitrepontes as his model. Given these parameters, one gets the impression that, on the Menandrian stage, rape is a "harmless" event that affects neither the world of the male citizen rapist nor even the final outcome of the play, the inevitable Happy End. What we glean from a parallel reading of the forensic speeches and Menander's comedies is a continuity of values from one genre to the other-an unsurprising result, given the fact that Menander's plays date to a time not too long after the bulk of fourth-century oratory.

On the other hand, Sommerstein has worked out a disconcerting undercurrent in New Comedy. In Old Comedy, only slaves are potential rape victims; in New Comedy, only free citizen girls are raped, and they always become pregnant. In New Comedy, the rape is always carried out; in Old Comedy, it is only imagined or threatened. Another blatant discrepancy between Aristophanes and Menander is the fact that rape never triggers the plot in Old Comedy, whereas it almost always does so in New Comedy. Thus, as the type of sexual violence changes from Old to New Comedy, rape gains heightened importance in Menandrian plays. What all of this amounts to is a deliberate reversal and aggravation of the Aristophanic rape motif by Menander. ${ }^{309}$ Since the differences in the treatment of rape in the two authors are obvious, I suggest the hypothesis that Menander intentionally inscribed ambiguity into the substance of his rape plots. This chapter seeks to explicate the reasons for this startling phenomenon, first by briefly examining the Menandrian texts and how they express "rape" verbally, then by exploring current controversial interpretations and determining what they can add to the study of this topic.

309 Sommerstein 1998a, 105-109. The development of the rape plot was probably underway in Middle Comedy: rape plots with mythological themes may have been common in Middle Comedy and were then projected onto the oikoslevel by Menander. 
In the extant, but fragmentary, corpus of New Comedy, rapes occur in Synaristosai, ${ }^{310}$ Plocion, Citharistes, Phasma, the fabulae incertae 1 (P. Cairensis 43227, from Aphroditopolis in Egypt) and 6 (P. Antinoopolis $15=\mathrm{F}$ adesp. 1084 [K.-A.], from a codex of the fourth century CE), ${ }^{311}$ twice in Heros, ${ }^{312}$ maybe twice in Georgos, and prominently in Samia and Epitrepontes. ${ }^{313}$ Dyscolus and Misoumenos are exceptions, because rapes do not occur within these plays, but are either alluded to or, interestingly enough, the sexual union featured in the play requires the consent of the woman.

Fragment 1 of Synaristosai, quoted by an ancient commentator, includes a portion of a speech by the character Plangon, apparently the victim of a rape: " $<$ For $>$ the Dionysia had a procession $\langle\ldots\rangle$ He followed me right to the door, and then with always dropping in and flattering $<$ me and my mother $>$ he knew me too well. $>^{314}$ The ancient commentator continues: 'By describing seduction and sexual assault in a dignified way as 'he knew me too well,' he glossed over a disgusting act by the greater dignity of his language. ${ }^{315}$ As we will see, this smoothing over of the sexual act is typical of Menander's diction, which is a far cry from Aristophanes' direct and deliberately gross language.

We do not know much about Menander's Plocion, on which Caecilius Statius' Plocium is based. Aulus Gellius renders the relevant passage in Caecilius' Plocium thus: Filia hominis pauperis in pervigilio vitiata est. Ea res clam patrem fuit, et habebatur pro virgine. Ex eo vitio gravida mensibus exactis parturit, 'The daughter of a poor man was violated during a religious vigil. This was unknown to her father, and she was looked upon

310 Plaut. Cist. $177-178$.

311 On this text, cf. now Olson 2007, pp. 142-143 (C15) with p. 434 (transl).

312 Hypothesis of the play, line 3.

313 The play Hiereia (P. Oxy. 1235b = pp. 619-625 of Arnott's 2000 Loeb edition) is preserved in too fragmentary a state to be treated here (the title character was raped as a young girl, bore a son, and met her rapist again a generation later). Very fragmentary are also Perinthia, fabula incerta 7, and Titthe, which may all have featured rapes as well. In fabula incerta 5 (P. Hamburg 656, from unknown Egyptian provenance), perhaps a mother was raped, but the play is too fragmentary for us to know for sure.

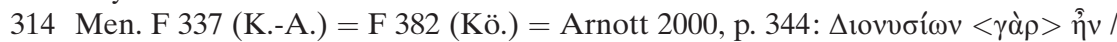

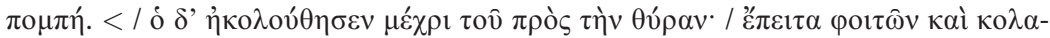

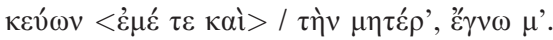

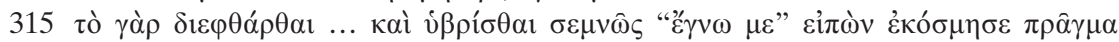

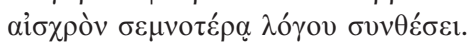


as a virgin. Being with child as the result of that assault, at the proper time she is in labour. ${ }^{316}$

In Citharistes, the young Athenian Moschion rapes and impregnates Phanias' daughter in Ephesus. The plot might have been as follows: upon his return to Athens, Moschion perhaps leaves the girl temporarily, but then determines that he is in love with her, confesses his guilt to his mother, and asks his father to allow him to marry the girl, despite her Ephesian origin. In the end, the young couple marries, of course, but only because it turns out that Phanias' wife is, in fact, Athenian, not Ephesian. Thus, Phanias' daughter is fully Athenian and therefore fit for marriage. Moschion only hints at his misdeed and addresses his father: 'Father, if we avoid the victims of a wrong, who [sic] else can we help easi-

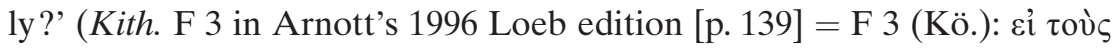

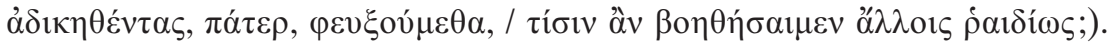

The plot of Phasma is complicated and unclear. Either husband A or $\mathrm{B} 2$ raped wife $\mathrm{A} 2$ a long time ago at the Brauronia festival, where many young girls were gathered to worship Artemis. Wife B talks about this in-

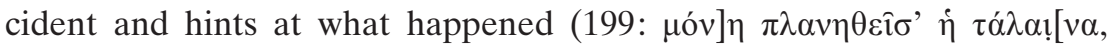
'The poor girl wandering [on her own [?]').

In fabula incerta 1, Moschion's rape of Cleaenetus' daughter, which neighbors witness, is mentioned several times. We can surmise that this sexual act is the reason for Cleaenetus' imprisoning of Moschion until he agrees to marry the girl. In this play, the protagonists several times call rape a wrong and violent act full of injustice. Chaereas, for example, says, 'Yes, rape's effective! Must I ask him to give away my girl, when I'm

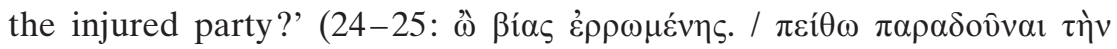

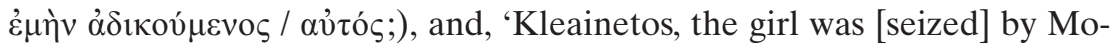

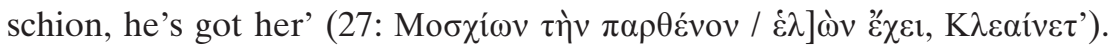

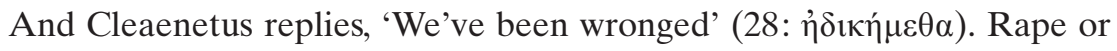
seizure is mentioned again in line 4 of P. Oxy. 429 (F adesp. 1010 [K.-A.]: Eis $\dot{\alpha} \rho \pi \alpha[\gamma)$, which is attributed to this play.

In fabula incerta 6, a young man, while drunk (as so often in New Comedy), rapes a girl before her marriage. She manages to keep his cloak. He thinks that, since he married, he has not cheated on his wife,

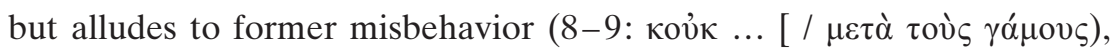
'since my wedding [I've] not [misbehaved here ...]').

316 Gel. 2.23.15-18 compares some passages from the Menandrian play to the Latin version. 
The play Heros has two rapes in its background. Laches rapes Myrrhine and marries her without knowing that she has been his victim. The twins Gorgias and Plangon are the result of this sexual act. Tibeius, Laches' former slave, now a freedman shepherd, rears the two children. Tibeius is so much in debt to Laches that the two children have to work off the debt of their "father." The free and rich Pheidias rapes Plangon. He marries her after it becomes clear that she is also free and Athenian. She is already pregnant by Pheidias at the time of their marriage. The hypothesis to the play speaks about sexual violence $(6-7: \gamma \varepsilon i ́ \tau \omega v$

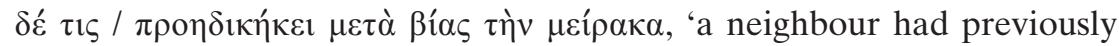
forced the maid') and refers to the young rapist as a doer of injustice

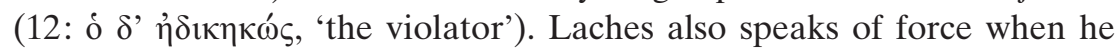
asks his wife, Myrrhine, whether she was raped in her younger years

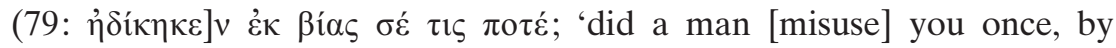
force?').

In Georgos, the old Myrrhine has two children, a son named Gorgias, and a daughter who is pregnant. It is possible that Myrrhine herself was raped in her younger years. Since the family is poor, Gorgias works for the old but rich and wise farmer Cleaenetus, who may be his and his sister's father. Cleaenetus plans to marry Myrrhine's daughter (Gorgias' sister), who is possibly his own daughter. Another wealthy neighbor wishes to marry his step-daugther to his own son, but the young man has already raped and impregnated Myrrhine's daughter. It is unclear why he must not marry his victim immediately, but in the end they are certainly united in wedlock. Philinna, an old woman who is perhaps Myrrhine's nurse, speaks about the young rapist in negative terminology (29-30: $\gamma \alpha \mu \varepsilon \hat{\imath} / \dot{o}$

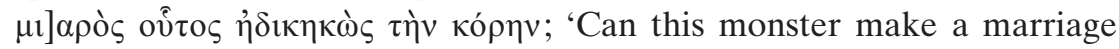
when he's wronged this girl?'). A young man, probably a friend of the rapist, scolds him and reminds him of his moral duty toward the pregnant girl: 'Are you crazy? It's preposterous! Here you've lost your heart to a free-born girl, and then you say nothing! When a wedding's fixed for you,

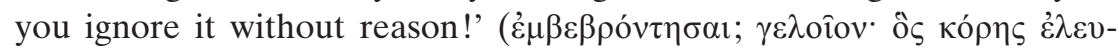

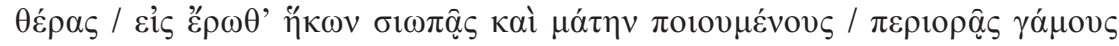

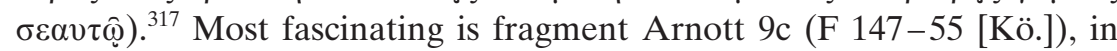
which Myrrhine presumably describes her own or her daughter's rape.

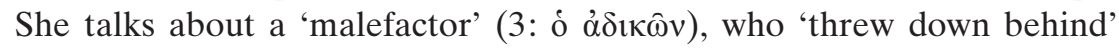

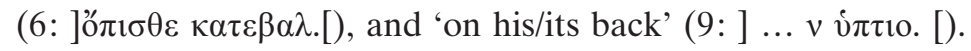

317 Men. Georg. F 4 in Arnott's 1979 Loeb edition (p. 131) = F 4 (Kö.): quoted by Maximus Planudes on Hermogenes, On Types (Rhet. Gr. V 525). 
Some of Menander's most hotly discussed texts regarding rape come from his Samia. With regard to moicheia, Demeas, in a great monologue (325-356), absolves his son, Moschion, of blame, on grounds of his youth and the power of wine. The whore Chrysis, who allegedly seduced his son, is to blame instead, he declares. Even more spectacular is Moschion's prologue, in which he frankly confesses his guilt and shows quite a bit of remorse about what he has done: $:^{318}$ 'must I cause distress? [...] is painful.

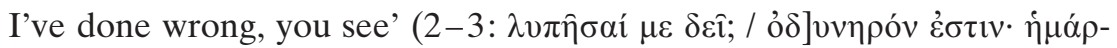

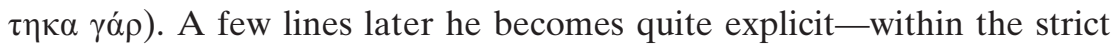
conventions of New Comedy, at least-and tells the audience what happened, without, however, going into graphic detail: ${ }^{319}$

"... I had rushed

Back from the farm, and found them [gathered] in

Our house here for the Adonis revels, with

Some [other] women. Naturally the rites

Proved [lots of] fun, and being there with them-

Oh dear!-I turned spectator, for [the] noise

They made kept me awake. They carried plants

Up [to] the roof, they [danced], they had an all

Night party—spread all through the house! I['m scared]

To say what happened next-ashamed perhaps

318 Omitowoju 2002, 43-51, 200-201, however, puts Moschion's confession into perspective. Moschion has feelings of guilt, less because of the violence he has exerted than because his act makes a wedding necessary. He does not know how his father will react, so he feels shame in front of his father rather than about his victim.

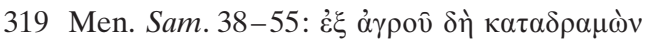

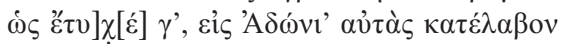

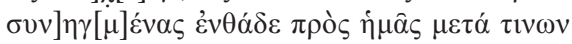

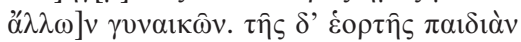

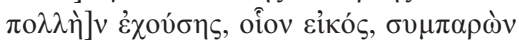

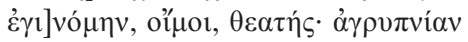

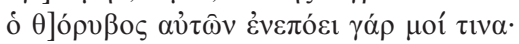

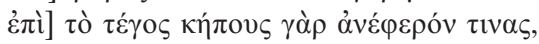

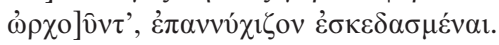

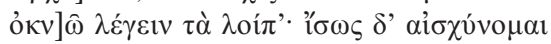

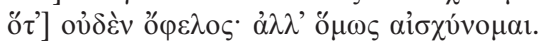

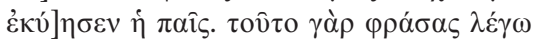

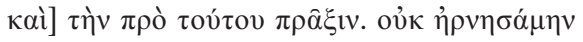

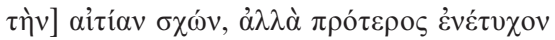

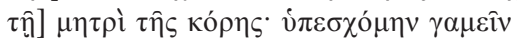

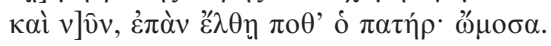

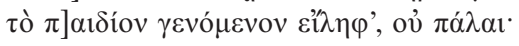


[When] there's no need, but still I am ashamed.

The girl got [pregnant]. Saying that I tell

What happened earlier, [too]. I didn't deny

I was to blame, but first I went to see

Her mother, I agreed to marry now,

[I mean] when father's back, I swore an oath.

[The] baby came quite recently, and I've

Accepted it." 320

In addition to this valuable scene, a papyrus fragment of twenty-one lines has been attributed to Samia, with all due caution (P. Berlin $8450=\mathrm{F}$ adesp. 1131 [K.-A.]). "Chrysis" talks about "Plangon" tearing her hair, perhaps after being raped. If the fragment belongs to Samia, its place must have been either in Moschion's monologue or right afterward at Chrysis' first entrance onstage. Both scenes make it abundantly clear that rape was not taken lightly. The girl's tearing of her hair is a gesture of utter despair and indicates her pain and shame. From line 716 on, we become witnesses of a last complication: Niceratus is eager to bind Moschion because, according to Niceratus, he is a moichos caught in the act, ${ }^{321}$ who has even confessed his guilt. According to Athenian law, such people were regarded as kakourgoi who could be executed immediately. ${ }^{322}$ Moschion, in an exaggerated pose of self-defense, draws his sword and menaces the furious Niceratus. The scene can be understood as a kind of comic relief, for immediately afterward the young lovers unite and Niceratus, with his rage completely calmed, speaks the betrothal formula. In my opinion, Niceratus' intention to tie up Moschion and deliver him to the authorities for execution cannot be meant seriously. Rather, this scene plays with the legal procedure of the apagôgê and the law on moicheia. ${ }^{323}$

As far as we can tell, rape is explicitly problematized for the first time in Attic comedy in Epitrepontes. The slave Onesimus tells Syrus that a girl was raped on the occasion of the Tauropolia (450-457). He uses the word biasmon (453) to denote the rape. Shortly afterward, the hetaira Habro-

320 On the Adonis festival and other festivals in whose contexts young men rape girls in New Comedy, cf. Bain 1983, ad Sam. 39.

321 Bain 1983, ad Sam. 717 makes it clear that this claim is not correct. Moschion confesses his guilt, but he was not caught in the act. Even more detailed on legal issues is Lamagna 1998, ad Sam. 717.

322 Cf. above 43, n. 96 and 54, n. 146.

323 Neither Lamagna 1998 nor Bain 1983 recognize the playful character of this scene. Gomme - Sandbach 1973, ad Sam. 713 ff. are useful but do not discern the full irony either. 
tonon tells the slave Onesimus and the audience about the rape of Pamphile: 'She was there with us, and wandered off. Then all at once she ran up by herself, tearing her hair and sobbing. Gods! Her cloak, so filmy and so lovely, was quite ruined, all torn to rags. ${ }^{324}$ It is telling, however, that it is not Pamphile herself, but a prostitute who dares to speak out and talk about the pain inflicted on the young citizen woman. Similar to Moschion in Samia, the rapist, Charisius, repents what he has done, thinking that he has raped the whore Habrotonon and begotten a bastard child. Again, it is not the main protagonist who informs us, but his slave, Onesimus (878907), whose monologue relates, in direct speech, Charisius' reproaches to himself for having been implacable toward his wife Pamphile, who was forced to have sex, whereas he freely chose to rape the prostitute: ${ }^{325}$

"What a wife

I've married, and I'm in this wretched mess!"

When finally he'd heard the whole tale out,

He fled indoors. Then-wailing, tearing of

Hair, raging lunacy within. He went

On saying, "Look at me, the villain. I

Myself commit a crime like this, and am

The father of a bastard child. Yet I

Felt not a scrap of mercy, showed none to

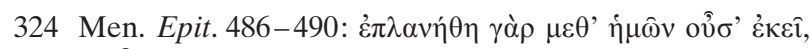

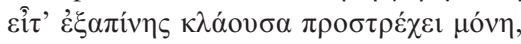

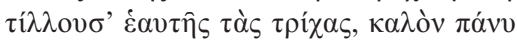

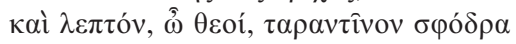

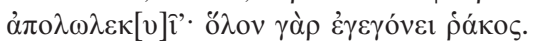

Omitowoju 2002,173-174 observes that the torn cloak is a symbol of the violence used, and hence the rape. Pamphile did not give her consent to what happened. Pierce 1997, 166 reveals the symbolism of the scene: torn clothes stand for the destroyed virginity of the girl. One did not need to tear a whore's clothes to have sex with her.

325 Men. Epit. 890-901: “oi̋ $\alpha v \lambda \alpha \beta \omega \nu v$

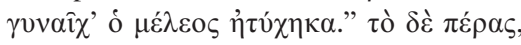

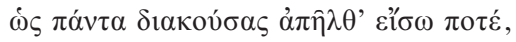

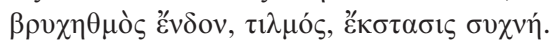

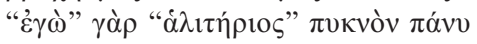

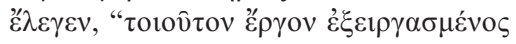

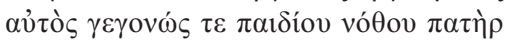

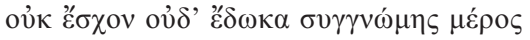

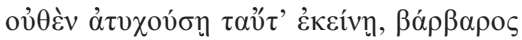

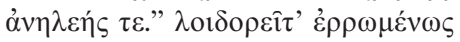

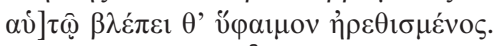

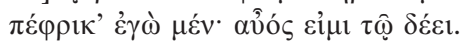


That woman in the same sad fortune. I'm

A heartless brute." Fiercely he damns himself,

Eyes bloodshot, overwrought.

Shortly afterward, Charisius enters the stage and, in a great monologue, accuses himself through the thundering voice of a supernatural power, a daimonion from above: ${ }^{326}$

A faultless man, eyes fixed on his good name,

A judge of what is right and what is wrong, In his own life pure and beyond reproachMy image, which some power above has well And quite correctly shattered. Here I showed That I was human. "Wretched worm, in pose And talk so bumptious, you won't tolerate A woman's forced misfortune. I shall show That you have stumbled just the same yourself. Then she will treat you tenderly, while you Insult her. You'll appear unlucky, rude, A heartless brute, too, all at once."

This monologue, spoken by one of the main protagonists, is unique in Menander, not least because it is only here that a daimonion speaks and the bad conscience of a rapist is clearly expressed. ${ }^{327}$ Konstan, however, raises important questions about Charisius' alleged feeling of guilt. The scene is famous because it seems that Charisius judges his wife and himself on equal terms, and shows humanity and a bad conscience because of the rape he committed. But is this really true? According to Konstan, Charisius has left Pamphile not because she was raped, but because she had borne a bastard child, a nothos from an unknown father. It is clear, according to Konstan, that it is not rape itself that is at

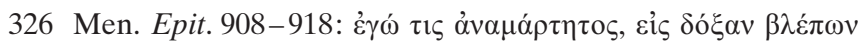

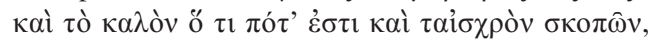

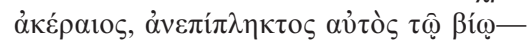

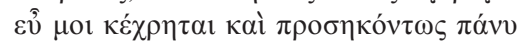

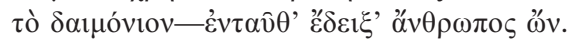

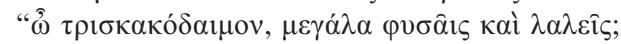

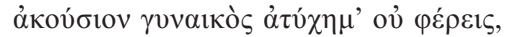

$\alpha$ $\alpha$

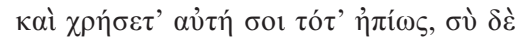

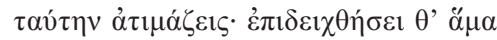

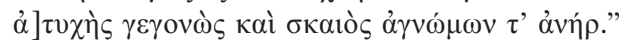

327 Cf. Gomme - Sandbach 1973, ad Epit. 912 on the daimonion; Omitowoju 2002, 177. 
stake, but the begetting of illegitimate children. The same applies to Charisius himself. He does not repent the rape per se, but the procreation of a child out of wedlock. He has pity on Pamphile because she was forced to have sex, whereas he acted on his own free will. Nevertheless, he left her, which he now deems a merciless act. This is what he feels sorry about. ${ }^{328}$ Konstan's remarks notwithstanding, Charisius' remorse is of paramount importance for two reasons: (1) for the first time in Greek literature, a man repents, for whatever reasons, having committed rape; (2) his remorse has political implications. The system of values underlying Greek oratory and New Comedy is the same. Civilized society can only persist if its citizens can control themselves. We have been able to deduce this point from Menander's portrayal of anger control. The same normative code of behavior also applies to men's sex drive. Adult men have a responsibility to their families and to society as a whole; they have to suppress their anger and all troublesome emotions, as well as their sexual urges. Only the liminal phase of adolescence allows for some ritualized license; afterward, the self-controlled and temperate citizen is the ideal. ${ }^{329}$ Yielding to one's irrational feelings and sexual desires is either ridiculous, because inappropriate in one's advanced age, or dangerous, because it could trigger stasis in a worst-case scenario. Marrying a foreign woman or fathering a bastard child has immediate repercussions for the maintenance of society-the reason why Charisius is so concerned. His private emotions, and especially his moral lapse in begetting a nothos, are directly related to society. Private and public are intertwined throughout pre-modern times-the invention of a private realm as a separate sphere from the public occurred only after the Enlightenment-but this

328 Konstan 1994, 220. Similar are Lape 2004, 246 and Pierce 1997, 165-166, according to whom Charisius left his wife because she was pregnant, in his eyes by another man. He-and the audience-do not care whether the sexual act was rape or seduction. The child was the problem, not the rape. If there had not been a child, the sexual intercourse, no matter if rape or seduction, would hardly have mattered. This also holds true mutatis mutandis for the situation in Samia (Pierce 1997, 167-168).

329 Pierce 1998, 144-145 differentiates between two types of men with distinct concepts of masculinity. Young and unmarried men can engage in debauchery and drinking; the macho image is the prerogative of their youth. Married men, in contrast, have to live a more settled lifestyle with their wives and children, because they have assumed responsibility toward their families and society. They still compete against each other, but do so on a more peaceful, less exuberant level. Violence and rape were tolerated, if at all, only during the first phase. Outbursts of anger were deemed inappropriate for a mature man. 
interconnectedness has hardly ever found more lasting expression than in Menandrian comedy. Hence, the domestication of one's basic instincts and the channeling of them toward marriage is a genuinely political act.

Lape suggests that Epitrepontes has a subversive power. When the male hero accepts that his wife has given birth to a bastard, he deviates from the normal, official attitude toward reproduction. ${ }^{330}$ Similar to Demosthenes' speech against Meidias, in which the former calls the latter a barbarian, ${ }^{331}$ Charisius now calls himself a barbaros $(898,924)$; "the text ethnicizes the moral code." 332 Pamphile becomes a paragon of virtue and successfully claims for herself a high degree of emancipatory power. She makes her will prevail: against her father's wishes, she does not separate from her husband, an action that indicates that she is in charge of her sex life. Although the patriarchal norms are re-established at the end of the play, Pamphile emerges as morally superior. She has succeeded and Charisius has learned to question the traditional norms of reproduction. ${ }^{333}$

The passages quoted so far have already made it clear that rape is not a mere peccadillo in Menander. ${ }^{334}$ References to rape always mention, if only in passing, the pain and shame of the victim, but never as explicitly as in Epitrepontes. We nevertheless have to wonder about the degree to which the rapes are meant to be taken seriously when they are glossed over or only hinted at (as in the majority of cases), or when the brutal act itself is only discussed by subordinate figures in the play. These restrictions notwithstanding, what is new in Menander is that the victim's plight is actually addressed, whereas it never figured into Aristophanes' texts. The subtle problematization of rape and the elaborate challenge to gender relations and their inherent power relations helped to put social conventions into question, criticize their inflexibility, ${ }^{335}$ and thus soften their rigidity. In this way, New Comedy became a dynamic catalyst for social change and successful adaptation to new political, social, and economic conditions.

Two plays, however, present exceptions to the rule, because they contain no actual rape, but only allude to it. In Dyscolus, Chaereas suggests

330 Lape 2004, 247.

331 Dem. 21.48, 50 (indirectly), 150.

332 Lape 2004, 251.

333 Lape 2004, 251-252.

334 Cf. also Blume 1998, 114, n. 53.

335 Cf. Blume 1998, 121. 
to his love-sick friend Sostratus that he should abduct Cnemon's beautiful daughter $:^{336}$

Say a friend's in love

With a hetaira. I'm called in, snatch and bring

Her right away—get drunk, burn doors down ${ }^{337}$ - I'm

Deaf to all reason.

These lines contain a clear parody of a violent kômos and abduction marriage (Brautraub), ${ }^{338}$ as depicted in Lysias 3 and 4, and also parodied in the Colax fragment Arnott E 225-37 (= F 109-21 [Kö.] = F 126-38 [Pernerstorfer]). The most famous passage in Dyscolus regarding rape is Gorgias' euphemistic distinction between seduction and rape, where he, full of suspicion, tells Sostratus what he thinks he is up to: $:^{339}$

You've set your heart, I think,

On a foul deed. You're hoping to seduce

An innocent free girl, or looking for a chance

To do an action for which you deserve

The sentence of a thousand deaths!

This passage is important because it is the only one in classical Athenian literature besides Lysias 1.32-33 that distinguishes between seduction and rape. ${ }^{340}$ In the end, however, Gorgias regards both forms of illicit sex as hubris (293-298). Unlike Lysias, however, Gorgias takes it for granted that rape is worse than seduction. Because of Euphiletus' and Lysias' somewhat biased agenda in court, we have every reason to assume that Lysias manipulated Athenian law on behalf of his client and that Menander's play more correctly expresses Athenian opinion. ${ }^{341}$ The

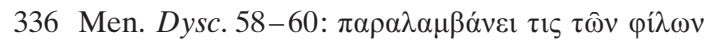

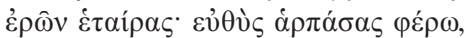

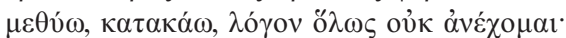

337 Ireland 1995, ad Dysc. 60 (with Theoc. 2.127-128) indirectly speaks of the exclusus amator motif.

338 Cf. Handley 1965, ad Dysc. 58-62 with more sources.

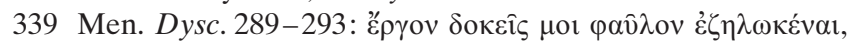

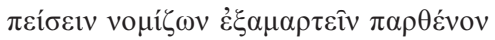

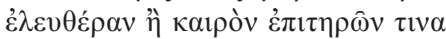

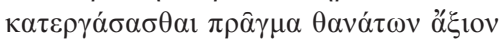
$\pi \mathrm{o} \lambda \lambda \hat{\omega} v$.

340 Goldberg 2007, 128 is right in observing that Gorgias means seduction and rape, although he cannot name them directly.

341 If this is the case, Sommerstein 1998a, 104; Brown 1991; E. Harris 1990 are right, contra Carey 1995a; Cole 1984, 101, 107. 
fact, however, that Lysias was able to present seduction as worse than rape testifies to the ambiguity and notorious open-endedness of Athenian law. ${ }^{342}$ The larger context of the Menandrian passage (271-298) neatly expresses the social tensions between rich and poor, town and countryside, and the mistrust of the latter toward the former. ${ }^{343}$

Misoumenos is special in so far as no is rape mentioned, but the possibility of it constantly looms in the background. The soldier Thrasonides truly loves Crateia and has no intention to take her by force. He is the figure of the likeable and sensitive mercenary eager to appear civilized and thus Athenian. ${ }^{344}$ Crateia, however, hates Thrasonides because he has allegedly killed her brother in battle. It is interesting to see that she can enforce her consent without a kurios. As far as I can see, this is an isolated situation in the corpus of classical Athenian literature. ${ }^{345}$ It demonstrates to what extent Menander, most progressively, questioned the existing hierarchical power relations between genders.

The passages quoted above show that the interpretation of rape in Menander cuts both ways. There is a certain, however indirect, criticism of rape-it is never a harmless incident-but its ill effects can always be mended by the marriage of the rapist and his victim. A short overview of the research on this subject will confirm the open-endedness and polyvalence of Menandrian rape scenes.

A good point of departure, because it raises an important question, is an article by Porter, who analyzes rape in a larger historical framework. According to Porter, rape is a typical feature of patriarchal and frontier societies. ${ }^{346}$ While the first is true for Athens, the second is manifestly not. Porter also makes a good point about sexuality being culturally rather than biologically shaped. It would therefore be anachronistic to assume that the rape rate in pre-modern societies was as high as it is nowadays in the U.S. All of this is true and raises the question of why Menander was so

342 Cf. above 143 , n. 539.

343 Arnott 1981, 224 analyzes the larger context of this scene (259-320) and concludes that traditional values are well expressed in it. Lape 2004, 116-117 sees in Gorgias' words the expression of democratic values against the potential hubristês.

344 Cf. Lape 2004, 171-173 on the new values as expressed in Misoumenos and Periceiromene. Civic ethics of the polis trump military force.

345 Exceptions confirm the rule and so this unique plot does not subtract anything from Omitowoju's apt observation that it was never the woman's consent that decided the legitimacy of a sexual relationship.

346 Porter 1986, 218, 231, 234-236. 
obsessed with the motif of rape, even though it plays only a minor role in other forms of Athenian literature. ${ }^{347}$

One strand of research argues that rape is a shockingly harmless occurrence in Menander, an expression of a chauvinist society steeped in a patriarchal ideology and mentality. Although Athenians well understood the difference between seduction and rape, Athenian law did not differentiate between them, because the consent of the woman did not matter to males, from whose perspective the law was written. ${ }^{348}$ And although illicit sex could incur heavy punishment, and New Comedy generally reflects Athenian law correctly, ${ }^{349}$ rapists or seducers are never called to justice in Menander, because the dramaturgy would otherwise collapse. ${ }^{350} \mathrm{In}$ fact, Menander sticks so closely to Athenian law that he often blurs the line between seduction and rape by using ambivalent vocabulary. ${ }^{351}$ Dyscolus is a notable exception, but Gorgias condemns rape especially because he wants to protect his own sister. We are right in assuming, however, that most cases of illicit sex in New Comedy are rapes, because forced sex protects the respectability of the citizen girl. In contrast to a hetaira, an honorable girl cannot have sexual desires, in the Greek imagination. If intercourse occurs at all, rape is by far the preferable option, because it keeps the girl's honor and thus her marriageability intact. ${ }^{352}$ The "only" problem, which we will deal with shortly, is the children who are born as a consequence of rape. Normally, rape is either glossed over or vaguely expressed via euphemisms. ${ }^{353}$ Exceptions, like Menan-

347 One must not forget that, aesthetically speaking, the motif of rape is a brilliant dramaturgical technique, because it enables the young man to marry the girl he feels attracted to.

348 As convincingly shown by Omitowoju 2002 passim.

349 Omitowoju 2002, 232.

350 Lape 2001, 80, 89.

351 Omitowoju 2002,191-197, 203, 232; Scafuro 1997, 242. This is clearly the case in Samia, for example (Pierce 1997, 167; Scafuro 1997, 260). Lape 2004, 145, however, thinks that what happens in Samia is seduction rather than rape. Niceratus calls Moschion a moichos, which means 'seducer,' not 'rapist.' This is true, but if Plangon had consensual sex with Moschion, her chastity would have been seriously compromised.

352 Omitowoju 2002, 180-181, 228, 232; Pierce 1997, 166-167. Since, in Samia, Moschion and Plangon are neighbors, she probably recognizes him during intercourse. Her respectability would have suffered less in the eyes of the audience if the sexual act was rape.

353 Rosivach 1998, 20-21; Goldberg 1980, 94. 
der's Epitrepontes and Terence's Eunuchus, confirm the rule. ${ }^{354}$ Slaves report the incidents. The emotions of the victims are so negligible that they are never further illuminated. ${ }^{355}$

What is worse, most victims do not even appear onstage. ${ }^{356}$ Notable exceptions are Pamphile in Epitrepontes, who evens speaks (but she is married from the outset of the play), and Plangon in Samia, who appears but remains a mute character. Why do the girls not speak, not even to their kurioi? Comedy might be closer to reality than has often been assumed. One possible reason for the silence of the traumatized girls is that they dare not speak about the shame they feel. ${ }^{357}$ Nevertheless, they speak through their (mostly absent) bodies. We encounter again, in a manner similar to that of oratory, the enactment of silence used for dramatic effect, albeit in a completely different function. Whereas the performance of aposiopesis in the orators emphasizes the misdeeds of the speaker's opponent, ${ }^{358}$ here it underlines the powerful hyperfertility of the young citizen woman: for each girl, rape is her first sexual experience that impregnates her immediately; she then gives birth to a boy. The role of these young citizen women is reduced to their reproductive function and embodies the statutes of the Periclean citizenship system. ${ }^{359}$ They are more beautiful than hetairai, ${ }^{360}$ and although young men in the plays do feel erôs toward both prostitutes and honorable citizen girls, they rape citizen girls exclusively. ${ }^{361}$ Since the rapist in any given play will always marry his victim, the aggressive sexual act is only an anticipation of mar-

354 But even in Epitrepontes the language is restrained (Omitowoju 2002, 175).

355 Rosivach 1998, 1, 37, who lists (pp. 36-37) twenty-five markers that define rape in New Comedy. Pierce 1997, 177 adds that neither drama nor other Athenian sources depict the trauma of a raped girl, but she also admits that, sadly enough, interest in the psychological consequences of rape has only recently developed. Omitowoju 2002, 182-186 compares rape in Menander with that as portrayed by Euripides. In Euripides it is always a god that rapes a woman; he never marries her. But, unlike in Menander, the victim's feelings are discussed, e.g., E. Ion $891-901$.

356 Rosivach 1998, 23.

357 Scafuro 1997, 272-278. But cf. below 358, n. 384 on the fact that the girls' silence has less to do with rape than with their marital status, social rank, and age.

358 Cf. above 109-111.

359 Lape 2004, e.g., 102.

360 Lape 2004, 104-105.

361 Lape 2004, 103-104, referring to Epitrepontes, in which Charisius does not even touch the noble whore Habrotonon. Cf. also Omitowoju 2002, 225-227 on the situation in Samia. 
riage consummated, and is therefore unproblematic in the end. Through giving birth, the citizen women fulfill their most noble task, even before marriage. This means that the stigma is not the sexual act per se, but conceiving and giving birth to a child prior to wedlock. Here is the core of the problem: premarital sex was not just about virginity and penetrationAthenian men married widows with children-but about a bastard child (nothos) born out of wedlock. In Epitrepontes, Charisius suffers from feelings of guilt not because he has allegedly raped a prostitute, but because he has begotten a nothos. ${ }^{362}$ Another source of remorse for the rapist, as developed in Samia, is that a rape that resulted in a child mandated a wedding ${ }^{363}$ that the young man's father might not approve of because of the social divide between the families of the rapist and his victim. Again, rape, whatever its immediate effects, turns out to be something harmless, if not even positive. It overcomes social barriers and makes possible a marriage between a "poor" girl and a rich young man, who feels irresistibly attracted to her. It almost seems as if the young man has to rape the girl he loves in order to be able to marry her. ${ }^{364}$ The baby is the medium that necessitates the marriage. From this perspective, rape is a social necessity and contains a good deal of utopian force.$^{365}$ This anti-structural utopia no longer refers to the polis, as it did in Aristophanes, but to the individual oikos. True affection becomes the hallmark of an allegedly civilized understanding of citizenship and procreation. ${ }^{366}$ The horror of rape is thus downplayed as a necessary act and-shockingly for us-as an act of true emotion on the part of the rapist.

362 Konstan 1994, 224, 226-229.

363 The wedding only becomes necessary because of the child (Pierce 1997, 167168). The rape alone would not have called for a wedding.

364 Sommerstein 1998a passim fleshes out that rape serves as an instrument for a boy and a girl to force marriage rather than allowing the girl's father to make the decision.

365 Lape 2004, 25, 106-108; Pierce 1997, 170.

366 Lape 2004, 114 sees an eminently political, democratically minded Menander at work, with the "comedies offer[ing] a veiled but nonetheless potent critique of the oligarchic ideology of citizenship." Similar is Omitowoju 2002, 231, who speaks of a "politicisation of heterosexual intercourse in Athens." Blanchard 2007, 31-42 is also in favor of a political reading of Dyscolus, but emphasizes Menander's careful treading and the reconciliatory aspects of the play. 
In addition, a young man or his father sometimes has mitigating factors that help excuse the brutal act. Often, under the influence of wine ${ }^{367}$ and uncontrollable sexual passion, "it simply happens" at night, on the occasion of a religious festival that allows women to spend some time outside their usual confines of the oikos. ${ }^{368}$ The rape scenes are not devoid of context but, rather, allow for a separation of the sexual act from hubris, ${ }^{369}$ because it is not the intention of the young man to humiliate his victim. Again we see that the performative context of the deed and the inner attitude of the perpetrator are what make an act a crime. The frame is often the same: the rape happens at a festival, under the protection of darkness. There are no witnesses. The malefactor does not have any hybristic intention; he simply "cannot help it." In the end, the sexual act turns out to be unproblematic, because it has occurred between a citizen girl and a citizen man. Since few taboos were broken, this kind of violence was not highly significant and belonged almost to the sphere of normalcy. The real boundary that has been crossed and requires mending is the procreation of an illegitimate child, because the victimized girl inevitably conceives prior to wedlock. The wedding at the end of the play, however, resolves this problem for good. The plight of the young man functions as a kind of initiation ritual, ${ }^{370}$ with the rape marking his transition from adolescence to adulthood. In the liminal phase of adolescence, he drinks and misbehaves by crossing a sexual boundary. But he repents and is finally reintegrated into human society at a higher level, now being the kurios over a wife and a child. Because of his remorse for his past actions, the rapist is rewarded instead of punished: the Happy End allows him to marry the girl he desires sexually. The birth of the baby has already guaranteed the continuity of the oikos ${ }^{371}$ the wedding is only a post-factum affirmation of what has already been accomplished. ${ }^{372}$ Even the rape victim does not show the slightest terror at the prospect of marrying her rapist. On the contrary, she is delighted to have found her rapist, the father of

367 Just as in the orators (sometimes), alcohol makes for mitigating circumstances. Cf. above 67-69.

368 According to Pierce 1997, 178, a religious festival constituted almost the only context in which a tryst could take place.

369 Lape 2004, 94-95 thinks that rape does not constitute hubris in Menander, because it is stripped of contexts.

370 Rosivach 1998, 37.

371 Sommerstein 1998a, 110.

372 Omitowoju 2002, 229. 
her child, who is willing to marry her $!^{373}$ Thus, New Comedy is basically conservative in confirming the existing status quo of a male-dominated society. ${ }^{374}$ Cultural cross-comparison-in modern-day Latin America, for example, many rape victims have to marry their rapists ${ }^{375}$ - makes New Comedy shockingly realistic. New Comedy mirrored the audience's expectations, worldview, and mentality, and thereby also reflects what fourth-century Athenian men understood by a Happy End. ${ }^{376}$ The huge cultural distance between Athenian society, in which rape was only viewed negatively in certain contexts and under certain circumstances, ${ }^{377}$ and modern Western societies, in which rape always constitutes a crime, no matter what the circumstances are, ${ }^{378}$ has rendered New Comedy difficult to perform on the modern stage.

In stark contrast to the views presented so far, another strand of research argues that rape is partly problematized in Menander. According to this view, Athenian society never took rape lightly. Even if Athenian law did not differentiate between seduction and rape, the penalties for both crimes could be severe. It is hard to believe that sex forced on a citizen girl was taken more lightly in comedy than in reality. Although Menander nowhere describes in detail the psychological scars of the young women, it is obvious that he thinks of rape as an act of violence which requires some kind of compensation. Although rape is a conventional plot device, Menander's theatrical renderings are at times unusual. The spectator and the reader, at least, are supposed to have pity on the victimized girl. ${ }^{379}$ Although the violence of rape is only hinted at, some derivatives of bia can be found in the Menandrian corpus, especially with regard to rape and above all in Epitrepontes. ${ }^{380}$ And the Athenian audience knew well that the non-rendering of violence does not mean

373 Rosivach 1998, 103; Sommerstein 1998a, 111.

374 Rosivach 1998, 9-10.

375 E. Harris 2006, 330-332 and Pierce 1997, 177 interpret the options a girl's family had against the backdrop of Athenian realities. Who wanted to marry a raped girl who had a child that was conceived prior to wedlock? It must have been a sad reality that girls often had to marry their rapists, or else grow old in the oikos of their fathers (Scafuro 1997, 277-278).

376 Cf. Rosivach 1998, 41-42, 140-143. Pierce 1997, 179 draws a somber conclusion: "it was a man's world, in which women received minimal consideration."

377 Cf. E. Harris 2004 passim.

378 Lape 2004, 95.

379 Pierce 1997, 170.

380 Raina 2006, 238-240. 
that no violence occurred. ${ }^{381}$ Moreover, women play prominent roles and are sometimes even in the foreground of the action. The prostitutes Habrotonon and Chrysis selflessly serve as foster mothers and heal the oikos by uniting the citizen couple. ${ }^{382}$ This means that the ritual of comedy resolves the fictional conflict in a poetic way: marginal women from the fringes of society re-establish the citizen family as a functioning social network. ${ }^{383}$ With the poetics of New Comedy influenced by myth, it comes as no surprise that the comic playwright transforms the rape plots of myths into a comic paradigm. In mythology, young women are half-willingly impregnated by gods, such as Europa and Alcmene by Zeus and Creusa by Apollo, to name just three examples. Since the supra-human rapists are unidentifiable or cannot be talked about, their victims are doomed to silence because people in their surroundings would not believe them anyway. The traces of this mythic paradigm can be found in New Comedy, most notably in Samia (589-602). Although the assailant has become human and therefore identifiable-a major innovation of New Comedy-most raped girls still do not speak up. ${ }^{384}$ But the replacement of the "mythic paradigm" with the "social paradigm," as Scafuro terms the different concepts, brings about tangible improvements for the victims. The situation is taken seriously now. The abused girl is not punished. The families meet to discuss the problem and seek redress within the parameters of Athenian law and social practice. In depicting this process, New Comedy is closer to Athenian realities than some speeches (Lysias 1, for example), with their exaggerated claims to forms of punishment that had actually become obsolete by the fourth century. Myth had been replaced by social practice and had become the

381 Raina 2006, 245.

382 Henry 1987, 145-147 rightly argues that we gain access to the core of the subject matter of New Comedy-i.e., the reconstitution of the broken family-by giving up an androcentric reading and interpretation of New Comedy.

383 Henry 1987, 148.

384 I thank Sharon James (Chapel Hill) for alerting me to the fact that the silence of these women has less to do with rape than with social class, marital status, and age. Raped citizen women do appear onstage and speak, if they are married or older. The following raped citizen women show up onstage and talk: Myrrhine in Georgos, Laches' wife in Heros, the priestess in Hiereia, Pheidias' stepmother in Phasma, Pamphile in Epitrepontes, Glycera in Periceiromene, Crateia in Misoumenos, Phanostrata in Plautus' Cistellaria, and Philippa in Plautus' Epidicus. The prohibition on female speech is limited to the unmarried and young citizen daughter, whether or not she has been raped, as long as she is known to be a citizen. 
foil against which comedy could unfold its human world. ${ }^{385}$ If it is true that the motif of rape in New Comedy is the comic reflection and reworking of the same motif in mythology, rape is indeed a stage convention in Menander. With this grounding in myth, "comic" rape may be less realistic than it seems at first glance. As a consequence, rape in New Comedy would lose some of its shocking normality for us.

Underneath the rape plot, we find in Menander the first traces of romantic love, which explains some of his popularity over the centuries. Although the playwright is not yet able to express romantic love verbally, he sometimes renders the consent of the woman crucial for marriage. ${ }^{386} \mathrm{In}$ this regard, women show remarkable emancipatory independence in Epitrepontes, Periceiromene, and above all Misoumenos. Lape explains the humanism and romanticism of New Comedy against the backdrop of contemporary politics. Marrying the partner one loves marks a paradigm shift in fourth-century Athens and is certainly a striking deviation from contemporary social and legal practices, as expressed in the orators. We do not know how many (if any) Athenian fathers respected their daughters' wishes more when marrying them off after watching a Menandrian comedy than before. And the romantic concept of a marriage for love does not exactly foreshadow the ideas of the Enlightenment period, ${ }^{387}$ but its underlying "individualist ethic" might have emerged "as a response to the general uncertainty" in the face of oligarchic rule in Hellenistic Athens. Menander successfully blends the old ideals of Periclean citizenship with romantic love. ${ }^{388}$

This new, romantic belief in love and the possibility of marrying a beloved partner also underlies the rape plot in other comedies and diminishes its horror on a poetic level, which brings us back to an interpretation of rape as a harmless occurrence. With regard to Epitrepontes, Lape sees rape as something structurally "positive," as having a certain purpose, in contrast to rape in Aristophanes, where it means only threat and intimidation. In spite of Pericles' racially exclusive citizenship law, rape allows

385 Scafuro 1997, 276-278.

386 Wiles 2001 passim.

387 Doblhofer's warning $(1994,104-111)$ must be taken seriously. Although he discerns a growing problematization of rape over time, he does not see a radical turn in the ancients' opinions about rape. The victim's individual psyche was never an issue, only her social value as a producer of legitimate offspring.

388 Lape 2004, 98. Whether or not one sees Dyscolus as an entirely political play with an enormous anti-oligarchic thrust (as Lape 2004, 110-136 suggests) is a matter of interpretation. 
for a renegotiation of gender relations and for a more "inclusionary and egalitarian" construction of citizenship. ${ }^{389}$ In Dyscolus, for example, we see how the tensions between city and countryside, between rich and poor, are resolved and a new, ideal community emerges. We could regard Dyscolus as a play reconciling oligarchic with democratic concepts in Athenian society rather than asserting an arch-democratic agenda.

In Samia, the friendship between two men overcomes class barriers. ${ }^{390}$ Because Niceratus' daughter has been raped or seduced, Demeas and Niceratus, a wealthier and a poorer man, respectively, come to an agreement. Herein lies the reconciliatory and utopian power of the rape plot.

The politically progressive potential of New Comedy provides some explanation for the popularity and frequency of the rape motif in Menander. The Thirty Tyrants used to intrude into private homes. Their violation of the threshold of the oikos was sexualized soon after their overthrow, and the illegitimate penetration of a household came to be metaphorically equated with seduction (moicheia). Conversely, a seducer (moichos) was more and more endowed with the anti-democratic qualities of a tyrant. In the imaginary and emotive vocabularies of the Athenians, sex and politics merged, with the result that sex became politicized and politics sexualized. Lysias' first oration, Lycurgus' speech against Lycophron, and Hyperides' defense are telling evidence for this ideological and linguistic development. Since moicheia carried such strong associations with tyranny, Menander opted for rape rather than seduction as a suitable motif to drive his plots forward. ${ }^{391}$ The rapist, after all, did not appear, in the end, as an aristocratic tyrant who would discredit the moderate oligarchy as embodied by Demetrius of Phaleron, but as a responsible young man guaranteeing the survival of society in the future by embracing the ideology of moderate oligarchy. We could hypothesize that part of the explanation for the frequent use of the rape motif in Menander lies in the discourse on the tyrannical character of moicheia.

Comparing the motif of rape in Aristophanes and Menander, we can draw the following conclusions. Old Comedy does not view rape negatively, but envisions it only occasionally and with regard to slaves and unreachable goddesses. Rape never actually happens and consequently never triggers the action. It is expressed in vulgar terms intended to amuse the male audience. In Menander, by contrast, initial signs of a

389 Lape 2004, 134-135, 252.

390 Lape 2004, 138.

391 Lape 2004, 88-91. 
problematization of rape are partly recognizable. Rape actually happens often and affects free citizen girls, who always become pregnant. Therefore, rape has a highly symbolic meaning and propels the action of the play forward. The discourse on rape always keeps to the rules of decency. Thus, Menander turns the rape motif as used by Aristophanes upside down. Oscillating between the depiction of rape as a harmless incident, on the one hand, and, on the other hand, a problematic event, Menander deliberately inscribed ambiguity and semantic polyvalence into his comedies that revolve around the rape motif.

\section{Violent Kômoi}

What remains in Menander of Old Comedy's violent kômoi, excessive examples of which are Philocleon's raging in Wasps and the old hags' quarrel about the young man (a perverted kômos) in Ecclesiazusae? Even a first reading of Menander's comedies makes it clear that most of his kômoi are peaceful events that occur at the end of the plays, often in the form of wedding feasts. They are very different from Aristophanes' exuberant and oftentimes utopian endings. ${ }^{392}$ The excessive and drunken revelry of the latter, full of sexual allusions, has given way to more civilized scenes. If put at the end of a play and at the end of dramatic festivals, Menandrian kômoi also merged with the outer frame of Dionysiac festivity after the end of the performance.

In contrast to its crucial role as a "shifter" in Aristophanes, the chorus has lost its active part in the plots of New Comedy. Its function is diminished to that of a mere means of dividing acts. ${ }^{393}$ A typically Menandrian feature is that the entrance of the chorus marks the end of the first act. At this point, the members of the chorus appear onstage in the guise of drunken revelers and deliver their first entr'acte performance in komastic fashion (Samia, Aspis, Epitrepontes, Periceiromene, Dyscolus). The other acts are also marked by choral performances, but not by the specific form

392 Cf., e.g., the kômoi in Ar. Ach.1227-1234 (Dicaeopolis dances off with two girls); Av. 1720-1765 (Peisetaerus' wedding to Basileia); Ec. 1149-1183 (Blepyrus dances off with a maid and two girls); Lys. 1296-1321 (Spartan delegate dances off, taking everyone with him); Ra.1524-1533 (the victorious Aeschylus marches offstage together with Dionysus, Xanthias, and the chorus); Pl. 11941209 (Chremylus, the old woman, and the priest walk offstage with the chorus, singing). In $N u$. 1490 Strepsiades perverts the ritual of the merry komos by demanding a torch to burn down Socrates' thinkery.

393 Cf. above 339, n. 306. 
of a kômos. ${ }^{394}$ Wedding kômoi conclude most Menandrian plays. Periceiromene, Samia, Misoumenos, Dyscolus, and Sicyonioi show special traits. Periceiromene and Dyscolus end in a double wedding. A high degree of standardized metatheatricality characterizes the finales of Samia (733737), Misoumenos (989-996), Dyscolus (963-969), and Sicyonioi ${ }^{395}$ (418-423). At least two of the four features that, according to Gutzwiller, ${ }^{396}$ define metatheatrical play in Menander are fulfilled in these concluding scenes: direct reference to staging or performance, and allusions to technical dramatic terminology. Exemplary is a passage from Samia that deserves to be quoted in full: ${ }^{397}$

Handsome boys, young men and old,

Gentlemen, now all together loudly give applause that's

prized

By our god of theatre, as evidence of your goodwill!

May [the] patron of our nobles games, immortal Vic-

tory,

Visit too my cast and chorus with her favour evermore!

These metatheatrical scenes and wedding kômoi are the exact opposite of violent komoi. The request for garlands and torches sets the signal; the metatheatrical exhortation is addressed to the audience; a brief prayer is dedicated to Victory.

The only violent kômos to be found in Menander is that in Dyscolus. The slaves Getas and Sicon, after physically carting Cnemon outside, help him get up, force him to dance, and carry him into the house next door to join the double wedding party (955-960). This forced reintegration into human society is the worst possible torture for the old, disgruntled man. That even this deviation from the main pattern of wedding kômoi is just a game with the traditional komos form is made clear by the finale.

394 Lape 2006 passim.

395 In this play in particular, Menander uses metatheatrical elements to demonstrate the staginess of both law courts and comedies (Lape 2004, 235-236). On the kômos finale in Sicyonioi and all other, comparable scenes in Old and New Comedy in detail, cf. Belardinelli 1994, 227-233.

396 Gutzwiller 2000, 102.

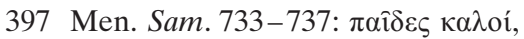

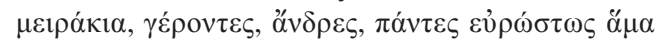

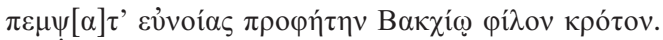

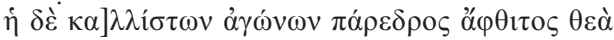

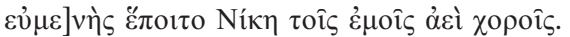

Bain 1983, ad loc. remarks that this ending is more elaborate than in other Menandrian plays. 
The play ends with conventional, hortative formulas, thus framing the harsh treatment of the misanthrope and mitigating its harsh aspects. ${ }^{398}$ Many researchers have had a negative reaction to this scene. Wiles summarizes their positions: ${ }^{399}$ while Sandbach (Gomme - Sandbach 1973, ad Dysc. 880-958) sees Cnemon as a rather comic figure, Handley is willing to accept this scene as providing comic relief, but hesitates to ascribe only laughableness to the old man. ${ }^{400}$ The problematic idea of having slaves force a free man to do something against his will even endangers, according to Handley, the elaborate mixture of comedy and seriousness, the famous spoudaiogeloion. ${ }^{401}$ Wiles himself stresses the contrast between a supposed Happy End and Cnemon's unaltered character. Is the scene not gruesome, with slaves manhandling a free Athenian citizen like a servant? In my opinion, Menander creates a dense web of literary allusions that made the whole scene comprehensible to the Athenian audience. He parodies here the kômoi of Old Comedy, ${ }^{402}$ in which it is always free citizens who initiate the komastic exodos. In Menander's Dyscolus, slaves take over this important responsibility of triggering the kômos and exhorting the citizens in the audience to join them in joy and laughter. The parody of the kômoi of Old Comedy is easily recognizable on several more levels. First, the sexual potency of the hero in Old Comedy is gone. Cnemon cannot even walk by himself but needs the help of slaves. He does not join hands with several girls, addressing them all the while with overt sexual language, but two men carry him inside, his role being totally passive. He neither sings a wedding song nor dances, but speaks about a cave he is going to enter. It is hard to imagine that all these carnivalesque reversals are pure accident. Menander reaches the highest form of irony when slaves have to force Cnemon, a citizen, to take part in his own daughter's wedding feast.

398 According to Zagagi 1994, 112, Getas and Sicon carry out their revenge "in the spirit of the ancient kômos," and their actions have "an unrealistic character." Thus, the end of Dyscolus oscillates between comedy and reality and thus gives the final scene a particular humorous flavor.

399 Wiles 1984, 176-177.

400 Handley 1965, ad Dysc. 880.

401 Blanchard 1983, 111-113 offers too benign an interpretation of the scene and even believes (113) that "la participation de Cnémon au banquet peut être le premier d'une longue série d'actes destinés à créer en lui des nouvelles habitudes."

402 Gomme - Sandbach's deliberations (1973, ad Dysc. 959) aim in the same direction: "We have here a muted echo of the more boisterous conclusions of some of Aristophanes' plays." 
Anti-structural elements during kômoi are discernible in both Old and New Comedy, but they are far more tangible in Aristophanes, with just a few examples being a son's beating of his father, and women's repelling of Scythian archers. The kômos, the reveling protagonists' merry and frolicsome marching across or exit from the orchêstra, sometimes shows transgressive features in Aristophanes. For example, the old and drunk Philocleon exudes Dionysian energies, dances through the night, and accosts passers-by on his way back home, an excess normally only granted to young men under special circumstances. In New Comedy, the role of the komos is largely curtailed. Cnemon's reintegration into society against his will, the only example of a transgression during a kômos in Menander, is no more than a shadow of what the kômos could be and accomplish.

\section{Menander's Discourse on Society - Summary}

Unlike Aristophanes, Menander remains faithful to a literary and partly idealized "reality." 403 Wrath and violence are still there as residual atavisms, because comedy needs them for generic reasons, but Menander directly and unmistakably demonstrates that violence, ire, rage, and fury are not suitable means of conflict resolution. In the final pacification in the Happy Ends of Samia and Dyscolus, for example, Menander explicitly problematizes violence and propagates the civil discourse of Athenian democracy, now more generalized into an overarching Greek concept of civilization. In spite of, or perhaps precisely because of the mitigated representation of violence onstage, we can assume that Menander regards the use of violence as harmful to society and not worthy of a free Athenian citizen. With Menandrian comedy, the violence discourse has reached out beyond the polis and reached the oikos level. Since, in Hellenistic times, society is also made up of individual oikoi, the violence discourse as spoken in New Comedy can be seamlessly combined and at times even be equated with the civil discourse of and on society. Two examples shall suffice. In Citharistes, an unknown speaker addresses Laches with the words 'Laches, I deem that learning never to do wrong's a civilised design for life. ${ }^{404}$ And in Georgos, Cleaenetus says: ${ }^{405}$

403 Préaux 1957 rightly sees New Comedy as a blend of reality and escapism.

404 Men. Kith. F 4 in Arnott's 1996 Loeb edition (pp. 138-139) = F 4 (Kö.) = F 284

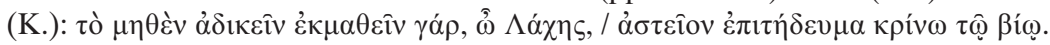


The best man, Gorgias, is he who can

Bear most offenses with self-discipline.

This venom and excessive rancour is

A sign of weakness simply in men's eyes.

In this passage Cleaenetus expresses an ideology on society and appropriate behavior that Pericles had already lived. ${ }^{406}$ The discourses on society and violence, presented and merged into one by Menander, agree that violence is detrimental, because it is barbaric and, in a word, un-Greek. It is more appropriate for a tyrant than for an Athenian citizen. Menander, hence, in this respect, is closer to the fourth-century forensic speeches than Aristophanes, who still takes delight in presenting tyrannical and hypertrophic behavior, however problematic it is.

Although Menandrian comedies show some anti-structural features, such as the questioning of the traditional gender system in Periceiromene and Misoumenos, Menander rather sticks to the conventional rules of interaction, thus being less violent and utopian, and therefore closer to society than Aristophanes. ${ }^{407}$ That a master threatens his slaves with blows, for example in Samia, is normal and belongs to the repertoire of comic stock motifs. If the bourgeois citizen commits violence on the Menandrian stage, it is now per definitionem more civilized and domesticated than the unbridled outbursts of violence in Aristophanic plays. Wrath is always wrong. Slapstick scenes are less frequent than in Old Comedy and have a very specific meaning that strikingly deviates from the Aristophanic model. As an extension of unreasonable wrath, they enact a specific vio-

405 Men. Georg. F 3 in Arnott's 1979 Loeb edition (pp. 128-129) = F 2 (Kö.) = F 95 (K.):

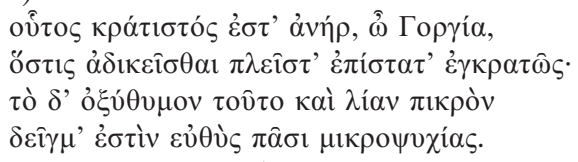

406 Cf. above 150, n. 563 (Plu. Per. 5.1-3; cf. also 7.5). An early praise of self-control in comedy is Epicharmus F 100 (K.-A.).

407 This is also reflected in Menander's relationship to Athenian law. As far as I can see, Brown 1983 passim stands alone in his opinion that Menander is vague and sometimes even wrong in his dealing with Athenian law. Turner 1984, Préaux 1960, and Taubenschlag 1926, to name just three, are convinced that Menander mirrors Athenian law correctly. Cf. E. Turner 1984, 253 on assault and battery. Menander could not afford serious blunders because the spectators and the judges of the plays, who were drawn by lot, knew Athenian law fairly well. Préaux 1960, 223: "le droit, dans la comédie, contribue au réalism de la fiction," and 227: "le poète se conforme strictement aux règles en vigueur." 
lence discourse by exemplifying what behavior within the family and among neighbors is not supposed to look like. Orderly weddings, not violent kômoi, now conclude the plays. No hybristic act is shown onstage, unlike in Aristophanes' plays. In comparison with the Aristophanic corpus, the semantics of hubris is narrowed down tremendously, having been reduced to the meaning of "rape" only. Rape is the only violent phenomenon that is open to interpretation in its negative quality. It looms in the background of most Menandrian comedies as a plot device triggering the plays' actions. In this function, however, it is partly problematized. Only rarely, as in Epitrepontes, can it be seen outright as negative. Apart from the discursive openness of the rape motif, however, most meanings are generally definite, with Menander overwhelmingly portraying violence as negative. These profound changes separating New from Old Comedy must have been deliberate. In opting to deviate from the presentation of violence as practiced in Old Comedy, Menander was no less reflective and political than Aristophanes and his colleagues. At stake are no longer the integration of primordial heroes into civilized democratic society and problematic utopias brought about by suprahuman protagonists through often violent means, but the psychology of the human soul and personal relationships between different types and social ranks of citizens. Their conflicts are to be overcome via open and honest communication. How people are supposed to speak with one another is in the foreground in New Comedy. Violence has turned into a private emotion that harms the individual and her or his social environment. The fact that a candid and refined discourse on this kind of violence is now possible allows for the explicit problematization of violence itself.

Menander's rejection of violence is to be seen against the backdrop of his worldview and ethical code. As a pupil of Theophrastus and friend of Demetrius of Phaleron, the playwright was also deeply influenced by Aristotle, especially his Rhetoric and Nicomachean Ethics. With regard to sôphrosunê and enkrateia, Menander is in close agreement with Aristotle. ${ }^{408}$ These new values are also praised in the orators, ${ }^{409}$ but Menander created fictional individuals for the stage and imbued them with the virtues of civil behavior, gentleness, temperate feelings, impeccable conduct (in

408 Blanchard 2007, 99-108; Quinn 2001; Webster 1974, 43-55. Cf. above 323, n. 253. O'Sullivan 2009, 145, nn. 120 and 198 is more skeptical about a close relationship between Menander and Demetrius of Phaleron's regime.

409 Arnott 1981, 217 stresses that Menander's values are also found in many other authors of the fourth century. 
the end), and generally exemplary humanity. Menander's genius lay in the fact that his stage characters never became too theoretical. They have flaws, commit mistakes, and thus seem real. Menander was able to breathe life into philosophical concepts and dramatize them onstage. He was not interested any longer in supra-human figures striving for utopias, but in ordinary people and their quite ordinary problems and how they can be resolved in the context of a more civilized Hellenistic society. ${ }^{410}$ The focus is now on how people communicate with each other and what the obstacles are on their way to a deeper mutual understanding. People should only act once they are properly informed. Acting out of ignorance is always rash and a mistake. ${ }^{411}$ By watching these actions onstage, the spectators were invited to learn about waiting, keeping a low profile, controlling themselves-in a word, about enkrateia, the opposite of orgê. A proper process of reflection in the Menandrian theater would consist of embracing and internalizing the humanitarian and cooperative worldview as fleshed out by the orators, Theophrastus, and Aristotle.

\section{Ritual Functions of Scenes of Violence in Comedy}

Aristophanic comedy opened up a ritual space in which messages could be freely negotiated and the grand experiment of breaking down the barriers of daily life could take place in an unhampered way. The flexible line between good and bad behavior, as described by the orators, was not just narrated in comedy, but corporeally envisioned. Battery, including fatherbeating, hubris, rape, public and hidden violence, violence perpetrated in a state of drunkenness or sobriety, by old or young men, violation of thresholds, disturbance of the public order, as well as the perversion of religious customs and gender roles, citizenship status, and social rank are all theatrically represented, but from a funny perspective. The speaker's opponent, as characterized in a forensic speech, is comparable to the comic hero in his fundamental traits. In the imagination of the courtroom speaker, his adversary is a deceiver, a barbarian, and a tyrant embodying pre-polis behavior and a mental state prior to that of civilization. In the dream-like Otherworld of Old Comedy, a primordial, hypertrophic, hybristic, tyrannical, and animal-like hero, the anti-type of the democratic

410 Treu 1981, 212-213.

411 Maurach 2005, 58-60. 
citizen, playfully transcends, with his or her enormous innate power, limits that cannot be overstepped in reality. ${ }^{412}$ From these transgressions stems the great pleasure the Athenians derived from watching these spectacles. And just because this kind of violence was not meant to be taken too seriously, it lent itself to be reflected upon.

Nothing is more ritualized in Aristophanes than the habitual occurrence of vulgar and obscene slapstick and farce that characterize the actions of the comic hero. They are the vestigial remains of ecstatic Dionysiac fertility rites. No comic author has been able to do without this atavistic core of comic motifs, up to the present day. This fact alone explains already the relative prominence, structurally and proportionally, of Dionysiac rites in Old Comedy. Consequently, slapstick and farce always lurk in the background of any comedy and will eventually erupt, whether the author is willing or unwilling to accept this fact. ${ }^{413}$

If these violent scenes are so ritualistic, they must also perform the function of rituals. They create communitas, the community of laughter, which leads to comic release ${ }^{414}$ and the short-term, carnivalesque relief from social norms. Playful and liberating laughter also engenders, however, detachment from and exclusion of evil forces. This is the healing aspect of ritual. If the audience laughs at Philocleon and Peisetaerus, these problematic heroes are also criticized and, in a way, cast out. Fictional violence is presented within a civic ritual and is thus also insulated from the audience because it remains problematic and threatening. The spectators are supposed to watch and deride it, but only in order to banish and reject it. Ultimately, Aristophanes may have been right in saying that his farces were different from those put on by his rivals. The fragments preserved from other authors of Old Comedy are not substantial enough to allow us to ascertain the truth of Aristophanes' statement, which could merely be part of a rhetorical pose, an ironic pretense designed to initiate

412 In this capacity, the comic hero can be compared to the anthropological concept of the shaman, the goês or magos in the Greek world (Bierl 2009b). The hero, endowed with supra-human powers, often fulfills a healing role and is certainly able to undertake excursions to heaven as well as to Hades. Research on the goetic motifs of Old Comedy has not even begun yet. At the same time, Freydberg 2008 rightly attributes to Aristophanic Comedy a philosophical messagei.e., striving for a measure, as expressed paradigmatically in Plato's Philebus. Again we see that the thought-world of forensic oratory, and even philosophy, is also expressed on the comic stage, but in a dialectical sense.

413 Cf. Dobrov 1988, 26-29.

414 Cf. above 247 , n. 37 on comic catharsis. 
an even funnier competition with his rivals, who might have used the same topos in creating sophisticated theater. If his claim is genuine, however, Aristophanes' brand of comedy was more intellectual than his rivals', created more distance and irony, and his sophisticated plots restricted violence more intensively than those of his opponents ever could. Aristophanes is deeply rooted in the genre of Old Comedy, but takes on an avant-garde standpoint, for example by criticizing in his parabaseis the traditional farcical use of violence, at least more than any other author of the Archaia we know of. And if the specific ritual of performing a comedy has as its goal the healing function of laughter (i. e., laughter also about farce, which amounts to an indirect criticism of weird, slapstick behavior), we can now go one step further. Farce as exemplified by phallic processions, rude personal invective, indecency, slapstick violence, intruders, food theft, marginal figures who speak in dialects and foreign accents, and many more motifs, may all be traceable to early ritual practices. In order to achieve this under-the-surface critique of violent slapstick, Aristophanes tried hard, probably harder than his colleagues, to sever his comedy from these ritual origins of the genre. However "unsuccessful" he was, it is his endeavor that counts (if it was not just a comic pose). If we take seriously his attempts at controlling violence onstage and charging slapstick with sophisticated meaning and if we are willing to lend some credence to his repeated criticism of other playwrights' relying on mere vaudeville stunts, a further thesis imposes itself: Aristophanes strove hard to create intellectual comedy. ${ }^{415}$ Obviously, he overtaxed his audience, which did not always understand him. The failure of Clouds and the playwright's disappointment afterward are telling enough. Aristophanes strove to make the impossible possible: although farce was ingrained in the genre and no comic author could do without it, he tried to overcome its premises even at the risk of transgressing the boundaries of the genre, as seen in Wasps, Birds, and Clouds. The contradiction between Aristophanes' constant railing against slapstick and his persistent use of it remains, but is explicable. His comedy is a hybrid oscillating between the rules of the genre and personal literary and theatrical ambi-

415 Dobrov 1988, 28 regards farce as the pharmakos (scapegoat) of comedy in a metaphorical sense. On a concrete, political level, Rosenbloom 2002 connects the idea of the scapegoat to that of the poneros. Ponêros is an abusive word meant to denigrate a member of the social elites. They are sycophants and enslave the people and therefore deserve to be driven out. Similar is Zimmermann 2006. 
tions. Unfortunately, the comedies of his rivals are not preserved well enough to verify Aristophanes' boast of having elevated comedy to new intellectual heights, but it is plausible that his criticism of farce, slapstick, and vulgarism went further than that of his colleagues, whose old Old Comedy would have been steeped even more deeply in the ritualistic slapstick of its origins. It comes as no surprise that comedy was officially introduced into the festive program of the Dionysia (486 BCE) and the Lenaea (440 BCE) after the establishment of the democracy. As in the depiction of violence in the orators and on the curse tablets, Old Comedy is similarly concerned with the topic of violence in its relation to the polis, with Aristophanes being more sensitive to this agenda than his rival colleagues, and thus foreshadowing the development brought about by Middle and New Comedy. As an element of the genre and atavistic remnant of its Dionysiac origins, violence is as prevalent in Old Comedy as in the forensic speeches and on the curse tablets, but it is nevertheless problematized indirectly, at least by the greatest representative of the genre, just as in other Athenian media of the time.

It is understandable that Old Comedy lost its Sitz im Leben early in the fourth century, with the new civic and civil discourses, firmly established after $403 \mathrm{BCE}$, that suppressed the open representation of violence. ${ }^{416}$ But comedy was able to adjust to new political conditions. Menander dared to complete what Aristophanes had begun: the final and direct shunning of violence onstage. The mostly indirect criticism of violence in Aristophanic comedy was not enough in the later fourth century. Bawdy humor did not correspond to the new conventions of the time. To what extent the growing degree of literalization contributed to the taming of exuberant license onstage must remain the subject of further research. It seems likely that the semi-oral scripts with which Aristophanes must have worked favored slapstick-type interludes. Let us not forget that Lycurgus had the most important tragedies of the fifth century codified and thus started to create a literary canon from the 330s on. Menander, thus, worked under different cultural conditions. The increasing reliance on the written and thus domesticated word of the theater script may have made it easier for him to ban violence more successfully from the comic stage than Aristophanes. The latter was no longer understood by the late fourth century, and against this background of changed tastes and aesthetics, Aristotle's and especially Plutarch's (much later)

416 Cf. above 222-227 on the effect these discursive changes had on the practice of binding magic. 
sharp criticism of Aristophanic vulgarity is understandable. ${ }^{417}$ From Middle Comedy on, many playwrights dissociated themselves from the phallic and violent origins of Dionysiac ritual. Menander made the final step and overcame Dionysiac reminiscences almost completely, not always to his own benefit. ${ }^{418}$ Only allusions remained. What had been exuberant kômoi in the old days of Attic democracy were now civilized wedding feasts. The genre had thus fundamentally changed. The claim that theater had nothing to do with Dionysus was now fulfilled.

As a complex civic ritual through which the city could represent itself, ${ }^{419}$ theater was actively engaged in all contemporary debates, transformed them on a literary level, and raised more questions than it answered in order to generate reflection. Attic comedy (and tragedy) staged, within a ritual frame, violence discourses and, with them, discourses on democracy and society in general. ${ }^{420}$ Every violence discourse is inseparable from the discourse on society, for a society can only survive if violence is held at bay. To this end, a society has to come to a basic consensus on how to define violence and what to do about it. This enormously difficult process of thinking, communicating, and making decisions requires civic spaces where opinions can be formed, continuously exchanged, questioned, re-shaped, and represented. Athenian culture found these forums in the ritual performance of oratory and drama. The political function of theater lay in its very ritual dimension, that is, in its capacity to dramatize and enact societally relevant discourses, thus enabling a deepened reflection about them. I would like to push the fundamental similarity between the lawcourt system and comedy one step further. Although the audience as a whole did not judge the comedies, but five jurors drawn by lot, ${ }^{421}$ it must have influenced these jurors through its reaction to the plays. ${ }^{422}$ Thus, the spectators did have a certain say in determining the winners of the dramatic contests. They not only decided, however indirectly, which playwright would win the comic agôn, but they were also

417 Cf. above 331, n. 285.

418 Sometimes Menander's contemporaries did not fully appreciate his methods and preferred some of his rivals' burlesque comedies over his more mannered plays (Nesselrath 1990, 333).

419 Burkert 1987, 35: "Der Ort der Selbstdarstellung der Stadt ist die Festgemeinschaft im Theater."

420 Cf. above 126-131 the remarks on tyrants and barbarians as uttered in the ritual frame of forensic speeches.

421 Pickard-Cambridge 1953, 96-100; cf. also above 246, n. 36.

422 Pl. Lg. 659a, 700c-701b. 
the moral judges of each and every word (legomena) and action (drômena) they heard and saw onstage (similar to the law courts). Thanks to the semantic openness of the comic scenes playing out before them, the spectators themselves, as participants in a ritual, were able to ascribe symbolic meanings to the discourses and actions enacted onstage. In doing so, they could become aware that it was their own agency that created and enhanced the identity of being Athenian through this large-scale community ritual, an experience similar to that in the courts and the Assembly of the People. This sense of community, which was to be attached to the discourses on violence and violent actions, helps us discern the ritual and political function of theater more clearly now. The symbolic meanings of actions and words represented onstage had to make the majority of spectators identify with them and make them laugh. At the same time, these meanings could only be partially identical to the views of most spectators, because the latter had to have the possibility to distance themselves from problematic actions and words through laughter. In the experiment of the downfall of the comic hero and his or her utopia, the Athenians gained a glimpse into the utopian and, at the same time, primordial Otherworld, which the playwright presented as not entirely positive, but highly problematic. In the realm of comic fiction, the Athenians' hypertrophic desires and bold alternatives to their often-depressing reality could be tried out without danger. In other words, the spectators assessed individually and as a collective, at least upon further reflection, the significance of the plot of any comic play and its highly complex interaction with the outer frame of the civic ritual. This means that the individual spectator, similar to the judge in court, had his share in determining the fair market value of a scene of violence on any given day of performance, including the overarching sense of the whole play. Even if we assume that defining the discourses on violence in public was a prerogative of the social elites, the under classes also participated in creating a socio-political consensus with regard to the definition and function of violence by serving as judges in court and watching plays in the theater of Dionysus. This fundamental agreement that was constantly called upon and asserted in the ritual venues of the courts, assemblies, and theater helped contain violence considerably. Thus, the audience was the ultimate master of a political artistic ritual, as would be expected from a direct and radical democracy. As far as this common ideology and trust in the political function of theater are concerned, Aristophanes and Menander were in agreement. But the specific means they used to reach their respective goals were very different. Both dramatists embraced the literary technique of spoudaiogeloion. 
The simultaneity of humor and seriousness onstage, as well as the dissociation from and play with reality, rendered a deepened reflection about violence and its place in society possible.

\section{Conclusion}

This study is concerned with the way Athenians reflected on violence in the different media they had at their disposal. The courtroom speeches provided a ritual frame through which, in theory at least, everyone who wished to had the freedom to discuss directly the injustice he suffered. The genre of the speeches left room enough for interpretation and manipulation of Athenian law. In a culture of public display, the meaning of important concepts such as hubris and moicheia was kept deliberately ambivalent and found its exact significance in a particular context only through the performative act of a courtroom trial. Drama surpasses even the semantic openness of oratory through its fictional character. As Geertz and Turner have shown, cultural performances such as rituals, ceremonies, carnivals, parades, sporting events, and plays provide explicit or implicit metacommentaries on their social contexts. Applied to Athens, this theory implies that stage theater in the form of tragedies and comedies, especially at the unsurpassed intellectual level of Attic drama, also provides a social metacommentary on violence in Athens; ${ }^{423}$ that is, drama comments on society by staging violence. This means that, regardless of their plots, Attic dramas must be taken seriously as historical sources. In the context of this book, I have focused on comedy both for chronological reasons and because their relationship to "reality" seems more "immediate" than that inscribed in tragedy.

The theater was the medium of reflection in Athens. We know about the festive ritual frame in which fictive plots were staged, and can discern their ambivalent meanings and socio-political functions. The communitas created in the theater, with its subjunctive mode of speaking, gave rise to a reflexivity never achieved by any other cultural event of Athens. Aristophanes and Menander enact highly complex discourses on violence in different ways. Both comic playwrights point to and play with the limits of acceptable behavior by staging high-wire acts of violence. The thrill lies in the question of whether or not the comic hero, by performing violence, slips and breaks the norms and, if he does, what the consequences

423 Turner 1989b, 125, 159, 163-164, 170. 
of this threshold transgression are. Dramatic works all show ambivalence, but there is a remarkable difference between Aristophanes and Menander.

In Aristophanes, rules of interaction are often blatantly broken. Hence, violence is more transgressive and primordial than in Menander. At times it is grotesquely exaggerated and is thus distanced from the audience. The discourse on the polis as political entity is in the foreground. Matters of constitution and foreign policy are negotiated on a literary level.

In Menander, by contrast, the violence discourse is firmly and directly tied to the discourse on Hellenistic society; it is even one of its integral parts. Just as in tragedy, violence is seldom directly represented on the Menandrian stage. By following discursive conventions, Menander is closer to fourth-century oratory, less utopian than Aristophanes, and therefore able to criticize violence more directly. As we did in the orators, we again grasp in comedy a process toward more direct problematization of violence from the late fifth to the fourth century.

How can we explain this development? The reasons for change are to be sought in politics and changing social and discursive patterns. In the atmosphere after the amnesty of 404/03, violence had become more problematic than ever before. The rules of democracy had stiffened and required the suppression of actual violence and even the medial expression of it (which does not mean that there was no violence). Fourth-century orators emphasize the rule of law more fervently than their predecessors, Antiphon and Andocides, in the fifth century. In contrast to the latter, the former articulate the new values directly and explicitly. Even on curse tablets one had to speak the moderate discourse of democracy; even on grave stelai one was not allowed to show unbridled emotions. At least in public, one had to comply with a strict code of behavior. Above all, one had to appear peaceful and rational, speak the "right" discourses, display sôphrosunê and enkrateia instead of anger, and, if violence was unavoidable, mask it by mediating it as far as possible and keeping to the normative rules of violent interaction.

Aristophanes and Menander reflect this process of change on the comic stage. Aristophanes discusses the rule of law indirectly; his larger-than-life characters often have difficulties remaining within the ideological boundaries of democratic Athens and subjecting themselves to tight democratic norms. Menander's characters chastise any irrational emotions that might block sensible solutions. The figures themselves embody the temperate citizen as the exemplary model to be emulated by 
every spectator. Ritually speaking, we could say that the ritual dynamics of the performative genres of forensic oratory, binding magic, and drama allowed them to react to societal change like a seismograph and adjust accordingly, so as to continue to fulfill their ritual functions. ${ }^{424}$

Looking more closely at Aristophanes' and Menander's respective audiences, we can account even better for the fundamental shifts that occurred between the lifetimes of the two playwrights. Transformation processes were ongoing from Aristophanes' later comedies on (Ecclesiazusae [391? BCE], Wealth [388 BCE]), via Middle to New Comedy. ${ }^{425}$ One way of explaining the manifold changes is to postulate that the aesthetics of literary production and performance (Produktionsästhetik) hinges on the way an audience responds to a literary work of art (Rezeptionsästhetik). Aristophanes and Menander had different audiences in mind when they composed their respective comedies. This point is not intended to rehearse the speculations about the social composition of the Menandrian audience, ${ }^{426}$ but rather to envision the cultural differences between a

424 According to Nijawan 2005, 274, rituals are always in need of being adjusted to new circumstances. In the ritual dynamics of the slow transition from Old to New Comedy, we can well observe this process. The abolition of the chorus or the complete change of its function in New Comedy should be explained by societal processes of transformation. According to Walton - Arnott 1996, 52, the diminished role of the chorus reflects the growing role that characters now play in relation to the plot.

425 On the development from Old via Middle to New Comedy, cf. Nesselrath 1990, 331-340; Arnott 1972. Csapo 2000, 133 rightly emphasizes that the transition from Old to New Comedy is not an abrupt succession of one form of comedy through another, but rather a shift. Elements of Old Comedy can be found in the Nea and vice versa.

426 Aristophanes must have written for a mass audience. The social composition of the Menandrian audience, in contrast, is highly controversial: Slater - Csapo 1995, 287 and Arnott 1981, 215 assume that only the wealthy were able to afford going to the theater, because the Macedonian oligarchy had abolished the theôrika and the choregy. Rosivach disagrees (2001 and 2000). The abolition of the theôrika cannot have changed the composition of the audience dramatically. Dramas were only performed on a few days of the year, so that attending a comedy would only have caused a minimal loss of income. Perhaps an admission fee was no longer charged after $324 \mathrm{BCE}$, when the theater of Dionysus was all in stone and the wooden benches did not have to be maintained any more (2000). Similar to E. Turner 1984, 244, who also postulates middle-class families as the main audience, Rosivach 2001 argues that New Comedy remained a form of mass entertainment. Most spectators must have been farmers and could easily identify, for example, with Gorgias in Dyscolus, and laugh about Sostratus (Rosivach 2001, 131). The poor in the audience had lost their citizenship only recent- 
mainly Athenian and a cosmopolitan audience. Menander also wrote for an Athenian audience, to be sure, but his plays nevertheless appealed to the Hellenistic oikoumenê and soon found widespread fame. Aristophanes wrote for the polis and some visitors who knew Athens well enough to understand the plots and their comic intricacies. The spectators laughed about Athenian institutions, problems of local politics, and above all about the satire of notorious public figures. The boundaries between good and bad behavior were drawn in compliance with the overall notion of the majority of the politai. The Athenians with whom Aristophanes communicated had divergent opinions and political leanings, but were culturally quite a homogeneous group. Aristophanes could expect them to understand all allusions to contemporary politics and to come to terms with the high degree of open-endedness and ambivalence inscribed in his plays.

Menander's plays, in contrast, ultimately also appealed to a diverse audience consisting of different peoples in far-off lands, who embraced cultural notions and value systems quite distinct from those cherished in Athens. Aristophanic openness of interpretation would have overtaxed these foreign audiences and made such comedies incomprehensible to them. The cognitive horizon of Menandrian comedy, by necessity, had to become more closed. ${ }^{427}$ Menander's culturally Greek message had to be clear and unequivocal: violence in whatever form is wrong, an evil we have to overcome to become civilized or, in a word, Greek. This mes-

ly (316 BCE) and must have been flattered by the message of the play, whose underlying "task" it may have been to reconcile the masses with the ruling oligarchy. Whatever the social composition of the audience, what we can say is that Menander was not a social revolutionary. Whoever sat in the audience, Menander's wish to reach an equilibrium between rich and "poor," to propagate marriages between wealthy and "poor" families, is undeniable. This is not a plea for social justice - the poor family remains poor — but a plea for mutual understanding and recognition of the moral worth of a poor family and its equal right to marry up (cf. similarly Wiles 1984, 178; Treu 1981, 214). This theoretical bridging of social gaps, at least in the private realm of marriage contracts, was later understood as Menander's deep-rooted belief in a timeless humanitas. Therefore his comedies, or rather excerpts from his comedies, were collected as sententiae. On Menander's Nachleben and influence on later dramatists, cf. Walton - Arnott 1996, 119-136.

427 There are also political reasons for this process toward more thematic closure. The Athens of New Comedy was no longer a democracy, but an oligarchy in which a pluralism of opinions could not be expressed as freely as in the times of Old Comedy. 
sage was easy enough to grasp for cosmopolitan Hellenistic audiences from Egypt and Asia Minor to Bactria and the boundaries of India. They no longer understood the intricacies of Athenian local politics. Therefore, Menander and his colleagues had to compose their comedies in a more timeless fashion, by referring less directly and often to daily politics, without becoming apolitical. The oikos as the nucleus of society was understandable everywhere in the vast expanse of the Alexandrian empire. It was clear to everyone that whatever happened at home would also affect society as a whole. Whoever understood this timeless message and could comprehend New Comedy, with its ingrained sense of philanthrôpia, and especially its language, was Greek because of his paideia. Athenian playwrights were successful in creating a cultural koinê, a community whose values and language were based on but finally detached from Athens, the oikoumenê of the Greek world of Hellenism and the later Roman Empire.

Paradoxically, Menander opened up Athenian comedy for the world and made it cosmopolitan by reducing its interpretive openness, ${ }^{428}$ to which growing literalization massively contributed. In its thrust and cultural repercussions, this development cannot be overestimated. If we regard Athenians today as the inventors of democracy, Cleisthenes and Pericles are not the only ones to be credited with this achievement; credit is due also to Menander, who, with his bourgeois comedy, made democracy a universal idea. ${ }^{429}$ From Menander on, at the latest, democracy and violence stand in opposition to each other, with violence becoming the stamp of tyranny. By giving lasting expression to this connection in a literary form, Menander dissociates himself from the origins of democracy, which emerged in and through violence and struggle, civil strife and external war.

Looking at these diachronic developments, we can say that the perception and artistic treatment of violence underwent profound changes from the fifth to the fourth century BCE. This gradual change was discussed, negotiated, shaped, and represented in contemporary performances, in literature as well as in sculpture and on vase paintings. The trage-

428 Although I do not deny Lape's claim that Menander's comedy is characterized by "simultaneously conservative and subversive plots" (Lape 2004, 246) and that New Comedy fulfills a variety of functions on different levels, I do not think that Menander's plays are as polyphonic as those of Aristophanes.

429 Menander actually means a moderate oligarchy compatible with Macedonian rule (Major 1997), but older, democratic discourses permeate his idealized characterization of oligarchy. 
dians, Aristophanes, and Menander all came back to the central topic of violence again and again, demonstrated its senselessness, and urgently recommended that it be overcome, not least for reasons of foreign policy (cf. Aristophanes' "comedies of war"). During the fifth and fourth centuries, no other fictional medium in which these questions could have been treated was more readily at hand than theater. Ancient historiography and biography follow different rules, and the novel had not yet been born. Theater provided a public space in which meaning and sense of words and deeds could be dynamically negotiated. Aristophanes and Menander articulated and visualized onstage the thin line, which had been mainly constructed in lawcourt speeches, between the use of violence that was still acceptable and that which was just not acceptable any more. Often enough, this balance gets lost in the plays. Aristophanes and Menander brought utopias and mock realities onto the stage and demonstrated to their respective audiences how to overcome political and social boundaries, at least in theory, by expelling evil forces, strengthening the community through the civic ritual of theater performances, and, within this ritual fame, providing guidelines for the regulation of conflicts. 


\title{
V. Conclusions
}

\author{
Was den Institutionen und \\ Gesetzen eines Landes Macht verleiht, \\ ist die Unterstützung des Volkes, die \\ wiederum nur die Fortsetzung jenes \\ ursprünglichen Konsenses ist, welcher \\ Institutionen und Gesetze ins Leben \\ gerufen hat. \\ (Hanna Arendt, Macht und Gewalt, \\ München ${ }^{2} 1971,42$.)
}

\section{Chronological Development of the Violence Discourse in Different Genres}

When the city of Athens underwent a profound shift from archaic to classical times, a highly self-conscious recognition of what havoc civic violence could wreak led the Athenians to introduce a sophisticated court system, supplemented by a system of arbitration and the philosophical and ethical postulate of self-control. Despite the indubitable efficiency of these measures - the blood feud was abolished for good-they could not be enough to pacify Athens indefinitely, ensure the social control of outsiders, and stabilize the demanding norms of the democratic polis. Above all, disruptive emotions like hatred and the yearning for revenge could not be eradicated: whereas the official discourse under the democracy was moderate and civil-even on curse tablets people were not supposed to wish openly for the destruction of their opponents-feelings like envy, anger, and the desire to harm one's enemy, even to kill him, persisted underneath the polite surface. This unquenchable desire for revenge and violence was now written between the lines and, today, must be carefully elicited by us. What Athens experienced during the fifth and fourth centuries was a historically unique process of re-interpretation. Revenge was an all-pervasive concept in Greek culture; it permeated many aspects of social relations, even in Athens. For the Athenians, it became possible to satisfy the drive for revenge not through physical violence against a rival or enemy, but through the law courts, viewed as a means of revenge, through the use of binding magic, also seen as a means toward violence, 
and through designing media like the courts and the theater to discuss the problems of violence and transmit a new civic and civil concept of citizenry to a broad audience.

Although the idea of vengeance plays a more prominent role in Antiphon than in later orators, ${ }^{1}$ fourth-century forensic speeches do not fundamentally deviate from the system of values as embraced by Antiphon, Andocides, the speakers in Thucydides, or the characters in Euripides. What emerges clearly during the fourth century, however, is the clash between the archaic canon of values (the aristocratically shaped constant struggle for honor) and the more recent, civil discourse on sôphrosunê and enkrateia in the democratically constituted hoplite polis. It is not without reason that the word for private revenge and state-issued punishment is one and the same (timôria). The amnesty of 404/03 BCE reinforced the ideological insistence on temperance that had been ongoing from the early fifth century on.

How did the Athenians cope with this double standard, the tension between the official civil discourse of the polis and the more long-lived natural inclinations of personal impulses? Athens is unique in so far as negotiating the definition of violence and raising the question of legitimate violence took place in ritual venues with a real or imagined public in attendance to make a decision. The citizens' belief in dialogue, in collaborative reasoning, and their willingness to succumb to collective verdicts differentiate Athens from many other societies. It was a distinctly democratic feature that even the boundaries of acceptable behavior were discussed in rituals and so the gravity of transgressing a norm was freely negotiable. In modern representative democracies, offenses are less negotiable because they are more closely defined by professional legal experts. Given the sophistication of the Athenian legal system, we can assume that the Athenians very deliberately opted for this semantic openness of what, in our eyes, constitutes violence.

It was this very public negotiation of values that enabled Athenian democracy to develop organically over time and find appropriate responses to the challenges of an ever-changing world. In this respect, the transformative power and dynamic of the rituals of representation (trials, theater) come into play. Notwithstanding their repetitive and relatively stable character, they were flexible enough to adjust to new circumstances and surroundings. Citizens of post-amnesty Athens had opinions on vio-

1 In Antiphon 2.1.8 the archaic ideology of agonistic feuding behavior is vividly expressed: it is better to kill the enemy and be executed than to be a coward. 
lence different from those of their archaic ancestors, and yet the shifts occurred so gradually that Athenians of the fourth century thought themselves to be still in line with the patrios politeia as instigated by Solon. Ritualized social norms ensured these smooth transitions. The ritualistic rules of performance communicated what violence had to look like and how one was supposed to talk about it.

This book, then, deals with the performative representation of the Athenian violence discourse in the three source genres of forensic speeches, curse tablets, and comedies. Since all three genres left the decision about the notion of violence to a majority vote, all their discourses are characterized by a fundamental openness regarding the definition of violence. All three corpora further show that there was a continuous process of hedging in violence from the fifth century on. ${ }^{2}$ The reasons for this gradual change are to be sought in political and cultural paradigm shifts. In the atmosphere after the amnesty of 404/03 civic violence, especially retributive violence, became more problematic than ever before in Athenian history. ${ }^{3}$ The stiffened rules of democracy required the repression of violence and its medial representation, which does not mean that there was no violence. In fact, the image of a non-violent Athens was no more than an ideological construct.

In forensic speeches that emphasize the rule of law, the moderate discourse of democracy had to be spoken, regardless of how violent one wanted to be. At least in public one had to stick to this strict code of behavior. The ideal citizen had to appear peaceful, temperate, and rational, had to speak the "right" discourse, and had to flaunt sôphrosunê (temperance) and enkrateia (self-restraint), which even found expression in clothing and personal appearance, as visually embodied by the statue of Sophocles put up in the theater of Dionysus during the Lycurgan era. If violence was unavoidable, it was to be sanctioned by a collective of citizens or one had to pretend at least that one acted in accordance with the normative rules of violence control. ${ }^{4}$ In pleading for harsh verdicts against

2 From the dawn of Athenian democracy on, we see strong efforts to quell internal violence. The Oresteia and Pericles' moderate behavior in public testify to this trend, to name just two examples. The killing of Ephialtes in 461, as well as the oligarchic coup of 411 with its ensuing bloodshed, remained traumas in the collective memory of the Athenians.

3 Carawan 1998, 135, 284.

4 Even Athenians like Meidias and Euphiletus, who exerted violence without any qualms and must have considered themselves to be in line with archaic ideology, had to speak the new discourse, which actually "ostracized" their own behavior. 
their opponents, the orators used the courts in their performative function as a sanctioned, controlled, and channeled form of violence. This channeling worked all the more successfully, since the tension between the perspectives of the victims and the perpetrators were not only rhetorically but also ritually negotiated: in the eyes of the victim the violence experienced remained senseless and unacceptable. In the eyes of the perpetrator it was legitimate, pursued societal goals, and was therefore acceptable. The fact that these differing views could be negotiated in court makes the definition of violence appear as a ritual construct: it was only interpretation and construction, which culminated in the verdict of the judges, who labeled a certain behavior as "violent." The constructedness of "violence" is epitomized in a flexible line, adjustable to any given circumstances. Self-defense, for example, or the expulsion of a would-be tyrant, were legitimate reasons for exerting violence. In order to meet such challenges successfully, the question of legitimacy had to be negotiable. An inflexible boundary that would have laid down once and for all a strict definition of legitimate and illegitimate violence was impracticable in a society that knew neither a consistent law code nor a public prosecutor nor legal experts, but instead relied on kinship help and private initiative in cases of homicide. Hence, the definition of what violence meant and under what circumstances its use was justified had necessarily to be flexible. This discursive openness allowed for an unprecedented flexibility (critics of democracy speak of its fickleness!) and the participation of a major portion of the population in the formulation of its own moral and emotional economy. At the same time, Athenians politicized violence: by speaking about it, they commented on their constitution. The notion of hubris, for example, assimilated the perpetrator to a tyrant, the anti-democrat par excellence.

The changing notions of what constituted legitimate violence also informed Athenian legal practice, the "open texture of Athenian law." The prosecutor had to define what he was actually pleading for and could choose from a variety of legal proceedings. Whether Euphiletus picked a graphê moicheias or a dikê blabês, a graphê hubreôs or a dikê biaiôn, whether he chose the informal procedure of rhaphanismos, or accepted a sum of money in recompense for the seduction of his wife, whether he exacted vengeance or a penalty on the seducer Eratosthenes, a different notion of the injustice suffered lay at the heart of each procedure

5 Cf. above 145 , n. 546. 
chosen. A ritual understanding of violence, therefore, also helps to explain the complex variety of Athenian procedural law.

We encounter a similar openness of meaning in the realm of magic. It seems odd, at first glance, that the semantics of the curse word 'I bind' is so broad that it covers a wide range of negative wishes. The process of cursing was, to a certain extent, analogous to the Athenian system of law: the ultimate decision of whether or not to convict the opponent and, if yes, how to punish him, was left to a superior body, in court to the judges, in the world of malign magic to the gods of the underworld. As in the forensic speeches, it was crucial that violence was not perpetrated privately and directly, but was sanctioned by superior powers and thus mediated.

The number of curse tablets significantly dropped from the third century on. Under the Macedonian monarchy, democratic competition had ceased to be a major factor in civic life. After the demise of democracy, self-restraint was no longer an urgent necessity for the polis; the texts inscribed on curse tablets became increasingly longer, with the language becoming more and more elaborate and explicitly violent in the Hellenistic era. Consequently, it is the curse tablets and, as we will see, drama that underwent the most profound changes from classical to Hellenistic times.

The binary, opposing pairs that make up the fine line between permissible and impermissible conduct are basically one and the same in oratory and comedy. Old Comedy enacted what was prohibited in real life. Philocleon's behavior toward prostitutes in Wasps brings onstage what Lysias had described in his second and third speeches. Against this backdrop, it does not come as a surprise that, also in art, scenes of violence were mostly portrayed with semantic openness. The findings we can derive from the plays of Aristophanes correspond to the observations that Muth could glean from pictorial evidence of violence on Athenian vases: spectators were not guided in their value judgments in our sense, but violence was always depicted neutrally or in an open-ended way.

The tragedians, as well as Aristophanes and Menander, kept coming back to the topic of violence, laid open its senselessness, and recommended that it be overcome, also on grounds of foreign policy. Both comic playwrights problematize violence in different ways, Aristophanes, however, in a rather indirect way. He deliberately breaks rules of interaction, thus opening up his plays to the portrayal of utopian societies. The kind of utopian violence portrayed therein is distanced from the audience through its grotesquely exaggerated ridiculousness. Menander, in contrast, wants to see violence banned from families and, time and again, ad- 
dresses themes such as rape, hatred, and the suspicion of society as well as the withdrawal from it. By mostly respecting the rules of interaction, Menander deviates from Aristophanes strikingly. In criticizing violence as rustic and barbarian, Menander is closer than Aristophanes to the forensic speeches, which had to arrive at a finite version of events. From Aristophanes to Menander, a progression toward more problematization of violence is discernible, mirroring the development in forensic oratory from Antiphon to Demosthenes and Isocrates. It is also evident that Menander, heading toward more strictly defined social mores in his New Comedy, wrote at the change of an epoch, the increasing spread of a refined Hellenistic culture, which ultimately stigmatized all interpersonal violence as un-Greek. The change in the dramatic genres from the fifth to the end of the fourth century was thus profound. Whereas tragedy became classical toward the end of the fourth century, New Comedy turned into the medium to reflect upon contemporary reality, mainly the impact of Macedonian oligarchy. ${ }^{6}$ The way violence is discredited in New Comedy testifies to an increasing public awareness of its problematic nature.

\section{Three Theses on Athenian Violence}

Deciphering the notion of violence in Athens by determining the multiple semantic markers that circumscribed violence in the respective genres leads to the conclusion that the Athenian concept of violence differed radically from our understanding of violence. I would like to put forward three theses:

(1) By violence, Athenians meant a transgression, a violation of boundaries, a breach of a protected sphere, like that of the oikos. As long as such acts of violence happened outside this protected sphere, we do not hear of them, or only rarely. It was only when social norms were broken within the protected sphere that wounded, maltreated, and tortured bodies emerge in our highly selective sources. ${ }^{7}$ We only hear of these misdeeds if the victim was powerful enough to utter them in public. Socially low-ranking victims are mentioned only in passing. This finding suggests a mental concept of violence that is fun-

6 Lape 2004, 18, 38, 42, 61-63, 68, 107, 112-113, 141, 172-173, 177, 199, 226-230, $243-253$.

7 Cf. Groebner 1995, 189. 
damentally different from our own. The higher degree to which violent behavior was tolerated under certain circumstances points to connotations of violence that could be more positive than in modern Western societies. Violence did fulfill certain positive functions in the eyes of the male perpetrators: non-excessive violence against subordinates was a suitable means of maintaining the social and political order of Athens. Young men asserted their own identities by attacking peers. Social tensions could find an outlet in violent behavior. All these instances suggest that at least some men must have believed in an integrative function of violence, which they embraced as a means to achieve their goals.

(2) In order for an action to be labeled as violent, it had to be considered problematic by contemporaries. This follows from the first thesis: An action was brought to public attention because the breach of boundaries mentioned above was deemed unacceptable. For this reason, the executions that took place at Athens all the time and in public, but mostly in a bloodless way, are hardly mentioned in our sources. ${ }^{8}$ In Weber's terminology the execution-and in Athens the torture of slaves - is part of a state's legitimate rule, not power. ${ }^{9}$ Interpersonal violence against metics, women, and slaves remained in the background. Their bodies were in a sphere that was less effectively protected than that of the male citizen body and were therefore more or less exposed to abuse committed by their kurioi. ${ }^{10}$ As disconcerting as this may seem to moderns, this kind of violence, according to the perception of Athenian citizens, belonged to the realm of normalcy and was not regarded as worth speaking or writing about. Therefore, violent behavior against these underprivileged groups was almost completely omitted from fifth and fourth-century literature. Most victims had no voice, no advocate to speak on their behalf. Vi-

8 Although Athens does not seem to have been a theater of horror (Schmitz 2004, 407) - the term was coined by van Dülmen ${ }^{2} 1988$ in reference to executions in medieval and early modern times-at least some executions, such as stoning (Cantarella 1991a, 74-84; Barkan 1936, 41-53), apotumpanismos (Cantarella 1991a, 41-46; Barkan 1936, 63-72), and throwing the convicted person into a pit (barathron) (Cantarella 1991a, 91-105; Barkan 1936, 54-62) were staged publicly and thus bear some resemblance to executions in medieval and early modern Europe.

9 Weber 1925, 122-125. Cf. above 3, n. 11. Schwedler 2005, 171-172 interprets this differentiation in detail.

10 Cf. above 100, n. 339. 
olence that a society deems irrelevant or does not perceive as such is covered by a cloak of silence. In contrast to today's norms in the Western world, certain forms of violence that fulfilled social functions in the eyes of the perpetrators were regarded as positive or neutral by some members of society.

(3) A highly rhetorical culture of public display and theatricality brought it about that socially relevant violence-that is, violence committed against the inviolable body of a male citizen-often required an audience for both its actual perpetration and its discursive negotiation afterward. Violence mongers who felt they were in the right were eager to commit their deeds in open daylight. Exerting violence in a hidden place was beyond a citizen's threshold of dignity and is severely criticized in the sources. Often witnesses were called upon during a brawl not only to cite them later in court, but also to form a public and make the abusive action valid and meaningful. The spectators and passers-by constituted an imaginary audience, a dramaturgical frame, within which the violence could unfold its symbolic significance. It is important to note how witnesses reacted to violence. If an Athenian citizen came under attack, the bystanders would take notice, if not intervene themselves. With the citizen body representing Athenian democracy, the inviolability of both entities was at stake in the case of an assault. If non-citizens suffered maltreatment, passers-by would tend to ignore the critical situation in which they were. $^{11}$ No one came to rescue Alcibiades' wife, when he dragged her home across the Agora by pulling her hair. No one prevented her death only two weeks after this incident. No one would come to the aid of the young slave, whose letter to his mother is preserved and who suffered tremendous hardships in the smithy at the hands of his master. Athenians were often indifferent to violence inflicted on non-citizens. These discrete reactions confirm that male Athenian citizens "defined" violence with respect to political, legal, social, and economic status as well as circumstantial considerations. The cul-

11 Exceptions confirm the rule. Stephanus intervenes on behalf of Neaera (D. 59), who, as an ex-slave and hence metic, faced charges under a graphê xenias and was thus threatened by enslavement and loss of property. Stephanus pleads Neaera's case in court, but he cohabited with her and had a lot to lose in the lawsuit against Apollodorus. The crowd gathers around Pittalacus as he clings to the altar of the Mother of the Gods and begs for help (Aeschin. 1.60), but people could not know right away the legal status of each and every suppliant. 
ture of public display made sure that the relevant information was immediately conveyed to the citizenry.

These three markers "define" socially relevant violence in ancient Athens. This socially relevant violence was dramatized-that is, was made public. Violence against inferiors, by contrast, unfolded in the realm of the normal; there was no dramatization. We would speak of domestic violence. If we combine the dichotomy of dramatization versus normalcy with the thesis of transgression, we obtain an important finding: the forensic speakers described the symbolic power and meaning of a violent act as lying in the number and significance of rules and boundaries that their opponents had transgressed. Hence, democratic procedures of negotiating meanings in rituals, not the law, constructed the significance of violence. Our modern understanding is very different. It is this discrepancy, among many others, that marks the distance between ancient Athens and contemporary Western societies.

\section{Controlling Function of Ritualization}

Violence was an intrinsic part of the Athenian social fabric. It was unavoidable in the process of constructing and representing social relations, so that violence echoed the social structure on the levels of both interaction and representation. The violence discourse and its applicability created an in-group of Athenians by drawing a sharp line that excluded outsiders. ${ }^{12}$ By subjecting slaves to torture, for example, Athenians made it clear indirectly that citizens were exempt from this ordeal and therefore enjoyed a higher status. Status distinctions were thus also created by corporally inscribing them with violent force on the bodies of non-Athenians. We can speak of a ritual construction of community through the use of violence and its discursive treatment. ${ }^{13}$ This finding confirms what we know so far about Athenian society in general. ${ }^{14}$

Even within the sphere of Athenian citizens, violence and the discourse on it fulfilled vital functions. In an egalitarian and, at the same

12 Cf. Bergesen 1977 on how community and solidarity are created through ritual techniques of exclusion.

13 Cf. Girard 1972.

14 Cf. Ruiz 1994 and Cartledge 1993 on the various dichotomies in Athenian society: Greeks vs. barbarians (36-62), men vs. women (63-89), citizens vs. aliens (90-117), free vs. slaves (118-151), gods vs. mortals (152-174). 
time, highly competitive society, violence was an indispensable tool with which to create social boundaries, superiority, and predominance. The publicly legitimized use of violence against an opponent or people under one's kurieia made it clear to everyone which individuals were in a superior position, entitling them to use physical and verbal violence. Violence, if applied properly, did not bring about changes of status, but confirmed the status quo by reproducing and perpetuating existing social hierarchies.

At the same time, this form of violence could remain functional because it was also kept under control via ritual means. The large-scale rituals of staging trials and dramas-it was mainly the public enactment of the violence discourse that made violence against citizens perceptiblewere inextricably intertwined with the life of the polis and fulfilled vital functions. With violence becoming a matter of public discourse, it was possible to channel, if not to reduce it: by creating codes of behavior and disseminating them to a broader public, courtroom and theater demonstrated which forms of violence were unacceptable and which were still justifiable under certain circumstances. The diverse public performances of the violence discourse thus created rules of interaction which generally mitigated the level of violence. The fact that a controlling audience needed to be present enhanced this effect. We can say that the rules of representation had a healing and pacifying effect and contributed to containing violence, thus making Athens especially governable. Given the pre-modern conditions of Athens, the positive results are astonishing: a certain amount of unavoidable violence was framed in a socially functional way; massive, disruptive forms of violence, however, were banned from the polis, unlike in other Greek city-states. ${ }^{15}$ It is my hypothesis that the performative handling of violence both on the discursive level as well as on the concrete level of daily interaction contributed to the extraordinary stability of the Athenian social and political system at its historical peak. Although there was no legal certainty in our sense, a culture of open discussion and the operative decision-making process guaranteed

15 In other Greek poleis, internal strife could not be reduced to the same extent as in Athens. Xenophon's Hellenica and Diodorus' Bibliothêkê abound with blatant examples. Famous for ongoing staseis are Corinth, Thebes, and Rhodes. On stasis in the Greek word in general, cf. Gehrke 1985. Cf. also Riess 2006, 66-67, esp. nn. 8-10 with examples, sources, and secondary literature. Although Athens is far better documented in our sources than any other Greek community, we hear much less about internal strife there than in other parts of the Greek world. 
this kind of stability. Social control, a strong sense of civic obligations, ${ }^{16}$ a dense network of civic and religious associations, ${ }^{17}$ arbitration, a sophisticated court culture, religion, and-most crucially—a specific civic and civil violence discourse that was ritually staged, all joined together to form a framework that managed to restrain the most serious forms of violence. The dissemination of this civic discourse was possible only through the democratic structures of Athens and its vibrant political community, where texts circulated and speeches were freely discussed.

\section{Social Origins of Perpetrators of Violence}

All social classes perpetrated violence, even if its use is better attested among the upper classes. Although they invented and shaped the new civil discourse on democracy, including a new concept of restricted violence and self-help, they were not less aggressive than members of the less privileged classes. Nevertheless, the elite members of society must have regarded physical violence as unfashionable, mob-like, and antidemocratic. ${ }^{18}$ On the official level, the new discourse on democracy and violence made unrestrained violence look rustic and tyrannical. According to these new principles, violence and fits of anger ( $\operatorname{rg} \hat{e})$ had to be suppressed so as not to provoke stasis and endanger the observance of the amnesty. It was only possible to play with orgê and indignation against one's opponent in court. But the human mind is inventive in circumventing public ideology and finding outlets for aggression, even under pacified and tightly controlled circumstances. The upper classes had two safety valves at their disposal:

(1) Officially, all citizens were encouraged to take conflicts to the courts so that the assembled dêmos in the form of the dikastêria could adjudicate them. In many public trials, the prosecutors did not plead for fines, but demanded the death penalty. Many defendants could escape into exile, true, but exile constituted a kind of social death.

16 Cf. Liddel 2007 passim.

17 Unfortunately, I gained access to the magisterial study of Ismard 2010 too late for me to consider it for this book.

18 Cf. Pericles, who remained stoic in the face of insults hurled at him (Plu. Per. 5.1-2; 7.5), and Demosthenes, who did not strike back when beaten by Meidias. 
What ostracism had accomplished in fifth-century Athens was the court's business in the fourth.

(2) Many curse tablets stem from the judicial context ${ }^{19}$ and therefore from the upper classes, because the poor could hardly afford the services of logographers and sorcerers. Moreover, the underprivileged rarely went to court. ${ }^{20}$ This is not to say that they did not resort to binding magic - the commercial spells are a clear testimony that they did-but the fact that upper classes also transferred their secret aggressions into the realm of magic confirms that they were indeed not less prone to violence than non-elite members of society. We can only speculate about the reasons for their stress and anxiety. The elites were more exposed to a fierce agôn than more humble members of society. The political system of democratic Athens must have had effects similar to a pressure cooker on the elites. Exposed to constant public checks and screening events, they had more to lose in terms of prestige than members of the lower classes. Since their stakes in the highly participatory system were so high, they were highly sensitive to any damage of their symbolic capital, their reputation in all relevant domains.

The new discourse, which became increasingly stronger during the fourth century, did set a limit on the use of violence. To what extent the lower classes were affected by this new ideology of civic peacefulness, a concept that, in all probability, only elite members discussed, cannot be discovered in our sources. If even trierarchs, who were among the richest Athenians, did not shrink from physical attacks and resorting to malign magic, ${ }^{21}$ we can deduce that the inhibition threshold for violence was even lower in underprivileged social strata. ${ }^{22}$ Oftentimes, members of the lower classes might not have felt educated or skilled enough in the art of public speaking to pursue litigation, so that the courts were only available to them in theory, a clear indicator of class justice. ${ }^{23}$ Consequently, when wronged, some of the members of the lower classes may have resorted to violence at home and in their neighborhood, a behavior

19 There are business-related curses, but they are the minority. Most prevalent are tablets commissioned by the rich from professional magicians.

20 Ober 1989, 113.

21 Cf., e.g., Ps.-D. 47 (Against Euergus and Mnesibulus); Gager no. $38=$ DTA 103 $=$ SEG XXXVII 220; Gager no. $42=$ DT 60.

22 Cf. above 149, n. 560 and 175, n. 54.

23 Krause 2004, 22-23. 
that was not yet informed by the new discourse on democracy. This conduct was reprimanded in the leading circles and ridiculed as "rustic." 24 Another remedy was extra-judicial arbitration. Nevertheless, the underprivileged had their share in constructing the meaning and significance of violence. As judges in the courtroom and spectators in the theater, they also participated in shaping the violence discourse. Audience response could have tangible repercussions on a playwright's further literary activities, as the case of Aristophanes' reworked Clouds shows. The aesthetics of reception is intrinsically connected to the aesthetics of production in a never-ending dialectical relationship of mutual exchange.

\section{A State Monopoly on Violence?}

In democratic and ritual venues, Athenians defined not only the significance and meaning of violence and its appropriate use, but also its applicability as punishment. Perhaps this is the highest cultural achievement of the Athenians: the democratic idea of leaving the ultimate decision of whether or not to exert violence to the community, to the judges in court, and to the gods in the world of magic. The executioner in the legal system and the dead in the realm of magic, not the individual longing for violence and revenge, led the convicted person/the accursed away to his ultimate punishment. The community of the judges, and in magic that of the gods of the underworld, sanctioned violence against fellow citizens. In making the communal decision master of violence, civil democracy, with its insistence on sanctioned violence, had triumphed over the revenge ideology of archaic times.

Leaving magic aside, can we speak of a kind of monopoly of violence? What is the relationship between state and violence? Although Demosthenes postulates a state monopoly on violence several times, ${ }^{25}$ Athens was far from its realization. The partial ritualization of violent interaction and its discursive treatment constituted an important way to regulate behavior by making it comprehensible and, to an extent, predictable. Of course, the public violence discourse was an upper-class phenomenon. And yet, the elites did not at all abstain from violence, as the speeches show. We have to reckon with even more violence among the lower social strata, about which we have little information. But in the rit-

24 Cf. Menander's Cnemon in the Dyscolus.

25 Cf. above 78, n. 253. 
ual venues of courts and theater, they too were called upon to take part in the constant process of re-evaluating the perception of violence and its societal function. The actual level of violence, which is, again, not the topic of this work, remains hard to assess, but it must have been higher than the literary sources, focused on mitigation, want to make us believe. Sanctioned violence, officially the only acceptable form of violence, contained, on the one hand, the traditional exertion of violence and its justification (timôria as revenge); on the other hand, it also comprised the civil achievements of moderation and the containment of violence as well as the problematization of wrath in the speeches, curse tablets, and drama (timôria as punishment).

Consequently, Athens stands in between contemporaneous, unabashedly violent societies of other Greek poleis - Athens remains a part of ancient Greece-and modern civil societies. This ambiguity partly explains the uniqueness of Athens, which belongs to both forms of state. A deepened reflection on violence allows us to draw conclusions on the fundamentally hybrid character and ambivalent functioning of Athenian democracy.

\section{Outlook on Violence in Athenian Foreign Policy}

Were Athenians successful, in the end, at containing violence at home and abroad? The difference between the internal and external situation is striking and requires a more thorough investigation than can be accomplished here. Internally, Athens was amazingly stable during the classical period of the fifth and fourth centuries. Major political upheavals and unrest are only attested for 508/07, 462, 411, and 404/03 BCE. The democracy was only overthrown twice and each time just for a few months. And yet the struggle for restraint ultimately failed. In the domestic realm, the lower classes were in favor of democracy because it offered material advantages, but they were not willing to embrace the intellectual consequences democracy had brought about.

In international relations, the striving for temperance was unsuccessful because Athens remained a pressure cooker for temporary elites and, paradoxically, became even more so through democracy. In addition, warmongers like Demosthenes heated up the atmosphere by preaching and reinvigorating the old discourse on honor and shame.

For a short period of time only, when the Athenians kept a low profile right after the end of the war against the allies (357-355 $\mathrm{BCE}$ ), the new 
discourse seems also to have prevailed in foreign policy. The idea of a koinê eirênê, although doomed to failure, ${ }^{26}$ was popular with the Greeks at first. Tired of incessant wars, Athenians hired more and more mercenaries. The statue of Eirênê in the Agora testifies to the new discourse. ${ }^{27}$ Athenians were more and more reluctant to go to war, and Demosthenes had to work hard to resuscitate the old discourse and motivate his fellow countrymen to fight. ${ }^{28}$ But most of all, the Greek polis world in general was not in line with Athens' new violence discourse. The amnesty of 404/03 was unique in the Greek world. Its repercussions on Athenian history and mentality were profound. Whereas Athenians had learned their lesson from the civil war and through the amnesty, other city-states did not embrace Athenian values, but continued to believe in the right of the stronger party, especially in the realm of international relations. Athenian democracy failed not only because of its own deep-rooted, war-like traditions, the "demons" of its own past, but also because of the hard facts of a brutal Realpolitik that left no room for restraint in foreign policy, and did not concede to internal temperance any kind of application in international relations. Athens, albeit not wholly pacified, was an island of relative security in a sea of violence. ${ }^{29}$ Athens was not only part of this sinister world, but also played an active role in it, despite all efforts to keep violence at bay, at least in the internal realm.

Concepts of peace and conflict research will help widen the focus of this study and investigate to what extent the handling of situations of internal conflict and violence found its reflection in Athenian foreign policy. ${ }^{30}$ Aspects of violent and imperialistic language and strategies to justify

26 Jehne 1994, 270, 282-284.

27 Knell 2000, 73-80.

28 Of course, Demosthenes was not the only one to hail and glorify Athens' martial traditions. Cf. Isocrates' aggressive pamphlets that contributed to Alexander's invasion of Persia.

29 From an anthropological perspective, Bernand 1999 paints a gloomy picture of the violent Greeks. The agonistic ideology, so characteristic of the Greeks, persisted far into the Roman Empire. The Greek states found ways, however, to cope with minor conflicts in order to avoid wars. One way was to call in judges from abroad, whose task it was to mediate between the opposing parties with impartiality and wisdom. Cf. Dössel 2003, 249-272; Manley-Tannis 1998, 49.

30 This kind of research is postulated by historians of international relations, researchers of conflict, political scientists, and sociologists alike. It is only a thorough understanding of domestic violence that allows a critical evaluation of violence perpetrated in foreign policy. Programmatic on this stance is Risse-Kappen 1994, 213: "The focus on domestic structures as intervening variables between 
violence in the foreign realm will be the concern of a future project. The connection between ritualized containment of violence, its dramatization, or its passing over in silence within the polis, on the one hand, and violence and its representation in Greek interstate relations, on the other hand, has not yet been explored in the case of Athens. ${ }^{31}$ The extent to which Athens tried to make the newly developed discourse on internal, civic violence prevail also in international relations or, even further, what consequences these intellectual innovations had on Athenian foreign policy and policy with respect to the allies, are questions that warrant further treatment.

transnational coalitions and the foreign policy of states appears to offer a way of theorizing systematically about the interactions between states and transnational relations."

31 Giovannini 2007 and Low 2007; 2005 have made a start along these lines. 


\section{References}

Lexicon entries are not included in this bibliography. They are cited in full in the text. Major historical, epigraphic, and archaeological corpora are not listed here. Their abbreviations mostly follow the list in L'Année Épigraphique. Journals are abbreviated according to the list in L'Année Philologique.

\section{Corpora of Athenian Curse Tablets}

(citation without page number, i.e. the numbers given refer to the number of inscription within the volume)

In all other citations of curse tablets, the numbers refer to page numbers. In some cases, numbers (no.) are given in addition to page numbers in order to avoid confusion.

CIL Corpus Inscriptionum Latinarum

DT Audollent, A., Defixionum Tabellae quotquot innotuerunt tam in Graecis Orientis quam in totius Occidentis partibus praeter Atticas in Corpore Inscriptionum Atticarum editas, Paris 1904.

DTA Inscriptiones Graecae III 3, Appendix: Defixionum Tabellae Atticae, ed. by R. Wünsch, Berlin 1897.

Gager Gager, J., Curse Tablets and Binding Spells from the Ancient World, New York - Oxford 1992. To avoid confusion with page numbers, references to numbers of curse tablets within Gager are indicated with "no."

López López Jimeno, M., Nuevas tabellae defixionis Áticas. Estudio filológico, lingüístico, epigráfico y de realia de las nuevas tabellae defixionis áticas posteriores a la publicación de los corpora clásicos. Con textos, traducción, indices y laminas, Amsterdam 1999.

NGCT Jordan, D., "New Greek Curse Tablets (1985-2000)," GRBS 41, 2000, 5-46.

SEG Supplementum Epigraphicum Graecum

SGD Jordan, D., "A Survey of Greek Defixiones Not Included in the Special Corpora," GRBS 26, 1985, 151-197. 


\section{Abbreviated Works}

Dilts

Edmonds

GHI I

GHI II

GMP

PGM

HGIÜ I

HGIÜ II

I.Knidos

K.

K.-A.

Kö.

Liddell - Scott Liddell, H. - Scott, R., A Greek-English Lexicon. With a Revised Supplement, Oxford 1996.

M/L Meiggs, R. - Lewis, D., A Selection of Greek Historical Inscriptions to the End of the Fifth Century BC, Oxford 1969, rev. 1988.

OGIS Dittenberger, W., Orientis graeci inscriptiones selectae, 2 vols., Leipzig 1903/1905 (Hildesheim 1986).

OLD

Dilts, M., Scholia Demosthenica, vol. 2: Scholia in orationes 19-60 continens, Leipzig 1986.

neke, Bergk, and Kock. Augmented, Newly Edited with their Contexts, Annotated, and Completely Translated into English Verse, 4 vols, Leiden 1957-1961.

Tod, M., A Selection of Greek Historical Inscriptions I: To the End of the Fifth Century, Oxford ${ }^{2} 1946$.

Tod, M., A Selection of Greek Historical Inscriptions II: From 403 to 323 BC, Oxford ${ }^{2} 1948$.

Betz, H., The Greek Magical Papyri in Translation, Including the Demotic Spells, London - Chicago ${ }^{2} 1992$ (= Engl. translation and new edition of Stuttgart - Leipzig - Berlin 1928-1931; rev. edition by A. Henrichs, Stuttgart 1973/1974; vol. 2 ed. by K. Preisendanz 1931).

Griechische Inschriften in Übersetzung, Bd. I: Die archaische und klassische Zeit, Darmstadt 1992.

Brodersen, K. - Günther, W. - Schmitt, H., Historische Griechische Inschriften in Übersetzung, Bd. II: Spätklassik und früher Hellenismus (400-250 v. Chr.), Darmstadt 1996. Blümel, W., Die Inschriften von Knidos. Teil I, Bonn 1992. Kock, T., Comicorum Atticorum Fragmenta, 3 vols., Leipzig 1880-1888.

Kassel, R. - Austin, C., Poetae Comici Graeci, 8 vols., Berlin - New York 1983-1995.

Körte, A., Menandri quae supersunt, pars altera, Leipzig ${ }^{2} 1959$ (with addenda by A. Thierfelder) (1953).

Glare, P. (Ed.), Oxford Latin Dictionary, Oxford 1982. 
Paroem. Gr. Leutsch, E., Corpus paroemiographorum Graecorum, Göttingen 1839-1851.

P. Köln III Kramer, B. - Erler, M. - Hagedorn, D. - Hübner, R. (Ed.), Kölner Papyri (P. Köln). Bd. 3, Opladen 1980.

Rhet. Gr. Walz, C., Rhetores Graeci, 10 vols., Stuttgart 1832-1836 (repr. Osnabrück 1968).

StV II Bengtson, H., Die Staatsverträge des Altertums II. Die Verträge der griechisch-römischen Welt von 700 bis $338 v$. Chr., München ${ }^{2} 1975$ (1962).

Suda Adler, A., Suidae Lexicon, Leipzig 1928-1938 (repr. Stuttgart 1967-1971).

Syll. $\mathrm{I}^{3} \quad$ Dittenberger, W., Sylloge inscriptionum graecarum, 4 vols., Leizpig ${ }^{3}$ 1915-1924 (Hildesheim 1982), here vol. 1, Leipzig ${ }^{3} 1915$ (1883).

TGF III Radt, S. (Ed.), Tragicorum Graecorum fragmenta. Vol. 3: Aeschylus, Göttingen 1985.

\section{English Translations}

Arnott, W. (trans.)., Menander I. Aspis to Epitrepontes, Cambridge/MA - London 1979 (Loeb).

— Menander II. Heros to Perinthia, Cambridge/MA - London 1996 (Loeb).

— Menander III. Samia to Plot Summaries, Cambridge/MA - London 2000 (Loeb).

Babbitt, F., Plutarch's Moralia IV 263 D - 351 B, Cambridge/MA - London 1957 (1936).

Bers, V., Demosthenes, Speeches 50-59, Austin/TX 2003.

Bury, R., Plato. Laws II, Cambridge/MA - London 1961 (1926) (Loeb).

Carey, C., Aeschines, Austin/TX 2000.

Edmonds, J., The Fragments of Attic Comedy. After Meineke, Bergk, and Kock. Augmented, Newly Edited with their Contexts, Annotated, and Completely Translated into English Verse, 4 vols, Leiden 1957-1961.

Edwards, M., Isaeus, Austin/TX 2007.

Fowler, H. - Lamb, W., Plato I. Euthyphro, Apology, Crito, Phaedo, Phaedrus, Cambridge/MA - London 1960 (1914) (Loeb).

Gagarin, M. - MacDowell, D., Antiphon \& Andocides, Austin/TX 1998.

Gager, J., Curse Tablets and Binding Spells from the Ancient World, New YorkOxford 1992.

Harris, E., Demosthenes Speeches 20-22, Austin/TX 2008.

Henderson, J. (trans.), Aristophanes I. Acharnians. Knights, Cambridge/MA London 1998 (Loeb). 
Aristophanes II. Clouds, Wasps, Peace, Cambridge/MA - London 1998 (Loeb).

— Aristophanes III. Birds, Lysistrata, Women at the Thesmophoria, Cambridge/MA - London 2000 (Loeb).

- Aristophanes IV. Frogs, Assemblywomen, Wealth, Cambrige/MA - London 2002 (Loeb).

—- Aristophanes V. Fragments, Cambridge/MA - London 2007 (Loeb).

Lamb, W., Plato III. Lysis, Symposium, Gorgias, Cambridge/MA - London 1967 (1925) (Loeb).

MacDowell, D., Demosthenes, Speeches 27-38, Austin/TX 2004.

Mirhady, D. - Lee Too, Y., Isocrates I, Austin/TX 2000.

Most, G., Hesiod. Theogony. Works and Days. Testimonia, Cambridge/MA London 2006 (Loeb).

Papillon, T., Isocrates II, Austin/TX 2004.

Rolfe, J., The Attic Nights of Aulus Gellius, 3 vols., Cambridge/MA - London 1927 (Loeb).

Scafuro, A., Demosthenes, Speeches 39-49, Austin/TX 2011.

Shorey, P., Plato. The Republic I. Books I-V, Cambridge/MA - London 1963 (1930) (Loeb).

Todd, S., Lysias, Austin/TX 2000.

Vince, J., Demosthenes III. Against Meidias, Androtion, Aristocrates, Timocrates, Aristogeiton XXI-XXVI, Cambridge/MA - London 1986 (1935) (Loeb).

Worthington, I. - Cooper, C. - Harris, E., Dinarchus, Hyperides, and Lycurgus, Austin/TX 2001.

Worthington, I., Demosthenes, Speeches 60 and 61, Prologues, Letters, Austin/ TX 2006.

Yunis, H., Demosthenes, Speeches 18 and 19, Austin/TX 2005.

\section{Secondary Literature}

Abt, A., "Bleitafeln aus Münchner Sammlungen," Archiv für Religionswissenschaft 14, 1911, 143-158.

Ackermann, R., The Myth and Ritual School. J. G. Frazer and the Cambridge Ritualists, New York - London 1991.

Adkins, A., Moral Values and Political Behaviour in Ancient Greece, London 1972.

Adrados, F., Festival, Comedy, and Tragedy. The Greek Origins of Theater, Leiden 1975.

Allen, D., "Greek Tragedy and Law," in M. Gagarin - D. Cohen (Ed.), The Cambridge Companion to Ancient Greek Law, Cambridge 2005, 374-393.

_- "Angry Bees, Wasps, and Jurors: the Symbolic Politics of Orge in Athens," in S. Braund - G. Most, (Ed.), Ancient Anger. Perspectives from Homer to Galen, Cambridge 2003, 76-98.

- The World of Prometheus. The Politics of Punishing in Democratic Athens, Princeton 2000.

—_, "Imprisonment in Classical Athens," CQ 47, 1997, 121-135. 
Althoff, G., Inszenierte Herrschaft. Geschichtsschreibung und politisches Handeln im Mittelalter, Darmstadt 2003a.

— stadt 2003b.

- , Spielregeln der Politik im Mittelalter. Kommunikation in Frieden und Fehde, Darmstadt 1997.

Ambos, C. - Hotz, S. - Schwedler, G. - Weinfurter, S. (Ed.), Die Welt der Rituale. Von der Antike bis zur Gegenwart, Darmstadt 2005

Ambrosino, D., "Nuages et sens: autour des Nuées d'Aristophane," Quaderni di Storia 18, 1983, 3-60.

Anderson, M., "Knemon's Hamartia," G\&R 17, 1970, 199-217.

Andrews, M., "Euripides and Menander," CQ 18, 1924, 1-10.

Ankarloo, B. - Clark, S., "Introduction," in B. Ankarloo - S. Clark (Ed.), Witchcraft and Magic in Europe: Ancient Greece and Rome, Philadelphia 1999, xi-xvi.

Arena, R., Iscrizioni Greche Arcaiche di Sicilia e Magna Grecia. Iscrizioni di Sicilia I: Iscrizioni di Megara Iblea e Selinunte, Milano 1989.

Arendt, H., Macht und Gewalt, München ${ }^{2} 1971$ (1970).

Arlen, S., The Cambridge Ritualists. An Annotated Bibliography of the Works by and about Jane Ellen Harrison, Gilbert Murray, Francis M. Cornford and Arthur Bernard Cook, Metuchen/NJ 1990.

Arnaud, L., "La baskania ou le mauvais œil chez les Grecs modernes," Échos d'Orient 15, 1912, 385-394.

Arnott, G., "Moral Values in Menander," Philologus 125, 1981, 215-227.

Arnott, P., Public and Performance in the Greek Theatre, London - New York 1989.

Arnott, W., "From Aristophanes to Menander," G\&R, NS 19, 1972, 65-80.

— , "The Confrontation of Sostratos and Gorgias," Phoenix 18, 1964, 110 123.

Aronen, J., "Notes on Athenian Drama as Ritual Myth-Telling within the Cult of Dionysos," Arctos 26, 1992, 19-37.

Arrowsmith, W., "Aristopahnes' Birds: The Fantasy Politics of Eros," Arion 1, 1973, 119-167.

Assmann, A., Die Legitimität der Fiktion. Ein Beitrag zur Geschichte der literarischen Kommunikation, München 1980.

Assmann, J., Religion und kulturelles Gedächtnis. Zehn Studien, München 2000.

Aubert, J., "Threatened Wombs. Aspects of Ancient Uterin Magic," GRBS 30, 1989, 421-449.

Auffarth, C., "Der Opferstreik: Ein altorientalisches 'Motiv' bei Aristophanes und im homerischen Hymnus," GB 20, 1994, 59-86.

Auger, D., "Le théâtre d'Aristophane: Le mythe, l'utopie et les femmes," in D. Auger - M. Rosellini - S. Said (Ed.), Aristophane: Les femmes et la cité, Fontenay-aux-Roses 1979, 71-101.

Austin, C. - Olson, D., Aristophanes. Thesmophoriazusae, Edited with Introduction and Commentary, Oxford 2004.

Austin, J., How to do Things with Words, Oxford ${ }^{2} 1975$ (1962). 
Bänninger, R., "Violence, Aggression, and Targets: An Overview," in R. Bänninger, (Ed.), Targets of Violence and Aggression, Amsterdam - New York 1991, 443-460.

Bain, D., Menander. Samia, Edited with Translation and Notes, Warminster 1983.

Balme, C., "Verwandt der Kern aller Menschen - Zur Annäherung von Theaterwissenschaft und Kulturanthropologie," in B. Schmidt - M. Münzel (Ed.), Ethnologie und Inszenierung. Ansätze zur Theaterethnologie, Marburg 1998, 19-44.

Balot, R., Greed and Injustice in Classical Athens, Princeton 2001.

Barkan, I., Capital Punishment in Ancient Athens, Chicago 1936.

Baroja, J., "Magic and Religion in the Classical World," in M. Marwick (Ed.), Witchcraft and Sorcery. Selected Readings, Harmondsworth 1982, 73-80.

Bauman, R., Verbal Art as Performance, Rowley/MA 1977.

Belardinelli, A., Menandro. Sicioni. Introduzione, testo e commento, Bari 1994.

Bell, C., Ritual. Perspectives and Dimensions, Oxford - New York 1997.

- Ritual Theory, Ritual Practice, New York 1992.

Belliger, A. - Krieger, D. (Ed.), Ritualtheorien. Ein einführendes Handbuch, Wiesbaden 1998.

Benston, K., "Being There: Performance as Mise-en-Scène. Abscene, Obscene, and Other Scene," PMLA 107, 1992, 434-449.

Bergemann, J., Demos und Thanatos. Untersuchungen zum Wertsystem der Polis im Spiegel der attischen Grabreliefs des 4. Jhs. v. Chr. und zur Funktion der gleichzeitigen Grabbauten, München 1997.

Bergesen, A., "Political Witch Hunts: The Sacred and The Subversive in CrossNational Perspective," American Sociological Review 42, 1977, 220-233.

Bernand, A., Guerre et Violence dans la Grèce antique, Paris 1999.

- Sorciers grecs, Paris 1991.

Bers, V., Genos dikanikon. Amateur and Professional Speech in the Courtrooms of Classical Athens, Cambridge/MA - London 2009.

_ - "Just Rituals. Why the Rigmarole of Fourth-Century Athenian Lawcourts?" in P. Flensted-Jensen - T. Nielsen - L. Rubinstein (Ed.), Polis \& Politics. Studies in Ancient Greek History. Presented to Mogens Herman Hansen on his Sixtieth Birthday, August 20, 2000, Kopenhagen 2000, 553 560.

- "Tragedy and Rhetoric," in I. Worthington (Ed.), Persuasion: Greek Rhetoric in Action, London - New York 1994, 176-195.

Bertelli, L., "L'utopia sulla scena: Aristofane e la parodia della città," Civiltà classica e cristiana 4, 1983, 215-261.

Bertrand, J.-M., La violence dans les mondes grec et romain. Actes du colloque international (Paris, 2-4 mai 2002), Paris 2005.

Bierl, A., "Dionysus in Old Comedy. Staging of Experiments on Myth and Cult," in A. Bernabé (Ed.), Redefining Dionysus: Myth and Cult, Berlin New York 2011a (in print)

_ - "Fest und Spiele in der griechischen Literatur", in: ThesCRA chapter 3 IV (The J. Paul Getty Museum), Los Angeles 2011b (in print). 
-, Ritual and Performativity. The Chorus in Old Comedy, Cambridge/MA London 2009a (Der Chor in der Alten Komödie. Ritual und Performativität, München - Leipzig 2001).

_ , "Schamanismus und die Alte Komödie. Generischer Rückgriff auf einen Atavismus und Heilung (mit einer Anwendung am Beispiel von Aristophanes' Frieden)," in Religion. Lehre und Praxis. Akten des Kolloquiums Basel. 22. Oktober 2004, Athens 2009b, 13-35.

_, ,Literatur und Religion als Rito- und Mythopoetik. Überblicksartikel zu einem neuen Ansatz in der Klassischen Philologie," in A. Bierl - R. Lämmle - K. Wesselmann (Ed.), Literatur und Religion 1. Wege zu einer mythisch-rituellen Poetik bei den Griechen, Berlin - New York 2007a, 1-76.

_, "L'uso intertestuale di Alcmane nel finale della Lisistrata di Aristofane. Coro e rito nel contesto performativo," in F. Perusino - M. Colantonio (Ed.), Dalla lirica corale alla poesia drammatica. Forme e funzioni del canto corale nella tragedia e nella commedia greca, Pisa 2007b, 259-290 (now “Alcman at the End of Aristophanes' Lysistrata: Ritual Interchorality," in L. Athanassaki - E. Bowie (Ed.), Archaic and Classical Choral Song. Performance, Politics and Dissemination, Berlin - Boston 2011, 415-436).

_ _ "Alt und Neu bei Aristophanes (unter besonderer Berücksichtigung der Wolken)," in A. von Müller - J. von Ungern-Sternberg (Ed.), Die Wahrnehmung des Neuen in Antike und Renaissance, München - Leipzig 2004, 1-24.

_, , "Viel Spott, viel Ehr!' - Die Ambivalenz des onomasti komodein im festlichen und generischen Kontext," in A. Ercolani (Ed.), Spoudaiogeloion. Form und Funktion der Verspottung in der aristophanischen Komödie, Stuttgart - Weimar 2002a, 169-187.

$\longrightarrow$, "Experimentelle Innovation und ihre rituell-pragmatischen Grenzen in der Alten Komödie," QUCC n.s. 72 (101), 2002b, 7-21.

_, "Karion, die Karer und der Plutos des Aristophanes als Inszenierung eines anthesterienartigen Ausnahmefestes," in A. Bierl - P. von Möllendorff (Ed.), Orchestra. Drama - Mythos - Bühne. Festschrift für Hellmut Flashar anläßlich seines 65. Geburtstages, Stuttgart - Leipzig 1994, 30-43.

—, Dionysos und die griechische Tragödie. Politische und 'metatheatralische' Aspekte im Text, Tübingen 1991.

Bierl, A. - Lämmle, R. - Wesselmann, K. (Ed.), Literatur und Religion 1. Wege zu einer mythisch-rituellen Poetik bei den Griechen, Berlin - New York 2007.

Black, D., "Crime as Social Control," American Sociological Review 48, 1983, $34-45$.

Black-Michaud, J., Cohesive Force: Feud in the Mediterranean and in the Middle East, Oxford 1975.

Blanchard, A., La comédie de Ménandre. Politique, éthique, esthétique, Paris 2007.

— Essai sur la composition des comédies de Ménandre, Paris 1983.

Blome, P., "Das Schreckliche im Bild," in F. Graf (Ed.), Ansichten griechischer Rituale. Geburtstags-Symposion für Walter Burkert, Stuttgart - Leipzig 1998, $72-95$. 
Blomqvist, K., The Tyrant in Aristotle's Politics. Theoretical Assumptions and Historical Background, Stockholm 1998.

Blume, H.-D., Menander, Darmstadt 1998.

—, Menanders Samia. Eine Interpretation, Darmstadt 1974.

Bobonich, C. - Destrée, P. (Ed.), Akrasia in Greek Philosophy. From Socrates to Plotinus, Leiden - Boston 2007.

Boegehold, A., The Lawcourts at Athens. Sites, Buildings, Equipment, Procedure, and Testimonia, Princeton 1995.

Bohrer, K., "Zur ästhetischen Funktion von Gewalt-Darstellung in der griechischen Tragödie," in B. Seidensticker - M. Vöhler (Ed.), Gewalt und Ästhetik. Zur Gewalt und ihrer Darstellung in der griechischen Klassik, Berlin New York 2006, 169-184.

Bonacker, T. (Ed.), Sozialwissenschaftliche Konflikttheorien. Eine Einführung, Opladen ${ }^{2} 2002$ (1996).

Bonanno, M., "All the (Greek) World's a Stage: Notes on (Not just Dramatic) Greek Staging," in L. Edmunds - R. Wallace (Ed.), Poet, Public, and Performance in Ancient Greece, Baltimore - London 1997, 112-123.

Bonner, R., "Wit and Humor in Athenian Courts," CP 1922, 97-103.

Borg, B., "Gefährliche Bilder? Gewalt und Leidenschaft in der archaischen und klassischen Kunst," in B. Seidensticker - M. Vöhler, (Ed.), Gewalt und Ästhetik. Zur Gewalt und ihrer Darstellung in der griechischen Klassik, Berlin 2006, 223-257.

Bowie, A., Aristophanes. Myth, Ritual and Comedy, Cambridge 1993.

- "Ritual Stereotype and Comic Reversal: Aristophanes' Wasps," BICS 34, 1987, 112-125.

Bowie, E., "Ioanian Iambos and Attic Komoidia: Father and Daughter. Or Just Cousins?" in A. Willi (Ed.), The Language of Greek Comedy, Oxford 2002, $33-50$.

Brandt, H., Wird auch silbern mein Haar. Eine Geschichte des Alters in der Antike, München 2002.

Brask, P. - Morgan, W., "Towards a Conceptual Understanding of the Transformation from Ritual to Theater," Anthropologica 30, 1988, 175-202.

Braun, K., "Der Dipylon-Brunnen B 11. Die Funde," AM 85, 1970, 197-198.

Bravo, B., "Une tablette magique d'Olbia pontique, les morts, les héros et les démons," in Poikilia: études offertes à Jean-Pierre Vernant, Paris 1987, $185-218$.

Breitholz, L., Die dorische Farce im griechischen Mutterland vor dem 5. Jahrhundert. Hypothese oder Realität?, Stockholm 1960.

Bremmer, J., "Scapegoat Rituals in Ancient Greece," HSCP 87, 1983, 299-320 (repr. in R. Buxton (Ed.), Oxford Readings in Greek Religion, Oxford 2000, 271-293).

Brockmann, C., Aristophanes und die Freiheit der Komödie. Untersuchungen zu den frühen Stücken unter besonderer Berücksichtigung der Acharner, München - Leipzig 2003.

Brodersen, K., Apollodoros, Gegen Neaira (Demosthenes 59). Antiphon, Gegen die Stiefmutter, Darmstadt 2004. 
, "Briefe in die Unterwelt: Religiöse Kommunikation auf griechischen Fluchtafeln," in K. Brodersen (Ed.), Gebet und Fluch, Zeichen und Traum. Aspekte religiöser Kommunikation in der Antike, Münster 2001, $57-68$.

Brodersen, K. - Kropp, A. (Ed.), Fluchtafeln: Neue Funde und neue Deutungen zum antiken Schadenzauber, Frankfurt/M. 2004.

Brown, P., "Athenian Attitudes to Rape and Seduction: The Evidence of Menander, Dyskolos 289-293," CQ 41, 1991, 533-534.

_- "Menander's Dramatic Technique and the Law of Athens," CQ 33, 1983, 412-420.

Buis, E., "El hombre y el castigo de su hybris en Aves de Aristófanes: justicia de Zeus o ley ateniense?" in G. Grammatico - A. Arbea (Ed.), El hombre, todo el hombre, Santiago de Chile 2002, 159-169.

Burckhardt, A., Spuren der athenischen Volksrede in der alten Komödie, Basel 1924 (Diss.).

Burckhardt, L., “Vom 'Agon' zur 'Nullsummenkonkurrenz': Bemerkunen zu einigen Versuchen, die kompetitive Mentalität der Griechen zu erfassen," Nikephoros 12, 1999, 71-93.

Burckhardt, L - Ungern-Sternberg, J. von (Ed.), Grosse Prozesse im antiken Athen, München 2000.

Burkert, W., Homo necans. Interpretation altgriechischer Opferriten und Mythen, Berlin - New York ${ }^{2} 1997$ (1972).

_, "Die antike Stadt als Festgemeinschaft," in P. Hugger (Ed.), Stadt und Fest. Zu Geschichte und Gegenwart europäischer Festkultur, Stuttgart 1987, 25-44.

— München 1984.

— , "Transformations of the Scapegoat," in Id., Structure and History in Greek Mythology and Ritual, Berkeley - Los Angeles - London 1982, 59-77.

— Orestes," Antike und Abendland 20, 1974, 97-109.

Burnett, A., Revenge in Attic and Later Tragedy, Berkeley - Los Angeles - London 1998.

Bushala, E., "Torture of Non-Citizens in Homicide Investigations," GRBS 9, 1968, 61-68.

Butler, Judith, Hass spricht. Zur Politik des Performativen, Berlin 1998 (Excitable Speech. A Politics of the Performative, New York - London 1997).

Cairns, D., "Hybris, Dishonour, and Thinking Big," JHS 116, 1996, 1-32.

—, "review of N. Fisher, Hybris. A Study in the Values of Honour and Shame in Ancient Greece, Warminster 1992," CR 44, 1994, 76-79.

- Aidos. The Psychology and Ethics of Honour and Shame in Ancient Greek Literature, Oxford 1993.

Calame, C. (Ed.), Poétique d'Aristophane et langue d'Euripide en dialogue, Paris 2004.

Calder III, W. (Ed.), The Cambridge Ritualists Reconsidered, Atlanta 1991. 
Calhoun, G., The Growth of Criminal Law in Ancient Greece, Westport/CT 1927 (repr. 1973).

— Athenian Clubs in Politics and Litigation, New York 1913 (repr. 1970).

Cantarella, E., "Gender, Sexuality, and Law," in M. Gagarin - D. Cohen (Ed.), The Cambridge Companion to Ancient Greek Law, Cambridge 2005, 236253.

, I supplizi capitali in Grecia e a Roma, Milano 1991a.

"Moicheia: Reconsidering a Problem," in M. Gagarin (Ed.), Symposion 1990. Vorträge zur griechischen und hellenistischen Rechtsgeschichte, Köln Weimar - Wien 1991b, 289-296.

_- "Spunti di riflessione critica su hybris e time in Omero," in P. Dimakis (Ed.), Symposion 1979. Vorträge zur griechischen und hellenistischen Rechtsgeschichte, Köln - Wien 1983, 85-96.

Carastro, M., La Cité des Mages. Penser la magie en Grèce ancienne, Grenoble 2006.

Carawan, E., Rhetoric and the Law of Draco, Oxford 1998.

"Akriton Apokteinai: Execution without trial in Fourth-Century Athens," GRBS 25, 1984, 111-121.

Carey, C., Lysiae Orationes cum Fragmentis, Oxford 2007.

, "Offence and Procedure in Athenian Law," in E. Harris - L. Rubinstein

(Ed.), The Law and the Courts in Ancient Greece, London 2004, 111-136.

- "Rape and Adultery in Athenian Law," CQ 45, 1995a, 407-417.

, "The Witness's Exomosia in the Athenian Courts," CQ 45, 1995b, 114 119.

—, "Comic Ridicule and Democracy," in R. Osborne - S. Hornblower (Ed.), Ritual, Finance, Politics. Athenian Democratic Accounts Presented to David Lewis, Oxford 1994, 69-83.

, "The Purpose of Aristophanes' Acharnians," RhM 136, 1993, 245-263.

, Apollodoros Against Neaira [Demosthenes] 59, Warminster 1992.

-, "A Note on Torture in Athenian Homicide Cases," Historia 37, 1988, $241-245$.

Carlson, M., Performance. A Critical Introduction, London 1996.

Carnicelli, A., Patterns of Aggressive Comedy in the Chorus of Aristophanes, Cambridge/MA 1975 (Diss.).

Cartledge, P., "'Deep Plays': Theatre as Process in Greek Civic Life,” in P. Easterling (Ed.), The Cambridge Companion to Greek Tragedy, Cambridge 1997, 3-35.

— Aristophanes and his Theatre of the Absurd, Bristol ${ }^{3} 1995$ (1990).

—, The Greeks. A Portrait of Self and Others, Cambridge 1993.

Cartledge, P. - Millett, P. - Todd, S. (Ed.), Nomos. Essays in Athenian Law, Politics, and Society, Cambridge - New York 1990.

Casson, L., "The Athenian Upper Class and New Comedy," TAPA 106, 1976, 29-59.

Chaniotis, A., "Rituals Between Norms and Emotions: Rituals as Shared Experience and Memory," in E. Stavrianopoulou (Ed.), Ritual and Communication in the Graeco-Roman World, Liège 2006, 211-238. 
- "Ritual Dynamics in the Eastern Mediterranean: Case Studies in Ancient Greece and Asia Minor," in W. Harris (Ed.), Rethinking the Mediterranean, Oxford 2005, 141-166.

— , "Ritual Dynamics: Der Kaiserkult im Osten des Römischen Reiches im Kontext der zeitgenössischen Ritualpraxis," in H. Cancik - K. Hitzl (Ed.), Die Praxis der Herrscherverehrung in Rom und seinen Provinzen, Tübingen 2003, 3-28.

_ - F. van Straten - J. Strubbe (Ed.), Kykeon. Studies in Honour of H.S. Versnel, Leiden - Boston - Köln 2002a, 23-48.

- , "Old Wine in a New Skin: Tradition and Innovation in the Cult Foundation of Alexander of Abonouteichos," in E. Dabrowa (Ed.), Tradition and Innovation in the Ancient World, Krakau 2002b, 67-85.

__, "Reinheit des Körpers - Reinheit der Seele in den griechischen Kultgesetzen," in J. Assmann - T. Sundermeier (Ed.), Schuld, Gewissen und Person, Gütersloh 1997, 142-179.

Chapman, G., "Some Notes on Dramatic Illusion in Aristophanes," AJP 104, 1983, 1-23.

Christ, M., The Litigious Athenian, Baltimore - London 1998a.

, "Legal Self-Help on Private Property in Classical Athens," AJP 119, 1998b, $521-545$

Cohen, D., "Introduction," in M. Gagarin - D. Cohen (Ed.), The Cambridge Companion to Ancient Greek Law, Cambridge 2005a, 1-26.

— , "Theories of Punishment," in M. Gagarin - D. Cohen (Ed.), The Cambridge Companion to Ancient Greek Law, Cambridge 2005b, 170-190.

_ - "Crime, Punishment, and the Rule of Law in Classical Athens," in M. Gagarin - D. Cohen (Ed.), The Cambridge Companion to Ancient Greek Law, Cambridge 2005c, 211-235.

_ , "Women, Property and Status in Demosthenes 41 and 57," Dike 1, 1998, 53-61.

—, Law, Violence, and Community in Classical Athens, Cambridge 1995.

_- "Consent and Sexual Relations in Classical Athens," in A. Laiou (Ed.), Consent and Coercion to Sex and Marriage in Ancient and Medieval Societies, Washington, DC 1993, 5-16.

— "Sexuality, Violence, and the Athenian Law of Hybris," G\&R 38, 1991a, $171-188$.

- Law, Sexuality, and Society. The Enforcement of Morals in Classical Athens, Cambridge 1991b.

— , "The Social Context of Adultery at Athens," in P. Cartledge - P. Millett - S. Todd (Ed.), Nomos. Essays in Athenian Law, Politics, and Society, Cambridge 1990, 147-165.

— , "The Athenian Law of Adultery," RIDA 31, 1984, 147-165.

- Theft in Athenian Law, München 1983.

Cole, S., Landscape, Gender, and Ritual Space. The Ancient Greek Experience, Berkeley - Los Angeles - London 2004. 
, "Oath Ritual and the Male Community at Athens," in J. Ober - C. Hedrick (Ed.), Demokratia. A Conversation on Democracies, Ancient and Modern, Princeton 1996, 227-248.

—_, "Greek Sanctions Against Sexual Assault," CP 79, 1984, 97-113.

Collins, D., Magic in the Ancient Greek World, Oxford - Malden/MA 2008. , "Nature, Cause, and Agency in Greek Magic," TAPA 133, 2003, 17-49.

_ "Theoris of Lemnos and the Criminalization of Magic in Fourth-Century Athens," CQ 51, 2001, 477-493.

Connor, W., City Dionysia and Athenian Democracy," Cl\&Med. 40, 1989, 7-32.

— , "Early Greek Land Warfare as Symbolic Expression," P\&P 119, 1988a, $3-29$.

— sical Greece," CA 7, 1988b, 155-189.

_ ens," JHS 107, 1987, 40-50.

— , "The Razing of the House in Greek Society," TAPA 115, 1985, 79-102.

Cooper, C., "Hyperides and the Trial of Phryne," Phoenix 49, 1995, 303-318.

Coppet, D. de, Understanding Rituals, London - New York 1992.

Cornford, F., The Origins of Attic Comedy, Garden City/NY ${ }^{2} 1961$; ed. by T. Gaster; introduction by J. Henderson, Ann Arbor 1993 (London 1914).

Corsini, E., "Gli ucelli di Aristofane: Utopia o satira politica?" in R. Uglione (Ed.), Atti del convegno nazionale di studi su La città ideale nella tradizione classica e biblico-cristiana, Torino 2 -4 Maggio 1985, Torino 1987, 57-136.

Coser, L., Continuities in the Studies of Social Conflict, New York 1967.

- The Functions of Social Conflict, New York ${ }^{2} 1966$ (1956).

_ Sociological Theory, New York 1964.

Costabile, F., "Defixiones dal Kerameikos di Atene IV," Minima Epigraphica et Papyrologica 7/8, 2004/5, 136-192.

_, "La triplice defixio: Nuova lettura, processo e norma libraria attica nel V-IV sec. A.C. Defixiones dal Kerameikos di Atene - III," Minima Epigraphica et Papyrologica 4, 2001, 143-208.

— yrologica 4, 2000, 37-122 (= "Fluchtafeln," Ath. Mitt. 114, 1999 [2001], 87104).

— ed un logografo attico del IV sec. A.C.," Minima Epigraphica et Papyrologica 1, 1998, 9-54.

Cottone, R., Aristofane e la poetica dell'ingiuria. Per una introduzione alla loidoria comica, Roma 2005.

Coulon, V., Aristophane, vol. 1, Paris 1952.

Craik, E., "One for the Pot: Aristophanes' Birds and the Anthesteria," Eranos $85,1987,25-34$.

Csapo, E., "From Aristophanes to Menander? Genre Transformation in Greek Comedy," in M. Depew - D. Obbink (Ed.), Matrices of Genre: Authors, Canons, and Society, Cambridge/MA 2000, 115-134.

_ 1993, 1-28; Part II: 115-124. 
Csapo, E. - Miller, M. (Ed.), The Origins of Theater in Ancient Greece and Beyond. From Ritual to Drama, Cambridge - New York 2007a.

Csapo, E. - Miller, M., "General Introduction," in E. Csapo - M. Miller (Ed.), The Origins of Theater in Ancient Greece and Beyond. From Ritual to Drama, Cambridge - New York 2007b, 1-38.

Curbera, J.- Jordan, D., "A Curse Tablet from the 'Industrial District' Near the Athenian Agora," Hesperia 67, 1998, 215-218.

D'Agostino, F., Bia. Violenza e giustizia nella filosofia e nella letteratura della Grecia antica, Milano 1983.

Dahrendorf, R., Class and Class Conflict in Industrial Society, Stanford 1973 (Soziale Klassen und Klassenkonflikt in der industriellen Gesellschaft, Stuttgart 1957).

Davies, M., "Popular Justice and the End of Aristophanes' Clouds," Hermes 118, 1990, 237-242.

Davis, N., Fiction in the Archives: Pardon Tales and their Tellers in SixteenthCentury France, Stanford 1987.

— , "The Rites of Violence," in Id. (Ed.), Society and Culture in Early Modern France, Stanford 1975, 152-187.

Deacy, S. - Pierce, K. (Ed.), Rape in Antiquity, London 1997.

Dedoussi, C., "The Samia," in E. Turner (Ed.), Ménandre. Entretiens sur l'antiquité classique XVI, Vandœuvres - Genève 1970, 159-170.

Degani, E., "Aristofane e la tradizione dell'invettiva personale in Grecia," in: J. Bremer - E. Handley (Ed.), Aristophane, Vandœuvres - Genève 1993, 2 49.

—_, "Insulto ed escrologia in Aristofane," Dioniso 57, 1987, 31-47.

De Ste. Croix, G., The Origins of the Peloponnesian War, London 1972.

Dettenhofer, M., "Praxagoras' Programm. Eine politische Deutung von Aristophanes' Ekklesiazusen zur inneren Geschichte Athens im 4. Jahrhundert v. Chr.," Klio 81, 1999, 95-111.

Deubner, L., Attische Feste, Darmstadt ${ }^{3} 1969$ (1932).

Diamond, E. (Ed.), Performance and Cultural Politics, London 1996.

Dickie, M., Magic and Magicians in the Greco-Roman World, London - New York 2003.

— Philosophy: Studies in Honour of L. Woodbury, Chicago 1984, 83-109.

Diels, H., Die Fragmente der Vorsokratiker. Griechisch und Deutsch, 2. Bd., ed. by W. Kranz, Berlin ${ }^{9} 1959$ (1903).

Dillon, J., Salt and Olives. Morality and Custom in Ancient Greece, Edinburgh 2004.

Dinges, M., "Formenwandel der Gewalt in der Neuzeit. Zur Kritik der Zivilisationstheorie von Norbert Elias," in R. Sieferle - H. Breuninger (Ed.), Kulturen der Gewalt. Ritualisierung und Symbolisierung von Gewalt in der Geschichte, Frankfurt/M. - New York 1998, 171-194.

Dionisopoulos-Mass, R., "Greece: The Evil Eye and Bewitchment in a Peasant Village," in C. Maloney (Ed.), The Evil Eye, New York 1976, 42-62.

Doblhofer, G., Vergewaltigung in der Antike, Stuttgart - Leipzig 1994. 
Dobrov, G., Figures of Play. Greek Drama and Metafictional Poetics, Oxford 2001.

— - "Language, Fiction, and Utopia," in G. Dobrov (Ed.), The City as Comedy. Society and Representation in Athenian Drama, Chapel Hill - London 1997, 95-132.

, "The Dawn of Farce," in J. Redmond (Ed.), Farce. Themes in Drama 10, Cambridge 1988, 15-31.

Dobson, J., The Greek Orators, Freeport/NY 21971 (1967).

Dodd, D. - Faraone, C. (Ed.), Initiation in Ancient Greek Rituals and Narratives: New Critical Perspectives, London 2005.

Dössel, A., Die Beilegung innerstaatlicher Konflikte in den griechischen Poleis vom 5.-3. Jh. v. Chr., Frankfurt/M. et al. 2003.

Douglas, M., Ritual, Tabu und Körpersymbolik. Sozialanthropologische Studien in Industriegesellschaft und Stammeskultur, Tübingen 1974 (Natural Symbols: Explorations in Cosmology, Harmondsworth 1970).

Dover, K., Aristophanes. Frogs. Edited with Introduction and Commentary, Oxford 1993.

—, Greek Popular Morality in the Time of Plato and Aristotle, Oxford 1974. , Aristophanic Comedy, London 1972.

Drake, H. (Ed.), Violence in Late Antiquity. Perceptions and Practices, Aldershot - Burlington/VT 2006.

Dressel, G., Historische Anthropologie. Eine Einführung, Wien 1996.

Dreyer, B., "Der Tod des Nikodemos von Aphidnai und die Meidias-Rede des Demosthenes," The Ancient History Bulletin 14, 2000, 56-63.

Dubois, L., Inscriptions Grecques Dialectales De Sicile. Contribution à l'étude du vocabulaire grec colonial, Paris - Rome 1989.

DuBois, P., Torture and Truth, New York - London 1991.

, Centaurs and Amazons. Women and the Pre-History of the Great Chain of Being, Ann Arbor 1982.

Dülmen, R. van, Theater des Schreckens. Gerichtspraxis und Strafrituale in der Frühen Neuzeit, München ${ }^{2} 1988$ (1985).

Dunbar, N., Aristophanes. Birds, Oxford 1995.

Dundes, A., The Evil Eye: a Casebook, Madison/WI 1992.

Easterling, P., "Actors and Voices: Reading Between the Lines in Aischines and Demosthenes," in S. Goldhill - R. Osborne (Ed.), Performance Culture and Athenian Democracy, Cambridge 1999, 154-166.

Edmunds, L., "Aristophanes' Socrates," Proceedings of the Boston Area Colloquium in Ancient Philosophy, vol. 1, Lanham/MD 1986, 209-230.

Eduntoulakis, F., Violence and Theatricality: Studies on Violence as a Dramatic Element in Classical and Post-Classical Greek Tragedy, Manchester 1995 (Diss.).

Edwards, M., The Attic Orators, Bristol - London 1994.

Ehrenberg, V., Aristophanes und das Volk von Athen. Eine Soziologie der altattischen Komödie, Zürich - Stuttgart 1968 (The people of Aristophanes, Oxford 1943).

Eidinow, E., Oracles, Curses, and Risk among the Ancient Greeks, Oxford 2007a. 
— "Why the Athenians Began to Curse," in R. Osborne (Ed.), Debating the Athenian Cultural Revolution, Cambridge 2007b, 54-71.

Eitrem, S., "Rezension von Erich Ziebarth, Neue Verfluchungstafeln aus Attika, Boiotien und Euboia," Gnomon 12, 1936, 557-558.

Elderkin, G., "Two Curse Inscriptions," Hesperia 6, 1937, 382-395.

Elias, N., Über den Prozeß der Zivilisation. Soziogenetische und psychogenetische Untersuchungen, 2 vols., Frankfurt/M. ${ }^{5} 1978$ (Basel 1939).

Ellis, W., Alcibiades, London - New York 1989.

Engels, J., Funerum sepulcrorumque magnificentia. Begräbnis- und Grabluxusgesetze in der griechisch-römischen Welt mit einigen Ausblicken auf Einschränkungen des funeralen und sepulkralen Luxus in Mittelalter und in der Neuzeit, Stuttgart 1998.

Erbse, H., "Antiphons Rede (or. 5) über die Ermordung des Herodes," RhM 120, 1977, 209-227.

_- "Sokrates im Schatten der aristophanischen Wolken," Hermes 82, 1954, $385-420$.

Ercolani, A., "Names, Satire and Politics in Aristophanes," in L. Kozak - J. Rich (Ed.), Playing Around Aristophanes: Essays in Celebration of the Completion of the Edition of the Comedies of Aristophanes by Alan Sommerstein, Oxford 2006, 17-26.

—, "Gewalt in der griechischen Tragödie," in G. Fischer - S. Moraw (Ed.), Die andere Seite der Klassik. Gewalt im 5. und 4. Jahrhundert v. Chr., Stuttgart 2005, 89-101.

— spiel der Acharner," in A. Ercolani (Ed.), Spoudaiogeloion. Form und Funktion der Verspottung in der aristophanischen Komoedie, Stuttgart Weimar 2002, 225-254.

Eriksson, M. - Krug-Richter, B. (Ed.), Streitkulturen. Gewalt, Konflikt und Kommunikation in der ländlichen Gesellschaft (16.-19. Jahrhundert), Köln - Weimar - Wien 2003.

Evjen, H., "Apagoge and Athenian Homicide Procedure," Revue d'histoire du Droit 38, 1970, 403-415.

Fantham, E., "Sex, Status and Survival in Hellenistic Athens: A Study of Women in New Comedy," Phoenix 29, 1975, 44-74.

Faraone, C., "Priestess and Courtesan: The Ambivalence of Female Leadership in Aristophanes' Lysistrata," in C. Faraone - L. McClure (Ed.), Prostitutes and Courtesans in the Ancient World, Madison 2006, 207-223.

_ - "Thumos as Masculine Ideal and Social Pathology in Ancient Greek Magical Spells," in S. Braund - G. Most (Ed.), Ancient Anger. Perspectives from Homer to Galen, Cambridge 2003, 144-162.

- "Curses and Social Control in the Law Courts of Classical Athens," Dike 2, 1999a, 99-121.

—_, Ancient Greek Love Magic, Cambridge/MA 1999b.

- Talismans and Trojan Horses: Guardian Statues in Ancient Greek Myth and Ritual, Oxford 1992. 
, "The Agonistic Context of Early Greek Binding Spells," in C. Faraone -

D. Obbink (Ed.), Magika Hiera: Ancient Greek Magic and Religion, Oxford - New York 1991a, 3-32.

, "Binding and Burying the Forces of Evil: the Defensive Use of Voodoo Dolls in Ancient Greece," CA 10, 1991b, 165-220.

- "An Accusation of Magic in Classical Athens (Ar. Wasps 946-48)," TAPA 119, 1989, 149-160.

- Talismans, Voodoo Dolls, and Other Apotropaic Statues in Early Greece, Stanford 1988 (Diss.).

—_, "Aeschylus' Hymnos Desmios (Eum. 306) and Attic Judicial Curse Tablets," JHS 105, 1985, 150-154.

Farenga, V., Citizen and Self in Ancient Greece. Individuals Performing Justice and the Law, Cambridge 2006.

Farioli, M., Mundus alter. Utopie e distopie nella commedia greca antica, Milano 2001.

Felton, D., "The Dead," in D. Ogden (Ed.), A Companion to Greek Religion, Malden/MA - Oxford 2007, 86-99.

Feyel, C., $\triangle \mathrm{OKIMA \Sigma IA.} \mathrm{La} \mathrm{place} \mathrm{et} \mathrm{le} \mathrm{rôle} \mathrm{de} \mathrm{l'examen} \mathrm{préliminaire} \mathrm{dans} \mathrm{les} \mathrm{in-}$ stitutions des cités grecques, Paris 2009.

Fischer, G. - Moraw, S. (Ed.), Die andere Seite der Klassik. Gewalt im 5. und 4. Jahrhundert v. Chr., Stuttgart 2005.

Fischer-Lichte, E., "Performance, Inszenierung, Ritual: Zur Klärung kulturwissenschaftlicher Schlüsselbegriffe," in J. Martschukat - S. Patzold (Ed.), Geschichtswissenschaft und Performative Turn. Ritual, Inszenierung und Performanz vom Mittelalter bis zur Neuzeit, Köln - Weimar - Wien 2003, $33-54$.

— , "Für eine Ästhetik des Performativen," in E. Göbel - W. Klein (Ed.), Literaturforschung heute, Berlin 1999, 221-228.

_ , "Grenzgänge und Tauschhandel. Auf dem Wege zu einer performativen Kultur," in E. Fischer-Lichte - F. Kreuder - I. Pflug (Ed.), Theater seit den 60er Jahren. Grenzgänge der Neo-Avantgarde, Tübingen - Basel 1998a, 120.

—, "Verwandlungen als ästhetische Kategorie. Zur Entwicklung einer neuen Ästhetik des Performativen," in E. Fischer-Lichte - F. Kreuder - I. Pflug (Ed.), Theater seit den 60er Jahren. Grenzgänge der Neo-Avantgarde, Tübingen - Basel 1998b, 21-91.

Fisher, N., "Body-Abuse: The Rhetoric of Hybris in Aeschines' Against Timarchus," in J.-M. Bertrand (Ed.), La violence dans les mondes grec et romain. Actes du colloque international (Paris, 2-4 mai 2002), Paris 2005, 67-89.

- "The Perils of Pittalakos: Settings of Cock Fighting and Dicing in Classical Athens," in S. Bell - G. Davies (Ed.), Games and Festivals in Classical Antiquity. Proceedings of the Conference held in Edinburgh 10-12 July 2000, Oxford 2004, 65-78.

— - "Let Envy be Absent: Envy, Liturgies and Reciprocity in Athens," in D. Konstan - K. Rutter (Ed.), Envy, Spite and Jealousy. The Rivalrous Emotions in Ancient Greece, Edinburgh 2003, 181-215. 
, "Hybris, Revenge and Stasis in the Greek City-States," in H. van Wees

(Ed.), War and Violence in Ancient Greece, London 2000, 83-123.

_, "Violence, Masculinity, and the Law in Classical Athens," in L. Foxhall J. Salmon (Ed.), When Men were Men: Masculinity, Power, and Identity in Classical Antiquity, London 1998a, 68-97.

_, , "Workshops of Villains': Was there much Organised Crime in Classical Athens?" in K. Hopwood, (Ed.), Organised Crime in Antiquity, London 1998b, 53-96.

— tophanes' Acharnians," G\&R 40, 1993, 31-47.

- , Hybris. A Study in the Values of Honour and Shame in Ancient Greece, Warminster 1992.

- "The Law of Hubris in Athens," in P. Cartledge - P. Millett - S. Todd (Ed.), Nomos. Essays in Athenian Law, Politics, and Society, Cambridge 1990, 123-138.

— "Hybris and Dishonour: II," $G \& R$ 26, 1979, 32-47.

- "Hybris and Dishonour: I," $G \& R$ 23, 1976, 177-193.

Fisher, R., Aristophanes' Clouds: Purpose and Technique, Amsterdam 1984.

Fitton, J., "Menander and Euripides: Themes and Treatment," Pegasus 20, 1981, $25-31$.

Flaig, E., "Gewalt als präsente und als diskursive Obsession in der griechischen Klassik," in B. Seidensticker - M. Vöhler, (Ed.), Gewalt und Ästhetik. Zur Gewalt und ihrer Darstellung in der griechischen Klassik, Berlin 2006, 2956.

— der Aufstand von 507 v. Chr. vergessen wurde," HZ 279, 2004a, 35-61.

— athenischen Demokratie," in G. Butzer - M. Günther (Ed.), Kulturelles Vergessen: Medien - Rituale - Orte, Erinnerungskulturen, Göttingen 2004b, $101-114$.

— tingen 2003.

_ Warburg-Haus 3, 1999, 31-100.

—, "Amnestie und Amnesie in der griechischen Kultur. Das vergessene Selbstopfer für den Sieg im athenischen Bürgerkrieg 403 v. Chr.," Saeculum 42, 1991, 129-149.

Foley, H., "Tragedy and Politics in Aristophanes' Acharnians," JHS 108, 1988, $33-47$.

Fornasier, J., Amazonen: Frauen, Kämpferinnen und Städtegründerinnen, Mainz 2007.

Forsdyke, S., "Street Theater and Popular Justice in Ancient Greece. Shaming, Stoning, and Starving Offenders Inside and Outside the Courts," Past \& Present 201, 2008, 3-50.

- Exile, Ostracism, and Democracy. The Politics of Expulsion in Ancient Greece, Princeton - Oxford 2005. 
Fowler, R., "Greek Magic, Greek Religion," in R. Buxton (Ed.), Oxford Readings in Greek Religion, Oxford 2000, 317-343.

Foxhall, L. - Salmon, J. (Ed.), When Men were Men. Masculinity, Power, and Identity in Classical Antiquity, London - New York 1998.

Frank, M., Dörfliche Gesellschaft und Kriminalität. Das Fallbeispiel Lippe 1650_ 1800, Paderborn - München et al. 1995.

Frazer, J., The Golden Bough. A Study in Magic and Religion, 12 vols., London ${ }^{3} 1907-1915$ (1890 2 volumes, 1900 six volumes).

Freydberg, B., Philosophy and Comedy: Aristophanes, Logos, and Eros, Bloomington/IN 2008.

Friedrich, R., "Drama and Ritual," in J. Redmond (Ed.), Drama and Religion. Themes in Drama 5, Cambridge 1983, 159-223.

Fuchs-Heinritz, W. - Lautmann, R. - Rammstedt, O. - Wienold, H. (Ed.), Lexikon zur Soziologie, Opladen ${ }^{3} 1994$ (1978).

Fuks, A., Social Conflict in Ancient Greece, Leiden 1984.

Gänszle, M., "Sind Rituale bedeutungslos? Rituelles Sprechen im performativen Kontext," in K.-P. Köpping - U. Rao (Ed.), Im Rausch des Rituals. Gestaltung und Transformation der Wirklichkeit in körperlicher Performanz, Hamburg 2000, 33-44.

Gagarin, M., "Litigants' Oaths in Athenian Law," in A. Sommerstein - J. Fletcher (Ed.), Horkos. The Oath in Greek Society, Exeter 2007, 39-47.

_ - "La violence dans les plaidoyers attiques," in J.-M. Bertrand (Ed.), La violence dans les mondes grec et romain. Actes du colloque international (Paris, 2-4 mai 2002), Paris 2005, 365-376.

- Athenian Homicide Law: Case Studies. CHS lecture (http://chs.harvard. edu/chs/gargarin_athenian_homicide_law_case_studies; 2003a).

—, Telling Stories in Athenian Law. CHS lecture (http://www.apaclassics. org/Publications/PresTalks/Gagarin.html; 2003b).

_- Antiphon the Athenian. Oratory, Law, and Justice in the Age of the Sophists, Austin/TX 2002.

_ , "Women in Athenian Courts," Dike 1, 1998, 39-51.

_ "The Torture of Slaves in Athenian Law", CP 91, 1996, 1-18.

—_, "Bouleusis in Athenian Homicide Law," in G. Nenci - G. Thür (Ed.), Symposion 1988. Vorträge zur griechischen und hellenistischen Rechtsgeschichte, Köln - Wien 1990, 81-99.

- The Murder of Herodes. A Study of Antiphon 5, Frankfurt/M. 1989. , Drakon and Early Athenian Homicide Law, New Haven - London 1981. , "The Athenian Law against Hybris," in G. Bowersock - W. Burkert - M. Putnam (Ed.), Arktouros. Hellenic Studies Presented to Bernard M. W. Knox on the Occasion of His 65th Birthday, Berlin - New York 1979a, 229-236.

- "The Prosecution of Homicide in Athens," GRBS 20, 1979b, 301-323. , Self-Defense in Athenian Homicide Law, GRBS 19, 1978, 111-120.

Gagarin, M. - Cohen, D. (Ed.), The Cambridge Companion to Ancient Greek Law, Cambridge 2005.

Gager, J., Curse Tablets and Binding Spells from Antiquity and the Ancient World, New York 1992.

Galtung, J., Strukturelle Gewalt, Reinbek 1975. 
Garner, R., Law and Society in Classical Athens, London - Sydney 1987.

Geertz, C., Dichte Beschreibung. Beiträge zum Verstehen kultureller Systeme, Frankfurt/M. 1987 (1983) ("Thick description: Toward an interpretive theory of culture," in Id., The Interpretation of Cultures: Selected Essays, New York 1973, 3-30).

— The Interpretation of Cultures: Selected Essays, New York 1973.

_- "Deep Play: Notes on the Balinese Cockfight," in Id. (Ed.), Myth, Symbol, and Culture, New York 1971, 1-37.

Gehrke, H.-J., "Die Griechen und die Rache. Ein Versuch in historischer Psychologie," Saeculum 38, 1987, 121-149.

_- Jenseits von Athen und Sparta: das dritte Griechenland und seine Staatenwelt, München 1986.

- Stasis: Untersuchungen zu den inneren Kriegen in den griechischen Staaten des 5. und 4. Jahrhunderts v. Chr., München 1985.

Gelzer, T., Aristophanes. Komödie für den Demos der Athener, Basel 1999.

—_, "Aristophanes und sein Sokrates," MH 13, 1956, 65-93.

Gennep, A. van, Les rites de passage. Etude systematique des rites, Paris 1909 (repr. 1981; Übergangsriten, Frankfurt/M. - New York 1986; The Rites of Passage, London - Chicago 1960).

Gentili, B., "Remarks at the American Academy in Rome, February 12, 1994," in L. Edmunds - R. Wallace (Ed.), Poet, Public, and Performance in Ancient Greece, Baltimore - London 1997, 124-127.

Gerhardt, U., "Die zwei Gesichter des Rituals. Eine soziologische Skizze," in D. Harth - G. Schenk (Ed.), Ritualdynamik. Kulturübergreifende Studien zur Theorie und Geschichte rituellen Handelns, Heidelberg 2004, 49-72.

Gernet, L., The Anthropology of Ancient Greece, Baltimore - London 1981.

Gernet, L. - Bizos, M., Lysias, Discours, vol. 2, Paris 1955 (Budé).

Giovannini, A., Les relations entre états dans la Grèce antique du temps d'Homère a l'intervention romaine (ca. 700-200 av. J.-C.), Stuttgart 2007.

Girard, R., La Violence et le Sacré, Paris 1972 (Violence and the Sacred, London - Baltimore 1977; Das Heilige und die Gewalt, Frankfurt/M. 1992).

Glotz, G., La solidarité de la famille dans le droit criminel en Grèce, New York 1973 (Paris 1904).

Goff, B., Citizen Bacchae. Women's Ritual Practice in Ancient Greece, Berkeley - Los Angeles - London 2004.

Goffmann, E., Interaction Ritual. Essays on Face-to-Face Behavior, New York 2005 (1967).

Goldberg, S., "Comedy and Society from Menander to Terence," in M. McDonald - J. Walton (Ed.), The Cambridge Companion to Greek and Roman Theatre, Cambridge 2007, 124-138.

- The Making of Menander's Comedy, London 1980.

Goldhill, S., "Der Ort der Gewalt. Was sehen wir auf der Bühne?" in B. Seidensticker - M. Vöhler (Ed.), Gewalt und Ästhetik. Zur Gewalt und ihrer Darstellung in der griechischen Klassik, Berlin 2006, 149-168.

$\longrightarrow$, Reding Greek Tragedy, Cambridge ${ }^{2} 2001$ (1986).

-, "Violence in Greek Tragedy," in J. Redmond (Ed.), Violence in Drama.

Themes in Drama 13, Cambridge 1991, 15-33. 
- "The Great Dionysia and Civic Ideology," in J. Winkler - F. Zeitlin (Ed.), Nothing to do with Dionysus? Athenian Drama in its Social Context, Princeton 1990, 97-129.

_ - "Reading Performance Criticism," G\&R 36, 1989, 172-182.

Goldhill, S. - Osborne, R. (Ed.), Performance Culture and Athenian Democracy, Cambridge 1999.

Gomme, A. "Aristophanes and Politics," CR 52, 1938, 97-109.

Gomme, A. - Sandbach, F., Menander. A Commentary, Oxford 1973.

Gordon, R., "What's in a List," in: D. Jordan - H. Montgomery - E. Thomassen (Ed.), The World of Ancient Magic: Papers from the First International Samson Eitrem Seminar at the Norwegian Institute at Athens, 4-8 May 1997, Bergen 1999a, 239-277.

_ _ "Imagining Greek and Roman Magic," in B. Ankarloo - S. Clark (Ed.), Witchcraft and Magic in Europe: Ancient Greece and Rome, Philadelphia 1999b, 159-275.

_ , "Aelian's Peony: The Location of Magic in Graeco-Roman Tradition," Comparative Criticism 9, 1987, 59-95.

Gould, J., Herodotus, New York 1989.

Grace, E., "Note on Dem. 47.72 Touton tas episkepseis einai," Eirene 13, 1975, $5-18$.

Graf, F., "Religion and Drama," in M. McDonald - M. Walton (Ed.), The Cambridge Companion to Greek and Roman Theatre, Cambridge 2007a, 55-71.

_ _ "Untimely Death, Witchcraft, and Divine Vengeance. A Reasoned Epigraphical Catalog," ZPE 162, 2007b, 139-150.

$\longrightarrow$, (Ed.), Ansichten griechischer Rituale. Geburtstag-Symposium für Walter Burkert, Stuttgart - Leipzig 1998a.

— Effe (Ed.), Das antike Theater. Aspekte seiner Geschichte, Rezeption und Aktualität, Trier 1998b, 11-32b.

- Gottesnähe und Schadenzauber: die Magie in der griechisch-römischen Antike, München 1996 (La magie dans l'antiquité gréco-romaine, Paris 1994; Magic in the Ancient World, Cambridge/MA - London 1997).

Grant, J., "The Father-Son Relationship and the Ending of Menander's Samia," Phoenix 40, 1986, 172-184.

Green, J., "Let's Hear it for the Fat Man: Padded Dancers and the Prehistory of Drama," in E. Csapo - M. Miller (Ed.), The Origins of Theater in Ancient Greece and Beyond. From Ritual to Drama, Cambridge - New York 2007, 96-107.

Gribble, D., Alcibiades and Athens. A Study in Literary Presentation, Oxford 1999.

Grimes, R., Beginnings in Ritual Studies, New York - London 1982.

Groebner, V., "Der verletzte Körper und die Stadt. Gewalttätigkeit und Gewalt in Nürnberg am Ende des 15. Jhs.," in T. Lindenberger - A. Lüdtke (Ed.), Physische Gewalt. Studien zur Geschichte der Neuzeit, Frankfurt/M. 1995, $162-189$.

Gröschel, S.-G., Waffenbesitz und Waffeneinsatz bei den Griechen, Frankfurt/M. 1989. 
Groton, A., “Anger in Menander's Samia,” AJP 108, 1987, 437-443.

Guarducci, M., "Defixiones," in Id., Epigrafia greca IV, Roma 1978, 240-257.

Gutsfeld, A. - Schmitz, W. (Ed.), Am schlimmen Rand des Lebens? Altersbilder in der Antike, Köln - Weimar - Wien 2003.

Gutzwiller, K., "The Tragic Mask of Comedy: Metatheatricality in Menander," CA 19, 2000, 102-137.

Habicht, C., "Attische Fluchtafeln aus der Zeit Alexanders des Großen," in C. Habicht, Athen in Hellenistischer Zeit. Gesammelte Aufsätze, München 1994, 14-18 (= ICS 18, 1993, 113-118).

Hall, E., The Theatrical Cast of Athens. Interactions Between Ancient Greek Drama and Society, Oxford 2006.

— , "Lawcourt Dramas: The Power of Performance in Greek Forensic Oratory," BICS 40, 1995, 39-58.

_ Inventing the Barbarian. Greek Self-Definition Through Tragedy, Oxford 1989a.

_, "The Archer Scene in Aristophanes' Thesmophoriazusae," Philologus 133, 1989b, 38-54

Halliwell, S., Greek Laughter: A Study of Cultural Psychology from Homer to Early Christianity, Cambridge - New York 2008.

__ "Aischrology, Shame, and Comedy," in I. Sluiter - R. Rosen (Ed.), Freedom of Speech in Classical Antiquity, Leiden 2004, 115-144.

_ - "The Uses of Laughter in Greek Culture," CQ 41, 1991a, 279-296.

_- "Comic Satire and Freedom of Speech in Classical Athens," JHS 111, 1991b, 48-70.

Hamel, D., Trying Neaira. The True Story of a Courtesan's Scandalous Life in Ancient Greece, New Haven - London 2003.

Hamerton-Kelly, R. - Rosaldo, R. - Burton, M., Violent Origins: Walter Burkert, René Girard, and Jonathan Z. Smith on Ritual Killing and Cultural Formation, Stanford 1987.

Handley, E. (Ed.), The Dyskolos of Menander, London 1965.

Hansen, M., "Was the Polis a State or a Stateless Society?" in T. Nielsen (Ed.), Even More Studies in the Ancient Greek Polis, Stuttgart 2002, 17-47.

_- Was Athens a Democracy? Popular Rule, Liberty, and Equality in Ancient and Modern Political Thought, Kopenhagen 1989a.

— racy," $C \& M 40,1989$ b, 107-113.

__ "Graphe or Dike Traumatos?" GRBS 24, 1983, 307-320.

_- "The Prosecution of Homicide in Athens: A Reply," GRBS 22, 1981, $11-30$.

—- Apagoge, Endeixis and Ephegesis against Kakourgoi, Atimoi and Pheugontes: A Study in the Athenian Administration of Justice in the Fourth Century B.C, Odense 1976.

_ Eisangelia. The Sovereignty of the People's Court in Athens in the Fourth Century BC and the Impeachment of Generals and Politicians, Odense 1975.

Harding, P., "Comedy and Rhetoric," in I. Worthington (Ed.), Persuasion: Greek Rhetoric in Action, London - New York 1994, 196-221. 
Harrell, H., "Public Arbitration in Athenian Law," The University of Missouri Studies 11, 1936, 1-42.

Harriott, R., Aristophanes. Poet and Dramatist, London 1986. $1-8$.

Harris, E., "Who Enforced the Law in Classical Athens?" in E. Cantarella (Ed.), Symposion 2005. Vorträge zur griechischen und hellenistischen Rechtsgeschichte, Wien 2007, 159-176.

- Democracy and the Rule of Law in Classical Athens. Essays on Law, Society, and Politics, Cambridge 2006.

_- "Feuding or the Rule of Law? The Nature of Litigation in Classical Athens. An Essay in Legal Sociology," in R. Wallace - M. Gagarin (Ed.), Symposion 2001. Vorträge zur griechischen und hellenistischen Rechtsgeschichte, Wien 2005, 125-141.

_ - "Did Rape Exist in Classical Athens? Further Reflections on the Laws about Sexual Violence," Dike 7, 2004, 41-83 (= in Democracy and the Rule of Law in Classical Athens. Essays on Law, Society, and Politics, Cambridge 2006, 297-332).

_- "Open Texture in Athenian Law," Dike 3, 2000, 27-79.

, "The Penalty for Frivolous Prosecution in Athenian Law," Dike 2, 1999, $123-142$.

_, "review of D. M. MacDowell, Demosthenes against Meidias," CP 87, 1992, 71-80.

- "Did the Athenians Regard Seduction as a Worse Crime than Rape?" CQ 40, 1990, 370-377 (= in Democracy and the Rule of Law in Classical Athens. Essays on Law, Society, and Politics, Cambridge 2006, 283-295).

_- "Demosthenes' Speech Against Meidias," HSCP 92, 1989, 117-136.

Harris, E. - Leão, D. - Rhodes, P. (Ed.), Law and Drama in Ancient Greece, London 2010.

Harris, E. - Rubinstein, L. (Ed.), The Law and the Courts in Ancient Greece, London 2004.

Harris, W., Restraining Rage. The Ideology of Anger Control in Classical Antiquity, Cambridge/MA - London 2001.

__ "Lysias III and Athenian Beliefs about Revenge," CQ 47, 1997, 363 366.

Harrison, A., The Law of Athens, 2 vols., Oxford 1968/1971 (new edition, foreword and bibliography by D. M. MacDowell, London 1998).

Harrison, T. (Ed.), Greeks and Barbarians, New York 2002.

Harth, D., "Handlungstheoretische Aspekte der Ritualdynamik," in D. Harth G. Schenk - G. Jasper (Ed.), Ritualdynamik. Kulturübergreifende Studien zur Theorie und Geschichte rituellen Handelns, Heidelberg 2004, 95-113.

Harth, D. - Schenk, G. (Ed.), Ritualdynamik. Kulturübergreifende Studien zur Theorie und Geschichte rituellen Handelns, Heidelberg 2004.

Harvey, D., "Phrynichos and his Muses," in D. Harvey - J. Wilkins (Ed.), The Rivals of Aristophanes. Studies in Athenian Old Comedy, London 2000, $91-134$.

Harvey, F., "Nubes $1493 \mathrm{ff}:$ Was Socrates Murdered?” GRBS 22, 1981, 339-343. 
Hatzfeld, J., Alcibiade, Paris 1940.

Heath, M., "Aristophanes and the Discourse of Politics," in: G. Dobrov (Ed.), The City as Comedy: Society and Representation in Athenian Drama, Chapel Hill 1997, 230-249.

—, Political Comedy in Aristophanes, Göttingen 1987.

Heberlein, F., Plythygieia. Zur Gegenwelt bei Aristophanes, Frankfurt/M. 1980.

Hedreen, G., "Myths of Ritual in Athenian Vase-Paintings of Silens," in E. Csapo - M. Miller (Ed.), The Origins of Theater in Ancient Greece and Beyond. From Ritual to Drama, Cambridge - New York 2007, 150-195.

Heftner, H., "Die Pseudo-Andokideische Rede 'Gegen Alcibiades' (And. 4) Ein authentischer Beitrag zu einer Ostrakophoriedebatte des Jahres 415 v. Chr?" Philologus 145, 2001, 39-56.

Heitsch, E., Antiphon aus Rhamnus. Abhandlungen der Geistes- und Sozialwissenschaftlichen Klasse der Akademie der Wissenschaften und der Literatur; Jg. 1984, 3, Wiesbaden 1984.

Henderson, J., "Demos, Demagogue, Tyrants in Attic Old Comedy," in K. Morgan (Ed.), Popular Tyranny: Sovereignty and its Discontents in Ancient Greece, Austin/TX 2003, 155-179.

— , "Attic Old Comedy, Frank Speech, and Democracy," in D. Boedeker K. Raaflaub (Ed.), Democracy, Empire, and the Arts in Fifth-Century Athens, Cambridge/MA - London 1998a, 255-273.

_, "Mass versus Elite and the Comic Heroism of Peisetairos," in G. Dobrov (Ed.), The City as Comedy: Society and Representation in Athenian Drama, Chapel Hill 1998b, 135-48.

— Sommerstein - B. Zimmermann (Ed.), Tragedy, Comedy and the Polis, Bari 1993, 307-19.

— Aristophanes. Lysistrata, Edited with Introduction and Commentary, Oxford - New York 1987.

— London 1975 (repr. with corrections and additions, Oxford - New York 1991).

Henrichs, A., "Blutvergießen am Altar: Zur Ritualisierung der Gewalt im griechischen Opferkult," in B. Seidensticker - M. Vöhler (Ed.), Gewalt und Ästhetik. Zur Gewalt und ihrer Darstellung in der griechischen Klassik, BerlinNew York 2006, 59-87.

Henry, M., "Ethos, Mythos, Praxis: Women in Menander's Comedy," in M. Skinner (Ed.), Rescuing Creusa: New Methodological Approaches to Women in Antiquity. A Special Issue of Helios New Series 13(2), Lubbock/TX 1987, 141-150.

_- Menander's Courtesans and the Greek Comic Tradition, Frankfurt/M. New York 1985.

Herman, G., Morality and Behaviour in Democratic Athens. A Social History, Cambridge 2006.

— , "Athenian Beliefs about Revenge: Problems and Methods," PCPS 46, 2000, 7-27. 
— , "Review of D. Cohen, Law, Violence and Community in Classical Athens, Cambridge 1995," Gnomon 70, 1998, 605-615.

— , "Ancient Athens and the Values of Mediterranean Society," Mediterranean Historical Review 11, 1996, 5-36.

- "Honour, Revenge and the State in Fourth-Century Athens," in W. Eder (Ed.), Die athenische Demokratie im 4. Jh. v. Chr. Vollendung oder Verfall einer Verfassungsform?, Stuttgart 1995, 43-66.

- "How Violent was Athenian Society?" in R. Osborne - S. Hornblower (Ed.), Ritual, Finance, Politics. Athenian Democratic Accounts Presented to David Lewis, Oxford 1994, 99-117.

_ _ "Tribal and Civic Codes of Behaviour in Lysias 1," CQ 43, 1993, 406419.

Hillmann, K.-H., Wörterbuch der Soziologie, Stuttgart ${ }^{3} 1972$ (1969).

Hölkeskamp, K.-J., Schiedsrichter, Gesetzgeber und Gesetzgebung im archaischen Griechenland, Stuttgart 1999.

Hoff, R. von den, "Achill, das Vieh? Zur Problematisierung transgressiver Gewalt in klassischen Vasenbildern," in G. Fischer - S. Moraw (Ed.), Die andere Seite der Klassik. Gewalt im 5. und 4. Jahrhundert v. Chr., Stuttgart 2005, 225-246.

Hoffman, R., "Ritual License and the Cult of Dionysus," Athenaeum n.s. 67, 1989, $91-115$.

Hoffmann, H., "Hahnenkampf in Athen. Zur Ikonographie einer attischen Bildformel," Revue Archéologique 1974, 195-220.

Hofmann, H., Mythos und Komödie. Untersuchungen zu den Vögeln des Aristophanes, Hildesheim - New York 1976.

Hooker, J., "The Original Meaning of Hybris," Archiv für Begriffsgeschichte 19, 1975, 125-137.

Hopwood, K., "Aspects of Violent Crime in the Roman Empire," in P. McKechnie (Ed.), Thinking Like a Lawyer: Essays on Legal History and General History for John Crook on His Eightieth Birthday, Leiden - Boston Köln 2002, 63-80.

- (Ed.), Organised Crime in Antiquity, London 1998.

Hose, M., Drama und Gesellschaft Studien zur dramatischen Produktion in Athen am Ende des 5. Jahrhunderts, Stuttgart 1995a.

— , "Der Aristophanische Held," in B. Zimmermann (Ed.), Griechisch-römische Komödie und Tragödie, Stuttgart 1995b, 27-50.

Hubbard, T., "Utopianism and the Sophistic City in Aristophanes," in G. Dobrov (Ed.), The City as Comedy. Society and Representation in Athenian Drama, Chapel Hill - London 1997, 23-50.

- The Mask of Comedy. Aristophanea and the Intertextual Parabasis, Ithaca - London 1991.

Hugger, P. - Stadler, U. (Ed.), Gewalt. Kulturelle Formen in Geschichte und Gegenwart, Zürich 1995.

Hughes-Freeland, F. - Crain, M. (Ed.), Recasting Ritual. Performance, Media, Identity, London - New York 1998. 
Huizinga, J., Homo Ludens. A Study of the Play-Element in Culture, Boston ${ }^{4} 1964$ (1955) (Homo Ludens. Versuch einer Bestimmung des Spielelements der Kultur, Amsterdam 1939).

Humpers, A., "Le duel chez Ménandre," $R P h$ 46, 1922, 76-86.

Humphreys, S., "The Discourse of Law in Archaic and Classical Greece," Law and History Review 6.2., 1988, 465-493.

(Ed.), The Discourse of Law. Special Edition of History and Anthropology I 2, 1985a.

—_ "Social Relations on Stage: Witnesses in Classical Athens," in S. Humphreys (Ed.), The Discourse of Law. Special Edition of History and Anthropology I 2, London 1985b, 313-369 (repr. in E. Carawan (Ed.), Oxford Readings in the Attic Orators, Oxford - New York 2007, 140-213).

Hunter, V., "The Prison of Athens: A Comparative Perspective," Phoenix 51, 1997, 296-326.

—, Policing Athens. Social Control in the Attic Lawsuits, 420-320 BC, Princeton 1994.

- "Constructing the Body of the Citizen: Corporal Punishment in Classical Athens," Échos du Monde Classique 11, 1992, 271-291.

Hurst, A., "Ménandre et la tragédie," in E. Handley - A. Hurst (Ed.), Relire Ménandre, Genève 1990, 93-122.

Iggers, G., "Zur 'Linguistischen Wende' im Geschichtsdenken und in der Geschichtsschreibung," Geschichte und Gesellschaft 21, 1995, 557-570.

Imbusch, P. - Zoll, R. (Ed.), Friedens- und Konfliktforschung. Eine Einführung mit Quellen, Opladen 1999.

Ireland, S., Menander. The Bad-Tempered Man (Dyskolos). Edited with Translation, Introduction and Commentary, Warminster 1995.

Iser, W., "Akte des Fingierens oder: Was ist das Fiktive im fiktionalen Text?" in W. Iser - D. Henrich (Ed.), Funktionen des Fiktiven, München 1983, 121 151.

—_, "Die Wirklichkeit der Fiktion - Elemente eines funktionsgeschichtlichen Textmodells," in R. Warning (Ed.), Rezeptionsästhetik: Theorie und Praxis, München ${ }^{2} 1979,277-324$ (1975).

Ismard, P., La cité des réseaux. Athènes et ses associations, $V I^{e}-I^{e r}$ siècle av. J.-C., Paris 2010.

Jacquinod, B, "L'ambiguité volontaire dans le comique d'Aristophane," in L. Basset - F. Biville (Ed.), Les jeux et les ruses de l'ambiguïté volontaire dans les textes grecs et latins. Actes de la Table Ronde organisée à la Faculté des Lettres de l'Université Lumière-Lyon 2 (23-24 novembre 2000), Lyon 2005, 101-116.

Jeffery, L., "Further Comments on Archaic Greek Inscriptions," ABSA 50, 1955 , $67-84$.

Jehne, M., "Integrationsrituale in der römischen Republik. Zur einbindenden Wirkung der Volksversammlungen," in G. Urso (Ed.), Integrazione, mescolanza, rifiuto. Incontri di popoli, lingue e culture in Europa dall'Antichità all'Umanesimo, Atti del convegno internazionale, Cividale del Friuli, 21 23 settembre 2000, Roma 2001, 89-113. 
-, Koine eirene. Untersuchungen zu den Befriedungs- und Stabilisierungsbemühungen in der griechischen Poliswelt des 4. Jhs. v. Chr., Stuttgart 1994. Jehne, M. (with F.-H. Mutschler), "Texte, Rituale und Stabilität der römischen Republik. Zu zwei Teilprojekten des Dresdener Sonderforschungsbereichs 'Institutionalität und Geschichtlichkeit'," Antike Welt 31, 2000, 551-556.

Johnston, S., "Magic and the Dead," in J. Petropoulos (Ed.), Greek Magic. Ancient, Medieval and Modern, London - New York 2008, 14-20.

$\longrightarrow$ - Restless Dead. Encounters Between the Living and the Dead in Ancient Greece, Berkeley - Los Angeles - London 1999a.

— dan - H. Montgomery - E. Thomassen (Ed.), The World of Ancient Magic: Papers from the First International Samson Eitrem Seminar at the Norwegian Institute at Athens, 4-8 May 1997, Bergen 1999b, 83-102.

Johnstone, S., Transforming Disputes into Cases: Demosthenes 55, Against Kallikles. Center for Hellenic Studies lecture (http://www.chs.harvard.edu/ online_disc/athenian_law/lect_johnstone.htm; 2003).

_ D Disputes and Democracy. The Consequences of Litigation in Ancient Athens, Austin/TX 1999.

Jordan, D., "A Personal Letter Found in the Athenian Agora," Hesperia 69,

2000, 91-103. (Ed.), The World of Ancient Magic: Papers from the First International Samson Eitrem Seminar at the Norwegian Institute at Athens, 4-8 May 1997, Bergen 1999, 115-124.

— , "Curse Tablets at Selinous," in: M. Jameson - D. Jordan - R. Kotansky (Ed.), A Lex Sacra from Selinous, Durham/NC 1993, 125-131.

- "New Archeological Evidence for the Practice of Magic in Classical Athens," in Praktika of the 12th International Congress of Classical Archaeology 1983-1984, vol. 4, Athens 1988, 273-277.

_, "Defixiones from a Well near the Southwest Corner of the Athenian Agora," Hesperia 54, 1985, 205-255.

_ - "Two Inscribed Lead Tablets from a Well in the Athenian Kerameikos," AM 95, 1980a, 225-239.

—_, "Hekatika," Glotta 58, 1980b, 62-65.

Jordović, I., Anfänge der Jüngeren Tyrannis. Vorläufer und erste Repräsentanten von Gewaltherrschaft im späten 5. Jahrhundert v.Chr., Frankfurt/M et al. 2005.

Kagarow, E., Griechische Fluchtafeln, Lemberg - Paris1929.

Kaimio, M., "Violence in Greek Tragedy," in T. Viljamaa - A. Timonen - C. Kroetzl (Ed.), Crudelitas: the Politics of Cruelty in the Ancient and Medieval World. Proceedings of the International Conference, Turku (Finnland), May 1991, Krems 1992, 28-40.

—_, "Comic Violence in Aristophanes," Arctos 24, 1990, 47-72.

sinki 1988.

Kaiser, R., Trunkenheit und Gewalt im Mittelalter, Köln - Weimar - Wien 2002. 
Kapparis, K., Apollodoros 'Against Neaira' [D. 59]: Edited with Introduction, Translation and Commentary, Berlin - New York 1999.

- "Humiliating the Adulterer: the Law and the Practice in Classical Athens," RIDA 43, 1996, 63-77.

_, "When were the Athenian Adultery Laws Introduced?" RIDA 42, 1995, 97-122.

Katsouris, A., Tragic Patterns in Menander, Athens 1975.

Kelly, A., Damaging Voice. Language of Aggression for the Athenian Trial, Berkeley 1994 (Diss.).

Kenner, H., Das Phänomen der verkehrten Welt in der griechisch-römischen Antike, Klagenfurt 1970.

Kerkhof, R., Dorische Posse, Epicharm und attische Komödie, München 2001.

Kertzer, D., Ritual, Politics, and Power, New Haven 1988.

Keuls, E., The Reign of the Phallus: Sexual Politics in Ancient Athens, Berkeley 1993.

- "The Samia of Menander. An Interpretation of its Plot and Theme," ZPE 10, 1973, 1-20.

Kidd, I., "The Case of Homicide in Plato's Euthyprho," in E. Craik (Ed.), Owls to Athens. Essays on Classical Subjects Presented to Sir Kenneth Dover, Oxford 1990, 213-221.

Kiernan, P., "Britische Fluchtafeln und 'Gebete um Gerechtigkeit' als öffentliche Magie und Votivrituale," in K. Brodersen - A. Kropp (Ed.), Fluchtafeln. Neue Funde und neue Deutungen zum antiken Schadenzauber, Frankfurt/M. 2004, 99-114.

King, L., Babylonian Magic and Sorcery: Being "The Prayers of the Lifting of the Hand," Hildesheim 1975.

Klees, H., Sklavenleben im klassischen Griechenland, Stuttgart 1998.

Knell, H., Athen im 4. Jh. v. Chr. Eine Stadt verändert ihr Gesicht, Darmstadt 2000.

Köpping, K.-P., "Ritual and Theater," in D. Kennedy (Ed.), The Oxford Encyclopedia of Theatre and Performance, Oxford 2003, 1139-1141.

Köpping, K.-P. - Rao, U. (Ed.), Im Rausch des Rituals. Gestaltung und Transformation der Wirklichkeit in körperlicher Performanz, Hamburg 2000a.

Köpping, K-P. - Rao, U., "Die 'performative Wende': Leben - Ritual - Theater," in K.-P. Köpping - U. Rao (Ed.), Im Rausch des Rituals. Gestaltung und Transformation der Wirklichkeit in körperlicher Performanz, Hamburg 2000b, 1-32.

Konstan, D., The Emotions of the Ancient Greeks. Studies in Aristotle and Classical Literature, Toronto - Buffalo - London 2006.

—, "Pity and the Law in Greek Theory and Practice," Dike 3, 2000, 125 145.

— nes' Birds," in G. Dobrov (Ed.), The City as Comedy. Society and Representation in Athenian Drama, Chapel Hill - London 1997, 3-22.

— 
__ "Premarital Sex, Illegitimacy, and Male Anxiety in Menander and Athens," in A. Boegehold - A. Scafuro (Ed.), Athenian Identity and Civic Ideology, Baltimore - London 1994, 217-235.

Konstan, D. - Rutter, N. (Ed.), Envy, Spite and Jealousy. The Rivalrous Emotions in Ancient Greece, Edinburgh 2003.

Kopff, E., "Nubes 1493ff: Was Socrates Murdered?” GRBS 18, 1977, 113-122.

Koster, S., Die Invektive in der griechischen und lateinischen Literatur, Meisenheim am Glan 1980.

Kotini, V., The Dialects of Myth in Aristophanic Comedy, London 2005 (Diss. King's College London).

Koziol, G., "Review article: The Dangers of Polemic: Is Ritual still an Interesting Topic of Historical Study?" Early Medieval Europe 11, 2002, 367-388.

Kraus, W., Aristophanes' Politische Komödien: Die Acharner/Die Ritter, Wien 1985.

Krause, J.-U., Kriminalgeschichte der Antike, München 2004.

- Witwen und Waisen im Römischen Reich II. Wirtschaftliche und gesellschaftliche Stellung von Witwen, Stuttgart 1994.

Krentz, P., The Thirty at Athens, Ithaca - London 1982.

Kropp, A., "Defigo Eudemum: necetis eum: Kommunikationsmuster in den Texten antiker Schadenzauberrituale," in K. Brodersen - A. Kropp (Ed.), Fluchtafeln. Neue Funde und neue Deutungen zum antiken Schadenzauber, Frankfurt/M. 2004, 81-97.

Krummen, E., "Ritual und Katastrophe. Rituelle Handlung und Bildersprache bei Sophokles und Euripides," in F. Graf (Ed.), Ansichten griechischer Rituale. Geburtstag-Symposium für Walter Burkert, Stuttgart - Leipzig 1998, 296-325.

Kunze, C., "Dialog statt Gewalt. Neue Erzählperspektiven in der frühklassischen Vasenmalerei," in G. Fischer - S. Moraw (Ed.), Die andere Seite der Klassik. Gewalt im 5. und 4. Jahrhundert v. Chr., Stuttgart 2005, 45-71.

Kurihara, A., "Personal Enmity as a Motivation in Forensic Speeches," CQ 53, 2003, 464-477.

Lada-Richards, I., Initiating Dionysus. Ritual and Theatre in Aristophanes' Frogs, Oxford 1999.

Lalonde, G. - Langdon, M. - Walbank, M., Inscriptions. Horoi, Poletai Records, Leases of Public Land, Princeton 1991.

Lamagna, M., La donna di Samo. Testo critico, introduzione, traduzione e commentario, Napoli 1998.

Landwehr, A. - Stockhorst, S., Einführung in die europäische Kulturgeschichte, Paderborn - München - Wien - Zürich 2004.

Lanni, A., Law and Justice in the Courts of Classical Athens, Cambridge 2006. , "Spectator Sport or Serious Politics? Hoi periestekotes and the Athenian Lawcourts," JHS 117, 1997, 183-189.

Lape, S., "The Poetics of the Komos-Chorus in Menander's Comedy," AJP 127, 2006, 89-109.

$\longrightarrow$, Reproducing Athens. Menander's Comedy, Democratic Culture, and the Hellenistic City, Princeton 2004. 
"Democratic Ideology and the Poetics of Rape in Menandrian Comedy," CA 20, 2001, 79-119.

Latte, K., Heiliges Recht. Untersuchungen zur Geschichte der sakralen Rechtsformen in Griechenland, Aalen 1964 (1920).

Lechat, H., "Inscription imprécataire trouvée à Athènes," BCH 13, 1889, 77-80.

Lehmann, G., Demosthenes von Athen. Ein Leben für die Freiheit, München 2004.

Lewis, S., Greek Tyranny, Exeter 2009. (Ed.), Ancient Tyranny, Edinburgh 2006.

Liddel, P., Civic Obligation and Individual Liberty in Ancient Athens, Oxford 2007.

Lindenberger, T. (Ed.), Physische Gewalt im Alltag, Hamburg 1993.

Lissarague, F., "The Athenian Image of the Foreigner," in T. Harrison (Ed.), Greeks and Barbarians, New York 2002, 101-124.

Loomis, W. "'The Nature of Premeditation in Athenian Homicide Law," JHS 92, 1972, 86-95.

López Jimeno, M. del Amor, Las Tabellae Defixionis De La Sicilia Griega, Amsterdam 1991.

—_, "Las cartas de maldición," Minerva 4, 1990, 134-144.

Loraux, N., The Divided City: On Memory and Forgetting in Ancient Athens, New York 2002.

Low, P., Interstate Relations in Classical Greece: Morality and Power, Cambridge 2007.

_ 93-111.

Luck, G., Arcana Mundi. Magic and the Occult in the Greek and Roman Worlds. A Collection of Ancient Texts, Translated, Annotated, and Introduced by G. Luck, Baltimore ${ }^{2} 2006$ (1985).

—, Ancient Pathways and Hidden Pursuits: Religion, Morals, and Magic in the Ancient World, Ann Arbor 2000.

MacCary, W., "Philocleon Ithyphallos: Dance, Costume and Character in the Wasps," TAPA 109, 1979, 137-147.

MacDowell, D., Demosthenes the Orator, Oxford 2009.

— , "Prosecution for Homicide," CR 111, 1997, 384-385.

—, Aristophanes and Athens. An Introduction to the Plays, Oxford 1995.

-, Demosthenes, Against Meidias (oration 21). Edited with Introduction, Translation, and Commentary, Oxford 1990.

— - "Clowining and Slapstick in Aristophanes," in J. Redmond (Ed.), Farce. Themes in Drama 10, Cambridge 1988, 1-13.

—, The Law in Classical Athens, Ithaca 1978.

, "Hybris in Athens," G\&R 23, 1976, 14-31.

- Athenian Homicide Law in the Age of the Orators, Manchester ${ }^{2} 1966$ (1963; repr. 1999).

Mader, G. - Eberwein, W.-D. - Vogt, W. (Ed.), Konflikt und Gewalt. Ursachen Entwicklungstendenzen - Perspektiven, Münster 2000. 
Maggidis, C., "MАГIKOI KАTА $\triangle \mathrm{E} \Sigma \mathrm{MOI}$ or Binding Curse Tablets: A Journey on the Greek Dark Side," in R. Holloway (Ed.), Miscellanea Mediterranea, Providence/RI 2000, 83-100.

Major, W., "Menander in a Macedonian World," GRBS 38, 1997, 41-73.

Malinowski, B., Magic, Science, and Religion, and other Essays, Garden City/NY 1974 (New York 1954).

- Coral Gardens and Their Magic. A Study of the Methods of Tilling the Soil and of Agricultural Rites in the Trobriand Islands vol. 2, London 1935.

Manley-Tannis, R., Greek Arbitration: Homer to Classical Athens. An Investigation into the Role of the Community in Private and Public Arbitration, MAThesis of Queen's University, Kingston, Ontario 1998.

Manthe, "Die Tötung des Ehebrechers," in L. Burckhardt - J. von UngernSternberg (Ed.), Große Prozesse im antiken Athen, München 2000, 219 233.

Marianetti, M., Aristophanes: The Clouds. An Annotated Translation, Lanham/ MD - New York - London 1997.

Clouds," SO 68, 1993, 5-31.

—, Religion and Politics in Aristophanes' Clouds, Hildesheim 1992.

Martin, R., "Fire on the Mountain: Lysistrata and the Lemnian Women," CA 6 , 1987, 77-105.

Martschukat, J. - Patzold, S. (Ed.), Geschichtswissenschaft und Performative Turn. Ritual, Inszenierung und Performanz vom Mittelalter bis zur Neuzeit, Köln - Weimar - Wien 2003.

Maurach, G., Kleine Geschichte der antiken Komödie, Darmstadt 2005.

Mauss, M., A General Theory of Magic, London - New York 1972 (Esquisse d'une théorie générale de la magie (with H. Hubert), Paris 1902, 1950).

Maza, S., "Stories in History: Cultural Narratives in Recent Works in European History," AHR 101, 1996, 1493-1515.

McGlew, J., Tyranny and Political Culture in Ancient Greece, Ithaca - London 1993.

McHardy, F., Revenge in Athenian Culture, London 2008.

McLeish, K., The Theatre of Aristophanes, London 1980.

Meyer, B., Formen der Konfliktregelung. Eine Einführung mit Quellen, Opladen 1997.

Meyer, M. - Mirecki, P. (Ed.), Ancient Magic and Ritual Power: Conference on "Magic in the Ancient World," held in August 1992 at the University of Kansas, Leiden 1995.

Michelini, A., "Hybris and Plants," HSCP 82, 1978, 35-44.

Middleton, J., Magic, Witchcraft, and Curing, Austin/TX 1977.

Milanezi, S., "Introduction," in V. Coulon (Ed.), Aristophane. Nuées, Paris 2009, VII-XXX.

Mirhady, D., "The Dikast's Oath and the Question of Fact," in A. Sommerstein - J. Fletcher (Ed.), Horkos. The Oath in Greek Society, Exeter 2007, 48-59.

_- "Athens' Democratic Witnesses," Phoenix 56, 2002, 255-274. 
_- "Torture and Rhetoric in Athens," JHS 116, 1996, 119-131 (repr. in E. Carawan (Ed.), Oxford Readings in the Attic Orators, Oxford - New York 2007, 247-268).

Mitchell, L., Panhellenism and the Barbarian in Archaic and Classical Greece, Swansea 2007.

Möllendorff, P. von, "In alter Frische - Generationen und Generationskonflikt in der Aristophanischen Komödie der zweiten Schaffensperiode," in T. Baier (Ed.), Generationenkonflikte auf der Bühne. Perspektiven im antiken und mittelalterlichen Drama, Tübingen 2007, 83-100.

—

_ tophanes und Michail Bachtin, Tübingen 1995.

Moore, S. - Myerhoff, B. (Ed.), Secular Ritual, Assen - Amsterdam 1977.

Morris, I., "Remaining Invisible: The Archaeology of the Excluded in Classical Athens," in S. Joshel - S. Murnaghan (Ed.), Women and Slaves in Greco-Roman Culture. Differential Equations, London - New York 1998, 193-220.

Morrow, G., "The Murder of Slaves in Attic Law," CP 32, 1937, 210-227.

Moulinier, L., Le pur et l'impur dans la pensée des Grecs, Paris 1952.

Muecke, F., "Playing with the Play: Theatrical Self-Consciousness in Aristophanes," Antichthon 11, 1977, 52-67.

Muir, E., Ritual in Early Modern Europe, Cambridge 1997.

Murphy, C., "Popular Comedy in Aristophanes," AJP 93, 1972, 169-189.

Murray, G., "Ritual Elements in the New Comedy," CQ 37, 1943, 46-54.

Muth, S., Gewalt im Bild. Das Phänomen der medialen Gewalt im Athen des 6. und 5. Jh. v. Chr., Berlin 2008.

—, "Als die Gewaltbilder zu ihrem Wirkungspotential fanden," in B. Seidensticker - M. Vöhler, (Ed.), Gewalt und Ästhetik. Zur Gewalt und ihrer Darstellung in der griechischen Klassik, Berlin 2006, 259-293.

— , "Zwischen Pathetisierung und Dämpfung. Kampfdarstellungen in der attischen Vasenmalerei des 5. Jhs. v. Chr.," in G. Fischer - S. Moraw (Ed.), Die andere Seite der Klassik. Gewalt im 5. und 4. Jahrhundert v. Chr., Stuttgart 2005, 185-209.

Nemeth, G., Kritias und die Dreissig Tyrannen. Untersuchungen zur Politik und Prosopographie der Führungselite in Athen 404/403 v. Chr., Stuttgart 2006.

Neri, V., I Marginali nell'Occidente Tardoantico. Poveri, 'Infames' e Criminali nella nascente societá cristiana, Bari 1998.

Nesselrath, H.-G., "Myth, Parody, and Comic Plots: The Birth of Gods and Middle Comedy," in G. Dobrov (Ed.), Beyond Aristophanes. Transition and Diversity in Greek Comedy, Atlanta 1995, 1-27.

— Die attische Mittlere Komödie. Ihre Stellung in der antiken Literaturkritik und Literaturgeschichte, Berlin - New York 1990.

Nielsen, I., Cultic Theatres and Ritual Drama: A Study in Regional Development and Religious Interchange Between East and West in Antiquity, Aarhus 2002.

Nijhawan, M., "Rituale ändern: Ausblick," in C. Ambos - S. Hotz - G. Schwedler - S. Weinfurter (Ed.), Die Welt der Rituale. Von der Antike bis heute, Darmstadt 2005, 269-276. 
Nilsson, M., Geschichte der griechischen Religion. 1. Bd.: Die Religion Griechenlands bis auf die griechische Weltherrschaft, München ${ }^{4} 1976$ (1941).

—, Geschichte der griechischen Religion. 2. Bd.: Die Hellenistische und Römische Zeit, München ${ }^{3} 1974$ (1950).

Nippel, W., "The Construction of the 'Other," in T. Harrison (Ed.), Greeks and Barbarians, New York 2002, 278-310.

, "Die 'Barbaren' aus der Sicht der Griechen," in B. Jostes - J. Trabant (Ed.), Fremdes in fremden Sprachen, München 2001, 43-56.

, Public Order in Ancient Rome, Cambridge 1995.

North, H., Sophrosyne, Self-Knowledge and Self-Restraint in Greek Literature, Ithaca 1966.

Nussbaum M., "Aristophanes and Socrates on Learning Practical Wisdom," YCS 26, 1980, 43-97.

Ober, J., Athenian Legacies. Essays on the Politics of Going on Together, Princeton - Oxford 2005.

- The Athenian Revolution. Essays on Ancient Greek Democracy and Political Theory, Princeton 1996.

_ - "Power and Oratory in Democratic Athens: Demosthenes 21, against Meidias," in I. Worthington (Ed.), Persuasion: Greek Rhetoric in Action, London - New York 1994, 85-108

- Mass and Elite in Democratic Athens. Rhetoric, Ideology, and the Power of the People, Princeton 1989.

Ober, J. - Strauss, B., "Drama, Political Rhetoric, and the Discourse of Athenian Democracy," in J. Winkler - F. Zeitlin (Ed.), Nothing to do with Dionysus? Athenian Drama in its Social Context, Princeton 1990, 237-270.

Oberwittler, D. - Karstedt, S. (Ed.), Soziologie der Kriminalität, Wiesbaden 2003.

Ogden, D., Magic, Witchcraft, and Ghosts in the Greek and Roman Worlds. A Sourcebook, Oxford ${ }^{2} 2009$ (2002).

—_, Night's Black Agents, London - New York 2008.

Roman Worlds," in B. Ankarloo - S. Clark (Ed.), Witchcraft and Magic in Europe: Ancient Greece and Rome, Philadelphia 1999, 1-90.

- "Rape, Adultery and Protection of Bloodlines in Classical Athens," in S. Deacy - K. Pierce (Ed.), Rape in Antiquity, London 1997, 25-41.

Olson, D., "Comedy, Politics, and Society," in G. Dobrov (Ed.), Brill's Companion to the Study of Greek Comedy, Leiden - Boston 2010, 35-69.

— Broken Laughter. Select Fragments of Greek Comedy, Oxford 2007.

- Aristophanes. Acharnians, Edited with Introduction and Commentary, Oxford 2002.

- Aristophanes. Peace, Edited with Introduction and Commentary, Oxford 1998.

— 150.

-, "Dicaeopolis' Motivations in Aristophanes' Acharnians," JHS 111, 1991, 200-203. 
Omitowoju, R., Rape and the Politics of Consent in Classical Athens, Cambridge 2002.

O'Regan, D., Rhetoric, Comedy, and the Violence of Language in Aristophanes' Clouds, New York - Oxford 1992.

Osborne, R., "Law in Action in Classical Athens," JHS 105, 1985, 40-58.

Osborne, R. - Hornblower, S. (Ed.), Ritual, Finance, Politics. Athenian Democratic Accounts Presented to David Lewis, Oxford 1994.

O'Sullivan, L., The Regime of Demetrius of Phalerum in Athens, 317-307 BCE. A Philosopher in Politics, Leiden - Boston 2009.

Padilla, M., Rites of Passage in Ancient Greece: Literature, Religion, Society, Lewisburg/PA 1999.

Pakaluk, M., Aristotle's Nicomachean Ethics. An Introduciton, Cambridge 2005.

Panagiotou, S., "Plato's Euthyphro and the Attic Code on Homicide," Hermes 102, 1974, 419-437.

Paradiso, A., "Le rite de passage du Ploutos d' Aristophane," Metis 2, 1987, 249-267.

Parke, H., Festivals of the Athenians, London 1977.

Parker, A. - Sedgwick, E., "Introduction: Performativity and Performance," in A. Parker - E. Sedgwick (Ed.), Performativity and Performance, New York 1995, 1-18.

Parker, R., Polytheism and Society at Athens, Oxford 2005.

, Miasma. Pollution and Purification in Early Greek Religion, Oxford 1983.

Parker, V., "The Semantics of a Political Concept from Archilochus to Aristotle", Hermes 126, 1998, 145-172

Patzer, A., "Sokrates in den Fragmenten der Attischen Komödie," in: A. Bierl P. von Möllendorff (Ed.), Orchestra. Drama, Mythos, Bühne, Leipzig 1994, $50-81$.

Pébarthe, C., Cité, démocratie et écriture. Histoire de l'alphabétisation d'Athènes à l'époque classique, Paris 2006.

Peek, W., "Attische Inschriften," AthMitt 67, 1942, 1-217.

- Kerameikos. Ergebnisse der Ausgrabungen III: Inschriften, Ostraka, Fluchtafeln, Berlin 1941, 89-100.

Pernerstorfer, M., Menanders Kolax: Ein Beitrag zur Rekonstruktion und Interpretation der Komödie. Mit Edition und Übersetzung der Fragmente und Testimonien sowie einem dramaturgischen Kommentar, Berlin - New York 2009.

Perotti, P., "La I Orazione di Lisia fu mai pronunciata?” Sandalion 12-13, 1989/ 1990, 43-48.

Perusino, F., "Violenza degli uomini e violenza delle donne nella Lisistrata di Aristofane," QUCC 92, 1999, 71-78.

Petropoulos, J. (Ed.), Greek Magic. Ancient, Medieval and Modern, London New York 2008.

- "The Erotic Magical Papyri," in Proceedings of the $18^{\text {th }}$ International Congress of Papyrology, Athens 1988, 215-222.

Phillips, D., Avengers of Blood: Homicide in Athenian Law and Custom from Draco to Demosthenes, Stuttgart 2008. 
, "Trauma ek pronoias in Athenian Law,” JHS 127, 2007, 74-105.

, "Why Was Lycophron Prosecuted by Eisangelia?" GRBS 46, 2006, 375 394.

- Homicide, Wounding, and Battery in the Fourth-Century Attic Orators, Ann Arbor 2000 (Diss.).

Pickard-Cambridge, A., The Dramatic Festivals of Athens, Oxford ${ }^{3} 1988$, rev. with a new supplement by J. Gould and D. Lewis (Oxford 1953).

- Dithyramb, Tragedy and Comedy, Oxford ${ }^{2} 1962$, rev. by T. B. L. Webster (Oxford 1927).

- The Theatre of Dionysos in Athens, London 1946.

Pierce, K., "Ideals of Masculinity in New Comedy," in L. Foxhall - J. Salmon (Ed.), Thinking Men. Masculinity and its Self-Representation in the Classical Tradition, London - New York 1998, 130-147.

_ , "The Portrayal of Rape in New Comedy," in S. Deacy - K. Pierce (Ed.), Rape in Antiquity, London 1997, 163-184.

Platter, C., Aristophanes and the Carnival of Genres, Baltimore 2007.

Pöhlmann, E., "Die Funktion des Chores in der Neuen Komödie," in E. Pöhlmann, Beiräge zur antiken und neueren Musikgeschichte, Frankfurt/M Bern 1988, 41-55.

Poliakoff, M., Combat Sports in the Ancient World. Competition, Violence, and Culture, New Haven - London 1987.

Porter, J., "Adultery by the Book: Lysias 1 (On the Murder of Eratosthenes) and Comic Diegesis," Échos du Monde Classique 40, 1997, 421-453 (repr. in E. Carawan (Ed.), Oxford Readings in the Attic Orators, Oxford - New York 2007, 60-88).

Porter, R., "Rape - Does it Have a Historical Meaning?" in S. Tomaselli - R. Porter (Ed.), Rape, Oxford 1986, 216-236; 270-279.

Préaux, C., "Les fonctions du droit dans la comédie nouvelle. A propos du Dyscolos de Ménandre," Chronique d'Égypte 35, 1960, 222-239.

—_, "Ménandre et la société athénienne," CE 32, 1957, 84-100.

Preisendanz, K, "Fluchtafel (Defixion)," RAC 8, 1972, col. 1-29.

Pütz, B., The Symposium and Komos in Aristophanes, Oxford 2007.

Quinn, T., “Aristotle, Comedy, and Menander," CB 77, 2001, 3-18.

Rabehl, W., De sermone defixionum atticarum, Berlin 1906 (Diss.).

Rademaker, A., Sophrosyne and the Rhetoric of Self-Restraint: Polysemy \& Persuasive Use of an Ancient Greek Value Term, Leiden - Boston 2005.

Raina, G., "Menandro: la violenza negata?" in G. Raina (Ed.), Dissimulazioni della violenza nella Grecia antica, Como - Pavia 2006, 229-246.

Rakoczy, T., Böser Blick, Macht des Auges und Neid der Götter. Eine Untersuchung zur Kraft des Blickes in der griechischen Literatur, Tübingen 1996.

Ramage, E., "City and Country in Menander's Dyskolos," Philologus 110, 1966, $194-211$.

Rapoport, A., Ursprünge der Gewalt. Ansätze zur Konfliktforschung, Darmstadt 1990.

Rau, P., "Das Tragödienspiel in den 'Thesmophoriazusen'," in H.-J. Newiger (Ed.), Aristophanes und die Alte Komödie, Darmstadt 1975, 339-356. 
, Paratragodia. Untersuchung einer komischen Form des Aristophanes, München 1967.

Reckford, K., Aristophanes' Old-and-New Comedy, Chapel Hill - London 1987. —_, "Father-Beating in Aristophanes' Clouds," in S. Bertman (Ed.), The Conflict of Generations in Ancient Greece and Rome, Amsterdam 1976, 89-118.

Reinhold, G. - Lamnek, S. - Recker, H. (Ed.), Soziologie Lexikon, München Wien ${ }^{4} 2000$ (1992).

Revermann, M., Comic Business. Theatricality, Dramatic Technique, and Performance Contexts of Aristophanic Comedy, Oxford - New York 2006a.

_ , "The Competence of Theatre Audiences in Fifth- and Fourth-Century Athens," JHS 126, 2006b, 99-124.

Rex, J., Key Problems in Sociological Theory, London 1961.

Rhodes, P., "Enmity in Fourth-Century Athens," in P. Cartledge - P. Millett - S. von Reden (Ed.), Kosmos. Essays in Order, Conflict and Community in Classical Athens, Cambridge 1998, 144-161.

_ $21-30$.

Rhodes, P. - Osborne, R., Greek Historical Inscriptions 404-323 BC, Oxford 2003.

Richer, N., "La violence dans les mondes grec et romain. Introduction," in J.-M. Bertrand (Ed.), La violence dans les mondes grec et romain. Actes du colloque international (Paris, 2-4 mai 2002), Paris 2005, 7-35.

Riches, D. (Ed.), The Anthropology of Violence, Oxford - New York 1986.

Riess, W., "Private Violence and State Control - The Prosecution of Homicide and Its Symbolic Meanings in Fourth-Century BC Athens," in C. Brélaz - P. Ducrey (Ed.), Sécurité collective et ordre public dans les sociétés anciennes, Genève 2008, 49-101.

— tion in Fourth-Century Greece," in G. Urso (Ed.), Terror et Pavor. Violenza, intimidazione, clandestinità nel mondo antico. Atti del convegno internazionale della Fondazione Niccolò Canussio 22-24 settembre 2005, Milano 2006, 65-88.

— Apuleius und die Räuber, Stuttgart 2001.

Risse-Kappen, T., "Ideas do not Float Freely: Transnational Coalitions, Domestic Structures, and the End of the Cold War," International Organization 48, 1994, 185-214.

Riu, X., Dionysism and Comedy, Lanham - Boulder - New York - Oxford 1999.

Robert, L., Collection Froehner I: Inscriptions Grecques, Paris 1936.

Robson, J., Aristophanes: an Introduction, London 2009.

—, Humour, Obscenity and Aristophanes, Tübingen 2006.

Rösler, W. - Zimmermann, B., Carnevale e utopia nella Grecia antica, Bari 1991.

Roisman, J., The Rhetoric of Conspiracy in Ancient Athens, Berkeley - Los Angeles - London 2006.

- The Rhetoric of Manhood. Masculinity in the Attic Orators, Berkeley Los Angeles - London 2005. 
, "The Rhetoric of Courage in Athenian Orators," in R. Rosen - I. Sluiter (Ed.), Andreia. Studies in Manliness and Courage in Classical Antiquity, Leiden - Boston 2003, 127-143.

Romilly, J. de, La Grèce antique contre la violence, Paris 2000.

—_ Alcibiade, ou, Les dangers de l'ambition, Paris 1995.

_. Magic and Rhetoric in Ancient Greece, Cambridge/MA 1975.

Roselli, D., "Theorika in Fifth-Century Athens," GRBS 49, 2009, 5-30.

Rosen, R., "Aristophanes, Old Comedy, and Greek Tragedy," in R. Bushnell (Ed.), A Companion to Tragedy, Oxford - Malden/MA - Victoria 2005, $251-268$.

- Old Comedy and the Iambographic Tradition, Atlanta 1988.

Rosen, R. - Sluiter, I. (Ed.), Andreia. Studies in Manliness and Courage in Classical Antiquity, Leiden - Boston 2003.

Rosenbloom, D., "Empire and its Discontents: Trojan Women, Birds, and the Symbolic Economy of Athenian imperialism," in J. Davidson - F. Muecke - P. Wilson (Ed.), Greek Drama III. Essays in Honour of Kevin Lee, London 2006, 245-272.

— in Athens, 428-404 BCE," CA 21, 2002, 283-346.

Rosivach, V., "Class Matters in the Dyskolos of Menander," CQ 51, 2001, 127 134.

—_, "The Audiences of New Comedy," G\&R 47, 2000, 169-171.

- When a Young Man Falls in Love. The Sexual Exploitation of Women in New Comedy, London - New York 1998.

—_, "The Tyrant in Athenian Democracy," QUCC 30 (59), 1988, 43-57.

- "Execution by Stoning in Athens," CA 6, 1987, 232-248.

Rothwell, K., Nature, Culture, and the Origins of Greek Comedy: A Study of Animal Choruses, Cambridge 2007.

- "The Continuity of the Chorus in Fourth-Century Attic Comedy," in G. Dobrov (Ed.), Beyond Aristophanes. Transition and Diversity in Greek Comedy, Atlanta 1995, 99-118.

Roy, J., "An Alternative Sexual Morality for Classical Athenians," $G \& R 44$, 1997, 11-22.

Rozik, E., The Roots of Theater. Rethinking Ritual and Other Theories of Origin, Iowa City 2002.

Rubinstein, L., “'Arai' in Greek Laws in the Classical and Hellenistic Periods: Deterrence or Concession to Tradition?" in E. Cantarella (Ed.), Symposion 2005. Vorträge zur griechischen und hellenistischen Rechtsgeschichte, Wien 2007, 269-286.

—, "Main Litigants and Witnesses in the Athenian Courts: Procedural Variations," in R. Wallace - M. Gagarin (Ed.), Symposion 2001. Vorträge zur griechischen und hellenistischen Rechtsgeschichte, Wien 2005a, 99-120.

_ , "Differentiated Rhetorical Strategies in the Athenian Courts," in M. Gagarin - D. Cohen (Ed.), The Cambridge Companion to Ancient Greek Law, Cambridge 2005b, 129-145. 
—_, "Stirring up Dicastic Anger," in D. Cairns - R. Knox (Ed.), Law, Rhetoric and Comedy in Classical Athens: Essays in Honor of D. MacDowell, Swansea 2004, 187-203.

- Litigation and Cooperation: Supporting Speakers in the Courts of Classical Athens, Stuttgart 2000.

Ruff, J., Violence in Early Modern Europe 1500-1800, Cambridge 2001.

Ruffell, I., "The World Turned Upside Down: Utopia and Utopianism in the Fragments of Old Comedy," in D. Harvey - J. Wilkins (Ed.), The Rivals of Aristophanes. Studies in Athenian Old Comedy, London 2000, 473-506.

Ruiz, F., Use and Control of Violence in Classical Athens, Johns Hopkins University 1994 (Diss.).

Ruschenbusch, E., "Hybreos Graphe. Ein Fremdkörper im athenischen Recht des 4. Jhs. v. Chr.," ZRG 82, 1965, 302-309.

—_, "Phonos. Zum Recht Drakons und seiner Bedeutung für das Werden des athenischen Staates," Historia 9, 1960, 129-154.

Russo, C., Aristophanes, an Author for the Stage, London - New York 1994 (Ital. 1962/1992).

Sagan, E., The Lust to Annihilate. A Psychoanalytic Study of Violence in Ancient Greek Culture, New York 1979.

Scafuro, A., The Forensic Stage. Settling Disputes in Graeco-Roman New Comedy, Cambridge 1997.

Schäfer, A., Menanders Dyskolos. Untersuchungen zur dramatischen Technik, Meisenheim am Glan 1965.

Scharffenberger, E., "Peisetaerus' 'Satyric' Treatment of Iris: Aristophanes' Birds 1253-1256," JHS 115, 1995, 172-173.

Schechner, R., Theateranthropologie. Spiel und Ritual im Kulturvergleich, Hamburg 1990.

— says on Performance Theory, revised again 2004).

— Between Theater and Anthropology, Philadelphia 1985.

—_, Essays on Performance Theory 1970-1976, New York 1977.

, "From Ritual to Theatre and Back," in R. Schechner - M. Schuman (Ed.), Ritual, Play, and Performance. Readings in the Social Sciences/Theatre, New York 1976, 196-222.

Schechner, R. - Appel, W. (Ed.), By Means of Performance. Intercultural Studies of Theatre and Ritual, Cambridge 1990.

Scheid, E., "Remarques sur les fondements de la vengeance en Grèce archaique et classique," in J.-M. Bertrand (Ed.), La violence dans les mondes grec et romain. Actes du colloque international (Paris, 2-4 mai 2002), Paris 2005, $395-410$.

Schlesier, R., "Zauber und Neid: Zum Problem des bösen Blicks in der antiken griechischen Tradition," in C. Elsas et al. (Ed.), Tradition und Translation: Festschrift C. Colpe, Berlin - New York 1994, 96-112.

Schmid, W., "Das Sokratesbild der Wolken," Philologus 97, 1948, 209-228.

Schmitt Pantel, P., "Über die Konstruktion der Gewalt im Alten Griechenland. Frauen, die töten, und Männer, die verführen," Metis 7, 1998, 39-52. 
Schmitz, W., "Gewalt in Haus und Familie," in G. Fischer - S. Moraw (Ed.), Die andere Seite der Klassik. Gewalt im 5. und 4. Jahrhundert v. Chr., Stuttgart 2005, 103-128.

- Nachbarschaft und Dorfgemeinschaft im archaischen und klassischen Griechenland, Berlin 2004.

_, "Drakonische Strafen. Die Revision der Gesetze Drakons durch Solon und die Blutrache in Athen," Klio 83, 2001, 7-38.

— , "Der nomos moicheias - Das athenische Gesetz über den Ehebruch," ZRG 114, 1997, 45-140.

Scholten, H., "Das Spiel mit dem Mythos in Aristophanes' Acharnern," Archiv für Kulturgeschichte 88, 2006, 1-22.

Schomburg-Scherff, S., Nachwort zu A. van Gennep. Übergangsriten, Frankfurt/ M. - New York 1986, 233-253.

Schuller, W., Die Welt der Hetären. Berühmte Frauen zwischen Legende und Wirklichkeit, Stuttgart 2008.

Schwedler, G., "Rituale als Ausdruck von Herrschaft," in C. Ambos - S. Hotz G. Schwedler - S. Weinfurter (Ed.), Die Welt der Rituale. Von der Antike bis heute, Darmstadt 2005, 171-175.

Schwerhoff, G., Köln im Kreuzverhör. Kriminalität, Herrschaft und Gesellschaft in einer frühneuzeitlichen Stadt, Bonn - Berlin 1991.

Schwinge, E., "Aristophanes und die Utopie," WüJbb N.F. 3, 1977, 43-67.

Seaford, R., Euripides' Bacchae, Warminster 1996.

Sealey, R., "The Athenian Courts for Homicide," CP 78, 1983, 275-296.

Searle, J., Speech Acts. An Essay in the Philosophy of Language, Cambridge 1969.

Segal, C., "The Bacchae as Metatragedy," in P. Burian (Ed.), Directions in Euripidean Criticism. A Collection of Essays, Durham/NC 1985, 156-173.

- Dionysiac Poetics and Euripides' Bacchae, Princeton 1982.

Seidensticker, B., "Distanz und Nähe: Zur Darstellung von Gewalt in der griechischen Tragödie," in B. Seidensticker - M. Vöhler, (Ed.), Gewalt und Ästhetik. Zur Gewalt und ihrer Darstellung in der griechischen Klassik, Berlin 2006, 91-122.

Seidensticker, B. - Vöhler, M. (Ed.), Gewalt und Ästhetik. Zur Gewalt und ihrer Darstellung in der griechischen Klassik, Berlin 2006.

Sfyroeras, P., "From Sacrifice to Feast: A Ritual Pattern in Aristophanic Comedy," in D. Cairns - R. Knox (Ed.), Law, Rhetoric, and Comedy in Classical Athens, Swansea 2004, 251-268.

- The Feast of Poetry: Sacrifice, Foundation, and Performance in Aristophanic Comedy, Princeton 1992 (Diss.).

Sharpe, J., Crime in Early Modern England 1550-1750, London - New York 1984.

- Crime in Seventeenth-Century England: A County Study, Cambridge New York 1983.

Shaw, B., "Bandits in the Roman Empire," $P \& P$ 105, 1984, 3-52.

Shear, T., "The Athenian Agora. Excavations of 1972," Hesperia 42, 1973, 359 407. 
Sidwell, K., Aristophanes the Democrat: the Politics of Satirical Comedy during the Peloponnesian War, Cambridge 2009.

Sieferle, R. - Breuninger, H. (Ed.), Kulturen der Gewalt. Ritualisierung und Symbolisierung von Gewalt in der Geschichte, Frankfurt/M. - New York 1998.

Siegenthaler, H., "Geschichte und Ökonomie nach der kulturalistischen Wende," Geschichte und Gesellschaft 25, 1999, 276-301.

Sifakis, G., Parabasis and Animal Choruses. A Contribution to the History of Attic Comedy, London 1971.

Signer, D., Die Ökonomie der Hexerei - oder Warum es in Afrika keine Wolkenkratzer gibt, Wuppertal 2005.

Silk, M., Aristophanes and the Definition of Comedy, Oxford 2000.

_, "Aristophanic Paratragedy," in A. Sommerstein - S. Halliwell - J. Henderson - B. Zimmermann (Ed.), Tragedy, Comedy, and the Polis. Papers from the Greek Drama Conference, Nottingham, 18-20. July 1990, Bari 1993, 477-504.

Simmel, G., "Der Streit," in Id., Soziologie. Untersuchungen über die Formen der Vergesellschaftung, Berlin 1908, 186-255.

Slater, N., Spectator Politics: Metatheatre and Performance in Aristophanes, Philadelphia 2002.

—_, "Making the Aristophanic Audience," AJP 120, 1999, 351-368.

—, "The Fabrication of Comic Illusion," in G. Dobrov (Ed.), Beyond Aristophanes. Transition and Diversity in Greek Comedy, Atlanta 1995, 29-45.

Slater, W., "The Theatricality of Justice," CB 71, 1995, 143-157.

Slater, W.- Csapo, E., The Context of Attic Drama, Ann Arbor 1995.

Smith, T., "The Corpus of Komast Vases: From Identity to Exegesis," in E. Csapo - M. Miller (Ed.), The Origins of Theater in Ancient Greece and Beyond. From Ritual to Drama, Cambridge - New York 2007, 48-76.

Sofsky, W., Traktat über die Gewalt, Frankfurt/M. 1996.

Sommerstein, A., Talking About Laughter: And Other Studies in Greek Comedy, Oxford - New York 2009.

— Clouds (The Comedies of Aristophanes 3), Warminster 2007a (1982). - Ecclesiazusae (The Comedies of Aristophanes 10), Warminster 2007b (1998).

—, Lysistrata (The Comedies of Aristophanes 7), Warminster 2007c (1990).

—, Peace (The Comedies of Aristophanes 5), Warminster 2005 (1985).

_ , "Violence in Greek Drama," Ordia Prima 3, 2004a, 41-56.

_, "Harassing the Satirist: the Alleged Attempts to Prosecute Aristophanes," in I. Sluiter - R. Rosen (Ed.), Freedom of Speech in Classical Antiquity, Leiden 2004b, 145-174.

— Wasps (The Comedies of Aristophanes 4), Warminster 2004c (1983). , "Die Komödie und das Unsagbare," in A. Ercolani (Ed.), Spoudaiogeloion. Form und Funktion der Verspottung in der aristophanischen Komödie, Stuttgart - Weimar 2002, 125-145.

- Thesmophoriazusae (The Comedies of Aristophanes 8), Warminster 2001a (1994).

— Wealth (The Comedies of Aristophanes 11), Warminster 2001b. 
— "Rape and Young Manhood in Athenian Comedy," in L. Foxhall - J. Salmon (Ed.), Thinking Men. Masculinity and its Self-Representation in the Classical Tradition, London - New York 1998a, 100-114.

_- Acharnians (The Comedies of Aristophanes 1), Warminster 1998b (1980).

— Knights (The Comedies of Aristophanes 2), Warminster 1997 (1981).

_ - Frogs (The Comedies of Aristophanes 9), Warminster 1996.

_ Birds (The Comedies of Aristophanes 6), Warminster 1991 (1987).

_ , "The Decree of Syrakosios," CQ n.s. 36, 1986, 101-108.

Stähli, A., "Die Rhetorik der Gewalt in Bildern des archaischen und klassischen Griechenland," in G. Fischer - S. Moraw (Ed.), Die andere Seite der Klassik. Gewalt im 5. und 4. Jahrhundert v. Chr., Stuttgart 2005, 19-44.

Stark, I., Die hämische Muse. Spott als soziale und mentale Kontrolle in der griechischen Komödie, München 2004.

_ sche. Die Warnung vor politischer Devianz und das Spiel mit den Namen prominenter Zeitgenossen," in A. Ercolani (Ed.), Spoudaiogeloion. Form und Funktion der Verspottung in der aristophanischen Komödie, Stuttgart - Weimar 2002, 147-167.

_ - "Who Laughs at Whom in Greek Comedy," in S. Jaekel - A. Timonen (Ed.), Laughter down the Centuries, vol. 2, Turku 1995, 99-116.

Stavrianopoulou, E. (Ed.), Ritual and Communication in the Graeco-Roman World, Liège 2006.

Steen, G. van, "Politics and Aristophanes: Watchword 'Caution,"” in M. McDonald - J. Walton (Ed.), The Cambridge Companion to Greek and Roman Theatre, Cambridge 2007, 108-123.

Steinwenter, A., Die Streitbeendigung durch Urteil, Schiedsspruch und Vergleich nach griechischem Rechte, München ${ }^{2} 1971$ (1925).

Stengel, P., Die griechischen Kultusaltertümer, München 1898.

Sternberg, R., Tragedy Offstage. Suffering and Sympathy in Ancient Athens, Austin/TX 2006.

- "The Nature of Pity," in Id. (Ed.), Pity and Power in Ancient Athens, Cambridge 2005, 15-47.

Stoessl, F., "Unkenntnis und Missverstehen als Prinzip und Quelle der Komik in Menanders Samia," RhM 116, 1973, 21-45.

Stone, L., "Interpersonal Violence in English Society 1300-1980," $P \& P$ 101, 1983, 22-33.

Storey, I., "Origins and Fifth-Century Comedy," in G. Dobrov (Ed.), Brill's Companion to the Study of Greek Comedy, Leiden - Boston 2010, 179-225.

Stratton, K., Naming the Witch. Magic, Ideology \& Stereotype in the Ancient World, New York 2007.

Strauss, B., "Ritual, Social Drama, and Politics in Classical Athens," $A J A H 10$, 1985, 67-83.

Strauss, L., Socrates and Aristophanes, New York 1966.

Stroud, R., Drakon's Law on Homicide, Berkeley - Los Angeles 1968.

Strubbe, J., APAI ЕПITYMBIOI. Imprecations against Desecrators of the Grave in the Greek Epitaphs of Asia Minor. A Catalogue, Bonn 1997. 


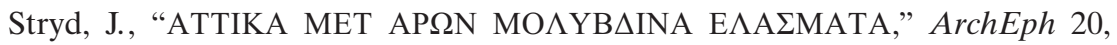
1903, 55-60.

Sutton, D., The Catharsis of Comedy, Lanham/MD 1994. , "Dicaeopolis as Aristophanes, Aristophanes as Dicaeopolis," LIMC 13, 1988, 105-108.

— Self and Society in Aristophanes, Washington/DC 1980.

Tambiah, S., Magic, Science, Religion, and the Scope of Rationality, Cambridge 1990.

_ _ "Form and Meaning of Magical Acts," in S. Tambiah, Culture, Thought and Social Action. An Anthropological Perspective, Cambridge/MA - London 1985a, 60-86 (orig. in R. Horton - R. Finnegan (Ed.), Modes of Thought, London 1973, 199-229).

_ , "The Magical Power of Words," in S. Tambiah, Culture, Thought and Social Action. An Anthropological Perspective, Cambridge/MA - London 1985b, 17-59 (orig. in Man 3, 1968, 175-208).

— , "A Performative Approach to Ritual," in S. Tambiah, Culture, Thought and Social Action. An Anthropological Perspective, Cambridge/MA - London 1985c, 123-166 (orig. in Proceedings of the British Academy 65, 1979, 113-169).

Taplin, O., "Fifth-Century Tragedy and Comedy: A Synkrisis," JHS 106, 1986, 163-174.

Taubenschlag, R., "Das attische Recht in der Komödie Menanders 'Epitrepontes," ZRG 46, 1926, 68-82.

Tetlow, E., Women, Crime, and Punishment in Ancient Law and Society, vol. 2: Ancient Greece, New York - London 2005.

Thalheim, T., Lysiae Orationes, Leipzig 1901 (Teubner editio maior).

Thalheim, T. - Thalheim F. - Blass, T. (Ed), Antiphon: Orationes et fragmenta, post Fridericum Thalheim edidit Theodorus Blass, Leipzig 1914 (repr. Stuttgart 1982).

Thiercy, P., Aristophane. Fiction et dramaturgie, Paris 1986.

Thomassen, E., "Is Magic a Subclass of Ritual?" in D. Jordan - H. Montgomery - E. Thomasson (Ed.), The World of Ancient Magic: Papers from the First International Samson Eitrem Seminar at the Norwegian Institute at Athens, 4-8 May 1997, Bergen 1999, 55-66.

Thompson, H. - Wycherley, R., The Agora of Athens: the History, Shape and Uses of an Ancient City Center, Princeton 1972.

Thür, G., "The Role of the Witness in Athenian Law," in M. Gagarin - D. Cohen (Ed.), The Cambridge Companion to Ancient Greek Law, Cambridge 2005, $146-169$.

— , "Das Gerichtswesen Athens im 4. Jh. v. Chr.," in L. Burckhardt - J. von Ungern-Sternberg (Ed.), Große Prozesse im antiken Athen, München 2000, 30-49.

— , "Reply to D. C. Mirhady: Torture and Rhetoric in Athens," JHS 116, 1996, 132-134.

-, "The Jurisdiction of the Areopagos in Homicide Cases," in M. Gagarin (Ed.), Symposium 1990. Akten der Gesellschaft für griechische und hellenistische Rechtsgeschichte, Köln 1991, 53-72. 
_, Beweisführung vor den Schwurgerichtshöfen Athens: Die Proklesis zur Basanos, Wien 1977.

Todd, S., A Commentary on Lysias, Speeches 1-11, Oxford 2007.

- "The Rhetoric of Enmity in the Attic Orators," in P. Cartledge - P. Millett - S. von Reden (Ed.), Kosmos. Essays in Order, Conflict and Community in Classical Athens, Cambridge 1998, 162-169.

- The Shape of Athenian Law, Oxford 1993.

- "The Purpose of Evidence in Athenian Courts," in P. Cartledge - P. Millett - S. Todd (Ed.), Nomos. Essays in Athenian Law, Politics, and Society, Cambridge 1990, 19-39.

Traill, A., Women and the Comic Plot in Menander, Cambridge 2008.

Tremel, J., Magica Agonistica: Fluchtafeln im antiken Sport, Hildesheim 2004.

Treu, K., "Menanders Menschen als Polisbürger," Philologus 125, 1981, 211 214.

Treu, M., Undici cori comici. Aggressività, derisione e techniche drammatiche in Aristofane, Genova 1999.

Trevett, J., Apollodoros the Son of Pasion, Oxford - New York 1992.

Trotha, T. von (Ed.), Soziologie der Gewalt, Wiesbaden 1997.

Trumpf, J, "Fluchtafel und Rachepuppe," AM 73, 1958, 94-102.

Tschopp, S., Grundfragen der Kulturgeschichte, Darmstadt 2007.

Tulin, A., Dike Phonou. The Right of Prosecution and Attic Homicide Procedure, Stuttgart - Leipzig 1996.

Turner, E., "Menander and the New Society," in J. Harmatta (Ed.), Proceedings of the VIIth Congress of the International Federation of the Societies of Classical Studies, vol. 1, Budapest 1984, 244-259.

Turner, V., "Are there Universals of Performance in Myth, Ritual, and Drama?" in R. Schechner - W. Appel (Ed.), By Means of Performance. Intercultural Studies of Theatre and Ritual, Cambridge 1990, 8-18.

—, Das Ritual. Struktur und Anti-Struktur, Frankfurt/M. - New York 1989a (The Ritual Process. Structure and Anti-Structure, Harmondsworth ${ }^{2} 1974$, London - New York 1969).

_ - Vom Ritual zum Theater. Der Ernst des menschlichen Spiels, Frankfurt/ M. - New York 1989b (From Ritual to Theatre: The Human Seriousness of Play, New York 1982).

_

Drama, Festival, Spectacle: Rehearsals toward a Theory of Cultural Performance, Philadelphia 1984, 19-41.

—, "Dramatic Ritual/Ritual Drama: Performative and Reflexive Anthropology," Kenyon Review N.S. 1, 1979, 80-93.

- Revelation and Divination in Ndembu Ritual, Ithaca 1975.

_ - "Social Dramas and Ritual Metaphors," in Id., Dramas, Fields, and Metaphors. Symbolic Action in Human Society, Ithaca - London 1974a, 23-59 (repr. in R. Schechner - M. Schuman (Ed.), Ritual, Play, and Performance. Readings in the Social Sciences/Theatre, New York 1976, 97-120).

- Dramas, Fields, and Metaphors. Symbolic Action in Human Society, Ithaca - London 1974b. 
, The Forest of Symbols: Aspects of Ndembu Ritual, Ithaca - London 21973a (1967).

- "Betwixt and Between: The Liminal Period in Rites de Passage," in Id., The Forest of Symbols. Aspects of Ndembu Ritual, Ithaca - London ${ }^{2} 1973 b$, 93-111 (orig. in M. Spiro (Ed.), Symposium on New Approaches to the Study of Religion, Seattle 1964).

- The Drums of Affliction. A Study of Religious Processes among the Ndembu, Oxford 1968.

Tzanetou, A., "Something to do with Demeter: Ritual and Performance in Aristophanes' Women at the Thesmophoria," AJP 123, 2002, 329-367.

Usher, S., Greek Oratory. Tradition and Originality, Oxford 1999.

Ussher, R., "Old Comedy and 'Character': Some Comments," G\&R 24, 1977, $71-79$.

Vaio, J., “Aristophanes' Wasps. The Relevance of the Final Scenes," GRBS 12, 1971, 335-351

Van Looy, H., "Youth Violence in Ancient Athens: 5th and 4th Century BC," in A. Hess - P. Clement (Ed.), History of Juvenile Delinquency: a Collection of Essays on Crime Committed by Young Offenders, in History and in Selected Countries; 2 vols., Aalen 1990, 71-125.

Versnel, H., "Prayers for Justice in East and West: Recent Finds and Publications," in: R. Gordon - F. Simón (Ed.), Magical Practice in the Latin West. Papers from the International Conference held at the University of Zaragoza 30. Sept. - 10. Oct. 2005, Leiden - Boston 2010, 275-354.

- , Fluch und Gebet: Magische Manipulation versus religiöses Flehen? Religionsgeschichtliche und hermeneutische Betrachtungen über antike Fluchtafeln, Berlin - New York 2009.

— , "Ritual Dynamics: The Contribution of Analogy, Simile and Free Association," in E. Stavrianopoulou (Ed.), Ritual and Communication in the Graeco-Roman World, Liège 2006, 317-327.

_ - "The Poetics of the Magical Charm. An Essay in the Power of Words," in P. Mirecki - M. Meyer (Ed.), Magic and Ritual in the Ancient World, Leiden - Boston - Köln 2002, 105-158.

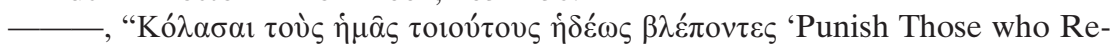
joice in our Misery': On Curse Texts and Schadenfreude," in D. Jordan - H. Montgomery - E. Thomasson (Ed.), The World of Ancient Magic: Proceedings of the First International Samson Eitrem Seminar, Norwegian Institute Athens, 4-8 May 1997, Bergen 1999, 125-162.

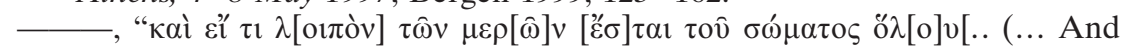
Any Other Part of the Entire Body There May Be...). An Essay on Anatomical Curses," in F. Graf (Ed.), Ansichten griechischer Rituale: Geburtstags-Symposium für Walter Burkert, Stuttgart 1998a, 217-267.

—_, "Komödie, Utopie und verkehrte Welt," in G. Binder - B. Effe (Ed.), Das antike Theater. Aspekte seiner Geschichte, Rezeption und Aktualität, Trier 1998b, 93-114.

- Inconsistencies in Greek and Roman Religion II: Transition and Reversal in Myth and Ritual, Leiden - New York - Köln 1993. 


\section{5.}

, "The Festival for Bona Dea and the Thesmophoria," $G \& R$ 39, 1992, 31 aone - D. Obbink (Ed.), Magika Hiera: Ancient Greek Magic and Religion, New York -Oxford 1991a, 60-106.

- "Some Reflections on the Relationship Magic-Religion," Numen 38, 1991b, 177-197.

Viano, C., "Competitive Emotions and thumos in Aristotle's Rhetoric," in D. Konstan - K. Rutter (Ed.), Envy, Spite and Jealousy. The Rivalrous Emotions in Ancient Greece, Edinburgh 2003, 85-97.

Vierhaus, R., "Die Rekonstruktion historischer Lebenswelten. Probleme moderner Kulturgeschichtsschreibung," in R. Vierhaus - H. Lehmann (Ed.), Wege zu einer neuen Kulturgeschichte, Göttingen 1995, 7-28.

Volonaki, E., "Apagoge in Homicide Cases," Dike 3, 2000, 147-176.

Voutiras, E., $\triangle \mathrm{IONY} \Sigma \mathrm{O} \Phi \Omega$ NTO $\Sigma$ ГAMOI. Marital Life and Magic in FourthCentury Pella, Amsterdam 1998.

Walcot, P., Envy and the Greeks: a Study of Human Behaviour, Warminster 1978.

Wallace, R., "Law, Attic Comedy and the Regulation of Comic Speech," in M. Gagarin - D. Cohen (Ed.), The Cambridge Companion to Ancient Greek Law, Cambridge 2005, 357-373.

- The Areopagos Council, to 307 BC, Baltimore - London 1989 (1985).

Walton, J. - Arnott, P., Menander and the Making of Comedy, Westport/CT London 1996.

Warning, R., "Elemente einer Pragmasemiotik der Komödie," in W. Preisendanz - R. Warning (Ed.), Das Komische, München 1976, 279-333.

Watson, L., Arae. The Curse Poetry of Antiquity, Leeds 1991.

Wax, M. - Wax, R., "The Magical World View," Journal for the Scientific Study of Religion 1, 1962, 179-188.

Weber, M., Wirtschaft und Gesellschaft, Tübingen 1925 (1922).

Webster, T., An Introduction to Menander, Manchester - New York 1974.

- Studies in Menander, Manchester 1950.

Wees, H. van, Greek Warfare. Myths and Realities, London 2004.

—, "Greeks Bearing Arms. The State, the Leisure Class, and the Display of Weapons in Ancient Greece," in N. Fisher - H. van Wees (Ed.), Archaic Greece: New Approaches and New Evidence, London 1998, 333-378.

Whitehorne, J., “Aristophanes' Representation of Intellectuals," Hermes 130, 2002, 28-35.

Whitman, C., Aristophanes and the Comic Hero, Cambridge/MA 1964.

Wiles, D., "Marriage and Prostitution in Classical New Comedy," in E. Segal (Ed.), Oxford Readings in Menander, Plautus, and Terence, Oxford 2001, 42-52.

—, Greek Theatre Performance. An Introduction, Cambridge 2000.

_ _ "Reading Greek Performance," G\&R 34, 1987, 136-151.

, "Menander's Dyskolos and Demetrios of Phaleron's Dilemma: A Study of the Play in its Historical Context - the Trial of Phokion, the Ideals of a 
Moderate Oligarch, and the Rancour of the Disfranchized," $G \& R 31,1984$, $170-180$.

Wilhelm, A., "Über die Zeit einiger attischer Fluchtafeln," JOAI 7, 1904, $105-$ 126.

Willemsen, F., "Die Fluchtafeln," in W. Kovacsovics (Ed.), Die Eckterrasse an der Gräberstraße des Kerameikos, Berlin - New York 1990, 142-151.

Willi, A., The Languages of Aristophanes. Aspects of Linguistic Variation in Classical Attic Greek, Oxford 2003.

Wilson, P., The Athenian Institution of the Khoregia. The Chorus, the City and the Stage, Cambridge 2000.

— 1991/92, 164-195.

Winkler, J., "The Constraints of Eros," in C. Faraone - D. Obbink (Ed.), Magika Hiera: Ancient Greek Magic and Religion, New York - Oxford 1991, 214243. (orig. "The Constraints of Desire: Erotic Magic Spells," in Id., The Constraints of Desire. The Anthropology of Sex and Gender in Ancient Greece, New York - London 1990, 71-98).

— , "Lollianos and the Desperadoes," JHS 100, 1980, 155-181.

Winkler, J. - Zeitlin, F., "Introduction," in J. Winkler - F. Zeitlin (Ed.), Nothing to do with Dionysus? Athenian Drama in its Social Context, Princeton 1990, 3-11.

Wirth, U. (Ed.), Performanz. Zwischen Sprachphilosophie und Kulturwissenschaften, Frankfurt/M. 2002.

Wohl, V., Love Among the Ruins. The Erotics of Democracy in Classical Athens, Princeton - Oxford 2002.

Wolff, C., Les brigands en Orient sous le Haut-Empire romain, Rome 2003.

Wolff, H. J., Beiträge zur Rechtsgeschichte Altgriechenlands und des Hellenistisch-Römischen Ägypten, Weimar 1961.

Wolpert, A., Remembering Defeat: Civil War and Civic Memory in Ancient Athens, Baltimore 2002.

—, "Lysias 1 and the Politics of the Oikos," CJ 96, 2001, 415-424.

Wünsch, R., "Eine antike Rachepuppe," Philologus 61, 1902, 26-31.

_, "Neue Fluchtafeln I; Neue Fluchtafeln II," RhM 55, 1900, 62 -85; 232 271.

Wysocki, L., "Aristophanes, Thucydides, b. VIII, and the Political Events of 413-411 BC," Eos 76, 1988, 237-248.

Yatromanolakis, D. - Roilos, P. (Ed.), Greek Ritual Poetics, Cambridge/MA 2004.

- Towards a Ritual Poetics, Athens 2003.

Young, R., "An Industrial District of Ancient Athens," Hesperia 20, 1951, 221 223.

Zagagi, N., The Comedy of Menander. Convention, Variation \& Originality, London 1994.

Zanetto, G., "Iambic Patterns in Aristophanic Comedy," in A. Cavarzere - A. Aloni - A. Barchiesi (Ed.), Iambic Ideas: Essays on a Poetic Tradition from Archaic Greece to the late Roman Empire, Lanham/MD 2001, 65-76. 
Zannini Quirini, B., Nephelokokkygia. La prospettiva mitica degli Ucceli di Aristofane, Roma 1987.

Zeitlin, F., "Aristophanes: the Performance of Utopia in the Ecclesiazousae," in S. Goldhill - R. Osborne (Ed.), Performance Culture and Athenian Democracy, Cambridge 1999, 167-197.

, "Travesties of Gender and Genre in Aristophanes' Thesmophoriazusai," CI 8, 1981, 301-327.

Ziebarth, E., "Besprechung von Werner Peek, Kerameikos III," GGA 204, $1942,19-21$.

_ - "Neue Verfluchungstafeln aus Attika, Boiotien und Euboia," in Sitzungsberichte der Preussischen Akademie der Wissenschaften, Phil.-hist. Klasse, vol. 33, Berlin 1934a, 1022-1050.

__ " "Aus neuen attischen Fluchtafeln," Praktika tes Akademias Athenon 9, 1934b, 132-136.

—_, "Neue attische Fluchtafeln," in Nachrichten der K. Gesellschaft der Wiss. zu Göttingen, Phil.-hist. Klasse (NGG) 1899, 105-135.

—_ "Der Fluch im griechischen Recht," Hermes 30, 1895, 57-70.

Zimmermann, B., "Väter und Söhne - Generationenkonflikt in den Wolken und Wespen des Aristophanes," in T. Baier (Ed.), Generationenkonflikte auf der Bühne. Perspektiven im antiken und mittelalterlichen Drama, Tübingen 2007, 73-81.

—_, Die griechische Komödie, Düsseldorf ${ }^{2} 2006$ (1998).

-, "Poetics and Politics in the Comedies of Aristophanes," in L. Kozak - J. Rich (Ed.), Playing Around Aristophanes: Essays in Celebration of the Completion of the Edition of the Comedies of Aristophanes by Alan Sommerstein, Oxford 2006, 1-16.

—_, "Innovation und Tradition in den Komödien des Aristophanes," Seminari Romani della cultura greca 1, 1998, 275-287.

_ - "Utopisches und Utopie in den Komödien des Aristophanes," WüJbb N.F. 9, 1983, 57-77 (repr. in W. Rösler - B. Zimmermann, Carnevale e utopia nella Grecia antica, Bari 1991, 55-98: "Nephelokokkygia. Riflessioni sull'utopia comica").

Zimmermann, M. (Ed.), Extreme Formen von Gewalt in Bild und Text des Altertums, München 2009.

Zografou, A., Chemins d'Hécate. Portes, routes, carrefours et autres figures de l'entre-deux, Liège 2010.

Zweig, B., "The Mute Nude Female Characters in Aristophanes' Plays," in A. Richlin (Ed.), Pornography and Representation in Greece and Rome, New York - Oxford 1992, 73-89. 


\section{Index Locorum}

\section{Literary Sources}

Aeschin. 1.15: 120

Aeschin. 1.15-16: 88, 120

Aeschin. 1.19-22: 25

Aeschin. 1.23: 23

Aeschin. 1.25-26: 24, 133

Aeschin. 1.28: 273

Aeschin. 1.28-30: 25

Aeschin. 1.38: 110

Aeschin. 1.53-62: 123

Aeschin. 1.58: 67

Aeschin. 1.58-59: 66

Aeschin. 1.59: 72, 87

Aeschin. 1.59-60: 106

Aeschin. 1.60: 100, 386

Aeschin. 1.60-61: 106

Aeschin. 1.62: 128

Aeschin. 1.81-84: 114

Aeschin. 1.91: 36

Aeschin. 1.107-108: 128

Aeschin. 1.114: 26

Aeschin. 1.135: 33

Aeschin. 1.137: 128

Aeschin. 1.141: 128

Aeschin. 1.153-155: 124

Aeschin. 1.171-172: 25, 40, 94

Aeschin. 1.172: 109

Aeschin. 1.173: 128

Aeschin. 1.182: 44

Aeschin. 1.183: 37

Aeschin. 2: 114

Aeschin. 2.4: 24, 90, 124

Aeschin. 2.87: 27

Aeschin. 2.93: 50, 51

Aeschin. 2.148: 25, 40, 94

Aeschin. 2.153-155: 90, 124

Aeschin. 2.166: 25, 40, 94

Aeschin. 3: 114
Aeschin. 3.51: 50, 51

Aeschin. 3.52: 59

Aeschin. 3.110-111: 202

Aeschin. 3.131: 127

Aeschin. 3.212: 50

Aeschin. 3.224: 84

Aeschin. 3.235: 38, 136

Aeschin. 3.257: 133

Aeschin. scholion 2.148: 25, 40, 94 Aeschin. scholion 2.166: 25, 40, 94

A. Ch. 129-130: 180

A. $C h .456: 180$

A. Ch. 489-509: 180

A. Ch. 727: 212

A. Eu. 273-275: 215

A. $E u .305-396: 223$

A. Eu. 566-777: 45

A. Pers. 618-80: 180

A. Pers. 623-651: 212

A. Supp. 228-231: 215

Alcaeus F 31 (K.-A.): 280

Alexis F 150.5 (K.-A.): 256

Alexis F 160 (K.-A.): 98, 228, 288

Alexis F 223 (K.-A.): 307

Alexis F 239 (K.A.): 67

And. 1: 326

And. 1.15: 176

And. 1.31: 24, 202

And. 1.73-79: 25, 249

Ps.-And. 4: 99 
Ps.-And. 4.14: 44, 55

Ps.-And. 4.15: 46

Ps.-And. 4.17: 125

Ps.-And. 4.20: 83

Ps.-And. 4.20-21: 56

Ps.-And. 4.23: 136

Ps.-And. 4.36: 136

Anonym. F 148 (Edmonds): 72

Anonym. F 435 (Edmonds): 72

Antiphanes F 202 (K.-A.): 276, 340

Antiphanes F 202 (K.-A.): 340

Antiphon 1: 42, 93, 167, 177

Antiphon 1.2: 153

Antiphon 1.3: 153

Antiphon 1.15: 86, 105

Antiphon 1.17: 45, 86, 322

Antiphon 1.17-19: 83

Antiphon 1.20: 88

Antiphon 1.21: 153

Antiphon 1.24: 153

Antiphon 1.25: 153

Antiphon 1.27: 83, 153

Antiphon 2: 69

Antiphon 2.1: 62, 65

Antiphon 2.1.4: 69, 108

Antiphon 2.1.6-7: 147

Antiphon 2.1.8: 135, 380

Antiphon 2.2.2: 153

Antiphon 2.4.11: 153

Antiphon 3.3.9: 153

Antiphon 4: 67

Antiphon 4.1.6: 120

Antiphon 4.2.2-3: 35

Antiphon 4.2.8: 173

Antiphon 4.3.1: 153

Antiphon 4.3.2: 67, 70

Antiphon 4.4.2: 34, 68, 70

Antiphon 5: 39

Antiphon 5.9: 43

Antiphon 5.29-56: 88

Antiphon 5.47-48: 88
Antiphon 6: 105

Antiphon 6.6: 27

Antiphon 6.14: 27

Antiphon 6.16: 27, 55, 94

Antiphon 6.19: 56

Antiphon 6.21: 153

Antiphon 6.24: 153

Antiphon 6.27: 153

Antiphon fr. 67 (Thalheim - Blass): 44

A.R. 4.1635-1690: 169

Ar. Ach. 22: 23

Ar. Ach. 40: 270

Ar. Ach. 44: 23

Ar. Ach. 176-177: 334

Ar. Ach. 204-236: 277

Ar. Ach. 263-275: 280

Ar. Ach. 271-275: 156

Ar. Ach. 271-276: 300

Ar. Ach. 272-273: 280

Ar. Ach. 272-275: 280

Ar. Ach. 280-283: 277, 307

Ar. Ach. 314-325: 280

Ar. Ach. 321: 259

Ar. Ach. 321-322: 256, 259

Ar. Ach. 326-365: 277

Ar. Ach. 352-354: 259

Ar. Ach. 352-356: 259, 288

Ar. Ach. 377-382: 248

Ar. Ach. 377-384: 252

Ar. Ach. 479: 262

Ar. Ach. 497-507: 252

Ar. Ach. 502-505: 248

Ar. Ach. 530: 258

Ar. Ach. 631: 262

Ar. Ach. 655-656: 266, 312

Ar. Ach. 824-825: 269

Ar. Ach. 824-828: 269

Ar. Ach. 925-952: 269

Ar. Ach. 926: 304

Ar. Ach. 980: 294

Ar. Ach. 990-999: 283

Ar. Ach. 994: 300

Ar. Ach. 994-999: 280

Ar. Ach. 1117: 262 
Ar. Ach. 1165-1173: 275

Ar. Ach. 1166-1168: 294

Ar. Ach. 1167-1168: 276

Ar. Ach. 1197-1231: 281

Ar. Ach. 1227-1234: 361

Ar. Ach. 1991: 276

Ar. Ach. F 24 (Henderson): 248

Ar. $A v .40-41: 296$

Ar. Av. 44: 296

Ar. $A v .383: 260$

Ar. $A v .401-402: 260$

Ar. Av. 463-465: 23

Ar. $A v .495-498: 276$

Ar. Av. 531-538: 298

Ar. Av. 665-673: 300

Ar. $A v .712: 276$

Ar. Av. 757-758: 298

Ar. Av. 859-894: 297

Ar. Av. 904-958: 297

Ar. Av. 959-991: 297

Ar. Av. 990: 304

Ar. Av. 992: 297

Ar. Av. 1016-1020: 297

Ar. Av. 1019: 304

Ar. Av. 1021-1034: 297

Ar. Av. 1031: 304

Ar. Av. 1035-1057: 125, 297

Ar. Av. 1046-1052: 297

Ar. Av. 1199-1261: 297

Ar. Av. 1223-1336: 267

Ar. Av. 1238-1242: 300

Ar. Av. 1253-1256: 300

Ar. Av. 1256: 280

Ar. $A v .1259: 300$

Ar. Av. 1313-1336: 298

Ar. Av. 1323-1336: 267, 277, 278

Ar. Av. 1349-1350: 299

Ar. Av. 1353-1357: 299

Ar. Av. 1360-1369: 299

Ar. Av. 1375-1409: 297

Ar. Av. 1410-1469: 298

Ar. Av. 1466: 304

Ar. Av. 1482-1493: 276

Ar. Av. 1485-1493: 276

Ar. Av. 1536-1543: 301

Ar. Av. 1565-1692: 276
Ar. Av. 1579-1590: 298

Ar. Av. 1634-1693: 301

Ar. Av. 1688-1689: 298, 300

Ar. Av. 1708: 298

Ar. $A v .1720: 301$

Ar. $A v .1720-1765: 301,361$

Ar. Ec. 202: 259

Ar. Ec. 378-379: 23

Ar. Ec. 635-643: 274

Ar. Ec. 638-640: 274

Ar. Ec. 663-664: 261, 294

Ar. Ec. 664: 294

Ar. Ec. 668-670: 276

Ar. Ec. 893-1111: 272

Ar. Ec. 1137-1138: 284

Ar. Ec. 1149-1183: 361

Ar. Eq. 1-29: 269

Ar. Eq. 41: 255

Ar. Eq. 64-72: 269

Ar. Eq. 247-254: 238

Ar. Eq. 285-302: 238

Ar. Eq. 304-312: 238

Ar. Eq. 367-374: 238

Ar. Eq. 451-456: 269

Ar. Eq. 510: 266, 312

Ar. Eq. 537: 257

Ar. Eq. 570: 255

Ar. Eq. 691-725: 238

Ar. Eq. 752: 255

Ar. Eq. 902-940: 238

Ar. Eq. 993-994: 257

Ar. Eq. 1384-1386: 281

Ar. Eq. 1387-1391:281

Ar. Eq. 1388-1391: 280

Ar. Eq. 1391: 281

Ar. Lys. 3: 291

Ar. Lys. 4: 291

Ar. Lys. 160-161: 155

Ar. Lys. 160-166: 275, 283

Ar. Lys. 162: 155

Ar. Lys. 225-227: 155, 275, 283

Ar. Lys. 306-403: 294

Ar. Lys. 321: 259

Ar. Lys. 352-386: 271

Ar. Lys. 387-475: 270 
Ar. Lys. 399-401: 261

Ar. Lys. 425: 261

Ar. Lys. 464: 255, 256

Ar. Lys. 503: 274, 275

Ar. Lys. 504-505: 259

Ar. Lys. 516: 274

Ar. Lys. 520: 274

Ar. Lys. 550: 259

Ar. Lys. 655-687: 262

Ar. Lys. 658-660: 261

Ar. Lys. 670-671: 262

Ar. Lys. 973-979: 283

Ar. Lys. 1023: 255

Ar. Lys. 1112-1189: 283

Ar. Lys. 1114: 281

Ar. Lys. 1216-1222: 294

Ar. Lys. 1216-1224: 267

Ar. Lys. 1216-1227: 277

Ar. Lys. 1218: 277

Ar. Lys. 1296-1321: 361

Ar. Nu. 57-59: 305

Ar. Nu. 494-498: 305

Ar. Nu. 495: 304

Ar. Nu. 518-562: 302

Ar. Nu. 537-562: 266

Ar. Nu. 545-550: 312

Ar. Nu. 549: 275

Ar. Nu. 560-562: 312

Ar. Nu. 587-594: 249

Ar. $N u$. 610: 255

Ar. Nu. 833: 256

Ar. Nu. 889-1104: 302

Ar. Nu. 911: 305

Ar. Nu. 1068-1069: 304

Ar. Nu. 1083-84: 53

Ar. Nu. 1154-1166: 309

Ar. Nu. 1206-1213: 309

Ar. Nu. 1214-1302: 304

Ar. Nu. 1297-1302: 125, 304

Ar. Nu. 1321: 306

Ar. Nu. 1321-1324: 306

Ar. Nu. 1327: 306

Ar. Nu. 1369: 259, 304

Ar. Nu. 1437-1439: 306

Ar. Nu. 1443: 306

Ar. Nu. $1443 \mathrm{ff}: 274$

Ar. Nu. 1447-1451: 306
Ar. Nu. 1454-1455: 306

Ar. Nu. 1465-1466: 307

Ar. Nu. 1476: 304

Ar. Nu. 1476-1511: 303

Ar. Nu. 1478: 304

Ar. Nu. 1484-1485: 307

Ar. Nu. 1484-1509: 307

Ar. Nu. 1490: 361

Ar. Nu. 1506: 305

Ar. Nu. 1508-1509: 307

Ar. Clouds I, Testimonia (ii) Hypothesis A7 (Henderson): 302

Ar. Hypothesis VII (Coulon 1952, p. 162): 302

Ar. Pax 66: 256

Ar. Pax 204: 259

Ar. Pax 255-256: 269

Ar. Pax 523-867: 282

Ar. Pax 613: 259

Ar. Pax 659: 259

Ar. Pax 729-774: 266

Ar. Pax 739-750: 278

Ar. Pax 742-747: 268

Ar. Pax 748-753: 312

Ar. Pax 752: 255

Ar. Pax 868-908: 282

Ar. Pax 889-891: 282

Ar. Pax 905-906: 282

Ar. Pax 1118-1126: 297

Ar. Pax 1119: 304

Ar. Pax 1229: 263

Ar. Pax 1264: 263

Ar. Pax 1329-1340: 282

Ar. Pl. 454-612: 270

Ar. Pl. 564: 261

Ar. Pl. 886: 263

Ar. Pl. 886-936: 125

Ar. Pl. 894-1008: 271

Ar. Pl. 899: 263

Ar. Pl. 932: 304

Ar. Pl. 1044: 263

Ar. Pl. 1074: 263

Ar. Pl. 1194-1209: 361

Ar. Ra. 1-24: 266 
Ar. Ra. 4: 255, 260

Ar. Ra. 21: 263

Ar. Ra. 145-146: 273

Ar. Ra. 297: 244

Ar. Ra. 528-529: 304

Ar. Ra. 584: 260

Ar. Ra. 635-673: 271

Ar. Ra. 686-705: 249

Ar. Ra. 700: 258

Ar. Ra. 715-716: 275

Ar. Ra. 814: 257

Ar. Ra. 844: 256

Ar. $R a$. 856-857: 256

Ar. Ra. 994: 257

Ar. Ra. 997-998: 256

Ar. Ra. 1006: 257

Ar. Ra. 1017: 255

Ar. Ra. 1524-1533: 361

Ar. Th. 59-62: 262, 282

Ar. Th. 63: 262

Ar. Th. 157-158: 283

Ar. Th. 295-371: 202

Ar. Th. 331-371: 24

Ar. Th. 465: 263

Ar. Th. 466: 256

Ar. Th. 468: 255

Ar. Th. 518: 256

Ar. Th. 535: 263

Ar. Th. 5.70: 259

Ar. Th. 655-687: 262

Ar. Th. 670-671: 262

Ar. Th. 689-761: 277

Ar. Th. 726-727: 337

Ar. Th. 749: 337

Ar. Th. 903: 263

Ar. Th. 930-1225: 270

Ar. Th. 1172-1225: 283

Ar. Th. II? 5A (Edmonds): 280

Ar. Triphales F 563 (Henderson): 257

Ar. V. 54-66: 266, 312

Ar. V. 223-224: 287

Ar. V. 243-244: 257

Ar. V. 383: 259

Ar. V. 397-402: 289
Ar. V. 398-399: 290

Ar. V. 403: 255, 256, 287

Ar. V. 424: 287

Ar. V. 560: 287

Ar. V. 567: 287

Ar. V. 574: 287

Ar. V. 646: 287

Ar. V. 646-649: 287

Ar. V. 726: 287

Ar. V. 768-770: 290

Ar. V. 859-874: 26

Ar. V. 883-885: 287

Ar. V. 891-1008: 286, 287

Ar. V. 894-1008: 271

Ar. V. 1043-1045: 312

Ar. V. 1082/83: 255, 286

Ar. V. 1122-1164: 286

Ar. V. 1252-1255: 288, 292, 294

Ar. V. 1253-1254: 294

Ar. V. 1292: 292

Ar. V. 1292-1296: 268

Ar. V. 1296: 292

Ar. $V .1299-1341: 288$

Ar. V. 1303: 288, 292

Ar. V. 1306: 288

Ar. V. 1307: 292

Ar. V. 1319: 292

Ar. $V .1322-1331: 294$

Ar. $V .1322-1449: 68$

Ar. V. 1323: 292

Ar. V. 1326: 292

Ar. $V .1326-1387: 286$

Ar. $V .1326-1537: 268$

Ar. V. 1327-1331: 292

Ar. $V .1341-1381: 290$

Ar. V. 1345-1381: 292

Ar. V. 1351-1353: 290

Ar. V. 1382-1386: 290

Ar. V. 1386: 292

Ar. V. 1388ff.: 274

Ar. V. 1389-1391: 292, 294

Ar. V. 1390: 292

Ar. V. 1406: 292

Ar. V. 1417-1426: 292

Ar. $V .1417-1441: 288$

Ar. V. 1417-1449: 125

Ar. V. 1418: 292

Ar. V. 1418-1419: 288, 292 
Ar. V. 1422: 292

Ar. V. 1436-1445: 304

Ar. $V .1441: 288,292$

Ar. V. 1442-1449: 286

Ar. V. 1449: 292

Ar. V. 1476-1496 : 294

Ar. V. 1484: 292

Ar. V. 1486: 292

Ar. V. 1491: 292

Ar. V. 1496: 292

Ar. V. 1503: 293

Ar. scholia V. 946-948: 208

Ar. F. 9 (K.-A.): 155, 275

Ar. F 10 (Edmonds): 155, 275

Ar. F 300 (K.-A.): 332

Ar. F 452 (Henderson, K.-A.): 47

Ar. F 653 (Henderson): 267

Ar. F 676 (Henderson): 275

Aristophon F 10 (K.-A.): 307

Aristophon F 12 (K.-A.): 307

Arist. Ath. 34-40: 38

Arist. Ath. 41.1-2: 146

Arist. Ath. 52.1: 43, 214

Arist. Ath. 55.2-3: 273

Arist. Ath. 57.3: 36, 84, 177

Arist. Ath. 57.3-4: 27

Arist. Ath. 57.4: 25

Arist. Ath. 59.3-4: 37

Arist. EN 1125b26-1126a1: 132

Arist. EN 1126a4-8: 117, 325

Arist. EN 1128a15-19: 331

Arist. EN 1131a9: 152

Arist. EN 1135b24-27: 49

Arist. EN 1145a15-1152a36: 132

Arist. EN 1146b27-1147a18: 132

Arist. EN 1151b32-1152a6: 132

Arist. EN 1160a3-8: 90

Arist. EN 1177a28-36: 334

Arist. EN 1180a5-14: 127

Arist. $M M$ 1188b31-37: 84
Arist. Po. 1448a25-1448b3: 240

Arist. Po. 1449a5-12: 239

Arist. Pol. 1253a1: 334

Arist. Pol. 1259b3: 306

Arist. Pol. 1262a27: 152

Arist. Pol. 1275a22-33: 146

Arist. Pol. 1275b13-21: 146

Arist. Pol. 1302b5-21: 97

Arist. Pol. 1311b18-1315a28: 77

Arist. Pr. 953b4: 261

Arist. Rh. 375a6-7: 49

Arist. Rh. 1373a35: 120

Arist. Rh. 1373b38-1374a15: 120

Arist. $R h$. 1374a11-15: 49

Arist. Rh. 1374a32-b1: 49

Arist. Rh. 1374b35-1375a2: 125

Arist. Rh. 1375a6-7: 49

Arist. Rh. 1378a31-33: 120

Arist. Rh. 1378b13-30: 120

Arist. Rh. 1379a30, 32: 120

Arist. Rh. 1380a29: 120

Arist. Rh. 1380b5: 120

Arist. Rh. 1382b35-1383a3: 120

Arist. Rh. 1384a16-19: 120

Arist. Rh. 1385b19-24, 31: 120

Arist. Rh. 1389a: 125

Arist. Rh. 1389b7, 12: 120

Arist. Rh. 1390a19: 120

Arist. Rh. 1390b32-34: 120

Arist. Rh. 1391a14-19: 120

Arist. Rh. 1395a1: 120

Arist. Rh. 1398a25: 120

Arist. Rh. 1402a: 323

Arist. Rh. 1402a1-2: 34, 120

Arist. Rh. 1408a16: 120

Arist. Rh. 1419b8: 331

Ath. 13.569: 36

Ath. 13.590d-591f: 111

Chrysippus SVF ii 891: 321

Cic. Brut. 60.217: 172, 208, 219

Cic. Brut. 142: 10 
Cic. De Orat. 3.213: 10

Cic. Orat. 37.129: 172, 208, 219

Cic. Orat. 56: 10

Clem. Al. Protr. 2.22: 232

1 Cor. 5:11-13: 127

Cratinus F 19 (K.-A.): 261

D. $5.7: 24$

D. $18.10: 65$

D. $18.132-133: 74,80$

D. $18.137: 84$

D. $18.138: 115$

D. $19.70-71: 24,202$

D. $19.196-198: 90,124$

D. 19.251-252: 24

D. 19.281: 233

D. $19.337-338: 158$

D. $20: 163$

D. $20.107: 24,202$

D. $21: 1,19,97,99,120$

D. $21.5-6: 55$

D. $21.10: 75,133$

D. $21.13-18: 108$

D. $21.15-17: 57$

D. 21.16 : $66,78,81$

D. $21.20: 92,136$

D. 21.22: 57

D. $21.26: 128$

D. $21.30: 81,136$

D. $21.36-40: 125$

D. $21.37: 137$

D. 21.38-40: 67

D. $21.41: 118,133$

D. $21.45: 78$

D. $21.47-48: 88,120$

D. $21.48: 350$

D. $21.50: 350$

D. $21.58-61: 133$

D. $21.59: 163$

D. $21.61: 58$
D. $21.62: 163$

D. $21.66: 136$

D. $21.66-67: 128$

D. $21.69: 92$

D. $21.70: 133$

D. 21.71: 69

D. 21.71-74: 135

D. $21.71-75: 35,116$

D. $21.71-76: 125$

D. $21.72: 122$

D. 21.73 : 69,118

D. $21.74: 58,66,69,83$

D. $21.76: 78$

D. $21.78-79: 77$

D. $21.79: 110$

D. $21.85-86: 128,136$

D. 21.87-94: 110

D. $21.91: 128,136$

D. $21.92: 81$

D. $21.96: 92,128$

D. 21.96-98: 136

D. 21.98: 92

D. 21.104-122: 40

D. 21.112: 92

D. $21.112-113: 136$

D. $21.123: 118$

D. $21.123-124$ : $93,129,136$

D. 21.127: 118,129

D. 21.129: 110

D. 21.131: 129

D. 21.131-132: 136

D. $21.135: 129,136$

D. $21.138: 93,136$

D. $21.143: 93,136$

D. $21.143-150: 128$

D. $21.147: 56,81,125$

D. $21.150: 131,350$

D. $21.151: 115$

D. 21.171: 115

D. $21.175: 118$

D. 21.178-181: 124

D. 21.180: 67

D. 21.182: 96

D. 21.183 : 93,136

D. $21.189: 82$

D. $21.193-195: 136$

D. $21.195: 123$

D. $21.196: 118$ 
D. $21.201: 129,136$

D. $37: 73$

D. $21.204: 129$

D. $37.33: 33$

D. 21.207: 93,129

D. 21.207-213: 136

D. $40.32: 97$

D. 21.209 : 129

D. 40.32-33: 51

D. $21.213: 129$

D. $40.57: 51$

D. $21.215: 118$

D. 21.217: 63

Ps.-D. 43: 147

D. $21.224-225: 134$

Ps.-D. 43.57: 36

D. $21.226: 118,146$

Ps.-D. 45.3-5: 125

D. $22.2: 45,48$

D. $22.52: 126$

D. $22.53-56: 124$

D. $22.55-56: 62$

D. $22.63: 67$

D. $22.68: 24,133$

D. $23.22: 36,84,177$

D. $23.24: 84,177$

D. $23.28: 62,87$

D. $23.40-41: 25$

D. $23.50: 34$

D. $23.53-56: 36$

D. $23.53-57: 143$

D. $22.55-56: 62$

D. $23.56: 43,134$

D. 23.60-61: 36

D. 23.65-79: 27

D. 23.67-69: 27

D. $23.69: 78$

D. $23.80: 25$

D. 23.97: 24, 202

D. $24.113: 36$

D. $24.113-114$ : 66

D. 24.149-151: 25

D. 24.164 : 77,126

D. 24.197: 77

D. 24.204 : 214

D. $25.1 .56-57: 85$

D. $25.32: 135$

D. $25.60-62: 34,111$

D. $25.79-80: 233$

D. $26.17: 131$

D. $36.52: 202$

Ps.-D. 47: 33, 44, 51, 73, 78, 82, 90, 107, $137,147,390$

Ps.-D. 47.7-8: 34

Ps.-D. 47.19: 34, 73, 74

Ps.-D. 47.19-21: 80

Ps.-D. 47.19-48: 74, 78

Ps.-D. 47.34: 51

Ps.-D. 47.35: 34

Ps.-D. 47.35-38: 134

Ps.-D. 47.39-40: 34

Ps.-D. 47.41-42: 82

Ps.-D. 47.47: 34

Ps.-D. 47.48: 82

Ps.-D. 47.52: 88

Ps.-D. 47.52-57: 79

Ps.-D. 47.58-59: 107

Ps.-D. 47.58-62: 44

Ps.-D. 47.60-61: 51

Ps.-D. 47.61: 88

Ps.-D. 47.63-64: 79

Ps.-D. 47.67: 44

Ps.-D. 47.68-70: 44

Ps.-D. 47.68-73: 36

Ps.-D. 47.70: 27, 45

Ps.-D. 47.79-80: 81

Ps.-D. 48.14-19: 88

Ps.-D. 53: 105, 136, 147

Ps.-D. 53.1-6: 208

Ps.-D. 53.3: 110

Ps.-D. 53.15: 65, 74, 81

Ps.-D. 53.15-16: 81

Ps.-D. 53.16: 87, 88, 124, 125

Ps.-D. 53.17: 51, 65

Ps.-D. 53.17-18: 49, 62 
Ps.-D. 53.19: 208

Ps.-D. 53.23: 208

Ps.-D. 53.28: 208

D. $54: 19,97,99,120$

D. 54.1 : $42,130,133$

D. 54.3-4: 67

D. $54.4: 115$

D. 54.5-6: 98

D. 54.7-8: 59, 67, 107

D. $54.8: 133$

D. $54.9: 110,123$

D. $54.14: 33$

D. $54.16: 67$

D. 54.17-19: 134

D. $54.18: 50$

D. $54.18-19: 78$

D. $54.19: 98$

D. $54.20: 50,60$

D. 54.21-22: 69

D. $54.24: 133$

D. $54.25: 67,94,116$

D. $54.32-34: 47$

D. $54.33: 34$

D. $54.37: 78$

D. $54.39: 23,83,139$

D. $54.44: 92$

D. $57: 147$

Ps.-D. 58: 147

Ps.-D. 58.28-29: 48

Ps.-D. 59: 46, 136, 147, 291, 386

Ps.-D. 59.9-10: 46

Ps.-D. 59.10: 27

Ps.-D. 59.40: 125

Ps.-D. 59.66: 88

Ps.-D. 59.86-87: 37

D. scholion 21.95: 110

D. scholion 21.102: 40

D. scholion 21.104: 40

D. scholion 21.116: 40

D. scholion 21.147: 125

D. scholion 21.200: 129

D. scholion 21.205: 40
Dig. 4.2.7.1: 66

Dig. 9.2.4.1: 66

Dig. 47.17.1: 66

Din 1: 114

Din 1.23: 124, 125

Din. 1.30-31: 40

Din. 1.47: 24, 40

Din 2.4: 96

Din. 2.14-16: 23

Din. 2.16: 24, 202

Din 2.20: 96

D.C. $57.18 .9: 219$

D.Chr. 47.24: 127

D.S. $8.22: 44$

D.S. $11.29 .2-3: 202,207$

D.S. $14.3-6: 38$

D.S. 14.5.6: 100

D.S. $14.32-33$ : 38

D.L. 8.1.3: 307

Diogenian. 7.18 (289.11): 235

Diphilus F 74 (K.-A.): 256

Diyllos ap. Athen. 155a: 323

Duris FGrHist 76 F 56: 207

Epicharmus F 100 (K.-A.): 365

Epicharmus F 146 (K.-A.): 288

Eubulus F 61 (K.-A.): 255

Eubulus F 93 (K.-A.): 288

Eubulus F 93.6-7 (K.-A.): 261

Eubulus F 93.8-10 (K.-A.): 294

Eubulus F 93.9 (K.-A.): 256

Eupolis F 386 (K.-A.): 305

Eupolis F 395 (K.-A.): 305

E. Alc. 743: 212 
E. Alc. 1003: 180

E. Alc. 1004: 180

E. Cyc. 179-182: 300

E. Cyc. $424: 256$

E. Cyc. 445-446: 294

E. Cyc. 507-509: 294

E. Cyc. 534-537: 294

E. Hec. 823: 307

E. Ion 891-901: 354

E. $R h .675-676: 307$

E. Supp. 980-1030: 307

E. $T r .1256-1283: 307$

Gel. 2.23.15-18: 343

Gorgias (Diels ${ }^{9} 1959,82$ B 11, 10): 232

Heraclid. Lemb. Epit. Ath. Pol. 1: 44

Hermippus F 51 (K.-A.): 267

Hdt. 1.5.3: 35

Hdt. 3.1: 116

Hdt. 3.25: 116

Hdt. 3.32-36: 116

Hdt. 3.80.5: 129

Hdt. 7.11: 116

Hdt. 7.39: 116

Hdt. 9.111: 116

Hes. Op. 25-26: 169

Hes. Op. 124: 180

Hes. Op. 238-247: 204

Hes. Op. 254: 180

Hes. Op. 708: 34

Hieronymus, Vita S. Hilarionis eremitae 12.9: 219

Hieronymus, Vita S. Hilarionis eremitae 21: 219
Hp. Morb.Sacr. 2: 232

Hp. Morb.Sacr. 18: 256

Hom. Epigr. 14: 169

Hom. Il. 9.448-463: 322

Hom. Il. 22.358-360: 180

Hom. Il. 23.802-825: 323

Hom. Od. 11.12-224: 212

Hom. Od. 11.72-73: 180, 212

Hom. Od. 11.568: 215

Hor. Epod. 5: 226

Hyp. Lyc.: 43, 76

Hyp. Lyc. Speech B, fr. 1.1: 78, 127

Hyp. fr. 21 (97-99): 33, 86, 96

Hyp. fr. 60: 111

Hyp. fr. 210: 141

Iamb. VP 249: 307

Idomeneus FGrHist 338 F 12: 40

Is. $3: 73$

Is. $3.13-14: 76$

Is. $8: 33$

Is. $8.3: 46$

Is. $8.41: 47,88,94,125$

Is. $8.44: 46$

Is. $9: 33,86$

Is. $9.16-19: 45,51,97$

Is. $9.20: 147$

Is. $11: 147$

Is. fr. $5: 88,95,125$

Isoc. 1.15: 24

Isoc. 1.21: 116

Isoc. 3.39: 77

Isoc. 15.252: 37 
Isoc. 18: 99

Isoc. 18.6: 51

Isoc. $18.52-54: 46$

Isoc. $20: 39,50,93,97,99,120$

Isoc. 20.1: 34, 51, 62, 108

Isoc. 20.4: 119

Isoc. $20.5: 130$

Isoc. 20.5-6: 123

Isoc. 20.7: 50, 119

Isoc. 20.8: 96, 98

Isoc. 20.8-9: 134

Isoc. 20.10-11: 126

Isoc. 20.11: 126

Isoc. 20.19: 93

Just. Epit. 5.8.11-10.4: 38

Lib. 1.245-250: 215

Liv. 8.6: 207

Liv. 8.9-11: 207

Liv. 10.26-30: 207

Liv. 31.44.4-6: 201

Luc. 6.413-830: 226

Lucianus, DMeretr. 4.4-5: 167, 181

Lucianus, Peregr. 9: 53

Lycurg. 1.31: 24, 202

Lycurg. 1.80-81: 202, 207

Lycurg. 1.112-115: 41

Lycurg. frr. 10-11: 76, 127

Lycurg. frr. 10-11.6: 78

Lys. 1: 19, 22, 33, 36, 53, 76, 358

Lys. 1.2: 118

Lys. 1.4: 114

Lys. 1.23-24: 53

Lys. 1.25: 53

Lys. 1.26: 81

Lys. 1.27: 104

Lys. 1.28: 43, 54

Lys. 1.29: 53

Lys. 1.30: 36, 43, 54

Lys. 1.30-33: 36, 54
Lys. 1.31: 43, 54

Lys. 1.32-33: 351

Lys. 1.34: 36,114

Lys. 1.36: 114

Lys. 1.42: 50

Lys. 1.43-45: 34

Lys. 1.44: 37, 137

Lys. 1.45-50: 118

Lys. 1.47-49: 114

Lys. 1.49: 36

Lys. 3: 33, 37, 68, 73, 91, 99, 120, 128, 291

Lys. 3.1: 91

Lys. 3.4: 71

Lys. 3.5: 91

Lys. 3.5-8: 119

Lys. 3.7: 91

Lys. 3.9: 71, 91

Lys. 3.10: 73, 133

Lys. 3.11-12: 67, 125

Lys. 3.12: 100

Lys. 3.13: 50

Lys. 3.14: 50

Lys. 3.15: 125

Lys. 3.15-18: 64, 106

Lys. 3.16: 51

Lys. 3.18: 34

Lys. 3.18-19: 67

Lys. 3.23: 66, 125

Lys. 3.25-26: 91

Lys. 3.28: 49

Lys. 3.37: 119, 125

Lys. 3.39: 137

Lys. 3.42: 37, 137, 149

Lys. 3.43: 34, 68

Lys. 3.44: 128

Lys. 3.45: 91, 94

Lys. 4: 33, 68, 73, 80, 291

Lys. 4.6: 49

Lys. 4.7: 68

Lys. 4.8: 68

Lys. 4.9: 50, 108

Lys. 4.9-10: 106

Lys. 4.11: 34, 323

Lys. 4.15: 34, 80

Lys. 4.18: 106 
Lys. 6.24-25: 25

Lys. 6.50-53: 127

Lys. 6.51: 201

Lys. 7.4: 41

Lys. 10.10: 214

Lys. 10.11: 27

Lys. 12: 38, 100

Lys. 12.8: 126

Lys. 13: 38

Lys. 13.42: 147

Lys. 13.70-72: 41

Lys. 14.2: 147

Lys. 14.42: 44

Lys. 20.9-11: 41

Lys. 23: 33, 125

Lys. 24: 22, 64

Lys. 25.9: 41

Lys. 29.1: 208

Lys. 32.22: 147

Lys. fr. XXVII 58-61: 54

Lys. fr. XLVII 103: 163

Lys. fr. LXIV 129-130: 163

Lys. fr. LXV 151: 163

Lys. fr. CXXIX 279: 71, 91, 93, 99, $106,124,125$

Lys. fr. CXXIX 279.4: 66

Lys. fr. CXXIX 279.4-6: 73

Lys. fr. CXXIX 279.6: 60

Men. Aspis 180-181: 328

Men. Aspis 422: 328

Men. Aspis 439: 328

Men. Aspis 451: 328

Men. Colax 120-132: 337
Men. Colax E 225-237 (Arnott 1996, pp. 182-183): 337, 351

Men. Dis exapaton 99: 329

Men. Dysc. 58-60: 351

Men. Dysc. 58-62: 351

Men. Dysc. 60: 351

Men. Dysc. 80-123

Men. Dysc. 81-123: 334

Men. Dysc. 83: 334

Men. Dysc. 89: 321, 327

Men. Dysc. 153-178: 334

Men. Dysc. 168: 323

Men. Dysc. 176-178: 334

Men. Dysc. 230-232: 294

Men. Dysc. 259-320: 352

Men. Dysc. 285: 332

Men. Dysc. 289-293: 351

Men. Dysc. 293-298: 351

Men. Dysc. 271-298: 352

Men. Dysc. 295-298: 333

Men. Dysc. 315: 333

Men. Dysc. 328-335: 175

Men. Dysc. 430-455: 334

Men. Dysc. 466-486: 334

Men. Dysc. 500-503: 334

Men. Dysc. 631-632: 334

Men. Dysc. 711-723: 334

Men. Dysc. 722-729: 335

Men. Dysc. 729-747: 335

Men. Dysc. 730-747: 335

Men. Dysc. 842-844: 335

Men. Dysc. 880: 363

Men. Dysc. 880-958: 363

Men. Dysc. 890-905: 175

Men. Dysc. 893-960: 335

Men. Dysc. 955-960: 362

Men. Dysc. 959: 363

Men. Dysc. 963-969: 362

Men. Epit. 128-131: 326

Men. Epit. 169-171: 294

Men. Epit. 393: 321, 327

Men. Epit. 450-457: 346

Men. Epit. 453: 346

Men. Epit. 486- 490: 347

Men. Epit. 878-879: 327 
Men. Epit. 878-907: 347

Men. Epit. 880-881: 327

Men. Epit. 890-901: 347

Men. Epit. 898: 350

Men. Epit. 908-918: 348

Men. Epit. 912: 348

Men. Epit. 924: 350

Men. Epit. 1026: 327

Men. Epit. 1126: 327

Men. Georg. 3: 344

Men. Georg. 6: 344

Men. Georg. 9: 344

Men. Georg. 29-30: 344

Men. Georg. F 3 (Arnott 1979, pp. 128-129): 365

Men. Georg. F 4 (Arnott 1979, pp. 130-131): 344

Men. Her. 6-7: 344

Men. Her. 12: 344

Men. Her. 79: 344

Men. Her. Hypothesis, line 3: 342

Men. Hiereia (Arnott 2000, pp. 619-625): 342

Men. Kith. 8-9: 343

Men. Kith. 24-25: 343

Men. Kith. 27: 343

Men. Kith. 28: 343

Men. Kith. 199: 343

Men. Kith. F 3 (Arnott 1996, pp. 138-139): 343

Men. Kith. F 4 (Arnott 1996, pp. 138-139): 364

Men. Mis. 989-996: 362

Men. Pk. 163: 328

Men. Pk. 368: 329

Men. Pk. 375-393: 340

Men. Pk. 378: 329

Men. Pk. 379: 329

Men. Pk. 379-380: 329

Men. Pk. 469-471: 340
Men. Pk. 476: 340

Men. Pk. 481: 340

Men. Pk. 489: 329

Men. Pk. 499-503: 329

Men. Pk. 500-503: 329

Men. Pk. 722: 332

Men. Per. $1 \mathrm{ff} .: 337$

Men. Phasm. 199 (Arnott 2000, pp. 398-399): 343

Men. Sam. 2-3: 345

Men. Sam. 38-55: 345

Men. Sam. 39: 346

Men. Sam. 48-49: 320

Men. Sam. 77-86: 320

Men. Sam. 83: 320

Men. Sam. 130-136: 335

Men. Sam. 206-282: 320

Men. Sam. 302-324: 336

Men. Sam. 305-306: 336

Men. Sam. 320-322: 336

Men. Sam. 325-356: 345

Men. Sam. 339-342: 321

Men. Sam. 341: 321

Men. Sam. 361: 321

Men. Sam. 363: 321

Men. Sam. 370-398: 321, 335

Men. Sam. 415: 321

Men. Sam. 416: 321, 327

Men. Sam. 447: 321

Men. Sam. 462: 321

Men. Sam. 492-520: 322

Men. Sam. 495: 322

Men. Sam. 495-496: 322

Men. Sam. 495-497: 322

Men. Sam. 495ff.: 322

Men. Sam. 498: 322

Men. Sam. 498-499: 322

Men. Sam. 498-500: 322

Men. Sam. 506-520: 322

Men. Sam. 507-508: 331

Men. Sam. 529: 322

Men. Sam. 532-534: 322

Men. Sam. 533-540: 322

Men. Sam. 535-538: 323

Men. Sam. 550-585: 323 
Men. Sam. 553-556: 323

Men. Sam. 560-561: 323

Men. Sam. 570: 323

Men. Sam. 572-576: 323

Men. Sam. 575ff.: 324

Men. Sam. 576: 34

Men. Sam. 578: 324

Men. Sam. 580: 323

Men. Sam. 589-595: 324

Men. Sam. 589-602: 358

Men. Sam. 660: 336

Men. Sam. 663: 336

Men. Sam. 678: 336

Men. Sam. 679: 336

Men. Sam. 695: 324

Men. Sam. 702-703: 324

Men. Sam. 703: 324

Men. Sam. 707-708: 324

Men. Sam. $713 \mathrm{ff}$ : 346

Men. Sam. 717: 346

Men. Sam. 717-718: 324

Men. Sam. 722: 332

Men. Sam. 733-737: 362

Men. Sicyonioi 418-423: 362

Men. Synaristosai F1 (Arnott 2000, pp. 344-345): 342

Men. fabula incerta 1.24-25: 343

Men. fabula incerta 1.27: 343

Men. fabula incerta 1.28: 343

Men. fabula incerta 5: 342

Men. fabula incerta 6.8-9: 343

Men. fabula incerta 7: 342

Men. F 2 (Kö.): 365

Men. F 3 (Kö.): 343

Men. F 4 (Kö.): 344, 364

Men. F 95 (K.): 365

Men. F 109-121 (Kö.): 337, 351

Men. F 126-138 (Pernerstorfer): 337, 351

Men. F 147-155 (Kö., Arnott 1979, pp. $136-136,9 c): 344$
Men. F 284 (K.): 364

Men. F 337 (K.-A.): 342

Men. F 382 (Kö.): 342

Men. F 453 (Edmonds): 325

Men. F 574 (Edmonds): 325

Men. F 614 (Edmonds): 325

Men. F 627 (Edmonds): 69

Men. F 629-630 (Edmonds): 325

Men. F 728 (Edmonds): 333

Men. F 780 (Edmonds): 325

Men. F 1089 (Edmonds): 325

Men. F adesp. 1010 (K.-A.): 343

Men. F adesp. 1084 (K.-A.): 342

Men. F adesp. 1131 (K.-A.): 346

Paroem. Gr. I 137.10: 235

Paus. 9.36.8: 36

Pherecrates F 121 (K.-A.):273

Pherecrates F 136 (Edmonds): 267

Pherecrates F 144 (K.-A.): 267

Philemon F 156-157 (K.-A.): 325

Philippides F 26 (Edmonds): 91

Philippides F 27 (K.-A.): 68, 91

Philochorus FGrHist 328 F 60: 233

Philyllius F 9 (K.-A.): 280

Phrynichus F 33 (Edmonds): 306

Phrynichus F 34 (K.-A.): 306

Pi. P. 4.219: 217

Pl. Ap. 18c: 249

Pl. Ap. 19c: 249

Pl. Ap. 41a: 215

Pl. Chrm. 155e-156c: 232

Pl. Criti. 119e: 202

Pl. Euthd. 303a: 184 
Pl. Euthphr. 3e-4e: 42

Pl. Euthphr. 3e7-5d6: 36

Pl. Grg. 523e-524a: 215

Pl. Lg. 659a: 371

Pl. Lg. 700c-701b: 371

Pl. Lg. 853d-855a: 127

Pl. Lg. 862d-e: 127

Pl. Lg. 865e: 180

Pl. Lg. 871b: 202

Pl. Lg. 871d: 127

Pl. Lg. 873a-b: 127

Pl. Lg. $874 a-b: 127$

Pl. Lg. $874 \mathrm{e}-879 \mathrm{~b}: 49$

Pl. Lg. $877 \mathrm{a}-\mathrm{b}: 127$

Pl. Lg. 880e-882c: 127

Pl. Lg. 909a-c: 217, 220

Pl. Lg. 926e-927b: 180

Pl. Lg. 928e: 269

Pl. Lg. 932e-933e: 232

Pl. Lg. 933d-e: 220

Pl. Lg. 936c: 127

Pl. Men. 80a-b: 184

Pl. Men. 80b 2-7: 232

Pl. Men. 80b 5-7: 233

Pl. Phd. 69c: 192

Pl. Phd. 95b: 169

Pl. Phd. 107c-108b: 215

Pl. Phd. 113d-114d: 215

Pl. Phdr. 272d-e: 31

Pl. R. 364b-c: 174, 216, 232

Pl. R. $439 \mathrm{e}-440 \mathrm{a}: 152$

Pl. R. 460c-d: 274

Pl. R. 461c-e: 274

Pl. R. 463c-d: 274

Pl. R. 465a-b: 274

Pl. R. 564a: 130

Pl. R. 573c: 130

Pl. R. 574b-c: 130

Pl. Smp. 223c-d: 310

Plaut. Cist. 177-178: 342
Plin. Nat. 28.4.19: 169

Plu. Alc. 7.1: 55, 224

Plu. Alc. 8.1: 34

Plu. Alc. 8.4: 44

Plu. Alc. 16.4: 125

Plu. Alc. 16.5-8: 56

Plu. Alc. 22: 201

Plu. Alc. 33: 201

Plu. Arist. 4.1: 149

Plu. Arist. 10.6: 202, 207

Plu. Dem. 12: 59

Plu. Dem. 12.2-6: 93

Plu. Dem. 14: 233

Plu. Dem. 14.6: 152

Plu. Dem. 25.7-8: 81

Plu. Mor. 10.853-854: 331

Plu. Per. 5.1-2: 389

Plu. Per. 5.1-3: 150, 365

Plu. Per. 7.5: 150, 365, 389

Plu. Per. 38: 232

Plu. Q. Rom. 275d: 202

Plu. Sol. 19.3-4: 234

Plu. Sol. 23.1: 36

Plu. Vit. X Orat. 845b: 10

Plb. 12.6b9: 202

Rhet. Gr. V 525: 344

Rhet. Gr. VIII 48: 40

Sen. Med. 6-23: 226

Sen. Med. 670-843: 226

S. Aj. 832: 212

S. El. 1491-1495: 51

S. OT 22-30: 204 
S. OT 269-275: 202

S. OT 873: 126

S. $\operatorname{Tr}$. 555-587: 167

S. Tr. 1138-1142: 167

Str. 6.3c279: 202

Suda o 806: 235

Tac. Ann. 2.69.3: 219

Theoc. Ep. 2: 181, 187

Theoc. Ep. 2.127-128: 351

Thphr. Char. 16: $205 \mathrm{f}$.

Theopompus F 79 (K.-A.): 297

Th. 2.21.3-22.2: 116

Th. 3.36-49: 116

Th. 6.15-16: 56

Th. 6.27-29: 326

Th. 6.53: 326

Th. 6.60-61: 326
Th. 8.90-92: 41

Th. 8.97: 202

Verg. Ecl. 8.64-109: 181

X. An. 5.7.21: 307

X. Cyr. 1.5.13: 323

X. $H G$ 1.7.22-23: 96

X. $H G$ 2.3-4: 38

X. $H G$ 2.3.21: 100

X. $H G$ 2.4.14: 126

X. Mem. 2.1.5: 53

X. Mem. 2.2.13: 273

X. Mem. 4.4.20: 298

Ps.-X. Ath. 1.5: 132

Ps.-X. Ath. 1.10: 88

Ps.-X. Ath. 2.18: 258

X. Eph. 5.7.7-8: 180

Zen. 5.40: 235

\section{Inscriptions}

Abt 1911, pp. 143-149, no. 1: 192

Abt 1911, pp. 155-158, no. 5: 175, 190

AG XVI 20: 124

AG XVI 35: 124

Aubert 1989, p. 435, no. 23: 195

Audollent 1904, 1-13: 201

BE 1938, 23: 195

BE 1963, p. 125, no. 32: 163, 170, 176, 197

Boegehold 1995, 55-57: 188

Braun 1970, 197-198: 170, 176
Bravo 1987, pp. 195 with 213, nn. 19 and 20: 171

Bravo 1987, p. 206: 187

CIL VI 19747: 219

CIL VIII 2756: 219

Costabile 2004/5, 137-169: 163, 170, 176

Costabile 2004/5, 176-182: 170, 176

Costabile 2004/5, 182-192: 163, 176

DT 43: 187, 213

DT $44: 187,213$

DT 49: 190

DT 50: 191

DT 51: 191

DT 52: 171, 213

DT 60: 170, 176, 188, 390 
DT 66: 172

DT 68: 171, 192, 213

DT 69: 191, 198, 213

DT 72: 192

DT 85: 192

DT 92: 191, 226

DTA 10: 171

DTA 11: 171

DTA 12: 171

DTA 24: 176

DTA 26: 188

DTA 30: 171

DTA 33: 171, 188

DTA 33-34: 188

DTA 34: 171

DTA 45: 171

DTA 47-50 (a-d): 172

DTA 53: 191

DTA 55: 171, 174, 190, 213

DTA 57: 171

DTA 58: 172

DTA 65: 171, 176

DTA 67: 186

DTA 68: 188

DTA 69: 171, 191

DTA 69-71: 171

DTA 75: 171, 191

DTA 76: 191

DTA 77: 171

DTA 78: 171

DTA 80: 209

DTA 85: 211

DTA 86: 171, 211

DTA 87: 175, 190, 211, 213

DTA 88: 172, 211

DTA 88-91: 211

DTA 89: 171

DTA 90: 171

DTA 91: 209, 211

DTA 92-93: 171

DTA 93: 211

DTA 94: 163, 176

DTA $95: 172$

DTA 96: 171

DTA 96-97: 186

DTA 97: 171, 172, 186

DTA 98: 194, 203
DTA 99: 195, 213

DTA 100: 195, 203, 211, 213

DTA 102: 171, 187, 188, 195, 203, 213

DTA 103: 170, 176, 187, 203, 210, 213 , 390

DTA 105-106: 186

DTA 107: 172, 186

DTA 108: 185

DTA 109: 195, 211

DTA 120: 195, 203

DTA 158: 195, 203

DTA 161: 211

Eitrem 1936, 558: 170, 175, 176, 190

Elderkin 1937, 389-395: 195

Faraone 1991a, 15: 186

Faraone 1991a, 156, n. 20: 197

Faraone 1991b, p. 201, no. 5: 197

Gager no. 1: 171

Gager no. 20: 192

Gager no. 22: 171, 192, 213

Gager no. 23: 171

Gager no. 24: 171

Gager no. 38: 170, 176, 187, 210, 390

Gager no. 39: 172

Gager no. 40: 172, 186

Gager no. 41: 163, 170, 176, 197

Gager no. 42: 170, 176, 188, 390

Gager no. 44: 190

Gager no. 56: 170, 176, 190

Gager no. 57: 170, 176

Gager no. 58: 176

Gager no. 59: 172

Gager no. 61: 211

Gager no. 62: 175, 190, 211, 213

Gager no. 63: 171, 191

Gager no. 64: 171, 174, 190, 213

Gager no. 65: 171, 191

Gager no. 66: 171, 172

Gager no. 67: 171, 211

Gager no. 68: 188

Gager no. 70: 175, 208

Gager no. 71: 171

Gager no. 74: 192 
Gager no. 83: 194

Gager no. 84: 195

Gager no. 102: 171

Gager no. 104: 171, 187, 188, 213

Gager no. 105: 171, 213

Gager no. 136: 219

Gager no. 140: 174

Gager no. 141: 220

GHI I 23: 201, 207

GHI I 86: 41

GHI I 87: 36

GHI II 142: 40

GHI II 204: 202, 207

Guarducci 1978, 244-245, figs. 68 - 69: 163, 170, 176, 197

Hansen 1976, 133, no. 16: 40

HGIÜ I 6: 202

HGIÜ I 40: 202, 207

HGIÜ I 47: 201, 207

HGIÜ I 140: 41

HGIÜ I 145: 36

HGIÜ II 231: 40

IG I $^{2}$ 110: 41

$\mathrm{IG} \mathrm{I}^{2}$ 115: 36

IG I $I^{3}$ 102: 41

IG I $^{3}$ 104: 36

IG I ${ }^{3} 104$, lines 26-28: 25

IG I $^{3} 104$, lines 33-34: 34

IG I $^{3} 104$, lines 33-36: 36

IG I $^{3} 104$, lines 37-38: 36

IG I ${ }^{3}$ 164: 124

IG I $^{3}$ 179: 124

IG I ${ }^{3} 228: 124$

IG II $^{2}$ 46: 124

$\mathrm{IG} \mathrm{II}^{2} 72: 124$

$\mathrm{IG} \mathrm{II}^{2}$ 73: 124

IG II $^{2}$ 111: 40

IG XII 9 1179: 206
IKnidos 147-159: 201

ILS 8522: 219

Jeffery 1955, p. 75, no. 19: 171, 213

Jeffery 1955, p. 75, no. 20: 213

Jeffery 1955 , p. 75 , no. $23: 171$

Jeffery 1955 , p. 75 , no. $24: 171$

Jeffery 1955 , p. 75 , no. $25: 171$

Jordan 1980a, 229-236: 171, 176

Jordan 1980b, 62-65: 195

Jordan 1988, 275-276: 163, 170, 176, 197

Jordan 1999, 117, side A: 232

Jordan 2000, 95: 89

Lechat 1889, 77-80: 191

López 1990, pp. 134-144, no. 27: 187

López 1992, 201-202: 163, 171, 176

López 1: 171, 213

López 2: 213

López 5: 171

López 6: 171

López 7: 171

López 8: 171

López 9: 163, 170, 176, 197

López 14: 171, 176

López 18: 171

López 20: 171

López 24: 171, 176

López 26: 175, 208

López 30: 170, 176, 190

López 31: 175, 190

López 45: 175

López 48: 191, 195

López 51: 191, 198

López 55: 163, 171, 176

López 57: 171

López 59: 171, 176

López 63: 195

López 67: 210

M/L 5.40-51: 202

M/L 30: 201, 207 
M/L 85: 41

M/L 86: 36

NGCT 1: 163, 171, 176

NGCT 3: 171, 195

NGCT 5: 171, 176

NGCT 9: 176

NGCT 14: 195, 203

NGCT 15: 188

NGCT 23: 203

NGCT 24: 169, 195, 203, 232

NGCT 31: 226

NGCT 66: 203

OGIS I 55.30-33: 202

Peek 1941, pp. 91-93, no. 3: 171, 213

Peek 1941, pp. 93-94, no. 4: 171

Peek 1941, pp. 94-95, no. 5: 171

Peek 1941, pp. 95-96, no. 6: 213

Peek 1941, p. 96, no. 7: 171

Peek 1941, p. 97, no. 8: 171

Peek 1941, pp. 97-100, no. 9: 175, 208

Peek 1942, pp. 166-167: 170, 176, 190

Petropoulos 1988, 219-220: 171, 192

Rhodes - Osborne 2003, 39: 40

Robert 1936, pp. 12-13, no. 11: 171, 176

Robert 1936, pp. 13-14: 170, 176, 190

Robert 1936, pp. 14-16, no. 12: 192

SEG XII 100: 208

SEG XXI 1093: 163, 170, 176, 197

SEG XXX 325.2: 171, 176

SEG XXX 326: 195

SEG XXXI 67: 124

SEG XXXIII 96: 124

SEG XXXV 211: 171, 176

SEG XXXVII 214: 171

SEG XXXVII 215: 174, 190

SEG XXXVII 216: 175, 190, 211

SEG XXXVII 217: 195, 211

SEG XXXVII 219: 171, 187, 188

SEG XXXVII 220: 170, 187, 210, 390

SEG XXXVII 221: 172, 186
SEG XXXVII 223: 195

SEG XXXVII 673: 213

SEG XXXVIII 31: 163, 170, 176, 197

SEG XXXIX 293: 170, 176

SEG XXXIX 1847: 195

SEG XL 273: 171

SEG XLI 981: 205

SEG XLII 217: 163, 171, 176

SEG XLIII 434: 226

SEG XLV 47: 124

SEG XLIX 320: 169, 195, 232

SEG XLIX 321: 171, 213

SGD 1: 171, 213

SGD 2: 213

SGD 3: 171

SGD 5: 171

SGD 6: 171, 176

SGD 7: 171

SGD 8: 171

SGD 9: 163, 170, 176, 197

SGD 14: 171,176

SGD 18: 171, 215

SGD 20: 171

SGD 21: 195

SGD 42: 171, 176

SGD 44: 175, 208

SGD 48: 170, 171, 176, 190

SGD 49: 175,190

SGD 52: 171

SGD 54: 180, 191, 203

SGD 58: 203

SGD 72: 171, 175

SGD 75: 191, 195

SGD 78: 191, 198

SGD 89: 191

SGD 91: 171, 203

SGD 104: 226

SGD 105: 213

SGD 109: 180, 187

SGD 115: 190

SGD 173: 180

Shear 1973, 127-128: 188

StV II 235: 124

StV II 268: 124 
Strubbe 1997, no. 40: 206

Strubbe 1997, no. 146: 206

Stryd 1903, col. 59-60, no. 5: 171

Syll. I ${ }^{3}$ 37-38: 201, 207

Syll. I ${ }^{3}$ 108: 41

Syll. $I^{3}$ 111: 36

Syll. I ${ }^{3}$ 173: 40

Syll. I I 527.78-94: 202

Trumpf 1958: 176

Trumpf 1958, 94-102: 163

Trumpf 1958, 97-101: 170, 197

Twelve Tables (Roman) 8.12 -13: 66

Versnel 1991a, 65: 187

Versnel 1991a, 65-66: 195, 211

Versnel 1991a, 66-67: 195

Voutiras 1998, p. 8: 214, 226

Wilhelm 1904, 107-108: 171, 174, 190

Wilhelm 1904, 112: 172, 186

Wilhelm 1904, 112-113: 171, 187, 188

Wilhelm 1904, 113: 171

Wilhelm 1904, 114-115: 172

Wilhelm 1904, 115: 171

Wilhelm 1904, 115-122: 176

Wilhelm 1904, 119-120: 172

Wilhelm 1904, 120-122: 171

Wilhelm 1904, 122-125: 170, 187, 210

Willemsen 1990, 142-143: 163, 171, 176

Willemsen 1990, 145-147: 171

Willemsen 1990, 148-149: 171, 176

Wünsch 1900, p. 63, no. 6: 170, 176, 188

Wünsch 1900, pp. 63-64, no. 10: 190

Wünsch 1900, pp. 64-65, no. 15: 191

Wünsch 1900, p. 65, no. 16: 171, 192, 213

Wünsch 1900, pp. 65-66, no. 17: 171, 191, 198, 213
Wünsch 1900, p. 66, no. 18: 192

Wünsch 1900, p. 66, no. 19: 192

Wünsch 1900, p. 67, no. 20: 171, 213

Wünsch 1900, p. 70, no. 1: 192

Wünsch 1900, pp. 70-71, no. 2: 191

Wünsch 1900, p. 72, no. 4: 172

Young 1951, 221-223: 171

Ziebarth 1899, p. 108, no. 6: 170, 176, 188

Ziebarth 1899, pp. 109-110, no. 10: 190

Ziebarth 1899, pp. 113-114, no. 15: 191

Ziebarth 1899, pp. 114-116, no. 16: $171,192,213$

Ziebarth 1899, pp. 116-117, no. 17: $171,191,198,213$

Ziebarth 1899, pp. 117-118, no. 18: 192

Ziebarth 1899, pp. 118-120, no. 20: 171,213

Ziebarth 1899, pp. 132-133, no. 1: 192

Ziebarth 1899, p. 133, no. 2: 191

Ziebarth 1934a, pp. 1023-1027, no. 1 A - B: 170, 176, 190

Ziebarth 1934a, p. 1027, no. 2: 176

Ziebarth 1934a, pp. 1030-1031, no. 4: 175,190

Ziebarth 1934a, pp. 1033-1034, no. 7: 175

Ziebarth 1934a, p. 1036, no. 13: 191, 195

Ziebarth 1934a, p. 1038, no. 17: 191, 198

Ziebarth 1934a, p. 1039, no. 20: 188

Ziebarth 1934a, pp. 1040-1042, no. 23: 192,213

Ziebarth 1934b, 132-136: 170, 176, 190

Ziebarth 1942, 19: 171, 213

Ziebarth 1942, 19-20: 175, 208, 213 


\section{Papyri}

P. Abinn. 45: 78

P. Ant. I 15: 342

P. Berl. 8450: 346

BGU II 522: 93

P. Cair. 43227: 342

GMP pp. 44-47: 180

GMP p. 65: 180

GMP p. 66: 180

GMP p. 89: 180

GMP p. 94: 180

GMP pp. 106-107: 179

PGM IV 296-466: 180

PGM IV 1416-1431: 180

PGM IV 1460-1495: 180

PGM IV 2725-2739: 180

PGM IV 2943-2966: 180

PGM V 304-369: 179

P. Hamb. 656: 342

P. Köln III 125: 212

P. Lond. II 245: 78
P. Mich. Inv. no. 3267: 78

P. Mich. IX 525: 93

P. Oxy. III 429: 343

P. Oxy. VIII 1120: 93

P. Oxy. X 1235b: 342

P. Oxy. XVI 1837: 93

P. Oxy. IL 3467: 78

P. Ryl. II 114: 93

P. Ryl. II 127: 78

P. Sakaon 36: 93

SB XIV 11904: 93

SB XX 14679: 78

PSI VIII 883: 93

TGF III fr. 273: 212

TGF III fr. 273a: 212

TGF III fr. 275: 212

\section{Iconographical Sources}

LIMC I 2 no. 101: 85

LIMC I 2 no. 104a: 85

LIMC I 2 no. 104f: 85

LIMC I 2 no. 344: 85

LIMC I 2 no. 349a: 85

LIMC I 2 no. 354: 85

LIMC I 2 no. $355: 85$

LIMC I 2 no. 356: 85

LIMC I 2 no. $372: 85$

LIMC I 2 no. $373: 85$

LIMC I 2 no. $374: 85$

LIMC IV 2 no. 24 : 85
LIMC IV 2 no. 60: 85

LIMC IV 2 no. 322 : 85

LIMC VII 2 no. 99: 85

LIMC VII 2 no. 100: 85

LIMC VII 2 no. 102: 85

LIMC VII 2 no. 104: 85

LIMC VIII 2 no. 7: 85

LIMC VIII 2 no. 11: 85

LIMC VIII 2 no. 16: 85

LIMC VIII 2 no. 30a: 85

LIMC VIII 2 no. 31: 85 
LIMC VIII 2 no. 181: 85

LIMC VIII 2 no. 271: 85

LIMC VIII 2 no. 212: 85

LIMC VIII 2 no. 285: 85 


\section{General Index}

Terms with nearly synonymous meanings, which are categorized under one entry, are separated by a slash (e.g. accused/defendant). Morphologically related words are separated by a comma (e.g. neighbor, neighborhood). Cross references are introduced by a semicolon (e.g. adultery; cf. seduction).

abduction marriage $143,332,351$ abuse $2,51,70,74,77,80,89$, 97-99, 107, 117, 119, 123, 133, $136,152,231,238,313,317,322$, 385

accused/defendant $\quad 25-27,29,31$, $32,40,45,46,50,56,65,67,68,70$, $71,79,84,91,90,104-106,108$, $111,126,129,135,158,172,216$, 218, 219, 286, 287, 307, 324, 336, 389

accuser/prosecutor $\quad 8,26,29$, 31-33, 39, 40-42, 44, 45, 50, 67-69, 70, 71, 79, 82-84, 86, 88, 91, 93, 94, 96, 98, 104, 105, 107, 108, $130,134,135,143,152,158,172$, $173,216,217,219,288,382,389$

Acropolis 243, 255, 261, 271

adultery; cf. moicheia; seduction $33,36,43,53,76,78,114,121$, $127,129,143,256,322,328$

Aenus 39

aesthetics of production $\quad 375,391$ aesthetics of reception $\quad 375,391$

Africa 165, 169, 219

Agora 24, 25, 41, 44, 52, 55, 56, 59, $64,72,78,87,89,126,166,181$, $221,224,244,269,271,285,286$, $290,293,386,393$

allotment machine/klêrôtêrion 13, 26

altar of the Mother of the Gods $100,106,386$

Amazons 85, 154

- Amazonomachy 84, 85 amnesty (of 404/03 BCE) 219, $224,232,374,380,381,393$ anger/fury/ire/orgê/rage/wrath $35,67,76,82,85,98,115-120,122$, $132,149,159,160,162,173,183$, 198, 230, 231, 237, 254-260, 285-288, 295, 297, 300, 304, 319-328, 330, 331, 333, 335, 336, $346,349,364,365,367,374,379$, 389,392

Anthesteria 245

Aphidna $\quad 25,40,46,109,124,176$ aposiopesis $\quad 109-111,301,354$ arbitration $14,17,172,221,233$, $379,389,391$

Areopagos 9, 17, 26, 35-37, 39, 49- 51, 84, 94, 114, 116, 177, 233, 234, 314

Arginusae, battle of 138

arrogance $3,91,121,123,125,129$, $161,261,275,296,300$

arson $307,314,338$

Asia Minor $\quad 202,206,377$

assault $\quad 50,87,96,98,129-130,137$, 143, 152, 261, 292, 294, 332, 342, 343, 365, 386

Assembly of the People/Ekklêsia $23,24,30,63,110,114,126,133$, 170, 202, 224, 235, 244, 249, 250, 372

Assyria 222

Babylonia $\quad 222,249$

Bactria 377 
barbarian/barbaros 1,129-131, $139,152,157,159,160,163,221$, $270,273,312,317,319,325,330$, $335,350,367,371,384,387$

bastard child/nothos $\quad 347-349,355$ Bath 184, 192, 201

battery $19,70,71,79,86,261,288$, 292, 297, 365, 367

beating $50,60,65,72,78,87,88$, $92,100,110,115,121,122,124$, 130, 149, 155, 156, 183, 259, 264, 265, 267-269, 271, 273-275, 278, 280, 281, 288, 290, 292, 293, 297-299, 302, 304-307, 313, 314, $321,334,335,338,364,367,389$ bile/gall 254-256, 327, 328, 329 biography 378 biting $34,92,111,115,255,267$, $286,304,308$

blow $\quad 34,44,51,52,61,79,80,82$, $88,89,94,96-98,101,108,115$, $122,126,135,252,265,271,278$, 292, 299, 312, 314, 323, 327, 336, 365

Boeotia 192

Boulê/Council 17, 24, 40, 41, 79, $80,82,90,170,215,243,249$

braid model 16,103

Brauron 94, 116

- Brauronia festival 343 brawl $33,49,50,52,63,67,69,98$, $124,137,140,149,267,269,329$, 386

burglar, burglary $\quad 214,306$

bystander/passer-by 22,29,31,33, $49,51,54,55,60,63,65,76,85,91$, 99 106, 114, 160, 271, 288, 292, 294, 364, 386

Cambridge ritualists, school 240-242

catharsis $\quad 142,157,244,247,368$

centaurs 85

- Centauromachy 85

Ceos 40

certainty, legal $\quad 138,144,388$ charivari; cf. justice, popular; rough music; Rügebrauch 72, 73, 75, $76,103,105,133,257,339$

chase $\quad 255,297,304,307$

Chersonese 226

chorus; cf. chorêgia; chorêgos 1 , $25,33,55-57,62,95,105,212,236$, $238,242,245,249,251,255-258$, $261,262,264,268,271,275,276$, $277,278,280,282,286-289,298$, $303,306,312,314,339,361,362$, 375

Cirrha 202

citizenship 28, 41, 87, 154, 223, $249,289,331,340,355,360$

- Periclean 322, 354, 359

- status 33, 37-39, 45, 57, 84, 87, $89,98,101,106,125,138,147,160$, 367,375

civil war/stasis $36,43,82,97,219$, $349,388,389,393$

Clarus 205

cleansing; cf. purity $\quad 23,45,54,178$

Cloudcuckooland/Nephelokokkugia 278, 296-299

Cnidus 201

cockfight; cf. fighting cock; rooster $8,60,106$

coercion $\quad 61,72-73,89,155,161$, 184

concubine/pallakê, also hetaira, prostitute, whore $66,72,76$, 77, 125, 132, 149, 171, 176, 177, 205, 281, 283, 290-292, 295, 320-322, 326, 329, 331, 335-337, 345-347, 351, 353-355, 358, 383

consumption (illness) 191

Corinth $8,239,328,329,388$

Council; cf. Boulê

councilors/bouleutai $\quad 9,40,41,79$, 282

countryside $\quad 151,332,352,360$

(law)court system 7, 63,71,136, $138,146,147,150,153,157,163$, $165,173,218,228,230,232,233$, $269,287,334,371,379$

Croton 307 
culture of public display $\quad 52,65,76$, $112,140,156,172,373,383$

Cyrene, decree of 202

dagger; cf. sidêrion; sword $\quad 50,53$ defendant; cf. accused

Delphinion $\quad 9,27,35,143$

denigration, of character $2,38,47$, $51,68,102,110,114,126,151,313$, 322

Dionysia, Great $\quad 1,56-58,82,83$, 93, 146, 243, 246, 291

Dirae Teiorum 201 divorce $\quad 36,44,55,99,100$ dramatization $52,55,56,58,62$, $99,100,129,139,155,161,236$, $312,316,341,367,371,387,394$

Dreriorum ius iurandum 202 duel 323

effigy/figurine/voodoo doll 178, 197, 199-201

Egypt $78,93,180,181,223,342$, 377

Ekklêsia; cf. Assembly of the People

Eleusinia 124,308

The Eleven 17, 53, 126, 152, 214-216, 219

enemy, enmity; cf. rival $24,37,63$, $69,77,81,84,87,90,92,100$, 104-106, 109, 113, 117, 123, 126, 129, 134-137, 152, 154, 159, 160, 169, 170, 174, 175, 197, 201, 202, 216, 222, 229, 257, 259, 275, 294 , $296,308,333,370,375,379,381$ envy/phthonos $\quad 29,165,169,177$, 230,379

ephebes 232, 289, 343

Ephesus 205

Erinyes/Furies 180, 201, 233

escalation $51,52,60,63,77,79,80$, 86, 90, 96-98, 101, 133, 134, 139, $141,149,229,271,288,321$

Evil Eye/baskania 29, 165, 169, 177

execution $38,40,49,50,53,54,84$, $88,94,104,118,124,126,127,133$, $135,138,150,152,154,177$,
214-217, 219, 220, 233, 276, 306, $309,326,346,380,385,391$ exile $\quad 25,37,39,40,94,97,116,154$, $217,257,308,389$

farce $265,266,269,318,322,323$, $336,368-370$

father-beating $130,268,271,273$, 274, 290, 299, 304, 305, 307, 338

feeling of belonging; cf. communitas $13,241,330$

feud $\quad 7,97,137,172,380$

- blood feud 36, 97, 137, 138, 146, $148,149,152,157,233,379$

fight $\quad 34,68,70,85,96,147,270$, 271, 393

fighting cock; cf. cockfight; rooster $66,73,106,123$

figurine; cf. effigy

fistfight $\quad 67-69,109$

fisticuff $\quad 34,50,64$

flogging; cf. scourging; whipping 66, 269

Fluchzustand/loimos 201, 204-206, 215

foreigner 40,270

foreign policy $40,163,374,378$, 383, 392-394

fracas 51

fratricide $\quad 45,109$

Furies; cf. Erinyes

furniture $\quad 66,72-74,79,81,123$

fury; cf. anger

gall; cf. bile

gender $5,43,84,86,98,101,154$, 261, 268, 270-273, 289, 294, 318, $329,338,350,360,365,367$

gentleness; cf. enkrateia; mildness; moderation; praotês; sôphrosunê; temperance 132,338, 366

Germanicus 219

Gigantes 85

- Gigantomachy 85

gods of the underworld 16, 96, 180, 186, 188, 195, 201, 202, 207, 
208, 213, 216, 219, 229, 231, 233 , $316,383,391$

gossip $18,169,177,182$

grief; cf. mourning 112,162

gynecocracy 272, 284, 294, 339

hair $\quad 86,181,186,263,328,346,347$

- hair pulling/dragging 84-86, 346,386

hemlock 152, 257

Hephaisteion 87

hero $83,85,148,192,224$, 267-269, 276, 293, 295, 302, 303, $317,350,363,368$

- comic hero 238, 244, 251, 253, 256, 259, 264, 267-270, 277, 281, 283-285, 293, 294, 296, 301-303, $309,311,313-318,338,350,363$, $366-368,372,373$

historiography $11,35,51,378$

hitting $34,48,86,89,96,97,105$, $124,201,275,288,290,298,307$, 336,338

homicide/murder; cf. killer; murderer $\quad 5,9,19,25-27,34-52$,

$54-56,62,65,69,71,83,84,86,88$, 90, 94-98, 101, 104, 105, 109, 113, $118,119,132,134,144,147$, 150-152, 177, 220, 233, 234, 307, 382 homicide statute/law; cf. Draco 5,
$25,36,39,40,42-44,54,90,95$, 134

honor $6,35,42,43,54,58,64,73$, $76,78,80,82,96,97,107-109,111$, 117-119, 127, 134, 135, 148, 150, $155,169,205,219,239,244,249$, 291, 293, 297, 353, 380, 392

humiliation $1,3,60,61,69,65,73$, 75-77, 80, 84-87, 92, 107, 110, $122,123,328,333,356$

identity $13,14,18,26,28,30,76$, $104,129,131,153,154,157,200$, $239,301,321,331,372$

Ilioupersis 85

imprisonment 34, 39, 111,154, 213-215, 217, 257, 343
India 377

initiation $11,14,26,35,181,192$, 212, 291, 356

injury/wound $50,51,68,94,98$, $101,106-108,384$

injustice $35,36,60,83,117,126$, 141, 144, 146, 152, 193, 196, 203, $238,262,273,323,343,344,373$, 382

insult; cf. offense $1,33,35,58,65$, $69,73,77,79,86,96,97,110,115$, 117-119, 121, 123, 135, 149, 151, 238, 248, 261-265, 297, 304, 311, $314,333,334,348,389$

interpreters of law/exêgêtai $\quad 37,42$, $44,45,90$

Ionia 223,280

ire; cf. anger

jail/desmôtêrion/prison $\quad 34,78,85$, 154, 213, 214

justice, class $\quad 93,390$

justice, popular; cf. charivari; rough music; Rügebrauch $72,73,75$, $76,257,339$

Kerameikos $\quad 174,179,182,197$

killer; cf. homicide; murderer 40-42, 44, 45, 48, 53, 62, 63, 94, $109,135,214,233$

killing $26,27,35-46,48,50,52-54$, $62,63,66,67,69,70,73,76,84-86$, $90,93,94,96,97,100,104,106$, 108, 111, 116-118, 121, 123, 127, 134-136, 147, 150-153, 168, 189, 191, 196, 212, 214-218, 220, 226, 251, 276, 307, 323, 352, 379-381

- intentional 26,35,94

- justified 36, 43

- lawful 27

- of relatives $38,40,45-47,55,93$, 95, 96, 105, 109, 233, 276, 298

- self-help 44, 150

- unintentional 27

Lacedaemonians 202

Lenaea $243,246,291,317,332$, 370 
Lesbos $\quad 39$

libation 26, 83

licentiousness 75,132

limen, liminal phase/sphere, liminality $13-15,28,102,103,142$, 158, 179, 188, 211, 237, 244, 246, $257,286,295,327,349,356$

litigant $7,19,20,22,23,26,29,32$, $46,47,49,51,65,70,79,90-92$, $102,103,112,122,128,131,132$, 137, 142, 144, 145, 153,158, 170, $172,173,215,217,271$

liturgy $\quad 55,71,95,115$ logographer $29,108,127,145,172$, $175,247,390$

Macedonia 52, 226 machismo $\quad 76,116,329$ magic, malign $2,127,164,169$, 173, 177, 182, 200-202, 205, 208, 214, 217, 219-221, 223, 224, 230, $232,383,390$

magic, sympathetic $\quad 181,198-200$ magician; cf. magos; shaman; sorcerer; witch 145, 169, 172, 174, 179, 182, 183, 187, 195, 198, $205,223,233,265,390$

malicious joy (Schadenfreude) 57 maltreatment $62,66,70,84,86$, $107,115,123,124,199,200,268$, $273,274,284,305,339,384,386$

manhandle 278, 363

Marathon 255, 260, 295, 330

maritime cases/dikai emporikai 117,144

marriage $22,105,143,211,214$, $226,301,320-322,324,326,332$, $336,343,344,350-352,355,359$, 376

matricide 45

Megara 41

mercenary $324,336,338,340,352$, 393

Mesopotamia 210, 222

Messenians 202

metatheatricality 245,247 , 250-253, 271, 277, 278, 317, 362

Methymna 39 metic $3,5,23,38,41,44,53,85,88$, $100,132,155,157,176,233,385$, 386

mildness; cf. enkrateia; gentleness; moderation; praotês; sôphrosunê; temperance 108, 130, $132,225,229,338$

mockery; cf. taunting $\quad 60,91,114$, 115, 247, 256-258, 263, 291, 311, 313,334

moderation; cf. enkrateia; gentleness; mildness; praotês; sôphrosunê; temperance 92, 96-98, 131, 133, 135-137, 148, 151, 224 , 225, 228, 229, 287, 329, 330, 335, $360,374,377,379,381,392$

molesting $284,285,300$

monopoly $3,35,78,133,134,136$, 150,391

- on power 134

- on violence $35,78,133,134$, $136,150,391$

mother $73,77,84,89,94,100,106$, $130,155,273,276,302,306,320$, $322,332,342,343,346,386$

Mother of the Gods 100, 106, 386

mourning; cf. grief 112, 219

mugger 129, 268, 274-276, 339

murder; cf. homicide

murderer; cf. homicide; killer 25 , $36,37,41,48,53,63,70,87,143$, 202

mutilate 111, 197

- mutilation of the Herms $\quad 65,83$, 248, 326

mysteries $\quad 83,181,248$

- Eleusinian 308

- profanation of $83,176,201$

Mytilene 39

Naxos 83

neighbor, neighborhood $\quad 6,33,35$, $51,53,60,61,66,72,87,88,105$, $147,175,205,221,302,306,320$, $321,323,334,335,340,343,344$, $353,366,390$

Nephelokokkugia; cf. Cloudcuckooland 
normalcy/normality $139,161,268$, $275,284,341,356,359,385,387$ novel 378

oath $26,27,47,202,203,207,283$, 346

obscenity/vulgarism/vulgarity

$110,260,262,267,271,281,282$, 285, 292, 303, 313, 337, 360, 368, 370,371

offend, cf. insult $\quad 33,72,75,90,92$, $116,117,137,138,146,148,151$, 155, 201, 219, 262, 263, 298, 307, 333

offense; cf. insult $\quad 5,20,36,83,117$, $126,138,141,143,144,146,152$, $158,260,262,273,365,380$

offensive $\quad 62,84,119,133,256,305$, 313

Olbia $\quad 180,187,213$

oligarchy $41,86,99,129,162,224$, $249,258,331,355,359,360$, $375-377,381,384$

Olynthus 89

openness, semantic/polyvalence 104, 229, 264, 285, 295, 310, 312, $315,318,331,352,361,372,373$, 380,383

open texture

- of Athenian law 145, 318, 382

- of Old Comedy 318

Oresteia $\quad 233,381$

ostracism 97, 99, 154, 163, 221, 230, 390

Otherworld/topsy-turvy world 179, 244, 245, 272, 275, 296, 299, $315,317,367,372$

outsider $\quad 34,127,133,379,387$

Palladion $\quad 9,27,55,56,100$

Pallene 124

Panathenaea 224

parricide $\quad 45,47,48,306$

passer-by; cf. bystander

peace and conflict research 2,393

Peloponnesian War 224, 258, 259, 308, 326

pelting 289,334 penetration $12,16,76,78,280$, $281,300,355,360$

Persia $\quad 35,144,148,154,157,202$, $223,255,286,393$

phallus $149,239,271,280,281$, 285, 293 (ithyphallos), 299, 315, 369,371

Phrygia 202

pimp 337

Piraeus $\quad 49,79,80$

Plataea 124, 125, 202, 207

Pnyx 23, 26

poison; cf. pharmakon $\quad 45,62,83$, $84,86,93,177,220$

pollution/miasma $23,37,45,47$, $54,86,127,192,204-206,218,219$ polyvalence; cf. openness, semantic prayer for justice 167 , 179,192-196, 201, 203, 215, 218 pressure cooker $\quad 65,162,390,392$ priest 23, 216, 244, 297, 361

priestess 94, 116, 152, 233, 295 , 358

prison; cf. jail

prosecuter; cf. accuser

prostitute; cf. concubine

punch $59,63,79,82,105,108,119$, 136, 267, 336

punishment; cf. revenge; timôria; vengeance $27,36,37,41,53$, $61,70,73,75,86,87,90,93,96$, $117,126,127,137,138,144,146$, $152,154,156,162,167,193-196$, 206, 214-216, 220, 231, 232, 234, 253, 262, 272, 273, 277, 280, 291, $300,327-329,337,353,356,358$, $377,380,383,391,392$

purity; cf. cleansing $\quad 23,206,348$ Pyanopsia 290

quarrel $33,46,51,66,69,74,76$, $86,92,97,134,136,137,143,147$, $172,174,175,272,321,327,329$, 361

rage; cf. anger

ransom money 53 
reflectory/phrontistêrion/thinkery $\quad 302-305,307,312,361$

revenge; cf. punishment; timôria; vengeance $4,34,35,38,43,48$, $54,63,73,75,79,90,96,97$, 116-118, 132, 134-138, 147, 153, 159, 160, 167, 169, 183, 192, 201, 208, 212, 219, 229, 230, 234, 307, $316,335,336,363,379,380,391$, 392

Rhodes $\quad 8,24,40,74,129,236,388$ riot 292

rites de passage/rites of passage $11,13,14$

rites of

- reaggregation 13-15, 142, 182, 247

- separation $13,15,25,142,178$, 243

ritual dynamics $\quad 15,375$

rival, rivalry; cf. enemy $14,31,50$, 51, 54-57, 64, 76, 80, 83, 91, 92, 96, 100, 104, 106, 113, 134, 136, 147 , $152,159,160,161,169,170,175$, 217, 222, 257, 258, 278, 291, 296, $302,313,368,369,370,371,379$

robber, robbery $127,152,214$

rooster; cf. cockfight; fighting cock 60

- rooster dance $\quad 60,103,115,123$ rough music; cf. charivari; justice, popular; Rügebrauch 72

Rügebrauch; cf. charivari; justice, popular; rough music 72,73 , $75,133,257,339$

rules/rituals of (violent) interaction $15-18,21,30-32,34,68$, $70,81,87,99,101,103,113,119$, 140-142, 154, 157, 159, 179, 269, $338,365,374,383,384,388,391$ rules/rituals of representation 15 , $16,18-21,30-32,102,103,113$, 139, 140, 142, 157, 158, 179, 252, 380,388

sacrifice $\quad 4,11,14,23,26,27,53,54$, $83,84,207,216,217,244,334$ sacrilege/asebeia

$83,111,158,162$, 204, 307, 326

Sardis 205

satyr $239,252,293,300$

- satyr play $243,283,300$

scapegoat 127, 221, 369

scourging; cf. flogging; whipping 34

scuffle $\quad 64,294,323,329$

Scythian archers $8,255,259,270$, $271,313,364$

seduction; cf. adultery; moicheia $33,36,43,53,54,88,121,127,143$, $150,155,283,321,328,332,342$, $345,349,351-353,357,360,382$

self-aggrandizement 122

- assertiveness 296

- confidence 71,127,161, 296

- control 48, 70, 76, 77, 97, 116, 126, 131-133, 135, 148, 150, 183, $228,254,322,328,349,379$

- defense 34-37, 98,101,119,150, $161,346,382$

- execration 26, 47

- help 35, 43, 44, 54, 74, 75, 78-80, 90, 134, 138, 150, 160, 203, 308, 389

- restraint 120,130,131,133,160, 224, 225, 228, 229, 328, 335, 336, 381,383

Selinous 192, 226

Sentinum 207

shaman; cf. magician; magos; sorcerer; witch 368

shame $\quad 6,97,99,121,134,135,141$, $148,150,169,219,262,263,345$, $346,350,354,392$

shifter $\quad 251,361$

Sicily 52, 164, 180, 190, 191, 203, 224

skirmish $\quad 50,63,141$

slander $46,80,89,97,115,151$, $163,228,248$

slave $\quad 3,5,27,39,42,44-48,51$, 61-63, 65, 66, 68, 79, 85, 87, 88-90, 93-95, 99, 100, 115, 120, 124-126, 131, 132, 152, 155-157, 176, 177, 267-269, 271, 274, 277, 278, 
280-282, 284, 289-292, 294, 295, 297, 298, 305-307, 313, 317, 320, 326-329, 331, 332, 334-341, 344, $346,347,354,360,362,363,365$, $369,385-387$

slight/oligôria 116, 118

slur 305

social control $18,44,65,72,75$, $106,140,152,177,239,379,389$

Social Drama $14,22,170,236$

sophistic 150, 270, 297-299, 302, 303

sorcerer; cf. magician; magos; shaman; witch 29, 145, 174, 177-179, 188, 205, 211, 220, 233, 390

Sparta 148, 272, 278, 339

speech act 23, 77, 110, 136, 151, $152,183,184,262$

sports $\quad 4,22,167,373$

stelai, grave $162,331,374$

stoning $152,214,385$

strike $\quad 1,34,51,53,69,80,85,87$, $88,93,94,96,97,108,116$, 133-136, 148, 150, 175, 225, 273, 274, 283, 289, 294, 296, 312, 323, $336,338,339,389$

strip $\quad 263,272,275,282$

sword; cf. dagger; sidêrion 49, $324,336,346$

sycophant $128,263,269,304,324$, 369

symposion, symposiast $\quad 33,35,72$, $89,91,116,239,242,261,285,286$, 288, 290-292, 294

taunting; cf. mockery $\quad 60,91,115$ Tauropolia 346

Telmessus $\quad 202$

temperance; cf. enkrateia; gentle-

ness; mildness; moderation;

praotês; sôphrosunê $\quad 24,112$,

$132,135,148,228,289,349,366$, $374,380,381,392,393$

Teos 201, 207, 233

theater of Dionysus $1,9,17,24$, 56-58, 66, 83, 106, 150, 158, 243, $252,276,316,372,375,381$ theatricality/staginess (of life) 9, $16,17,24,31,52,57,58,65,102$, $103,110,143,144,156,158,167$, 168, 170, 227, 236, 238, 245-247, 251, 252, 266, 271, 277, 278, 285, 291, 293, 315, 357, 362, 367, 369, 386

Thebes $\quad 8,270,388$

theft, thief $\quad 36,66,129,167,192$, $193,214,280,369$

Thesmophoria 245, 261, 262, 272, 277

Thessaly 52

thinkery; cf. reflectory

Thirty Tyrants 3, 28, 37-39, 46, 76, $77,80,101,103,106,119,120,126$, $128,148,149,265,278,291,314$, $360,374,386,390$

Thrace $\quad 39$

thrash 336

threshold $32,37,46,60,63,72$, 75-77, 80, 101, 106, 119, 120, 126, 128, 148, 149, 265, 278, 291, 314, $360,374,386,390$

topsy-turvy world; cf. Otherworld

torture/basanos $\quad 5,27,39,84,87$, $88,94,99,131,196,271,362,384$, 385,387

trample $57,98,100,127,267,303$ trespass $74,76,80,81,125$

trickster (figure) 295, 309, 311, 316

trierarch, trierarchy $\quad 82,88,90,91$, 128, 134, 141, 147, 149, 176, 390 Troy 307

utopia $\quad 245,261,270,272,274,275$, 280, 284, 294, 296, 298, 315, 317, $338,355,360,361,365,372,374$, 383

vase (vase painting) $6,12,20,85$, $117,153,162,225,239,269,300$, $331,377,383$

vengeance; cf. punishment; revenge; timôria $36,45,48,54,75,96$, 136, 137, 177, 205, 228, 233, 234, 380,383 
virgin $44,77,320,322,323,342$, $343,347,355$

voodoo doll; cf. effigy

vulgarism/vulgarity; cf. obscenity

wedding 43, 214, 242, 291, 298, $300,320,335,336,343-345,355$, $356,361-363,366,371$

wedlock $\quad 327,344,349,355-357$

whip; cf. flogging; scourging 60 , $62,66,84,87,89,93,99,106,124$, 263, 269, 271, 297, 336 whore; cf. concubine

witch; cf. magician; magos; shaman; sorcerer 154, 176, 226, 233, 326

witness $18,27,45-47,49,51,53$, $54,60,62,64,80,99,101,109-111$, $123,131,145,160,170,208,209$, 244, 288, 297, 304, 305, 314, 343, $346,356,386$ wound; cf. injury wrath; cf. anger

\section{Important Greek and Latin terms}

\begin{tabular}{|c|c|}
\hline $\begin{array}{l}\text { agôgai } 167 \\
\text { agonistic } \\
\quad 60,97,116,136,196,225,\end{array}$ & $\begin{array}{l}\text { barbaros; cf. barbarian } \\
\text { basanos; cf. torture } \\
\text { baskania; cf. Evil Eye }\end{array}$ \\
\hline agôn timêtos & biaiothanatoi $\quad 180,197,211$ \\
\hline oranomoi & biasmon \\
\hline 204 & bouleusis \\
\hline $\begin{array}{ll}\text { groikos } & 325 \\
\text { dôs } & 225\end{array}$ & bouleutai; cf. councilors \\
\hline keia 34 & $116,254-256,330$ \\
\hline $\begin{array}{l}\text { schrologia } \\
317\end{array} \quad 238,248,313,315$, & chorêgia, chorêgos; cf. chorus 1, \\
\hline rolasia 132 & $119,133,149,171$ \\
\hline $\begin{array}{l}\text { krasia } \\
\text { ntidikos } \\
169,170\end{array}$ & chytra 181 \\
\hline $\begin{array}{l}\text { agoi } 211,212,232 \\
\text { agôe } 38-41,47,53,62,75,87 \text {, } \\
\quad 133,276,346\end{array}$ & $\begin{array}{l}\text { communitas; cf. feeling of belon- } \\
\text { ging 14, 28, 32, 244, 257, 293, } \\
368,373\end{array}$ \\
\hline agôgế kakourgôn 39,4 & \\
\hline $\begin{array}{l}\text { agôgê phonou } \\
\text { otumpanismos }\end{array}$ & $\begin{array}{ll}\text { daimon } & 212 \\
\text { daimonion } & 311,348\end{array}$ \\
\hline $\begin{array}{l}\text { otumpanismos } \\
\text { ragmôn (polis) }\end{array}$ & $\begin{array}{ll}\text { daimonion } & 311,348 \\
\text { dêmêgoria } & 236\end{array}$ \\
\hline $\begin{array}{l}r \text { ragmón (polis) } \\
a \quad 201-207,215,226,239\end{array}$ & dêmos $1,18,28,39,58,79,144$, \\
\hline $\begin{array}{l}\text { chôn basileus 44, 55, } 99 \\
\text { ebeia; } \text { cf. sacrilege }\end{array}$ & $\begin{array}{l}146,165,245,246,249,255,258 \\
260,262,269,281,282,285,299\end{array}$ \\
\hline elgeia 132 & $308,309,317,389$ \\
\hline iphoi & $182-184,187,207,316$ \\
\hline elês, atelestoi & desmôtêrion; cf. jail \\
\hline $\begin{array}{l}\text { imia, atimos } \\
\quad 144\end{array}$ & 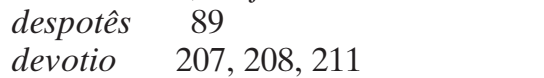 \\
\hline tarkeia & $\begin{array}{lc}\text { diabole } & 46,257,300 \\
\text { diakopoi } & 167\end{array}$ \\
\hline $152,306,385$ & dikaiosunê \\
\hline
\end{tabular}


dikê (also personified as Dikê) $\quad 50, \quad$ hubristês $\quad 62,69,77,92,121,123$,

$117,172,193,203,210,317$

dikê aikeias $\quad 75,86,125,130,297$

dikê biaiôn 43, 53, 54, 75, 382

dikê blabês $\quad 43,75,233,382$

dikê emporikê; cf. maritime cases

dikê exoulês 74

dikê kakêgorias 110

dikê phonou 26, 36, 39-42, 44-48, $55,94,95,109,233$

diômosia 26,46

dirae 201,207

dokimasia $18,65,273$

drômena $14,23,178,247,318,372$

eisangelia $\quad 25,53,56,127$

ek pronoias $27,34,49-51,71,94$

endeixis 53

126, 129-131, 133, 138, 139, 157, $262,288,311,352$

hybristic $61,69,93,98,115,120$, 122-127, 130, 136, 139, 154, 160, 221, 264, 291, 295, 296, 300, 315, $356,366,367$

humanitas 376

huperbolê 132

isêgoria 248

kakourgos $39,43,133,214,276$, 324,346

katad(e)ô 184, 206, 207, 209, 214, $215,225,229,316$

katadesmos $164,165,187,209$

katochos 191, 195, 209, 211, 215

klepsudra 27

klêrôtêrion; cf. allotment machine

koinê 223, 377

koinê eirênê 393

kômos, komast, komastic $\quad 6,33,72$, $73,75,237,239,242,263,268,271$, 285, 291-296, 307, 308, 319, 332, $333,351,361-364,366,371$

kurbeis 224

kurios, kurieia $\quad 36,42-44,55,72$, $74,77,78,80,81,85,86,89,100$, $151,155,161,284,335,340,352$, $354,356,385,388$

graphê adikôs eirchthênai hôs moichos 88

graphê asebeias

$47,48,233$

graphê hubreôs $53,75,86-88,125$, $130,133,261,382$

graphê kakôseôs goneôn 273

graphê moicheias $\quad 37,53,54,382$

graphê paranomôn 25

graphê traumatos ek pronoias $\quad 50$,

$51,71,94$

graphê xenias 136, 386

gumnasion 33

gunaikonomos 225

hekousios 27

hetaira; cf. concubine

hieros gamos 301

ho boulomenos $\quad 23,40,130$

legomena $14,23,178,182,247$,

318,372

leitourgiai 165

loimos; cf. Fluchzustand

magos; cf. magician; shaman; sorcerer; witch 29, 223, 368

mania 116

maschalismos 197

mê ek pronoias 27

mê mnêsikakein 43

miasma; cf. pollution

moicheia, moichos; cf. adultery; seduction $3,36,37,43,53,54$, $345,346,360,373,382$

moirai 85 
muthopoiêsis 266

nomophylax 225

nomos tôn kakourgôn

nomothesia 144,224

nothos; cf. bastard child

oikos $54,72,74,76-78,81,86,98$, $126,127,132,148,150,155,221$, 285, 286, 290, 292, 293, 318, 330, $338,341,355-358,360,364,377$, 384

oikoumenê $\quad 376,377$

oligôria; cf. slight

onomasti kômôdein $\quad 248,257,301$ orchêstra 243, 244, 252, 262, 273, $282,292,293,364$

orgê; cf. anger

ostrakon 49

paideia 377

palaistra 91

pallakê; cf. concubine

pankration 37, 43

parabasis $255,266,268,302,303$, $305,312,369$

paranoia 304

parodos 266, 280

parrhêsia 248

patrios politeia 148,381

peithô 2, 29, 152, 216, 217, 220

pelatês 42

peristiarch 23, 26, 244

pharmakon; cf. poison 177, 220, 233

pharmakos 369

phasis 52

philanthrôpia 332,377

phonos akousios 95

phonos ek pronoias 94 phrontistêrion; cf. reflectory

phthonos; cf. envy

politês 148, 376

polupragmôn 278, 296, 298

pompê 291

ponêria, ponêros $\quad 309,369$

praotês; cf. enkrateia; gentleness; mildness; moderation; sôphrosunê; temperance 132

probolê $59,63,125,146$

prostatês $89,90,100,155$

psuchopompos 181, 212, 215, 216, 218, 229, 231

rhaphanidôsis, rhaphanismos 75,382

sidêrion; cf. dagger; sword 50 skômmata 291

sophos 304

sôphrosunê; cf. enkrateia; gentleness; mildness; moderation; praotês; temperance $131,132,225$, $228,319,323,366,374,380,381$

spoudaiogeloion $310,318,363$, 372

stasis; cf. civil war

stratêgos 96, 249

sundikos $\quad 169,170,175$

sunêgoros $\quad 46,127,170$

taxiarchai 97

theôrika 250, 375

thumos 76,116, 254, 255, 259, 286, 304, 330

timôria; cf. punishment; revenge;

vengeance $219,380,392$

trauma ek pronoias $\quad 34,49,50$

voces magicae 193 


\section{Ancient proper names (historical and fictional persons)}

Ancient authors mostly if mentioned in main text (several persons have the same name, they are not always listed under separate entries)

Achilles $\quad 85,325$

Adonis $\quad 320,345,346$

Aeacus 215, 271

Aegisthus 51

Aerope 322

Aeschines 44, 51, 84, 88-90, 109, $110,114,120,124,127,128,133$

Aeschylus 255-257, 304, 397

Aesion 40

Agamemnon 86, 276

Agatharchus 125

Agathon 272, 282, 283, 310

Agave 111

Agoratus 38, 41

Agrius 85

Ajax 111, 323

Alcibiades $\quad 34,44,46,55-58,64$, $83,85,99,100,125,128,150,160$, $201,224,299,386$

Alcmene $\quad 358$

Amyntor 322

Anaxicrates 210

Anaxinus 84

Andocides $\quad 46,98,99,128,176$, 374,380

Androtion 24, 47, 48, 62, 126, 133

Antimachus $\quad 62,99$

Antiphilus 210

Antiphon $19,62,67,69,70,83,94$, $95,108,135,153,173,374,380$, 384

Apelles 111

Apollo 26, 205, 290, 327, 358

Apollodorus, son of Pasion 46, $48,51,62,65,74,81,87,105,124$, $125,136,147,210,386$

Apollodorus from Megara 41

Archippus $\quad 60-62,66,71,73,84$, $87,91,93,99,106,124$

Aristaichmus 166

Aristarchus $\quad 40,41,109$

Aristocrates 176

Aristodemus 310
Aristogeiton $34,41,53,85,96$, $111,127,131,135$

Ariston $42,47,50,59,60,70,91$, $92,97,98,103,107,108,110,115$, $123,127,133,137$

Aristophon 176

Aristotle 117, 120, 146, 239, 334, $366,367,370$

Artemis (goddess) 205, 343

Artemis (wife) 190

Assurbanipal 222

Astyphilus 86, 109

Aulus Gellius 342

Autolycus 114

Bacchis $\quad 330$

Basileia $\quad 284,301,361$

Bdelycleon 266, 271, 285, 287-290, 292

Bias 337

Blepyrus 261, 272, 274, 284, 294, 361

Boeotus $\quad 35,51,69,116$

Caecilius Statius 342

Callenicus 210

Callias 34, 46, 176, 276

Callicles 81

Callicrates 210

Callimachus $\quad 46,47,52,99,147$

Calliphanes 176

Callipides $\quad 332,335,336$

Callisthenes 176

Callistratus 176

Canidia 226

Carcinus 292

Cassander 173, 176, 323

Chaereas $332,334,350$

Chaerephon 256,307

Chaerestratus 326-328

Chaerestratus of Collytus 176

Charinus 210 
Charisius $\quad 326,327,347-350,354$, 355

Chremylus 270, 361

Chrysis 320-323, 335, 338, 345, 346,358

Cineias 210

Cinesias 283, 297

Ciron 95

Cleaenetus $\quad 343,344,364,365$

Cleigenes 275

Cleisthenes 377

Cleon (politician) 238, 248, 249, $253,256,257,260,275,330$

Cleon (Thudippus' grandson) 109

Cleostratus 328

Clytemnestra $\quad 45,86,322$

Cnemon 332, 334-336, 338, 351, 362-364, 391

Conon $33,42,47,50,59,60,67$, $70,78,83,91,92,97-99,103,107$, $110,114,115,123,129,133,137$. 139

Crateia $\quad 352,358$

Crates 257

Cratinus 46, 47, 261

Creusa 358

Croesus 35

Ctesias $\quad 59,60$

Ctesiphon 25

Dardanis 290

Daus $\quad 326-329,337,339,340$

P. Decius Mus 207

Delphis 180

Demeas 320-324, 327, 331, 335, $336,345,360$

Demeas of Paeania 176

Demeter 188, 296

Demetrius of Phaleron 162,176, $225,228,360,366$

Demochares 48

Democrates 176,210

Demomeles 51

Demophilus 176, 210

Dêmos 269, 281, 282, 285

Demosthenes 1,19,33, 34, 40-42, $51,57-59,63-66,68,69,71,73$,
78, 82-84, 88-90, 92-94, 98, 99, 105, 108-111, 115, 116, 118-120, 126-129, 133-135, 137, 150, 176, 183, 228, 255, 269, 301, 350, 384, 391-393

Diallage, also Reconciliation 280, 283-285

Dicaeopolis 156, 252, 258, 259, 262, 269, 270, 276, 277, 280, 281, $288,295,338,361$

Diocles $45-47,87,95,125,176$, 276

Diodorus $\quad 45,47,48,388$

Diodotus $\quad 25,55,56,95,105$

Diomedes 323

Dionysophon 214

Dionysus, Dionysiac (rites, farce etc.) $1,9,17,24,56-58,66,82$, 83, 100, 150, 158, 235, 239, 242-245, 248, 252, 256, 257, 260, 263, 266, 268, 269, 271, 276, 279 , 280, 282, 289, 291-295, 297, 307, 311, 315-318, 338, 339, 361, 368, $370,371,372,375,381$

Diotimus 128

Dioxippus 43

Doris 85

Draco; cf. homicide statute/law $5,25,36,90,143,151$

Eirene, statue of

393

Epaenetus $\quad 88$

Ephialtes 381

Epicharmus 240, 288, 365

Epigenes 272, 294

Eratosthenes, the adulterer 22, $43,50,53,66,81,104,114,118$, $129,132,150,151,382$

Eratosthenes, the oligarch 38,76

Erichtho 226

Euaeon 35, 65, 116

Euctemon $\quad 47$

Eudidactus 210

Euelpides $\quad 260,276,296,300$

Euergus $\quad 44,73,79,81,88,90,390$

Eupherus 176 
Euphiletus 36, 43, 50, 53, 54, 64, Hubbub 269 $66,76,81,104,114,118,132,133$, Hygia 191

135, 143, 150, 151, 351, 381, 382 Hyperides 43, 76, 86, 111, 129,

Eupolemus 176

Euripides 256, 257, 260, 262, 263, $272,276,282,325,326,330,337$, 380

Europa 358

Eurydike 323

Euryptolemus 194

Euthycrates $\quad 45,51,108,109 \quad$ Jocasta 322

Euthydicus 51

$\begin{array}{lr}\text { Euthymachus } & 124 \\ \text { Euthyphro } & 42,51\end{array}$

Euxitheus $\quad 39$ $141,176,360$

Iris $\quad 284,297,300$

Isocrates $46,50,93,96,98,99$, $105,116,119,126,128,134,384$ Itys 300

Kallippus 190

Kore 188

Kynna 323

Fawn 283

$\begin{array}{ll}\text { Gaia/Ge } & 188,195 \\ \text { Gameta } & 191\end{array}$

Getas $\quad 332,334,335,362,363$

Glycera $\quad 328,329,331,340,358$

Gorgias $332-336,344,351-353$, 365,375

Habrotonon $326,327,338,340$, $347,354,358$

Hades/Pluto 188, 191, 192, 208, $212,213,215,216,218,233,273$, 368

Hagesis 166

Hagnias 147

Hagnotheus 191

Harmodius $\quad 41,53,127$

Harpalus 81,138

Hecate $\quad 83,188,206,208,212,215$

Hegesander 66, 72, 87, 106

Helen 29, 184, 263

Heracles $\quad 85,255,273,274,276$, 332

$187,188,191,195,198$,

Hermes
$208-212,215,259,304$

Herodes 39, 40, 88

Hierocles 109, 297

Hipparchus 41, 78, 127

Hipparete 44

Hippomenes 44

Hipponicus $\quad 34,176$

Labes (dog) 286

Laches $\quad 337,344,358,364$

Laius 202

Lamachus $\quad 262,281$

Leimone 44

Leontius 152

Leptines $\quad 163,176$

Lesis $\quad 89,124,155$

Litias 208

Lochites $50,51,93,96,98,99$, $105,108,126,128,129$

Lycophron $\quad 43,76,78,127,360$

Lycurgus, Lycurgan era 9, 24, 76, $78,127,176,360,370,381$

Lysias $19,22,33,37,38,43,49,50$, $53,54,63,64,68,71,73,76,91$, $99,105,106,124,125,132,150$, 151, 163, 197, 351, 352, 358, 360, 383

Lysicles 176

Lysimachus 202, 210

Lysistrata 155, 247, 248, 259, 261, 264, 266, 267, 270-272, 274, 275, $277,280,283,284,291,295,338$

Manes 278, 298

Mantitheus 51

Marcus Aurelius 205

Meidias 1, 24, 27, 36, 40, 41, $57-59,63,64,66,71,73,77,78$, 81-83, 92, 93, 99, 105, 108, 110, 112, 114-116, 118, 119, 128, 129, 
131-133, 135, 137, 146, 150, 160, Pamphile $326,327,338,347-350$, $183,301,350,381,389$

Menecles 163

Menelaus 263

Menestratus 38

Menon 124

Meton 297

Mica 277

Minos 215

Mnesarchides 128

Mnesibulus 79, 81, 88, 90, 350

Mnesilochus, also In-Law 256, 354,358

Pan 334

Pancleon 124

Pantaenetus 73

Paphlagon 238, 269

Parmenon 320, 336

Pataecus $\quad 329,331,340$

Patrocleides, decree of 249

Patrocles 52

Peisetaerus 260, 270, 276, 278, 295-301, 328, 361, 368 262, 263, 272, 273, 277, 282, 283, Peisistratus, Peisistratids 78, 96, 285

Mnesimachus 176, 197, 210 $127,129,224$

Peleus 304

Moschion 320-324, 328, 329, 331, Pelopia 322 335, 336, 340, 343, 345, 347, $353 \quad$ Penia/Poverty 222, 261, 270, 271

Moschus 329

Myrrhine $155,191,283,332,334$, $340,344,358$

Myrtia 292

Neaera $\quad 46,88,125,136,147,386$

Neoptolemus $\quad 85,128$

Nereus 85

Niceratus $\quad 320-325,327,331,335$, $336,346,353,360$

Nicias 175,269

Nicobolus 73

Nicodemus of Aphidna 25, 40-42, 94, 109

Nicomachus 197

Nicomedes 124

Nicostratus $\quad 48,49,51,62,65,74$, $81,82,87,105,110,124,136,147$

Nino 233

Oceanus 85

Oedipus 202, 322

Olympiodorus 210

Onesime 195

Onesimus $327,328,346,347$

Opora, also Cornucopia $\quad 282,284$

Orestes 45, 46, 51, 233, 251, 276, 325,326

Orpheus 181

Palaemon Pancrates 195

Pericles 149, 223, 228, 248, 250, $258,359,365,377,381,389$

Perinthia 20, 237, 337, 342

Persephone 187, 188, 191, 195, 208, 210, 215

Phales 280

Phanias 343

Phanostrata 358

Pheidias $337,344,358$

Pheidippides 271, 299, 302-304, 306, 307, 309, 321

Philinna 344

Philip V of Macedon 201

Philippa 358

Philippides $\quad 68,91,128,129$

Philocleon 29, 63, 68, 266, 268, 271, 285-293, 295, 296, 330, 338, $361,364,368,383$

Philocles 210

Philocrates $\quad 25,55,56,95$

Philomela $\quad 300,301,322$

Philoneus 83

Philumene 340

Phocion 138, 176

Phoenix 322

Phormio 125

Phryne 111, 114

Phrynichus 41, 52, 53, 306

Phrynion 125

Pittalacus 66, 72, 87, 100, 106, 123,386 
Plangon $\quad 320-324,323,335,342, \quad$ Syracosius, decree of 248

$$
344,346,353
$$

Plato 42, 51, 116, 130, 132, 180, 212, 220, 221, 224, 232, 233, 249, Taureas 56, 57, 83, 100, 150 $274,309,310,368$

Pleistarchus 176

Polemarchus 38

Teiresias 212

Polemon $328,329,332,339,340$

Polemos 269

Polyeuctus 176

Praxagora $259,261,274,275,284$, $294,295,338$

Praxiteles 111

Priam 85

Procne 300

Pyrrhias $\quad 166,332,334$

Pythagoras 307

Pythodorus 163

Rhadamanthys 215

Rhinon 52

Sabazius 233

Sausage-Seller 238, 269, 281

Sicon 332, 334, 335, 362, 363

Simaetha 180

Simon $37,50,65,71,73,91,93$, $105,106,125,128,129,133$

Smicrines $\quad 326-328,338$

Smindyrides 176

Socrates $42,138,213,233,249$, $255,256,302-314,326,361$

Solon 24, 36, 120, 133, 148, 224, 234,381

Sophocles $\quad 9,24,111,300,381$

Sophrone 327

Sosias $\quad 166,329,339,340$

Sostratus $\quad 329,332-335,351,375$

Spondai, also Peace terms 281

Stephanus $\quad 46,88,125,136,147$, 386

Straton $\quad 110,111,114,128,301$

Stratophanes 340

Strepsiades $271,295,299,302$, 304-309, 314, 321, 361

Strombichides 176

Strombichus 176

Sulis Minerva 184

Teisis $\quad 60-62,66,71,73,84,87,91$, $93,99,124$

Telephus 276, 277

Telestes $\quad 163$

Terence 341,354

Tereus 300, 301, 322

Themistius 124

Theocrines 48

Theodotus $\quad 71,73,125$

Theomnestus 136,147

Theophemus $\quad 44,51,74,78,79,82$, $90,91,107,134$

Theophilus 210

Theophrastus 366, 367

Theoria, also Holiday, Show-time 282,284

Theoris of Lemnos 233

Theozotides 163, 176, 197

Theseus 85

Thetima 214, 226

Thetis 304

Thoas 85

Thrasonides 328,352

Thrasybulus $\quad 41,259$

Thrasybulus from Calydon 41

Thucydides 116,380

Thudippus $\quad 45,108,109$

Thyestes 322

Tibeius 344

Timarchus $24,25,66,72,87,106$, $110,114,127-129,133$

Timocrates 77, 78, 276

Timon 332

Triballoi 139, 276

Triptolemus 215

Troilus 85

Trygaeus 256, 259, 263, 270, 282, 297, 338

Xanthias $\quad 260,263,268,271,287$, $289,292,307,361$

Xenocles $\quad 89,176$

Xenophon 388 
Xenophron 89

Zenobia 85
Zeus $83,118,204,212,257,280$, $283,297,300,317,358$

Zopurus 210 
